\title{
Recepcija neoficijelne češke književnosti u Hrvatskoj od 1968. do 1990.
}

\section{Roštaš, Helena}

Doctoral thesis / Disertacija

2020

Degree Grantor / Ustanova koja je dodijelila akademski / stručni stupanj: University of Zagreb, University of Zagreb, Faculty of Humanities and Social Sciences / Sveučilište u Zagrebu, Filozofski fakultet

https://doi.org/10.17234/diss.2020.7814

Permanent link / Trajna poveznica: https://urn.nsk.hr/urn:nbn:hr:131:839727

Rights / Prava: In copyright/Zaštićeno autorskim pravom.

Download date / Datum preuzimanja: 2023-04-26

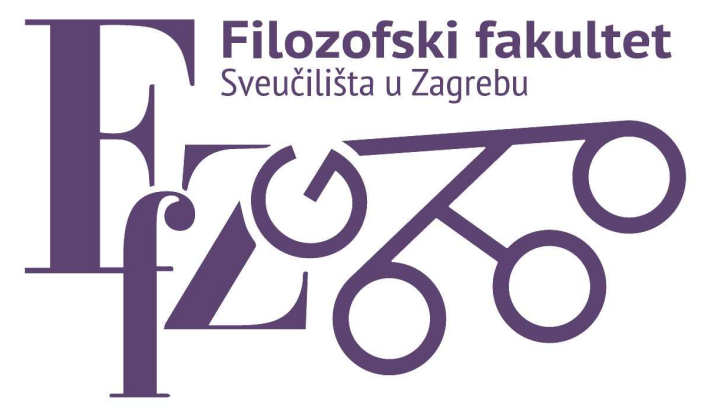

Repository / Repozitorij:

ODRAZ - open repository of the University of Zagreb Faculty of Humanities and Social Sciences
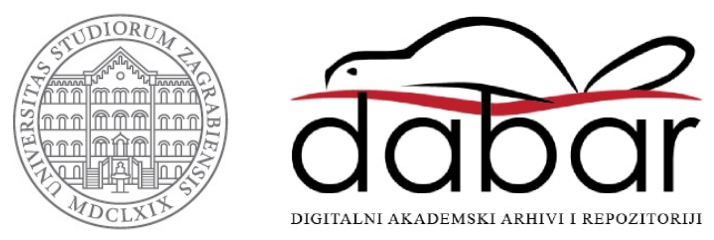


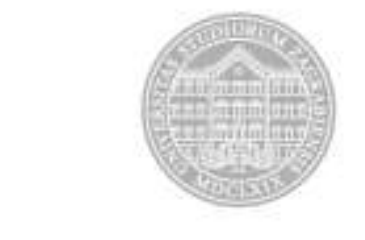

Sveučilište u Zagrebu

Filozofski fakultet

Helena Roštaš

\section{RECEPCIJA NEOFICIJELNE ČEŠKE KNJIŽEVNOSTI U HRVATSKOJ OD 1968. DO 1990.}

DOKTORSKI RAD

Zagreb, 2020. 


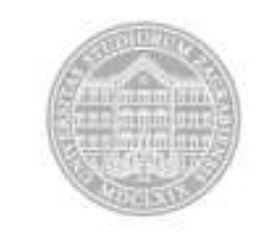

Sveučilište u Zagrebu

Filozofski fakultet

Helena Roštaš

\title{
RECEPCIJA NEOFICIJELNE \\ ČEŠKE KNJIŽEVNOSTI U HRVATSKOJ \\ OD 1968. DO 1990.
}

\author{
DOKTORSKI RAD \\ Mentorica: dr. sc. Katica Ivanković, red. prof.
}

Zagreb, 2020. 


\section{University of Zagreb}

Faculty of Humanities and Social Sciences

Helena Roštaš

\section{THE RECEPTION OF THE CZECH \\ UNOFFICIAL LITERATURE IN CROATIA \\ FROM 1968 TO 1990}

DOCTORAL THESIS

Supervisor: Katica Ivanković, PhD

Zagreb, 2020. 


\section{ŽIVOTOPIS MENTORICE}

Dr. sc. Katica Ivanković, red. prof., rođena je 1961. u Banjaluci. Na Filozofskom fakultetu u Zagrebu diplomirala je 1984. na studiju komparativne književnosti i češkoga jezika i književnosti, a 1987. postala je asistentica za češku književnost na Odsjeku za slavistiku Filozofskoga fakulteta u Zagrebu.

Akademsku godinu 1988./89. provela je na studijskom boravku u Pragu. U Češkoj je radila kao lektorica hrvatskoga jezika i književnosti na Masarykovu sveučilištu u Brnu u ak. godinama 1993./94. i 1994./95., a potom u ljetnom semestru 1996. i u ak. godini 1996./97. na Karlovu sveučilištu u Pragu.

Na Filozofskom fakultetu u Zagrebu magistrirala je 1996. godine, a doktorirala 2001. U zvanje docenta izabrana je 2003. U razdoblju od 2003. do 2008. bila je predstojnica Katedre za češki jezik i književnost, a od 2005. do 2007. obavljala je dužnost pročelnice Odsjeka za zapadnoslavenske jezike i književnosti. Ponovo je izabrana za predstojnicu Katedre za češki jezik i književnost 2013. U znanstveno nastavno zvanje izvanrednog profesora izabrana je 2009., a u zvanje redovitog profesora 2014. Na studiju češkog jezika i književnosti nositeljica je svih kolegija iz češke književnosti i kulture, a sama izvodi šest kolegija na preddiplomskom i diplomskom studiju.

Sudjelovala je u znanstvenom projektu voditeljice dr. sc. Dubravke Dorotić Sesar, red. prof., Istraživanje zapadnoslavenskih jezika 130717(1996.-2002.). Sama je od 2006. do 2014. bila voditeljica znanstvenog projekta Kanoni i stereotipi. Zapadnoslavenske književnosti iz hrvatske perspektive (130-1301070-1053), u koji je bilo uključeno još šest suradnika s Odsjeka za zapadnoslavenske jezike i književnosti. 


\section{SAŽETAK NA HRVATSKOME JEZIKU}

U središtu je istraživanja recepcija češke neoficijelne književnosti među čitateljima u Hrvatskoj u razdoblju od praškoga proljeća i vojne intervencije zemalja Varšavskoga ugovora u Čehoslovačkoj u kolovozu 1968. do pada komunizma u srednjoj i istočnoj Europi na prijelomu osamdesetih i devedesetih godina 20. stoljeća te mogući utjecaj tog dijela češke književnosti na hrvatsku književnost istoga razdoblja.

Disertacija pokazuje u kojoj su mjeri fikcionalna i nefikcionalna djela češke samizdatske i emigrantske književne scene u analiziranome razdoblju bila dostupna čitateljima u Hrvatskoj, na koji su način bila prihvaćena među njima, je li tijekom toga razdoblju dolazilo do promjena u recepciji te u kojem su se smjeru te promjene kretale. Istraživanje obuhvaća i analizu prisutnosti drama čeških neoficijelnih dramatičara na repertoarima kazališta diljem Hrvatske, kritičku recepciju djela češke samizdatske i emigrantske produkcije, njihovu recepciju u hrvatskoj znanosti o književnosti te utjecaj toga korpusa na hrvatsku književnost postmodernizma.

Recepcija češke samizdatske i emigrantske književnosti u hrvatskoj je kulturi nedovoljno istražena. Vjerujemo da disertacija upotpunjuje spoznaje o hrvatsko-češkim književnim i kulturnim vezama u drugoj polovici 20. stoljeća.

ključne riječi: češka književnost, neoficijelna književnost, samizdatska književnost, egzilna književnost, cenzura, recepcija, hrvatska kultura, Hrvatska, Jugoslavija, 20. stoljeće 


\section{SUMMARY}

The period of normalization in Czechoslovakia started after the military intervention of the Warsaw Pact countries in August 1968. The military intervention was the response of the official regimes of the Eastern Bloc countries to the reform movements that developed in the Czechoslovak Communist Party and, later, during the 1960s, in the whole Czechoslovak society. A consequence of the breakdown of reform movements was a ban of public action on all persons who participated in the reform movement. Censorship served as one of the strongest tools for shaping the society in Czechoslovakia after 1968 and expelling influential intellectuals from the public.

At the beginning of the 1970s, Czech literature was divided into official, unofficial and, so-called, gray zone. The official part of Czech literature belonged to the writers who continued to publish their works in the state publishing houses. Unofficial writers published in samizdat and emigration, and their plays were performed in the theaters abroad. The grey scene was composed of authors working in both fields, depending on the changing circumstances and their propensity to compromise.

Although the socio-political circumstances hindered the development of Czech culture, art and literature during the period of normalization - they were constantly controlled by the official regime through censorship measures - one of the most difficult periods of Czech history developed one of the brightest periods of Czech art. The literature of that time was gaining enormous attention from the public outside of the country, led by the names of Milan Kundera, one of the most popular writers in Europe in the 1980s, and a dissident and playwright Václav Havel.

The research concentrates on the reception of the Czech unofficial literature by readers in Croatia between the Prague Spring and military intervention of the Warsaw Pact countries in Czechoslovakia in August 1968 and the fall of communism in Central and Eastern Europe at the end of the eighties and the beginning of the nineties. The research includes a possible impact of the unofficial Czech literature on Croatian literature of the same period. The dissertation demonstrates the extent to which fictional and non-fictional works of Czech samizdat and emigrant literature scene in the analyzed period was available to readers in Croatia, the way in which it was accepted among readers, whether there was a change in reception during that period, and what the direction of that change was. The research shows that the reception of the unofficial Czech literature is realized in all three manifestations according to the classification of Manfred Schmeling - the passive, the reproductive and the 
productive one. The thesis complements the knowledge on the Croatian-Czech literary and cultural connections in the second half of the 20th century.

The bibliography of the translations included in this analysis has been compiled according to the library databases of two libraries: Nacionalna i sveučilišna knjižnica (Zagreb, Republic of Croatia) and Národní knihovna České Republiky (Prague, Czech Republic), supplemented by the exile issues of the digital exile library database Libri Prohibiti. Also, research involves the analysis of the reception of Czech unofficial literature in periodicals and magazines Republika, 15 dana, Dubrovnik, Pitanja, Revija, Rival, Vjesnik u srijedu, Vidik, Forum, Gordogan, Quorum, Oko, Polet, Književna smotra, Prolog, Novi prolog, Danas, and daily newspapers Večernji list and Vjesnik.

In the introductory part of the research, four hypotheses were put forward, and, ultimately, confirmed:

- the works of the unofficial Czech literature in the analyzed period were well received by readers in Croatia

- readers in Croatia haf more access to works by writers who worked in exile than to those who self-published in Czechoslovakia

- Croatian publishers, by publishing works of the unofficial Czech literature, primarily listened to market demands of the 1980s

- towards the end of the 1980s, there was a change in the intensity of reception in the fields of publishing and theatre, and in the critical reception due to a new constellation of sociopolitical relations in Yugoslavia and Croatia.

During the twenty years of normalization in Czechoslovakia, publishing houses in Yugoslavia continuously published Czech exile and samizdat literary works. The intensification of the publishing activity was noticeable during the 1980s, especially from 1984 to 1988 when, in just four years, $56 \%$ of all books were published. In the whole period of normalization, $81 \%$ of all published books in Yugoslavia belong to exile production of the Czech unofficial scene.

Due to a unique market and the country they shared, Croatian readers are strongly focused on the editions published by Belgrade and Sarajevo publishers. The translations of Czech unofficial authors were also published in Ljubljana and Skopje. However, due to a language barrier, readers in Croatia were not introduced to these publications. The largest and most reputable Yugoslav publishers published the translations of Czech unofficial authors in their market-leading editions. 
The most translated and published texts among readers in Croatia are novels. Novels and short stories of Milan Kundera and Josef Škvorecký make up more than $86 \%$ of the total prose book publications, most of them in the most successful publisher's editions. Milan Kundera's novel Žert (Croatian Šala, English The Joke) was published eight times in Zagreb, Belgrade and Sarajevo from 1968 to 1990, and was often taken as the starting point of the evaluation of the critical reception of Kundera's work.

Due to the fact that Croatian libraries were not digitized during the 1970s and 1980s, it was not possible to obtain information on the borrowing of publications by unofficial authors. However, the lists of the most read and best-selling books in Croatian libraries and bookstores that can be found in newspapers from the 1980s often contain titles written by unofficial Czech authors.

The reception of these authors in Croatia was not delayed during the two analyzed decades. Most of the translations of Zagreb, Sarajevo and Belgrade publishing houses were published within a very short period of time, after the first issues were published.

Poetry translations were mostly published by magazines such as Republika, Forum, 15 dana and Rival. The only Czech poet whose collection of poetry was published was the 1984 Nobel Prize laureate for literature, Jaroslav Seifert. Poetry provides a greater distance from reality than novels and drama, so unofficial Czech poets in the 1970s and the 1980s in Croatia and writers who published their works freely in Czechoslovakia often published side by side.

Due to the fact that the primary area of expression of dramatic literature is theater, we note a small number of print editions of plays written by unofficial playwrights. The theater reception of unofficial writers grew extremely during the 1980s, which corresponded to the situation in the publishing market. Plays by Václav Havel, Pavel Kohout and Milan Kundera account for as much as $75 \%$ of all premiere titles. These plays, and plays written by other playwrights less known to Croatian audience, were performed in national theaters in Zagreb, Rijeka and Split, but also in g Teatar ITD in Zagreb, aimed mostly at students, and a touring theatre Kazalište u gostima which, in 1974, began its work with Milan Kundera's play Ševa.

During the analyzed period, and especially at the end of the 1980s, Zagreb's theaters often brought to the stage, during one season, a play by an unofficial playwright, a play that belongs to the classics of Czech literature, as well as guest performances by Czechoslovak theaters. Also, performances of unofficial authors were often considered the culmination of the theatre production of the particular season, so there is a number of examples showing that these plays represented Croatian theaters at festivals such as Gavelline večeri and Festival malih i eksperimentalnih scena Jugoslavije. A strong theatre reception was accompanied by a 
developed theatre-critical reception, but its scope depends, in part, on extra-literary factors. For example, the number of stage plays written by Václav Havel and Pavel Kohout were almost equal in Croatia in the 1970s and the 1980s, but the critical reception of Havel's plays was much stronger due to the Havel's dissident activities.

Croatian publishers were not interested in publishing editions of the official Czech literature and the reception of these works was not developed during the 1970s and the 1980s. Those representatives of the official literature that were published and read in Croatia, such as Ladislav Fuks and Vladimír Páral, represent the qualitative highlights of the official literary production. Although the reception of the unofficial production was exceptional and the reception of the official literature was very poor, the cooperation at the institutional level existed, so the representatives of Czech official writers regularly participated in professional gatherings such as Zagrebački književni razgovori.

An increased reception in Croatia occurred after 1980. The first decade of the normalization saw a good reception of Czech unofficial authors as a result of an interest in the events during the military intervention of Warsaw Pact and the events that followed. By the 1980s, Czech literature among readers in Yugoslavia had built up such a reputation that publishing unofficial authors made excellent profits for publishers in Yugoslavia. The popularity of unofficial writers in Western Europe, especially Milan Kundera, certainly contributed to this.

Social changes in Yugoslav society in the second half of the 1980s affected the changes in critical reception. In the previous period, the excellent reception of the unofficial works in Yugoslavia was explained by the horizon of expectations of readers in Croatia, ie. Yugoslavia, that was built on the Czech literary tradition of Karel Čapek and Jaroslav Hašek and the brilliant acceptance of specific "Czech humor". Towards the end of the 1980s, the analysis began focusing on good reception as a consequence of a similar historical experience in Czechoslovakia and Yugoslavia during the 20th century. Several critics have agreed with the thesis that in the works of Czech writers, the readers and theatre audience in Croatia could see the image of Yugoslav society. Croatian writers could not or did not want to write about similar situation in Yugoslavia.

There is no reception of the unofficial Czech literature in the Croatian educational system. This fact can be explained by the lack of affinity of the Croatian secondary school curriculum authors towards contemporary writers. By the beginning of the 2019/2020 school year, the chronological principle of teaching literature prevailed in all Croatian secondary schools. School curriculum included an extremely small number of works written after 1970, 
and most of the works included were written by Croatian authors. The proposed reform of the national curriculum, published in 2016, included Milan Kundera's novel and Václav Havel's play. However, the implementation of this proposal in the Croatian educational system has not occurred.

The topic of this research, the reception of the unofficial Czech literature in Croatia from 1968 to 1990 , the changes in the reception due to the changing social circumstances in Croatian society and the possible influence of the Czech unofficial literature on the works of Croatian writers, complete the knowledge of Croatian-Czech literary and cultural connections in the second half of the twentieth century.

Keywords: Czech literature, unofficial literature, samizdat literature, literature in exile, censorship, reception, Croatian culture, Croatia, Yugoslavia, 20th century 


\section{SADRŽAJ}

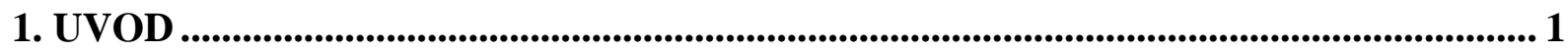

1. 1. Metodologija i plan istraživanja, cilj i hipoteze ....................................................... 1

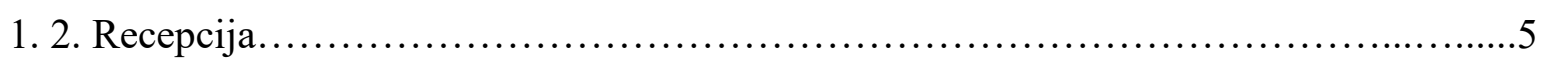

1. 2. 1. Pojam recepcije.................................................. 5

1. 2. 2. Prethodna istraživanja recepcije češke književnosti u Hrvatskoj ..................7

1. 2. 3. Zaključak ............................................................ 15

\section{DRUŠTVENO-POLITIČKE OKOLNOSTI RAZVOJA HRVATSKOGA I}

\section{ČEŠKOGA DRUŠTVA OD ŠEZDESETIH DO DEVEDESETIH GODINA 20.}

STOLJEĆA..........................................................................17

2. 1. Praško proljeće...........................................................18

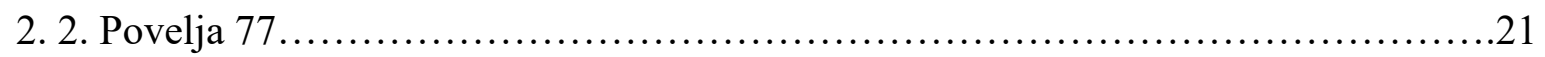

2. 3. Liberalizacija u osamdesetim godinama......................................23

2. 4. Reakcije hrvatskoga društva na vojnu intervenciju zemalja Varšavskoga ugovora...24

2. 5. Jugoslavenske paralele.................................................27

2. 6. Zaključak.......................................................... 33

3. RAZVOJ ČEŠKE KNJIŽEVNOSTI TIJEKOM NORMALIZACIJE..................35

3. 1. Egzilna češka književnost tijekom normalizacije..............................42

3. 2. Samizdatska češka književnost tijekom normalizacije............................45

3. 3. Oficijelna češka književnost u Hrvatskoj od 1968. do 1990........................47

3. 4. Hrvatska recepcija tzv. sive zone češke književnosti od 1968. do 1990...............53

3. 5. Zaključak...........................................................60

\section{NEOFICIJELNA ČEŠKA KNJIŽEVNOST U HRVATSKOJ}

OD 1968. DO 1990...................................................................62

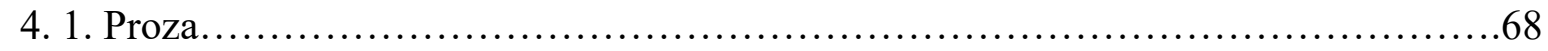

4. 1. 1. Milan Kundera.......................................................... 73

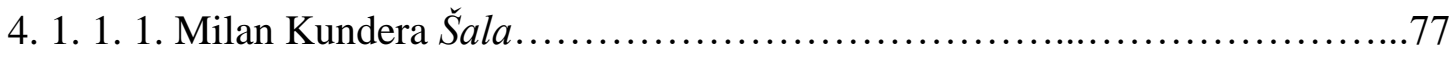

4. 1. 1. 2. Kritička recepcija ostalih izdanja Milana Kundere..........................79

4. 1. 2. Josef Škvorecký....................................................... 81 
4. 1. 3. Ostala prozna izdanja neoficijelne češke književnosti.........................85

4. 1. 4. Nefikcionalna proza.................................................... 86

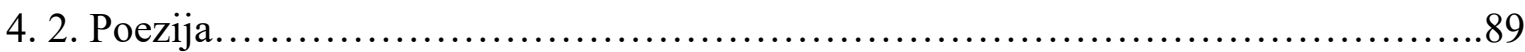

4. 2. 1. Poezija neoficijelnih pjesnika u časopisu Vidik $1970 \ldots \ldots \ldots \ldots \ldots \ldots \ldots \ldots . \ldots 9 . \ldots \ldots$

4. 2. 2. Nova generacija pjesnika u časopisu Rival $1990 \ldots \ldots \ldots \ldots \ldots \ldots \ldots \ldots \ldots . . \ldots . \ldots . \ldots 4$

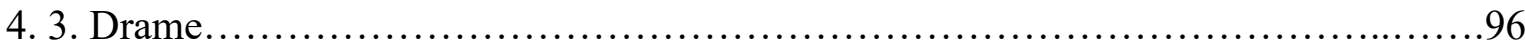

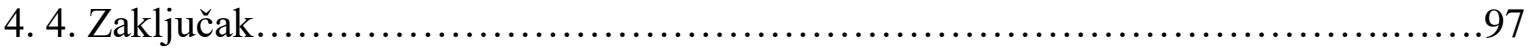

5. NEOFICIJELNA ČEŠKA KNJŽEVNOST U HRVATSKIM ČASOPISIMA.......100

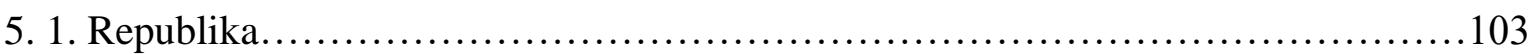

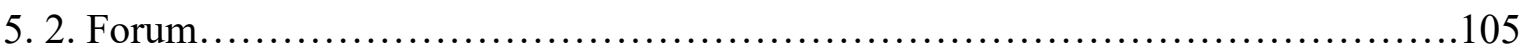

5. 3. Prolog i Novi prolog .................................................... 107

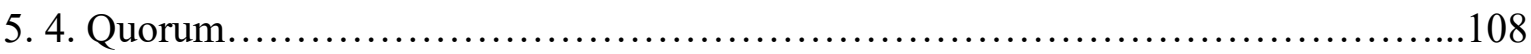

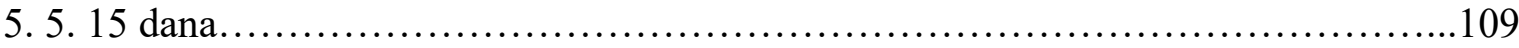

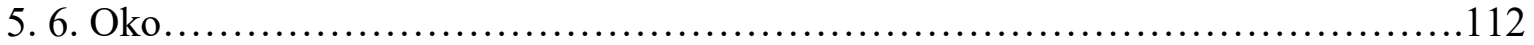

5. 7. Tragedija Srednje Europe Milana Kundere i njeni odjeci u hrvatskom tisku.........114

5. 8. Zaključak............................................................... 120

\section{RECEPCIJA NEOFICIJELNE ČEŠKE KNJIŽEVNOSTI U HRVATSKOJ} ZNANOSTI O KNJIŽEVNOSTI I ZNANSTVENOGA RADA NEOFICIJELNIH ZNANSTVENIKA......................................................................122

6. 1. Neoficijelna češka književnost u Povijesti svjetske književnosti (1975.)..............122

6. 2. Češka znanost o književnosti u Hrvatskoj od 1968. do 1990.......................124

6. 3. Zaključak............................................................... 127

7. KAZALIŠNA RECEPCIJA NEOFICIJELNIH DRAMATIČARA..................129

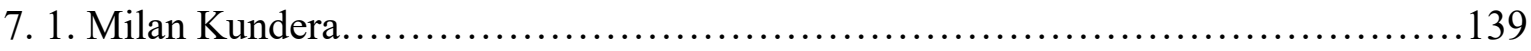

7. 1. 1. Milan Kundera Monada (HNK Split, 1971.)...............................140

7. 1. 2. Milan Kundera Ševa (Teatra u gostima, 1974.)..............................141

7. 1. 3. Milan Kundera Žak Fatalist i njegov gospodar (Teatar ITD, 1980.)............144

7. 1. 4. Milan Kundera Žak Fatalist i njegov gospodar (HNK Split, 1981.)............146

7. 1. 5. Milan Kundera Šala (Satiričko kazalište Jazavac, 1983.).......................147

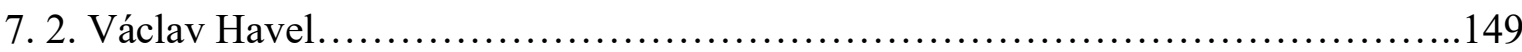

7. 2. 1. Václav Havel Audijencija i Izložba (Dramsko kazalište Gavella, 1980.)......157 
7. 2. 2. Václav Havel Očajno smiješno (Dramsko kazalište Gavella, 1989.)...........164

7. 2. 3. Václav Havel Asanacija (HNK Zagreb, 1990.)............................169

7. 3. Pavel Kohout.................................................................... 176

7. 3. 1. Václav Havel Protest i Pavel Kohout Atest (Teatar ITD, 1981.)...............178

7. 3. 2. Pavel Kohout Marija se bori s anđelima (Dramsko kazalište Gavella, 1985.).184

7. 4. Izvedbe drama ostalih neoficijelnih čeških dramatičara.......................... 188

7. 5. Kazališne smotre, festivali i gostovanja kazališnih kuća iz ostalih jugoslavenskih

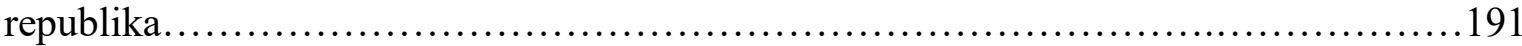

7. 6. Zaključak............................................................... 194

8. NEOFICIJELNA ČEŠKA KNJIŽEVNOST U BIJELOJ KNJIZI 1984. ............198

8. 1. Zaključak..........................................................201

\section{NEOFICIJELNA ČEŠKA KNJǏEVNOST I HRVATSKA KNJIŽEVNOST OD}

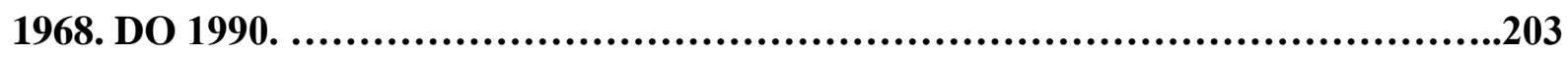

9. 1. Zaključak ........................................................... 211

10. ZAKLJUČAK......................................................................213

POPIS IZVORA I LITERATURE................................................219

BIBLIOGRAFIJA PRIJEVODA...............................................227

BIBLIOGRAFIJA TEKSTOVA U ČASOPISIMA I NOVINAMA...................233

POPIS KAZALIŠNIH PREDSTAVA.................................................254

POPIS DIJAGRAMA I TABLICA.............................................260

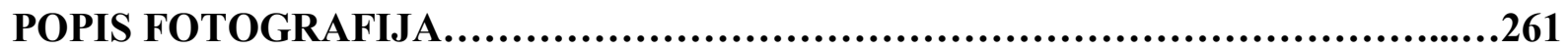

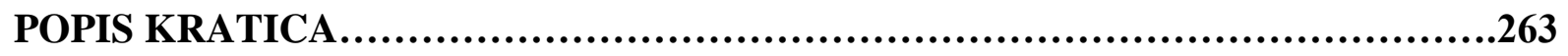

ŽIVOTOPIS DOKTORANDICE...............................................264 


\section{UVOD}

1. 1. Metodologija i plan istraživanja, cilj i hipoteze

Pod utjecajem društveno-političke situacije nakon vojne intervencije zemalja Varšavskoga ugovora na teritoriju Čehoslovačke u kolovozu 1968., a koja je bila reakcija političkih struktura zemalja istočnoga bloka na reformne promjene u češkome društvu, češka književnost doživljava specifičan razvoj u razdoblju nazvanome normalizacijom koje traje do pada komunizma u toj zemlji 1989. Pojam normalizacija primarno je označavao povratak češkoga društva u uobičajen, normalan način funkcioniranja nakon vojne intervencije, no, kako je vrijeme pokazalo, bio je to povratak na ustroj prije reformnih procesa koji su se razvili u društvu u šezdesetim godinama dvadesetoga stoljeća. Tema je ovoga rada recepcija neoficijelne češke književnosti, samizdatske i egzilne, među čitateljima u Hrvatskoj i u hrvatskim kazalištima u razdoblju od 1968. do sloma komunizma u nizu zemalja srednje i istočne Europe na prijelomu osamdesetih i devedesetih godina dvadesetoga stoljeća.

Istraživanjem čiji su rezultati obuhvaćeni ovim radom utvrđuje se frekventnost prijevoda češke neoficijelne književnosti dostupnih čitateljima u Hrvatskoj te uključenost drama dramatičara samizdatske i egzilne književne scene u repertoare hrvatskih kazališta. Rad, također, istražuje dolazi li tijekom analiziranoga razdoblja do promjena u recepciji neoficijelne češke književnosti i čime su eventualne promjene uvjetovane.

Hipoteze istraživanja su:

- djela neoficijelne češke književnosti u analiziranome su razdoblju dobro prihvaćena od strane čitatelja u Hrvatskoj

- čitateljima u Hrvatskoj dostupnija su djela književnika koji su stvarali u egzilu, no onih koji objavljuju u Čehoslovačkoj u samizdatu

- objavljujući djela neoficijelne češke književnosti, hrvatski nakladnici primarno osluškuju zahtjeve tržišta

- tijekom analiziranoga razdoblja, osobito prema kraju osamdesetih godina dvadesetoga stoljeća, dolazi do promjene u intenzitetu recepcije na području izdavaštva i kazališta te promjena u kritičkoj recepciji uvjetovanih novom konstelacijom društveno-političkih odnosa u Hrvatskoj.

Istraživanje nastoji utvrditi i što je omogućilo da u razdoblju u kojemu predstavnici neoficijelne češke književnosti, poput Milana Kundere, uživaju izuzetnu popularnost među 
čitateljima u Hrvatskoj i ostvaruju niz izdanja u izdavačkim kućama diljem Jugoslavije, koje su u državnome vlasništvu što službenome režimu otvara mogućnost uplitanja u uređivačku politiku nakladnika, isti autor nalazi svoje mjesto i na stranicama Bijele knjige, tj. doživljava kritiku službene politike.

Zbog specifičnih okolnosti koje su bile određene životom u zajedničkoj državi, postojanjem jedinstvenoga književnog tržišta i intenzitetom kulturne razmjene između republika koje su činile Jugoslaviju, čitatelji u Hrvatskoj bili su snažno upućeni i na izdanja neoficijelnih čeških autora objavljena u drugim jugoslavenskim republikama, u prvome redu na srpska i bosanskohercegovačka (i danas se, 2020. godine, izdanja sarajevskoga „Veselina Masleše“ i gornjomilanovačkih Dečjih novina nalaze na policama hrvatskih knjižnica, čitatelji ih posuđuju i čitaju). Povremeno se u tekstu disertacije spominju i prijevodi izdavačkih kuća drugih jugoslavenskih republika, poput slovenskih i makedonskih, no jezična je barijera, uglavnom, priječila da čitatelji iz Hrvatske budu recipijenti njihovih izdanja.

Bibliografija prijevoda koji su temelj analize izrađena je prema knjižničnim bazama podataka dviju knjižnica: Nacionalne i sveučilišne knjižnice u Zagrebu i Národní knihovna České Republiky iz Praga, a dopunjene su podacima egzilnih izdanja digitalne baze knjižnice egzilne i samizdatske češke književnosti Libri Prohibiti. Analizirana periodika i časopisi, poput Republike, 15 dana, Dubrovnika, Pitanja, Revije, Rivala, Vjesnika u srijedu, Vidika, Foruma, Gordogana, Quoruma, Oka, Poleta, Književne smotre, Prologa i Novog prologa, tjednika Danas i dnevnih novina Večernjega lista i Vjesnika, pohranjena je u knjižnici Filozofskoga fakulteta u Zagrebu, Nacionalnoj i sveučilišnoj knjižnici u Zagrebu i Knjižnicama grada Zagreba.

Polazišta su za istraživanje kazališne recepcije predstavnika neoficijelne scene knjige Branka Hećimovića Repertoar hrvatskih kazališta: 1840-1860-1980. Knj. 1, Repertoari kazališta, kazališnih družina i grupa, partizanskih kazališta, festivala, smotri i susreta te Repertoar hrvatskih kazališta, knjiga 3 - Repertoari 1981. - 1990. Knjige bilježe uprizorenja drama neoficijelnih dramatičara u nizu kazališnih kuća: Kazalištu Virovitica, Hrvatskom narodnom kazalištu u Splitu, Gradskom dramskom kazalištu Gavella, Teatru ITD, Teatru u gostima, Kazalištu Marina Držića u Dubrovniku, Satiričkom kazalištu Jazavac, Hrvatskom narodnom kazalištu u Zagrebu. Dio povijesti hrvatskoga kazališta su i gostovanja kazališnih kuća iz drugih jugoslavenskih republika na kazališnim festivalima i smotrama poput Gavellinih večeri, Dana satire Satiričkoga kazališta Jazavac, Splitskoga ljeta i Susreta profesionalnih kazališta Hrvatske u Slavonskome Brodu. U analizi je korišten arhivski 
materijal pohranjen u arhivu Odsjeka za povijest hrvatskoga kazališta Hrvatske akademije znanosti i umjetnosti.

U dijelovima rada u kojima se uspoređuju društveno-političke okolnosti razvoja češke i hrvatske književnosti tijekom sedamdesetih i osamdesetih godina 20. st. te u kojima se daje prikaz razvojnoga puta češke književnosti tijekom normalizacije korištene su povijesna metoda i metoda komparacije. Metodom klasifikacije prijevodi književnih tekstova neoficijelnih čeških književnika raspoređeni su na prozu, poeziju i dramu. Učestalost objavljivanja tih prijevoda na hrvatskome tržištu te zastupljenost dramskih tekstova predstavnika neoficijelne dramaturgije na pozornicama hrvatskih kazališta istraženi su metodom kronologije.

Istraživanje je započelo proučavanjem stručne literature navedene u popisu na kraju disertacije. Slijedilo je prikupljanje primarne građe u knjižničnim (Filozofski fakultet Sveučilišta u Zagrebu, Nacionalna i sveučilišna knjižnica u Zagrebu, Knjižnice grada Zagreba, mrežno Národní knihovna České Republiky) i arhivskim (arhiv Odsjeka za povijest hrvatskoga kazališta HAZU-a) fondovima. Nakon završetka te faze istraživanja pristupilo se obradi prikupljenje građe i usustavljivanju spoznaja koje su uključene u tekst disertacije podijeljen u deset poglavlja.

Na početku je priložen sažetak na hrvatskome i engleskome jeziku s ključnim riječima. Slijedi uvodno poglavlje koje, osim uvida u metodologiju, realizaciju plana provedbe istraživanja te pojašnjavanja njegova cilja i navođenja postavljenih hipoteza, donosi i razjašnjavanje pojma recepcije metodološkim postupcima definicije i eksplikacije. U završnome dijelu uvodnoga poglavlja nalazi se pregled dosadašnjih istraživanja recepcije češke književnosti u Hrvatskoj.

Slijedi poglavlje u kojemu su opisane društveno-političke okolnosti razvoja češke i hrvatske književnosti od šezdesetih do kraja osamdesetih godina 20. st., tj. društvena pozadina razdoblja u kojemu promatramo recepciju neoficijelne češke književnosti u Hrvatskoj. Naglasak je stavljen na uzajamne poticaje i utjecaje.

Treći se dio rada bavi razvojem češke književnosti nakon 1968. koji je obilježen snažnim valom cenzure nakon sloma praškoga proljeća, a čiji su mehanizmi u potpunosti ovladali tim poljem kulture početkom sedamdesetih godina. Prostor slobode dio čeških književnika osvaja objavljivanjem u samizdatu, a dio se njih odlučuje na stvaranje izvan granica matične države - u egzilu. Završni dio trećega poglavlja daje kratak pregled reakcija hrvatskoga tržišta i javnosti na oficijelnu češku književnost i tzv. sivu zonu češke književnosti istoga razdoblja. 
Središnji dio rada započinje četvrtim poglavljem podijeljenim u tri cjeline, a koji obrađuje prijevode djela predstavnika neoficijelne književne scene među hrvatskim čitateljima. Prvi dio četvrtoga poglavlja obuhvaća prozna izdanja Milana Kundere, Josefa Škvoreckog, Ivana Klíme, Jiříja Pelikana, Zdeněka Mlynářa, te pregled kraćih proznih tekstova objavljenih u tisku. Slijedi pregled prevedene poezije neoficijelnih autora uključujući objavljene zbirke pjesama te prijevode poezije raspršene u časopisima. Tema posljednjega dijela ovoga poglavlja prijevodi su dramskih tekstova.

Peto poglavlje problematizira recepciju neoficijelne književnosti u časopisima i književnoj periodici. Tijekom istraživanja obrađena su izdanja sljedećih časopisa koji su, dulje ili kraće vrijeme, izlazili od 1968. do 1990.: Republike, Poleta, Književne smotre, Foruma, Prologa, Novog prologa, Vidika, Dubrovnika, Revije, Rivala, Gordogana, Quoruma, 15 dana i Oka. Kako su na stranicama navedenih časopisa uočeni i prilozi nastali u okvirima neoficijelne češke kulturne scene, a koji ne pripadaju polju književnosti, završno poglavlje petoga dijela uključuje kratak pregled takvih sadržaja.

Recepcija neoficijelne češke književnosti u hrvatskoj znanosti o književnosti, u prvome redu povijesti književnosti, tema je šestoga poglavlja. Ovaj dio rada donosi i pregled prijevoda tekstova čeških znanstvenika kojima društvene promjene nakon 1968. priječe djelovanje na državnim ustanovama te koji, mahom, svoj znanstveni rad nastavljaju u inozemstvu. Većina prijevoda takvih tekstova u Hrvatskoj objavljena je u književnoj periodici.

Sedmi dio rada usredotočava se na uprizorenja dramskih tekstova neoficijelnih dramatičara na pozornicama kazališnih kuća diljem Hrvatske te na kazališna gostovanja glumačkih družina iz drugih jugoslavenskih republika, poput onih sarajevskoga Kamernoga teatra 55 i beogradskoga Ateljea 212 koji u različitim prigodama, uglavnom je riječ o književnim smotrama i festivalima, pred hrvatskom publikom izvode tekstove neoficijelnih dramatičara i, uglavnom, privlače njenu veliku pozornost.

Osma cjelina analizira prisutnost predstavnika neoficijelne češke književne scene u tekstu Bijele knjige iz 1984., a deveto se poglavlje bavi odjecima prevedenih i objavljenih tekstova čeških autora u hrvatskoj književnosti tijekom razdoblja koje je predmet analize ovoga rada, povlači motivske paralele te istražuje zajedničke poticaje.

Zaključno poglavlje usustavljuje rezultate istraživanja, a slijede ga popis kratica, bibliografija izdanja predstavnika neoficijelne češke književnosti, popis kazališnih predstava na repertoarima hrvatskih kazališta, u programima kazališnih smotra i festivala, popis korištenih izvora, literature, ilustracija te životopis doktorandice. 
Budući da su spoznaje o recepciji neoficijelne češke književnosti u Hrvatskoj tijekom sedamdesetih i osamdesetih godina 20. stoljeća oskudne, istraživanjem koje je rezultiralo tekstom ove disertacije došlo se do novih spoznaja o prijevodima djelâ te grane češke književnosti među čitateljima u Hrvatskoj i njihovoj recepciji na stranicama hrvatske periodike, dnevnih i tjednih novina i zastupljenosti dramskih tekstova na repertoarima hrvatskih kazališta. Osim toga, rezultati istraživanja doprinose boljem razumijevanju hrvatsko-čeških kulturnih i književnih veza u drugoj polovici dvadesetoga stoljeća.

\section{2. Recepcija}

\section{2. 1. Pojam recepcije}

Pojam recepcije (lat. receptio - primanje, dočekivanje) primarno je pripadao povijesti prava u kojoj je tijekom renesanse označavao prihvaćanje i primjenu rimskoga prava u Europi. Pojam, potom, prelazi u humanističke znanosti u kojima podrazumijeva različite oblike prihvaćanja antičkih uzora. ${ }^{1}$

U književnu teoriju pojam recepcije uvodi teorijom recepcije šezdesetih godina 20. st. na Sveučilištu u Konstanzu skupina znanstvenika čije je najzvučnije ime Hans Robert Jauss². Njome se, zapravo, usustavljuju spoznaje o prihvaćanju, djelovanju i utjecaju književnih tekstova čime se znanost o književnosti bavila od samih svojih početaka. Prema Jaussu recepcija djela mjesto je potvrđivanja njegove estetske vrijednosti. Za razliku od prijašnjih tendencija u proučavanju književnoga djela koje su u središte zanimanja stavljale autora, poput pozitivističkoga proučavanja književnosti, potom književni tekst kao jezičnu strukturu što je temeljna postavka strukturalizma, teorija recepcije fokus zanimanja premješta na čitatelja s kojim književno djelo u interakciji u potpunosti oblikuje svoje značenje, smisao i vrijednost. ${ }^{3} \mathrm{Na}$ taj način čitatelj, sudjelujući u oblikovanju estetske vrijednosti djela, posredno

\footnotetext{
${ }^{1}$ Teorija recepcije u nauci o književnosti, ur. Dušanka Maricki, Nolit, Beograd, 1978., str. 11.

2 Jauss, Hans Robert (1921. - 1997.), njemački romanist i književni teoretičar. Od 1966. profesor na Sveučilištu u Konstanzu. Uz Wolfganga Isera utemeljitelj je i glavni predstavnik tzv. teorije recepcije. www.enciklopedija.hr (natuknica Hans Robert Jauss, pristupljeno 3. 8. 2019.)

${ }^{3}$ Teorija recepcije u nauci o književnosti, ur. Dušanka Maricki, Nolit, Beograd, 1978., str. 10; ,,Historijski život književnoga dela ne može se zamisliti bez aktivnog učešća njegova adresata. “ H. R. Jauss Teorija recepcije u znanosti o književnosti, ur. Dušanka Maricki, Nolit, Beograd, 1978., str. 37; , Svako književno delo sadrži u sebi sliku svog čitaoca. Čitalac je, možemo reći, jedan od likova toga dela. "Harald Weinrich Teorija recepcije u znanosti o književnosti, ur. Dušanka Maricki, Nolit, Beograd, 1978., str. 84; ,, U trouglu autor-delo-publika
} 
utječe i na povijesni razvoj književnosti i određivanje njene društvene funkcije. ${ }^{4}$ Uloga čitatelja kao sutvorca djela dovela je do razlikovanja „stvarnoga“ čitatelja i tzv. imaginarnoga, intencionalnoga ili intendiranoga čitatelja kojega kao recipijenta svojih djela zamišlja autor. ${ }^{5}$

Uz čitatelja središnji je pojam cijele koncepcije teorije recepcije „horizont očekivanja“ koji se definira kao sustav predodžaba kojima čitatelj pristupa književnom djelu, a koji je izgrađen na temelju njegova prethodnog poznavanja književnosti i povijesti djelovanja teksta na naraštaje čitatelja. ${ }^{6}$ Rekonstrukciju horizonta očekivanja za neko djelo omogućuje sâmo djelo trima odnosima - prema književnim normama i poetici književne vrste kojoj pripada, prema poznatim djelima svoje književnopovijesne okoline te prema stvarnosti i praktičnoj funkciji jezika. ${ }^{7}$ Odgonetavanje zagonetke tzv. primarnoga horizonta jest pokušaj rekonstrukcije horizonta očekivanja za čitatelja iz prošlosti. Karl Robert Mandelkow ${ }^{8}$ i Felix Vodička ${ }^{9}$ smatraju da se pri pokušaju takve rekonstrukcije u obzir moraju uzeti tri čimbenika: očekivanje s obzirom na djelo, očekivanje s obzirom na autora i očekivanje s obzirom na epohu u kojoj je djelo nastalo. ${ }^{10}$ Horizont očekivanja djela doveo je do fenomena da se kao polazna točka u vrednovanju opusa nekoga autora utvrdi određeno djelo koje postaje mjerilo za sva njegova sljedeća djela. Rekonstrukcija horizonta očekivanja pred kojim je djelo u prošlosti stvarano i prihvaćeno omogućuje rekonstrukciju pitanja na koja je tekst dao odgovor i rekonstrukciju razumijevanja teksta od strane nekadašnjega, primarnoga čitatelja. Hans-Georg Gadamer ${ }^{11}$ smatra da rekonstruirano pitanje ne može stajati u okviru svoga prvobitnog horizonta jer je on već obuhvaćen horizontom naše suvremenosti. ${ }^{12}$

Treći je bitan pojam estetike recepcije „,konkretizacija“ koja je nužna kako bi se tekst razvio u književno djelo, a sastoji se od ,iskustv[a] usvajanja od strane njegovih primalaca“"13. Konkretizaciju Jauss shvaća u skladu s idejama estetičke teorije praškog strukturalizma kao

poslednja ne predstavlja samo pasivni deo, lanac pukih reakcija, već i energiju koja tvori istoriju. " H. R. Jauss Estetika recepcije, Nolit, Beograd, 1978., str. 57.

${ }^{4}$ Teorija recepcije u nauci o književnosti, ur. Dušanka Maricki, Nolit, Beograd, 1978., str. 14.

${ }^{5}$ Isto, str. 24.

${ }^{6}$ Biti, Vladimir Pojmovnik suvremene književne teorije, natuknica recepcija, Matica hrvatska, Zagreb, 1997., str. 466.

${ }^{7}$ Teorija recepcije u nauci o književnosti, ur. Dušanka Maricki, Nolit, Beograd, 1978., str. 18.

${ }^{8}$ Mandelkow, Karl Robert (1926. - 2008.), njemački germanist i povjesničar književnosti.

${ }^{9}$ Vodička, Felix (1909. - 1974.), češki teoretičar i povjesničar književnosti. Početkom normalizacije Vodička je morao napustiti mjesto ravnatelja Zavoda za češku književnost ČSAV-a. www.slovnikceskeliteratury.cz (natuknica Felix Vodička, pristupljeno 2. 9. 2019.)

${ }^{10}$ Teorija recepcije u nauci o književnosti, ur. Dušanka Maricki, Nolit, Beograd, 1978., str. 19., 120.

${ }^{11}$ Gadamer, Hans-Georg (1900. - 2002.), njemački filozof. Osnivač i glavni zastupnik filozofske hermeneutike. www.enciklopedija.hr (natuknica Hans-Georg Gadamer, pristupljeno 2. 9. 2019.)

${ }^{12}$ Jauss, Hans Robert Estetika recepcije, Nolit, Beograd, 1978., str. 57.

${ }^{13}$ Isto, str. 215. 
„uvek novi karakter koji celovita struktura dela može dobiti pod promenjivim društvenoistorijskim uslovima recepcije“"14.

Temelj za rekonstrukciju horizonta očekivanja prijašnjih razdoblja prema Jaussu trebaju biti dokumenti o empirijskim čitateljskim reakcijama. Jauss smatra da se odnos djela i publike može i treba motriti u sinkronijskoj i dijakronijskoj ravnini. U sinkronijskoj se ravnini motri susret djela i njegova prvobitnog čitatelja, njemu suvremenoga, a u dijakronijskoj ravnini riječ je o susretu djela iz prošlosti sa svim čitateljima kroz povijest, sve do današnjih. U ovoj je disertaciji predmet istraživanja odnos djela i publike na sinkronijskoj osi, odnosno recepcija neoficijelne češke književnosti u Hrvatskoj među njenim suvremenicima, tj. prvobitnim čitateljima, budući da recepcija neoficijelne češke književnosti u Jugoslaviji nije zakašnjela - izdavačke kuće u Jugoslaviji objavljuju tekstove neoficijelnih autora s veoma kratkim vremenskim odmakom u odnosu na premijerno izdanje naslova.

Prilog klasifikaciji recepcije dao je i njemački komparatist Manfred Schmeling ${ }^{15}$ koji razlikuje pasivnu, reproducirajuću i produktivnu recepciju. Prema Schmelingu, pasivna recepcija obuhvaća reakcije čitatelja na književna djela, odnosno kazališne publike na kazališnu predstavu. Obujam se te vrste recepcije može sagledati statističkim proučavanjem učestalosti objavljivanja, naklada, učestalosti uprizorenja i broja kazališnih repriza. Reproducirajućom recepcijom smatra se reakcija na umjetničko djelo profesionalaca poput književnih i kazališnih kritičara, dok je produktivna recepcija mjerljiva utjecajem književnoga djela na stvaranje drugoga književnika. ${ }^{16}$ Istraživanje recepcije neoficijelne češke književnosti u Hrvatskoj usredotočeno je na sve tri vrste recepcije prema Schmelingovoj klasifikaciji.

\section{2. 2. Prethodna istraživanja recepcije češke književnosti u Hrvatskoj}

Tijekom 19. st. hrvatsko-češke kulturne veze bilježe dva razdoblja intenzivna rasta. Prvo smještamo u vrijeme hrvatskoga narodnog preporoda ${ }^{17}$ u prvoj polovicu stoljeća iz kojeg datira prvi književnopovijesni zapis o češkoj književnosti dostupan hrvatskim čitateljima. Taj

\footnotetext{
${ }^{14}$ Jauss, Hans Robert Estetika recepcije, Nolit, Beograd, 1978., str. 215.

${ }^{15}$ Schmeling, Manfred (1943.), profesor opće i komparativne književnosti na Sveučilištu Saarland, Saarbrücken, Savezna Republika Njemačka. https://www.uni-saarland.de/lehrstuhl/soltegresser/lehrstuhl/mitarbeiterinnen/manfredschmeling/manfredschmeling.html (pristupljeno 2. 8. 2019.)

${ }^{16}$ Beker, Miroslav Uvod u komparativnu književnost, Školska knjiga, Zagreb, 1996.

${ }^{17}$ Karpatský, Dušan Prijevodi hrvatske književnosti u Čeha, Forum, god. 23(1984), knj. 47, br. 1-2, str. 412-415
} 
je tekst objavljen u prvome broju prvoga hrvatskog književnog časopisa Kola, pokrenutoga 1843. Riječ je o kratkome pregledu povijesti češke književnosti Ćeska literatura autora Ismaila Ivanovića. ${ }^{18}$ Prijevodi tekstova češke, ali i ostalih slavenskih književnosti, objavljivani u novinama i časopisima poput Kola i Danice ilirske, u ovome su razdoblju u prvome redu imali zadaću izgradnje „nacionalne svijesti kao 'ilirske ${ }^{1 “},{ }^{19}$ tj. ,općeslavenske“620. Drugi se val intenziviranja hrvatsko-čeških kulturnih veza u 19. st. primjećuje krajem stoljeća zahvaljujući praškoj skupini hrvatskih književnika koja se oblikuje u Pragu nakon protjerivanja dijela studenta sa zagrebačkoga Sveučilišta 1895. koje je bilo posljedica javnoga demonstriranja otpora mađarizaciji spaljivanjem mađarske zastave prilikom dolaska cara Franje Josipa u Zagreb.

Autori koji istražuju hrvatsko-češke kulturne veze u 20. stoljeću, a svoje tekstove objavljuju na prijelomu šezdesetih i sedamdesetih godina primjećuju da je u razdoblju nakon Drugoga svjetskog rata kvantitativno očita prevaga prijevoda hrvatske književnosti u Čehoslovačkoj. Dušan Karpatský21 u tekstu iz 1968. objavljenome u Republici bilježi da zastupljenost čeških, a osobito slovačkih književnika na hrvatskome izdavačkom tržištu nije ni izbliza tako snažna kao prisutnost prijevoda književnika jugoslavenskih književnosti u Čehoslovačkoj. ${ }^{22}$

Kratak pregled recepcije od pedesetih do sedamdesetih godina 20. st. u istome časopisu 1970. pruža Krsto Špoljar ${ }^{23}$ u tekstu Roman iz češkog ,mrtvog doma“24. Špoljar zaključuje da je prethodna dva desetljeća recepcija suvremenih čeških autora u Hrvatskoj slaba, da se iscrpljuje u povremenim „kritičko-informativnim zabilješkama“25 te prijevodima objavljivanima u časopisima. Recepcijom češke književnosti socrealizma među hrvatskim

\footnotetext{
${ }^{18}$ Bacalja, Robert Slavenske književnosti u dalmatinskim periodicima u razdoblju hrvatske moderne, Fluminensia, god. 22(2010), br. 2, str. 22.

${ }^{19}$ Hrvatska književnost prema evropskim književnostima: od narodnog preporoda k našim danima, ur. Aleksandar Flaker i Krunoslav Pranjić, Liber, Zagreb, 1970., str. 259.

${ }^{20}$ Isto, str. 259.

${ }^{21}$ Karpatský, Dušan (1935. - 2017.), češki prevoditelj i književni povjesničar. Prevodio s hrvatskoga na češki, i obrnuto. Dopisni član HAZU-a od 1990. www.enciklopedija.hr (natuknica Dušan Karpatský, pristupljeno 2. 8. 2019.)

${ }^{22}$ Karpatský, Dušan Jugoslavensko-čehoslovački mozaik, Republika, br. 5, 1968.

${ }^{23}$ Špoljar, Krsto (1930. - 1977.), hrvatski književnik. Urednik časopisa Književna tribina i Republika, urednik izdavačke kuće Zora i član uredničkoga odbora edicije Pet stoljeća hrvatske književnosti. Prve pjesme objavljuje u časopisu Krugovi početkom 1950-ih pa ga književni povjesničari najčešće svrstavaju u književnu generaciju krugovaša. www.enciklopedija.hr (natuknica Krsto Špoljar, pristupljeno 2. 8. 2019.)

${ }^{24}$ Špoljar, Krsto Roman iz češkog „mrtvog doma“, Republika, br. 26, 6(1970), str. 286.

25 Isto, str. 286.
} 
čitateljima bavi se Katica Ivanković ${ }^{26}$ u tekstu Socrealizam u tragovima, Uz hrvatsku recepciju češke književnosti u 50-ima. ${ }^{27}$ Ivanković u tome tekstu navodi da su se u prosjeku prevodile tri češke knjige godišnje i da pri tome korpus prevedenih djela nije bio ograničen isključivo na socrealističku poetiku, već je uključivao i književnike iz 19. st. te klasike prve polovice 20. st. Na vrhu prevoditeljske hijerarhije još od tridesetih godina stajalo je ime kroatista i bohemista Ljudevita Jonkea. U najpoznatijem književnom časopisu toga desetljeća, Krugovima, recepcija češke književnosti nije bila zamjetna budući da je časopis programski uglavnom bio usmjeren zapadnim književnostima, u prvome redu angloameričkim. ${ }^{28}$

Kao pozitivan prilog recepciji češke i slovačke književnosti u Hrvatskoj u šezdesetima Krsto Špoljar navodi poseban tematski broj Republike iz prosinca 1968., nastao kao izravna reakcija na vojnu intervenciju zemalja Varšavskoga ugovora u kolovozu iste godine, no tom izdanju Republike Špoljar prigovara nepostojanje sustavnijega uvida u književnost dvaju naroda. U specifičnim i turbulentnim društveno-političkim okolnostima kraja šezdesetih Špoljar vidi uzrok situacije u kojoj su nam ,[i]mena autora srednje i mlađe generacije poznatija (...) kao potpisnici raznoraznih proglasa i autori književno-političkih polemika nego kao stvaraoci“629.

Tezu o nedostatnom prevođenju čeških i slovačkih književnika u Jugoslaviji potvrđuje i četiri godine kasnije Predrag Jirsak ${ }^{30}$ u tekstu o češkoj književnosti šezdesetih godina 20. st. Prostor raspoznavanja (O antiiluzivnosti moderne češke proze $)^{31}$ u kojem daje i kratak uvid u recepciju češke književnosti među hrvatskim čitateljima u razdoblju koje je neposredno prethodilo normalizaciji. Jirsak navodi da hrvatska sredina i čitateljstvo „o predmetu ima tek slučajnu i nesustavnu informaciju, često iz druge ruke i ponajčešće u posve izvanliterarnom kontekstu“ ${ }^{\text {‘32 }}$ i da je „,domaćem čitatelju (...) dostupan tek poneki značajniji tekst ${ }^{\text {‘33 }}$. U

\footnotetext{
${ }^{26}$ Ivanković, Katica (1961.), hrvatska bohemistkinja, sveučilišna profesorica češke književnosti na Katedri za češki jezik i književnost Filozofskoga fakulteta u Zagrebu.

${ }^{27}$ Ivanković, Katica Socrealizam u tragovima. Uz hrvatsku recepciju češke književnosti u 50-ima, Književna smotra: časopis za svjetsku književnost, XLV/2013, 167 (1), str. 43-52.

${ }^{28}$ Isto, str. 43-52.

${ }^{29}$ Špoljar, Krsto Roman iz češkog mrtvog doma, Republika, br. 26, 6(1970), str. 286.

${ }^{30}$ Jirsak, Predrag (1941. - 2011.), hrvatski književnik, povjesničar književnosti, dugogodišnji nastavnik češke književnosti na Katedri za bohemistiku Filozofskoga fakulteta u Zagrebu, prevoditelj s engleskog i češkog jezika. www.enciklopedija.hr (natuknica Predrag Jirsak, pristupljeno 2. 8. 2019.)

${ }^{31}$ Predrag Jirsak Prostor raspoznavanja (O antiiluzivnosti moderne češke proze), Književna smotra, VI(1974), br. 18, str. 89-96.

${ }^{32}$ Isto, str. 89.

${ }^{33}$ Isto, str. 89.
} 
osamdesetima u tekstu o beogradskome prijevodu poezije nobelovca Jaroslava Seiferta o kvantitativnoj podbačaju prijevoda češke poezije u Jugoslaviji piše Katica Ivanković. ${ }^{34}$ Takve ocjene književnih povjesničara potvrđuju zagrebački dnevni listovi koji tijekom 1980-ih donose niz statističkih podataka o Čehoslovačkoj kao važnom inozemnom tržištu jugoslavenskim autorima. ${ }^{35}$ Vjerojatno su navedeni podaci razlog što se tekstovi koji problematiziraju hrvatsko-češke književne veze, a objavljivani su u posljednjem desetljeću 20. st., uglavnom bave recepcijom hrvatske književnosti u Češkoj, odnosno Čehoslovačkoj. To je tema niza tekstova u zborniku Krležini dani objavljenome u Osijeku 1997. ${ }^{36}$ Godinu dana kasnije u knjizi Miroslava Kvapila ${ }^{37}$ Češko-hrvatske književne veze predmet je zanimanja recepcija hrvatske književnosti u Češkoj u razdoblju od nastanka Hankinih i Lindinih rukopisa početkom 19 . st. do sredine 20. st.

Povjesničari književnosti pojačanu recepciji češke književnosti u Hrvatskoj u drugoj polovici 20. st. primjećuju krajem šezdesetih i krajem osamdesetih godina. Zanimanje hrvatskih čitatelja za češku književnost na prijelomu šezdesetih i sedamdesetih godina povezuje se sa zbivanjima u kolovozu 1968. s kojima je jugoslavenska javnost bila izuzetno dobro upoznata. ${ }^{38}$ Isti proces ponavlja se dvadesetak godina kasnije, krajem osamdesetih, a

\footnotetext{
${ }^{34}$ Ivanković, Katica Sve Seifertove promjene, Quorum, br. 2, 1985., str. 140-143.

${ }^{35}$ Konkretne brojke kojima se potvrđuju navedene teze objavljene su u dnevnim listovima Vjesnik i Večernji list 1985. (Pasini, Sineva Šutljivi dijalog knjigom, Vjesnik, br. 13468, 9. 3. 1985., str. 12; Tko nas čita, Večernji list, br. 7996, 2. 9. 1985., str. 9). U Vjesnikovu tekstu autor navodi da je na češki i slovački jezik od 1950. preveden 481 naslov autora s područja Jugoslavije, a po brojnosti prevedenih književnih djela Čehoslovačku je slijedio Sovjetski Savez. Istu tezu o Čehoslovačkoj kao prvoj zemlji na svijetu po broju prevedenih i objavljenih naslova iz književnosti jugoslavenskih naroda navodi i Ivan Dorovský pišući o recepciji hrvatske dramske književnosti u Češkoj i Slovačkoj u razdoblju od 1945. do 1990. (Krležini dani u Osijeku 1997., zbornik, knjiga 1., prir. Branko Hećimović, Zavod za povijest hrvatske književnosti, kazališta i glazbe HAZU, Zagreb - Osijek, 1999., str. 268). Slični su podaci navedeni i na izložbi Jugoslavenska književnost u svijetu 1968. - 1980. održanoj u sklopu 25. međunarodnoga sajma knjiga u Beogradu 1980. koji govore da po broju prijevoda prednjači Sovjetski Savez sa 197 naslova, a na drugom je mjestu Čehoslovačka sa 155 prevedenih i objavljenih djela (Stojanović, M. Koliko nas prevode?, Večernji list, br. 6518, 28. 10. 1980., str. 11). Tekstove o recepciji drama hrvatskih dramatičara u kazalištima u Čehoslovačkoj objavljuje i Vjesnik u srijedu: Puljizević, Jozo U slavnim kolima tradicije, Vjesnik u srijedu, br. 1118, 10. 10. 1973., str. 31; Puljizević, Jozo Pometove intrige izazvale Prag, Vjesnik u srijedu, br. 1092, 11. 4. 1973.

${ }^{36}$ Navedeni Zbornik sadrži sljedeće tekstove: Ivan Dorovski Recepcija hrvatske dramske književnosti u Češkoj i Slovačkoj 1945. - 1990., Borislav Mrkšić Češko-hrvatski kazališni dodiri u doba moderne, Aloisie Gašparević Gavellin doprinos u širenju južnoslavenske dramatike u području Čehoslovačke, Aloisie Zmekšalová Gavellino kazališno djelovanje u Češkoj i Slovačkoj, Radoslava Brabcová Krležin dramski opus u Češkoj, Nikša Stančić Ideja o ,slavenskoj uzajamnosti “ Jána Kollara i njezina hrvatska recepcija.

${ }^{37}$ Kvapil, Miroslav (1930.), češki književni povjesničar, dugogodišnji profesor slavenskih književnosti na Filozofskom fakultetu Karolova sveučilišta u Pragu. Jedno mu je od glavnih znanstvenih interesa kulturne i književne veze slavenskih književnosti, osobito češke i hrvatske. https://leksikon.muzej-marindrzic.eu/kvapil-

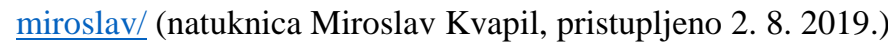

${ }^{38}$ Senker, Boris Miles gloriosus s perom u ruci, Gordogan, br. 5-6, siječanj-travanj 1980., str. 339-343.
} 
tada ga Katica Ivanković povezuje uz razvoj zanimanja za češku književnost u svjetskim okvirima, izuzetnu kvalitetu tekstova te specifičan razvoj u više smjerova uvjetovan društveno-političkim okolnostima nakon sloma praškoga proljeća. ${ }^{39}$ Ista autorica primjećuje da ta generacija čeških pisaca, čija su djela vrhunac zanimanja javnosti u Hrvatskoj i drugim jugoslavenskim republikama doživjela tijekom osamdesetih godina 20. st., snažnu ponovljenu recepciju ostvaruje i u prvim desetljećima 21. st. Naime, uz relativno malen broj izdanja slabije poznatih čeških autora novije generacije, veliki dio izdavačkoga kolača koji se odnosi na češku književnost u izdavačkim planovima hrvatskih izdavača posljednjih dvadesetak godina čine dobro poznata imena poput Milana Kundere, Bohumila Hrabala, Ludvíka Vaculíka, Jiř́ja Šotole i Josefa Škvoreckog. ${ }^{40}$

Sredinom osamdesetih godina 20. st. kvantitetom i kvalitetom tekstova koji u središte svoga zanimanja stavljaju likove i djela disidenata zemalja srednje i istočne Europe, pa tako i onih čeških, ističe se zagrebački tjednik Danas. ${ }^{41}$ I u tim se tekstovima korijeni uspjeha češke literature među čitateljima pripisuju kvaliteti tekstova, no i političkim okolnostima u kojima ona nastaje. Novinar političkoga tjednika Danas Vladimir Tomić navodi niz primjera česte istočnoeuropske motivike s naglašenim stereotipima o tome dijelu svijetu, toliko česte da govori o tzv. „,istočnome sindromu“ i u djelima književnika koji ne pripadaju nekoj od srednjoeuropskih ili istočnoeuropskih nacionalnih književnosti, a koji nerijetko razvijaju i „karikaturalni antikomunizam“. ${ }^{42}$ Kada je riječ o disidentskoj literaturi, zaključuje da se „,[u]spjeh disidentske literature na Zapadu ne može (...) jednostavno objasniti samo ideološkim motivima njenih promotora; bez obzira na motive izdavača, djela Milana Kundere, Czeslawa Milosza, Tadeusza Konwickog ili Györgyja Konráda danas su snažni 'istočni val' koji kritika svrstava u vrh suvremene svjetske literature ${ }^{643}$. Kada je riječ o samome Kunderi i njegovu položaju u francuskome društvu, Tomić naglašava da „nije čudo da se Francuzi ponose 'svojim Kunderom' jer boljeg pisca teško da trenutačno sami imaju.“

\footnotetext{
${ }^{39}$ Ivanković, Katica Mladi češki narkomani, Quorum, br. 3, god. IV, 1988., str. 329-333.

${ }^{40}$ Ivanković, Katica Stereotypy o Češich a české kultuře a recepce české literatury 20. století v Chorvatsku, u: Hodnoty a hranice, Svět v české literatuře, česká literatura ve světě, Otázky českého kánonu. Sborník př̀spěvků z III. kongresu světové literárněvědné bohemistiky, ur. Stanislava Fedrová - Ústav pro českou literaturu AV ČR, Prag, 2006., str. 162.

${ }^{41} \mathrm{O}$ tradiciji i kulturi knjige u Čehoslovačkoj u kratkome osvrtu 1985. piše Đorđe Milošević koji Čehoslovačku oslikava kao zemlju ,u kojoj se svake godine štampa više od 6500 naslova knjiga, u nakladi od oko 80 milijuna, u kojoj se pred knjižarama čeka u redu da bi se kupila najnovija izdanja, u kojoj ljudi čitaju knjige u tramvajima, u metrou i autobusima... “ Milošević, Đorđe Prijelomne šezdesete, Danas, 23. 4. 1985., str. 63.

42 Tomić, Vladimir Istočni val u zapadnim knjižarama, Danas, 2. 4. 1984., str. 61-62.

${ }^{43}$ Isto, str. 61.
} 
U tekstovima istoga tematskog kruga toga zagrebačkog tjednika Predrag Matvejevićc ${ }^{44}$ izlaže sljedeću misao:

„Jugoslavija je na neki način druga domovina tim piscima: jedina slavenska zemlja u kojoj se oni slobodno objavljuju (premda ne uvijek bez teškoća) ${ }^{45}$ gdje se čitaju i prate, ponekad više nego domaći pisci. Sama ta činjenica mnogo je važnija od rezerve koju sadrže pitanja: jesmo li suglasni s 'porukama' u ovom ili onom djelu i 'trebaju li nam' djela te vrste. Takva pitanja postavljaju oni koji još uvijek sude o književnosti - sude književnosti - jedino prema njezinim (političkim) 'porukama' i (društvenokorisnim) 'potrebama', ne shvaćajući pravo značenje razlike koju je Jugoslavija odabrala nakon raskida 1948.“46

Dio toga novinskog teksta Matvejević ponavlja godinu dana kasnije u svom pogovoru romana Mirakl (Mirákl) Josefa Škvoreckog u izdanju zagrebačkoga Grafičkog zavoda Hrvatske. $^{47}$

U razdoblju neposredno nakon sloma praškoga proljeća najistaknutija imena disidentske scene sljedećih dvadesetak godina još uvijek su relativno nepoznata hrvatskoj javnosti. Pišući 1969. o javnoj polemici Milana Kundere i Václava Havela, Predrag Jirsak ih naziva „nepoznatima našoj kulturnoj sredini““48. Navodi da je ime Václava Havela ipak poznatije jer ,dramska djela nešto lakše i brže prelaze jezične barijere, države i geografske granice $^{\text {‘49 }}$. No, u godinama koje su slijedile, to se stubokom promijenilo. Kundera i Havel postaju književnici o kojima nalazimo najveći broj zapisa koji se bavi recepcijom neoficijelne češke književnosti u Hrvatskoj. Napisi o Havelovu dramskome radu i građanskoj biografiji u dnevnome se tisku osobito intenziviraju nakon njegova stupanja na mjesto predsjednika Čehoslovačke u prosincu 1989.

\footnotetext{
${ }^{44}$ Matvejević, Predrag (1932. - 2017.), hrvatski publicist, književni teoretičar i esejist. Bio je profesor na više svjetskih sveučilišta i predsjednik Hrvatskoga centra PEN-a od 1980. do 1989. Svojim se znanstvenim i publicističkim radom zauzimao za odbacivanje ideološkog dogmatizma i slobodu stvaranja i izražavanja. www.enciklopedija.hr (natuknica Predrag Matvejević, pristupljeno 2. 8. 2019.)

${ }^{45}$ Početkom 1980-ih u zemljama europskoga istočnog bloka izvedbe drama Václava Havela Audijencije (Audience), Izložbe (Vernisáž) i Protesta (Protest) zabilježene su na Maloj sceni Suvremenoga kazališta u Varšavi. Šömen, Branko Češki sanjar: Václav Havel od disidenta do prezidenta, Profil, Zagreb, 2012., str. 128. Također, do pada komunizma prikazivane su i u kazalištima u Lublinu i Krakovu. Državnik i dramatičar Václav Havel, HAZU, Zagreb, 2000.

${ }^{46}$ Matvejević, Predrag Književnost i emigracija (Sivocrni humor), Danas, 4. 11. 1986., str. 36-38.

${ }^{47}$ Matvejević, Predrag Srednja Evropa, emigracija, književnost (pogovor romanu Mirakl Josefa Škvoreckog), Grafički zavod Hrvatske, Zagreb, 1987., str. 511-517.

${ }^{48}$ Jirsak, Predrag Češki usud, Književna smotra, br. 1, 1969.

${ }^{49}$ Isto.
} 
Sa sve većim brojem izdanja prozâ Milana Kundere sve je više i objavljenih tekstova o recepciji njegovih djela u Hrvatskoj koji su, mahom, utkani u književne kritike njegovih romana. Tako, primjerice, u kritici romana Život je drugdje (Život je jinde) Boris Senker ${ }^{50}$ razloge autorove dobre prihvaćenosti među hrvatskim čitateljima i objavljivanja u javnosti iznimno popularnoj i komercijalno uspješnoj Biblioteci Hit zagrebačke izdavačke kuće Znanje vezuje uz šezdesetosmaška zbivanja u Čehoslovačkoj i razvoj događaja nakon njih koji je jugoslavenska javnost pažljivo pratila. ${ }^{51}$ Međutim, prema izjavama Zlatka Crnkovića, urednika Kunderinih izdanja u zagrebačkoj Biblioteci Hit, hrvatski čitatelji nisu olako i na prvu prihvatili njegove proze. Prvo zagrebačko izdanje Šale (Žert) 1969., romana hrvatskim čitateljima tada slabo poznatoga češkog pisca, nije ostvarilo značajniju recepciju niti kod čitatelja, niti kod kritike. Naklada toga romana od 4000 primjeraka, što je za kraj šezdesetih prilično skromna brojka, prodavala se sljedećih pet godina. Pravi Kunderin prodor na jugoslavensko izdavačko tržište korespondira s njegovim međunarodnim uspjehom u drugoj polovici sedamdesetih. To se, posljedično, odražava i na naklade izdanja njegovih romana pa je sljedeće jugoslavensko izdanje $\breve{S}$ ale objavljeno u 20000 primjeraka koji su prodani u izuzetno kratkom roku. ${ }^{52}$ Kronološki pregled jugoslavenskih izdanja Kunderinih romana i kazališnih adaptacija u jugoslavenskim kazalištima pruža i Goran Bujićs ${ }^{53}$ u uvodnome dijelu kritike Oproštajnoga valcera (Valčík na rozloučenou) objavljene 1982. povodom beogradskoga izdanja toga romana. ${ }^{54}$

Uporišnom točkom recepcije češke književnosti, pa i filmske umjetnosti, među hrvatskim recipijentima u drugoj polovici 20. stoljeća Katica Ivanković smatra sintagmu „češkoga humora“, uvriježenu kada se o češkoj književnosti i filmu govori u hrvatskome javnom prostoru. Kamenom temeljcem takve češke humoristične tradicije, s odličnom percepcijom čitatelja u Hrvatskoj, smatra Doživljaje dobroga vojaka Švejka za svjetskog rata Jaroslava Hašeka. Ukorjenjivanju stereotipa o specifičnome češkom humoru svoj je obol dala i generacija osamdesetih godina, u kojoj se ističe ime Milana Kundere, iako njihova djela nisu primarno doživljavana kao humoristična. ${ }^{55}$

\footnotetext{
${ }^{50}$ Senker, Boris (1947.), hrvatski teatrolog, dramatičar, kazališni kritičar, leksikograf i prevoditelj, redoviti član HAZU-a od 2012. www.enciklopedija.hr (natuknica Boris Senker, pristupljeno 2. 9. 2019.)

${ }^{51}$ Senker, Boris Miles Gloriosus s perom u ruci, Gordogan, br. 5-6, god. 2, 1980., str. 339-343.

${ }^{52}$ Crnković, Zlatko Pisac za sva vremena, u: Crnković, Zlatko Knjigositnice, Otokar Keršovani d. o. o., Rijeka, 2003. str. 46-47.

${ }^{53}$ Bujić, Goran (1955. - 2011.), hrvatski pjesnik, kritičar, esejist i novinar.

${ }^{54}$ Bujić, Goran Milan Kundera Oproštajni valcer, Revija, br. 3, 1982., str. 97-101.

${ }^{55}$ Ivanković, Katica Stereotypy o Češich a české kultuře a recepce české literatury 20. století
} 
Činjenice postojanja zajedničkoga izdavačkog tržišta, snažne isprepletenosti i visoke razine suradnje kulturnih radnika te nepostojanja jezične barijere uvjetuju posljedicu da je pri analizama recepcije neoficijelnih autora u jednoj jugoslavenskoj republici nemoguće isključiti izdanja iz onih ostalih. Kao što tekst ove disertacije uključuje pojedina izdanja neoficijelnih autora u izdavačkim kućama drugih republika bivše Jugoslavije, o recepciji neoficijelnih čeških autora u hrvatskoj sredini možemo puno saznati iz radova znanstvenika drugih jugoslavenskih republika. Tako, primjerice, prijevode čeških književnika na hrvatski jezik u svoje analize uključuje srpska slavistica Aleksandra Korda-Petrović ${ }^{56}$ u svojim tekstovima Fenomen prihvaćenosti čeških disidentskih autora u srpskoj sredini ${ }^{57}$ i Srbské preklady české poezie 20. stoleti $^{58}$. Korda-Petrović u prvome tekstu primjećuje da su najsnažniju recepciju među srpskim čitateljima tijekom osamdesetih godina imale proze Milana Kundere i Josefa Škvoreckog te dramski tekstovi Václava Havela. Dok u prijevodima i objavljivanju Kunderinih romana prednjače beogradske i sarajevske izdavačke kuće, romane Josefa Škvoreckog srpski čitatelji upoznaju uglavnom iz zagrebačkih, tj. hrvatskih prijevoda. Povijest srpskoga kazališta bilježi i nekoliko predstava neoficijelnih dramatičara srpskih kazališnih kuća priređenih prema prijevodima hrvatskih prevoditelja, poput prijevoda Kunderine Šale Nikole Kršića u Beogradskom dramskom pozorištu 1976., prijevoda Havelova i Kohoutova Protesta i Atesta Ivana Kušana u beogradskome Narodnom pozorištu 1984. te prijevoda Predraga Jirsaka Žaka Fatalista i njegova gospodara u Beogradskom dramskom pozorištu 1985. U pregledu kazališne recepcije Korda-Petrović dvaput bilježi ime hrvatskoga redatelja Želimira Oreškovića kao redatelja predstava neoficijelnih dramatičara. U Srpskome narodnom pozorištu u Novome Sadu Orešković je 1970. redatelj i autor dramatizacije, uz Petra Marjanovića, predstave Simpozijum ili o ljubavi prema pripovijetki Simpozijum iz zbirke Smiješne ljubavi Milana Kundere, a javlja se i kao redatelj jednočinki Protest i Atest Václava Havela i Pavela Kohouta u Beogradu 1984. Razloge odlične recepcije dijela neoficijelne češke književne scene među srpskim čitateljima, a Korda-Petrović na nekoliko mjesta u svojim tekstovima područje analize zbog specifičnih okolnosti proširuje na cijeli kulturni krug bivše države ili barem zagrebačko-sarajevsko-beogradski trokut u kojemu

v Chorvatsku, u: Hodnoty a hranice. Svět v české literatuře, česká literatura ve světě. Otázky českého kánonu. Sborník př́spěvků z III. kongresu světové literárněvědné bohemistiky, ur. Stanislava Fedrová, Ústav pro českou literaturu AV ČR, Prag, 2006. str. 157.

${ }^{56}$ Korda-Petrović, Aleksandra (1965.), srpska bohemistkinja i prevoditeljica, profesorica na Katedri za bohemistiku Filološkoga fakulteta u Beogradu.

${ }^{57}$ Korda-Petrović, Aleksandra Fenomen prihvaćenosti čeških disidentskih autora u srpskoj sredini, Zbornik Matice srpske za slavistiku, Matica srpska, Odeljenje za književnost i jezik, Novi Sad, 2008., str. $227-239$. ${ }^{58}$ Česká literatura na konci tisíciletí II., Ústav pro českou literaturu AV ČR, Prag, 2001., str. 685-692. 
su kolali prijevodi, autorica prepoznaje i u društveno-političkim okolnostima, no i u umjetničkoj kvaliteti tekstova. Potonje potvrđuje odlična recepcija nekih bivših čeških disidenata u Srbiji u razdoblju kada više nisu bili zabranjeni u matičnoj zemlji. Autoričini tekstovi navode i teze brojnih srpskih analitičara koji će korespondirati s onim što su, pokazat će tekst ovoga rada, tvrdili i hrvatski im sustručnjaci - naime, da je slika čehoslovačkoga društva u prozama i dramama čeških disidenata bila slika jugoslavenskoga društva o kojemu književnici s područja Jugoslavije nisu mogli ili nisu htjeli pisati, i da je upravo to bilo izuzetno privlačno za čitatelje i kazališnu publiku diljem Jugoslavije. Korda-Petrović zaključuje da je kritika socijalističkoga društva koja je dolazila u tekstovima Kundere, Škvoreckoga, Kohouta, Havela i ostalih, javnosti manje poznatih, autora, a koja je slobodno nalazila put do publike u Jugoslaviji, službenome jugoslavenskom režimu bila dokaz nepostojanja cenzure i slobode umjetničkoga izražavanja. ${ }^{59}$

\section{2. 3. Zaključak}

Predmet istraživanja ovoga rada jest recepcija neoficijelne češke književnosti na sinkronijskoj osi, odnosno među svojim primarnim čitateljima, u vrijeme kada književni tekstovi nastaju. Neoficijelna češka književnost u Hrvatskoj recepciju ostvaruje u sva tri pojavna oblika prema klasifikaciji Manfreda Schmelinga - razvija se i pasivna, i reproducirajuća, i produktivna recepcija.

Tekstovi koji se u cijelosti bave ili se jednim svojim dijelom dotiču recepcije češke književnosti u Hrvatskoj mahom su raspršeni po časopisima. Sustavnija istraživanja recepcije češke književnosti među hrvatskom čitateljskom publikom, osobito neoficijelne književnosti u razdoblju od sloma praškoga proljeća do pada komunizma, ne postoje. U tekstovima Dušana Karpatskog, Krste Špoljara i Predraga Jirsaka objavljenima u časopisima Republika i Književna smotra, a koji tematiziraju recepciju od kraja Drugoga svjetskog rata do sedamdesetih godina, uočava se kvantitativna nadmoć prijevoda i izdanja djela hrvatske književnosti u Čehoslovačkoj.

\footnotetext{
${ }^{59}$ Korda-Petrović, Aleksandra Fenomen prihvaćenosti čeških disidentskih autora u srpskoj sredini, Zbornik Matice srpske za slavistiku, Matica srpska, Odeljenje za književnost i jezik, Novi Sad, 2008., str. $227-239$.
} 
U korpusu tekstova koji se bave recepcijom češke književnosti u Jugoslaviji, odnosno Hrvatskoj, tijekom sedamdesetih i osamdesetih godina nalaze se oni Katice Ivanković, Borisa Senkera i Predraga Matvejevića, a tema recepcije nerijetko je uklopljena u književnu kritiku pojedinoga objavljenog književnog djela. Također, pojačana se recepija primjećuje na prijelomu šezdesetih i sedamdesetih godina 20. st. - što se pripisuje snažnim odjecima zbivanja iz kolovoza 1968., te krajem osamdesetih godina - što jest posljedica društveno-političkih okolnosti, ali i kvalitete neoficijelne literature te, u velikoj mjeri, izuzetna međunarodna ugleda koji je tijekom dva desetljeća neoficijelna kulturna scena izgradila.

Tijekom osamdesetih godina kvantitetom i kvalitetom tekstova o kulturnim kretanjima u zemljama srednje i istočne Europe, pa tako i Čehoslovačke, prednjači zagrebački tjednik Danas čiji analitičari, među kojima se ističe ime Predraga Matvejevića, razinu recepcije češke književnosti u Hrvatskoj tumače kvalitetom književnih tekstova i izvanliterarnim razlozima. Jednim od razloga kontinuirane dobre prihvaćenosti češke književnosti među hrvatskim čitateljima Katica Ivanković smatra stereotip o „,̌eškome humoru“, toplome, blagome i specifičnome koji Hrvate privlači zgodama likova čeških romana i filmova još od legendarnoga Švejka Jaroslava Hašeka. Pri stvaranju cjelovite slike o recepciji češke književnosti u Hrvatskoj tijekom razdoblja socijalističke Jugoslavije nikako ne smijemo isključiti istraživanja recepcije i podatke iz drugih jugoslavenskih republika. 


\section{DRUŠTVENO-POLITIČKE OKOLNOSTI RAZVOJA HRVATSKOGA I ČEŠKOGA DRUŠTVA OD ŠEZDESETIH DO DEVEDESETIH GODINA 20. STOLJEĆA}

Do rascijepa u smjerovima kojima će čehoslovačko i jugoslavensko društvo krenuti u drugoj polovici dvadesetoga stoljeća dolazi nakon završetka Drugoga svjetskog rata. Čehoslovačka bez rasprave u državnome parlamentu odbija program američke i kanadske pomoći Europi čiji je cilj bio njen gospodarski oporavak, tzv. Marshallov plan, te time zauzima mjesto na strani željezne zavjese pod dominacijom Sovjetskoga Saveza, dok jugoslavensko državno vodstvo međunarodni položaj zemlje počinje graditi na trima kolosijecima: u odnosu prema državama Varšavskoga ugovora, zemljama zapadne Europe te Sjedinjenim Američkim Državama, a od sredine pedesetih i zemljama Pokreta nesvrstanih. ${ }^{60}$ Dobro organizirane komunističke strukture u Jugoslaviji još u ratnom razdoblju omogućavaju Josipu Brozu Titu ${ }^{61}$ zauzimanje neovisnijega stava u odnosu na Sovjetski Savez i izgradnju socijalističkoga društvenog uređenja koje se od onoga pod sovjetskim utjecajem razlikuje u mogućnosti slobodnijeg putovanja građana u inozemstvo, jačoj privrednoj, političkoj i kulturnoj povezanosti sa zapadom, tržišnim mehanizmima bliskima zapadnim zemljama te relativno slobodnim medijima. ${ }^{62} \mathrm{U}$ takvim su okolnostima dva društva reformne ideje koje se rađaju šezdesetih dočekala u različitom društvenom ozračju koje utječe i na odnos stanovništva prema njima - Jugoslavija se od kraja Drugoga svjetskog rata, kada je bila gospodarski zaostala zemlja pretežno seoskoga stanovništva, premetnula u zemlju opipljiva gospodarskog rasta koji je pratio porast životnoga standarda ljudi, ${ }^{63}$ a s druge je strane Čehoslovačka, u predkomunističkom razdoblju izuzetno kapitalistički orijentirana i 1949. po bruto društvenom proizvodu razvijenija od Austrije i Zapadne Njemačke, ${ }^{64}$ sredinom šezdesetih na rubu bankrota. ${ }^{65}$

\footnotetext{
${ }^{60}$ Rada, Ivan i dr. Povijest Češke, Sandorf, Zagreb, 2013., str. 650; Klasić, Hrvoje Jugoslavija i svijet 1968., Naklada Ljevak, Zagreb, 2012., str. 250-252.

${ }^{61}$ Broz Tito, Josip (1892. - 1980.), hrvatski i jugoslavenski političar i državnik. Članom Komunističke partije Jugoslavije postaje 1920., tijekom Drugoga svjetskog rata vrhovni je zapovjednik Narodnooslobodilačke vojske Jugoslavije. Jedan je od osnivača i vođa Pokreta nesvrstanih. Nakon završetka Drugoga svjetskog rata zauzima vodeće državne i političke položaja u socijalističkoj Jugoslaviji sve do svoje smrti. www.enciklopedija.hr (natuknica Josip Broz - Tito, pristupljeno 2. 8. 2019.)

${ }^{62}$ Bilandžić, Dušan Hrvatska moderna povijest, Golden marketing, Zagreb, 1999., str. 644-645.

${ }^{63}$ Od 1952. do 1960. BDP u Hrvatskoj narastao je 106\%, a od 1961. do 1970. još 76\%. (Goldstein, Ivo Povijest Hrvatske, EPH media d. o. o., Zagreb, 2011., str. 157)

${ }^{64}$ Đodan, Šime Ekonomska podloga aktualnim političkim zbivanjima u Čehoslovačkoj, Kolo, br. 5, 1968., prema: Klasić, Hrvoje Jugoslavija i svijet 1968., Naklada Ljevak, Zagreb, str. 372.
} 


\section{1. Praško proljeće}

Druga polovica šezdesetih godina 20. st. u češkome je društvu obilježena pokušajima liberalizacije i demokratizacije, težnjama za reformama ekonomskoga sustava i značajnim porastom slobode medija ${ }^{66}$ Poticaji za takve promjene dolaze od političkih elita na vlasti, odnosno reformne struje Komunističke partije koja rukovođenje preuzima smjenama koje započinju Trećim plenumom koji se održava od listopada 1967. do siječnja sljedeće godine, a od kojih je najsnažnije odjeknula promjena na čelu Centralnoga komiteta KPČ-a kada Antonína Novotnog ${ }^{67}$ zamjenjuje Alexander Dubček ${ }^{68} .69$

Reformne ideje koje se ovome razdoblju razvijaju nerijetko se tumače kao kontinuitet građanskoga društva u Čehoslovačkoj koje je postojalo u predkomunističkoj eri. ${ }^{70} \mathrm{Tu}$ ideju razrađuje i Ludvík Vaculík ${ }^{71}$ u najznačajnijem tekstu praškoga proljeća, manifestu Dvije tisuće riječi (Dva tisice slov které patři dělnikưm, zemédělcưm, úredníki̊m, umělcům a všem) objavljenome 26. lipnja 1968. u milijunskoj nakladi u dnevnim novinama Mladá fronta,

\footnotetext{
${ }^{65}$ Klasić, Hrvoje Jugoslavija i svijet 1968., Naklada Ljevak, Zagreb, str. 31, 46.

${ }^{66}$ Kao nultu točku praškoga proljeća na polju slobode izražavanja nekoliko analitičara uzima IV. kongres književnika Čehoslovačke održan 28. lipnja 1967. na kojemu skandal izazivaju Pavel Kohout i Aleksander Klíment zahtjevom za javnim čitanjem Solženjicinova pisma o cenzuri. Taj događaj češki povjesničar Jan Měchýř naziva „imaginarnim početkom praškoga proljeća“ (Vilímek, Tomáš Občanská společnost a jeji význam v obdobi Pražského jara. Revue pro studium totalitních režimů, 2(2), 2008., str. 9), a Jiří Pelikán u svojim memoarskim zapisima jednim od „,detonatora praškoga proljeća“ (Pelikán, Jiří Praško proljeće, OOUR Globus, Izdavačka djelatnost, Biblioteka Globus, Zagreb, 1982., str. 207).

${ }^{67}$ Novotný, Antonín (1904. - 1975.), čehoslovački političar. Predsjednik Republike od 1957. do 1968. kada ustupa mjesto Alexanderu Dubčeku. Nakon sloma praškoga proljeća predsjednik je Komunističke partije Čehoslovačke od 1971. do 1975. www.britannica.com (natuknica Antonín Novotný, pristupljeno 2. 8. 2019.) ${ }^{68}$ Dubček, Alexander (1921. - 1992.), slovački političar. Predvodnik reformne struje čehoslovačkih komunista tijekom praškoga proljeća. S čela Centralnoga komiteta KPČ-a smijenjen je 1969. kada odlazi na mjesto čehoslovačkoga veleposlanika u Turskoj. No, nakon godine dana isključen je iz članstva KPČ-a i ne obavlja nikakvu javnu dužnost do 1989. Nakon pada komunizma od 1989. do 1992. predsjednik je Savezne skupštine. www.enciklopedija.hr (natuknica Alexander Dubček, pristupljeno 2. 8. 2019.)

${ }^{69}$ Osim u Hrvatskoj reformne se ideje razvijaju i u ostalim jugoslavenskim republikama. U Hrvatskoj su ugušene smjenjivanjem vodećih političara reformnoga smjera Saveza komunista Hrvatske nakon prosinca 1971. te učvršćivanjem položaja Josipa Broza Tita koji tijekom 1972. smjenjuje i reformna, liberalna vodstva Srbije i Slovenije čime jača svoj položaj partijskoga vođe.

${ }^{70} \mathrm{Za}$ usporedbu je zanimljivo spomenuti zapis britanskoga veleposlanika u Jugoslaviji Dugalda Stewarta o razgovoru s predsjednikom Saveza komunista Srbije Markom Nikezićem iz siječnja 1972. u kojem se navode Nikezićeve riječi, a tema razgovora bila je Jugoslavija, da je „teško upravljati zemljom koja nema demokratske tradicije“. (Batović, Ante Liberalno-nacionalni pokret u Hrvatskoj od 1966. do 1972. i svijet-doktorski rad, Sveučilište u Zadru, Zadar, 2010., str. 222)

${ }^{71}$ Vaculík, Ludvík (1926. - 2015.), češki prozaist i publicist. Tijekom normalizacije jedna od najistaknutijih osobnosti češkoga samizdata. U svojoj nakladi Petlice do pada komunizma objavio je oko četiri stotine naslova. Autor je manifesta Dvije tisuće riječi te jedan od prvih potpisnika Povelje 77.

http://www.slovnikceskeliteratury.cz (natuknica Ludvík Vaculík, pristupljeno 2. 8. 2019.)
} 
Práce, Zemědělské noviny i tjedniku Literární listy, a u sljedećim danima i u regionalnim medijima. Objavljivanje toga teksta jedna je od prijelomnih točaka cijeloga razdoblja jer pokazuje sasvim novo poimanje novinarskih sloboda i mjeru u kojoj su se čehoslovački mediji uspjeli otrgnuti kontroli Komunističke partije. Vaculík tekst sadržajno dijeli u tri cjeline. Na početku iznosi oštru osudu komunističkoga upravljanja zemljom u posljednjih dvadesetak godina, zatim poziva na pružanje potpore reformnome krilu Komunističke partije, a u završnome, trećem, dijelu problematizira pitanje federalizacije zemlje te građane poziva na građanski neposluh. Od sedamdeset potpisnika manifesta trećina su članovi KPČ-a, a dvojica su, filozof Karel Kosík i predstojnik neurološke klinike praškoga Medicinskog fakulteta Oldřich Starý, bili članovi Centralnoga komiteta Partije. ${ }^{72} \mathrm{Na}$ dan objave o Vaculíkovu tekstu raspravljalo je Predsjedništvo CK-a KPČ-a i obje su struje, konzervativna i reformna, objavljivanje manifesta označile negativno. Dok je konzervativna struja tekst doživjela kao protusovjetsku provokaciju, reformisti su, bojeći se radikalizacije zbivanja, smatrali da on može ugroziti započete promjene. Definitivan slom reformnoga pokreta $u$ Čehoslovačkoj označava vojna intervencija zemalja Varšavskoga ugovora na čelu sa Sovjetskim Savezom u kolovozu 1968.

U godinama koje slijede tzv. normalizacija društva s radnih mjesta i iz javnoga života uklanja stotine pojedinaca koji nisu bili na liniji službene vlasti te preobražava Čehoslovačku $\mathrm{u}$, ,kulturnu pustinju“673. Čistke nepoželjnih obavljene su na državnoj televiziji ${ }^{74} \mathrm{u}$ kazalištima, ${ }^{75}$ znanstvenim institucijama, školama, $^{76}$ a dio stanovništa emigrira iz zemlje ${ }^{77}$.

\footnotetext{
${ }^{72}$ Končelík, Jakub Dva tisíce slov, Zrod a di̊sledky nečekaně vlivného provolání. Soudobé dějiny, XV(3-4), 2008., str. 522.

${ }^{73}$ „Kulturnom pustinjom“ Čehoslovačku nakon 1968. slikovito naziva poljski disident Adam Michnik u eseju napisanu povodom smrti Václava Havela u kojemu normalizaciju opisuje kao vrijeme ,kapitulacije jednih $i$ emigracije drugih“. (Michnik, Adam Velika priča Václava Havela, Zarez, Zagreb, 18. 1. 2012., godište XIV, broj 325-326, str. 14-15)

${ }^{74}$ U kolovozu 1969. na čelo javne televizije stupa Jan Zelenka koji na toj funkciji ostaje dvadeset godina. Ubrzo nakon Zelenkina preuzimanja televizije, bez posla ostaje 137 njenih djelatnika. Tijekom njegova ravnateljevanja uloga javne televizije dobiva sve više na važnosti što osobito dolazi do izražaja nakon potpisivanja Povelje 77 kada je u program uvršten niz televizijskih emisija čija su tema bili lik i djelo najistaknutijih disidenata poput Václava Havela i Pavela Kohouta. Državna je televizija izravno prenosila i potpisivanje Antipovelje iz praškoga Narodnoga kazališta. (Janoušek, Pavel i suradnici Dějiny české literatury 1945-1989, IV. knjiga 1969-1989, Academia, Prag, 2008., str. 792)

${ }^{75}$ Postupci marginalizacije umjetnika u kazalištima bili su različiti: dio njih svoju prašku adresu zamjenjujem djelovanjem u nekom od kazališta u provinciji, nekim je autorima (npr. Evald Schorm) onemogućeno režiranje filmova, no toleriran rad u kazalištu, dijelu kazalištaraca omogućen je rad u inozemstvu, a dio odlučuje zatomiti svoj stvaralački ego i pristaje na izvedbu svojih djela pod imenom osoba kojima službeni režim nije priječio javno djelovanje. (Janoušek, Pavel i suradnici Dějiny české literatury 1945-1989, IV. knjiga 1969-1989, Academia, Prag, 2008., str. 92-94)
} 
Cenzura koja nakon 1968. počinje ovladavati društvom onemogućila je distribuciju književnih i filmskih uradaka koji su te godine već bili tiskani ili snimljeni u obliku u kojemu su mogli pred publiku. ${ }^{78}$ Ograničavanje javnoga djelovanja obuhvaća puno šire područje od književnoga stvaralaštva. O tome svjedoči češki kroatist Dušan Karpatský koji tijekom desetogodišnje onemogućenosti javnoga istupanja prijevode tekstova poput Priča iz davnina Ivane Brlić-Mažuranić, Kratkoga izleta Antuna Šoljana i Predstave Hamleta u selu Mrduša Donja Ive Brešana objavljuje zaštićen pseudonimom, tj. djevojačkim prezimenom svoje supruge i imenima drugih osoba. ${ }^{79}$

Društvena apatija nakon kolovoza 1968. uvelike pridonosi stabilnosti režima. Zabilježene su sporadične snažnije reakcije neposredno nakon vojne intervencije, a njihov je vrhunac samospaljivanje studenata Jana Palacha, Jana Zajíca i radnika Evžena Ploceka. ${ }^{80} \mathrm{U}$

\footnotetext{
${ }^{76}$ Tijekom 1969. iz osnovnih i srednjih škola otpuštena je četvrtina učitelja i nastavnika. (Rada, Ivan i dr. Povijest Češke, Sandorf, Zagreb, 2013., str. 683)

${ }^{77}$ Broj stanovnika Čehoslovačke koji tijekom normalizacije emigriraju varira ovisno o izvoru. Aron Pecnik u tekstu Od Praškoga proljeća do Baršunaste revolucije navodi podatak o 200000 građana. Povijest Češke (Sandorf, Zagreb, 2013., str. 707) brojku od 700000 do 800000 ljudi. Sinteza povijesti češke književnosti od 1945. do 1989. navodi da je u prve dvije godine nakon kolovoza 1968. iz zemlje iselilo oko 244000 ljudi, a, zatim, do 1989., još njih 50 000. (Janoušek, Pavel i suradnici Dějiny české literatury 1945-1989, IV. knjiga 1969-1989, Academia, Prag, 2008., str. 25)

${ }^{78}$ Primjerice, film Jiř́ja Menzela Skřivánci na niti snimljen je 1969., no premijerno je prikazan tek 1990., godine 1970. uništena je cijela naklada zbirke pjesama Antonína Brouseka Nouzový východ, djela Bohumila Hrabala Poupata i Domácí úkoly tiskana su 1970., no onemogućena im je distribucija na tržištu.( Janoušek, Pavel i suradnici Dějiny české literatury 1945-1989, IV. knjiga 1969-1989, Academia, Prag, 2008., str. 486, 767)

${ }^{79}$ Kamenski, Branka Pseudonimom protiv „grijeha“, Večernji list, br. 9600, 13. 5. 1990., str. 20.

O češkome prijevodu Dušana Karpatskog romana Kratki izlet progovara sâm autor romana u tekstu objavljenome u Republici 1990.: „Posebno je zanimljiva češka priča. Sjajni češki prevodilac i prijatelj hrvatske literature, Dušan Karpatsky preveo je Kratki izlet. Međutim, dijelom valjda i zbog tog svog prijateljstva, on je sam dospio u nemilost nakon gušenja praškog proljeća, i njegov prijevod nije mogao biti objavljen u izdavačkom poduzeću Odeon, za koji ga je naručila isto tako vjerna i vrijedna prijateljica naše književnosti, Irena Wenigova. Da bi se ipak spasilo što se spasiti dade, prijevod Karpatskog potpisao je Viktor Kudelka, a sam je Karpatsky morao svoj prijevod mijenjati, pa čak, kako sam kaže, 'i malo kvariti', da neki budni i pedantni čistunac u poduzeću ne bi otkrio da je posrijedi isti tekst koji je već odbijen zbog nepodobnosti prevoditelja. Tako je jednog dana stigao do mene Kratky vylet, mali narandžasti svezak koji čuvam s posebnom sentimentalnošću: on mi nekako pokazuje kako ta mala knjiga, unatoč suđenicama koje su je obilježile pri rođenju, unatoč svim preobrazbama teksta, unatoč tome što je smola prati i kad promijeni jezik i sredinu, kao da ima nekakvu ugrađenu (ma kako sramežljivu, ma kako rubnu) tvrdoglavu sposobnost preživljavanja. “ Šoljan, Antun Kratka povijest Kratkog izleta, Republika, br. 7/8, 1990., str. 59-65.

${ }^{80}$ U prvoj polovici 1969. studenti Jan Palach i Jan Zajíc te radnik Evžen Plocek izražavaju svoje nezadovoljstvo sovjetskom intervencijom i stanjem u Čehoslovačkoj činom samospaljivanja. Takve je prosvjedne akcije pokrenuo Jan Palach samospaljivanjem 16. 4. 1969. na glavnome praškom trgu, slijedili su ga Zajíc i Plocek čija je aktivnost javno manje poznata. Kako bi iskazali potporu stanovnicima Čehoslovačke nakon sovjetske intervencije, studentski klub u Rijeci nakon Palachove smrti nazvan je njegovim imenom. Prema nepotvrđenoj priči, inicijativa za preimenovanje kluba došla je od riječkih studenata strojarstva koji su u vrijeme vojne intervencije bili na ekskurziji u Čehoslovačkoj. Godine 1977. klub je preimenovan u Omladinski kulturni centar Ivo Lola Ribar, prema partizanskome junaku, no novo ime nikada nije zaživjelo pa je ime Jana Palacha klubu
} 
literaturi o tome razdoblju javlja se i teza o tzv. češkoj šutnji, odnosno lojalnosti građana čije je javno neiskazivanje neslaganja s potezima službenoga režima honorirano relativno visokim standardom života, u usporedbi s ostalim zemljama istočnoga bloka poput Poljske i

Rumunjske, ${ }^{81}$ te povlačenju u osamu i izbjegavanju javnoga angažmana koje dovodi do sve veće apolitičnosti građana. Osim toga, gospodarstvo, kulturne i obrazovne institucije u potpunosti su pod kontrolom države tako da ona postaje i gotovo jedini poslodavac što joj daje gotovo neograničenu moć nad egzistencijom građana. U takvoj je situaciji „stranačka iskaznica za većinu svojih članova [članova KPČ-a] istovremeno bila i radna knjižica“882. Pripadnost Partiji upravljala je mogućnošću zaposlenja do te mjere da je određivala hoće li se pojedinac uopće moći baviti svojom strukom. ${ }^{83}$

\section{2. Povelja 77}

U dva desetljeća tzv. normalizacije društva prijelomnu točku čini 1977., odnosno objavljivanje Povelje 77, dokumenta kojim se kritizira politika Komunističke partije Čehoslovačke i iznose zahtjevi za poštovanjem ljudskih i građanskih prava. ${ }^{84}$ Promjena stanja svijesti koja je slijedila nakon 1977. i objavljivanja Povelje ${ }^{85}$ uspoređuje se s promjenom paradigme 1989. koja označava cezuru u kontekstu periodizacije suvremene češke

vraćeno 1990. Benčić, Luka Može li Palach opet biti središte riječke kulture www.jutarnji.hr/kultura/glazba /moze-li-palach-opet-biti-srediste-rijecke-kulture/1200890/ (objavljeno 8. 3. 2013., pristupljeno 20. 12. 2018.) ${ }^{81}$ Janoušek, Pavel i suradnici Dějiny české literatury 1945-1989, IV. knjiga 1969-1989, Academia, Prag, 2008., str. 15 .

${ }^{82}$ Kopeček, Lubomír Cesta k listopadu: komunistický režim, společnost a opozice vére normalizace, u: Éra nevinnosti. Česká politika 1989 - 1997., Barrister \& Principal, Brno, 2010., str. 4.

${ }^{83}$ Primjerice, oni članovi Čehoslovačke akademije znanosti i umjetnosti koji su potpisali manifest Dvije tisuće riječi, degradirani su i onemogućena su im putovanja u inozemstvo. (Končelík, Jakub Dva tisíce slov, Zrod a důsledky nečekaně vlivného provolání. Soudobé dějiny, XV(3-4), 2008., str. 522)

${ }^{84}$ www.proleksis.lzmk.hr (natuknica Povelja 77, pristupljeno 22. 12. 2018.)

${ }^{85} \mathrm{O}$ intenziviranju disidentskih aktivnosti u drugoj polovici sedamdesetih godina u intervjuu Karelu Hvižd'alu govori i Václav Havel: „Ljudi kao da postupno opet dolaze $k$ sebi, staju na svoje noge, iznova se počinju zanimati za stvari pred kojima su se tada tako energično zatvorili; $i$ opet se javljaju otočići samoosvještenja $i$ samooslobođenja, iznova se javljaju i umnažaju tada tako brutalno prekinute veze među njima. (...) Uzmimo samo onaj nezadrživi razvitak nezavisne kulture: tu prije deset godina nije postojao nijedan samizdatni periodik i njegovo se osnivanje smatralo ravno samoubojstvu, a danas ih ima na desetke i u njima suraduju ljudi nadaleko poznati po svojoj opreznosti; koliko tu samo ima novih naslova i izdanja u samizdatu, koliko nepoznatih i nevjerojatnih ljudi prepisuje sve moguće i kakvu pozornost to u javnosti pobuđuje! S počecima sedamdesetih godina to se jednostavno ne može usporediti. “ Havel, Václav Saslušanje na daljinu (razgovor s Karelom Hvižd'alom), Irida, Zagreb, 2000., str. 200-201. 
književnosti. ${ }^{86}$ Djelatnost disidentskih aktivista okupljenih oko Povelje, među kojima su najzvučnija imena Václava Havela, Jana Patočke ${ }^{87}$ i Jiř́ja Hájeka ${ }^{88}$, protegla se sve do pada komunizma 1989. U tih je dvanaestak godina tekst Povelje potpisalo oko 2000 osoba. ${ }^{89}$

Objavljivanju Povelje 77 prethodila su dva snažna poticaja u drugoj polovici sedamdesetih. Međunarodni se sastojao od zaključaka helsinške Europske konferencije o sigurnosti i suradnji iz 1975. koji su se ticali problematike ljudskih prava. I dok službeni režimi srednjoeuropskih i istočnoeuropskih komunističkih zemalja u zaključcima Konferencije nisu vidjeli išta što bi potaknulo društvene promjene, disidentski krugovi iskoristili su ih kao snažan poticaj za daljnje aktivnosti. ${ }^{90}$ Unutardržavni poticaj bilo je društveno ozračje nakon montiranoga sudskog procesa članovima rock-skupine The Plastic People of the Universe ${ }^{91}$ tijekom $1976 .^{92}$

Upravo se potpisivanje Povelje 77 nerijetko tumači kao polazna točka procesa koji se razvijao dugo i mukotrpno, no koji je u konačnici rezultirao osnivanjem Građanskoga foruma i baršunastom revolucijom. ${ }^{93}$

\footnotetext{
${ }^{86}$ Sesar, Dubravka Povelja 77 u kontekstu češke disidentske književnosti, u: Egzil, emigracija: Novi kontekst, zbornik, ur. Irena Lukšić, Hrvatsko filološko društvo, Zagreb, 2002., str. 224; Brabec, Jiří Otazníky nad literární historii sedmdesátých a osmdesátých let, u: Život je jinde...?, Česká literatura, kultura a společnost v sedmdesátých a osmdesátých letech dvacátého století, prir. Jan Matonoha. Ústav pro českou literaturu AV ČR, Prag, 2002., str. 13-19; Kopeček, Lubomír Cesta k listopadu - komunistický režim, společnost a opozice v éře normalizacie, u: Éra nevinnosti. Česká politika 1989 - 1997., Barrister \& Principal, Brno, 2010., str. 10-22 ${ }^{87}$ Patočka, Jan (1907. - 1977.), češki filozof.

${ }^{88}$ Hájek, Jiř́ (1913. - 1993.), čehoslovački političar. Dugogodišnji član Komunističke partije Čehoslovačke i diplomat. Nakon sloma praškoga proljeća smijenjen je sa svih političkih dužnosti. Jedan je od utemeljitelja Čehoslovačkog helsinškog odbora 1988.

${ }^{89}$ Janoušek, Pavel i suradnici Dějiny české literatury 1945-1989, IV. knjiga 1969-1989, Academia, Prag, 2008., str. 41.

${ }^{90}$ Mikulić, Borislav Poietički pojam prakse i njegov kulturni kontekst (Filozofija praxis u političkim, teorijskim i umjetničkim previranjima 60-ih), u: Prostor u jeziku; Književnost i kultura šezdesetih: zbornik radova 37. seminara Zagrebačke slavističke škole, ur. Krešimir Mićanović, Filozofski fakultet, Zagrebačka slavistička škola, Zagreb, 2009., str. 88.

${ }^{91}$ Rock-skupina The Plastic People of the Universe osnovana je 1969., a vođa joj je bio Ivan Martin Jirous. Skupina je bila jedno od vodećih pojmova češkoga undergrounda čiji je cilj bio stvaranje „druge kulture“ neovisne o službenim komunikacijskim kanalima koji su bili pod kontrolom državnoga režima. Članovi skupine uhićeni su i osuđeni na višemjesečne kazne 1976. nakon festivala u mjestu Bojanovice pod izlikom da njihove pjesme ispunjene vulgarizmima loše utječu na moralne odlike društva. www.totalita.cz/norm/norm_03.php, pristupljeno 22. 12. 2018.

92 Janoušek, Pavel i suradnici Dějiny češké literatury 1945-1989, IV. knjiga 1969-1989, Academia, Prag, 2008., str. 37.

${ }^{93}$ Sesar, Dubravka Povelja 77 u kontekstu češke disidentske književnosti, u: Egzil, emigracija: Novi kontekst, zbornik, ur. Irena Lukšić, Hrvatsko filološko društvo, Zagreb, 2002., str. 222.
} 


\section{3. Liberalizacija u osamdesetim godinama}

Međunarodni poticaj društvenim promjenama krajem osamdesetih politika je koju u Sovjetskom Savezu vodi Mihail Gorbačov ${ }^{94}$ pokretima perestrojke ${ }^{95}$ i glasnosti ${ }^{96} \cdot{ }^{97} \mathrm{Na}$ unutardržavnom planu to je društveno ozračje koje se u Čehoslovačkoj razvilo 1989. povodom obilježavanja dvadesete godišnjice samospaljivanja Jana Palacha. ${ }^{98}$

No, krajem osamdesetih niz je katalizatora promjena koji obuhvaćaju različite društvene sfere i skupine građana. Kolovoz 1989. bio je obilježen prosvjedima kojima se obilježava dvadeset i prva godišnjica vojne intervencije zemalja Varšavskoga ugovora, promjene u zapadnoj Europi dovode do prijelaza građana Istočne Njemačke u Zapadnu preko čehoslovačkoga teritorija, a zatim i do rušenja Berlinskoga zida u studenome, isti je mjesec u dijelu čehoslovačkoga građanstva katoličke orijentacije odjeknulo proglašenje sveticom Aněške Přemyslovné. ${ }^{99}$ Sva navedena zbivanja kulminiraju 17. studenoga kada studentski prosvjedi povodom pedesete godišnjice nacističke okupacije čeških sveučilišta, koji su bili službeno dopušteni, prerastaju u prosvjede protiv aktualne vlasti. Razvoj događaja vodio je raspadu komunističkoga uređenja, uvođenju višestranačja, principa tržišnoga gospodarstva i ukidanju cenzure.

\footnotetext{
${ }^{94}$ Gorbačov, Mihail Sergejevič (1931.), sovjetski i ruski političar i državnik. Godine 1985. postaje generalni sekretar Centralnoga komiteta Komunističke partije Sovjetskoga Saveza. U drugoj polovici osamdesetih pokreće programe reformi perostrojku i glasnost, a vanjsku politiku usmjerava prema smanjenju napetosti između predstavnika dvaju blokova i završetku hladnoga rata. Za prvog predsjednika SSSR-a izabran je 1990. Iste mu je godine dodijeljena i Nobelova nagrada za mir. www.enciklopedija.hr (natuknica Mihail Sergejevič Gorbačov, pristupljeno 2. 8. 2019.)

${ }^{95}$ Perestrojka (rus. preustroj) je naziv za program restrukturiranja gospodarskog i političkog sustava Sovjetskoga Saveza koji započinje tadašnji generalni sekretar CK-a KPSS-a Mihail Gorbačov 1987., a koji se sastojao od pokušaja gospodarske reforme na tržišnim osnovama i uvođenja elemenata izborne konkurencije. Perestrojka je pridonijela slomu komunizma u Sovjetskom Savezu te konačnom raspadu te zemlje 1991. www.enciklopedija.hr (natuknica perestrojka, pristupljeno 22. 12. 2018.)

${ }^{96}$ Glasnost (rus. otvorenost) je naziv za liberalizaciju sovjetskoga javnog života koju, također, uvodi Mihail Gorbačov u drugoj polovici osamdesetih godina 20. st. Cilj glasnosti bilo je uvođenje slobode izražavanja i informiranja ukidanjem cenzure te veća otvorenost zapadu. www.proleksis.lzmk.hr (natuknica glasnost, pristupljeno 22. 12. 2018.)

${ }^{97}$ Janoušek, Pavel Dějiny české literatury 1945-1989, IV. knjiga 1969-1989, Academia, Prag, 2008., str. 50.

${ }^{98}$ Višednevne demonstracije kojima su građani obilježavali dvadesetu godišnjicu samospaljivanja Jana Palacha u siječnju 1989. vlast je policijskim snagama ugušila, a među uhićenima bio je i Václav Havel. One su bile uvertira u prosvjede i baršunastu revoluciju do koje je došlo ujesen iste godine. Otáhal, Milan Tvưrči inteligence vobdobí tzv. normalizace. u: Život je jinde...?, Česká literatura, kultura a společnost v sedmdesátých a osmdesátých letech dvacátého století, prir. Jan Matonoha. Ústav pro českou literaturu AV ČR, Prag, 2002., str. 91.

${ }^{99}$ Janoušek, Pavel Dějiny české literatury 1945-1989, IV. knjiga 1969-1989, Academia, Prag, 2008., str. 53.
} 
2. 4. Reakcije hrvatskoga društva na vojnu intervenciju zemalja Varšavskoga ugovora

Kako u vrhu Saveza komunista Jugoslavije krajem šezdesetih godina ne vlada homogenost, reakcije njegovih članova na zbivanja u Čehoslovačkoj 1968. koja su kulminirala okupacijom zemlje u noći s 20. na 21. kolovoza dvojake su. Reformama skloni jugoslavenski političari, kojih je tada bilo i visoko u hijerarhiji jugoslavenskoga Saveza komunista, smatraju da je praško proljeće poticaj za nastavak reformi i u jugoslavenskome društvu, dok njihovi protivnici smatraju da su ideje reformnoga vrha KPČ-a na tragu oživljavanja višestranačja, čemu su se oštro protivili. ${ }^{100}$ Sve to vrijeme niti jedan od vodećih jugoslavenskih političara nije dovodio u pitanje potrebu poštovanja državnoga suvereniteta Čehoslovačke koji je vojnom intervencijom bio oskvrnut.

Razvoj je događaja bio pomno praćen i u tadašnjim pisanim medijima - kako sve snažnije razbuktavanje reformnoga pokreta tijekom 1968., tako, osobito, zbivanja nakon 21. kolovoza. Prema novome vodstvu čehoslovačke Komunističke partije i reformnim idejama koje pokušava implementirati u društvu, tekstovi u hrvatskim medijima mahom su pozitivno intonirani. Novinski napisi objavljeni netom nakon kolovoških zbivanja uglavnom se bave brojnim čehoslovačkim turistima koji se u to vrijeme nalaze na odmoru na hrvatskoj obali Jadrana, a s kojima građani Hrvatske i drugih jugoslavenskih republika iskazuju solidarnost na različite načine. ${ }^{101}$ Vjesnik u srijedu prenosi i tekst na češkome jeziku Dušana Hamšíka, glavnoga urednika novina Literarné listy, koji se u danima vojne intervencije također našao na ljetovanju na jadranskoj obali. Kako je tekst namijenjen čitateljima novina kojima je urednik u Čehoslovačkoj, Vjesnik u srijedu poziva jugoslavenske radioamatere da svojim resursima pokušaju doprijeti do što više slušatelja u Hamšíkovoj domovini. ${ }^{102}$

U najvećim jugoslavenskim gradovima organiziraju se skupovi potpore građanima Čehoslovačke na kojima sudjeluju govornici iz vrha hijerarhije Saveza komunista Jugoslavije čime se nedvosmisleno daje znak da skupovi imaju snažnu potporu službene politike.

Beogradski skup 22. kolovoza 1968. okuplja 250000 građana, a govorom ga otvaraju sekretar

\footnotetext{
${ }^{100}$ Klasić, Hrvoje Jugoslavija i svijet 1968., Naklada Ljevak, Zagreb, 2012., str. 74.

${ }^{101}$ Solidarnost s građanima Čehoslovačke koji su u kolovozu 1968. na godišnjemu odmoru u Jugoslaviji građani iskazuju organizacijom skupova podrške na gradskim trgovima, stožera za prihvat čehoslovačkih turista koji se nisu mogli vratiti u svoju zemlju, omogućavanjem besplatnoga javnog prijevoza u Zagrebu, besplatnoga prijevoza Jugoslavenskim željeznicama (Osuda i zaprepaštenje, Vjesnik, br. 7727, 22. 8. 1968., str. 5; Čehoslovaci dragi gosti Zagrepčana, Vjesnik, br. 7728, 23. 8. 1968., str. 15; Čehoslovaci na putu u domovinu, Vjesnik, br. 7734, 29. 8. 1968., str. 3). Kako bi zahvalili na pruženoj pomoći, čehoslovački turisti u Puli daruju krv. (Čehoslovaci na putu u domovinu, Vjesnik, br. 7734, 29. 8. 1968., str. 3)

102 Hamšík, Dušan Atentat na socijalizam, Vjesnik u srijedu, br. 852, 28. 8. 1968., str. 4.
} 
beogradskog Gradskog komiteta SK-a Simeon Zatezalo i sekretar IK-a CK-a SKJ-u Mijalko Todorović. Na skupu u Sarajevu okupilo se 140000 ljudi, a jedan je od govornika bio predsjednik CK-a SKBiH-a Cvijetin Mijatović. ${ }^{103}$

Nekoliko mjeseci kasnije hrvatski intelektualci na okupaciju Čehoslovačke reagiraju tribinom Duh se ne može okupirati koju 4. listopada 1968. organizira Centar za humanističko obrazovanje Narodnoga sveučilišta grada Zagreba u sklopu tradicionalne manifestacije Književni petak, a koju je te godine uređivao književnik Bruno Popović. Nositelji su programa na toj tribini Slavko Mihalić i Dubravko Horvatić, književnici koji su, prema tekstu u Večernjemu listu, u vrijeme okupacije bili u Čehoslovačkoj. ${ }^{104}$

Unatoč načelnoj potpori čehoslovačkim reformistima, službena jugoslavenska politika u godinama koje su slijedile postupa oportuno ne želeći narušiti odnose s obama blokovima. Vrlo brzo u diskurzu jugoslavenskoga političkog vrha pojam dubčekovštine poprima negativne konotacije. U razgovoru s istaknutim hrvatskim političarima tijekom hrvatskoga proljeća Savkom Dabčević-Kučar i Perom Pirkerom jedan od najbližih Titovih suradnika Edvard Kardelj ${ }^{105}$ njihovo djelovanje, čiji je cilj bio oslabiti centralizaciju Jugoslavije i ojačati ekonomsku samostalnost republika, naziva „dubčekovštinom“ koja ugrožava „tekovine revolucije“"106. Kada je 1977. jedno od vodećih imena u reformnoj struji čehoslovačkih komunista Zdeněk Mlynář podnio zahtjev za azilom u Jugoslaviji, naglašavajući da ne želi otići u egzil u neku kapitalističku zemlju, Jugoslavija njegov zahtjev odbija. ${ }^{107}$

Dvadesetak godina kasnije, u osvit velikih promjena u cijeloj srednjoj i istočnoj Europi, hrvatski mediji snažno reagiraju i na ponovno uhićenje disidenta, a ubrzo će se vidjeti i budućeg predsjednika Republike, Václava Havela, početkom 1989. Povodom Havelova uhićenja časopis Oko objavljuje tekst izjave s Trećeg europskog sastanka urednika književnih časopisa održanoga u ožujku iste godine u Zapadnome Berlinu koja je kao izraz prosvjeda poslana čehoslovačkoj vladi, a potpisali su je svi urednici koji su sudjelovali na Sastanku osim predstavnika Njemačke Demokratske Republike i Bugarske. U tom broju Oka slijede dva pisma Predraga Matvejevića, oba nastala kao reakcija na Havelova uhićenja - aktualno 1989. i uhićenje iz 1979. kada je Havel osuđen na zatvorsku kaznu zbog aktivnosti oko objavljivanja

\footnotetext{
103 Goldstein, Ivo Povijest Hrvatske, Zagreb, EPH media d. o. o., 2011., str. 183.

${ }^{104}$ Književni petak Duh se ne može okupirati, Večernji list, br. 2839, 30. 9. 1968., str. 7.

${ }^{105}$ Kardelj, Edvard (1910. - 1979.), slovenski političar. Dugi niz godina obavljao istaknute funkcije u Savezu komunista Jugoslavije, glavni partijski ideolog i teoretičar.

106 Bilandžić, Dušan Hrvatska moderna povijest, Golden marketing, Zagreb, 1999., str. 589.

${ }^{107}$ Pelikán, Jan Pokušaj stvaranja jezgra čehoslovačke emigracije u Jugoslaviji nakon sovjetske okupacije Čehoslovačke u augustu 1968. godine. Tokovi istorije,1-2, 2007., str. 99-100.

www.scindeks.ceon.rs (pristupljeno 9. 6. 2014.)
} 
Povelje 77. U prvome pismu Matvejević, razočaran postupcima čehoslovačke vlasti prema disidentima krajem sedamdesetih, podsjeća na povijest čehoslovačko-jugoslavenskih društvenih veza i međusobne utjecaje u kojima je čehoslovačko društvo svojom razvijenom demokracijom bilo uzor jugoslavenskome. ${ }^{108} \mathrm{U}$ pismu vezanome uz aktualno Havelovo uhićenje Matvejević analizira situaciju u kojoj val promjena koji zahvaća Europu s istoka, pa i iz službenih struktura Sovjetskoga Saveza, ovaj put ne nailazi na dobar prijam u čehoslovačkome državnom vodstvu. Dok se u sovjetskome društvu javljaju kritike Brežnjevljevih postupaka, razvijaju perestrojka i glasnost, čehoslovačko društvo na te promjene ostaje gluho, neovisno o tome koliko se prethodnih desetljeća modeliralo upravo prema svojim istočnoeuropskim susjedima. ${ }^{109}$

Novinski tekstovi koji nastaju kao reakcija na Havelovo uhićenje dio su šire društvene priče koja otvara prostor raspravi o temi ljudskih prava i u jugoslavenskome društvu. ${ }^{110}$ Tim povodom Vjesnik izvještava o aktivnostima srpskoga PEN-centra koji u svome pismu Savezu čehoslovačkih pisaca izražava solidarnost s uhićenima te o protestnoj večeri održanoj u Udruženju književnika Srbije tijekom koje su održana izlaganja o Havelovu opusu i izvedba ulomka jednočinke Audijencija. ${ }^{111}$ Havelovu građansku biografiju te represivan odnos čehoslovačke vlasti tijekom normalizacije Zdravko Zima ${ }^{112}$ uspoređuje s odnosom jugoslavenskoga službenog režima prema crnogorskome intelektualcu Jevremu Brkoviću kojemu je u vrijeme objavljivanja Zimina teksta prijetila egzistencijalna nesigurnost zbog oduzimanja republičke nagrade, a time i nacionalne mirovine, tj. postupci koje Zima uočava kao modus operandi nedemokratskih režima kojima je cilj discipliniranje neposlušnih mislilaca. $^{113}$

\footnotetext{
108 „Ponosili smo se Vama u vremenu u kojem se nismo imali sami čime ponositi.“ Matvejević, Predrag Za oslobođenje Václava Havela, ponovno, Oko, br. 445, 1989., str. 2, 3.

Ideja o čehoslovačkome i jugoslavenskome društvu kao međusobnim uzorima razvija se kroz povijest, a učenik i učitelj mijenjaju svoja mjesta. Govoreći o situaciji kasnih 1960-ih i sjećajući se atmosfere na filmskome festivalu u Karlovym Varyma 1968., Branko Šömen navodi da su ondje jugoslavenski gosti festivala uživali posebne povlastice jer su „češki i slovački intelektualci bili uvjereni da će doseći naš standard, našu slobodu pa i naše oholo ponašanje “. Šömen, Branko Češki sanjar: Václav Havel od disidenta do prezidenta, Profil, Zagreb, 2012., str. 82.

${ }^{109}$ Matvejević, Predrag Za oslobođenje Vaclava Havela, ponovo, Oko, br. 445, 1989., str. 2, 3.

${ }^{110}$ Tim brojem časopis Oko počinje objavljivati niz tekstova Predraga Matvejevića koji su reakcija na kršenja ljudskih prava u prvome redu u jugoslavenskim republikama. U sljedećem broju Oka (br. 446, str. 2) Matvejević objavljuje tekst o suspenziji dubrovačkoga dramaturga Milana Milišića i oduzimanju jugoslavenske putovnice franjevcu Šimunu Ćoriću. U br. 453 (str. 2) objavljeno je Matvejevićevo pismo koje je reakcija na sudsku presudu makedonskome književniku Jovanu Koteskom.

${ }^{111}$ Protest zbog hapšenja Havela, Vjesnik, br. 14877, 17. 2. 1989., str. 9.

${ }^{112}$ Zima, Zdravko (1948.), hrvatski esejist, publicist i književni kritičar.

${ }^{113}$ Zima, Zdravko Tko je Havel?, Vjesnik, br. 14890, 2. 3. 1989., str. 11.
} 
U dijelu tekstova hrvatskih pisanih medija nakon što se Havel preodjenuo „iz zatvorskog u predsjedničko ruho“ ${ }_{114}$ autori uspoređuju promjene u Čehoslovačkoj s onima koje se naziru u jugoslavenskome, odnosno hrvatskome društvu. Novinar zagrebačkoga tjednika Danas, časopisa koji u drugoj polovici osamdesetih ostvaruje iznimnu popularnost, Tomislav Butorac ${ }^{115}$ progovara o demokratskoj potkapacitiranosti političara tadašnje zemlje te zaključuje da se u Jugoslaviji ,[k]omunisti raspopovi ponašaju (...) kao prevareni ljubavnici žestoko mrze dragu za kojom su do jučer ludovali. A pri tome nemaju ni Havelovog humanizma a još manje njegove političke mudrosti““116. Na tragu razmišljanja Tomislava Butorca je, u istome tjedniku, i novinarka Branka Kamenski ${ }^{117}$ koja, također, izražava nevjericu u mogućnosti hrvatskoga društva za stvarne i kvalitetne promjene. Smatra, naime, da je priroda promjena u Hrvatskoj drugačija te pita ,nije li u našim prilikama to tek krabuljni ples u kojemu su maske, unutar postojećeg političkog i kulturnog sustava - i dalje pravilno raspoređene ${ }^{\text {(118. }}$.

\section{5. Jugoslavenske paralele}

Uspoređujući razvojnu liniju jugoslavenskoga i čehoslovačkoga društva od šezdesetih godina prošloga stoljeća do pada komunizma i prestanka hladnoratovske podjele svijeta, unatoč svim specifičnostima dviju društava, možemo uočiti niz podudarnosti. U obama se društvima tijekom šezdesetih godina razvijaju reformne ideje koje će u Čehoslovačkoj kulminirati nasilno prekinutim praškim proljećem u kolovozu 1968., a u većini jugoslavenskih republika smjenom reformnih republičkih partijskih rukovodstava od strane moćnoga doživotnog predsjednika socijalističke Jugoslavije Josipa Broza Tita. Razdoblje bujanja reformnih ideje vodstva hrvatskoga Saveza komunista s kraja šezdesetih naziva se, analogno s praškim, hrvatskim proljećem. No, želja za promjenama u šezdesetima nije bila posebnost

\footnotetext{
${ }^{114}$ Kamenski, Branka Samica ili prijestolje, Danas, 13. 3. 1990., str. 37.

115 Butorac, Tomislav (1928. - 2008.), hrvatski novinar. Tijekom praškoga proljeća i neposredno nakon njega novinski dopisnik iz Praga. U rujnu 1968. Butorčeve tekstove u kojima detaljno izvještava o situaciji u Čehoslovačkoj objavljuje Vjesnik u srijedu (Sedam dana koji su smirili Prag, br. 853, 4. 9. 1968., str. 6)

${ }^{116}$ Butorac, Tomislav Prevareni ljubavnici, Danas, 6. 3. 1990., str. 55.

${ }^{117}$ Kamenski, Branka (1959.), hrvatska novinarka. Od 1985. do 1995. novinarka kulturne rubrike Večernjega lista, a nakon toga prelazi na Hrvatsku radioteleviziju te ondje više od dvadeset godina uređuje emisiju Pola ure kulture.

${ }^{118}$ Kamenski, Branka Samica ili prijestolje, Danas, 13. 3. 1990., str. 37.
} 
samo hrvatskoga društva i republičkoga vodstva hrvatskih komunista. ${ }^{119}$ Hrvatski politolog Dragutin Lalović za razdoblje u drugoj polovici šezdesetih godina dvadesetoga stoljeća u kojemu u cijeloj Jugoslaviji dolazi do „ekonomske liberalizacije i političke demokratizacije, političkog subjektiviranja republika, pluralizacije kulturnog pogona, slobodnog tiska i kritičke javnosti“120 rabi sintagmu ,jugoslavensko proljeće“"121. Snažniji su razvoj demokratizacije u Jugoslaviji u velikoj mjeri ograničavali i vanjski čimbenici, odnosno međunarodni položaj zemlje. Jugoslavija je, baš takva kakva je bila, odgovarala obama blokovima - zapadu kao dobar uzor za ostale komunističke zemlje srednje i istočne Europe da je moguć i drugačiji put u komunizam od sovjetskoga, a istoku kao partner koji će, bude li potrebno, držati stranu Sovjetskoga Saveza. ${ }^{122}$ Liberalizacija je mogla značiti destabilizaciju Titove vlasti, ${ }^{123}$ a, kako je to bilo protivno njegovim interesima, zapad je bio ,spreman tolerirati autoritativnu narav jugoslavenskoga režima“"124. Neuspjeh razvijanja disidentske scene u Jugoslaviji nalik onima u nekim drugim komunističkim zemljama, poput Čehoslovačke ili Poljske, tumači se različitim uzrocima - specifičnim međunarodnim položajem zemlje koji je uvjetovao činjenicu da disidentima nije dolazila snažna inozemna potpora, relativnom otvorenošću zemlje zapadu, većom mogućnošću putovanja u inozemstvo ${ }^{125}$ te uvođenjem tržišnih elemenata na području kulture puno ranije no u zemljama istočnoga bloka.

\footnotetext{
${ }^{119}$ Zahtjevi za liberalizacijom i demokratizacijom društva ono su što povezuje glavne ideje hrvatskoga proljeća sa sličnom procesima u drugim komunističkim zemljama srednje i istočne Europe, pa tako i onim u Čehoslovačkoj 1968. Batović, Ante Liberalno-nacionalni pokret u Hrvatskoj od '66. do '72. i svijet, doktorska disertacija, Sveučilište u Zadru, Zadar, 2010., str. 265. „Po analogiji s Praškim proljećem Aleksandra Dubčeka, i Hrvatsko je proljeće bilo reakcija građana na prostor slobode koji je otvorila liberalna struja unutar vladajuće partije. “ Tripalo, Miko Hrvatsko proljeće, pogovor Vesne Pusić, 3., dopunjeno izdanje, Nakladni zavod Matice hrvatske, Zagreb, 2001., str. 353.

${ }^{120}$ Lalović, Dragutin Prijelomno desetljeće (1962. - 1972.) - od krize stabilnosti do stabilizacije krize. Politička misao, 49(2), 2012., str. 25; D. Lalović sintagmu jugoslavensko proljeće stvara prema analogiji s hrvatskim proljećem, poetičnim nazivom kojim se naziva razdoblje liberalizacije i jačanja reformnih kretanja u Hrvatskoj na prijelomu šezdesetih i sedamdesetih godina prošlog stoljeća. Uz taj se naziv, ovisno o kontekstu, rabe i nazivi hrvatski nacionalni pokret, masovni pokret (maspok) te hrvatska kriza (naziv kojem su bili skloni zapadni povjesničari). Sintagma hrvatsko proljeće, pak, nastala je po analogiji s praškim proljećem. Bilandžić, Dušan Hrvatska moderna povijest, Golden marketing, Zagreb, 1999., str. 553.

${ }^{121}$ Isto, str. 26.

${ }^{122}$ Bilandžić, Dušan Hrvatska moderna povijest, Golden marketing, Zagreb, 1999., str. 445.

${ }^{123}$ Golemu moć koju je desetljećima u Jugoslaviji imao Josip Broz Tito hrvatski povjesničari uspoređuju s „,monarhom iz doba apsolutnih monarhija“ (Bilandžić, Dušan Hrvatska moderna povijest, Golden marketing, Zagreb, 1999., str. 554), a njegove ovlasti s diktatorskima (Klasić, Hrvoje Jugoslavija i svijet 1968., Naklada Ljevak, Zagreb, 2012., str. 28).

${ }^{124}$ Batović, Ante Liberalno-nacionalni pokret u Hrvatskoj od 1966. do 1972. i svijet, doktorski rad, Sveučilište u Zadru, Zadar, 2010., str. 90.

${ }^{125}$ Državljani Jugoslavije mogućnost putovanja na zapad dobivaju od 1962. Lalović, Dragutin Prijelomno desetljeće (1962. - 1972.) - od krize stabilnosti do stabilizacije krize. Politička misao, 49(2), 2012., str. 19.
} 
Između reformnih ideja reformnih struja u dvjema partijama uočavaju se sličnosti koje su, vjerojatno, dijelom posljedica i činjenice da je njihovo strujanje između Čehoslovačke i Jugoslavije tijekom šezdesetih godina dvosmjerno. Zagovornici reforma u vodstvu čehoslovačke komunističke partije Jugoslaviju smatraju uzorom, zemljom koja se uspjela osloboditi sovjetskoga utjecaja i razviti demokratsko i pravedno društvo, ${ }^{126} \mathrm{a}$, u istome trenutku, dio jugoslavenske političke elite i intelektualaca nada se da će uspjeh reformnoga vodstva čehoslovačkih komunista biti poticaj za liberalizaciju Titova režima. ${ }^{127}$

Jedna je od središnjih ideja toga vremena u objema zemljama promjena ekonomskoga modela i veće okretanje zakonima tržišta. ${ }^{128}$ U Jugoslaviji su ti zahtjevi osobito glasni iz Slovenije i Hrvatske koje se, kao najrazvijenije jugoslavenske republike, snažno protive centralizaciji države te zahtijevaju veću republičku ekonomsku suverenost. Vodeće ime generacije mladih i obrazovanih hrvatskih komunista političarka je i ekonomistica Savka Dabčević-Kučar. ${ }^{129}$ Pripadnici nove generacije, u Hrvatskoj na čelu s Dabčević-Kučar, krajem šezdesetih počinju zauzimati čelna mjesta u partijskoj hijerarhiji što je dalo vjetar $u$ jedra jačanju reformnih strujanja i oblikovanju reformnih partijskih krila. Istovjetnu smjenu generacija možemo pratiti u čehoslovačkoj komunističkoj partiji kada na čelo Centralnoga komiteta dolazi Alexander Dubček. ${ }^{130}$

\footnotetext{
${ }^{126}$ Povjesničar Dušan Bilandžić u Akcijskom programu CK-a KPČ-a objavljenom u travnju 1968., a koji je bio programska platforma praškoga proljeća, uz zahtjeve za zaštitom ljudskih prava i promjenu ustavnoga odnosa Čeha i Slovaka, uočava utjecaj jugoslavenskoga modela samoupravljanja. Bilandžić, Dušan Hrvatska moderna povijest, Golden marketing, Zagreb, 1999., str. 525.

${ }^{127}$ Pelikán, Jan Pokušaj stvaranja jezgra čehoslovačke emigracije u Jugoslaviji nakon sovjetske okupacije Čehoslovačke u augustu 1968. godine. Tokovi istorije,1-2, 2007., str. 82; Pelikán, Jiří Praško proljeće, OOUR Globus, Izdavačka djelatnost, Biblioteka Globus, Zagreb, 1982., str. 203.

${ }^{128}$ Iste godine, 1965., u Čehoslovačkoj je izrađen Novi ekonomski model čiji je cilj bio snažnija povezanost društvenog planiranja sa zakonima tržišta i veća ekonomska samostalnost poduzeća, a u Jugoslaviji Savezna skupština prihvaća niz zakona kojima počinje najradikalnija privredna reforma od uvođenja radničkoga samoupravljanja 1950. koja je značila okretanje kapitalističkome načinu poslovanja s ograničenom mogućnošću privatnoga vlasništva. (Bilandžić, Dušan Hrvatska moderna povijest, Golden marketing, Zagreb, 1999., str. 478, Goldstein, Ivo Hrvatska povijest, Novi liber, Zagreb, 2008., str. 165, Klasić, Hrvoje Jugoslavija i svijet 1968., Naklada Ljevak, Zagreb, 2012., str. 17)

${ }^{129}$ Dabčević-Kučar, Savka (1923. - 2009.), hrvatska ekonomistica i političarka. Dugogodišnja profesorica političke ekonomije na Ekonomskome fakultetu u Zagrebu. Tijekom šezdesetih penje se u hijerarhiji Saveza komunista Hrvatske da bi 1968. postala predsjednica Centralnoga komiteta SKH-a. Nakon što je Josip Broz Tito u prosincu 1971. smjenjuje s političkih funkcija, isključena je i iz SKH-a i mora napustiti profesorsko mjesto na fakultetu. Do 1990. isključena je iz javnoga života, nakon čega se ponovno politički aktivira i u prvoj polovici devedesetih postaje saborska zastupnica i predsjednica parlamentarne Hrvatske narodne stranke.

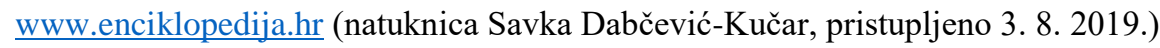

${ }^{130} \mathrm{U}$ objema komunističkim partijama tijekom šezdesetih u prvi plan iskaču nova imena. U Jugoslaviji kadrovske promjene nisu zahvatile samo Savez komunista Hrvatske koji preuzimaju Savka Dabčević-Kučar (predsjednica CK-a SKH-a), Miko Tripalo (sekretar Izvršnog komiteta SKH-a od 1968.), Pero Pirker (sekretar Izvršnog komiteta SKH-a od 1969.) i Srećko Bijelić (čelnik Gradskog komiteta SKH-a za grad Zagreb), već i
} 
U objema je državama, budući da su višenacionalne, krajem šezdesetih izraženo pitanje međusobnoga odnosa nacionalnih zajednica koje je u društvu izazivalo snažne prijepore. U Jugoslaviji se to pitanje u prvome redu odnosilo na problematiziranje položaja srpske nacionalne manjine u Hrvatskoj i odnos Albanaca i Srba na Kosovu, a položaj Slovaka u Čehoslovačkoj dovela je u pitanje ustavna odredba iz 1960. kojom su ukinuti do tada postojeći elementi slovačke autonomije.

Sličnosti i razlike u odnosu čehoslovačke i jugoslavenske komunističke vlasti prema kritičkim tonovima koji dolaze iz vlastite zemlje dobro ilustrira stav Saveza komunista Jugoslavije prema filozofskome časopisu Praxis koji izlazi od 1964. do 1974., a čiji suradnici organiziraju i Korčulansku ljetnu školu s kojom surađuju i neka od najzvučnijih imena inozemne filozofske scene, poput Čeha Karela Kosíka. ${ }^{131}$ I objavljivanje časopisa i održavanje ljetnih susreta na Korčuli, unatoč kritičkome stavu prema službenome jugoslavenskom režimu, u samome početku prati izdašna financijska potpora države. Izdvajanje proračunskih sredstava za financiranje vlastitih kritičara povjesničar Hrvoje Klasić smatra „nezamisliv[im] u bilo kojoj socijalističkoj državi osim Jugoslavije“132. Tolerantan stav vlasti prema kritičkome tonu Praxisa tumači se premalenom publikom te, posljedično, neznatnim javnim utjecajem koji je časopis imao. No, s Praxisovim širenjem društvenoga utjecaja jačaju i posredni pokušaji opstrukcije smanjivanjem državnih sredstava koji se nastavljaju sve do konačnoga prestanka objavljivanja časopisa $1974 .{ }^{133}$

Na društveno ozračje obiju zemalja od sredine šezdesetih godina snažno utječe razvoj novih medija, osobito televizije. Posebnosti toga medija omogućuju pojavu novih oblika izvještavanja poput izravnih prijenosa događaja, mitinga i okupljanja građana koji imaju

partijska rukovodstva drugih republika. Vodstvo Saveza komunista Srbije preuzimaju liberali Marko Nikezić i Latinka Perović, a slovenske komuniste predvodi Stane Kavčič. Sve navedene političare Josip Broz Tito smijenit će i isključiti iz javnog života nakon 1972.

Do niza kadrovskih promjena u Komunističkoj partiji Čehoslovačke dolazi na prijelomu 1967. i 1968. kada na čelo CK KPČ-a stupa Alexander Dubček, na mjesto predsjednika Čehoslovačke Ludvík Svoboda, a u hijerarhiji Partije penju se i ostali pripadnici reformne struje poput Josefa Smrkovskog (član predsjedništva CK-a KPČ-a), Čestmíra Císařa (tajnik CK-a KPČ-a), Oldřicha Černíka (predsjednik Vlade) i Františeka Krigela (predsjednik Narodne fronte).

${ }^{131}$ Kosík, Karel (1926. - 2003.), češki filozof. Do 1970. profesor filozofije na Karlovu sveučilištu u Pragu. Nakon sloma praškoga proljeća ostaje bez profesorskoga mjesta i isključen je iz javnoga života. www.enciklopedija.hr (natuknica Karel Kosík, pristupljeno 1. 7. 2019.)

${ }^{132}$ Klasić, Hrvoje Jugoslavija i svijet 1968., Naklada Ljevak, Zagreb, 2012., str. 57.

${ }^{133}$ Pazeći na međunarodni ugled, jugoslavenska vlast ne zabranjuje časopis Praxis, no odlučuje se za metodu cenzure u kojoj cenzorski položaj zauzimaju tiskari pa, tako, sisačka tiskara „J. Ražanković““ 19. 3. 1975. uredništvu Praxisa šalje dopis kojim ga obavještava da je ,politički aktiv našeg OUR-a i organi upravljanja donio odluku da se ne vrši usluga štampanja časopisa Praxis“. Stipčević, Aleksandar O savršenom cenzoru, Nakladni zavod Matice hrvatske, Zagreb, 1994., str. 33. 
veliku gledanost i pobuđuju veliko zanimanje. Tako je, primjerice, u Čehoslovačkoj u ožujku 1968. televizija izravno prenosila javno okupljanje u Horoměřicama na kojemu su članovi poljoprivrednih zadruga tražili omogućavanje djelovanja i drugim političkim strankama osim KPČ-a, ${ }^{134}$ a u siječnju 1970. Televizija Zagreb tri dana izravno prenosi 10. sjednicu CK-a SKH-a koja se smatra prekretnicom u razvoju hrvatskoga proljeća.

Dio su heterogenoga reformnog procesa i ideje o osnivanju nekomunističkih političkih stranaka. U Zadru je takva inicijativa zabilježena 1966. kada skupina intelektualaca, uglavnom profesora zadarskoga Filozofskog fakulteta, pokušava osnovati oporbenu stranku i pokrenuti nezavisno glasilo. ${ }^{135}$ Pokretači inicijative zbog te su aktivnosti privedeni, a jednome od njih aktivirana je prije dosuđena kazna uvjetnoga zatvora. Postojala je distinkciji između reformnih komunista u čehoslovačkoj i jugoslavenskoj partiji s obzirom na odnos prema nekomunističkim političkim strankama. Alexander Dubček i suradnici bili su spremni dopustiti osnivanje drugih, lijevo orijentiranih, stranaka, dok istu ideju u socijalističkoj Jugoslaviji nisu podržavali ni najveći liberali bilo iz hrvatskoga političkog vodstva, poput Mike Tripala i Savke Dabčević-Kučar, bilo iz rukovodstva drugih republičkih Partija. ${ }^{136}$ Na reformne poticaje iz redova vladajuće partije u Čehoslovačkoj i Jugoslaviji skupine građana različito reagiraju što se, uglavnom, objašnjava njihovim različitim povijesnim iskustvima. Naime, kritika vladajućega režima u Jugoslaviji najvećim dijelom dolazi iz redova intelektualaca i studenata. ${ }^{137}$ Izostanak potpore reformnim idejama srednjega sloja, tj. radnih kolektiva, posljedica je porasta životnoga standarda u prethodnih petnaestak godina koji je uvelike amortizirao moguće nezadovoljstvo. ${ }^{138}$ Nasuprot jugoslavenskome iskustvu, reformna kretanja u Čehoslovačkoj uključuju aktivnosti gotovo svih razina društva koje imaju raznolike ciljeve i interese. Studenti i intelektualci naglasak stavljaju na demokratizaciju društva i političkoga sustava, radnicima su u žarištu zanimanja socijalna pitanja i politika zapošljavanja, a zabilježene su i aktivnosti građana koji istupaju iz katoličkoga dijela svoga

\footnotetext{
${ }^{134}$ Růžička, Daniel Televize v roce 1968 - krátké období bez cenzury https://cz.ejo-online.eu/5542/svobodatisku/televize-v-roce-1968-kratke-obdobi-bez-cenzury (objavljeno 24. 4. 2018., pristupljeno 31. 7. 2019.)

135 Goldstein, Ivo Hrvatska povijest, Novi liber, Zagreb, 2008., str. 509.

${ }^{136}$ Raspad Jugoslavije se vidio još 1968., intervju s Hrvojem Klasićem (intervju vodila Branka Mihajlović) http://www.slobodnaevropa.org/content/klasic_raspad_jugoslavije_se_vidio_jos_1968_godine/24534252.html (objavljeno 2. 4. 2012., pristupljeno 3. 7. 2014.)

137 Spehnjak, Katarina i Cipek, Tihomir Disidenti, opozicija i otpor - Hrvatska i Jugoslavija 1945. - 1990. Časopis za suvremenu povijest, 39(2), 2007., str. 255-297.

${ }^{138}$ Od 1952. do 1960. BDP u Hrvatskoj narastao je 106\%, a od 1961. do 1971. dodatnih 76\%. Goldstein, Ivo Povijest Hrvatske, EPH media d. o. o., Zagreb, 2011., str. 157.
} 
identiteta u pokretu Dílo koncilní obnovy. ${ }^{139}$ Udruživanje generacija u čehoslovačkome reformnom pokretu može se tumačiti njihovim istim ciljem, unatoč različitom iskustvu. Starija generacija snagu je crpila iz iskustva generacije iz razdoblja prije Drugoga svjetskog rata, dok su mladi, rođeni tijekom rata ili nakon njega, bili razočarani staljinizmom. Međutim, kada je, sredinom sedamdesetih, čehoslovačka opozicija opet krenula s aktivnostima, analitičari se slažu da radništvo ostaje pasivno te da većina građana ne zna za Povelju 77 i njene ciljeve. Jedan je od razloga, zasigurno, medijska blokada, no i uzak krug intelektualaca koji se oko tih inicijativa okupio što je cijeloj priči dalo notu intelektualizma. ${ }^{140}$

Nakon smjene reformnih vodstava partije, u Čehoslovačkoj nakon kolovoza 1968., a u Hrvatskoj nakon prosinca 1971., obnavlja se prijašnji poredak i uspostavlja snažnija kontrola državne vlasti nad društvom i javnosti. Odumiranje reformnih ideja u komunističkim partijama olakšano je kadrovskim čistkama, zamiru pokreti građanskoga društva koji su se razvili u prethodnom razdoblju, jača kontrola nad medijima pa prestaje izlaziti niz časopisa i novina. U Čehoslovačkoj počinje razdoblje tzv. normalizacije koje je donijelo i snažnu cenzuru u književnosti koja uvjetuje specifičan razvoj češke književnosti sljedećih dvadesetak godina.

Promjene koje sredinom osamdesetih većinu zemalja srednje i istočne Europe vode prema raspadu komunističkoga uređenja, u javni život vraćaju, nakon skoro dvadesetogodišnjega izbivanja, najzvučnija imena reformnih strujanja s prijeloma šezdesetih i sedamdesetih godina 20. st. Hrvatske izdavačke kuće objavljuju memoare čeških disidenata Jiř́ija Pelikána i Zdeněka Mlynářa 1982. i 1985., no domaći disidenti poput Mike Tripala i Ivana Zvonimira Čička izlazak u hrvatsku javnost morat će pričekati do samoga kraja osamdesetih. ${ }^{141} \mathrm{Niz}$ istaknutih imena praškoga i hrvatskoga proljeća krajem osamdesetih obnavlja svoj politički angažman, no raspršeni u različitim političkim opcijama ${ }^{142} \mathrm{i}$, u bitno

\footnotetext{
${ }^{139}$ Vilímek, Tomáš Občanská společnost a její význam v obdobi Pražského jara, Revue pro studium totalitních režimů, 2(2), 2008., str. 10-11.

Katolička Crkva u Hrvatskoj tijekom maspoka, uglavnom, šuti u ozračju uzlazne putanje jugoslavensko-vatikanskih međudržavnih odnosa i u razdoblju nakon ponovne uspostave diplomatskih odnosa Jugoslavije i Vatikana do koje dolazi 1970. Naime, cijele 1971. u središnjem glasilu Katoličke Crkve u Hrvatskoj, Glasu koncila, nije objavljen niti jedan članak o aktualnim zbivanjima u zemlji. Markešić, Ivan „Crkvena šutnja“ u vrijeme hrvatskog proljeća, u: Tvrtko Jakovina (ur.), Hrvatsko proljeće 40 godina poslije (XXXIII), Centar za demokraciju i pravo Miko Tripalo, Filozofski fakultet Sveučilišta u Zagrebu, Fakultet političkih znanosti Sveučilišta u Zagrebu, Pravni fakultet Sveučilišta u Zagrebu, Zagreb, 2012., str. 245-271.

${ }^{140}$ Kopeček, Lubomír Cesta k listopadu: komunistický režim, společnost a opozice vére normalizace, u: Éra nevinnosti, Česká politika 1989 - 1997, Barrister \& Principal, Brno, 2010., str. 6.

${ }^{141}$ Memoari Hrvatsko proljeće Mike Tripala objavljeni su 1989.

${ }^{142}$ Savka Dabčević-Kučar i Miko Tripalo na čelu su Koalicije narodnoga sporazuma koja je, uz SKH - SDP i HDZ, jedan od triju političkih blokova tijekom prvih parlamentarnih izbora 1990. Studentski predstavnik iz
} 
promijenjenoj konstelaciji odnosa s obzirom na kraj šezdesetih, promjenjiva uspjeha. Tako, primjerice, Dubčekove ideje krajem osamdesetih češka i slovačka politička elita smatra zastarjelima, ${ }^{143}$ a u nacionalizmom nabijenoj atmosferi početka devedesetih nisu se najbolje snašli ni prvaci hrvatskoga proljeća. ${ }^{144}$

\section{6. Zaključak}

Smjerovi u kojima će se razvijati čehoslovačko i jugoslavensko društvo u razdoblju od kraja Drugoga svjetskog rata do pada komunizma u zemljama istočne i srednje Europe uvjetovane su odlukama i postupcima državnih rukovodstava u kasnim četrdesetim i ranim pedesetim godinama 20. stoljeća. Čehoslovačka tada postaje jedna od zemalja tzv. istočnoga bloka, pod snažnim utjecajem Sovjetskoga Saveza, dok Jugoslavija pokušava održati ravnotežu između obaju blokova, a kasnije postaje i jedna od osnivačica Pokreta nesvrstanih.

Tijekom šezdesetih godina nova generacija obrazovanih političara koji preuzimaju sve značajnija mjesta u hijerarhijama obiju partija razvijaju reformne ideje koje su, uglavnom, išle u smjeru liberalizacije i demokratizacije društva te reforma ekonomskoga sustava na tragu tržišnoga gospodarstva. U Jugoslaviji su bili glasni i zahtjevi za decentralizacijom države i većim ekonomskih slobodama pojedinih republika, osobito Slovenije i Hrvatske kao najrazvijenijih republika federacije.

Činjenice da je Čehoslovačka iz zemlje s demokratskom tradicijom i razvijene ekonomije u predkomunističkom razdoblju prerasla u osiromašenu jednopartijsku zemlju

razdoblja hrvatskoga proljeća Ivan Zvonimir Čičak na čelu je Hrvatske seljačke stranke, a potom predsjednik Hrvatskoga helsinškog odbora. Ante Paradžik, u proljeće 1971. predsjednik Saveza studenata Hrvatske, osnivač je desno orijentirane Hrvatske stranke prava, a Dražen Budiša, 1970. na čelu Saveza studenata, Hrvatske socijalno-liberalne stranke te 2000. kandidat na predsjedničkim izborima. Obojica su na prijelomu šezdesetih i sedamdesetih bili jaka imena studentskoga pokreta.

Alexander Dubček 1989. dolazi na čelo Federalnoga parlamenta, a od ožujka 1992. predsjednik je slovačke Socijaldemokratske stranke. Václav Havel predvodi Občanský forum, politički pokret osnovan 1989. s ciljem ukidanja monopola Komunističke partije, a, potom, postaje i predsjednik Republike. Čestmír Císař osniva društvo Obrod u kojem okuplja komuniste isključene iz KPČ-a tijekom normalizacije, a Jiří Hájek 1988. postaje predsjednikom Čehoslovačkoga helsinškog odbora.

${ }^{143}$ Kopeček, Lubomír Cesta k listopadu: komunistický režim, společnost a opozice v ére normalizace, u: Éra nevinnosti, Česká politika 1989 - 1997, Barrister \& Principal, Brno, 2010., str. 10-22.

${ }^{144}$ Zakošek, Nenad Hrvatsko proljeće: promjene u političkom sustavu, u: Tvrtko Jakovina (ur.), Hrvatsko proljeće 40 godina poslije (XXXIII), Centar za demokraciju i pravo Miko Tripalo, Filozofski fakultet Sveučilišta u Zagrebu, Fakultet političkih znanosti Sveučilišta u Zagrebu, Pravni fakultet Sveučilišta u Zagrebu, Zagreb, 2012., str. 23. 
ugroženih ljudskih prava krajem šezdesetih, a da se Jugoslavija od siromašne zemlje pretežno seoskoga stanovništva krajem Drugoga svjetskog rata razvila u zemlju osjetna rasta standarda građana, uvjetovale su stavove širih društvenih slojeva prema glasovima koji su zahtijevali promjene. U Jugoslaviji, osim pristaša reforma unutar Saveza komunista, zahtjevi za promjenama i kritike vladajućega sustava uglavnom dolaze od uskoga kruga intelektualaca i studenata. Nasuprot tome, reformne ideje u Čehoslovačkoj imaju široku potporu svih društvenih slojeva.

Slom reformnoga pokreta u Čehoslovačkoj označila je vojna intervencija zemalja Varšavskoga ugovora u kolovozu 1968. U Jugoslaviji je taj događaj izazvao snažne reakcije, kako građana koji se masovno solidariziraju s Česima i Slovacima, osobito onima koji se $\mathrm{u}$ danima intervencije nalaze na ljetovanju na jadranskoj obali, tako i vodećih političara. Kasnije, vjerojatno ne želeći pogoršati odnose s moćnim Sovjetskim Savezom, jugoslavenske vlasti vuku poteze drastično drugačije od prvotnih reakcija nakon kolovoza 1968. Reformna kretanja u Jugoslaviji prekida tijekom 1971. i 1972. Josip Broz Tito smjenom vodstava većine republičkih saveza komunista.

U obama društvima slijedi razdoblje jačanja cenzure, snažne kontrole javnoga izražavanja i potiskivanja na marginu, ili čak potpunog isključenja iz javnoga života, osoba koje su na bilo koji način bile uključeni u reformne procese. Između ostalih, i dijela književnika. Nakon početne apatije u prvim godinama tzv. normalizacije, u Čehoslovačkoj se disidentske aktivnosti počinju buditi od sredine sedamdesetih godina, a osobito nakon 1977. i potpisivanja Povelje 77 kojom se iznose zahtjevi za poštovanjem ljudskih prava i kritizira praksa komunističke vlasti.

Inicijative za reformama ekonomskoga uređenja i slobodom izražavanja koje će, u konačnici, dovesti do sloma blokovske podjele svijeta krajem osamdesetih godina dolaze iz Sovjetskoga Saveza na čijem je čelu Mihail Gorbačov. Principom efekta domina takve se težnje prelijevaju i na ostale zemlje istočne i srednje Europe komunističkoga uređenja. Istovremeno, u Jugoslaviji kulminira borba za prevlast vodstava republičkih saveza komunista koja traje od smrti Josipa Broza Tita 1980. S padom komunizma i razvojem višestranačja na prijelomu osamdesetih i devedesetih godina politički se aktiviraju osobe kojima je to bilo dvadesetak godina onemogućeno. Najugledniji čehoslovački disidenti preuzimaju značajne političke funkcije na čelu s novim predsjednikom Republike Václavom Havelom. Nasuprot tome, u osvit krvavoga raspada Jugoslavije retorika vodećih osobnosti hrvatskoga proljeća nije uspjela u većoj mjeri privući glasove građana na višestranačkim izborima. 


\section{RAZVOJ ČEŠKE KNJIŽEVNOSTI TIJEKOM NORMALIZACIJE}

Tzv. normalizaciji društva koja započinje slomom reformnih pokreta vojnom intervencijom zemalja Varšavskoga ugovora u kolovozu 1968. i čistkama u vodstvu Komunističke partije Čehoslovačke prethodi razdoblje liberalizacije društva i relativnoga oslobađanja od kontrole službene vlasti tijekom šezdesetih. Književnik Milan Kundera to razdoblje naziva „dikataturom u raspadanju“145 čija će kulturna scena ostati zapamćena kao vrijeme filmova Miloša Formana, Jiř́ija Menzela, Věre Chytilové, drama Václava Havela, romana Josefa Škvoreckog i Bohumila Hrabala. Kundera napominje da ne zna „u kojoj je mjeri taj sistem bio životno sposoban i kakvi su mu bili izgledi; ali zna[m] da je sekunda koliko je trajao, da je ta sekunda bila veličanstvena“. ${ }^{146}$ Iako tijekom šezdesetih cenzura u Čehoslovačkoj nije iščezla u potpunosti, češka je književnost zahvaćena valom liberalizacije koji prodire i u druge društvene sfere što omogućuje otvaranje tržišta tekstovima nastalima još u prethodnome desetljeću koji do tada nisu imali pristup čitateljstvu. ${ }^{147}$ Osim toga, književna djela problematiziraju teme koje su u prethodnome razdoblju bile tabuizirane, poput komunističkih zločina nakon Drugoga svjetskog rata. ${ }^{148}$

Nekoliko godina kasnije, nakon sloma praškoga proljeća, češka se književnost nalazi u paradoksalnoj situaciji da u izuzetno nepovoljnim društveno-političkim okolnostima ostvaruje neke od svojih kvalitativnih vrhunaca, no, uglavnom, u uvjetima samizdata i egzila. Govoreći

${ }^{145} \mathrm{Tu}$ sintagmu Kundera rabi u predgovoru francuskoga izdanja romana Mirakl Josefa Škvoreckog. Hrvatsko izdanje romana iz 1987. donosi Kunderin predgovor u prijevodu Dagmar Ruljančić. Škvorecký, Josef Mirakl, Grafički zavod Hrvatske, Zagreb, 1987., str. 5.

${ }^{146}$ Isto, str. 6.

${ }^{147}$ Fenomen zakašnjele recepcije po Heleni Koskovoj ono je što povezuje stanje na češkom književnom tržištu šezdesetih tijekom liberalizacije i devedesetih nakon pada komunizma. Naime, u oba su se ta desetljeća mladi, još neafirmirani književnici na književnoj sceni borili sa zakašnjelim izdanjima mnogo poznatijih i renomiranijih autora kojima je u prethodnom razdoblju bilo onemogućeno objavljivati. Kosková, Helena Šedesáta leta - zlatý věk české prózy, u: Zlatá šedesátá. Česká literatura a společnost v letech tání, kolotání a ... zklamání, ur. R. Denemarková, Ústav pro českou literaturu AV ČR, Prag, 2000., str. 19-30.

${ }^{148}$ Analogne procese možemo pratiti i u hrvatskoj književnosti šezdesetih. Prema kraju toga desetljeća raste kritički ton prema socijalizmu. Prvim takvim romanom Krešimir Nemec smatra Sante Josipa Barakovića iz 1969. (Nemec, Krešimir Povijest hrvatskog romana od 1945. do 1990., Školska knjiga, Zagreb, 2003., str. 53). No, istodobno, neki se od vrhunaca hrvatske romaneskne proze toga desetljeća ili bave temom ideologije, poput Mirisa, zlata i tamjana Slobodana Novaka, ili ih povjesničari književnosti tumače kao političke alegorije, poput Kratkoga izleta Antuna Šoljana. (Stamać, Ante Šoljanovo doba, $u$ : Šoljanov zbornik: Dani Antuna Šoljana u Rovinju, 1996. - 2000., ur. Boris Biletić, Pučko otvoreno učilište grada Rovinja, Istarski ogranak Društva hrvatskih književnika, Rovinj, Pula, 2001., str. 18) Do ponovnog buđenja kritičkoga tona prema socijalističkoj zbilji u hrvatskoj književnosti dolazi u osamdesetima, nakon smrti Josipa Broza Tita, no izravna kritika lika i djela bivšega jugoslavenskog doživotnog predsjednika pričekala je raspad Jugoslavije i roman Sjaj epohe Borivoja Radakovića. (Kolanović, Maša Udarnik! Buntovnik? Potrošač... popularna kultura i hrvatski roman od socijalizma do tranzicije, Naklada Ljevak, Zagreb, 2011., str. 332) 
o razvoju češke književnosti nakon 1968., Dubravka Sesar tvrdi da se „nikada (...) u povijesti nije probila u svijet kao u tom razdoblju i nikada ranije nije bila europskija“" ${ }^{\text {"149 }}$. Navedeni fenomen Milan Kundera u svome eseju Tragedija Srednje Europe ${ }^{150}$ objašnjava pojačanom brigom za pojedine kulture u razdobljima opasnosti kako bi one, kao potvrda identiteta, opstale. Takav razvoj događaja uočava u zemljama srednje Europe nakon 1945., a u češkoj kulturi osobito nakon 1968.

Preslagivanja na češkoj književnoj sceni koja slijede s jačanjem cenzure uvjetuju račvanje češke književnosti u nekoliko smjerova. Međutim, cenzorskim je škarama na prijelomu šezdesetih i sedamdesetih potrebno određeno vrijeme za čišćenje javne scene od svega što, prema njihovoj procjeni, predstavlja opasnost društvenom uređenju ili je autorstvo osoba čije je djelovanje bilo suprotstavljeno službenome režimu. Zahvaljujući tome, u prvome je razdoblju nakon smjene reformnoga vodstva Komunističke partije Čehoslovačke put do publike još uvijek otvoren umjetnicima koji će u godinama koje dolaze postati najzvučnija imena disidentske scene. Tako, primjerice, u proljeće 1969. Komorní divadlo prikazuje dramu Porota Ivana Klíme, Divadlo na Zábradli Ptákovinu Milana Kundere, a godinu dana kasnije objavljena je i nova naklada Kunderine zbirke pripovijedaka Smiješne ljubavi (Směšné lásky). ${ }^{151}$ Do konačnoga formiranja odvojenih struja češke književnosti dolazi početkom sedamdesetih. Simboličkim krajem oblikovanja odvojene oficijelne književne scene smatra se govor književnika Jana Kozáka na kongresu Saveza čeških književnika 1972. u kojemu nedvosmisleno naglašava razliku, u kontekstu češke književnosti, između „zdrave jezgre“ $\mathrm{i}$ „štetočina“" 152

Od početka sedamdesetih godina dio književne scene izopćen iz javnoga života ili napušta zemlju u jednome od najsnažnijih emigracijskih valova u povijesti Čeha i Slovaka (a, potom, u inozemstvu utemeljuje izdavačke kuće) ili se u domovini povlači u ilegalu i objavljuje u samizdatu. Na taj se način razvija književni fenomen neoficijelne književne scene koja u godinama koje slijede predstavlja opoziciju vladajućoj, službenoj književnoj produkciji kojoj pripadaju pisci kojima je dopušteno objavljivanje u državnim izdavačkim kućama.

Središnje su tematske osi oko kojih svoje stvaralaštvo grade neoficijelni autori moć totalitarne ideologije i njen utjecaj na život pojedinca te, u kasnijem razdoblju u dijelu

\footnotetext{
${ }^{149}$ Sesar, Dubravka Povelja 77 u kontekstu češke disidentske književnosti: pogled na jedan pokret, u: Književna smotra, 29(1997), 2/3(104/105), str. 125-130.

${ }^{150}$ Kundera, Milan Tragedija Srednje Europe, Gordogan, God.07(1985), br. 17/18, br. 19, str. 289-305.

151 Janoušek, Pavel i suradnici Dějiny české literatury 1945-1989, IV. knjiga 1969-1989, Academia, Prag, 2008. str. 90, 389.

152 Isto, str. 389.
} 
korpusa nastaloga u egzilu, motiv života u novoj sredini. ${ }^{153}$ Cenzorski postupci koji nakon 1968. ograničavaju djelovanje književnika i potiskuju njihovo stvaranje u sferu ilegalnoga različiti su. Neposredno nakon sloma praškoga proljeća javnosti je onemogućen uvid u već tiskana izdanja, ${ }^{154}$ a u godinama koje su slijedile cenzorski postupci mahom pripadaju tzv. preventivnoj cenzuri ${ }^{155}$ kao jednoj od najučinkovitijih cenzorskih metoda koja u tkivo proskribiranoga teksta zasijeca prije, za vlast neugodna, trenutka njegova objavljivanja. Dio književnika, potaknutih različitim motivima, pribjegava autocenzuri kao najuspješnijem načinu preventivne cenzure. ${ }^{156}$ Oni čine, iako ne isključivo - dio je njih jednostavno uživao lukrativne položaje koje im je donosilo pristajanje uz službenu politiku ili su im stvaralački kapaciteti bili ograničeni - treću i četvrtu granu češke književnosti. Treću nazivamo sivom zonom kojoj pripadaju autori koji objavljuju i na službenoj sceni i neoficijelno, u samizdatu i egzilu. Ponekad njihova djela supostoje na objema scenama istovremeno, dok se neki autori tijekom dugih dvadeset godina, a uslijed promijenjenih okolnosti, repozicioniraju. Zasigurno su najzvučnija imena toga puta do državnih izdavačkih kuća Jiří Šotola i Bohumil Hrabal kojima je put iz samizdata otvoren sredinom sedamdesetih te klasik češke književnosti i dobitnik Nobelove nagrade za književnost 1984. Jaroslav Seifert. ${ }^{157}$ Polju oficijelne književnosti pripadaju autori koji objavljuju kod službenih, državnih nakladnika, a, samim time, otvoreni su im i kanali distribucije.

U hrvatskom tisku kratak pregled razvoja češke književnosti nakon 1968. daje Predrag Matvejević tekstom objavljenim 1986. u tjedniku Danas. Autore poput Bohumila Hrabala i Vladimíra Párala naziva ruskim terminom promežnutočaja literatura, tj. „književnost između onoga što može proći i što ne prolazi, što se propušta i što se zaustavlja“"158. Dopuštajući objavljivanje njihovih djela, službena vlast, prema Matvejeviću, želi pokazati svoju benevolentnost i ostaviti dojam demokratičnosti. ${ }^{159} \mathrm{U}$ skupinu autora „koji

\footnotetext{
153 Janoušek, Pavel i suradnici Dějiny české literatury 1945-1989, IV. knjiga 1969-1989, Academia, Prag, 2008. str. 385 .

${ }^{154}$ U tekstu ovoga rada već su spomenuti primjeri uništavanja naklada zbirke pjesama Antonína Brouseka Nouzový východ i Hrabalovih djela Poupata i Domácí úkoly na prijelomu šezdesetih i sedamdesetih godina. 155 Stipčević, Aleksandar O savršenom cenzoru, Nakladni zavod Hrvatske, Zagreb, 1994., str. 8.

${ }^{156}$ Autocenzurom smatra najuspješnijim oblikom cenzure književnik Danilo Kiš jer autor svome tekstu, čitajući ga, pridaje značenja koja mu cenzor nikada ne bi dao. U svome govoru održanome u Budimpešti 1985. Kiš ide korak dalje pa autocenzuru naziva „sestrom laži, duhovnom korupcijom i mentalnom manipulacijom“. Kiš, Danilo Cenzura/autocezura, u: Život, literatura - Sabrana dela Danila Kiša (knj. 14), Beogradski izdavačkografički zavod, Beograd, 1995., str. 97-102.

157 Janoušek, Pavel i suradnici Déjiny české literatury 1945-1989, IV. knjiga 1969-1989, Academia, Prag, 2008. str. 390 .

${ }^{158}$ Matvejević, Predrag Književnost i emigracija (Sivocrni humor), Danas, 4. 11. 1986., str. 36-38.

159 Isto.
} 
ne prolaze ili uopće ne bivaju propušteni“ ubraja Ivana Klímu, Ludvíka Vaculíka, Václava Havela, Karela Kosíka.

Tijekom sedamdesetih i osamdesetih godina 20. st. recepciju u Hrvatskoj ostvaruje i dramski dio neoficijelne produkcije. Naime, od kazališne sezone 1971./1972. s repertoara kazališta diljem Čehoslovačke istisnute su drame svih dramatičara koji su se u razdoblju reformnoga pokreta tijekom šezdesetih te tijekom i nakon praškoga proljeća politički angažirali. Osim domaćih autora, repertoari čeških kazališta postali su zabranjen teritorij i za drame kazališta apsurda i egzistencijalističke tematike poput onih Samuela Becketta, Alberta Camusa i Eugèna Ionesca. ${ }^{160} \mathrm{U}$ novonastaloj situaciji dio domaćih dramatičara pribjegava različitim mehanizmima kako bi svoje tekstove, ipak, čuli s kazališnih pozornica svjesni činjenice da svoju cjelovitost dramski tekst ostvaruje kazališnim uprizorenjem. Neki se dramatičari odlučuju na objavljivanje svojih djela pod tuđim imenima te životu svoga umjetničkog djela daju prednost pred stvaralačkim egom. Kod kazališnih su uprizorenja tekstovi dramatičara čija predstava ne bi prošla cenzorsku selekciju najčešće prikazivani pod imenom redatelja ili dramaturga. Tako je, u prosincu 1975. u mjestu Ústí nad Labem, Kunderina drama Žak Fatalist i njegov gospodar (Jakub a jeho pan) premijerno izvedena pod imenom redatelja Evalda Schorma, ${ }^{161}$ godine 1978. Jiří Menzel svoje ime ,posuđuje“ Jaroslavu Vostrom za izvedbu drame Tri u drugom (Tři $v$ tom) koja je pod Menzelovim autorstvom izvedena i u Hrvatskoj, ${ }^{162}$ a Václav Havel potvrđuje da je tekst svoje Prosjačke opere (Žebracká opera) pisao po narudžbi za jedno praško kazalište koje ga je trebalo uprizoriti pod imenom druge osobe ${ }^{163} \cdot{ }^{164}$ Sljedeći je fenomen kojim neoficijelni dramatičari pokušavaju izbjeći cenzorske škare tzv. bytové divadlo čija je suština izvedba dramskoga teksta za uzak krug ljudi, najčešće poznanike, prijatelje, suradnike u kazališnome svijetu, nerijetko disidentske istomišljenike. Tako u svojoj kući za odmor u Hrádečku kod Trutnova Václav Havel 1976. premijerno izvodi Audijenciju (Audience), a u drugoj polovici istoga desetljeća najpoznatije je bytové divadlo koje organizira glumica Vlasta Chramostová. ${ }^{165}$

\footnotetext{
160 Janoušek, Pavel i suradnici Dějiny české literatury 1945-1989, IV. knjiga 1969-1989, Academia, Prag, 2008., str. 96.

${ }^{161}$ Isto, str. 650.

${ }^{162}$ Isto, str. 96.

${ }^{163}$ Šömen, Branko Češki sanjar: Václav Havel od disidenta do prezidenta, Profil, Zagreb, 2012., str. 107.

${ }^{164}$ Primjer sličan Havelovu je i onaj Jiř́ja Šotole čija je komedija Zázrak na Louži, radnje smještene u vrijeme vladavine Václava IV., 1974. premijerno prikazana u jednom praškome kazalištu pod imenom dramaturga i redatelja Milana Calábeka. Janoušek, Pavel i suradnici Dějiny české literatury 1945-1989, IV. knjiga 1969-1989, Academia, Prag, 2008., str. 622.

${ }^{165}$ Janoušek, Pavel i suradnici Dějiny české literatury 1945-1989, IV. knjiga 1969-1989, Academia, Prag, 2008., str. 108.
} 
Analognih primjera dramskoj produkciji objavljivanja tekstova pod imenima režimski dopuštenih autora pronalazimo i u izdavačkoj djelatnosti. Primjerice, 1970. u Pragu je objavljena zbirka pripovijedaka Variace na zločinu autorâ Vladimíra Škutine i Jaromíra Šikla. No, kako je te godine Vladimír Škutina već djelovao u egzilu, na praškome izdanju njegovo je ime izostavljeno. Deset je godina kasnije ista zbirka pripovijedaka objavljena u egzilu, u švicarskome Zürichu, no to je izdanje ,prešutjelo“ autorstvo Jaromíra Šikla koji je tih godina u Čehoslovačkoj bio jedan od suradnika pri produkciji vrlo popularne televizijske serije Třicet prípadi̊ majora Zemana. ${ }^{166}$

Kriterij za razvrstavanje književnika u oficijelni ili neoficijelni dio češke književnosti rijetko se kada temeljio na njegovu književnom opusu. Češće je o tome tko će uživati zaštitu i mecenatstvo države, a tko će biti potisnut u ilegalu odlučivala građanska biografija pisca i njegov eventualni politički angažman. ${ }^{167}$ Pripadnost oficijelnoj sceni zahtijevala je urednu građansku biografiju pisca, izostanak političkoga aktivizma prije i tijekom praškoga proljeća

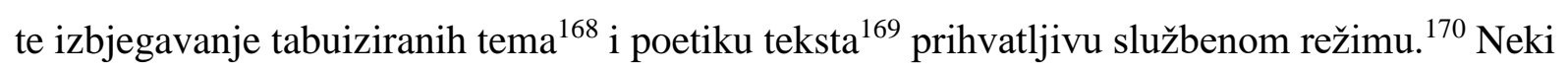
analitičari, poput Jiříja Brabeca, motivaciju pripadnika oficijelne književne scene za lojalnost službenome režimu vide u osobnom konformizmu i privilegijama koje su ti književnici uživali kao zahvalu za svoje umjetničko djelovanje. ${ }^{171}$ Međutim, objavljivanje povijesti češke književnosti 1994. pokazalo je da je „oštra podjela na 'službenu' i 'zabranjenu' suvremenu

\footnotetext{
166 Janoušek, Pavel i suradnici Dějiny české literatury 1945-1989, IV. knjiga 1969-1989, Academia, Prag, 2008. str. 725 .

${ }^{167}$ Isto, str. 238.

${ }^{168}$ Kvalitativni vrhunci oficijelne produkcije sedamdesetih tematski su usmjereni obiteljskoj problematici, krizi međuljudskih odnosa, povijesnim temama (u kojima neki iščitavaju alegorijom zaogrnuto progovaranje o aktualnim temama). Janoušek, Pavel i suradnici Dějiny české literatury 1945-1989, IV. knjiga 1969-1989, Academia, Prag, 2008., str. 551.

${ }^{169}$ Primjerice, u poeziji je službena poetika zahtijevala razumljivost širokim krugovima čitateljstva bez eksperimentiranja na planu izraza i sadržaja. Janoušek, Pavel i suradnici Dějiny české literatury 1945-1989, IV. knjiga 1969-1989, Academia, Prag, 2008., str. 235.

170 Janoušek, Pavel i suradnici Dějiny české literatury 1945-1989, IV. knjiga 1969-1989, Academia, Prag, 2008. str. 390 .

${ }^{171}$ Brabec, Jiří Otazniky nad literární historii sedmedesátých a osmdesátých let, u: Panství ideologie a moc literatury. Studie, kritiky, portréty (1991-2008), Akropolis, Prag, 2009., str. 156-167.

O motivu osobnih privilegija kojima službeni režim pokušava otupiti oštricu kritike javnosti u kontekstu hrvatske književnosti piše Slavko Mihalić u tekstu o reakcijama na govor Antuna Šoljana u ožujku 1964. povodom 50. obljetnice smrti A. G. Matoša zbog kojega doživljava optužbe za nacionalizam: ,,Onaj koji tvrdi suprotno, 'zaboravlja' da je taj govor, koji će Tonko kasnije objaviti kao dio svoje literature, zapravo bio $i$ formalni razlaz s onima koji su ga silom, a i nudeći ga viskijem, htjeli uvući u tzv. 'avangardu' (dakako, političku).“ Mihalić, Slavko Dvije pjesme posvećene Tonku, u: Šoljanov zbornik: Dani Antuna Šoljana u Rovinju, 1996. - 2000., ur. Boris Biletić, Pučko otvoreno učilište grada Rovinja, Istarski ogranak Društva hrvatskih književnika, Rovinj, Pula, 2001., str. 44.
} 
književnost praktički nemoguća“ ${ }^{\text {(172 }}$ jer ,u oba poglavlja nalazimo mnoštvo istih imena, ali ne $\mathrm{i}$ istih djela“173.

Iako na polju neoficijelne književnosti tijekom normalizacije nastaju neke od najboljih stranica češke književnosti ikada i iako je recepcija neoficijelnih autora u Europi sjajna, povjesničari književnosti koji u tom razdoblju djeluju u Čehoslovačkoj prema samizdatskoj i egzilnoj produkciji imaju ignorantski stav. Pregledi povijesti češke književnosti sastavljeni tijekom normalizacije, ako i uključuju imena neoficijelnih autora, ne sadrže dio njihova opusa nastao u tome razdoblju.

Dijagram I: Razvoj češke književnosti nakon 1968.

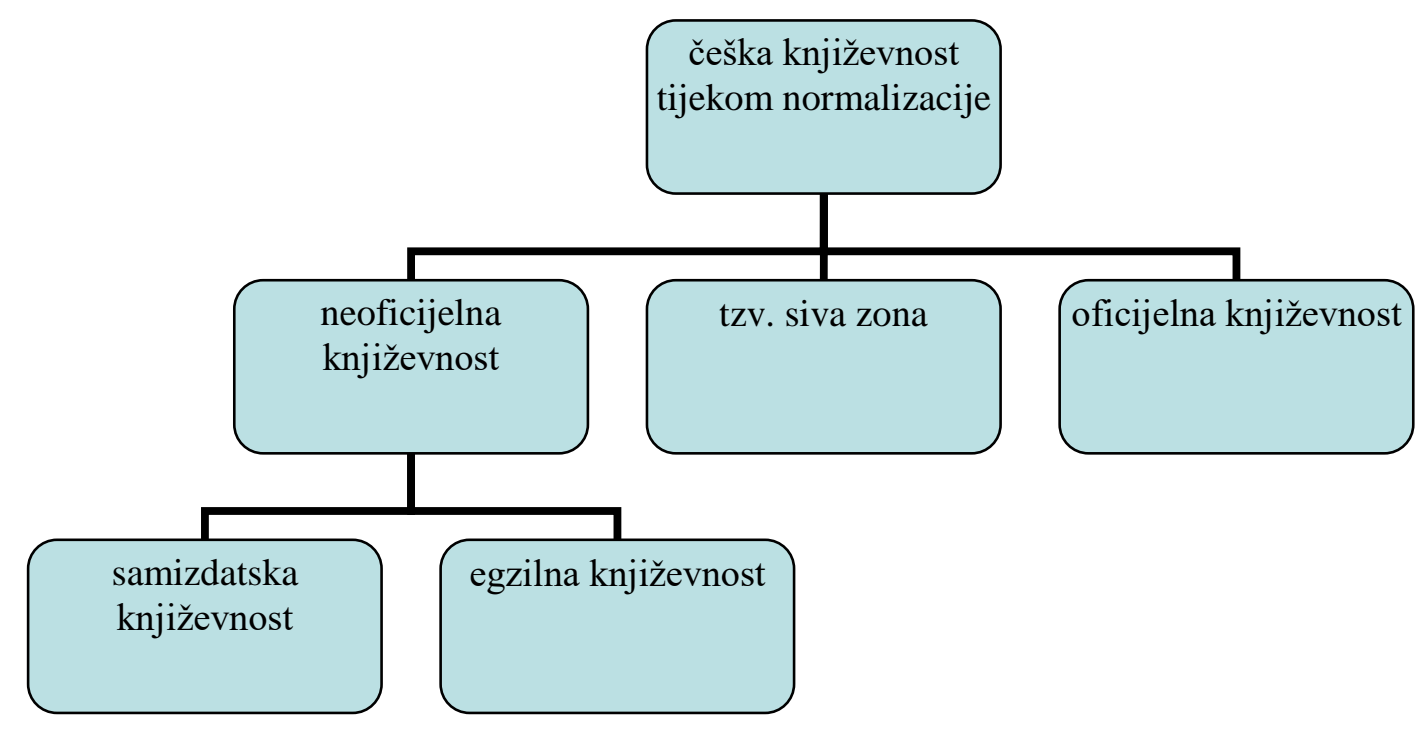

U drugoj polovici osamdesetih razvoj događaja u čehoslovačkome društvu i razvoj tehnologije donose velike promjene i na književnoj sceni. Društvene okolnosti idu u prilog integraciji triju struja češke književnosti koje su supostojale u prethodna dva desetljeća, a razvoj tehnologije koji je desetak godina ranije bio nezamisliv, omogućava dodatnu afirmaciju neoficijelne scene i distribucijske kanale kojima dolazi do recipijenata. Tako, primjerice, 1988. ilegalnim putevima počinju kolati snimke predstave Václava Havela

\footnotetext{
${ }^{172}$ Sesar, Dubravka Povelja 77 u kontekstu češke disidentske književnosti, u: Egzil, emigracija Novi kontekst, zbornik, ur. Irena Lukšić, Hrvatsko filološko društvo, Zagreb, 2002., str. 215.

${ }^{173}$ Isto, str. 215.
} 
Iskušavanje (Pokoušení). ${ }^{174}$ Istodobno, oficijelna i neoficijelna književna scena prvi put započinju intenzivniju suradnju koja se vremenom prelijeva i na institucionalnu razinu. U ožujku 1989. u zaključke plenarne sjednice Saveza čeških književnika ulazi mišljenje da u pregled češke književnosti nastale od kraja Drugoga svjetskog rata treba uključiti i djela neoficijelnih autora. Zaključcima sjednice Savez podržava uvrštavanje neoficijelnih autora u planove izdavačkih kuća. Samo dva mjeseca kasnije u Njemačkoj je organiziran sastanak predstavnika Saveza čeških književnika Petra Prouze i Ondřeja Neffa te predstavnika egzilne scene Jiř́ja Gruše, Petra Krála, Antonína Brouseka i Jaroslava Hutke. ${ }^{175}$ Sve te inicijative i šire društveno-političke okolnosti tijekom 1989. na scenu vraćaju donedavno proskribirane autore. $^{176}$

Oficijelna se kultura počinje otvarati i nekim drugim tekstovima do tada potisnutima $u$ ilegalu. O njihovu prevrednovanju od strane predstavnika kulture scene koju kontrolira čehoslovački službeni režim vijesti počinju donositi i hrvatske novine od 1987. Tako Vjesnik izvještava o tekstu o Franzu Kafki ${ }^{177}$ objavljenome u časopisu Tvorba u kojemu se poziva na „preispitivanje vrijednosti dugo zapostavljenih djela češke i strane književnosti““178. Isti dnevnik šest mjeseci kasnije objavljuje izvještaj Tanjugova dopisnika iz Praga Save Bosanca o anketi časopisa Rudé právo među 30000 čehoslovačkih čitatelja čiji odgovori navještavaju da u javnosti postoji percepcija o određenoj razini medijske cenzure. ${ }^{179}$ U ožujku 1989. Vjesnik prenosi intervju koji Michal Černík, aktualni predsjednik Saveza književnika Čehoslovačke, daje talijanskim novinama povodom uhićenja Václava Havela. Iako, kako

\footnotetext{
${ }^{174}$ Janoušek, Pavel i suradnici Dějiny české literatury 1945-1989, IV. knjiga 1969-1989, Academia, Prag, 2008. str. 812 .

175 Janoušek, Pavel i suradnici Dějiny češké literatury 1945-1989, IV. knjiga 1969-1989, Academia, Prag, 2008. str. 52-53.

176 Tijekom 1989. u kazališne repertoare opet su uvrštene drame Josefa Topola, a na festivalu Divadlo dneška javno su čitani dramski tekstovi Milana Uhdea i Ivana Klíme. Janoušek, Pavel i suradnici Dějiny české literatury 1945-1989, IV. knjiga 1969-1989, Academia, Prag, 2008., str. 110.

${ }^{177}$ Krajem osamdesetih simpozij u Beču okuplja književnu elitu srednje Europe, među kojima i češke egzilante Pavela Kohouta i Libušu Moníkovu koja je 1989. dobitnica austrijske književne nagrade Franz Kafka. Ondje hrvatski pjesnik i, kasnije, akademik Nikica Petrak razliku u recepciji opusa Franza Kafke nakon Drugoga svjetskog rata u čehoslovačkome i jugoslavenskome društvu navodi kako bi pojasnio distinkciju komunističkih uređenja tih dviju država. Dok su opusi književnika poput Kafke i Thomasa Manna u Čehoslovačkoj bili politički upitni, u jednom razdoblju i proskribirani, u Jugoslaviji to nije bio slučaj. (Petrak, Nikica Beč između ostalog, Oko, br. 13(477), 28. 6. 1990., str. 3)

Zanimljivo je primijetiti da povratak Franza Kafke u javni prostor i krajem osamdesetih, ali i šezdesetih označava simbolički nagovještaj promjena. Naime, prema nekim tumačenjima, liberalizaciju čehoslovačke javnosti u šezdesetima možemo pratiti još od 1963. kada je u Libicama pokraj Praga održana konferencija u organizaciji Instituta za književnost ČSAV-a, a koja je označila početak procesa rehabilitacije toga književnika. (Pelikán, Jiří Praško proljeće, OOUR Globus, Biblioteka Globus, Zagreb, 1982., str. 206)

178 Zapostavljen Kafka, Vjesnik, br. 14469, 25. 12. 1987., str. 12.

${ }^{179}$ Bosanac, Savo Cenzura - društveni teret, Vjesnik, br. 14623, 2. 6. 1988., str. 3.
} 
izjavljuje u intervjuu, ne podržava Havelove stavove i djelovanje - u to je vrijeme Havel na izdržavanju zatvorske kazne zbog aktivnosti u obilježavanju dvadesete godišnjice samospaljivanja Jana Palacha, Černík izražava neslaganje s represivnim postupcima službene vlasti. Istom prilikom progovara i o osjetnoj demokratizaciji javnoga prostora do koje u zemlji dolazi, a čiji poticaj nedvosmisleno uočava u sovjetskoj glasnosti, te se nada da će „međunarodna klima“ olakšati propuštanje u javni prostor do tada prešućivanih egzilnih i samizdatskih književnika. ${ }^{180}$

Tijekom 1989. i 1990. dnevni tisak u Hrvatskoj donosi niz vijesti o sve snažnijim kontaktima čehoslovačke oficijelne i neoficijelne kulturne scene, a vrhunac napora u tome smjeru zasigurno predstavlja prva javna legalna izvedba drame Václava Havela u Pragu nakon praškoga proljeća te, na inozemnoj sceni, pokretanje časopisa simbolična naziva Most koji je trebao postati mjesto susreta oficijelne i emigrantske kulture. ${ }^{181}$ Komunikacija teče i u suprotnome smjeru tako što se samizdat otvara osobama koje do tada nisu bile njen dio. Samizdatski časopis Lidové noviny uz tekstove predstavnika neoficijelne scene objavljuje i tekstove autora, zaštićene pseudonimima, zaposlenih u državnim institucijama i medijskim redakcijama. ${ }^{182}$

\section{1. Egzilna češka književnost tijekom normalizacije}

Egzilna produkcija generacije koja iz Čehoslovačke iseljava nakon kolovoza 1968. nadovezuje se na tradiciju češkoga i slovačkoga egzila koji se počinje razvijati još 1948 . Te je godine, nakon odbijanja Marshallova plana, svrstavanja Čehoslovačke u skupinu zemalja pod snažnim utjecajem SSSR-a i sastavljanja republičke Vlade gotovo isključivo od pripadnika komunista, započeo val emigracije koji traje do 1951., a u kojemu zemlju napušta oko 25000 građana. ${ }^{183}$ Određeno vrijeme nakon 1968. kod dijela predstavnika dviju generacija češkoga egzila vlada nepovjerenje budući da su neke od najznačajnijih osobnosti druge generacije

\footnotetext{
180 „Ne možemo se praviti da ne postoje autori kao što su Havel, Škvorecký ili Klíma, samo zato što imaju različit pogled na svijet, niti se mogu vrednovati književna djela na temelju dogmatskih kriterija. " Presuda je stroga, ne podržavam je, Vjesnik, br. 14899, 11. 3. 1989., str. 7.

${ }^{181}$ I ČSSR ruši „,zavjesu“, Večernji list, br. 9443, 2. 12. 1989., zadnja stranica; Kurbel, Virgil Izlazak iz podruma, Večernji list, br. 9454, 13. 12. 1989., str. 40; Audijencija - i kod kuće, Večernji list, br. 9479, 10.1. 1990., str. 31; Janoušek, Pavel i suradnici Dějiny české literatury 1945-1989, IV. knjiga 1969-1989, Academia, Prag, 2008., str. 205.

182 Janoušek, Pavel Dějiny české literatury 1945-1989, IV. knjiga 1969-1989, Academia, Prag, 2008., str. 50.

183 Rada, Ivan i dr. Povijest Češke, Sandorf, Zagreb, 2013., str. 660.
} 
emigranata osobe koje su, zbog svojih političkih funkcija koje su u matičnoj zemlji obnašali tijekom šezdesetih, bile suradnici društvenoga sustava koji je generaciji iz 1948. onemogućavao djelovanje u domovini. ${ }^{184}$ Međutim, postupno se između dviju generacija razvija suradnja. ${ }^{185}$ Ponekad je ona bila od samoga početka kvalitetna. Tako, primjerice, u Kanadi 1967. Mirko Janeček pokreće egzilni časopis Hlas nových kako bi pružio informativnu i financijsku podršku egzilantima druge generacije. ${ }^{186}$

Utemeljenjem egzilne književne scene smatra se objavljivanje romana Oklopni bataljon (Tankový prapor) Josefa Škvoreckog 1971. u tek osnovanoj izdavačkoj kući 68 Publishers u kanadskome Torontu. U sljedeća dva desetljeća temelj egzilnoga izdavaštva činile su, uz torontski 68 Publishers, izdavačke kuće Index u Kölnu i Rozmluvy u Londonu te niz književnih časopisa od kojih su najčitaniji Listy ${ }^{187}$ Jiř́ja Pelikana i Svědectvi ${ }^{188}$ Pavela Tigrida. ${ }^{189}$ Predstavnicima egzilne scene koji iz Čehoslovačke odlaze nakon kolovoza 1968., a zahvaljujući pozitivnoj inozemnoj percepciji čehoslovačkoga reformnog pokreta šezdesetih, integracija u nove domovine, mahom je riječ o zapadnoeuropskim državama, Kanadi i Sjedinjenim Američkim Državama, u potpunosti je olakšana. ${ }^{190}$

U egzilnoj produkciji nakon 1968. kvantitativno prednjače proza i poezija. Poezija time nastavlja trend izuzetno visokih naklada u Čehoslovačkoj tijekom šezdesetih pa egzilni autori, iako su izdanja poezije tržišno neisplativa, nerijetko samostalno financiraju objavljivanje svojih zbirka pjesama. S druge strane, dramska produkcija ne zauzima značajan dio opusa književnika u egzilu što se tumači činjenicom da su rezultati pokušaja uprizorenja dramskih tekstova u takvim uvjetima u većoj mjeri neizvjesni. ${ }^{191}$

\footnotetext{
${ }^{184}$ Janoušek, Pavel i suradnici Dějiny české literatury 1945-1989, IV. knjiga 1969-1989, Academia, Prag, 2008. str. 140.

185 Josef Škvorecký svoju izdavačku kuću u Torontu 68 Publishers osniva u suradnji s Egonom Hostovským i Jiř́jem Voskovcem, emigrantima iz druge polovice četrdesetih godina 20. st. Janoušek, Pavel i suradnici Dějiny české literatury 1945-1989, IV. knjiga 1969-1989, Academia, Prag, 2008., str. 147.

186 Přibáň, Michal Poúnoroví na počátku posrpnového exilu, u: Život je jinde...?, Česká literatura, kultura a společnost v sedmdesátých a osmdesátých letech dvacátého století, prir. Jan Matonoha. Ústav pro českou literaturu $A V \check{C} R$, Prag, 2002., str. 65.

${ }^{187}$ Listy su jedini egzilni časopis čije objavljivanje nije prestalo nakon baršunaste revolucije. U egzilu objavljivan u Rimu, od 2003. objavljuje ga naklada Burián a Tichák u Olomoucu.

188 Časopis Svědectví pokrenut je još 1956. u New Yorku, od 1960. izlazi u Parizu, a, potom, još dvije godine nakon baršunaste revolucije u Pragu.

189 Janoušek, Pavel i suradnici Dějiny české literatury 1945-1989, IV. knjiga 1969-1989, Academia, Prag, 2008., str. $137,152$.

190 Janoušek, Pavel i suradnici Dějiny české literatury 1945-1989, IV. knjiga 1969-1989, Academia, Prag, 2008. str. 139.

${ }^{191}$ Měšt'an, Antonín Lesk a bida české exilové literatury sedmdesátých a osmdesátých let, u. Život je jinde...?, Česká literatura, kultura a společnost v sedmdesátých a osmdesátých letech dvacátého století, prir. Jan Matonoha. Ústav pro českou literaturu AV ČR, Prag, 2002, str. 37.
} 
Tijekom dvadesetak godina normalizacije u matičnoj zemlji egzilna scena neprestano dobiva na snazi ojačana novim imenima koja je obogaćuju u nekoliko valova iseljavanja tijekom sedamdesetih i osamdesetih. ${ }^{192}$ Valu emigranata s kraja šezdestih čije je najzvučnije ime Josef Škvorecký, 1975. pridružuje se Milan Kundera, a zatim i niz novih imena, među kojima Pavel Kohout i Vladimír Škutina nakon potpisivanja Povelje $77 .{ }^{193}$ Drugi razlog kontinuirana razvitka egzilne scene nalazi se u činjenici da predstavnici egzila postaju sve vještiji u pronalaženju izvora financiranja što im olakšava organizaciju i obogaćuje produkciju. U Stockholmu 1978. František Janouch osniva Nadace Charty 77 koju financira Institut Otvoreno društvo Georgea Sorosa te tijekom osamdesetih pokreće dvije nagrade čiji su laureati predstavnici neoficijelne književnosti, 1984. Nagradu Toma Stopparda, a dvije godine kasnije Nagradu Jaroslava Seiferta. ${ }^{194}$

Baze podataka izdanja nastalih na češkome jeziku izvan Čehoslovačke tijekom normalizacije bilježe i izdanja izdavačkih kuća koja nisu utemeljili češki egzilanti. U osamdesetima izdanja na češkome jeziku kršćanske, odnosno katoličke provenijencije objavljuju zagrebačka Kršćanska sadašnjost i Župni ured Međugorja. U popisu izdanja Kršćanske sadašnjosti iz 1984. nalazi se češki prijevod djela poljskoga liječnika i pedagoga židovskoga porijekla Janusza Korczaka Sám s Bohem: modlitby těch, kteři se nemodlí, a Župni ured Međugorje 1990. objavljuje knjižicu Jsem vaše Matka a Královna míru: Panna Maria v Medžugorje. ${ }^{195}$

Osim tih dvaju izdanja vjerske tematike objavljenih u izdavačkim kućama na tlu Jugoslavije, digitalna baza čeških egzilnih izdanja Libri Prohibiti donosi i podatake o izdanjima na češkome jeziku autora iz jugoslavenskih republika namijenjena češkim čitateljima izvan domovine, uglavnom je riječ o tekstovima religiozne tematike i zapisima političkih disidenata. Knjigu $O$ některých otazkách pohlavni etiky hrvatskoga kardinala Franje Šepera i belgijskoga kardinala Jérômea Hamera 1976. objavljuje rimska izdavačka kuća Křest'anská akademie. U ciriškom Demosu 1977. objavljena je studija crnogorskoga disidenta Milovana Đilasa ${ }^{196}$ Nová tř́da: kritika soudobého komunismu, ${ }^{197}$ a tekstovi su mu objavljeni i

\footnotetext{
${ }^{192}$ Urbanec, Jiři Básnické debuty sedmdesátých let, u: Život je jinde...?, Česká literatura, kultura a společnost v sedmdesátých a osmdesátých letech dvacátého století, prir. Jan Matonoha. Ústav pro českou literaturu AV ČR, Prag, 2002., str. 155.

193 Janoušek, Pavel i suradnici Dějiny české literatury 1945-1989, IV. knjiga 1969-1989, Academia, Prag, 2008. str. 398, 399.

${ }^{194}$ Isto, str. 156.

195 www.libpro.cz/katalog/emil/emil3.htm, pristupljeno 27. 12. 2018.

196 Đilas, Milovan (1911. - 1995.), crnogorski političar, književnik i publicist. Istaknuti član Komunističke partije Jugoslavije do 1953. kada objavljuje niz tekstova u kojima kritizira jednostranački sustav i privilegije
} 
1989. u knjizi Demokratická revoluce: stav a výhledy světa. ${ }^{198}$ U Zürichu je 1978. pokrenut i satirički zbornik Revue napětí a humoru, a na stranicama njegova prvog sveska nalaze se tekstovi hrvatskoga satiričara, utemeljitelja zagrebačkoga kazališta Jazavac (SK Kerempuh), Fadila Hadžića pod pseudonimom Zorana Zeca. Godine 1984. pariški zbornik Polská krize a východní Evropa sadrži i eseje srpskih praksisovaca, filozofa Mihajla Markovića i filozofkinje Zagorke Golubović. Kölnski Index 1988. objavljuje zbirku pripovijedaka Danila Kiša Hrobka pro Borise Davidoviče a tři dalši povidky te godinu kasnije tekst hrvatskog publicista Karla Štajnera u knjizi Svědkové revoluce: někdejši spolupracovníci Lenina a Stalina vypovídají.

Dio autora s egzilne književne scene svoja djela, nakon nekoga vremena u emigraciji, počinje pisati jezikom svoje druge domovine. Najpoznatiji od njih zasigurno je Milan Kundera koji 1995. objavljuje kratak roman Polaganost pisan francuskim jezikom. Osim Kundere, najpoznatiji bilingvalni autori češkoga egzila su Pavel Kohout, Jiří Gruša i Libuše Moníková ${ }^{199}$ koji stvaraju na njemačkome jeziku te Jan Novák koji piše engleskim. ${ }^{200}$

\section{2. Samizdatska češka književnost tijekom normalizacije}

Dio čehoslovačkih književnika kojima je onemogućeno slobodno objavljivanje, a ne odlaze u emigraciju, odlučuje se na umnažanje i distribuciju svojih tekstova u samizdatu ${ }^{201}$. Prva je samizdatska edicija tijekom normalizacije u Čehoslovačkoj, Texty prátel, pokrenuta 1972. u Olomoucu, a krajem iste godine Ludvík Vaculík pokreće i onu koja će u sljedeća dva

\footnotetext{
vladajućega sloja. Nakon toga izbačen iz Partije i javnoga života te osuđen na nekoliko zatvorskih kazni, ukupno je odslužio devet godina zatvora. Od sredine pedesetih premetnuo se u jednog od vodećih kritičara komunizma. www.enciklopedija.hr (natuknica Milovan Đilas, pristupljeno 1. 9. 2019.)

${ }^{197}$ Riječ je o drugom izdanju Đilasove knjige u češkome egzilu, prvi je put knjiga objavljena 1958. u švedskome Lundu. http://www.libpro.cz/katalog/emil/emil1.htm, pristupljeno 4. 1. 2019.

${ }^{198} \mathrm{http}: / /$ www.libpro.cz/katalog/emil/emil1.htm, pristupljeno 4. 1. 2019.

${ }^{199}$ Iako tekstovi Libuše Monikové tijekom normalizacije u prijevodu nisu dostupni čitateljima u Hrvatskoj, dnevne novine donose vijesti o toj autorici. U svibnju 1989. Večernji list u rubrici Prizma obavještava da je književnica dobitnica austrijske književne nagrade Franz Kafka. Prizma, Večernji list, br. 9255, 24. 5. 1989., str. 10.

200 Janoušek, Pavel i suradnici Dějiny české literatury 1945-1989, IV. knjiga 1969-1989, Academia, Prag, 2008., str. 393.

${ }^{201}$ Samizdat (rus. samizdat, od samyj: sam + izdatel'stvo: izdavanje, izdavaštvo) naziv je za publikaciju koju, u pravilu ilegalno, umnaža i distribuira sâm pisac. Termin je nastao u bivšem Sovjetskom Savezu iz kojega se proširio u druge zemlje s nedemokratskim društvenim uređenjima i ograničenom slobodom izražavanja.
} 
desetljeća biti najznačajnija - Edice Petlice.$^{202}$ Od tada do pada komunizma na tlu Čehoslovačke osnovano je devedesetak samizdatskih izdavača, ${ }^{203}$ od kojih se, uz Vaculíkovu Edice Petlice, kvantitetom izdanja izdvajaju Česká expedice, Edice Expedice, Krameriova expedice, Kvart, Popelnice i Pražská imaginace. Samizdatska je scena u Čehoslovačkoj imala dva razdoblja intenzivna uspona. Prvi, na početku sedamdesetih kada započinje njen razvoj, te od sredine osamdesetih koji je posljedica osuvremenjivanja tehnika umnažanja teksta. ${ }^{204}$

Izdanja većine samizdatskih izdavača bila su tematski i autorski heterogena, no dio njih specijalizira svoju djelatnost za djela jednoga autora, poput Jungiane koja objavljuje prijevode tekstova slavnoga psihijatra Carla Gustava Junga, njegovih učenika i sljedbenika te praškoga Alefa, izdavača autora židovskoga porijekla. Osim proskribiranih čeških književnika samizdatski izdavači tijekom normalizacije nerijetko objavljuju i djela predstavnika drugih nacionalnih književnosti. Višestruku recepciju kod samizdatskih izdavača ostvaruju romani Georgea Orwella objavljeni u Havelovoj Edice Expedice, ali i u nakladama Krameriova Expedice, Popelnice i Klenotnice. Samizdatski izdavači objavljuju i djela klasika poput Williama Shakespearea, Charlesa Baudelairea i Guillaumea Apollinairea. ${ }^{205}$

Između dviju scena češke neoficijelne književnosti, samizdatske i egzilne, suradnja je postojala u onoj mjeri u kojoj su to logističke okolnosti dopuštale. ${ }^{206}$ Zbog otežanih kanala distribucije egzilni i samizdatski izdavački prinuđeni su snalaziti se na različite načine kako bi komunikacija tekla i kako bi, u konačnici, tekstovi došli do čitatelja. Egzilni izdavači nerijetko objavljuju djela samizdatskih autora uz napomenu da je tekst objavljen bez znanja i suglasnosti autora. Tekstovi egzilnih autora nerijetko se čitateljima u Čehoslovačkoj dopremaju diplomatskim kanalima, a da bi se olakšala distribucija takvih izdanja, oni,

\footnotetext{
202 Janoušek, Pavel i suradnici Dějiny české literatury 1945-1989, IV. knjiga 1969-1989, Academia, Prag, 2008. str. 37.

203 Toliki broj samizdatskih nakladnika navodi Jitka Hanáková u knjizi Edice českého samizdatu (Národní knihovna České Republiky, Prag, 1997., str. 329), no napominje da popis samizdatskih izdavačkih kuća objavljen u knjizi nije konačan.

204 Janoušek, Pavel i suradnici Dějiny české literatury 1945-1989, IV. knjiga 1969-1989, Academia, Prag, 2008. str. 42.

205 Hanáková, Jitka Edice češkého samizdatu 1972-1991, Národni knihovna České Republiky, Prag, 1997.

206 Tekstovi većine neoficijelnih autora čija su djela ostvarila recepciju i među hrvatskim čitateljima paralelno su objavljivani i u samizdatu i u egzilu, najčešće, sa znatnom razlikom u brojnosti izdanja. Primarno samizdatsko izdanje Pisama Olgi Václava Havela u samizdatu je ostvarilo šest izdanja, u egzilu jedno, 1985. u izdavačkoj kući 68 Publishers J. Škvoreckog. Većina izdanja Milana Kundere objavljena je samo u egzilu, također u Torontu u izdavačkoj kući 68 Publishers. Edice českého samizdatu Jitke Hanákové bilježi samo tri Kunderina djela u samizdatu: zbirku pjesama Monology, roman Knjiga smijeha i zaborava (Kniha smichu a zapomnění) objavljen u izdavačkoj kući Červená Karkulka 1987. te Nepodnošljivu lakoću postojanja (Nesnesnitelná lehkost bytí) objavljenu 1988. (kao autor romana naveden je Ludvík Kundera - Hanáková, Jitka Edice českého samizdatu 1972-1991, Národní knihovna České Republiky, Prag, 1997., str. 148)
} 
ponekad, ne sadrže podatke o izdavaču ${ }^{207} \cdot{ }^{208}$ Međutim, i kada egzilna izdanja uspiju pronaći put do čitatelja u matičnoj zemlji, riječ je o vrlo malenom broju primjeraka dostupnih, uglavnom, uskom krugu čitatelja u Pragu. Najveći dio egzilne produkcije čitateljima u Čehoslovačkoj ostao je potpuna nepoznanica sve do pada komunizma.

Nasuprot tome, niti jedna od tih scena ne surađuje s predstavnicima oficijelne sve do kraja osamdesetih godina. I dok oficijelni povjesničari književnosti u domovini ignoriraju neoficijelnu scenu, predstavnici egzilne scene u pojedinim svojim izdanjima prate zbivanja $\mathrm{u}$ domovini i njima se bave u dijelu svoga književnokritičarskoga rada. ${ }^{209}$

\section{3. Oficijelna češka književnost u Hrvatskoj od 1968. do 1990.}

U razdoblju u kojem je hrvatska čitateljska publika bila usmjerena bestselerima predstavnika neoficijelne produkcije, poput Milana Kundere i Josefa Škvoreckog, a kazališta dramama Václava Havela i Pavela Kohouta, na institucionalnoj razini organizatori kulturnih događaja, najčešće predstavnici udruženja pisaca, surađuju sa službenim predstavnicima češke kulture.

Na tradicionalnim Zagrebačkim književnim razgovorima tijekom sedamdesetih i osamdesetih redovito sudjeluju i izaslanstva čehoslovačkih udruženja pisaca. Godine 1975. tema su Književnih razgovora književna pobuna i otpor, a među književnicima i prevoditeljima šesnaest europskih i afričkih zemalja su i Čeh Ladislav Fuks te Slovaci Ján Beňo i Fero Lipka. U još većem broju češki i slovački književni radnici pohode Književne razgovore 1982. čija je tema odnos ironije i suvremene književnosti. Slovački predstavnici su književnici Rudolf Chmel, Jan Buzássy i Štefan Balák, a češki Jarmila Urbánková, ${ }^{210}$ Josef

\footnotetext{
${ }^{207}$ Primjerice, izdanja kölnskoga Indexa objavljivanja su bez potpunih informacija o izdavaču kako bi ih bilo lakše distribuirati među čitateljima u Čehoslovačkoj. Janoušek, Pavel i suradnici Dějiny české literatury 1945 1989, IV. knjiga 1969-1989, Academia, Prag, 2008., str. 147.

208 Janoušek, Pavel i suradnici Dějiny české literatury 1945-1989, IV. knjiga 1969-1989, Academia, Prag, 2008. str. 145 .

${ }^{209}$ U Torontu 1979. Josef Škvorecký i Antonín Brousek u knjizi Na brigadě objavljuju svoje

književnokritičarske oglede o predstavnicima oficijelne scene u domovini. Janoušek, Pavel i suradnici Dějiny české literatury 1945-1989, IV. knjiga 1969-1989, Academia, Prag, 2008., str. 191.

${ }^{210}$ Urbánková, Jarmila (1911. - 2000.), češka prevoditeljica i pjesnikinja. Od 1960. profesionalna književnica. Većina joj je poezije objavljivana u časopisima. www.slovnikceskeliteratury.cz (natuknica Jarmila Urbánková, pristupljeno 1.9. 2019.)
} 
Peterka $^{211}$ i Kamil Mařík ${ }^{212}$ čije dnevničke zapise o boravku u Zagrebu iz češkoga tjednika Tvorba u nastavcima objavljuje zagrebački časopis Oko. ${ }^{213}$ Iste je godine Nagrada Julije Benešić Društva hrvatskih književnika, uz sovjetsku prevoditeljicu Nataliju Vagapovu, dodijeljena i Čehinji Ireni Wenigovoj. ${ }^{214}$ Dio je programa Književnih razgovora te godine i večer češke i slovačke poezije Milovanje prije sna na kojoj nastupaju članovi čehoslovačke delegacije. ${ }^{215}$ Poeziju izvedenu na toj pjesničkoj večeri na hrvatski jezik prevodi književnik Zvonimir Golob. Golobov je prijevod kasnije objavljen i u istoimenoj opsegom skromnoj zbirci poezije na dvadeset stranica u izdanju Društva književnika Hrvatske o kojoj je pozitivno intonirana kritika objavljena i u čehoslovačkome tisku. ${ }^{216}$ Tri godine kasnije, 1985. na Zagrebačkim književnim razgovorima sudjeluje tadašnji tajnik Saveza čehoslovačkih književnika Rudolf $\mathrm{Chmel}^{217}{ }^{218}$

Povremenim istupima na stanicama tiska, što se intenzivira krajem osamdesetih godina, hrvatski se čitatelji upoznaju i sa stavovima dužnosnika državnih strukovnih udruženja čeških i slovačkih književnika. Dulji intervju Mirka Galića s Věrom Adlovom, ${ }^{219}$ tajnicom za međunarodne odnose Saveza čehoslovačkih književnika, 1987. objavljuje tjednik Danas. Samo dvije godine prije pada komunizma, ukidanja cenzure i otvaranja javnosti bogate riznice neoficijelne produkcije Adlová iznosi svoje viđenje pojma slobode i slobode u kontekstu češke i slovačke književnosti te izjavljuje:

„Svatko ima toliko slobode koliko zasluži, koliko izbori i koliko može da podnese. Ne sjećam se da su postojali neki nesporazumi koji bi sada utjecali na to da se pisci plaše. Cenzura je ukinuta 1968. i sada je sve na odgovornosti pisca.

\footnotetext{
${ }^{211}$ Peterka, Josef (1944.), češki pjesnik, književni kritičar, povjesničar i teoretičar književnosti. Od 1971. zaposlen na Zavodu za češku i svjetsku književnost ČSAV-a. Tijekom normalizacije pod njegovim su imenom objavljivani prijevodi Miroslava Červenke. www.slovnikceskeliteratury.cz (natuknica Josef Peterka, pristupljeno 1. 9. 2019.)

${ }^{212}$ Mař́k, Kamil (1946.), češki pjesnik, prevoditelj, autor radijskih drama. www.slovnikceskeliteratury.cz (natuknica Kamil Mař́k, pristupljeno 1. 9. 2019.)

${ }^{213}$ Mařík, Kamil Zagrebački književni razgovori (očima jednog gosta), Oko, br. 269, 1982., str. 19.

${ }^{214}$ Prevoditeljica Irena Wenigová laureatkinja je i Nagrade Miroslava Krleže 1987., Krađa u crkvi, Vjesnik (Panorama subotom), br. 14403, 17. 10. 1987., str. 15.

${ }^{215}$ Dijalog o ironiji, Večernji list, br. 6980, 7. 5. 1982., str. 8; Milovanje prije sna, Večernji list, br. 6984, 12.5. 1982., str. 5

216 Senečić, Geno Pohvala prevodilaštvu, Vjesnik, br. 12528, 16. 7. 1982., str. 7.

${ }^{217}$ Chmel, Rudolf (1939.), slovački povjesničar književnosti. Tijekom normalizacije bio je zaposlen u nizu državnih institucija, a u vrijeme posjeta Zagrebu tajnik je Saveza čehoslovačkih pisaca. Glavno su područje njegova interesa slovačko-mađarske kulturne veze. Početkom 2000-ih ministar je kulture Republike Slovačke. www.databazeknih.cz (natuknica Rudolf Chmel, pristupljeno 1. 9. 2019.)

${ }^{218}$ Lendvaj, A. Što je poštena kritika, Večernji list, br. 8203, 7. 5. 1986., str. 19.

${ }^{219}$ Aldová, Věra (1919. - 1999.), češka književnica i prevoditeljica.
} 
Ako pisac ne vrijeđa državnog predstavnika, ako ne otkriva vojnu tajnu, može da piše sve što mu kažu srce i pamet. Neki ljudi miješaju otvorenost sa grubošću, kritiku sa nepristojnošću, i to je greška. Ipak, ne sjećam se da je u posljednjih 20 godina zabranjena neka knjiga.“220

Posljednje pitanje intervjua odnosilo se na status Milana Kundere i odnos čehoslovačkih kulturne javnosti prema književniku koji već desetak godina živi u inozemstvu gdje je ostvario svjetsku slavu. Aldová iznosi ne pretjerano optimistično mišljenje:

„S Kunderom je ovakva situacija: ima položaj kao i svi ostali koji su napustili Republiku, i prestali biti čehoslovački državljani. On je francuski državljanin, i prema našem zakonu može biti prevođen kao i svaki drugi pisac. (...) Danas on nije obuhvaćen čehoslovačkom literaturom. Znate, u literaturi je teško emigrirati: kad je pisac dugo izvan domovine, gubi tlo koje može biti najplodniji izvor njegove literature. (...) Slikar, muzičar, liječnik...može egzistirati izvan domovine. Pisac ne može.“'221

Suradnja s oficijelnom kulturnom scena proteže se i na područje kazališta. Dnevne novine donose niz napisa o razvijenim čehoslovačko-jugoslavenskim kazališnim vezama, odnosno uzajamnim gostovanjima kazališnih kuća. ${ }^{222} \mathrm{U}$ osamdesetim godinama sve su češće paralelno u program određene kazališne manifestacije uvrštavani predstavnici i oficijelne i neoficijelne češke scene. Na Danima satire Satiričkoga kazališta Jazavac 1988. u programu sudjeluju zagrebački Teatar ITD dramom Jiř́ja Menzela Tri u drugom (Tři v tom) - koju godinu kasnije javnost saznaje se da je autor drame, zapravo, neoficijelni autor Jaroslav Vostrý, sarajevski Kamerni teatar 55 Havelovim Largom desolatom, ali i Satirické divadlo Večerní Brno predstavom Bježi, Nitouche, bježi. ${ }^{223}$

Hrvatski se izdavači, odlučujući koje će naslove češke oficijelne književne produkcije uvrstiti u svoje izdavačke planove, zasigurno vode zahtjevima publike. Otegotna okolnost za pristup do hrvatskih čitatelja najkomercijalnijega dijela oficijelne češke književne scene, a riječ je o žanrovskoj prozi, bila je činjenica da je glad hrvatskih čitatelja za takvom vrstom proze sasvim dobro zadovoljavala književna produkcija domaćih autora - sedamdesete su godine u hrvatskoj književnosti obilježene procvatom fantastične proze, a osamdesete dominacijom žanrovske proze. Osim toga, hrvatskim su čitateljima, ali i konzumentima

\footnotetext{
${ }^{220}$ Sloboda prema zasluzi, (intervju s Věrom Aldovom, Mirko Galić), Danas, 2. 6. 1987., str. 50.

221 Isto.

${ }^{222}$ Stojanović, M. Malo, ali dobro, Večernji list, br. 7701, 13. 9. 1984. str. 9; Ilić, Jure Na dobrim tradicijama, Večernji list, br. 7706, 19. 9. 1984., str. 9.

${ }^{223}$ D. V. U čast Cervantesu, Vjesnik, br. 14624, 3. 6. 1988., str. 12.
} 
ostalih grana popularne kulture toga razdoblja u Jugoslaviji, zemlji koja je u usporedbi s drugim europskim zemljama komunističkoga uređenja bila otvorena zapadu, dostupni prijevodi tržišno iznimno uspješnih izdanja zapadnih autora tako da je ljestvica čitatelja u Jugoslaviji bila postavljena prilično visoko.

S oficijelnoga polja češke književne scene čitatelji u Hrvatskoj u najsnažnijem su dodiru s prozama Ladislava Fuksa ${ }^{224}$ i Vladimíra Párala ${ }^{225}$. Tijekom normalizacije Fuks i Páral, najčitaniji autor oficijelne scene, jedini su češki prvorazredni književnici, renomirani već tijekom šezdesetih godina, koji svoj put do publike ostvaruju službenim komunikacijskim putovima. $^{226}$

Proze tih autora hrvatski izdavači objavljuju u edicijama koje predstavljaju kvalitativne i kvantitativne vrhunce svoje djelatnosti. Tako, primjerice, tržišno izuzetno dobro prihvaćena Biblioteka Hit zagrebačkoga Znanja tijekom osamdesetih objavljuje čak tri proze Ladislava Fuksa, no sve tri napisane u razdoblju prije normalizacije: autorov romaneskni prvijenac Gospodin Theodor Mundstock (Pan Theodor Mundstock) iz 1963. te dva djela iz 1967. - roman Spaljivač leševa (Spalovač mrtvol) i zbirku pripovijedaka Put u obećanu zemlju (Cesta do zaslibené zemí). ${ }^{227}$ Kritika Fuksova romana Gospodin Theodor Mundstock objavljena je u časopisu Quorum. ${ }^{228}$

Iz Páralova opusa hrvatski su čitatelji upoznati tek s romanom Ljubavnici i ubojice (Milenci a vrazi) koji 1977. za zagrebačkoga izdavača Grafički zavod Hrvatske prevodi

\footnotetext{
${ }^{224}$ Fuks, Ladislav (1923. - 1999.), češki književnik. Od kraja šezdesetih živi isključivo od svoga književnog rada. Prozni su mu tekstovi nerijetko prerađivani u televizijske i filmske scenarije te dramatizirani. U pripovijetkama i romanima bavi se temama straha, tjeskobe, zločina i njihova utjecaja na pojedinca, a tijekom šezdesetih afirmirao se egzistencijalističkom prozom židovske tematike. www.slovnikceskeliteratury.cz (natuknica Ladislav Fuks, pristupljeno 1. 9. 2019.)

${ }^{225}$ Páral, Vladimír (1932.), češki književnik. Od kraja šezdesetih godina profesionalni književnik. Niz mu je proznih tekstova prilagođeno u oblik filmskoga scenarija i dramskoga teksta za kazalište. Jednim od načina bijega od cenzure tijekom osamdesetih smatraju se Páralove znanstveno-fantastične pripovijetke i romani. www.slovnikceskeliteratury.cz (natuknica Vladimír Páral, pristupljeno 1. 9. 2019.)

${ }^{226}$ Janoušek, Pavel i suradnici Dějiny české literatury 1945 - 1989, IV. knjiga 1969-1989, Academia, Prag, 2008., str. 171.

${ }^{227}$ Svoj prvi susret s Ladislavom Fuksom prepričava novinar Branko Šömen: „Prvi susret s poznatim piscem Ladislavom Fuksom bio je pomalo mističan. K njemu sam se, 1977. g., s Petrom Skarlantom odvezao taksijem. Dočekao nas je u crvenim papučama i uveo u stan krcat kipićima od muranskoga stakla, ali kod njega je kič postao ukras! A sa stropa su visjele drvene ptičje krletke, pune čeških knjiga. 'To su knjige mojih prijatelja, u nas zabranjene. Kad dođe velika amnestija, pustit ću ih iz krletki', objasnio je autor romana sa židovskom tematikom.“, Šömen, Branko Češki sanjar: Václav Havel od disidenta do prezidenta, Profil, Zagreb, 2012., str. 166.

${ }^{228}$ Tatarin, Milovan Apsurdno nepoimanje situacije, Quorum, br. 2, god. V, 1989., str. 387-389.
} 
Predrag Jirsak. Ulomak toga romana, također u Jirsakovu prijevodu, iste godine donosi časopis Republika. ${ }^{229}$

U drugoj polovici osamdesetih navedenim se prozaicima pridružuje i Jaroslav Boček čiji su romani, također, objavljivani u Biblioteci Hit izdavačke kuće Znanje. Po objavljivanju romana Slučaj dr. Karpete (Případ dr. Karpety) hrvatski književni kritičari uočavaju sličnosti toga romana sa suvremenim tržišno orijentiranim dijelom hrvatske književne produkcije. U svome osvrtu na Bočekov roman povjesničar književnosti Cvjetko Milanja povlači paralele s popularnom hrvatskom prozom toga razdoblja zbog postupka miješanja sastavnica kriminalističkoga i fantastičnoga žanra te naglašava da se sličnosti između Slučaja $d r$. Karpete i Kraja mandata hrvatskoga književnika Pavla Pavličića mogu naći i na fabularnoj razini. ${ }^{230} \mathrm{Na}$ istu podudarnost Bočekova i Pavličićeva romana u svome tekstu objavljenome u Quorumu podsjeća i Miroslava Vučić. ${ }^{231}$

Godine 1990. Bočekov je Prestolonasljednik (Čas korunního prince) na devetom mjestu ljestvice najtraženijih naslova u zagrebačkim knjižarama, a o romanu se pohvalno izražava i Julijana Matanović232 predviđajući mu sjajan tržišni uspjeh i zbog činjenice da su hrvatski čitatelji već upoznati s autorovim opusom romanom Slučaj dr. Karpete koji Zdravko Zima žanrovski određuje kao krimić s elementima fantastike, ${ }^{233}$ ali i zbog urednika Biblioteke Hit, u kojoj roman izlazi, Zlatka Crnkovića kojega Matanović smatra imenom koje ,zna izabratic $^{\text {(234. }}$.

Kraće proze te ulomke iz romana predstavnika oficijelne scene tijekom cijeloga razdoblja povremeno objavljuju i časopisi. Novelu Vampir Ltd. Josefa Nesvadbe iz 1964. u prijevodu Slobodana Šnajdera objavljuju zagrebačka Pitanja $1971 .{ }^{235}$ Isti prevoditelj autor je i prijevoda novele Anđeoska misija najpoznatijeg češkog pisca znanstvenofantastične proze tijekom normalizacije Ludvika Součeka koju objavljuje časopis Oko 1979. uz tekst Predraga Jirsaka Češka znanstvena fantastika. ${ }^{236}$

U drugoj polovici osamdesetih do čitatelja u Jugoslaviji dolaze i djela čeških autora koja su, na valu promjena iz Sovjetskoga Saveza i postupne liberalizacije društva, legalno

\footnotetext{
${ }^{229}$ Páral, Vladimír Ljubavnici i ubojice (ulomak), Republika, br. 10, 1977., str. 61-73.

${ }^{230}$ Milanja, Cvjetko Pouka izvana, Oko, br. 372, 1986., str. 20.

231 Vučić, Miroslava Enigma enigme, Quorum, br. 4/5, 1986., str. 217-220.

${ }^{232}$ Matanović, Julijana Jaroslav Boček Prestolonasljednik, Revija, br. 7, 1990., str. 112-115.

${ }^{233}$ Zima, Zdravko U labirintima krimića, Vjesnik (Panorama subotom), br. 14026, 27. 9. 1986., str. 16.

${ }^{234}$ Isto, str. 16.

235 Josef Nesvadba Vampir Ltd., Pitanja, br. 28, 1971., str. 856-860.

${ }^{236}$ Souček, Ludvík Anđeoska misija, preveo Predrag Jirsak, Oko, br. 184, 1979., str. 12; Jirsak, Predrag Češka znanstvena fantastika, Oko, br. 184, 1979., str. 12.
} 
dostupna i čitateljima u Čehoslovačkoj što bi samo koju godinu ranije bilo nemoguće. Tako Československý spisovatel 1986. objavljuje roman Memento mladoga romanopisca Radeka Johna, čiji je srpski prijevod ubrzo tiskan u Dečjim novinama u Gornjem Milanovcu. U tome se romanu prvi put u češkoj književnosti obrađuju teme narkomanije, kriminala, korupcije, bezvoljnosti i besciljnosti mlade generacije - sve ono što, prema tvrdnjama autora, do prije dvije godine od prvoga izdanja romana ne bi dobilo dozvolu za objavljivanje. ${ }^{237}$ Zagrebački tjednik Danas 1988. objavljuje intervju s Johnom ${ }^{238}$ u kojem autor prepričava svoja iskustva s policijskih saslušanja na kojima su policijski službenici tvrdili da u tekstu romana ima protudržavnih elemenata te navodi da su nagađanja da će film snimljen prema romanu biti zabranjen dovela do krađe kasete sa snimkom filma i njenom prodajom na crnom tržištu. Kritiku toga romana u časopisu Quorum objavljuje Katica Ivanković. ${ }^{239}$

Prijevodi češke poezije u Hrvatskoj tijekom sedamdesetih i osamdesetih godina kvantitativno kaskaju za prozom, neovisno o tome je li riječ o oficijelnoj ili neoficijelnoj književnoj produkciji i uglavnom se iscrpljuju na sporadičnim objavama u književnim časopisima. Samo dva češka pjesnička klasika, Jaroslav Seifert i Vladimír Holan, ostvaruju recepciju samostalnim zbirkama poezije. Holanovu poemu Noć s Hamletom i odabrane pjesme, u prijevodu Slavka Mihalića i Dušana Karpatskog, objavljuje Nakladni zavod Matice hrvatske 1981., dok se Seifertova poezija u Hrvatskoj pojavljuje u srpskom prijevodu nakon što pjesnik postaje laureatom Nobelove nagrade za književnost.

Ostali su prijevodi razasuti po časopisima. Poezija oficijelnih pjesnika Miroslava Floriana, Frantíšeka Hrubína, Miloša Macoureka i Jana Pilařa objavljena je u Republici 1978. u izboru češke ljubavne poezije Zbogom i maramica, a u prijevodu Zvonimira Goloba. ${ }^{240}$ Zagrebački Forum prijevode oficijelnih čeških pjesnika opet donosi 1984., riječ je o prijevodima na srpski jezik ,najaktualnijeg u pesničkim strujanjima u Čehoslovačkoj“, odnosno poeziji Josefa Hanzlíka (U detinjstvu sam čeznuo da slikam muziku, Modri pejzaž sa

\footnotetext{
${ }^{237}$ Janoušek, Pavel i suradnici Dějiny české literatury 1945-1989, IV. knjiga 1969-1989, Academia, Prag, 2008. str. 513.

${ }^{238}$ Majstorović, Andrea Moral u trapericama, Danas, 1. 11. 1988., str. 46-47.

${ }^{239}$ Katica Ivanković Mladi češki narkomani, Quorum, br. 3, god. IV, 1988., str. 329-333.

240 Tijekom normalizacije Miroslav Florian obavlja niz značajnih funkcija. Dugi je niz godina urednik u izdavačkoj kući Československý spisovatel, a potom se, u drugoj polovici sedamdesetih počinje baviti i politikom. Nagrađen je nizom uglednih državnih nagrada poput Državne nagrade Klementa Gottwalda i Narodne nagrade Čehoslovačke, proglašen je zaslužnim i narodnim umjetnikom. Jan Pilař smatran je jednim od glavnih oslonaca normalizacije u češkoj književnosti, tijekom sedamdesetih i osamdesetih godina 20. st. urednik je i direktor izdavačke kuće Československý spisovatel te predavač na praškome Filozofskom fakultetu, a Miloš Macourek scenarist je filma Čtyři vraždy stačí, drahoušku! snimljenoga 1970. prema romanu hrvatskoga književnika Nenada Brixija Mrtvacima ulaz zabranjen. www.slovnikceskeliteratury.cz (natuknice Miroslav Florian, Miloš Macourek, pristupljeno 10. 8. 2019.)
} 
Hamletom, Semafor, Smetište, Violinista u domu penzionera), ${ }^{241}$ Kamila Maříka (Sonet mojoj ženi Mariji, Kod kuće, Ljubavna, Sonet o ljudskoj nadi, Slika sa stenom i lovcem) i Miroslava Floriana (Kiše, Zvezdana noć, Pesma). ${ }^{242}$

Pojedinačne pjesme na svojim je stranicama objavljivalo i zagrebačko Oko: 1982. na naslovnici taj časopis donosi pjesmu Josefa Hanzlíka iz zbirke Potlesk pro Herodesa $\mathrm{u}$ prijevodu Radomira Mićunovića, ${ }^{243}$ te riječki Rival koji 1989. u rubrici Lijepa književnost objavljuje pjesmu Antonína Bartušeka Naopaka čuda u prijevodu Milana Nosića. ${ }^{244}$

3. 4. Hrvatska recepcija tzv. sive zone češke književnosti od 1968. do 1990.

U tzv. sivu zonu češke književnosti ubrajamo stvaralaštvo književnika koji, pod različitim okolnostima, svoja djela tijekom normalizacije objavljuju i u državnim izdavačkim kućama i kod neoficijelnih, samizdatskih izdavača. Od pripadnika sive zone češke književnosti tijekom normalizacije na hrvatskom su izdavačkom tržištu najzastupljeniji prozaici Bohumil Hrabal i Jiří Šotola te pjesnik Jaroslav Seifert, klasici češke književnosti. Nakon sloma praškoga proljeća Hrabal i Šotola niz su godina potisnuti u sferu ilegalnoga izdavaštva iz koje izlaze 1975. kada popuštaju pritiscima vlasti te se u intervjuu komunističkome tjedniku Tvorba ili javno odriču dijela svoga opusa, Hrabal to čini autobiografskim djelom Proluky u kojem opisuje svoje sudjelovanje u događajima iz prijelomne 1968., ili, poput Šotole, izražavaju kritički stav prema djelovanju Saveza čehoslovačkih književnika (Svaz československých spisovatelio) i Književnih novina (Literarní noviny). ${ }^{245}$ No, i nakon toga čina, kada su im otvorena vrata državnih izdavačkih kuća uz, ponekad, kompromisna rješenja poput pristajanja na djelomične preinake u nekim književnim tekstovima ${ }^{246}$ stvaralaštvo tih književnika ostaje sve do 1989. zanimljivo i neoficijelnim nakladnicima. ${ }^{247}$

\footnotetext{
${ }^{241}$ Hanzlík, Josef (1938. - 2012.), češki pjesnik. Od 1969. do 1991. dramaturg i scenarist filmskoga studija Barrandov. U istome razdoblju surađuje sa Čehoslovačkom televizijom i radijem koji filmski i radijski adaptiraju njegove tekstove za djecu. Na scenu službene književnosti, osim dječje književnosti, vraća se 1981. zbirkom pjesama Požár babylonské věže. Janoušek, Pavel i suradnici Dějiny české literatury 1945-1989, IV. knjiga 19691989, Academia, Prag, 2008., str. 367.

242 Tri češka pjesnika, preveli R. Mićunović i V. Koprivica, Forum, br. 7/8, 1984., str. 144-152.

${ }^{243}$ Oko, br. 275, 1982., naslovna stranica.

${ }^{244}$ Bartušek, Antonín Naopaka čudesa, preveo Milan Nosić, Rival, br. 3-4, 1989., str. 175-176.

245 www.slovnikceskeliteratury.cz (natuknica Jiří Šotola, pristupljeno 23. 12. 2018.)

${ }^{246}$ Primjerice, u tekstu pripovijetke Krasosmutnění promijenjen je naziv ulice pa, tako, Masarykova ulica u izdanju nakladnika Československý spisovatel 1976. postaje Boleslavká. (Machala, Lubomír Hrabalova tvorba
} 
Sudbina Hrabalovih proza u matičnoj zemlji, a objavljenih u Jugoslaviji tijekom sedamdesetih i osamdesetih godina 20. st. različita je. Roman Služio sam engleskoga kralja (Obsluhoval jsem anglického krále), hrvatskim čitateljima dostupan u beogradskome izdanju iz 1984., sve do pada komunizma nije objavljen kod državnog nakladnika. Suprotno tome, prozni zapisi Domaći zadaci iz marljivosti (Domácí úkoly), čiji je prijevod na srpski jezik objavljen u Gornjem Milanovcu 1988., tijekom normalizacije objavljuju i središnji državni nakladnik Československý spisovatel i samizatski izdavači. Osim samostalnih, knjižnih izdanja hrvatskim su čitateljima dostupne i kraće autorove proze čije prijevode povremeno objavljuju književni časopisi. Poseban broj Republike u prosincu 1968. donosi Hrabalovu prozu Dijamantno oko u prijevodu Predraga Jirsaka. ${ }^{248}$ Književna smotra 1974. objavljuje novelu Automat svijet istoga prevoditelja i kratak uvodni Jirsakov tekst o književnikovu opusu. ${ }^{249} \mathrm{U}$ mjesečniku Republika 1984. objavljena je novela Zeba, ${ }^{250}$ a četiri godine kasnije ulomak Hrabalova romana Praznine, koji tematizira praško proljeće, u prijevodu Renate Kuchar donosi časopis 15 dana. ${ }^{251}$

Nakon 1975. i istupa u časopisu Tvorba u kojem se kritički osvrće na djelovanje Saveza čehoslovačkih književnika i Književnih novina u razdoblju kada je u njima obavljao značajne funkcije, na oficijelnu scenu nakon pet godina u ilegali stupa i Jiř́ Šotola. Nakon toga čina Šotoline proze u prethodnom razdoblju objavljivane u samizdatu, poput romana Pile na ražnju (Kuře na rožni) objavljenoga u ediciji Petlice 1974., nalaze svoje mjesto i u planovima vodećih državnih izdavačkih kuća - isti je roman već 1976. objavljen u nakladi Československý spisovatel. ${ }^{252}$ Iz Šotolina su opusa hrvatskim čitateljima tijekom sedamdesetih i osamdesetih godina dostupni prijevodi romana Družba Isusova (Tovaryšstvo Ježišovo), ${ }^{253}$ Pile na ražnju (Kuře na rožni) $)^{254}$ i Ljepuškasta djeca (Malovaný děti) ${ }^{255}$.

\footnotetext{
pod normalizačni kruchty, u. Život je jinde...?, Česká literatura, kultura a společnost v sedmdesátých a osmdesátých letech dvacátého století, prir. Jan Matonoha. Ústav pro českou literaturu AV ČR, Prag, 2002., str. 112.

${ }^{247}$ Niz je Hrabalovih tekstova i nakon 1975. objavljeno u egzilu: Městečko, ve kterém se zastavil čas (Innsbruck, 1978.), Něžní barbaři (Köln, 1981.), Jak jsem obsluhoval anglického krále (Köln, 1980.), Př́liš hlučná samota (Köln, 1980.).

${ }^{248}$ Hrabal, Bohumil Dijamantno oko, Republika, god. XXIV, br. 12, 1968., str. 708-711.

${ }^{249}$ Hrabal, Bohumil Automat svijet, Književna smotra, VI(1974.), br. 19, str. 31-36.

${ }^{250}$ Hrabal, Bohumil Zeba, Republika, br. 4, 1984.

${ }^{251}$ Hrabal, Bohumil Praznine (ulomak romana), 15 dana, br. 3, 1988., str. 34-38.

252 www.slovnikceskeliteratury.cz (natuknica Jiří Šotola, pristupljeno 5. 1. 2019.)

${ }^{253}$ Zagrebačko Znanje roman objavljuje 1975. i 1988. u prijevodu Nikole Kršića.

${ }^{254}$ Roman 1983. objavljuje zagrebačka Izdavačka kuća August Cesarec u Biblioteci Bestseler i prijevodu Dagmar Ruljančić. Do 1975. i Šotolina javnog pokajanja u Tvorbi taj je roman objavljivan u samizdatu, da bi ga prvi put 1976. objavio i državni nakladnik Československý spisovatel.
} 
Od svih je Šotolinih proza objavljenih u Hrvatskoj najsnažniju književnokritičku reakciju izazvao povijesni roman Družba Isusova, prvi put objavljen u Čehoslovačkoj 1969. ${ }^{256}$ Iako u hrvatskom prijevodu objavljen tek 1975., neposredno nakon češkoga izdanja Ljudevit Bauer prvom rečenicom svoga teksta Bratstvo Isusovo ${ }^{257}$ zacrtava smjer u kojem će se kretati i kasnija čitanja Šotolina romana: „Kad pisac danas posegne za temom iz nekog drugog vremena, onda je to zato što želi reći nešto svom vremenu o njemu samom. “258 Bauer, dalje, tvrdi da ideje koje Šotola iznosi „odlično korespondiraju s ovim našim vremenom, uzduž i popreko meridijana i paralela““ ${ }^{259}$ no jasno se ograđuje od iščitavanja Šotolina teksta kao romana s ključem te navodi da ,puko šifriranje ipak nije književnost, a Šotolin je roman u svakom slučaju književno djelo“6260.

U kritici Družbe Isusove nakon hrvatskoga izdanja 1975. Irvin Lukežić ${ }^{261}$ romanu pridaje atribut „klasičnoga djela češke i svjetske književnosti“, 262 a o romanu se pohvalno očituje i Jaroslav Pecnik ${ }^{263}$ koji inzistira na tezi o aktualnosti romana tvrdeći da, kritizirajući dogmatizam i ideologiju te smještajući fabulu romana u prošlost, Šotola piše „o sadašnjosti, svome vremenu i svijetu, njegovim problemima, a nadasve o položaju čovjeka u svome vremenu“6264. Šotolina Družba Isusova konstruirana je u istoj maniri kao i hrvatski novopovijesni roman toga razdoblja u kojoj povijest više nije prikazana kao nositeljica prosvjetiteljske note koja nas podučava, već kao ponavljačica vlastitih grešaka i tragedija koja, pritom, snažno oblikuje živote pojedinaca koji je nemaju moć mijenjati. ${ }^{265}$

Krajem osamdesetih izuzetno dobru recepciju kod čitatelja ostvaruje roman Ljepuškasta djeca koji se u prvoj polovici 1987. nalazi na popisima najčitanijih i najprodavanijih knjiga u zagrebačkim knjižnicama i knjižarama koje objavljuju dnevne

\footnotetext{
${ }^{255}$ Roman je objavljen 1986. u prijevodu Dagmar Ruljančić.

${ }^{256}$ Prema tom je Šotolinu romanu 2004. hrvatski redatelj Silvije Petranović snimio istoimeni film.

${ }^{257}$ Bauer, Ljudevit Bratstvo Isusovo, Književna smotra, br. 3, 1970.

258 Isto.

259 Isto.

260 Isto.

${ }^{261}$ Lukežić, Irvin Priča o crnoj družbi, Rival, br. 1-2, 1989., str. 187-189.

262 Isto, str. 189.

${ }^{263}$ Pecnik, Jaroslav Sizifova istina, Republika, br. 7-8, 1976., str. 59-63.

264 Isto, str. 60.

265 Češka se povijesna proza razdoblja normalizacije razvija u dva smjera. Prvoj, građenoj na principu preslikavanja aktualnih problema u druga, povijesno udaljena vremenska razdoblja, pripadaju Šotolini povijesni romani. Drugi smjer povijesne proze čine trivijalizirana, zabavna literatura koja je u Čehoslovačkoj imala vrlo dobru recepciju kod čitatelja, a pišu je autori poput Vladimíra Neffa, Ludmile Vaňkové, Jarmile Loukotkové. Moldanová, Dobrava Historia magistra deziluze. u: Život je jinde...?, Česká literatura, kultura a společnost v sedmdesátých a osmdesátých letech dvacátého století, prir. Jan Matonoha. Ústav pro českou literaturu AV ČR, Prag, 2002., str. 29-35.
} 
novine Večernji list. ${ }^{266} \mathrm{U}$ tom se razdoblju razvija i Šotolina suradnja sa zagrebačkim Kazalištem Trešnja koje prikazuje dramatizaciju Pileta na ražnju u režiji Joška Juvančića, a čiji je tekst za pozornicu prilagodio sâm autor. ${ }^{267}$ Međutim, Trešnjina dramatizacija Šotolina romana nije pobrala pohvale kazališne kritike. Vjesnikova kritičarka Marija Grgičević negativno ocjenjuje većinu njenih sastavnica - od Šotoline dramatizacije koju naziva dijalogiziranom kronikom te književniku prigovara osiromašenje vlastita književnoga predloška, preko redateljskih rješenja, sve do izvedbe glumačkoga ansambla na čijem je čelu Vili Matula. U Vjesnikovoj kritici pozitivnu ocjenu kritičarke zaslužila su scenografska rješenja Perside Žutinić i kostimografija Rute Knežević. ${ }^{268}$

Šotoline pjesme Ljubavni razgovor, O suncu i Romeo i Julija, u prijevodu Mirka Jirsaka, objavljene su u posebnome, prosinačkome broju Republike 1968., uz poeziju Vladimira Holana (pjesme Bilo je prekasno, A oni, Poziv, Zar već opet?, Nedorečeno, Vrabac, Probuđen, ulomak spjeva Noć s Hamletom) i Milana Nápravníka. ${ }^{269}$ Poezija mu je, u prijevodu Renate Kuchar i Nives Opačić, 1986. objavljena i u časopisu 15 dana, ${ }^{270}$ a Oko 1987. objavljuje prijevod istih prevoditeljica Šotoline pjesme Mislim na tebe. ${ }^{271}$

Klasik češkoga pjesništva Jaroslav Seifert tijekom sedamdesetih i osamdesetih godina u hrvatskoj je periodici kontinuirano zastupljen prijevodima svoje poezije što se intenzivira 1984. dodjelom Nobelove nagrade. Iako početkom sedamdesetih u nemilosti novoga režima, recepcija Seifertove poezije među čitateljima, pjesnikov ugled u inozemstvu, a onda, u konačnici, i dodjela najprestižnije svjetske nagrade utječu na postupke službene vlasti koja nakon godina objavljivanja u samizdatu i egzilu pjesniku krajem sedamdestih godina dopušta proboj na izdavačko tržište. Istovremeno se njegova djela objavljuju u svim kanalima u kojima se češka književnost toga doba razvijala - primjerice, Seifertova proza Sve ljepote svijeta (Všecky krásy světa) objavljena je 1981. u samizdatu i egzilu, u suradnji izdavačkih kuća Index i 68 Publishers, a već sljedeće godine i u najprestižnijoj državnoj izdavačkoj kući Československý spisovatel. I u godinama koje su slijedile, svaki književnikov korak koji je

\footnotetext{
${ }^{266}$ Čitanje bez predaha, Večernji list, br. 8468, 5. 3. 1987., str. 19.

${ }^{267}$ Pile na ražnju nije bio jedini Šotolin tekst prilagođen kazalištu u Hrvatskoj tih godina. Prema motivima jedne književnikove ljubavne pjesme Zagrebački plesni ansambl 1988. izvodi balet Ja sad idem van koreografkinje Ksenije Čorić-Lešić. Nakon premijere toga baleta kritike u dnevnim novinama mahom idu u smjeru prigovora tehničkim uvjetima poput premale pozornice i lošeg razglasa. (N. O. Balet po Šotoli, Vjesnik, br. 14570, 7. 4. 1988. str. 8; Ožegović, Nina Ljubavna pjesma, Vjesnik, br. 14573, 10. 4. 1988., str. 3)

${ }^{268}$ S. Nč. Šotola za Trešnju, Večernji list, br. 8506, 12. 4. 1987., str. 7; Grgičević, Marija Roman je - bolji, Vjesnik, br. 14827, 26. 12. 1988., str. 8.

${ }^{269}$ Iz suvremene češke poezije, Republika, 12, XXIV(1968), str. 725-736

27015 dana, br. 3, 1986., str. 25-29.

${ }^{271}$ Šotola, Jiř́ Mislim na tebe, prevele Renata Kuchar i Nives Opačić, Oko, br. 388, 1986.
} 
iskakao iz strogo uređenih pravila ponašanja koja je vlast tolerirala izazivao je snažne pritiske. Godinu dana nakon dodjele Nobelove nagrade, 1985., Seifert nakon, pretpostavlja se, pritisaka kojima je bio podvrgnut povlači svoj potpis s otvorenog pisma Europskom kulturnom forumu kojim se ukazivalo na nedemokratske i ograničavajuće društvene okolnosti u kojima djeluje čehoslovačka kulturna scena. ${ }^{272}$

Godine 1984. u izdanju beogradske Srpske književne zadruge objavljen je izbor iz Seifertove poezije, uz izdanje Holanove poezije 1981. jedina samostalna zbirka pjesma nekog suvremenoga češkog pjesnika koja ostvaruje recepciju među čitateljima u Hrvatskoj u dva desetljeća koja su predmet analize ovoga rada. ${ }^{273}$ Autori su toga prijevoda Jara Ribnikar i Ivan L. Lalić čije prijevode u kritici objavljenoj u zagrebačkome časopisu Quorum Katica Ivanković ocjenjuje ,ppovršnima“6274. Osim toga, u Quorumovu tekstu prigovara se i izboru pjesama te se negativno vrednuje činjenica da dvije trećine objavljenih pjesama pripada posljednjoj fazi Seifertova stvaralaštva, a da su prethodnih četrdeset i pet godina njegova umjetničkoga rada zastupljeni s tek desetak pjesama.

Ostali su prijevodi Seifertove poezije razasuti po časopisima. Petnaest pjesničkih tekstova objavljuje časopis Razreda za suvremenu književnost Jugoslavenske akademije znanosti i umjetnosti Forum ${ }^{275}$ 1970. uz kratak popratni tekst, stvaralačku biografiju pjesnika, prevoditelja Dušana Karpatskog (pjesme Dedikacija, Išle su dvije i dvije, Pjesma četvrta, Da se može srcu reći, Kipovi Josefa Wagnera, Kad kiše peru, Park u Veltrusima, Glavni kolodvor, Kućni znakovi, Grančica, Prije nego se osuši, Nebeska brklja, Bolnica u Motolu, Marche funébre, Težina gline). ${ }^{276} \mathrm{U}$ tome tekstu Karpatský daje pregled pjesnikovih aktivnosti od urednikovanja časopisom Rudé právo, središnjim dnevnim listom Komunističke partije, i objavljivanja pjesničkoga prvijenca Město v slzách u 1920-ima, preko isključenja iz članstva Komunističke partije koje je slijedilo krajem toga desetljeća, ,nekoliko godina šutnje

\footnotetext{
272 Janoušek, Pavel i suradnici Dějiny české literatury 1945-1989, IV. knjiga 1969-1989, Academia, Prag, 2008. str. 46.

${ }^{273}$ Godinu dana kasnije objavljen je i slovenski prijevod zbirke Koncert na otoku u izdanju Cankarjeve založbe.

${ }^{274}$ Katica Ivanković Sve Seifertove promjene, Quorum, br. 2, 1985., str. 140-143.

${ }^{275}$ U svome tekstu Uvod u sedamdesete Krešimir Bagić iz produkcije časopisa u Hrvatskoj tijekom 1970-ih izdvaja dva časopisa: Pitanja i Akademijin Forum. Oba ih smatra reprezentativnim za razdoblje o kojemu piše, no Forum atribuira „konzervativnim časopisom koji nastoji djelovati urotnički“, časopisom koji se „drži kanona $i$ kanonizira (...) ne libeći se 'geste dobre volje' kada je prikliješten ideološkim razlozima“. Bagić, Krešimir Uvod u sedamdesete, u: Zbornik radova 38. seminara Zagrebačke slavističke škole, ur. Krešimir Mićanović, Filozofski fakultet, Zagrebačka slavistička škola, Zagreb, 2010., str. 130.

${ }^{276}$ Seifert, Jaroslav Koncert na otoku (izbor pjesama), prijevod Dušan Karpatský, Forum, god. 9(1970), knj. 20, br. 9 , str. $389-405$.
} 
u 1950-ima“‘277 zbog odbijanja ukalupljivanja u službenu poetiku socrealizma objavljivanjem Píseň o Viktorce, sve do ponovnoga aktiviranja u drugoj polovici šezdesetih kada nastaju tri zbirke pjesama: Koncert na ostrově 1965., Odlévání zvonů 1967. i Halleyova kometa 1967. iz kojih u tome broju časopisa Karpatský donosi prijevode pjesama nazvavši ih pjesnikovim „lirskim autobiografijama“‘278.

Sredinom osamdesetih, a nakon dodjele Nobelove nagrade za književnost, hrvatsku recepciju Seifertove poezije i književnoga rada uopće uvelike obilježava znanstveni i prevoditeljski rad dvojca koji čine jezikoslovke, prevoditeljice i sveučilišne nastavnice Nives Opačić i Renata Kuchar koje svoje tekstove o pjesnikovu radu i prijevode objavljuju u Forumu, Republici i 15 dana. Zagrebački Forum dodjelu Nobelove nagradu pjesniku 1985. obilježava objavom teksta Nobelovac Jaroslav Seifert, prijevodom izbora pjesama zbirke Halleyev komet iz 1967. (pjesme Posveta A. M. P., Otok na Vltavi, Halleyev komet, Kućno znamenje, Grančica ive, Put u Veneciju, Kavana Slavija, Kapi kiše) te ulomkom memoara Sve zemaljske ljepote. ${ }^{279} \mathrm{U}$ tekstu Nobelovac Jaroslav Seifert pjesnik se atribuira jednim od „najpopularnijih pjesnika najšireg kruga čitatelja“ ${ }^{\text {(280 }} \mathrm{i}$ jedan je od rijetkih koji tematizira Seifertov stvaralački put, a koji se u jednome svom dijelu dotiče i njegova potiskivanja iz prostora javnoga djelovanja nakon praškoga proljeća. Naime, Seifertovu izdavačku djelatnost u samizdatu autorice eufemistički nazivaju pjesnikovom „,desetogodišnjom šutnjom“ “281 koju prekida 1979. zbirkom pjesama Kišobran s Piccadillyja (Deštník z Piccadilly).

Na sličan način na dodjelu nagrade reagira i časopis Republika koji, također, objavljuje prijevod ulomaka pjesnikovih memoarskih zapisa, prijevod izbora poezije te popratni tekst Renate Kuchar Novi nobelovac. ${ }^{282}$ Nives Opačić i Renata Kuchar tekst o Seifertovu pjesništvu i prijevod izabranih pjesama iste godine objavljuju i u časopisu 15 dana (pjesme Kućno znamenje, Otok na Vltavi, Svadbena pjesma, Grančica ive, Karte i menuet, Put u Veneciju, Svadbeni put, Kapi kiše, Kavana ,,Slavija “, Posveta A. M. P.). ${ }^{283}$ Časopis Oko Seifertovu nagradu obilježava tekstom Tema seifertiana prevoditelja i sveučilišnoga

\footnotetext{
277 Seifert, Jaroslav Koncert na otoku (izbor pjesama), prijevod Dušan Karpatský, Forum, god. 9(1970), knj. 20, br. 9 , str. 387.

${ }^{278}$ Isto, str. 388.

${ }^{279}$ Kuchar, Renata, Opačić, Nives Nobelovac Jaroslav Seifert, Forum (časopis Razreda za suvremenu književnost JAZU-a), god. 25(1985), knj. 50, br. 7-8, str. 372-383.

${ }^{280}$ Isto, str. 372.

${ }^{281}$ Isto, str. 372.

${ }^{282}$ Kuchar, Renata Novi nobelovac, prijevodi pjesama Jaroslava Seiferta, prijevod ulomka memoara Sve zemaljske ljepote, Republika, br. 10/11/12, 1984.

${ }^{283} 15$ dana, br. 6, 1985. Časopis 15 dana prenosi tekst Renate Kuchar i Nives Opačić koji je već objavljen iste godine u Forumu te prijevode Seifertovih pjesama iz zbirka Halleyev komet i Na valovima TSF objavljenih 1925.
} 
nastavnika Predraga Jirsaka. ${ }^{284} \mathrm{U}$ prosincu iste godine Oko objavljuje intervju slovačkoga pisca i novinara Luboša Juríka s Jaroslavom Seifertom koji je objavljen u Juríkovoj knjizi Nemirni dijalozi, ${ }^{285}$ a dvije godine kasnije kratkim tekstom isti časopis reagira i na vijest o Seifertovoj smrti. ${ }^{286}$

Na vijest o dodjeli Nobelove nagrade 1984. najtiražnije hrvatske dnevne novine toga vremena Vjesnik $^{287}$ i Večernji list reagiraju, bez popratnoga komentara, čestitkom pjesniku čehoslovačkoga ministra kulture Milana Klusaka koja je objavljena u češkome tisku: „Vaša djela su draga našem narodu, jer ste podigli svoj glas protiv fašizma i rata, jer ste 1945. g. opjevali optimizam oslobođenja i s nježnošću i dirljivom ljepotom veličali svoju dragu zemlju, njen radni narod, čehoslovački pejzaž i naš voljeni Prag. ‘288

Osim teksta u Oku na dodjelu Nobelove nagrade Jaroslavu Seifertu u hrvatskome su tisku zabilježene još dvije reakcije bohemista Predraga Jirsaka. Pregled pjesnikove stvaralačke biografije Jirsak donosi u tekstu Mag poezije u tjedniku Danas, ${ }^{289}$ a tekstom u Vjesniku $^{290}$ reagira na tvrdnje dijela zapadnoeuropske kulturne javnosti, koje smatra neutemeljenima, da Seifert činjenicu da je laureat švedske Akademije može zahvaliti svojim oporbenim aktivnostima. Neposredno prije tog Jirsakova teksta u Vjesniku, sredinom listopada 1984., iste dnevne novine prenosi napise iz novina Rudé právo, glasila službenoga čehoslovačkog režima, da se dodjela Nobelove nagrade Jaroslavu Seifertu zbog njegove povijesti otpora u matičnoj zemlji iskorištava za „klevetničke napade na Čehoslovačku“291.

Nakon kraćega zatišja ime Jaroslava Seiferta u hrvatskom se tisku opet pojavljuje početkom 1986. Povodom pjesnikove smrti objavljen je niz penegiričkih tekstova koji čitatelje upoznaju i s podacima iz Seifertove stvaralačke biografije. Nekrolog pjesniku u tjedniku Danas objavljuje književnik Tito Bilopavlović koji Jaroslava Seiferta i Bohumila Hrabala navodi kao primjere književnika koji su nastojali i, unatoč okolnostima, uspijevali stvarati pravu umjetnost onkraj ideologije. Prema Bilopavloviću Seifert je pjesnik koji i u ,[p] ]edesetoj, pedeset i šestoj i šezdeset i osmoj godini ostaje čovjekom u kojega je uprt prst, ali jednako kao Bohumil Hrabal ostaje pisac u Čehoslovačkoj, pisac blizak običnim ljudskim

\footnotetext{
${ }^{284}$ Jirsak, Petar Tema saifertiana, Oko, br. 329, 1984., str. 20.

${ }^{285}$ Intervju s Jaroslavom Seifertom - Dopustite mi da s vremena na vrijeme budem tužan (Luboš Jurík, sa slovačkog preveo Geno Senečić), Oko, br. 332, 1984., str. 6-7.

${ }^{286}$ In memoriam Jaroslavu Seifertu, Oko, br. 362, 1986., str. 22.

${ }^{287}$ Čestitka Seifertu, Vjesnik, br. 13329, 16. 10. 1984., str. 11.

288 Čestitka Seifertu, Večernji list, br. 7729, 16. 10. 1984., str. 9.

289 Jirsak, Predrag Mag poezije, Danas, 16. 10. 1984., str. 48.

${ }^{290}$ Jirsak, Predrag, U pravim rukama, Vjesnik, 31. 10. 1984., br. 13327, str. 13.

${ }^{291}$ Kritički o manipuliranju Seifertom, Vjesnik, 14. 10. 1984., br. 13327, naslovnica
} 
dramama, daleko od tendencije i ideologizacije“6292. Krajem siječnja 1986. Večernji list u tekstu znakovita naziva Nemiran pokop donosi i zanimljivost o neuspješnom pokušaju Václava Havela da nakon pokopa položi vijenac na grob preminula pjesnika. ${ }^{293}$

Iako ime Dušana Hamšíka ${ }^{294}$ prosječnome hrvatskom čitatelju tijekom sedamdesetih i osamdesetih godina ostaje relativno nepoznato, prve informacije od izravnoga sudionika zbivanja u Čehoslovačkoj 1968. čitatelji zagrebačkoga Vjesnika u srijedu dobivaju iz Hamšíkovih „esejističko-dokumentarnih zapisa“ ujesen te godine. U njima Hamšík, primarno tematizirajući zbivanja oko Književnih novina u čijoj je redakciji bio urednik, daje niz detalja o situaciji u Čehoslovačkoj tijekom praškoga proljeća i neposredno nakon njegova sloma. I životni i stvaralački put Dušana Hamšíka u sljedećih dvadeset godina ilustrira koje je sve pozicije autor u svijetu čehoslovačke normalizacije mogao zauzeti. Svoja djela objavljuje u samizdatu, zatim pod imenom drugih osoba ili bez navođenja svoga autorstva. Samizdatska Edice Petlice 1974. objavljuje njegovo djelo Život a díle Heinricha Himmlera, a isti je tekst, pod nazivom Druhý muž třetí řiše, objavljen 1986. i u državnoj izdavačkoj kući. ${ }^{295}$

\section{5. Zaključak}

Nakon liberalizacije čehoslovačkoga društva u šezdesetima i sloma reformnoga pokreta vojnom intervencijom zemalja Varšavskoga ugovora na čelu sa Sovjetskim Savezom u kolovozu 1968., Čehoslovačka se po razini slobode izražavanja vraća na stanje prije liberalizacije te obnavlja cenzuru. U takvim, izrazito nepovoljnim društvenim okolnostima, a u godinama koje su slijedile, svoja najslavnija ostvarenja stvaraju neka od najznačajnijih imena u povijesti češke književnosti. No, ponekad zbog tematike tekstova, a češće zbog političkoga angažmana i detalja građanske biografije, većini njih nije bio omogućen slobodan pristup tržištu i distribucija tekstova. Kao posljedica toga češka se književnost normalizacije od početka sedamdesetih godina do pada komunizma - razvija u nekoliko smjerova.

\footnotetext{
${ }^{292}$ Bilopavlović, Tito In memoriam Jaroslav Seifert, Danas, 21. 1. 1986., str. 43.

${ }^{293}$ Nemirni pokop, Večernji list, 27. 1. 1986., br. 8118, str. 10.

${ }^{294}$ Hamšík, Dušan (1930. - 1985.), češki prozaik i publicist. Tijekom 1968. glavni urednik Literarnih novina (Literárni listy). U prvoj polovici osamdesetih suradnik, no bez navođenja njegova autorstva, na izradi filmskih scenarija. Prema novinskim napisima, tijekom sedamdesetih postaje suradnik čehoslovačke tajne službe. Hertl, David Dušan Hamšík - spisovatel, kterého semlela doba https://plus.rozhlas.cz/dusan-hamsik-spisovatelktereho-semlela-doba-7563434 (objavljeno 12. 7. 2018., pristupljeno 26. 12. 2018.) ${ }^{295}$ Janoušek, Pavel i suradnici Dějiny české literatury 1945-1989, IV. knjiga 1969-1989, Academia, Prag, 2008., str. 693.
} 
Dio književnika, koji se nisu ogriješili o zahtjeve službene vlasti ni svojim građanskim biografijama, ni poetikom svojih djela, objavljuje svoje tekstove u državnim izdavačkim kućama. Oni kojima to nije bilo dopušteno, život i karijeru nastavljaju u egzilu ili u Čehoslovačkoj objavljuju u samizdatu. Središte egzilne produkcije bila je izdavačka kuća 68 Publishers koju u Torontu osniva književnik Josef Škvorecký te kölnski Index i londonske Rozmluvy. Uz Škvoreckoga, najzvučnije ime egzilne scene, ali i cijele češke književnosti druge polovice 20. st., zasigurno je Milan Kundera koji od druge polovice sedamdesetih drugu domovinu nalazi u Francuskoj gdje od kraja osamdesetih godina svoja djela piše i na francuskome jeziku. U domovini u samizdatu književnici objavljuju u devedesetak izdavačkih kuća među kojima se svojom aktivnošću ističe Edice Petlice književnika Ludvíka Vaculíka. Imena nekih književnika nalazimo u tzv. sivoj zoni kojoj pripadaju autori koji, pod različitim okolnostima, svoja djela objavljuju i oficijelno i neoficijelno, u egzilu i samizdatu. Središnja su imena tzv. sive zone književni klasici Bohumil Hrabal i Jaroslav Seifert te romanopisac Jiří Šotola.

U drugoj polovici osamdesetih društvene promjene vode integraciji svih triju struja češke književnosti. To ubrzo dolazi do izražaja i na institucionalnoj razini pa u zaključke sjednice Saveza čeških književnika u ožujku 1989. ulazi odredba da u preglede češke književnosti treba uključiti i neoficijelnu produkciju.

Dok su na ljestvicama najčitanijih knjiga u Hrvatskoj redovno najnovija izdanja romana Milana Kundere i Josefa Škvoreckog, a drame neoficijelnih dramatičara na repertoarima hrvatskih kazališta, na institucionalnoj razini odvija se suradnja s predstavnicima oficijelne scene. Udruženja pisaca i kazališne kuće iz Čehoslovačke česti su sudionici Zagrebačkih književnih razgovora i gosti u hrvatskim kazalištima. Kada je riječ o oficijelnoj produkciji češke književnosti hrvatske izdavačke kuće zanimanje pokazuju samo za uzak krug spisatelja koji čine njen kvalitativni vrhunac, a riječ je o prozama Ladislava Fuksa, Vladimíra Párala i, u osamdesetima, Jaroslava Bočeka.

Od predstavnika tzv. sive zone do hrvatskih čitatelja, također, dolaze prijevodi najistaknutijih imena, klasika češke književnosti Bohumila Hrabala, Jiř́jja Šotole i dobitnika Nobelove nagrade Jaroslava Seiferta. Seifert je, ujedno, i pjesnik koji je svojom poezijom i u kvantitativnom smislu najsnažnije prodro na hrvatsko književno tržište i to beogradskim prijevodom poezije 1984. te nizom pjesama praćenih kritičkim i biografskim člancima razasutima u hrvatskim časopisima poput Foruma, Republike, 15 dana. 


\section{NEOFICIJELNA ČEŠKA KNJIŽEVNOST U HRVATSKOJ OD 1968. DO 1990.}

Tijekom razdoblja koje se u povijesti češke književnosti naziva razdobljem normalizacije, a obuhvaća sedamdesete i osamdesete godine 20. st., jugoslavenska je kulturna scena, iako jedan njen dio u isto vrijeme osjeća djelomičnu kontrolu službene vlasti koja različitim mehanizmima filtrira sadržaje dostupne javnosti, ${ }^{296}$ bila, pokazat će daljnja analiza, izuzetno prijemčiva za ostvarenja češke neoficijelne kulture. Kvantitativni porast recepcije primjećujemo osobito tijekom osamdesetih godina. Iz toga desetljeća, naime, datira većina knjižnih izdanja neoficijelnih čeških književnika na jugoslavenskome izdavačkom tržištu.

Prema katalogu zagrebačke Nacionalne i sveučilišne knjižnice, od sloma praškoga proljeća do pada komunizma čitateljima u Hrvatskoj u hrvatskim, srpskim i bosanskim prijevodima i izdanjima dostupno je dvadeset naslova neoficijelnih čeških autora, od kojih neki u više izdanja. U ponovljenim izdanjima prednjače proze Milana Kundere od kojih je rekordan broj izdanja romana $\breve{S}$ ala koji je u analiziranih dvadesetak godina u Beogradu, Sarajevu i Zagrebu objavljen čak osam puta. ${ }^{297}$

Reakcija jugoslavenskih izdavačkih kuća na novoobjavljene naslove neoficijelne produkcije kod većine je izdanja bila izuzetno brza, naslovi se prevode i objavljuju u veoma kratkome vremenu nakon njihovih premijernih izdanja, tako da nikako ne možemo reći da je riječ o zakašnjeloj recepciji. Na vrhuncu popularnosti Milana Kundere, tijekom osamdesetih,

\footnotetext{
${ }^{296}$ Tako, primjerice, o autocenzuri i ezopovskom govoru hrvatskih dramatičara progovara redakcija časopisa Prolog u uvodnome tekstu Zašto istupamo iz 1968. Redakcija koju su činili Darko Gašparović, Drago Kekanović, Miro Međimorec, Vladimir Roksandić, Ante Rumora i Slobodan Šnajder naglašava da je problem domaće drame postojanje autocenzure i unutrašnjih kočnica koje hrvatske dramatičare pritiskuju na polje alegorije ,zamatanjem drame u povijesne, mitološke i vanvremenske motive“. (Zašto istupamo, Prolog, god. 1 ., br. 1, 1968., str. 4) Dvadeset godina kasnije o istoj temi Novi prolog na svojim stranicama donosi ulomke razgovora održanih povodom Gavellinih večeri u Zagreba na temu cenzure i autocenzure, a u kojem sudjeluju Nedjeljko Fabrio, Mani Gotovac, Kosta Spaić, Krešimir Zidarić, Pero Kvrgić i dr. U tom se razgovoru kao oblici eskapizma od društveno suspektnih tema uočavaju geografska neodređenost mjesta radnje u dramama hrvatskih dramatičara - postupak koji je uočen i u tekstu iz 1968., te uključivanje u repertoare kazališta drama stranih autora čija je radnja ekvivalentna zbivanjima u hrvatskom društvu. (Prilozi za povijest cenzure u našem glumištu /Iz zagrebačkih kazališnih razgovora/, Novi prolog, br. 11, 1988./1989., str. 17-21) Isti časopis 1988. donosi tekst Andree Zlatar o intervencijama pri prikazivanju drame Mirisi, zlato i tamjan prema romanu Slobodana Novaka 1974. u režiji Božidara Violića. Zlatar navodi da je jedna scena predstave igrana na premijeri, no ne i u daljnjim izvedbama, a nakon intervencije iz Gradskoga komiteta. Predstava nije pozvana na ugledan kazališni festival Sterijino pozorje, a kada je prikazana na beogradskome BITEF-u, glumačka i autorska postava autocenzurom izbacuje dio teksta. Unatoč tome, tijekom beogradske izvedbe replika drame na ruskome jeziku toliko isprovocira sovjetskoga veleposlanika da on napušta dvoranu usred predstave. (Zlatar, Andrea Povijest predstave kao redateljska biografija, Novi prolog, br. 8/9, 1988., str. 106-115)

${ }^{297}$ Roman Šala Milana Kundere objavljen je 1969., 1982., 1984. u Zagrebu, 1984., 1985. i 1990. u Sarajevu te 1987. i 1990. u Beogradu.
} 
neke romanopiščeve proze ostvaruju jugoslavensko izdanje iste godine kada i prvo izdanje uopće, primjerice roman Život je negdje drugdje (Život je jinde) objavljen je 1979. i u Torontu, u izdavačkoj kući 68 Publishers, i u zagrebačkome Znanju, dok je Knjiga smijeha $i$ zaborava (Kniha smíchu a zapomnění) u Torontu objavljena 1981., a u Grafičkome zavodu Hrvatske u Zagrebu samo godinu dana kasnije. Sarajevsko izdanje romana Nepodnošljiva lakoća postojanja (Nesnesitelná lehkost bytí) objavljeno je 1984., čak godinu prije izdanja romana na češkom jeziku u torontskom 68 Publishers. Roman je, naime, prvi put objavljen 1984., no na francuskome jeziku u izdavačkoj kući Gallimard.

Od čeških neoficijelnih prozaika najdulje su stanke između prvoga izdanja na jeziku originala i onoga u Jugoslaviji imale neke proze Josefa Škvoreckog, i to, nerijetko, više od deset godina. Nakon brze izdavačke reakcije na roman Oklopni bataljon (Tankový prapor) prvo izdanje u Torontu 1971., a izdanje zagrebačkoga Znanja odmah godinu kasnije, između prvoga i jugoslavenskoga izdanja romana Sjajna sezona, tekst o najvažnijim stvarima u životu (Prima sezóna: Text o nejdi̊ležitějšich věcech života) i Mirakl (Mirákl) prošlo je jedanaest, odnosno čak petnaest godina.

Književnokritički i novinski napisi u hrvatskim pisanim medijima sedamdesetih i osamdesetih godina 20. st. uz analizu književnih tekstova neoficijelnih autora bilježe i izuzetne pohvale sveukupnoj tradiciji češke književnosti s naglaskom na aktualnu književnu produkciju, a češka se proza razdoblja normalizacije u njima nerijetko kvalificira kao jedna od najzanimljivijih u Europi. ${ }^{298} \mathrm{U}$ pogovoru zagrebačkoga izdanja romana Mirakl (Mirákl) Josefa Škvoreckog 1987. povjesničar književnosti Predrag Matvejević navodi da je Jugoslavija bila ,jedina slavenska zemlja u kojoj se oni [češki neoficijelni književnici] slobodno objavljuju“ “299. U istome tekstu Matvejević naglašava da na jugoslavenskome tržištu češki disidenti u tome nisu bili usamljeni, izdavačke su kuće objavljivale, a čitatelji izuzetno dobro prihvaćali, i proze disidenata ostalih europskih komunističkih zemalja poput Czesława Miłosza $^{300}$ i Aleksandra Solženjicina ${ }^{301}$.

\footnotetext{
${ }^{298}$ Matvejević, Predrag Književnost i emigracija (Sivocrni humor), Danas, 4. 11. 1986., str. 36-38; Že. V. Na listama ništa novo, Večernji list, br. 8496, 2. 4. 1987., str. 19.

${ }^{299}$ Škvorecký, Josef Mirakl, pogovor Predraga Matvejevića, Grafički zavod Hrvatske, Zagreb, 1987., str. 513. Ako u obzir uzmemo i dramsku produkciju, Matvejevićeva tvrdnja nije u potpunosti točna. Naime, početkom 1980-ih drame Václava Havela Audijencija, Izložba i Protest izvode se i na Maloj sceni Suvremenoga kazališta u Varšavi te u Krakovu i Lublinu. Branko Šömen Češki sanjar: Václav Havel od disidenta do prezidenta, Profil, Zagreb, 2012., str. 128; Državnik i dramatičar Václav Havel, HAZU, Zagreb, 2000.

${ }^{300}$ Miłosz, Czesław (1911. - 2004.), poljski književnik. Dobitnik Nobelove nagrade za književnost 1980.

${ }^{301}$ Solženjicin, Aleksandr (1918. - 2008.), ruski književnik. Žestok kritičar Staljinove vladavine i metoda. Dugi niz godina objaljivao u samizdatu, a od 1974. živi izvan Sovjetskoga Saveza. Dobitnik Nobelove nagrade za književnost 1970. www.enciklopedija.hr (natuknica Aleksandr Solženjicin, pristupljeno 1. 9. 2019.)
} 
U svojim analizama srpska slavistica Aleksandra Korda-Petrović ide korak dalje te primjećuje kvantitativnu dominaciju izdanja pojedinih neoficijelnih autora i kazališnih uprizorenja dramskih tekstova u različitim republičkim centrima bivše države. Dok se, primjerice, proze Josefa Škvoreckog uglavnom objavljuju u zagrebačkim izdavačkim kućama, dramski tekstovi Václava Havela imali su tijekom sedamdesetih i osamdesetih godina 20. st. znatno bolju recepciju u beogradskim, no zagrebačkim kazalištima. ${ }^{302}$

U ovome su poglavlju prijevodi djela predstavnika neoficijelne češke književnosti koji ostvaruju recepciju među čitateljima u Hrvatskoj od 1968. do 1990. klasificirani na prozu, kvantitativno najzastupljeniji dio korpusa koji uključuje romane, zbirke pripovijedaka te nefikcionalnu prozu - memoarske zapise, eseje i epistolarnu prozu, zatim dramske tekstove i poeziju.

U knjižnim je izdanjima očita prevaga proznih naslova. Od četrdeset i tri izdanja samo jedno sadrži dramske tekstove, Havelove drame Iskušenje i Asanacija objavljene u Gornjem Milanovcu već krajem ovoga razdoblja, 1990. Ta činjenica ne začuđuje budući da je primarni medij dramskoga teksta kazališna predstava, a na pozornicama hrvatskih kazališta, pokazat će 7. poglavlje ovoga rada, neoficijelni dramatičari itekako pronalaze svoje mjesto. U svim ostalim izdanjima riječ je o proznim tekstovima, a od njih četrdeset i dvoje dominiraju romani, objavljeni su u čak trideset izdanja.

Tablica I: Knjižna izdanja neoficijelnih čeških autora na hrvatskome izdavačkom tržištu od 1968. do 1990. prema književnome rodu

\begin{tabular}{|l|l|l|l|}
\hline književni rod & $\begin{array}{l}\text { proza (romani, zbirke pripovijedaka, } \\
\text { nefikcionalna proza) }\end{array}$ & poezija & drame \\
\hline broj knjižnih izdanja & 42 & 0 & 1 \\
\hline
\end{tabular}

${ }^{302}$ Korda-Petrović, Aleksandra Fenomen prihvaćenosti čeških disidenata u srpskoj sredini, Zbornik Matice srpske za slavistiku, 2006., str. 227-239. 
Dijagram II: Knjižna izdanja neoficijelnih čeških autora na hrvatskome izdavačkom tržištu od 1968. do 1990. prema književnome rodu
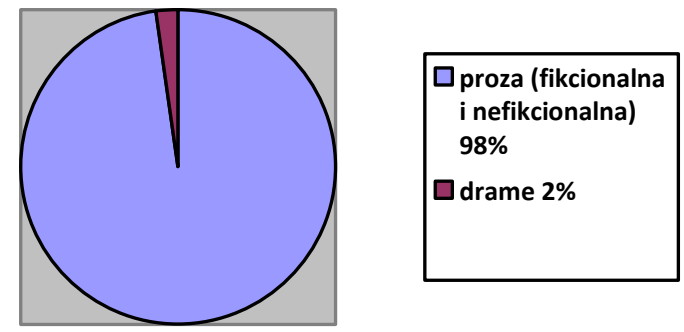

Tablica II: Knjižna izdanja proze neoficijelnih čeških autora na hrvatskome izdavačkom tržištu od 1968. do 1990. prema književnoj vrsti

\begin{tabular}{|l|l|l|l|}
\hline književna vrsta & romani & zbirke pripovijedaka & $\begin{array}{l}\text { ostalo (epistolarna proza, } \\
\text { memoarska proza) }\end{array}$ \\
\hline broj izdanja & 30 & 8 & 4 \\
\hline
\end{tabular}

Dijagram III: Knjižna izdanja proze neoficijelnih čeških autora na hrvatskome izdavačkom tržištu od 1968. do 1990. prema književnoj vrsti
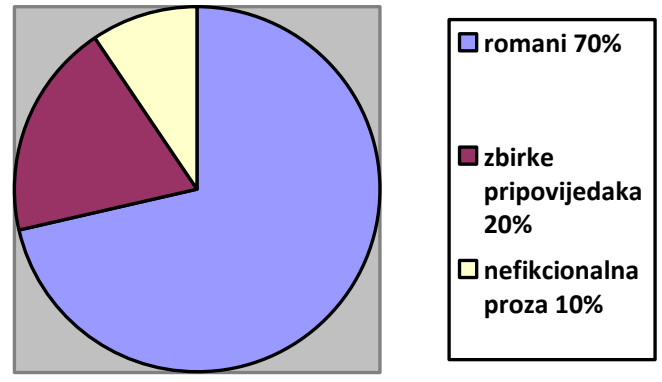

Kada govorimo o knjižnim izdanjima proznih tekstova, kvantitativno najbolju recepciju ostvaruju proze Milana Kundere te Josefa Škvoreckog koje, s 36 izdanja, čine čak 85\% ukupnih izdanja proze neoficijelnih čeških autora na hrvatskome tržištu od 1968. do 1990. 
Tablica III: Knjižna izdanja neoficijelnih čeških autora na hrvatskome izdavačkom tržištu od 1968. do 1990. prema autoru

\begin{tabular}{|l|l|l|l|l|l|l|l|l|}
\hline autor & $\begin{array}{l}\text { Havel, } \\
\text { Václav }\end{array}$ & $\begin{array}{l}\text { Klíma, } \\
\text { Ivan }\end{array}$ & $\begin{array}{l}\text { Kundera, } \\
\text { Milan }\end{array}$ & $\begin{array}{l}\text { Liehm, } \\
\text { Antonín }\end{array}$ & $\begin{array}{l}\text { Mlynář, } \\
\text { Zdeněk }\end{array}$ & $\begin{array}{l}\text { Pelikán, } \\
\text { Jiří }\end{array}$ & $\begin{array}{l}\text { Škvorecký, } \\
\text { Josef }\end{array}$ & $\begin{array}{l}\text { Vaculík, } \\
\text { Ludvík }\end{array}$ \\
\hline $\begin{array}{l}\text { broj } \\
\text { izdanja }\end{array}$ & 1 & 1 & 28 & 1 & 1 & 1 & 8 & 1 \\
\hline
\end{tabular}

Dijagram IV: Knjižna izdanja neoficijelnih čeških autora na hrvatskome izdavačkom tržištu od 1968. do 1990. prema autoru

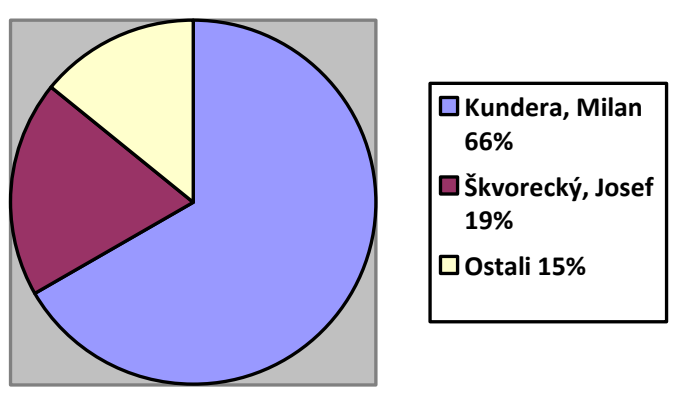

Intenziviranje izdavačke djelatnosti u jugoslavenskim izdavačkim kućama primjećuje se tijekom osamdesetih godina, sredinom toga desetljeća objavljen je najveći broj izdanja neoficijelnih čeških autora. U samo četiri godine - 1984., 1985., 1986. i 1987. - objavljena su čak 24 izdanja, što čini 56\% svih izdanja u 23 analizirane godine.

Do ponovnoga zamaha izdavačke djelatnosti dolazi krajem toga desetljeća što se može povezati s općim rastom zanimanja za promjenu društvene paradigme u zemljama istočne i srednje Europe, pa tako i u Čehoslovačkoj te, osobito, činjenicu da na čelo države s demokratskim promjenama dolazi jedan od najznačajnijih predstavnika neoficijelne kulturne scene u prethodnome razdoblju što i u Hrvatskoj, kako će pokazati ovaj rad, izaziva veliku pozornost medija. 
Tablica IV: Knjižna izdanja neoficijelnih čeških autora na hrvatskome izdavačkom tržištu od 1968. do 1990. prema godini objavljivanja

\begin{tabular}{|l|c|c|c|c|c|c|c|c|}
\hline godina & 1968. & 1969. & 1970. & 1971. & 1972. & 1973. & 1974. & 1975. \\
\hline broj izdanja & 0 & 2 & 0 & 0 & 1 & 1 & 0 & 0 \\
\hline godina & 1976. & 1977. & 1978. & 1979. & 1980. & 1981. & 1982. & 1983. \\
\hline broj izdanja & 0 & 0 & 0 & 1 & 0 & 0 & 3 & 1 \\
\cline { 1 - 7 } godina & 1984. & 1985. & 1986. & 1987. & 1988. & 1989. & 1990. & \multicolumn{1}{|c}{} \\
\cline { 1 - 6 } broj izdanja & 6 & 8 & 4 & 6 & 1 & 2 & 7 & \multicolumn{1}{|l}{}
\end{tabular}

Dijagram V: Knjižna izdanja neoficijelnih čeških autora na hrvatskome izdavačkom tržištu od 1968. do 1990. prema godini objavljivanja

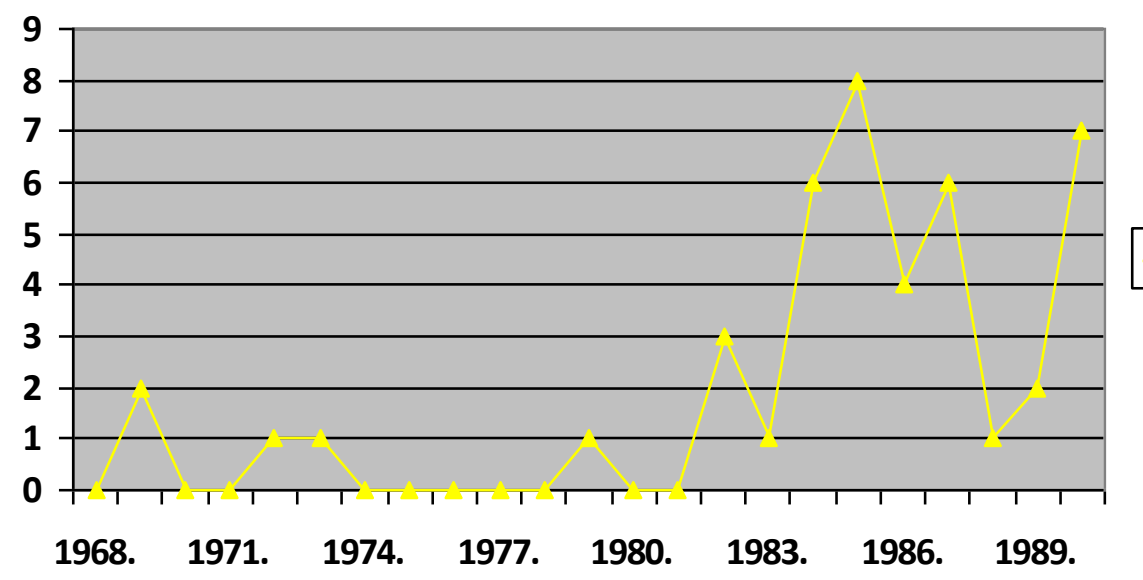

Broj izdanja u godini

Logistički i organizacijski uvjeti zasigurno su utjecali na činjenicu da se u knjižnim izdanjima djela neoficijelnih autora uočava očita nadmoć egzilne književnosti u odnosu na samizdatsku, odnosno onaj dio korpusa koji je nastajao u Čehoslovačkoj.

Analiza knjižnih izdanja - njih 43, pokazuje da u samo četiri primjera, Vaculíkove Sjekire koja je u Čehoslovačkoj objavljena prije normalizacije, Klímina Ljeta ljubavi koje je objavljeno i u egzilu, u Torontu 1979., te srpskih izdanja Havelovih drama i Pisama Olgi 1989. i 1990., nije riječ o egzilnim autorima. 
Tablica V: Omjer knjižnih izdanja egzilnih i samizdatskih autora na hrvatskome izdavačkom tržištu od 1968. do 1990.

\begin{tabular}{|l|l|}
\hline & broj izdanja \\
\hline samizdatski autori & 4 \\
\hline egzilni autori & 39 \\
\hline
\end{tabular}

Dijagram VI: Omjer knjižnih izdanja egzilnih i samizdatskih autora na hrvatskome izdavačkom tržištu od 1968. do 1990.

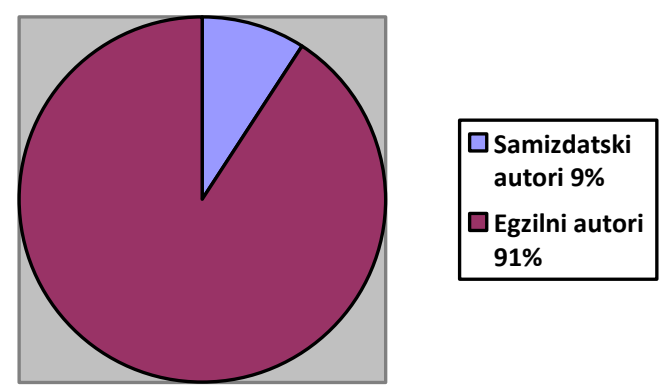

\section{1. Proza}

Kako proces potiskivanja autora i tekstova u prostor neoficijelnoga u Čehoslovačkoj traje nekoliko godina nakon sloma praškoga proljeća, u tome razdoblju jugoslavenski izdavači određene naslove, koji će kasnije pripadati isključivo neoficijelnoj sceni, objavljuju još uvijek paralelno s češkim državnim izdavačkim kućama. Primjerice, roman Sjekira (Sekyra) Ludvíka Vaculíka iste godine, 1969., objavljuje i beogradska izdavačka kuća Rad i najugledniji i najveći češki nakladnik Československý spisovatel iz Praga, no ubrzo nakon toga književni rad Ludvíka Vaculíka ulazi isključivo u sferu neoficijelnoga sve do pada komunizma u zemlji. $^{303}$

Proznome dijelu prevedena korpusa koji ostvaruje recepciju u Hrvatskoj pripadaju romani, zbirke pripovijedaka, memoarski zapisi, eseji i epistolarna proza, a njime, kao što je

${ }^{303}$ Roman je 1977. objavila egzilna izdavačka kuća Index iz njemačkoga Kölna. 
već navedeno, kvantitativno dominiraju naslovi dvojice prozaika, Josefa Škvoreckog i Milana Kundere. Brojni su analitičari pokušali proniknuti u razloge odlične prihvaćenosti njihovih tekstova među čitateljima u Hrvatskoj i pritom su te razloge tumačili dvojako. Dio se njih u svojim analizama nerijetko pozivao na ishodišta književnoga rada dvojice romanopisaca kojima se smatra prozna tradicija Karela Čapeka i Jaroslava Hašeka, a s kojom su hrvatski čitatelji već izgradili odličan odnos tijekom dvadesetoga stoljeća. ${ }^{304}$ Drugi je razlog humoristična sastavnica njihovih tekstova za koju se u hrvatskome javnom prostoru nerijetko rabi sintagma specifičnoga ,češkog humora“ koji isključuje humor kao svrhu samome sebi. Pišući o Kunderi, kritičar Zdravko Zima takav humor tumači sredstvom obrane protiv besmisla povijesti i politike, ${ }^{305}$ a i sâm Josef Škvorecký navodi da su duhovitost i humor univerzalna sredstva ljudskoga bijega od očaja. ${ }^{306}$

Neoficijelne češke prozaike od 1968. do 1990. objavljuju najuglednije jugoslavenske izdavačke kuće, poput zagrebačkoga Znanja i „Augusta Cesarca“, beogradske Prosvete, sarajevskoga „Veselina Masleše“ i Dečjih novina iz Gornjega Milanovca, u svojim tržišno najuspješnijim edicijama. Od zagrebačkih nakladnika u tome prednjači Znanje svojim bibliotekama Hit i Evergrin koje su, uglavnom, objavljivale tržišno izuzetno dobro prihvaćenu prijevodnu književnost uz nekoliko naslova hrvatskih autora koje je uključivalo svako kolo. Ondje su objavljeni romani Milana Kundere Šala (Žert), Život je negdje drugdje (Život je jinde) te Oklopni bataljon (Tankový prapor) Josefa Škvoreckog. Prijevodna su izdanja Biblioteke Hit, osobito u sedamdesetima, doživljavanja kao izuzetno važna za razvoj nacionalne književnosti te kao ,popunjavači rupa“307 koje je ostavljala tadašnja domaća produkcija. ${ }^{308}$ Najzvučnija imena češke neoficijelne proze u bibliotekama hrvatskih izdavača objavljuju se uz bok najzvučnijim imenima hrvatske i svjetske književnosti toga vremena poput Pavla Pavličića, Ivana Slamniga i Gabriela Garcije Marqueza. ${ }^{309}$ Dugogodišnji urednik te Biblioteke Zlatko Crnković ${ }^{310}$ uspijeva postići ravnotežu između zahtjeva za visokim

\footnotetext{
${ }^{304}$ Tomić, Vladimir Istočni val u zapadnim knjižarama, Danas, 2. 4. 1984., str. 61-62; Osporavanje kao stav (intervju s Aleksandrom Flakerom), Danas, 30. 10. 1984., str. 51-54; Humor kao oružje protiv očaja (intervju s Josefom Škvoreckým), Danas, 29. 10. 1985., str. 52-55.

${ }^{305}$ Zima, Zdravko Književni portreti - na otoku strasti, Vjesnik, 11. 10. 1981., br. 12258, str. 11.

${ }^{306}$ Humor kao oružje protiv očaja (intervju s Josefom Škvoreckým), Danas, 29. 10. 1985., str. 52-55.

${ }^{307}$ Horvatić, Dubravko Biblioteka „Hit“, Republika, br. 2/3, 1971., str. 301-311.

${ }^{308}$ Početkom sedamdesetih, u vrijeme kada je objavljen ovaj Horvatićev tekst, strani su autori u Hitovim izdanjima zastupljeni naslovima s vrhova ljestvica čitanosti. Primjerice, jedan je od takvih naslova roman Aerodrom američkoga književnika Arthura Haileya koji je u matičnoj zemlji vodeće mjesto na ljestvici bestselera držao čak osam mjeseci.

${ }^{309}$ Brenčun, Dragutin Prvenstveno domaći autori, Večernji list, 20. i 21. 12. 1980., br. 6562, str. 12.

${ }^{310}$ Crnković, Zlatko (1931. - 2013.), hrvatski prevoditelj, urednik i esejist.
} 
umjetničkim kriterijima i tržišne uspješnosti izdanja. Ili, riječima novinara Vjesnika povodom 200. izdanja Hita: „Do pojave Hita u izdavačkim su redovima, naime, prevladavali redaktori pogleda uprtih u Vječnost, Umjetnost, Metafizički Zadatak. Publika je bila na repu. Crnković ju je postavio na početak, ali tako da ni književnost nije zanemario.“" ${ }^{311}$

O aktualnoj situaciji početkom osamdesetih i smjernicama uređivačke politike najpoznatijih zagrebački izdavačkih kuća saznajemo iz niza intervjua koje 1980. objavljuje zagrebački Polet. ${ }^{312} \mathrm{U}$ tim su tekstovima uspoređene naklade tržišno najuspješnijih biblioteka pa saznajemo da je inicijalna naklada Biblioteke Bestseler Izdavačke kuće „August Cesarec“, koja, između ostaloga, 1983. objavljuje Šotolino Pile na ražnju (Kuře na rožni), a 1989. Inženjera ljudskih duša (Příběh inženýra lidských duší) Josefa Škvoreckog, 5000 komada, ${ }^{313}$ a da izdanja Biblioteke Hit ostvaruju izuzetno visoke naklade od 15000 primjeraka „kao da uz svaku knjigu Hita daju najmanje kilu kave“314 čiju nestašicu početkom osamdesetih Jugoslavija nerijetko bilježi. U Poletovu intervjuu urednik Zlatko Crnković posebno se osvrće na češku sastavnicu Hitovih izdanja napominjući da se romani Milana Kundere, Josefa Škvoreckog, Bohumila Hrabala i Jiř́ija Šotole ,nisu bogzna kako ni prodavali, ali samo zato što su češki pisci, a mislim da su oni među boljim autorima u Hitu. “315

Crnkovićeve tvrdnje iz toga intervjua djelomično opovrgavaju ljestvice najčitanijih i najtraženiji knjiga u zagrebačkim knjižnicama i knjižara koje tijekom osamdesetih objavljuju hrvatski dnevni listovi Večernji list i Vjesnik, najčešće u podliscima posvećenima kulturi. Oni nam svjedoče da su čitateljima u Hrvatskoj proze čeških autora bile itekako zanimljive. Iako statistički podaci objavljivani u dnevnome tisku ne donose sustavan pregled te, nerijetko, ni informacije o izvoru podataka, mogu pružiti opću sliku o raspoloženju hrvatske čitateljske publike toga vremena. ${ }^{316}$ Od neoficijelnih čeških prozaika na ljestvicama najčitanijih knjiga

\footnotetext{
311 200. hit, Vjesnik, br. 14820, 19. 12. 1988., str. 8.

312 Tijekom osamdesetih hrvatska je izdavačka scena djelomično bila oblikovana i potresima u jugoslavenskom gospodarstvu koji izazivaju manjak deviza što onemogućuje isplatu honorara stranim autorima. Izdavačke kuće, stoga, nerijetko pribjegavaju izdanjima autora s kojima su ugovori potpisani prije gospodarske krize ili izdanjima klasika za koje se više ne plaćaju autorska prava. S vremenom nedostatka deviza dovodi do nemogućnosti uvoza papira što, također, počinje utjecati na izdavačku djelatnost. A. L. Tinejdžerski HIT, Večernji list, 27. 1. 1984., br. 7509, str. 14; Zima, Zdravko Dobar dan, klasiko, Vjesnik, 9. 2. 1982., br. 12374, str. 6; Šigir, Mirjana Mogući put koprodukcija, Vjesnik, 31. 1. 1983.br. 12722, str. 8.

${ }^{313}$ Pezo, Zoran Ujed tržišta (razgovor sa Zdravkom Židovcem), Polet, br. 126, 1980.

${ }^{314}$ Pezo, Zoran Nevjerojatni „Hit“, Polet, br. 127, 1980.

315 Pezo, Zoran Zlatko Crnković: ulog je atrakcija, Polet, br. 127, 1980.

${ }^{316}$ Do egzaktnih, sustavnih i provjerenih podataka o evidenciji prodaje u knjižarama i posudbe knjiga u knjižnicama u razdoblju koje je tema ovoga rada nemoguće je doći jer se takva evidencija nije obavljala digitalno. Prilikom izrade ovoga rada upit o statističkim podacima iz sedamdesetih i osamdesetih godina, a na koji je odgovoreno negativno, poslan je Knjižnicama grada Zagreba.
} 
najčešće se pojavljuje ime Josefa Škvoreckog. Među najčitanijim naslovima osamdesetih godina njegove su proze Oklopni bataljon (Tankový prapor), ${ }^{317}$ Sjajna sezona: tekst o najvažnijim stvarima u životu (Prima sezóna: Text o nejdůležitějšich věcech života), ${ }^{318}$ Bas saksofon i druge priče o džezu (Hořkej svět/Dvě legendy) ${ }^{319}$ 1986. te Mirakl (Mirákl) ${ }^{320} 1988$. Škvoreckoga po zastupljenosti na popisima najtraženijih knjiga u zagrebačkim knjižnicama slijede memoarski zapisi Zdeněka Mlynářa Mraz dolazi iz Kremlja (Mráz přichazí z Kremlu), ${ }^{321}$ predstavnici oficijelne scene Jaroslav Boček s kriminalističkim romanom Slučaj dr. Karpete (Př́pad doktora Karpety) ${ }^{322}$ i Jiř́ Šotola s romanom Ljepuškasta djeca (Malovaný děti $)^{323}$ te Kunderina Nepodnošljiva lakoća postojanja (Nesnesitelná lehkost bytí) ${ }^{324}$. Godine 1982. hrvatski tisak donosi informaciju o tržišnoj dominaciji romana Šala (Žert) Milana Kundere koja je, uz Jedan dan u životu Ivana Denisoviča Aleksandra Solženjicina, jedan od najprodavanijih romana toga ljeta u Hrvatskoj. ${ }^{325}$

O utkanosti češke književne tradicije i prihvaćenosti suvremene produkcije među hrvatskim čitateljima govori i njihova zastupljenost u izborima deset omiljenih knjiga istaknutih osobnosti hrvatske društvene scene koje u svom prilogu o kulturi sredinom osamdesetih godina objavljuje zagrebački Vjesnik. Tako, primjerice, dramatičar Tahir Mujičić u svome izboru objavljenome u rujnu 1986. na šesto mjesto ljestvice smješta Hašekova Švejka obrazloživši svoj izbor time da je ,'švejkovština' postala životnom filozofijom i vrstom kulturne samoobrambene vještine srednjoevropskih narotčića dvadesetog

\footnotetext{
${ }^{317}$ Rang-lista Bestselera, Večernji list, br. 8350, 28. 10. 1986., str. 11; Ljestvica najtraženijih knjiga, Vjesnik, br. 14020, 21. 9. 1986., str. 15; Ljestvica najtraženijih knjiga, Vjesnik, br.14034, 5. 10. 1986., str. 15.

318 Že. V. O staljinizmu - ozbiljno i ironično, Večernji list, br. 8379, 3. 12. 1986., str. 15 (podaci iz zagrebačkih knjižnica „August Cesarec“, „Bogdan Ogrizović“ i Medveščak); Že. V. Knjiga - najbolji dar, Večernji list, br. 8393, 17. 12. 1986., str. 15 (podaci iz zagrebačkih knjižara Rad, Naprijed i Prosvjeta); Ljestvica najtraženijih knjiga, Vjesnik, br. 14034, 5. 10. 1986., str. 15; Že. V. Tematska raznovrsnost, Večernji list, br. 8440, 5. 2. 1987., str. 18 (podaci iz zagrebačkih knjižnica Prečko, „August Cesarec“ i „Vladimir Nazor")

${ }^{319}$ Ljestvica najtraženijih knjiga, Vjesnik, br. 14076, 16. 11. 1986., br. 14.

${ }^{320}$ Ljestvica najtraženijih knjiga, Vjesnik, br. 14580, 17. 4. 1988., str. 18; f. k. Rasprodane Balade, Večernji list, br. 9068, 10. 11. 1988., str. 21; Knjiga je najbolji dar, Večernji list, br. 9094, 8. 12. 1988., str. 21.

321 Že. V. O staljinizmu - ozbiljno i ironično, Večernji list, br. 8379, 3. 12. 1986., str. 15 (podaci iz zagrebačkih knjižnica „August Cesarec“, „Bogdan Ogrizović“ i Medveščak); Že. V. Poslije praznika dolazi knjiga, Večernji list, br. 8411, 9. 1. 1987., str. 15.

${ }^{322}$ Poseban prilog Bestseler, Večernji list, br. 8173, 1. 4. 1986., str. 11.

${ }^{323}$ Že. V. Čitanje bez predaha, Večernji list, br. 8468, 5. 3. 1987., str. 19 (podaci iz zagrebačkih knjižnica „S. S. Kranjčević“, „Vjekoslav Majer“ i Gradske knjižnice); Že. V. Na listama ništa novo, Večernji list, br. 8496, 2. 4. 1987., str. 19 (podaci iz zagrebačkih knjižnica Medveščak i „Bogdan Ogrizović“); Že. V. Horoskop u modi, Večernji list, br. 8516, 22. 4. 1987., str. 14 (podaci iz zagrebačke knjižare Rad i znanstvene knjižare Mladost) 324 Že. V. Stari znanci, Večernji list, br. 8333, 8. 10. 1986., str. 15 (podaci iz zagrebačkih knjižnica „Vladimir Nazor“, „Bogdan Ogrizović“" i „Silvije Strahimir Kranjčević“) ${ }^{325}$ Z. Z. Obavezno za jedriličare, Vjesnik, br. 12525, 13. 7. 1982., str. 8.
} 
stoljeća“. ${ }^{326}$ Odmah iza Hašeka, na sedmo mjesto, Mujičić stavlja opuse Milana Kundere, Jiř́ija Šotole i Josefa Škvoreckog. Upitan da obrazloži svoj izbor, dramatičar kratko upućuje „vidi pod 6.“327

U drugoj polovici osamdesetih proze neoficijelnih autora redovito se nalaze i na popisima sufinanciranih izdanja društveno vrijednih knjiga o čemu odlučuje Komisija za program društveno vrijede knjige kojoj je u tome razdoblju na čelu prof. dr. Milivoj Solar. Mirakl (Mirákl) Josefa Škvoreckog prepoznat je kao „društveno vrijedna knjiga“ 1987., ${ }^{328}$ a već godinu kasnije Komisija istovremeno sufinancira izdavanje i oficijelnog autora, Fuksova Gospodina Theodora Mundstocka (Pan Theodor Mundstock), i neoficijelnoga Inženjera ljudskih duša (Přiběh inženýra lidských duši) Josefa Škvoreckog. ${ }^{329}$

Među prevoditeljima neoficijelnih prozaika nezaobilazna su imena Dagmar Ruljančić ${ }^{330}$ i Aleksandra Ilića, ${ }^{331}$ a pri prijevodu proza Milana Kundere ono Nikole Kršića, ${ }^{332}$ prevoditelja svih Kunderinih romana i zbirke pripovijedaka Smiješne ljubavi (Směšné lásky) te romana Oklopni bataljon (Tankový prapor) Josefa Škvoreckog. U nekrologu tome prevoditelju postumno odlikovanom Nagradom za životno djelo Društva hrvatskih književnih prevodilaca 1986. književni urednik Zlatko Crnković prisjeća se da je ,[j]edan (...) kritičar u povodu Kršićeve smrti dobro primijetio da je on sâm učinio više za naše poznavanje suvremene češke književnosti nego cijela jedna katedra bohemistike“6333.334

Usporedo s izdanjima u izdavačkim kućama kraće ulomke proza i novelistiku neoficijelnih autora sporadično objavljuje i hrvatski tisak. Ulomci su proznih tekstova pri tome nerijetko uklopljeni u veće tematske cjeline poput one u časopisu 15 dana u kojoj fotografije legendi popularne kulture zapadnoga kruga Elvisa Presleyja i Freddieja Mercuryja

\footnotetext{
${ }^{326}$ Književna desetka - Tahir Mujičić, Vjesnik (Panorama subotom), br. 14005, 6. 9. 1986., str. 17 Na Mujičićevu opasku o „srednjoevropskim narotčićima“ zasigurno je utjecaj imao i slavni Kunderin esej Tragedija Srednje Europe koji je godinu dana ranije objavljen u hrvatskome prijevodu u časopisu Gordogan, a u hrvatskome tisku izaziva snažne reakcije o čemu detaljnije govori 4. poglavlje.

327 Isto.

${ }^{328}$ Popis prihvaćenih naslova za sufinanciranje programa društveno vrijednih knjiga u 1987., Oko, br. 393, 1987., str. 16-17.

${ }^{329}$ Popis prihvaćenih naslova za sufinanciranje programa društveno vrijednih knjiga u 1988., Oko, br. 418., 1988, str. 21.

${ }^{330}$ Ruljančić, Dagmar (1950.), hrvatska prevoditeljica.

${ }^{331}$ Ilić, Aleksandar (1945. - 2018.), srpski sveučilišni profesor, prevoditelj i književnik.

${ }^{332}$ Kršić, Nikola (1928. - 1985.), hrvatski prevoditelj.

${ }^{333}$ Crnković, Zlatko Posljednja prevodiočeva bitka, Vjesnik, br. 13875, 26. 4. 1986., str. 16.

${ }^{334}$ Istu misao Zlatko Crnković ponavlja i u tekstu objavljenu u Vijencu 2000. pišući o važnosti rada čeških kroatista Dušana Karpatskog i Irene Wenigové za razvoj češko-hrvatskih kulturnih veza. Crnković, Zlatko Naš čovjek u Pragu, Vijenac, 19. 10. 2000., preuzeto iz: Crnković, Zlatko Knjigositnice, Otokar Keršovani d. o. o., Rijeka, 2003., str. 34-36.
} 
prate ulomci Knjige smijeha i zaborava i Nepodnošljive lakoće postojanja Milana Kundere. ${ }^{335}$ Isti časopis 1988. objavljuje pripovijetku Ivana Klíme Srijeda ujutro (Vánoční povídka, středa ráno) u prijevodu Renate Kuchar, objavljenu u Klíminoj zbirci Má veselá jitra. ${ }^{336}$

\section{1. 1. Milan Kundera}

Iako najpoznatiji po svome romanesknom radu, Milan Kundera u književnosti se javlja 1953. zbirkom pjesama Člověk zahrada širá u izdanju izdavačke kuće Československý spisovatel, najznačajnijeg češkog nakladnika druge polovice dvadesetoga stoljeća. Godine 1968. Kundera je laureat Nagrade Saveza čehoslovačkih književnika za roman Šala (Žert), no već dvije godine kasnije javno djelovanje i objavljivanje radova mu je onemogućeno, a 1975. odlazi u egzil u Francusku gdje živi i danas.

Nakon odlaska u egzil većinu svojih proza Kundera prvotno objavljuje u renomiranim pariškim izdavačkim kućama, a tek potom na češkome jeziku u egzilnoj izdavačkoj kući 68 Publishers Josefa Škvoreckog u kanadskome Torontu. ${ }^{337}$ Sredinom osamdesetih pisac počinje pisati i jezikom svoje druge domovine - francuskim, a jedan dio toga proznog rada, poput eseja Umjetnost romana objavljenoga u Parizu 1986., u drugoj polovici osamdesetih u češkome prijevodu kola samizdatskim krugovima u Brnu. ${ }^{338}$

Tijekom analizirana razdoblja na području Hrvatske, Srbije i Bosne i Hercegovine, jugoslavenskih republika čije prijevode zbog nepostojanja jezične barijere recipiraju hrvatski čitatelji, u prijevodu su objavljeni sljedeći romani Milana Kundere: Šala (Žert), Život je negdje drugdje (Život je jinde), Knjiga smijeha i zaborava (Kniha smíchu a zapomnění), Oproštajni valcer (Valčík na rozloučenou), Nepodnošljiva lakoća postojanja (Nesnesitelná lehkost bytí) te zbirka pripovijedaka Smiješne ljubavi (Směšné lásky). Svi ti prijevodi na jugoslavensko tržište izlaze neposredno nakon izdanja na češkome jeziku. Iznimka je roman Nepodnošljiva lakoća postojanja koji je u Sarajevu objavljen 1984., godinu dana prije prvoga izdanja na jeziku originala u Torontu. Dio Kunderina opusa nastao tijekom normalizacije

\footnotetext{
${ }^{335}$ Rubrika Otisci, 15 dana, br. 7, 1987., zadnja stranica.

${ }^{336}$ Klíma, Ivan Srijeda ujutro, prijevod Renata Kuchar, 15 dana, br. 6, 1988., str. 34-38.

${ }^{337}$ Primjerice, Život je drugdje i Oproštajni valcer objavljeni su prvo u Parizu 1973., a potom na češkome jeziku u Torontu 1979., Knjiga smijeha i zaborava u Parizu 1979., a u Torontu na češkome jeziku 1981., Nepodnošljiva lakoća postojanja u Parizu na francuskome jeziku 1984. te u Torontu na češkome 1985.

338 Janoušek, Pavel i suradnici Dějiny české literatury 1945-1989, IV. knjiga 1969-1989, Academia, Prag, 2008. str. 410.
} 
hrvatsku recepciju ostvaruje i kazališnim predstavama postavljenima prema njegovim dramskim tekstovima ili prema dramatizacijama proznih predložaka.

I dijelom svoga opusa nastaloga prije normalizacije, a osobito nakon odlaska u egzil, Kundera ostvaruje izuzetan međunarodni uspjeh s kojim se u tome razdoblju ne može mjeriti niti jedan drugi češki književnik. ${ }^{339}$ Njegov je roman Nepodnošljiva lakoća postojanja u Italiji prodan u nakladi od 200000 primjeraka i tako postao, tijekom osamdesetih godina, najprodavanija knjiga stranoga autora nakon Drugoga svjetskog rata. ${ }^{340}$ Tijekom sedamdesetih i osamdesetih dobitnik je niza uglednih međunarodnih književnih nagrada poput Médicis International, ${ }^{341}$ talijanske nagrade Mondello, ${ }^{342}$ američke Common Wealth Award. S Jevgenijem Jevtušenkom i Marijem Vargasom Llosom ulazi u uži izbor za Književnu nagradu Ernest Hemigway, ${ }^{343}$ a estetsko oblikovanje njegovih sabranih djela u izdanju sarajevske Izdavačke kuće „Veselin Masleša“ nagrađeno je 1984. Prvom nagradom za najljepšu opremu na beogradskome Međunarodnom sajmu knjiga.

O Kunderinim uspjesima u Europi i Sjevernoj Americi redovito izvještava i hrvatski tisak vijestima o piščevim suradnjama s najistaknutijim imenima tadašnje kulturne scene poput Susan Sontag koja režira predstavu Jacques Fatalist i njegov gospodar, ${ }^{344}$ filmovima koji se trebaju snimati prema Kunderinim romanima ${ }^{345}$ poput Nepodnošljive lakoće postojanja koja redatelju Philipu Kaufmanu donosi nominaciju za Oscara u kategoriji prilagođenoga scenarija i uspjesima na ljestvicama najčitanijih knjiga američkoga Timea iz 1990. na kojima roman Nepodnošljiva lakoća postojanja nalazi svoje mjesto među najistaknutijim knjigama desetljeća na izmaku. ${ }^{346}$

Tržišni uspjeh Kunderinih proza potvrđuje tezu Aleksandra Stipčevića ${ }^{347}$ da je u slučaju objavljivanja proskribiranih autora neke nacionalne književnosti u inozemstvu ,profit inozemnog izdavača razmjeran s jačinom represije prema piscu u zemlji ${ }^{\text {‘348 }}$. Osim izuzetna

\footnotetext{
${ }^{339}$ Brabec, Jiří Otazníky nad literární historii sedmdesátých a osmdesátých let. u: Život je jinde...?, Česká literatura, kultura a společnost v sedmdesátých a osmdesátých letech dvacátého století, prir. Jan Matonoha. Ústav pro českou literaturu AV ČR, Prag, 2002., str. 13-19.

${ }^{340}$ Václav Havel Saslušanje na daljinu (razgovor s Karelom Hvižd'alom), Irida, Zagreb, 2000., str. 187.

${ }^{341}$ Zbornik radova 38. seminara Zagrebačke slavističke škole, ur. Krešimir Mićanović, Filozofski fakultet, Zagrebačka slavistička škola, Zagreb, 2010., kronologija događaja

342 Matvejević, Predrag Milan Kundera - naš pisac, Danas, 12. 10. 1982., str. 66-68.

343 Jevtušenko i Kundera, Večernji list, br. 7830, 15. 2. 1985., str. 20; Kandidati za „Hemingwaya“, Vjesnik, br. 14347, 16. 2. 1985., str. 13.

${ }^{344}$ Film Resnaisa i Kundere, Oko, br. 335, 1985., str. 30.

${ }^{345}$ Kundera u režiji Susan Sontag, Oko, br. 337, 1985., str. 30.

${ }^{346}$ Knjige i filmovi desetljeća - rang-lista „Timea“, Oko, br. 5(469), 1990,, str. 6.

347 Stipčević, Aleksandar (1930 - 2015.), hrvatski arheolog, bibliograf i bibliotekar.

${ }^{348}$ Stipčević, Aleksandar O savršenom cenzoru, Nakladni zavod Hrvatske, Zagreb, 1994., str. 16.
} 
međunarodna uspjeha koji je, zasigurno, potaknuo snažnu recepciju i u jugoslavenskim republikama, fenomen Kunderina uspjeha u Jugoslaviji objašnjava se i drugim razlozima. Predrag Matvejević uzroke vidi u dodirnim točkama hrvatske i češke kulture te povijesnoga iskustva obaju naroda. Svoj tekst objavljen u tjedniku Danas 1982. Milan Kundera-naš pisac $^{349}$ Matvejević započinje riječima: „Malo je koji strani pisac postao na takav način i toliko našim kao Milan Kudera. ${ }^{\text {“350 }}$ Osim kontakata dviju kultura u prošlosti i zajedničkoga iskustva otpora staljinizmu, glavni razlog privlačnosti Kunderine proze hrvatskim čitateljima Matvejević traži u činjenici da u svojim prozama piše o iskustvima koja su bila poznata i hrvatskim čitateljima. ${ }^{351}$ Kunderin istup na Kongresu čeških i slovačkih pisaca 1967. vidi kao korak dalje u odnosu na Krležino ljubljansko izlaganje iz 1952. na Kongresu Saveza književnika Jugoslavije kojim nastavlja liniju otpora dogmatizmu zalažući se za estetsku funkciju književnoga teksta. ${ }^{352}$

$\mathrm{U}$ istome se zagrebačkome tjedniku u intervjuu objavljenome 1985. fenomenom Kunderina uspjeha, i skromnije recepcije svoga opusa, bavi i Josef Škvorecký koji razloge izuzetne prihvaćenosti Kunderinih proza kod stranih čitatelja pronalazi ne toliko u tematskoj usmjerenosti teksta koliko u autorovu stilu i leksiku kojim izbjegava sleng, žargonske izraze i dijalektizme, odnosno stilu i jeziku koji je puno podatniji za prijevode od njegova. ${ }^{353}$

U osvit velikih društvenih promjena 1990. paralelu između Kunderinih proza i hrvatskoga povijesnog iskustva, pišući o hrvatskim književnicima koji se početkom devedesetih nakon desetljeća izbivanja iz javnoga života opet vraćaju na društvenu scenu, povlači i novinarka Branka Kamenski. Uspoređuje poznatu sliku s početka Knjige smijeha $i$ zaborava $^{354}$ s ozračjem u hrvatskoj javnosti nakon 1971. kada je ,zavladala epidemija

\footnotetext{
${ }^{349}$ Matvejević, Predrag Milan Kundera - naš pisac, Danas, 12. 10. 1982., str. 66-68. Navedeni tekst nije jedini koji Kunderu atribuira „našim piscem“, ukorijenjenost njegova opusa u hrvatsku, odnosno jugoslavensku sredinu naglašava se i u tekstu Stari znanci autora Že. V. objavljenu u Večernjemu listu 1986. (br. 8333, str. 15) koji tvrdi da je to „autor kojeg već držimo svojim“.

${ }^{350}$ Isto, str. 66.

${ }^{351}$ Istu tezu o Kunderi i njegovim romanima koji su bliski hrvatskim čitateljima za razliku od proza domaćih autora koji „s mnogo manje hrabrosti - o pripovjedačkom umijeću da i ne govorimo - žele zaviriti u to doba na našem tlu" govori u kritici romana Život je negdje drugdje i kritičar Boris Senker. Senker, Boris Miles gloriosus s perom u ruci, Gordogan, br. 5-6, siječanj-travaj 1980., str. 343.

${ }^{352}$ Isto.

${ }^{353}$ Humor kao oružje protiv očaja (intervju s Josefom Škvoreckým, razgovarala Dagmar Ruljančić), Danas, 29. 10. 1985., str. 52-55.

354 „U veljači 1948. izašao je na balkon praške barokne palače komunistički vođa Klement Gottwald da održi govor stotinama tisuća građana okupljenih na Starogradskom trgu. Bio je to prijelomni trenutak u povijesti Češke. Sudbonosni trenutak kakvih je jednom-dvaput na tisućljeće. Gottwald je bio okružen drugovima. Tik do njega stajao je Clementis. Bio je hladno, lepršao je snijeg, a Gottwald je bio gologlav. Brižni Clementis skinuo je krznenu šubaru i stavio je na Gottwaldovu glavu. Odjel za propagandu umnožio je na stotine tisuća
} 
iracionalnih krivnji, [kada su piscima] imena sustavno brisana iz tiska, a lica rezana s tv-snimki i novinskih fotografija, bilo je to vrijeme kada su mnogi fotografirani uz njih, stajali usamljeni poput Gottwalda s Clementisovom šubarom na glavi““. 355 Tijekom osamdesetih sve su brojnija čitanja tekstova neoficijelne književne scene, pa tako i proza Milana Kundere, koja u slici čehoslovačkoga društva koje oni pružaju vide probleme jugoslavenskoga društva o kojima književnici jugoslavenskih književnosti nemaju hrabrosti pisati. ${ }^{356}$ Navedeno će osobito doći do izražaja krajem osamdesetih u brojnim napisima u hrvatskome tisku o dramama Václava Havela o čemu govori 7. poglavlje ovoga rada.

$\mathrm{U}$ analizama Kunderine poetike $\mathrm{u}$ hrvatskome tisku ponavlja se tvrdnja da je horizont očekivanja hrvatskih čitatelja oblikovalo romanopiščevo baštinjenje češke književne tradicije s kojom je hrvatski recipijent njegove proze bio u velikoj mjeri upoznat. Niz tekstova u kojima se razrađuje ta teza započinje Zdravko Zima koji svoj tekst objavljen 1981. u Vjesnikov rubrici Književni portreti podnaslovljuje „Milan Kundera je tipičan češki intelektualac s prerogativima svjetskog pisca“. ${ }^{357}$ Zima opus Milana Kundere smatra impresivnim te autora opisuje kao ,jednog od prvaka na nebu naše izdavačke produkcije (...) koji je u nas popularniji od mnogih stranica propisane školske lektire“. ${ }^{358} \mathrm{O}$ književnim utjecajima na Kunderu, ali i na cijelu plejadu neoficijelnih autora Zima kaže sljedeće:

„To je gotovo teatarski okvir umornog Praga, grada u kojem su se rodili Kafka, Werfel i Rilke, i čiji su kavanski zidovi upili neodoljivi miris švejkovskih ludorija.

Ono što je nosio u dubinama svoj razjedinjenog bića, osjećaj za humor i nadmoćno distanciranje od ništavne svakodnevice, Kundera je postupno otkrivao kao kakav neuhvatljivi opsjenar koji izvlači iz cilindra unezvjerenog golubića! Škvorecký, Havel, Hrabal i mnogi drugi iskočili su iz tog istog (hašekovskog) cilindra, no posebno mjesto u tom velikom jatu pripada zacijelo Kunderi.“ 359

\footnotetext{
primjeraka fotografiju balkona na kojem Gottwald, sa šubarom na glavi i rame uz rame s drugovima, govori narodu. Na tom je balkonu počela povijest komunističke Češke. Fotografiju je poznavalo, s plakata, iz udžbenika i iz muzeja, svako dijete. Četiri godine kasnije Clementis je bio optužen za izdaju i obješen. Odjel za propagandu odmah ga je izbrisao iz povijesti i, naravno, sa svih fotografija. Otada Gottwald stoji na balkonu sam. Tamo gdje je bio Clementis, prazan je zid palače. Od Clementisa je ostala samo šubara na Gottwaldovoj glavi. “ Kundera, Milan Knjiga smijeha i zaborava, Grafički zavod Hrvatske, Zagreb, 1982., str. 2.

${ }^{355}$ Kamenski, Branka Samica ili prijestolje, Danas, 13. 3. 1990., str. 35-37.

${ }^{356}$ Senker, Boris Miles gloriosus s perom u ruci, Gordogan, br. 5-6, siječanj-travanj 1980., str. 339-343.

${ }^{357}$ Zima, Zdravko Književni portreti - na otoku strasti, Vjesnik, 11. 10. 1981., br. 12258, str. 11.

358 Isto.

${ }^{359}$ Zima, Zdravko Književni portreti - na otoku strasti, Vjesnik, 11. 10. 1981., br. 12258, str. 11.
} 
U rezimeu dotadašnje Kunderine romaneskne produkcije Zima uočava „eros i politiku“ ${ }^{\text {360 }}$ kao stupove na kojima pisac gradi svoje tekstove, a žudnju za slobodom kao središnju pokretačku snagu likova.

$\mathrm{Na}$ istome je tragu i povjesničar književnosti Aleksandar Flaker pri usporedbi češke i ruske disidentske književne scene u Danasu 1984. kada naglašava Kunderino oslanjanje na tradiciju Hašeka i Čapeka koje uvjetuje da „recipijent od njega očekuje da 'zaborav' prevlada 'smijehom'“‘.361 Novinar Vladimir Tomić primjećuje da se s odmakom vremena Kunderine proze sve manje oslanjaju na humornu tradiciju Jaroslava Hašeka, a sve više na Franza Kafku. ${ }^{362}$ Osim toga, pišući o Kunderinu opusu, hrvatski se kritičari nerijetko pozivaju na autobiografske korijene njegovih proza. Na autobiografsku pozadinu Knjige smijeha $i$ zaborava upućuje Hrvoje Pejaković u djelomično negativno intoniranoj kritici romana objavljenoj u Poletu te zaključuje da ,iako se radi o nešto slabijoj knjizi, još je to uvijek vrsno štivo za kojim nije zgorega poseći“363. Na „poluautobiografske piščeve crte“ koje uočava u liku Jakuba u romanu Oproštajni valcer upozorava i Goran Bujić u opširnome prikazu knjige objavljenom u osječkoj Reviji u kojemu navedeni roman ocjenjuje „solidn[im] djel[om] ovog gnjevnog autora“. ${ }^{364}$ Bujić lik Jakuba naziva Kunderinim dvojnikom te smatra da je autor u njega „urezao svoje osnovne misli o vlastitu životu i poimanju stvarnosti uopće“. ${ }^{365}$ Princip iščitavanja autobiografskih motiva bit će osobito izražen i u kritičkoj recepciji dramskih tekstova Václava Havela.

\section{1. 1. 1. Milan Kundera Šala}

Kunderin roman $\breve{S}$ ala najobjavljivaniji je naslov neoficijelne češke književnosti u Jugoslaviji od 1968. do 1990., u Beogradu, Sarajevu i Zagrebu ostvaruje čak osam izdanja, sva u prijevodu Nikole Kršića. Neposredno prije i nakon prvoga jugoslavenskog izdanja roman ostvaruje ogromnu popularnost i u domovinu, u kojoj još uvijek nije u potpunosti

\footnotetext{
${ }^{360}$ Zima, Zdravko Književni portreti - na otoku strasti, Vjesnik, 11. 10. 1981., br. 12258, str. 11.

${ }^{361}$ Osporavanje kao stav (intervju s Aleksandrom Flakerom), Danas, 30. 10. 1984., str. 51-54.

362 Tomić, Vladimir Istočni val u zapadnim knjižarama, Danas, 2. 4. 1984., str. 61-62.

${ }^{363}$ Pejaković, Hrvoje Milan Kundera Knjiga smijeha i zaborava, Polet, br. 220, 1983.

${ }^{364}$ Bujić, Goran Milan Kundera Oproštajni valcer, Revija, br. 3, 1982., str. 97-101.

${ }^{365}$ Isto, str. 101.
} 
zavladala cenzura pa ga Československý spisovatel objavljuje čak tri godine zaredom - 1967 ., 1968. i 1969.

Prvi je jugoslavenski prijevod toga romana onaj izdavačke kuće Znanje iz Zagreba 1969. Nešto ranije, u prosincu 1968., u tematskome broju zagrebačkoga mjesečnika Republika, koji je bio izravna reakcija na vojnu intervenciju na tlu Čehoslovačke u kolovozu, pronalazimo i prvi zapis o Šali u hrvatskoj periodici - prijevod Aragonova predgovora francuskome izdanju romana pod naslovom Budućnost je već bila ${ }^{366}$ u kojem taj francuski književnik o Kunderinu romanu piše biranim riječima nazvavši ga ,jednim od značajnijih romana ovog stoljeća“6367.

Iz novinskih kritika saznajemo da je neposredno nakon 1969., kada je objavljeno prvo izdanje Šale u Zagrebu, Kundera za hrvatske čitatelje još uvijek relativno nepoznat pisac. Krsto Špoljar naziva ga u tekstu objavljenu 1970. „nadarenim piscem““ 368 Špoljar analizira i ukupnu recepciju češke i slovačke književnosti među hrvatskim čitateljima te smatra njihovu zastupljenost u izdavačkim planovima hrvatskih nakladnika nezadovoljavajućom. Iste godine u varaždinskome lokalnom glasniku Varaždinskim vijestima pozitivnu kritiku Šale objavljuje Marijan Kraš u tekstu Značajan suvremeni roman. ${ }^{369}$ Kraš roman iščitava kao svjedočenje o događajima u Čehoslovačkoj u drugoj polovici dvadesetoga stoljeća, kvalificira ga kao „umjetnički zrelo“, ${ }^{370}$ no ,,angažirano djelo“, ${ }^{371}$ a za samoga Kunderu kaže da je gotovo nepoznat našoj čitateljskoj publici.

Terminologijom Karla Roberta Mandelkowa, u godinama koje slijede Šala postaje nulta točka hrvatskim čitateljima u izgradnji njihova horizontu očekivanja pri svakom sljedećem pojavljivanju nekog Kunderina prijevoda pa se u nizu književnih kritika tijekom osamdesetih prijevod neke nove Kunderine proze stavlja u suodnos s tim legendarnim romanom. Taj se postupak ponavlja u tekstovima o romanu Knjiga smijeha i zaborava. Poletova kritika toga romana iz pera Hrvoja Pejakovića navodi da je roman ,vjerojatno slabiji od drugih Kunderinih knjiga što smo ih imali prilike upoznati“ “372 a Marko Marić u

\footnotetext{
${ }^{366}$ Aragon, Louise Budućnost je već bila!, Republika, 24, 12(1968), str. 700-701.

${ }^{367}$ Isto, str. 700.

368 Špoljar, Krsto Roman iz češkog „mrtvog doma“, Republika, 24, 6(1970), str. 286.

${ }^{369}$ Kraš, Marijan Značajan suvremeni roman, Varaždinske vijesti, br. 1329, 10. 6. 1970., str. 4; https://library.foi.hr/novine/broj1.aspx?v=1\&t=1\&C=3\&godina=1970\&broj=000022\&stranica=004\&u=kundera (pristupljeno 12. 1. 2019.)

${ }^{370}$ Isto.

371 Isto.

372 Pejaković, Hrvoje Milan Kundera Knjiga smijeha i zaborava, Polet, br. 220, 1983.
} 
Večernjemu listu zaključuje da Knjiga smijeha i zaborava kvalitativno zaostaje za Šalom. ${ }^{373}$ Niz nastavlja Zdravko Zima koji, također, Šalu postavlja kao nultu točku vrednovanja Kunderina opusa te roman atribuira kao „najpopularniji i najčitaniji [Kunderin] roman“, 374 dok Knjigu smijeha i zaborava, koja razvija motiv zaborava prvi put obrađen u Šali, naziva „najtužnijim i najradikalnijim“‘375.

\section{1. 1. 2. Kritička recepcija ostalih izdanja Milana Kundere}

Unatoč sjajnoj prihvaćenosti među čitateljima, nisu rijetki negativno intonirani kritički napisi o Kunderinim romanima u hrvatskome tisku. Tako se, primjerice, u uvodu kritike romana Život je drugdje u časopisu Gordogan 1980. ${ }^{376}$ Boris Senker bavi i sjajnom recepcijom Kunderine Šale tijekom sedamdesetih te je veže uz društvenu reakciju koja je slijedila slom praškoga proljeća i vojnu intervenciju u Čehoslovačkoj. No, pritom primjećuje Kunderin romaneskni postupak ponavljanja motiva, na koji će kasnije ukazati i drugi kritičari, te paralelno navodi ulomke Šale i romana Život je drugdje kojim dokazuje svoje tvrdnje. ${ }^{377}$

Tri godine zaredom, 1984., 1985. i 1986., u sarajevskoj Izdavačkoj kući „Veselin Masleša“ objavljen je roman Nepodnošljiva lakoća postojanja o kojemu su kritičarske ocjene prilično podijeljene. U Gordoganovu tekstu, čijim naslovom Neoprostiva banalnost pisanja parafrazira naziv romana, Nenad Ivić roman kvalificira kao „dosadnu, poznatu i prozirnu knjigu“378 koja ostaje „banalan skup općih mjesta ilustriranih već viđenim sudbinama“6379 poput, primjerice, lika Sabine koji kritičar naziva „otrcani[m] kunderijanski[m] lik[om]“3800. Ivić je, tako, na tragu Senkerovih tvrdnji o romanu Život je drugdje.

Dalje, neprestano perpetuiranje istih tema, likova i pripovjednih postupaka Kunderi zamjeraju i Zdravko Zima, Goranka Lozanović i Hrvoje Pejaković. Dio tih kritika naglašava motivsku povezanost djela, što, doduše, nije rijetkost ni u opusima drugih književnika. Zdravko Zima u Knjizi smijeha i zaborava uočava temu straha od zaborava obrađenu u

\footnotetext{
${ }^{373}$ Svjedok povijesti (U fokusu kritike Marka Marića), Večernji list, br. 7214, 9. 2. 1983., str. 9.

374 Zima, Zdravko Svjetlo u grobnici, Vjesnik, br. 12699, 9. 1. 1983., str. 11.

375 Isto.

${ }^{376}$ Senker, Boris Miles gloriosus s perom u ruci, Gordogan, br. 5 - 6, siječanj-travanj, 1980., str. $339-343$.

${ }^{377}$ Isto, str. 340.

${ }^{378}$ Ivić, Nenad Neoprostiva banalnost pisanja, Gordogan, br. 19, 1985., str. 316-319.

${ }^{379}$ Isto, str. 319.

${ }^{380}$ Isto, str. 319.
} 
Šali, ${ }^{381}$ a Goranka Lozanović cijeli niz tema u usporedbi zbirke pripovijedaka Smiješne ljubavi i romana Oproštajni valcer - temu čovjekove slobode, lik pojedinca sputanoga društvenim normama, predrasudama, osjećajima i političkom podobnošću. ${ }^{382}$ Hrvoje Pejaković koncentrira se na pripovjedne postupke kolažiranja pripovjedne građe i esejističkih ulomaka u romanima Nepodnošljiva lakoća postojanja i Knjiga smijeha i zaborava. ${ }^{383}$

Najtemeljitije su se Nepodnošljivom lakoćom postojanja pozabavili književni kritičar Velimir Visković u tekstu Ljubav i skepsa objavljenu u zagrebačkome tjedniku Danas u veljači 1985. ${ }^{384}$ te Hrvoje Pejaković u časopisu Dubrovnik. U pozitivno intoniranoj kritici romana koji, prema Viskovićevim riječima, „svjedoči na drugi način o izuzetnoj spisateljskoj vještini, intelektualnoj lucidnosti i erudiciji autora“, ${ }^{385}$ Kunderinu stilu pripisuje se tipična postmodernistička značajka - združivanje ,visokoga““ i „,niskog“. Visković smatra da autor, iako piše o poznatim povijesnim zbivanjima iz 1968. i njihovim posljedicama u češkome društvu, uspijeva izbjeći angažirano-publicistički način. Kunderin prikaz povijesti, koja u postmodernističkoj maniri više nije ,učiteljica života“, već njome dominira princip cikličnosti i ponovljivosti, Visković povezuje s prikazom povijesti koji u svojim romanima grade Kunderini suvremenici u hrvatskoj književnosti, predstavnici novopovijesne proze. ${ }^{386}$ Dok Tomislav Sabljak roman kvalificira kao „klasičan ljubavni roman“, ${ }^{387}$ Visković smatra da to jest „roman o ljubavi, ali ne i ljubavni roman“388. Hrvoje Pejaković u svome prikazu romana Kunderu smatra jednim od središnjih predstavnika modernoga romana koji u sebi uspijeva ujediniti i sliku vremena i životnu priču pojedinca. ${ }^{389}$ Pozitivno intoniranu kritiku Nepodnošljive lakoće postojanja iste godine objavljuje i Zdravko Gavran u časopisu Quorum. ${ }^{390}$

\footnotetext{
${ }^{381}$ Zima, Zdravko Svjetlo u grobnici, Vjesnik, br. 12699, 9. 1. 1983., str. 11.

${ }^{382}$ Lozanović, Goranka Zbirka šesnaest autora (Milan Kundera Smiješne ljubavi i Oproštajni valcer), Polet, br. 177, 1981., str. 6 .

383 Pejaković, Hrvoje Milan Kundera Nepodnošljiva lakoća postojanja, Dubrovnik, br. 5/6, 1985., str. $141-144$.

384 Visković, Velimir Ljubav i skepsa, Danas, 26. 2. 1985., str. 58-59.

385 Isto, str. 59.

${ }^{386} \mathrm{Na}$ tragu usporedbe koncepta povijesti u Kunderinim romanima s novopovijesnom prozom je i Hrvoje Pejaković koji tvrdi da romanopisac nerijetko isprepleće tematiziranje intimnih preokupacija pojedinaca $i$ povijesnih zbivanja koji upravljaju sudbinama tih pojedinaca. Pejaković, Hrvoje Milan Kundera Nepodnošljiva lakoća postojanja, Dubrovnik, br. 5/6, 1985., str. 141-144.

${ }^{387}$ Sabljak, Tomislav Velikan science-fictiona, Večernji list, br. 7975, 8. 8. 1985., str. 9.

${ }^{388}$ Visković, Velimir Ljubav i skepsa, Danas, 26. 2. 1985., str. 59.

${ }^{389}$ Pejaković, Hrvoje Milan Kundera Nepodnošljiva lakoća postojanja, Dubrovnik, br. 5/6, 1985., str. $141-144$.

${ }^{390}$ Gavran, Zdravko Terra Kunderiana, Quorum, br. 1, 1985., str. 119-122.
} 
Negativne su kritike pratile i objavljivanje Knjige smijeha $i$ zaborava, no ni to nije utjecalo na sjajnu čitateljsku recepciju romana. Hrvoje Pejaković romanu zamjera plošnost likova:

„Svi likovi 'Knjige smijeha i zaborava' (izuzetak, pa i ona tek donekle, predstavlja jedino Tamina) nepopravljivo su plošni, svedeni na samo nekoliko najopćenitijih svojstava; piscu nedostaje strpljenja da, kao što je to činio nekad, živi sa svojim junacima i pusti njihove sudbine da pred našim očima ocrtaju prostor višeznačan i neuhvatljiv poput života samog. Umjesto toga, on njih i situacije u koje ih dovodi koristi isključivo kao izliku za esejiziranje čija povremena briljantnost ne može sasvim iskupiti nemarnost kojom je izrađen 'neesejistički' dio knjige. (...) Ukratko, 'Knjiga smijeha i zaborava' vjerojatno je slabija od drugih Kunderinih knjiga što smo ih imali priliku upoznati.“391

I kritičar Marko Marić u Večernjemu listu zaključuje da roman kvalitativno zaostaje za Šalom. ${ }^{392}$ Međutim, nešto ranije te godine, u siječnju 1983., iste dnevne novine prenose podatke iz ankete beogradskih Književnih novina u kojoj se Knjiga smijeha i zaborava nalazi među najzapaženijim godišnjim izdavačkim poduhvatima u Jugoslaviji. ${ }^{393}$

\section{1. 2. Josef Škvorecký}

Već na samom početku svoga književnog rada, tijekom 1950-ih, Josef Škvorecký izaziva žestoke reakcije čehoslovačke javnosti te biva podvrgnut cenzuri koja će mu dvadesetak godina kasnije u potpunosti onemogućiti slobodano objavljivanje. Roman Najlonsko doba (Konec nylonového věku) pokušava objaviti 1956., no to mu uspijeva tek desetak godina kasnije, 1967., budući da je roman, prema tvrdnjama osoba koje su sredinom pedesetih godina očito imale utjecaja na izdavačku politiku, posjedovao pornografske motive. U proklamiranu poetiku socrealizma nije se uklapao ni roman Kukavice (Zbabělci) koji Československý spisovatel objavljuje dvije godine kasnije. ${ }^{394}$

\footnotetext{
${ }^{391}$ Pejaković, Hrvoje Milan Kundera Knjiga smijeha i zaborava, Polet, br. 220, 1983.

${ }^{392}$ Marić, Marko Svjedok povijesti (U fokusu kritike Marka Marića), Večernji list, br. 7214, 9. 2. 1983., str. 9.

393 A. L. Dvoboj teorije i beletristike, Večernji list, br. 7187, 10. 1. 1983., str. 10.

${ }^{394}$ Buku u javnosti koju je izazvalo objavljivanje romana Kukavice 1958. Predrag Jirsak uspoređuje s reakcijama hrvatske javnosti prilikom prvog izdanja romana Čangi Alojza Majetića 1963. koje su dovele do sudskoga procesa. Majetićev je roman u prvotnoj inačici zabranjen zbog nemorala te u izmijenjenu obliku objavljen 1970.
} 
Za razliku od nekih drugih istaknutih predstavnika egzilne scene, Škvorecký Čehoslovačku napušta u prvom valu emigracije, neposredno nakon sloma praškoga proljeća te već 1971. u kanadskome Torontu objavljuje roman Oklopni bataljon (Tankový prapor). Sve do pada komunizma u domovini svoje tekstove objavljuje u izdavačkoj kući 68 Publishers koju u Kanadi osniva sa suprugom Zdenom Salivarovom i u kojoj od osnutka do 1993. objavljuje 224 naslova čeških neoficijelnih autora, ali i klasika češke književnosti poput Karela Hyneka Máche, Jaroslava Hašeka i Bohumila Hrabala. No, najbolju je recepciju od izdanja toga egzilnog izdavača ostvario upravo romanopiščev Oklopni bataljon s pet izdanja u nakladi većoj od 9000 primjeraka. ${ }^{395}$

Tijekom dva desetljeća normalizacije, koliko Škvorecký djeluje u egzilu, hrvatskim su čitateljima u prijevodu dostupne sljedeće autorove proze, kronološkim redoslijedom: Oklopni bataljon (Tankový prapor), Lavica (Lvíče), Bas saksofon i druge priče o džezu (Hořkej svět/Dvě legendy), ${ }^{396}$ Sjajna sezona: tekst o najvažnijim stvarima u životu (Prima sezóna: text o nejdůležitějších věcech života), Iz života češkog društva (Ze života české společnosti), Mirakl (Mirákl) i Inženjer ljudskih duša: osvrt na stare teme o životu, ženama, sudbini, sanjarenju, radničkoj klasi, uhodama, ljubavi i smrti (Přiběh inženýra lidských duší).

Osim prvoga izdanja Oklopnoga bataljona i Lavice, sve su navedene proze u Hrvatskoj objavljene od sredine osamdesetih godina te se od tada primjećuje i autorova pojačana prisutnost u hrvatskim medijima. Ujesen 1985. Škvorecký gostuje na Oktobarskim susretima pisaca u Beogradu kao predstavnik Kanade, budući da mu je neposredno prije dolaska u Jugoslaviju dodijeljena Nagrada za književnost generalnoga guvernera Kanade. ${ }^{397}$ Iste godine na međunarodnoj konferenciji pisaca koja se tradicionalno u Beogradu održavala

\footnotetext{
Jirsak, Predrag Prostor raspoznavanja (O antiiluzivnosti moderne češke proze), Književna smotra, br. 18, VI(1974.), str. 89-96.

395 Janoušek, Pavel i suradnici Dějiny české literatury 1945-1989, IV. knjiga 1969-1989, Academia, Prag, 2008. str. 147.

396 Jednu od pripovijedaka iz zbirke Bas saksofon i druge priče, Pjesmu zaboravljenih godina, objavljuje već u prosincu 1968. časopis Republika u svome tematskome broju kojim reagira na kolovoške događaje u Čehoslovačkoj, a u prijevodu Mirka Jirsaka.

397 Škvorecký nije prvi predstavnik češkoga egzila na beogradskome Sajmu knjiga. Godine 1980. u programu sajma sudjeluje satiričar Gabriel Laub kojemu je 1987. u izdanju Prosvete objavljena zbirka satira Otkrića u kadi, a 1989. u izdanju Dečjih novina zbirka aforizama Mišljenje kvari karakter. Iako je Laub rođen u Poljskoj, od 1946. živi u Čehoslovačkoj, dvije godine kasnije dobiva čehoslovačko državljanstvo i počinje pisati na češkome jeziku. (Š̈ömen, Branko Češki sanjar: Václav Havel od disidenta do prezidenta, Profil, Zagreb, 2012., str. 19, www.slovnikceskeliteratury.cz, natuknica Gabriel Laub) U mrežnome katalogu Knjižnica grada Zagreba Laub je klasificiran u njemačku književnost (www.kgz.hr, pristupljeno 15. 10. 2017.)
} 
u sklopu međunarodnoga sajma knjiga u službenom programu sudjeluju i Škvorecký, ali i oficijelni autor Alexej Pludek ${ }^{398}$.

Piščev boravak u Beogradu povod je za nekoliko intervjua u najtiražnijim jugoslavenskim časopisima i dnevnim novinama, poput zagrebačkoga Danasa i Vjesnika. Za tjednik Danas sa Škvoreckým razgovara prevoditeljica Dagmar Ruljančić, ${ }^{399}$ a u Vjesniku Branko Šömen opisuje i svoj susret s književnikom u beogradskome Hotelu Slavija ${ }^{400} \mathrm{u}$ kojemu pisac govori o djelatnosti svoje egzilne izdavačke kuće 68 Publishers te kao svoju i literaturu Milana Kundere navodi srpskoga književnika Danila Kiša ${ }^{401}$. Dio intervjua koji sa Škvoreckým vodi Dagmar Ruljančić bavi se i odnosom njegova književnoga rada i politike. Ondje Škvorecký navodi da ne smatra da zastupljenost političkih tema nužno za posljedicu ima smanjenu umjetničku kvalitetu proznoga rada spuštanjem teksta na razinu pamfletističkih napisa. Prema Škvoreckome, politika kao nezaobilazna sastavnica ljudskih života mjesto, sukladno tome, nalazi i u književnosti. ${ }^{402}$

Godinu dana ranije, u travnju 1984., Škvorecký je jedan od neoficijelnih autora čijim se opusom, s naglaskom na problematiku rastrganosti između dviju zemalja i dvaju jezika te dominirajuće motive usamljenosti i mita djetinjstva, bavi britanski slavist Robert B. Pynsent u svojoj raspravi u sklopu Zagrebačkih književnih razgovora. Pišući o odnosu prema češkome jeziku egzilnih autora Ivana Blatnog, Antonína Brouseka, Milana Kundere, Ivana Jelineka i Vladimíre Čerepkové, Pynsent naglašava da od njih jedino Škvorecký „,promišljeno piše za emigrantsku publiku“403, namjerno u svojim prozama potencirajući jezične igre na češko-engleskoj osnovi, a naziva ga piscem ,pučkih novela i kratkih priča, zaista trivijalne literature ${ }^{6404}$.

\footnotetext{
${ }^{398}$ Pludek, Alexej (1923. - 2002.), češki prozaist. Tijekom normalizacije objavljivao je književna djela namijenjena djeci te prozu povijesne i znanstveno-fantastične tematike. www.slovnikceskeliteratury.cz (natuknica Alexej Pludek, pristupljeno 1. 9. 2019.)

${ }^{399}$ Humor kao oružje protiv očaja (intervju s Josefom Škvoreckým, razgovarala Dagmar Ruljančić), Danas, 29. 10. 1985., str. 52-55.

400 Šömen, Branko Josef Škvorecký: liječnik ljudskih duša, Vjesnik, br. 13703, 2. 11. 1985., str. 18.

${ }^{401}$ Kiš, Danilo (1935. - 1989.), srpski književnik. Jedan od najznačajnijih srpskih književnika druge polovice 20. st. Od 1979. živio u Parizu.

${ }^{402}$ Humor kao oružje protiv očaja, (intervju s Josefom Škvoreckým, razgovarala Dagmar Ruljančić), Danas, 29. 10. 1985., str. 52-55.

${ }^{403}$ Pynsent B. Robert Jezik i mit u egzilu, u: Književnost između dviju domovina, zbornik radova 13. zagrebačkih književnih razgovora, ur. Ernest Fišer, posebno izdanje Društva književnika Hrvatske, Autorske agencije za SR Hrvatsku i uredništva časopisa Gesta, Zagreb - Varaždin, 1986., str. 16.

Zbornik Književnost između dviju domovina sadrži rasprave 13. zagrebačkih književnih razgovora na temu stvaralaštva autora koji zbog različitih razloga cijeli svoj opus ili dio njega stvaraju izvan matične zemlje i udaljeni od korpusa materinskoga jezika.

${ }^{404}$ Isto.
} 
Od prijevoda proza Josefa Škvoreckog najsnažniju je kritičku recepciju u Hrvatskoj ostvario romana Mirakl objavljen 1987. u nakladi Grafičkoga zavoda Hrvatske i prijevodu Dagmar Ruljančić. Iako je roman u drugoj polovici osamdesetih u Hrvatskoj dobro prihvaćen i među publikom, može se reći da je ukupna recepcija toga romana u našoj zemlji u određenoj mjeri zakašnjela budući da je od prvoga izdanja u Torontu do onoga zagrebačkoga 1987. prošlo čak petnaest godina. Mirakl je, tako, neoficijelni naslov koji je najdulje čekao svoje jugoslavensko izdanje. Posao grafičkoga oblikovanja naslovnice zagrebačkoga izdanja romana povjereno je dvojcu koji čine Mirko Ilićc ${ }^{405}$ i Luka Mjeda ${ }^{406}$, a koji su sredinom osamdesetih među najznačajnijim predstavnicima jugoslavenske pop-kulture. U vrijeme kada rade na naslovnici Mirakla Ilić i Mjeda laureati su 21. zagrebačkoga salona za naslovnicu tjednika Danas.

Zagrebačko izdanje Mirakla kao predgovor donosi tekst Milana Kundere preuzet iz francuskoga izdanja romana. U fusnoti predgovora, ali u pogovoru Predraga Matvejevića možemo iščitati odmak od Kunderinih stavova te pojedinih tema i ideja koje u svojim tekstovima iznose Kundera i Josef Škvorecký. Fusnota urednika izdanja naglašava da je „,[p]redgovor [je] pisan za francuskog čitaoca i donosi Kunderino viđenje knjige i događaja s kojima se ne moramo ili ne možemo složiti: zanimljivost njegova stava s druge strane ne možemo zanijekati te stoga njegov Predgovor uvrštavamo u naše izdanje.“407

Pogovor zagrebačkoga izdanja djelo je Predraga Matvejevića koji ga, dvije godine nakon objavljivanja Kunderina eseja Tragedija Srednje Europe na hrvatskom jeziku, započinje raspravom o tome pojmu. Kunderu i Škvoreckoga naziva književnicima koji „,ne priznaju postojeće granice između Istočne i Zapadne Europe kao kulturne granice [i time] pridonose da to pitanje dobije na važnosti i aktualizira se ${ }^{\text {‘408 }}$ te smatra da je ,,[p]revođenje njihovih knjiga u nas pozitivna strana našeg književnog života, bez obzira na to što u njima 'nije prihvatljivo' ili nam ne odgovara.“409

Stručna literatura, a tome se pridružuju i onodobne novinske književne kritike, Mirakl Josefa Škvoreckog nerijetko smatra romanom s ključem u čijim likovima možemo prepoznati glavne aktere češke političke scene druge polovice dvadesetoga stoljeća, a u njegovim recima

\footnotetext{
${ }^{405}$ Ilić, Mirko (1956.), hrvatski grafičar. Od kraja sedamdesetih godina 20. st. objavljuje ilustracije u nizu jugoslavenskih novina i časopisa, a od 1986. živi i stvara u Sjedinjenim Američkim Državama gdje surađuje s nizom poznatih i utjecajnih medija poput Timea i The New York Timesa. www.enciklopedija.hr (natuknica Mirko Ilić, pristupljeno 1. 9. 2019.)

${ }^{406}$ Mjeda, Luka (1952.), hrvatski fotograf.

407 Škvorecký, Josef Mirakl, Grafički zavod Hrvatske, 1987., str. 9.

408 Škvorecký, Josef Mirakl, Grafički zavod Hrvatske, 1987., str. 511.

${ }^{409}$ Isto, str. 512.
} 
iščitava i natruhe autorove biografije. ${ }^{410} \mathrm{Na}$ tom je tragu Poletova kritika Nenada Bartolčića koji se o romanu izuzetno pozitivno izražava, naziva ga „,novim potencijalnim knjižarskim hitom““411 postavljajući na kraju teksta retorički upit: „Roman godine (objavljen u nas)?!‘412 Osim Mirakla od proza Josefa Škvoreckog na ljestvicama najčitanijih i najprodavanijih knjiga u zagrebačkim knjižnicama i knjižarama nalazi se roman Oklopni bataljon prvi put objavljen u Hrvatskoj 1972. u izdanju Biblioteke Hit zagrebačke izdavačke kuće Znanje. ${ }^{413}$ Roman ponovljeno izdanje doživljava 1986. u Biblioteci Evergrin istoga zagrebačkoga izdavača, a, potom, član zagrebačkoga Dramskog kazališta Gavella Slobodan Milovanović tekst romana dramatizira te, uz stručnu pomoć redatelja Georgija Para, i režira. U monodramskom obliku ta je dramatizacija izvedena 1987. u Klubu Karaka u Zagrebu. ${ }^{414}$ No, o navedenu romanu, kao i o Milovanovićevoj izvedbi dramatizacije, u pisanim medijima nisu pronađeni tekstovi koji ga sustavnije kritički vrednuju.

4. 1. 3. Ostala prozna izdanja neoficijelne češke književnosti

Na samome početku analizirana razdoblja, 1969., u Beogradu je objavljen roman Sekira (Sekyra) jednoga od najsnažnijih ličnosti samizdatske scene u sljedeća dva desetljeća Ludvíka Vaculíka, osnivača i organizatora samizdatske Edice Petlice. Kvantitativno znatno skromnije od Kundere i Škvoreckoga hrvatski čitatelji upoznaju i prozni rad romanopisca Ivana Klíme. ${ }^{415}$ Zagrebački nakladnik Naprijed u svojoj biblioteci Odabrani ljubavni romani u prijevodu Renate Kuchar 1985. objavljuje Klímin roman Ljeto ljubavi (Milostné léto), no roman ne ostvaruje znatniju kritičku recepciju. Tri godine kasnije zagrebački časopis 15 dana,

\footnotetext{
410 Janoušek, Pavel i suradnici Dějiny české literatury 1945-1989, IV. knjiga 1969-1989, Academia, Prag, 2008., str. 404; Barni (Nenad Bartolčić) En passant, Polet, br. 378, 1987.

${ }^{411}$ Barni (Nenad Bartolčić) En passant, Polet, br. 378, 1987.

412 Isto.

${ }^{413}$ Uz Oklopni bataljon J. Škvoreckog u IV. kolu Biblioteke Hit objavljeni su sljedeći romani: Ivan Slamnig Bolja polovica hrabrosti, John le Carré Rat u ogledalu, Arthur Hailey Konačna dijagnoza i Louise Ferdinand Céline Putovanje nakraj noći.

${ }^{414}$ S. Nč. Smiřický vodi priču, Večernji list, br. 8689, 16. 10. 1987., str. 23; bvu Sam - a bataljon, Večernji list, br. 8691, 18. 10. 1987., str. 8.

415 Klíma, Ivan (1931.), češki romanopisac, dramatičar i scenarist. Tijekom normalizacije onemogućeno mu je slobodno objavljivanje pa objavljuje u samizdatu i uzdržava se poslovima koji nisu vezani uz književnost. Na prijelomu osamdesetih i devedesetih godina jedan je od osnivača Društva književnika, a potom, početkom devedesetih i predsjednik češkog PEN-a. http://www.slovnikceskeliteratury.cz (natuknica Ivan Klíma, pristupljeno 2. 8. 2019.)
} 
također u prijevodu Renate Kuchar, objavljuje novelu Srijeda ujutro, dio zbirke pripovijedaka Má veselá jitra. ${ }^{416}$

Osim Klímine pripovijetke i već spomenutih ulomaka Kunderinih romana koje mahom objavljuje časopis 15 dana, hrvatske novine i časopisi bilježe tek nekoliko prijevoda kraćih proznih oblika predstavnika neoficijelne književnosti. Mjesečnik Republika 1971. u prijevodu Božidara Škriteka donosi novelu Kiša češke književnice Jindřiške Smetanové uz kratak prevoditeljev biografski tekst o autorici, ${ }^{417}$ a četiri godine kasnije Vjesnik u srijedu u rubrici Smijeh na svim meridijanima i paralelama objavljuje novelu Jaje Ludvíka Aškenazyja ${ }^{418}$ koju prevodi Predrag Jirsak. ${ }^{419}$

\section{1. 4. Nefikcionalna proza}

Usporedo s intenziviranjem prijevoda fikcionalne proze tijekom osamdesetih hrvatskim čitateljima postaju dostupni i prijevodi memoarske proze čeških disidenata. Biblioteka Globus u prvoj polovici osamdesetih objavljuje memoarske zapise dvojice bivših visokopozicioniranih čeških političara, reformnih komunista, Praško proljeće Jiříja Pelikána ${ }^{420}$ 1982. te 1985. Mraz dolazi iz Kremlja (Mráz přichází z Kremlu) Zdeněka Mlynářa ${ }^{421} \cdot{ }^{422}$

\footnotetext{
${ }^{416}$ Klíma, Ivan Srijeda ujutro, prijevod Renata Kuchar, 15 dana, br. 6, 1988., str. 34-38.

${ }^{417}$ Smetanová, Jindřiška Kiša, Republika, br. 11, 1971., str. 1227-1232.
}

Smetanová, Jindřiška (1923. - 2012.), češka prozaistica i scenaristica. Tijekom normalizacije onemogućeno joj je slobodno objavljivanje te se uzdržava poslovima koji nisu vezani uz književnost. Neke svoje prijevode s poljskog jezika objavljuje pod imenima drugih osoba. www.slovnikceskeliteratury.cz (natuknica Jindřiška Smetanová, pristupljeno 2. 8. 2019.)

${ }^{418}$ Aškenazy, Ludvík (1921. - 1986.), češki dramatičar, prozaist, publicist, autor radijskih drama i književnosti za djecu. Nakon kolovoza 1968. s obitelji emigrira u München, a potom u Italiju, gdje živi do smrti. www.slovnikceskeliteratury.cz (natuknica Ludvík Aškenazy, pristupljeno 2. 8. 2019.)

${ }^{419}$ Aškenazy, Ludvík Jaje, Vjesnik u srijedu, br. 1194, 26. 3. 1975., str. 20.

${ }^{420}$ Pelikán, Jiř́ (1923. - 1999.), češki publicist, istaknutu član Komunističke partije Čehoslovačke, talijanski političar. Nakon sloma praškoga proljeća izbačen je iz Komunističke partije, odlazi u emigraciju, a vlast mu oduzima i čehoslovačko državljanstvo. Godine 1977. dobiva talijansko državljanstvo, a 1979. postaje talijanski zastupnik u Europskom parlamentu. Tijekom egzila u Rimu je pokrenuo jedan od najčitanijih egzilnih časopisa, Listy. http://www.listy.cz/pelikan.php?text=kdo-byl-kdo (pristupljeno 1. 9. 2019.)

Dvije godine nakon zagrebačkoga izdanja Praškoga proljeća Pelikánovi memoarski zapisi objavljeni su i u Ljubljani na slovenskome jeziku.

${ }^{421}$ Mlynář, Zdeněk (1930. - 1997.), češki pravnik, politolog i političar, jedan od najznačajnijih predstavnika praškoga proljeća. U hijerarhiji KPČS-a obavlja niz visokih dužnosti sve do 1970. kada je iz Partije izbačen. Pravo studira u Moskvi gdje mu je jedan od studentskih kolega i Mihail Gorbačov. Jedan je od inicijatora i potpisnika Povelje 77 nakon čega određeno vrijeme boravi u kućnom pritvoru, a zatim emigrira u Austriju gdje 
Pelikánovo Praško proljeće svoje prvo izdanje ostvaruje u Francuskoj na francuskome jeziku i upravo je prema tome izdanju iz 1975. nastao i hrvatski prijevod Tatjane Brodnjak. U tim se memoarskim zapisima, koje katalog Knjižnica grada Zagreba klasificira kao autobiografiju, autor dotiče duljega razdoblja čehoslovačke povijesti, od svojih srednjoškolskih dana u vrijeme Hitlerove vladavine, preko vlastite aktivnosti u Partiji i uspona u njenoj hijerarhiji, sve do praškoga proljeća i egzila u Italiju koji je slijedio nakon što su započele čistke na češkoj javnoj sceni.

Još snažniju recepciju kod nas, a i u drugim europskim zemljama, ostvarili su memoarski zapisi Zdeněka Mlynářa Mraz dolazi iz Kremlja koji su 1981. bili temelj i za dokumentarni film Invasion koji je za britansku televizijsku kuću Granada TV snimila Eva Kolouchová. Čak dvije godine ranije no što su objavljeni u hrvatskome prijevodu, o Mlynářevim memoarima pišu i neki hrvatski mediji. Časopis Gordogan na svojim stranicama 1983. donosi prijevod teksta Archiea Browna Život pri vrhu ${ }^{423}$ koji je, zapravo, recenzija Mlynářevih memoara objavljena u The Timesu povodom londonskoga izdanja knjige 1980. Na objavu prijevoda memoara reagira Željko Krušelj u tjedniku Danas 1986., no taj se tekst uglavnom iscrpljuje na iznošenju tijeka zbivanja tijekom praškoga proljeća i neposredno nakon njega. ${ }^{424}$

Oba izdanja, Pelikánovo kao urednika, a Mlynářevo kao recenzenta povezuje ime Lea Matesa $^{425}$ koji Mlynářeve zapise vrednuje kao „,izuzetnu knjigu“ ${ }^{426}$ a dio teksta koji opisuje događaje u Moskvi nakon sloma praškoga proljeća, kamo je Mlynář s nekolicinom čehoslovačkih političara odveden kako bi potpisali dokument koji daje legitimnost sovjetskoj intervenciji, Mates uspoređuje sa Sofoklovim tragedijama.

živi do smrti. Mach, Vladimír Zdeněk Mlynář http://www.totalita.cz/vysvetlivky/o_mlynarz.php (pristupljeno 1. 9. 2019.)

${ }^{422}$ Tijekom osamdesetih čitateljima u Hrvatskoj postaju dostupna još dva izdanja čeških disidenata: u Zagrebu je objavljen Treći put: marksističko-lenjinistička teorija i moderno društvo Ote Šika (Globus, prevoditelj Marijan Hanžeković st., 1983.), a u Beogradu Glavom kroz zid (izabrani ogledi i članci) Ivana Svítka (Mladost, prevoditelj Aleksandar Ilić, 1986.). Kako je riječ o politološkim studijama, njihova hrvatska recepcija nije predmet analize ovoga rada.

${ }^{423}$ Brown, Archie Život pri vrhu (prijevod Gordana Visković), Gordogan, br. 13-14, siječanj-travanj 1983., str. 329-332.

${ }^{424}$ Krušelj, Željko Zaleđeno proljeće, Danas, 23. 9. 1986., str. 53-55.

${ }^{425}$ Mates, Leo (1911. - 1991.), diplomat i istaknuti član Komunističke partije Jugoslavije, suradnik Josipa Broza Tita. Nakon Drugoga svjetskog rada urednik Tanjuga te direktor beogradskoga Instituta za međunarodnu politiku i gospodarstvo. www.enciklopedija.hr (natuknica Leo Mates, pristupljeno 1. 9. 2019.)

${ }^{426}$ Mlynář, Zdeněk Mraz dolazi iz Kremlja, OOUR Globus, Izdavačka djelatnost, Biblioteka Globus, Zagreb, 1985., str. 6. 
Privlačnosti Pelikánovih i Mlynářevih autobiografskih zapisa za hrvatske čitatelje zasigurno je pridonijela činjenica da ih na pojedinim mjestima povezuje motiv Jugoslavije, odnosno tematiziranje odnosa tadašnje čehoslovačke komunističke vlasti i Sovjetskoga Saveza prema Titu i Titovu načinu vladanja. Kako je riječ o autobiografskoj, subjektivnoj prozi bilo bi neopravdano na temelju ovih tekstova rekonstruirati onodobnu društvenu klimu. Pelikán, u pravilu, prema jugoslavenskome društvenom ustroju iznosi pozitivan stav što je, zasigurno, olakšalo prodor knjige na jugoslavensko tržište te izražava čuđenje zbog sovjetskoga odnosa prema Jugoslaviji nakon 1948.

„Za Jugoslaviju nas je vezalo tradicionalno i duboko prijateljstvo. Prilikom mobilizacije protiv hitlerovske agresije 1938. tisuće Jugoslavena prijavile su se kao dobrovoljci za Čehoslovačku. Kasnije nas je njihova oružana borba protiv nacističke vojske ispunjavala divljenjem. Nisu li oni prvi uzeli oružje u ruke? Oni su nam bili uzor, a osjećali smo da njihov ugled zadivljuje i same Sovjete.

Odjednom su ih ožigosali kao izdajice, nazivali ih fašistima, agentima Gestapoa, slugama imperijalizma. “427

Pišući o čehoslovačkome komunističkom vođi tijekom praškoga proljeća Alexanderu Dubčeku, isti mu autor prigovara nedostatak odlučnosti te kaže da ,[o]n nije bio čehoslovački Tito da se suoči s opasnošću otvorenog sukoba ${ }^{\text {“428. }}$. O Titovu stavu i postupcima kao uzoru piše i Mlynář koji, u kontekstu sovjetske intervencije 1968., naglašava da su članovi radikalnoga krila reformnih komunista „bili [su] skloni traženju saveznika u redovima komunističkih i ljevičarskih snaga mimo sovjetskoga bloka i računali su i na to da bi se Čehoslovačka morala otvoreno suprotstaviti tom bloku kao što je 1948. učinio Tito u Jugoslaviji. “429 Kao svoj drugi uzor Mlynář navodi djelovanje Edvarda Kardelja, jednoga od najistaknutijih jugoslavenskih komunista u razdoblju nakon Drugoga svjetskog rata, čija je analiza događaja u Mađarskoj 1956., koja se ilegalno širila Pragom, na njega ostavila takav dojam da je počeo učiti „,srpsko-hrvatski“4330.

I dok memoarski zapisi čeških disidenata tijekom osamdesetih godina ostvaruju zavidnu razinu recepcije kod hrvatskih čitatelja, analogna svjedočanstva hrvatskih političara koji su učinili otklon od službenoga smjera jugoslavenskoga Saveza komunista tijekom hrvatskoga proljeća na police hrvatskih knjižara dolaze tek na samom kraju toga desetljeća

\footnotetext{
${ }^{427}$ Pelikán, Jiří Praško proljeće, OOUR Globus, Izdavačka djelatnost, Biblioteka Globus, Zagreb, 1982., str. 80. ${ }^{428}$ Isto, str. 225.

${ }^{429}$ Mlynář, Zdeněk Mraz dolazi iz Kremlja, OOUR Globus, Izdavačka djelatnost, Biblioteka Globus, Zagreb, 1985., str. 213. ${ }^{430}$ Isto, str. 50.
} 
kada je promjena društvene paradigme bila izvjesna. Memoari Mike Tripala i zbornik tekstova Vlade Gotovca Moj slučaj objavljeni su tek 1989., a u travnju sljedeće godine i knjiga Ljudi iz 1971. - prekinuta šutnja.

Cjelini proznih zapisa neoficijelnih autora koji ne pripadaju fikcionalnoj prozi pridružujemo epistolarnu prozu Václava Havela Pisma Olgi (Dopisy Olze). Pisma koja iz zatvorske ćelije Václav Havel adresira svojoj supruzi Olgi od lipnja 1979. do rujna 1982., pisana tijekom izdržavanja četverogodišnje kazne nakon potpisivanja Povelje 77, do hrvatskih čitatelja dolaze fragmentarno u izboru objavljenom 1987. u časopisu 15 dana u prijevodu Renate Kuchar i Nives Opačić. ${ }^{431}$ U tom su broju časopisa objavljena pisma datirana $14.11 .$, 21. 11., 29. 11., 2. - 6. 1. te 1. 5. 1981. Kvantitativno veći izbor pisama objavljen je dvije godine kasnije na srpskom jeziku i izdanju beogradskoga nakladnika Prosvete. Pogovor tome izdanju čini djelomično skraćen govor prevoditelja Aleksandra Ilića u Udruženju književnika Srbije održan na protestnoj večeri povodom autorova uhićenja. Kritička recepcija Havelove epistolarne proze $u$ analiziranim pisanim medijima toga doba nije zabilježena.

\section{2. Poezija}

Od kraja šezdesetih do kraja osamdesetih godina 20. st. prijevodi poezije neoficijelnih čeških autora na hrvatskom su izdavačkom tržištu podzastupljeni u odnosu na prozni dio korpusa te su, u pravilu, razasuti po književnim časopisima i novinama poput Foruma, Republike, Književne smotre, 15 dana, Rivala, Oka i Vidika. Osim Vladimíra Holana ${ }^{432}$ čije pjesme i poemu Noć s Hamletom 1981. prevode i u Zagrebu objavljuju Slavko Mihalić i Dušan Karpatský, jedini češki pjesnik čija samostalna zbirka pjesama u prijevodu dopire do hrvatskih čitatelja tijekom analizirana razdoblja jest klasik češke književnosti i dobitnik Nobelove nagrade za književnost Jaroslav Seifert koji ne pripada sferi neoficijelne scene, no čija izdanja nerijetko istovremeno objavljuju i egzilni izdavači i državne izdavačke kuće. Seifertova zbirka izabranih pjesama objavljena je u Beogradu iste godine kada je pjesnik i laureat Nobelove nagrade te je možemo motriti u kontekstu reakcija na taj događaj.

\footnotetext{
${ }^{431}$ Havel, Václav Pisma Olgi (izbor), prevele Renata Kuchar i Nives Opačić, 15 dana, br. 3, 1987., str. 21-25.

${ }^{432}$ Holan, Vladimír (1905. - 1980.), češki pjesnik. Jedan od najznačajnijih književnika češke književnosti 20. st. J. Seifert i V. Holan jedini su suvremeni češki pjesnici koji samostalnim zbirkama pjesama ostvaruju recepciju među hrvatskim čitateljima tijekom sedamdesetih i osamdesetih godina 20. st. www.slovnikceskeliteratury.cz (natuknica Vladimír Holan, pristupljeno 1. 9. 2019.)
} 
I dok se od prozne oficijelne češke produkcije tijekom normalizacije do hrvatskih čitatelja uspijevaju probiti tek kvalitativni vrhunci - Fuks, Páral, Boček - od kojih je većina afirmirana još u prednormalizacijskom razdoblju, oficijelna češka poezija, zbog prirode poetske riječi koja olakšava veći odmak od propisane poetike no što je to moguće u prozi, nerijetko ni kvalitativno ni kvantitativno u hrvatskoj periodici ne zaostaje za neoficijelnim dijelom produkcije.

U većini izbora češke poezije objavljene u hrvatskoj periodici toga vremena pojavljuju se predstavnici svih smjerova češke književnosti i tako najbolje pokazuju svu šarolikost onodobne češke književne produkcije. Primjerice, u listopadu 1978. časopis Republika, koji u tome razdoblju uređuje književnik Zvonimir Majdak, donosi izbor češke ljubavne poezije naslovljen po pjesmi Vítězslava Nezvala Zbogom i maramica. U Republikinu izboru poeziju trinaestorice čeških pjesnika različitih generacija preveo je hrvatski pjesnik Zvonimir Golob. Većinu prevedenih pjesama čine tekstovi književnika koji pripadaju češkoj egzilnoj sceni pedesetih godina dvadesetoga stoljeća, poput Josefa Hore, Františeka Gellnera, Františeka Halasa. No, izbor donosi i poeziju Jaroslava Seiferta (Pjesma o djevojkama, Djevojci koja stanuje blizu groblja), Oldřicha Mikulášeka ${ }^{433}$ (Sedam čaša) i Jiř́ija Šotole (Koliko si imala ljubavnika, Ja sada idem), a čije stvaranje nakon sloma praškoga proljeća dijelom ili u potpunosti spada u sferu neoficijelne književnosti. Uz bok njihovoj poeziji, u Republici su objavljeni i prijevodi pjesama književnika koji su bili dio službeno dopuštene i kontrolirane književne produkcije Miroslava Floriana, Miloša Macoureka i Jana Pilařa.

U nastavku cjeline bit će navedeni prijevodi češke neoficijelne poezije klasificirani prema književnim časopisima u kojima su objavljivani, a više će prostora biti posvećeno opsežnijim prijevodima, poput izbora češke poezije objavljenje u časopisu Vidik 1970. te prijevoda poezije generacije mladih čeških pjesnika 1980-ih koji se krajem normalizacije dobrovoljno odlučuju stvarati na neoficijelnoj sceni budući da im poezija nikada nije službeno bila podvrgnuta cenzuri, a koje 1990. objavljuje riječki časopis Rival uz popratni esej slovenske bohemistkinje Alenke Jensterle.

U vrijeme kada cenzorske škare još nisu stigle zasjeći u tkivo češke književnosti, u prosincu 1968., zagrebački časopis Republika na zbivanja u Čehoslovačkoj reagira posebnim, tematskim, brojem. ${ }^{434}$ Uz poeziju Vladimíra Holana i Jiř́ija Šotole, pregled suvremene češke i,

\footnotetext{
${ }^{433}$ Mikulášek, Oldřich (1910. - 1985.), češki pjesnik i novinar. Tijekom prvoga desetljeća normalizacije nije mogao slobodno objavljivati, no na javnu se scenu vraća početkom osamdesetih. Pjesnička zbirka Agogh objavljena je u samizdatskoj Edice Petlice, a poeziju objavljuje i u nizu samizdatskih zbornika. Janoušek, Pavel i suradnici Dějiny české literatury 1945-1989, IV. knjiga 1969-1989, Academia, Prag, 2008., str. 362. ${ }^{434}$ Republika, br. 12, god. XXIV, 1968., str. 698-765.
} 
u manjoj mjeri, slovačke književnosti u tom broju Republike objavljuje i pjesmu Sve što bi trebalo reći Milana Nápravníka u prijevodu Branka Plivelića. Nápravník će već koji mjesec nakon prosinca 1968. svoj književni rad nastaviti u egzilu te u godinama koje su slijedile živjeti u Zapadnom Berlinu, Parizu, Kölnu i istočnoj Aziji. ${ }^{435}$ Isti časopis dvije godine kasnije u prijevodu Ljudevita Bauera objavljuje pjesmu Jana Skácela Stupanje u grob iz zbirke Smutenka objavljene 1965. ${ }^{436}$

Poput tematskoga broja Republike u prosincu 1968. izravna reakcija na zbivanja u Čehoslovačkoj te godine je i stalna rubrika Sa stranica čeških i slovačkih časopisa koju ujesen pokreće časopis 15 dana i u kojoj je, između ostaloga, objavljena pjesma Ludvíka Kundere ${ }^{437}$ Pokušaj pohvale Charliea Chaplina. ${ }^{438}$

Na stranicama časopisa Forum 1974. objavljen je tekst Pjesništvo Miroslava Holuba autora Ljudevita Bauera i prijevodi sljedećih pjesama: Muha, Vojnik, Pristanište, Guske, Brana, Krila, Geologija čovjeka, Vrata, Glava, Povijest svijeta. ${ }^{439}$ Holubovu poeziju u prijevodu Božidara Grubišića i Luke Štekovića na srpski jezik, uz kratak popratni biografski tekst, objavit će 1973. i osječka Revija (pjesme Učionica uveče, Bolesni bukvar, Ruka, Geologija čoveka, Kosti, Kiša u noći, Ljubav, Portret, Krila, Dezdemona, Azbuka, Podne, Buhenvald danas uveče, Devojka u laboratoriju, Oda radosti, Gospodin učitelj, Vežbenka mrtvog jezika, Iz biologije automobila). ${ }^{440}$

Kontinuiranu i kvalitetnu recepciju češke poezije tijekom sedamdesetih i osamdesetih godina pruža časopis Književna smotra u kojem je zastupljenost predstavnika neoficijelne scene zasigurno rezultat prevoditeljske aktivnosti bohemista Predraga Jirsaka koji u nekoliko svojih tekstova pruža i sustavnije preglede suvremene češke poezije kakve u ostalim hrvatskim književnim časopisima toga doba nije moguće naći. U tome časopisu Jirsak

\footnotetext{
${ }^{435}$ Nápravník, Milan Sve što bi trebalo reći, Republika, 12, prosinac 1968., str. 735-737.

${ }^{436}$ Skácel, Jan Stupanje u grob, Republika, br. 6, 1970., str. 251.

Skácel, Jan (1922. - 1989.), češki pjesnik. Tijekom šezdesetih uređuje časopis Host do domu, no tijekom normalizacije svoje tekstove objavljuje uglavnom u egzilu i samizdatu. www.slovnikceskeliteratury.cz (natuknica Jan Skácel, pristupljeno 1. 9. 2019.)

${ }^{437}$ Kundera, Ludvík (1920. - 2010.), češki pjesnik, dramatičar, prevoditelj i urednik. Tijekom normalizacije onemogućeno mu je javno djelovanje. 1970. isključen je iz članstva Komunističke partije. Objavljivao je u samizdatu i pod pseudonimima, a značajniji dio svojega rada posvećuje prijevodima njemačkih autora. http://www.slovnikceskeliteratury.cz (natuknica Ludvík Kundera, pristupljeno 20. 7. 2019.)

${ }^{438}$ Kundera, Ludvík Pokušaj pohvale Charliea Chaplina, 15 dana, br. 7/8, 1968., str. 36-37.

${ }^{439}$ Bauer, Ljudevit Pjesništvo Miroslava Holuba, prijevod pjesama Miroslava Holuba (prevoditelj Ljudevit Bauer), Forum, br. 6, 1974., str. 984-995.

Holub, Miroslav (1923. - 1998.), češki pjesnik, prozaist i esejist. Nakon 1970. nije smio javno objavljivati sve do prve polovice osamdesetih godina. www.slovnikceskeliteratury.cz (natuknica Miroslav Holub, pristupljeno 20. 7. 2019.)

${ }^{440}$ Poezija Miroslava Holuba, Revija, br. 2, 1973., str. 78-92.
} 
prijevode neoficijelnih autora počinje objavljivati 1976. kada prijevod teksta Jiř́ija Opelíka Zaumni stihovi Oldřicha Mikulášeka prati i prijevod Mikulášekovih pjesama. ${ }^{441}$ Godine 1984. Jirsak u Književnoj smotri objavljuje tekst nazvan prema zbirci pjesnika Jana Skácela iz 1962. Sat između psa i vuka (Ogled povijesne strukture modernog češkog pjesništva) uz prijevode Iz moderne češke poezije. ${ }^{442}$ Uz uvodni tekst u kojemu objašnjava književnopovijesni kontekst nastanka suvremene češke poezije poput nametanja poetike socijalističkoga realizma nakon dolaska komunista na vlast i okupljanja generacije pjesnika oko časopisa Květen, ${ }^{443}$ Jirsak donosi prijevode poezije Jana Skácela (pjesme Ima pjesma u srcu, Stihovi posvećeni uspomeni Isaka Babelja, Dom), Jiř́ija Šotole (U smrt Lamarcovu, Romeo i Julija), Miroslava Holuba (Enciklopedija suma znanja, Kaplar koji je probo Arhimeda, Starac u noći, Obljuba u srpnju), Vladimíra Holana (Sjećanje, Spilja riječi), Jaroslava Seiferta (Precizni popis daljinskih projektila, Stup kuge), Františeka Hrubína (Noćs Verlaineom), Oldřicha Mikulášeka (Presuda, Drama) i Josefa Kainara (Vrata, Šišali do gola malenog dječaka, Ložači velikih lokomotiva). ${ }^{444}$

S tri prijevoda poezije na stranicama hrvatske periodike, u Književnoj smotri 1976. i 1984. te Republici 1978., od čega su prva dva objavljena prije liberalizacije osamdesetih, Oldřich Mikulášek postaje najprevođeniji predstavnik neoficijelna pjesništva u Hrvatskoj. Primat, naravno, u cjelini češke književnosti sve te godine drži klasik Jaroslav Seifert.

4. 2. 1. Poezija neoficijelnih pjesnika u časopisu Vidik 1970.

Splitski časopis Vidik u travnju $1970 .{ }^{445}$ objavljuje izbor poezije dvanaestorice pjesnika rođenih, uglavnom, tridesetih godina dvadesetoga stoljeća, pripadnika generacije mladih pjesnika šezdesetih. Uvodni tekst autorstvo je češkoga slavista Dušana Karpatskog i u njemu su prevedeni pjesnici nazvani „mladom poezijom“446 i novom pjesničkom generacijom,

\footnotetext{
${ }^{441}$ Opelík, Jiř́ Zaumni stihovi Oldřicha Mikulášeka, prijevod pjesama Oldřicha Mikulášeka (prevoditelj Predrag Jirsak), Književna smotra, br. 23, 1976.

442 Jirsak, Predrag Sat između psa i vuka (Ogled povijesne strukture modernog češkog pjesništva), Književna smotra, br. 54/55, 1984., str. 97-108.

${ }^{443}$ Jirsak ovdje nastupa komparatistički pa tu generaciju književnika uspoređuje s krugovašima u hrvatskoj književnosti.

${ }^{444}$ František Hrubín i Josef Kainar umiru vrlo brzo nakon početka normalizacije, već 1971.

${ }^{445}$ Vidik, br. 21, travanj 1970., str. 30-56.

${ }^{446}$ Karpatský, Dušan Uvodna riječ, Vidik, br 21, travanj 1970., str. 31-32.
} 
a razdoblje u kojem stvaraju Karpatský kvalificira kao „normalizacij[u] u poeziji“4447 ni ne sluteći, vjerojatno, da će samo koju godinu kasnije pojam normalizacije uza se vezati potpuno drugačije konotacije. U Vidikovu izboru objavljene su pjesme Jana Zábrane ${ }^{448}$ (Krugovi, Upute), Pavela Janskog ${ }^{449}$ (Na osnovi svega ovog), Jiř́jja Gruše (Gost), Josefa Hanzlíka (Zebnja - Varijacije), Vladimira Janovica ${ }^{450}$ (Svakodnevnost, Vinograd za mlada mjeseca, Orač iz Češke), Vladimira Burde ${ }^{451}$ (Pjesme u boji), Pavela Šruta (Kamen u rujnu, fragmenti), Oldřicha Dadáka (Plivadon), Antonína Brouseka (Jona, Božicama sudbine Hölderlinska varijacija, San noći triju kralja), Věre Provazníkove (Božićne igre), Ivana Wernischa (Magla, Zima, Tišina, Moj kraj, Kraj svijeta, Kazalište buha) i Petra Kabeša (Odgoda safarija).

Dio objavljenih pjesnika pjesničkim zbirkama debitira tijekom 1960-ih, poput Ivana Wernischa, Petra Kabeša, Antonína Brouseka i Pavela Šruta, no svojim pjesničkim prvijencima odudaraju od službene poetike toga desetljeća koje preferira poeziju obojenu optimističnim tonom. Nasuprot tome, navedeni pjesnici pribjegavaju djelomičnoj hermetičnosti koju ostvaruju snažnim metaforama i jezičnim eksperimentima. ${ }^{452}$ Iako je Vidikov izbor objavljen 1970., neposredno nakon sloma praškoga proljeća, već su u tome kratkom razdoblju nakon kolovoza 1968. neki prevedeni i objavljeni pjesnici osjetili represivne mjere koje će kulminirati u sljedećim godinama. Antonín Brousek u Stuttgart emigrira već 1969. Nakon toga uništena je cjelokupna naklada njegove zbirke pjesama Nouzový výhod, a distrubucija njegova prijevoda Hölderlinove poezije onemogućena je. Sudbinu poput Brousekove zbirke pjesama doživjela je i naklada zbirke Odklad Petra Kabeša

\footnotetext{
${ }^{447}$ O normalizaciji u češkoj književnosti Karpatský u ovome tekstu govori u kontekstu prethodnoga razdoblja obilježena monotematičnošću i zahtjevima za odgojnom funkcijom i agitacijom. Do polaganih promjena dolazi od 1953. kada se poezija ,otvara tematski i sadržajno, nastoji (...) uspostaviti prekinuti kontinuitet s rezultatima prethodne avangarde is poticajima koji dolaze sa strane“, no, tvrdi Karpatský, tek je nova generacija, šezdesetih godina, donijela „,normalizaciju“. Karpatský, Dušan Uvodna riječ, Vidik, br. 21, travanj 1970., str. 31-32. ${ }^{448}$ Zábrana, Jan (1931. - 1984.), češki pjesnik. Tijekom normalizacije svoju poeziju objavljuje u samizdatskim zbornicima, a u slobodno distribuiranim časopisima pojavljuje se prijevodima. www.slovnikceskeliteratury.cz (natuknica Jan Zábrana, pristupljeno 1. 9. 2019.)

449 Janský, Pavel (1929. - 2006.), češki pjesnik. Od 1970. do mirovine radi u marketinškoj agenciji, a svoje tekstove objavljuje u samizdatskim zbornicima. Edicija Kvart 1978. objavljuje njegovu zbirku pjesama Území tekutých piski̊ koju 1982. objavljuje i egzilna izdavačka kuća u Münchenu. www.slovnikceskeliteratury.cz (natuknica Pavel Janský, pristupljeno 1. 9. 2019.)

${ }^{450}$ Janovic, Vladimír (1935.), češki pjesnik. Tijekom normalizacije urednik izdanja poezije u izdavačkoj kući Československý spisovatel. www.slovnikceskeliteratury.cz (natuknica Vladimír Janovic, pristupljeno 1. 9. 2019.)

${ }^{451}$ Burda, Vladimír (1934. - 1970.), češki pjesnik. Nakon Burdina samoubojstva poezija mu je postumno 1974. objavljena u samizdatskom zborniku Volné sebrání 2 te egzilnom časopisu Revue K u Parizu.

www.slovnikceskeliteratury.cz (natuknica Vladimír Burda, pristupljeno 1. 9. 2019.)

452 Janoušek, Pavel i suradnici Dějiny české literatury 1945-1989, IV. knjiga 1969-1989, Academia, Prag, 2008., str. 265.
} 
koja je, također, uništena 1970. Osim Brouseka i Kabeša daljnji se stvaralački put i ostalih pjesnika objavljenih u Vidikovu izboru s početkom normalizacije grana u različitim smjerovima u kojima se razvija češka književnost toga razdoblja, no najviše njih afirmira se u egzilu i samizdatu: Jiří Gruša, Antonín Brousek, Vladimír Burda, Ivan Wernisch, Petr Kabeš, Pavel Janský, Jan Zábrana. Dio književnika postaje dijelom oficijelne književne scene, poput Pavela Šruta, Věre Provazníkové i Josefa Hanzlíka, no, kompromisno, glavninu njihove produkcije čine knjige namijenjene djeci, ${ }^{453}$ dok Vladimir Janovic postaje dugogodišnji urednik (1973. - 1988.) najutjecajnije državne izdavačke kuće Československý spisovatel.

4. 2. 2. Nova generacija pjesnika u časopisu Rival 1990.

Godine 1990. riječki časopis Rival objavljuje prijevod teksta slovenske bohemistkinje Alenke Jensterle Mlađe češko pjesništvo: Na krhotinama slobode - esej o najmlađoj pjesničkoj generaciji u Češkoj. ${ }^{454}$ Rival uz taj uvodni esej u prijevodu Katice Ivanković i Miroslava Čihaka donosi prijevode poezije četvorice pjesnika, tada dvadesetogodišnjaka, J. H. Krchovskog ${ }^{455}$ (pjesme Na samom kraju, Hoću li bez traga nestati, Od mojih riječi danas tuga me je, Vlagom mi miriše magični listopad, Samo protiv plina maskom čuvan, Prah na gitari s jednom strunom, Pod bijelim zidom), Jana Kahana ${ }^{456}$ (pjesma Nadbradec 1985.), Petra Placáka ${ }^{457}$ (pjesme Križ po republici, Kriza, Labudovi, Mošt) i Jáchyma Topola ${ }^{458}$ (pjesme

\footnotetext{
${ }^{453}$ Iako su ti književnici javno vrlo uspješno djelovali, ponekad im je mogućnost objavljivanja ipak bila ograničena. Primjerice, Věra Provazníková tijekom normalizacije ima vrlo uspješnu suradnju s čehoslovačkom državnom televizijom i radijem u dječjem programu, no njena poezija nadahnuta grafičkim ciklusom Bohuslava Reynka, češkog pjesnika i grafičara čija su djela bila zabranjena nakon Drugoga svjetskog rata, napisana 1971. objavljena je tek 1989. http://www.slovnikceskeliteratury.cz (natuknica Věra Provazníková, pristupljeno 20. 7. 2019.)

454 Jensterle, Alenka Mlađe češko pjesništvo: Na krhotinama slobode (esej o najmlađoj pjesničkoj generaciji u Češkoj), Rival, Rijeka, 3-4(1990), str. 99-120.

${ }^{455}$ Krchovský, Jiří H. (1960.), češki pjesnik. Jiřri H. Krchovský pseudonim je književnika Jiříja Háseka. Od 1978. do 1989. poezija je toga pjesnika uglavnom distribuirana u strojopisnim prijepisima te u samizdatskim časopisima. www.slovnikceskeliteratury.cz (natuknica Jiří H. Krchovský, pristupljeno 1. 9. 2019.)

${ }^{456}$ Kahan, Jan (1963.), češki pjesnik i književni kritičar. Jan Kahan pseudonim je književnika Luděka Marksa. Svoje je tekstove objavljivao u samizdatu. www.slovnikceskeliteratury.cz (natuknica Jan Kahan, pristupljeno 1. 9. 2019.)

${ }^{457}$ Placák, Petr (1964.), češki pjesnik i prozaist. Tijekom normalizacije objavljivao u samizdatskim i egzilnim časopisima pri čemu je rabio niz pseudonima (Jan Středa, Petr Načeradský, Petr Zmrzlík, Bohumil Zmrzlík i dr.). Bio je član rock-sastava The Plastic People of the Universe koji je uglazbio i neke njegove pjesme. www.slovnikceskeliteratury.cz (natuknica Petr Placák, pristupljeno 1. 9. 2019.)

${ }^{458}$ Topol, Jáchym (1962.), češki pjesnik, prozaist, dramatičar i novinar. Svoje je tekstove objavljivao u samizdatskim zbornicima te samizdatskim i egzilnim časopisima, neke od Topolovih pjesama uglazbljene izvode
} 
Sad ali, Potrebno je steći duševni mir, Kamioni, Ratna lirika, Tajanstvena sezona, Vrtuljak, Eskimski pas, Zvjerinjak).

Pjesnici u Rivalovu izboru pripadaju generaciji koja u prvoj polovici osamdesetih objavljuje u časopisu Vokno, a od 1985. svoju djelatnost veže uz samizdatski časopis Jednou nohou, kasnije preimenovan u Revolver Revue. Književnu generaciju o kojoj piše Jensterle u svome eseju, osim pjesnika iz Rivala, čine i Miroslav Ptáček, Vít Kremlička, Ewald Murrer, a ona se odlučuje na djelovanje u samizdatu slijedeći primjer starijih književnih uzora. Njihovi tekstovi, sredinom osamdesetih navedeni su pjesnici uglavnom u svojim dvadesetima, nikada nisu bili zabranjeni, niti su oni mogli sudjelovati, primjerice, u zbivanjima tijekom praškoga proljeća ili potpisivanja Povelje $77 .{ }^{459}$ U kontekstu mladih predstavnika češke književnosti osamdesetih Topol i Placák uživaju izuzetan ugled te ih Martin Machovec smatra, uz prozaisticu Zuzanu Brabcovu, najznačajnijim mladim češkim književnicima toga desetljeća. ${ }^{460}$ Generacija kojoj pripadaju umjetnički je povezana i s onodobnom češkom glazbenom rock-scenom pa su njihove stihove nerijetko uglazbljivali rock-sastavi: uglazbljenu poeziju J. H. Krchovskog izvodi underground-sastav Invalidní diochod, a tijekom 1990-ih i The Plastic People of the Universe. ${ }^{461}$

U uvodnome dijelu svoga eseja Alenka Jensterle daje kratak pregled razvoja češke književnosti nakon 1968. te navodi niz promjena na društvenoj i kulturnoj sceni Čehoslovačke osamdesetih koje dovode do liberalizacije cijeloga sustava. Olabavljenje kontrola javnog prostora tih godina omogućuje proboj na službenu izdavačku scenu književnicima poput Jaroslava Seiferta i Bohumila Hrabala, a učvršćivanje komunikacije ,između underground-

rock-sastavi. Godine 1986. potpisuje Povelju 77. Objavljuje pod pseudonimima Jindra Tma, Rudolf Dušek i dr.

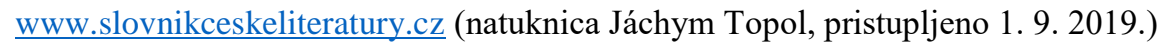

${ }^{459}$ O generaciji mladih pjesnika koji tijekom 1980-ih objavljuju u samizdatu progovara i Václav Havel u razgovoru vođenom s Karelom Hvížd'alom koji je u Hrvatskoj objavljen 2000. pod naslovom Saslušanje na daljinu: „Danas oko sebe vidim mnoge mlade autore, koji istom započinju pa kao početnici iza sebe ne mogu imati neku ovako ili onako ožigosanu književnu ili političku prošlost, i ne nalaze se ni na kakvom indeksu zabranjenih knjiga, i teoretski, dakle ništa ih ne sprječava da se svojski trude oko uspona na Parnas, pune stranice postojećih književnih časopisa, nastoje oko objavljivanja, ali koji, unatoč svemu tome, kao nešto samo po sebi razumljivo odabiru samizdat. Njihovo osjećanje života, njihovo ishodišnje iskustvo svijeta i njihova poetika toliko se razilaze sa svim oficijelnim, da bi objavljivanje u službenim časopisima i izdavačkim kućama uzimali gotovo kao izdaju sama sebe. “ Havel, Václav Saslušanje na daljinu (razgovor s Karelom Hvižd'alom), Irida, Zagreb, 2000., str. 36.

${ }^{460}$ Machovec, Martin The Types and Function of Samizdat Publications in Czechoslovakia 1948 - 1989, str. 7, https://read.dukeupress.edu/poetics-today/article/30/1/1/20983/The-Types-and-Functions-of-Samizdat-

Publications (pristupljeno 22. 1. 2019.)

461 Janoušek, Pavel i suradnici Dějiny české literatury 1945-1989, IV. knjiga 1969-1989, Academia, Prag, 2008. str. 293. 
-kulture i emigrantskih nakladnih zavoda““462 omogućuje inozemna izdanja tekstova koja su do tada objavljivani isključivo u samizdatu. Govoreći o poeziji oficijelne češke književnosti, Jensterle ističe da je taj dio književne produkcije tijekom normalizacije očuvao veći stupanj umjetničke autonomnosti zahvaljujući „osobnijem odnosu prema stvarnosti““463.

\section{3. Drame}

Kako je primaran medij kojim dramski tekstovi traže put do publike kazališna predstava, a njihova izdanja, baš poput zbirka poezije, tržišno znatno manje atraktivna od izdanja proze, tijekom analizirana dva desetljeća iznimno je malen broj tiskanih izdanja drama neoficijelnih dramatičara.

U analiziranoj periodici zabilježena su dva takva prijevoda. Prvi iz 1987. kada je u časopisu 15 dana objavljen ulomak, točnije četvrti prizor, drame Largo desolato Václava Havela. ${ }^{464}$ Ulomak prati kratak uvodni tekst prevoditeljice Renate Kuchar u kojem je drama ocijenjena kao „bez sumnje (...) autobiografska“4665 . Na samome kraju analizirana razdoblja, 1990., zagrebački Quorum donosi cjelovit prijevod Katice Ivanković, također, Havelove drame Iskušavanje (Pokoušení). ${ }^{466}$

Havel je, ujedno, i jedini neoficijelni dramatičar čije su drame objavljene i u samostalnome knjižnom izdanju. Iste godine kada izlazi zagrebački prijevod Iskušavanja u Quorumu, taj Havelov dramski tekst i dramu Asanacija (Asanace) objavljuje srpska izdavačka kuća Dečje novine iz Gornjega Milanovca. Havelove drame objavljene su u Biblioteci Književnost u egzilu koju Dečje novine pokreću u osvit tektonskih promjena na političkoj karti Europe, a u kojoj izlaze i djela drugih disidenata istočnoeuropskih i srednjoeuropskih zemalja poput mađarskoga egzilnog pisca Istvána Eörsija ${ }^{467}$ i ruskoga nobelovca Josifa

\footnotetext{
462 Jensterle, Alenka Mlađe češko pjesništvo: Na krhotinama slobode (esej o najmlađoj pjesničkoj generaciji u Češkoj), Rival, Rijeka, 3-4(1990), str. 101.

463 Isto.

${ }^{464}$ Havel, Václav Largo desolato (ulomak), prijevod Renate Kuchar, 15 dana, 1987., str. 26.

${ }^{465}$ Isto, str. 26.

${ }^{466}$ Havel, Václav Iskušavanje, prijevod Katice Ivanković, Quorum, Zagreb, 6(1990), 1(29), str. $18-77$.

${ }^{467}$ Eörsi, István (1931. - 2005.), mađarski pisac i politički aktivist. Zbog dvije objavljene antisovjetske pjesme tijekom pedesetih godina osuđen je na osmogodišnju zatvorsku kaznu, a djela mu nisu smjela biti objavljivanja dvanaest godina. Nakon izlaska iz zatvora bavi se prevođenjem, a tekstovi su mu objavljivani u samizdatu. Jedno vrijeme živi u egzilu u Zapadnoj Njemačkoj. www.britannica.com (natuknica István Eörsi, pristupljeno 1. 9.
} 2019.) 
Aleksandroviča Brodskog ${ }^{468}$. Za razliku od kazališnih izvedaba, objavljene knjižne prijevode drama i one u časopisima ne prati snažnija kritička recepcija.

4. 4. Zaključak

Tijekom sedamdesetih i osamdesetih godina 20. st. zbog nepostojanja jezične barijere čitatelji u Hrvatskoj usmjereni su, osim na hrvatska izdanja, i na izdanja čeških neoficijelnih autora izdavačkih kuća još dviju jugoslavenskih republika - Bosne i Hercegovine te Srbije. I danas se, krajem drugoga desetljeća 21. st., ta izdanja nalaze na policama hrvatskih knjižnica i rabljena prodaju na mrežnim stranicama antikvarijata i oglasnika.

$\mathrm{U}$ tih je dvadesetak godina hrvatskim čitateljima u prijevodu dostupno dvadeset naslova neoficijelnih autora, od kojih neki i u ponovljenim izdanjima među kojima prednjači roman Šala književnika Milana Kundere koji je od 1968. do 1990. u Beogradu, Sarajevu i Zagrebu objavljen čak osam puta. Recepcija prevedenih neoficijelnih autora među hrvatskim čitateljima zasigurno nije bila zakašnjela. Jugoslavenska izdanja slijede iste godine ili neposredno nakon prvoga izdanja na jeziku originala. U tom su kontekstu rijetki izuzeci proze Josefa Škvoreckoga koji svoje zagrebačke prijevode na hrvatski jezik mahom ostvaruju sredinom i u drugoj polovici 1980-ih, ponekad čak desetak godina nakon premijernoga izdanja romana na češkome jeziku.

U skladu s tržišnim zahtjevima među 43 izdanja neoficijelnih autora prevladavaju prozni naslovi, od čega čak 30 izdanja romana, a samo je jedan prijevod dramskoga sadržaja, onaj Havelovih dramskih tekstova Iskušenja i Asanacije 1990. iz Gornjega Milanovca. Među prijevodima proze urednici izdavačkih kuća triju jugoslavenskih republika najveće su zanimanje pokazali za tekstove Milana Kundere i Josefa Škvoreckog koji čine čak 85\% ukupnih proznih izdanja.

Uslijed društveno-političkih okolnosti koje su tome išle u prilog, poput sve snažnije liberalizacije u jugoslavenskome, ali i čehoslovačkome društvu, dramatičnih zbivanja u životima najuglednijih imena češke disidentske scene, popularnosti koju ostvaraju u nizu izuzetno tržišno usmjerenih zapadnoeuropskih zemalja, ozračju stavljanja u središte zanimanja teme kultura srednjoeuropskih naroda koje slijedi objavljivanje eseja Milana

\footnotetext{
${ }^{468}$ Brodski Aleksandrovič, Josif (1940. - 1996.), ruski pjesnik. Objavljivao u samizdatu, a početkom sedamdesetih odlazi u egzil u Sjedinjene Američke Države. Dobitnik Nobelove nagrade za književnost 1987.

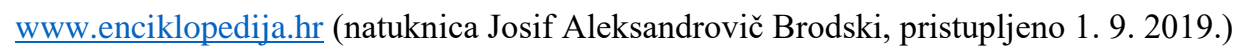


Kundere Tragedija Srednje Europe 1984., recepcija neoficijelne češke književnosti ostvaruje snažan zamah sredinom osamdesetih godina. U samo četiri godine - od 1984. do 1987. - u Hrvatskoj, Bosni i Hercegovini te Srbiji objavljeno je čak 56\% svih izdanja neoficijelne produkcije u razdoblju od kraja šezdesetih godina do pada komunizma. Usporedo s porastom zastupljenosti na tržištu, neoficijelni autori svoje mjesto dobivaju i na popisima najčitanijih i najprodavanijih knjiga u zagrebačkim knjižnicama i knjižarama koje objavljuju hrvatske dnevne novine u svojim podliscima za kulturu. Visoka mjesta na takvim ljestvicama zauzimaju proze Josefa Škvoreckog, Milana Kundere i memoarski zapisi Zdeněka Mlynářa, no istovremeno dobru recepciju kod hrvatskih čitatelja ostvaruju i autori koji su tada slobodno objavljivali u Čehoslovačkoj Jaroslav Boček i Jiří Šotola.

Tekstove neoficijelnih autora objavljuju najuglednije jugoslavenske izdavačke kuće poput zagrebačkoga Znanja i „Augusta Cesarca“, sarajevskoga „Veselina Masleše“, beogradske Prosvete i Dečjih novina iz Gornjega Milanovca u čijim su planovima ti naslovi dio tržišno najuspješnijih biblioteka. U zagrebačkoj izdavačkoj kući Znanje to su biblioteke Hit i Bestseler koje su bile izuzetno dugovječne i uvelike oblikovale ukuse hrvatskoga čitateljstva tijekom sedamdesetih i osamdesetih godina 20. st. Popis prevoditeljskih imena neoficijelne književnosti, uključujući i časopisne prijevode, sadrži niz imena, no među knjižnim izdanjima dominira prevoditeljska aktivnost Dagmar Ruljančić, Nikole Kršića te prevoditelja na srpski jezik Aleksandra Ilića.

Izdavačku aktivnost prati i snažna kritička recepcija u hrvatskoj periodici, osobito kada je riječ o prozama Milana Kundere. Hrvatski analitičari Kunderina opusa sjajnu recepciju među hrvatskim čitateljima nerijetko tumače bliskošću hrvatskoga i češkoga povijesnog iskustva koja dovodi do efekta prepoznavanja jugoslavenskih društvenih prilika u onima koje tematizira Milan Kundera u svojim romanima. Isto tumačenje dominira, pokazat će 7. poglavlje ovoga rada, pri analizi odlične recepcije Havelovih drama početkom osamdesetih, a osobito dobiva na snazi krajem toga desetljeća kada se sve više otvara javni prostor za kritiku komunističkoga režima. Osim toga, hrvatski kritičari Kunderu vide kao baštinika tradicije češke književnosti sa slavnim imenima poput Jaroslava Hašeka i Karela Čapeka, uz snažan utjecaj Franza Kafke, što mu je, također, otvorilo put do hrvatskih čitatelja kojima su opusi navedenih književnika izuzetno bliski. Nerijetko se u analizama Kunderinih proza kao nulta točka vrednovanja izdvaja roman $\breve{S} a l a$ pa hrvatski kritičari svoju ocjenu kvalitete ostalih romana, poput Knjige smijeha $i$ zaborava, grade u suodnosu s tim romanom. Na nefikcionalnom proznom polju u osamdesetima u zagrebačkim se prijevodima pojavljuju memoarski zapisi Jiř́ija Pelikána i Zdeněka Mlynářa, istaknutih članova reformne struje 
čehoslovačke Komunističke partije koji nakon marginalizacije u matičnoj zemlji odlaze u egzil. Jedna od poveznica Pelikánova Praškoga proljeća i Mlynářove knjige Mraz dolazi iz Kremlja jest naglašen pozitivan stav prema jugoslavenskome socijalističkom uređenju i državničkim potezima Josipa Broza Tita što, zasigurno, nije odmoglo njihovu prodoru na jugoslavensko tržište.

Tržišno manje atraktivni prijevodi poezije i dramskih tekstova mahom su razasuti po časopisima. Poezija predstavnika neoficijelne pjesničke scene u tim se izborima uglavnom objavljuje uz bok pjesnicima koji su i tijekom normalizacije slobodno objavljivali u čehoslovačkim državnim izdavačkim kućama. Najsustavnija i kvantitativno najbogatija recepcija češke poezije tijekom sedamdesetih i osamdesetih godina ostvarena je u časopisu Književna smotra na čiju je uređivačku politiku u tome razdoblju uvelike utjecao bohemist Predrag Jirsak. Književna smotra jedini je časopis koji pruža kraće, no sustavnije preglede suvremene češke poezije.

Dramska književnost neoficijelne produkcije, kako priroda dramskoga izraza zahtijeva, svoju pravu recepciju ostvaruje u hrvatskim kazalištima. Uz knjižno izdanje srpskoga prijevoda Havelovih drama Iskušenje i Asanacija 1990., hrvatska periodika bilježi istu dramu, no naslova prevedenog Iskušavanje, u zagrebačkome Quorumu u prijevodu Katice Ivanković te ulomak drame Largo desolato istoga dramatičara u časopisu 15 dana 1987. koji prevodi Renata Kuchar. 


\section{NEOFICIJELNA ČEŠKA UMJETNOST U HRVATSKIM ČASOPISIMA}

Osim književnosti i ostala neoficijelna umjetnička produkcija razdoblja normalizacije, bilo da je riječ o filmu, karikaturi, stripu, nalazi svoje mjesto na stranicama hrvatskih časopisa koje hrvatski povjesničar književnosti Vinko Brešić u svojoj studiji časopisa hrvatske književnosti od 1968. do 1990. naziva tzv. jezgrenim časopisima, a u koje ubraja Vidike, Domete, Prolog, Pitanja, Teku, Gestu, Off, Gordogan, Quorum i Rival. ${ }^{469}$

Pregled kritičke recepcije pojedinih izdanja predstavnika neoficijelne književnosti u Hrvatskoj te kazališnih predstava uprizorenih prema njihovim predlošcima sustavnije je prikazan u 4. i 7. poglavlju ovoga rada. Ovaj dio disertacije pokušat će dati pregled i nekih drugih osobitosti recepcije neoficijelne češke kulturne scene na stranicama hrvatskoga tiska u analiziranome razdoblju te donijeti podatke koje navedena dva poglavlja ne obuhvaćaju.

Zastupljenost prijevoda predstavnika neoficijelne književnosti i tekstova koji problematiziraju opuse tih književnika u hrvatskim književnim časopisima tijekom razdoblja koje se u češkoj književnosti naziva razdobljem normalizacije nerijetko je ovisio o osobnom angažmanu i profesionalnoj povezanosti pojedinih članova uredništva i prevoditelja s češkim kulturnim prostorom. Amblematski primjer takve uzročno-posljedične povezanosti jest časopis Književna smotra u kojemu se pojačan intenzitet recepcije neoficijelne češke književnosti, kvantitativan rast prijevoda i književno-kritičkih osvrta na tekstove neoficijelnih autora uočava u godinama kada kao član uredništva toga časopisa djeluje bohemist Predrag Jirsak. U tom razdoblju Književna smotra objavljuje nekoliko kratkih, ali sustavnih pregleda suvremene češke poezije, što tada nije slučaj s ostalim hrvatskim književnim časopisima. ${ }^{470} \mathrm{U}$ redakcijama Oka i 15 dana češkom se neoficijelnom književnošću najviše bavila prevoditeljica Renata Kuchar, nerijetko u suradnji s jezikoslovkom Nives Opačić. A u Oku i

\footnotetext{
${ }^{469}$ Brešić, Vinko Naraštaji i časopisi hrvatske književnosti (1968. - 1990.), u: Postmodernizam, iskustva jezika u hrvatskoj književnosti i umjetnosti (zbornik, ur. Cvjetko Milanja), Altagama, Zagreb, 2003.

${ }^{470}$ Književna smotra 1976. objavljuje Jirsakov prijevod teksta Jiř́ja Opelíka Zaumni stihovi Oldřicha Mikulášeka i prijevod Mikulášekovih pjesama, a 1984. Jirsakov tekst Sat između psa i vuka (Ogled povijesne strukture modernog češkog pjesništva) te prijevode Iz moderne češke poezije.
} 
Quorumu $^{471}$ prijevodima i književnokritičkim člancima sve se intenzivnije krajem osamdesetih javlja i zagrebačka bohemistkinja Katica Ivanković. ${ }^{472}$

Koliko su češka kultura i književnost tijekom sedamdesetih i osamdesetih zasijecale u hrvatski javni diskurz dokazuju nebrojeni primjeri u kojima autori tekstova u dnevnim novinama, časopisima i književnoj periodici pribjegavaju stilskom postupku parafraziranja naslova književnoga djela neoficijelnoga autora u naslovu svoga novinskog članka. Tekstovi s takvim naslovima ponekad i jesu, u manjoj ili većoj mjeri, tematski povezani s češkim kulturnim krugom, no uglavnom to nije slučaj.

Najviše naslova parafraze su naziva romana Milana Kundere. Ponekad se taj stilski postupak koristi pri naslovljavanju teksta koji problematizira književni tekst čiji je naslov parafraziran. Naprimjer, naslov teksta Neoprostiva banalnost pisanja ${ }^{473}$ u kojemu Nenad Ivić daje svoju negativnu kritiku Kunderina romana Nepodnošljiva lakoća postojanja. Češce, tekstovi koji u naslovu nose parafrazu naziva književnoga djela neoficijelne književnosti, ili popularne kulture, s češkom književnošću i kulturom tematski nisu bili povezani te svjedoče o dubokoj infiltriranosti češke književnosti u čitateljsko iskustvo hrvatskih čitatelja na koje su autori novinskih tekstova oblikovanjem parafraze računali. Takvom su stilskom postupku osobito skloni Poletovi novinari u drugoj polovici osamdesetih koji objavljuju tekstove sljedećih naslova: Mraz dolazi sa sjevera, ${ }^{474}$ Zemlja plača i zaborava, ${ }^{475}$ Bolnica na kraju pameti ${ }^{476}$ Nepodnošljiva teškoća mogućeg, ${ }^{477}$ Nepodnošljiva lakoća izvještavanja, ${ }^{478}$ Život je negdje ovdje ${ }^{479}$. Osim brojnih parafraza u naslovima tekstova Polet se, kao najznačajnije ime

\footnotetext{
${ }^{471}$ Ivanković, Katica Sve Seifertove promjene (kritika Izabranih pesama Jaroslava Seiferta), Quorum, br. 2, 1985., str. 140-143; Havel, Václav Iskušavanje, prijevod Katice Ivanković, Quorum, Zagreb, 6(1990), 1(29), str. $18-77$.

${ }^{472}$ Godine 1989. u suautorstvu sa Željkom Valentićem u Oku objavljuje tekst Socijalizam je mrzio knjigu (br. 464, str. 28-29), a godinu dana kasnije i intervju s Ivanom Jirousom, vodećim čovjekom češke rock-skupine The Plastic People of the Universe, naslovljen Magor protiv Husaka (br. 2/466/, 1990., str. 24).

${ }^{473}$ Ivić, Nenad Neoprostiva banalnost pisanja, Gordogan, br. 19, god. VII, 1985., str. 316.

${ }^{474}$ Kovačević, Neven Mraz dolazi sa sjevera, Polet, br. 405, 1989. Tekst o suzbijanju navijačkih nereda. Sjever u naslovu članka aluzija je na sjevernu tribinu nogometnoga stadiona.

${ }^{475}$ Avdić, Senad Zemlja plača i zaborava, Polet, br. 406, 1989. Tekst Senada Avdića problematizira aktualnu situaciju u Jugoslaviji krajem 1980-ih implicirajući da je zaborav o kojem govori Kundera u svome proslavljenome romanu stvarnost Jugoslavije krajem toga desetljeća.

${ }^{476}$ Dragojević Harapin, Snježana Bolnica na kraju pameti, Polet, br. 411, 1989. Tekst o izgradnju Sveučilišne bolnice u Zagrebu.

${ }^{477}$ Cvjetičanin, Marijan Nepodnošljiva teškoća mogućeg, Polet, br. 412, 1989. Tekst o ekonomskim mjerama jugoslavenskoga premijera Ante Markovića.

${ }^{478}$ Španović, Srđan Nepodnošljiva lakoća izvještavanja, Polet, br. 399, 1988., str. 5. Tekst o izvještavanjima novinara s Kosova.

${ }^{479}$ Bašić, Mate Život je negdje ovdje, Polet, br. 389, 1988., str. 16. Tekst o omladinskim organizacijama u Jugoslaviji.
} 
omladinskoga tiska socijalističke Hrvatske, ${ }^{480}$ neoficijelnom češkom književnošću bavi rijetko, riječ o tek tri književne kritike i jednoj kazališnoj, sve tri objavljene u osamdesetima i povezane imenom Milana Kundere. ${ }^{481}$

Osim u Poletu ovakav je tip parafraza izuzetno čest u naslovima novinskih članaka časopisa Oko: Teatar je ipak negdje drugdje, ${ }^{482}$ Nepodnošljiva lakoća čitanja ${ }^{483}$ Strogo kontrolirani teatar demokracije, ${ }^{484}$ Podnošljiva težina postojanja ${ }^{485}$ Nepodnošljiva lakoća antirasizma, ${ }^{486}$ Život je negdje drugdje ${ }^{487}$. Takvih je primjera, no znatno manje, i na stranicama drugih novina i časopisa. Svoj tekst u Književnoj smotri Rada Iveković naziva Nepodnošljiva lakoća besramlja ${ }^{488}$ a tekst u tjedniku Danas o prvome koncertu Vice Vukova nakon osamnaest godina naslovljen je Nepodnošljiva lakoća povratka ${ }^{489}$ ili obnavljanju endehaovskih ideja u Hrvatskoj početkom devedesetih godina 20. st. Nacizam nije negdje drugdje $e^{490}{ }^{491}$

${ }^{480} \mathrm{O}$ važnosti i ulozi Poleta na jugoslavenskoj javnoj sceni osamdestih godina pišu Maša Kolanović i Krešimir Bagić. Za Bagića je Polet ,,važno mjesto javnog dijaloga, žestoke društvene kritike, otvaranja tabuiziranih tema $i$ promicanja nove kulturne paradigme“. (Krešimir Bagić Od partije bez teksta do strasti razlike, u: Književnost $i$ kultura osamdesetih, zbornik radova 39. seminara zagrebačke slavističke škole, ur. Krešimir Mićanović, Filozofski fakultet, Zagrebačka slavistička škola, Zagreb, 2011., str. 90) Kolanović navodi da je časopis „redovito pratio i afirmirao popularnu kulturu s progresivnom političkom vrijednosti“", no pripisuje mu vezanost uz dominantu ideologiju budući da je ipak riječ o službenom glasilu Saveza socijalističke omladine Hrvatske.

(Maša Kolanović Udarnik! Buntovnik? Potrošač... ... popularna kultura i hrvatski roman od socijalizma do tranzicije, Naklada Ljevak, Zagreb, 2011., str. 133)

${ }^{481}$ U Poletu su 1981. objavljene kritike Goranke Lozanović Kunderine zbirke pripovijedaka Smiješne ljubavi i romana Oproštajni valcer, 1983. negativno intonirana kritika Hrvoja Pejakovića Kunderina romana Knjiga smijeha i zaborava, a godinu kasnije i jedina kazališna kritika u kojoj Vjeko Santrić piše o izvedbi Šale u Satiričkome kazalištu Jazavac.

${ }^{482}$ Teatar je ipak negdje drugdje?, Oko, br. 426, 1988., str. 12. Tekst o zagrebačkoj kazališnoj sezoni 1987./1988.

${ }^{483}$ Nikčević, Sanja Nepodnošljiva lakoća čitanja, Oko, br. 432, 1988., str. 21. Književna kritika Jednostavnosti srpskoga književnika Davida Albaharija.

${ }^{484}$ Strogo kontrolirani teatar demokracije, Oko, br. 449, 1989., str. 9. Tekst o jugoslavenskim medijima krajem osamdesetih godina 20. st.

${ }^{485}$ Podnošljiva težina postojanja, Oko, br. 449, 1989., str. 23. Tekst povodom dodjele Vjesnikove književne nagrade Goran srpskom književniku Borislavu Pekiću.

${ }^{486}$ Cvitan, Dalibor Nepodnošljiva lakoća antirasizma, Oko, br. 19(483), 1990., str. 26. Tekst o temi rasne jednakosti.

${ }^{487}$ Hedl, Drago Život je negdje drugdje, Oko, br. 335, 1985., str. 2. Tekst o javnoj sceni u Jugoslaviji.

${ }^{488}$ Iveković, Nada Nepodnošljiva lakoća besramlja, Književna smotra, br. 63/64, 1986., str. 81.

${ }^{489}$ Nepodnošljiva lakoća povratka, Danas, 21. 11. 1989.

${ }^{490}$ Nacizam nije negdje drugdje, Danas, 11. 12. 1990. U tjedniku Danas nalazimo još nekoliko analognih primjera: Nepodnošljiva lakoća pripadanja (7. 12. 1987.), Teatar je negdje drugdje (16. 9. 1986.)

${ }^{491}$ Čak i danas, krajem drugoga desetljeća 21. st., mrežne stranice na hrvatskome jeziku vrve sličnim jezičnim konstrukcijama, navest ćemo samo neke od njih: Buljan, Ivica Nepodnošljiva lakoća obećanja (https://www.skolskiportal.hr/clanak/10211-nepodnosljiva-lakoca-obecanja/, objavljeno 18. 5. 2018., pristupljeno 20. 7. 2019.), Rašović, Renata Nepodnošljiva lakoća bacanja blata na vozača kamiona (https://www.vecernji.hr/premium/nepodnosljiva-lakoca-bacanja-blata-na-vozaca-kamiona-1325450, objavljeno 12. 6. 2019., pristupljeno 20. 7. 2019.). 


\section{1. Republika}

Od književnih časopisa objavljivanih u Hrvatskoj krajem 1960-ih promptno na šezdesetosmaške kolovoške događaje u Čehoslovačkoj reagira mjesečnik Republika ${ }^{492}$ koji cijeli prosinački broj te godine posvećuje češkoj i slovačkoj književnosti. ${ }^{493}$ Cilj uredništva Republike, zasigurno, nije bio pružiti sustavan pregled tih dviju nacionalnih književnosti, izostanak čega su neki kritičari kasnije tom broju Republike prigovarali, ${ }^{494}$ već poslati simboličan signal hrvatskoj, odnosno jugoslavenskoj kulturnoj javnosti zbog zbivanja u Čehoslovačkoj.

Tematski broj Republike iz prosinca 1968. otvara cjelina Za slobodnu Čehoslovačku u sklopu koje je objavljen pogovor francuskoga književnika Louisa Aragona francuskome izdanju romana Milana Kundere Šala naslovljen Budućnost je već bila! Aragonov je penegirički tekst u kojem Šalu atribuira jednim od najznačajnijih romana 20. stoljeća, ujedno, i prvi zapis o slavnome Kunderinu romanu koji će u sljedeća dva desetljeća doživjeti čak osam izdanja u Beogradu, Sarajevu i Zagrebu, od čega prvo, ono zagrebačkoga Znanja, već sljedeće, 1969. godine. ${ }^{495}$

Osim tekstova čeških književnika prosinački broj Republike sadrži i tekstove slovačkih i autora drugih europskih književnosti. Ondje je iz hamburškoga tjednika Der Spiegel prenesen tekst Noć tenkova Ladislava Mňačka u kojemu slovački književnik iznosi svoja sjećanja na noć dolaska vojnih postrojbi zemalja Varšavskoga ugovora u Bratislavu, zatim Četiri dana Nijemca Heinricha Bölla o prvima danima vojne intervencije na ulicama

\footnotetext{
${ }^{492}$ Mjesečnik Republika pokrenut je u Zagrebu 1945. i časopis je ,najduljeg neprekinuta kontinuiteta u hrvatskoj književnosti“. Od 1946. do 1972. podnaslov mu je Mjesečnik za književnost, umjetnost i javni život, nakon toga, do 1982., nosi podnaslov Časopis za kulturna i društvena pitanja, a, potom, Časopis za književnost. U dugoj povijesti izlaženja uređivali su ga Ivan Dončević, Ivan Raos, Zvonimir Majdak, Branko Maleš, Velimir Visković i dr. www.enciklopedija.hr (natuknica Republika, pristupljeno 9. 7. 2015.)

Povjesničar književnosti Krešimir Nemec Republiku smatra središnjim nacionalnim književnim časopisom druge polovice 20. st. u Hrvatskoj, no navodi da se časopis pri odabiru tekstova drži „,nerizične 'srednje linije' kloneći se pretjerane zapadnjačke orijentacije i radikalizma u idejno-estetskim 'raščišćavanjima'“. (Krešimir Nemec Povijest hrvatskog romana od 1945. do 2000., Školska knjiga, Zagreb, 2003., str. 26) Vinko Brešić, govoreći o Republici u kontekstu 1980-ih, časopis smatra „vodeći[im] društveno (...) poželjn[im] $i$ privilegiran [im] “. (Brešić, Vinko Naraštaji i časopisi hrvatske književnosti 1968. - 1990., u: Postmodernizam, iskustva jezika u hrvatskoj književnosti i umjetnosti (zbornik, ur. Cvjetko Milanja), Altagama, Zagreb, 2003. str. 46)

${ }^{493}$ Republika, 12 god., XXIV, prosinac 1968.

${ }^{494}$ Tematskom broju Republike iz prosinca 1968. nedostatak sustavnoga pregleda češke i slovačke književnosti prigovara u istome časopisu 1970. hrvatski književnik Krsto Špoljar u književnoj kritici Kunderina romana Šala. Špoljar, Krsto Roman iz češkog „mrtvog doma“, Republika, 24, 6(1970), str. 286.

${ }^{495}$ Louise Aragon Budućnost je već bila, Republika, 24, 12(1968), str. 700.
} 
Praga u kojemu je tada boravio, otvoreno pismo Čuvajmo nadu! poljskoga književnika Jerzyja Andrzejewskog te brzojav ruskoga pjesnika Jevgenija Jevtušenka Ne mogu spavati upućen sovjetskim vođama Alekseju Nikolajeviču Kosiginu i Leonidu Brežnjevu.

U cjelini je toga broja Republike češka književnost kvantitativno podzastupljena, a prevoditelj većine tekstova s češkoga jezika je Mirko Jirsak ${ }^{496}$. U njegovu su prijevodu objavljene novela Bohumila Hrabala Dijamantno oko (Diamantové očko), pripovijetka Josefa Škvoreckog Pjesma zaboravljenih godina (Píseň zapomenutých let), poezija Jiř́ija Šotole, ulomak romana Spaljivač leševa (Spalovač mrtvol) kasnijega oficijelnog autora Ladislava Fuksa te tekst Miroslava Kačera K značenju izgradnje dramske groteske - Uz kazališnu igru Václava Havela , Vrtna svečanost“. Izuzeci su pripovijetka Ishitreni autostop (Falešný autostop) Milana Kundere čiji je prevoditelj Predrag Jirsak te poezija Vladimíra Holana koju Predrag Jirsak prevodi u suradnji s Brankom Plivelićem, a koji prevodi i pjesmu Milana Nápravníka Sve što bi trebalo reći.

Na valu zanimanja hrvatske javnosti za događaje u Čehoslovačkoj Republika u nastavcima objavljuje putopisnu prozu hrvatskoga književnika Dubravka Horvatića koja, naravno, ne pripada korpusu neoficijelne produkcije, no čitateljima pruža izravan uvid u zbivanja tijekom ljeta 1968. U putopisu Uz Vltavu, Berounku i Labu Horvatić opisuje svoj posjet Čehoslovačkoj koji je započeo 15. kolovoza 1968., nepunih tjedan dana prije vojne intervencije. Prenoseći dojmove s putovanja i susreta s čehoslovačkim građanima, Horvatić naglašava pozitivno ozračje koje vlada u društvu te duh promjene nabolje koju građani predviđaju. Autor zapisuje dijelove svojih razgovora sa suputnicima u javnome prijevozu koji kažu da će „sutra (...) biti bolje nego danas“, ${ }^{497}$ no ,,sutradan je osvanuo onaj zlosretni 21. VIII. “498.499

Krajem šezdesetih Republika objavljuje nekoliko tekstova o osobama iz češkoga javnog života koji su na različite načine uključeni u zbivanja vezana uz praško proljeće, a iz pera književnika Novaka Simića koji je tih godina jedan od urednika časopisa. Godine 1969. Simić objavljuje izuzetno pozitivnu recenziju knjige Iz dnevnika kontrarevolucionara $(Z$ deniku kontrarevolucionáře) Pavela Kohouta. Knjiga objavljena 1969. prvo je Kohoutovo prozno djelo i sadrži književnikove dnevničke zapise od svibnja 1953. do svibnja 1969. Tijekom normalizacije Kohoutov je dnevnik, za koji Simić kaže da „,̌ini istini čast i mogao bi

\footnotetext{
496 Jirsak, Mirko (1909. - 1999.), hrvatski književnik i prevoditelj.

${ }^{497}$ Dubravko Horvatić Uz Vltavu, Berounku i Labu, Republika, br. 5, 1969., str. 248-251.

498 Isto.

${ }^{499}$ Putopisnu prozu iz Praga autora Tome Podruga u kojemu se spominje mjesto spaljivanja Jana Palacha Republika će objaviti i 1976. Podrug, Toma Starim Pragom, Republika, br. 8, 1976., str. 915-925.
} 
u tome pogledu biti mnogima i udžbenik ${ }^{\text {“500 }}$, objavljen u nizu europskih zemalja, no ne i u Jugoslaviji. Dvije godine kasnije Simić kratkim tekstom reagira na smrt češkoga književnika Jana Drde, a zaključuje ga književnikovim riječima da sovjetskim okupatorima ne treba dati „ni kapi vode“6501 te da je dolazak vojnih postrojbi zemalja Varšavskoga ugovora „bila, jeste i ostaje okupacija“"502.

\section{2. Forum}

Za razliku od Republike koja, kao reakciju na kolovoške događaje u Čehoslovačkoj, u prosincu 1968. u svom tematskom broju donosi niz tekstova čeških i slovačkih književnika, Forum, mjesečnik Razreda za književnost tada Jugoslavenske danas Hrvatske akademije znanosti i umjetnosti ${ }^{503}$ na vojnu intervenciju zemalja Varšavskoga ugovora, a s time povezano i blokovsku podjelu Europe, reagira tekstovima povjesničara. Krajem 1968. i tijekom 1969. Forum objavljuje povijesno-politološku studiju slovačkoga povjesničara Miloša Gosiorovskog Povijesne pretpostavke češko-slovačke federacije ${ }^{504}$ te tekstove Franje Tuđmana Evropa u procijepu između Istoka i Zapada: ideja o evropskoj zajednici nasuprot razudbe evropskih naroda između dviju svjetskih velesila ${ }^{505}$ i Opasnost neostaljinističke ekspanzije $e^{506}$.

Forum od 1968. do 1990. u objavljenim tekstovima o hrvatsko-češkim književnim i kulturnim vezama naglasak stavlja na klasike češke književnosti. Jedini predstavnik

\footnotetext{
${ }^{500}$ Simić, Novak Žrtveni ovnovi „Dnevnik jednog kontrarevolucionara“ Pavela Kohouta, Republika, br. 8, 1969. str. 48 .

${ }^{501}$ Simić, Novak Trojica ispred zaborava, Republika, br. 2/3, 1971., str. 276.

502 Isto.

${ }^{503}$ Forum, mjesečnik Razreda za književnost Jugoslavenske akademije znanosti i umjetnosti, pokrenut je 1962. na poticaj Miroslava Krleže koji je u prvih deset godina objavljivanja časopisa u njemu aktivno i surađivao. www.enciklopedija.hr (natuknica Forum, pristupljeno 9. 7. 2015.) U svojoj knjizi Uvod u suvremenu hrvatsku književnost 1970. - 2010. Krešimir Bagić, želeći pružiti reprezentativan pregled tema koje su okupirale hrvatsku kulturnu scenu sedamdesetih godina, analizira izdanja dvaju hrvatskih časopisa toga doba: Foruma i Pitanja. Forum Bagić opisuje kao „Akademijin časopis koji se drži kanona i kanonizira, koji objavljuje priloge afirmiranih autora, časopis koji pokušava spojiti elitizam i srednji put, konzervativan časopis koji nastoji djelovati urotnički ne libeći se ,gesta dobre volje ‘ kada je prikliješten ideološkim nalozima. “ Krešimir Bagić Uvod u suvremenu hrvatsku književnost 1970. - 2010., Školska knjiga, Zagreb, 2016., str. 18.

${ }^{504}$ Gosiorovský, Miloš Povijesne pretpostavke češko-slovačke federacije, Forum, br. 10-11(1968), str. 10281056.

505 Tuđman, Franjo Evropa u procijepu između Istoka i Zapada, Forum, 7(1968), knjiga 16, str. 623-648.

506 Tuđman, Franjo Opasnost neostaljinističke ekspanzije, Forum, 8(1969), knjiga 17, str. 543-555.
} 
neoficijelne češke književne scene koji se uspijeva probiti na stranice Foruma je Miroslav Holub čija je poezija, u prijevodu Ljudevita Bauera, ondje objavljena 1974.

Najvažniji je za recepciju češke književnosti u Forumu bio češki kroatist Dušan Karpatský. S prijevodima čeških klasika počinje 1970. kada uz prijevod pjesama iz zbirke Jaroslava Seiferta Koncert na otoku (Koncert na ostrově) donosi i tekst o njegovu pjesništvu. ${ }^{507}$ Dvije godine kasnije isti prevoditelj objavljuje tekst Braća Čapek te prijevod drame Iz života kukaca. ${ }^{508}$ Godine 1978. Karpatský u Forumu pruža prikaz književno-kritičarskog rada Františeka Xavera Šalde te prijevod nekoliko njegovih književnih kritika. ${ }^{509}$ Karpatský se u Forumu bavi i recepcijom hrvatske književnosti u Češkoj pa 1984. objavljuje tekst Prijevodi hrvatske književnosti u Čeha. ${ }^{510}$

Baveći se temom recepcije hrvatske književnosti u Češkoj, poznati češki slavist nije bio usamljen na stranicama Foruma. Naime, od ostalih se analiziranih novina i časopisa u kontekstu češko-hrvatskih kulturnih veza Forum razlikuje, između ostaloga, po kvantitativnoj nadzastupljenosti tekstova koji tematiziraju recepciju hrvatske književnosti u Češkoj. Osim Karpatskog tekstove o recepciji opusa Miroslava Krleže među češkim čitateljstvom objavljuje kroatist Miroslav Kvapil, ${ }^{511}$ a 1982. ondje je objavljena i korespondencija Miroslava Krleže s češkim prevoditeljima svojih djela, ${ }^{512}$ Miroslava Tušek Šimunović objavljuje tekst August Šenoa u očima češke kritike, ${ }^{513}$ a časopis donosi i prijevod s češkoga teksta Vatroslava Jagića Hrvatska književnost. ${ }^{514}$

\footnotetext{
${ }^{507}$ Karpatský, Dušan Jaroslav Seifert, prijevod pjesama iz zbirke pjesama Koncert na otoku, Forum, br. 9, 1970., str. 389-405.

Osim Karpatskýjevih priloga i prijevoda na stranicama Foruma objavljeni su i prijevodi poezije Miroslava Floriana, Josefa Hanzlíka i Kamila Maříka na srpski jezik 1984. te Jaroslava Seiferta 1985.

${ }^{508}$ Karpatský, Dušan Braća Čapek, prijevod drame Iz života kukaca, Forum, br. 1-2, 1972.

${ }^{509}$ Karpatký, Dušan František Xaver Šalda, Forum, br. 1-2, 1978.

${ }^{510}$ Karpatský, Dušan Prijevodi hrvatske književnosti u Čeha, Forum, br. 1/2, 1984., str. 412-415.

${ }^{511}$ Kvapil, Miroslav O Miroslavu Krleži, njegovoj prozi i poeziji u Čehoslovačkoj između dva rata, Forum, br. 1-2, 1981., str. 96-121.

${ }^{512}$ Krleža, Miroslav Osam pisama Dušanu Karpatskom, Pismo Anni Urbanovoj, Sedam pisama Ireni Wenigovoj, Forum, br. 10-12, 1982., str. 1004-1027.

513 Tušek Šimunović, Miroslava August Šenoa u očima češke kritike, Forum, br. 11/12, 1989.

514 Jagić, Vatroslav Hrvatska književnost, Forum, br. 3/4, 1989.
} 


\section{3. Prolog i Novi prolog}

Kao časopisi koji primarno prate dramsku umjetnost, Prolog i Novi prolog ${ }^{515}$ tijekom analizirana razdoblja iznimno su važan izvor podataka za kritičku recepciju kazališnih uprizorenja neoficijelnih dramatičara. Kazališni kritičari Prologa i Novoga prologa svojim kritičarskim radom kontinuirano prate izvedbe dramskih tekstova neoficijelnih dramatičara na pozornicama hrvatskih kazališta. ${ }^{516}$ Oba časopisa, a osobito Prolog u prvoj polovici sedamdesetih godina, redovno objavljuju i repertoare manjih kazališnih smotri koje se održavaju u Hrvatskoj te se ondje mogu naći informacije o češkim kazališnim skupinama u programima tih festivala poput Internacionalnog festivala studentskih kazališta i Dana mladoga teatra. ${ }^{517}$

Dodana su vrijednost ovih časopisa za stvaranje slike o kontekstu u kojemu su prikazivani tekstovi neoficijelnih dramatičara tekstovi o kazališnim zbivanjima i analize kazališne scene u Hrvatskoj tijekom sedamdesetih i osamdesetih godina 20. st. Osim toga, tijekom sedamdesetih Prolog objavljuje niz intervjua s kazališnim redateljima, poput Mire Međimorca i Božidara Violića, i analiza njihova redateljskog rada, a koji će, pokazat će se ubrzo, postati vodeće osobnosti pri uvrštavanju Havelovih, Kunderinih i Kohoutovih dramskih tekstova na repertoare hrvatskih kazališta. ${ }^{518}$

Novi prolog tijekom 1988., 1989. i 1990. tekstovima u cjelinama Sindrom srednjoevropskog u suvremenom kazalištu, filmu... daje svoj obol raspravi o temi srednje Europe i njenom identitetu koja se razvija u nekoliko hrvatskih časopisa, a potaknuta je

\footnotetext{
515 Časopis za kazalište i dramsku umjetnost Prolog objavljivan je uglavnom tromjesečno od 1968. do 1984. i u tom je razdoblju bio središnji hrvatski časopis te tematike. Od 1971. uz časopis je pokrenuta i Biblioteka Prolog. Dvije godine nakon prestanka izlaženja Prologa, 1986., pokrenut je Novi prolog, podnaslova ,revija za dramsku umjetnost“", koji sve do 1990. izlazi jednom do triput godišnje. www.enciklopedija.hr (natuknica Prolog, pristupljeno 9. 7. 2015.)

${ }^{516} \mathrm{Na}$ stranicama Prologa i Novoga prologa objavljeni su sljedeći tekstovi koji izravno tematiziraju predstave neoficijelnih dramatičara ili se njih posredno dotiču, a o kojima u kontekstu kazališne recepcije neoficijelnih dramatičara detaljnije govori 7. poglavlje ovoga rada: Srećko Lorger Vrijeme športa i razonode (o kazališnoj situaciji u Splitu), Boris Senker Pegaz u ormi (o Havelovim predstavama Audijencija i Izložba), Igor Mrduljaš Diderot á la Pragois, Andrea Zlatar Tri u drugom, Menzel u Zagrebu, Zagreb iz Praga.

${ }^{517} \mathrm{Na}$ Internacionalnom festivalu studentskih kazališta 1968. gostuje praško Černé divadlo UKDDS predstavom Ivana Holečeka i Františeka Králičeka Nježna kosa, 1969. Divadlo za bránou iz Vyškova dramom Kuća na granici Sławomira Mrožeka, a 1970. praško Divadlo DISK dramom Fernanda Arrabala Bicikl osuđenika. (Repertoar Internacionalnog festivala studentskih kazališta u Zagrebu, Prolog, god. II, br. 4, ožujak/travanj/svibanj/lipanj, 1969.) U programu Dana mladoga teatra 1976. je praško Divadlo na okrají dramom Juliana Tuwina Bal u operi. (Prolog, br. 28, god. VIII, 1976., str. 60)

518 Može li Lemos biti od drveta? (intervju s Mirom Međimorcem, razgovarao Vlado Krušić), Prolog, br. 25, god. VII(1975), str. 24; Kazalište, umjetnost sjena (intervju s Božidarom Violićem, razgovarao Igor Mrduljaš), Prolog, dvobroj 36 - 37, god. X(1978)
} 
slavnim esejom Milana Kundere Tragedija Srednje Europe objavljenim 1985. u časopisu Gordogan.

\section{4. Quorum}

Časopis za književnost Quorum pokrenut je 1985. i sve do kraja razdoblja koje je predmet analize ovoga rada uređuje ga književnik Branko Čegec. Primarno namijenjen mladoj publici časopis je na više razina predstavljao novinu na onodobnoj časopisnoj sceni Jugoslavije, ${ }^{519}$ no, kao i većina ostalih, bez jasno artikuliranih kritika službenoga režima. Tekstovi i grafički dodaci časopisa koji su smatrani društveno suspektnima nisu kritičke naravi prema političkim elitama, već je, mahom, riječ o erotskome sadržaju. ${ }^{520}$

U pet godišta Quoruma objavljen je niz književnokritičkih tekstova i priloga o najmlađoj generaciji čeških književnika, a imena nekih od njih pripadaju i neoficijelnoj sceni. Ondje su objavljene kritike romana Milana Kundere Nepodnošljiva lakoća postojanja, ${ }^{521}$ Katica Ivanković objavljuje osvrt na beogradsko izdanje izabranih pjesama Jaroslava Seiferta ${ }^{522}$ te osvrti na hrvatska izdanja književnika koji nisu pripadali neoficijelnoj produkciji Jaroslava Bočeka, ${ }^{523}$ Radeka Johna, ${ }^{524}$ i Ladislava Fuksa ${ }^{525}$. Na Havelovo preuzimanje funkcije predsjednika države 1990. u časopisu reagira Katica Ivanković opširnim tekstom Havel na Hrad ${ }^{526}$ te prijevodom na hrvatski jezik Havelove drame Iskušavanje (Pokoušení) $^{527}$.

Uz Gordogan Quorum je jedini časopis u Hrvatskoj koji tijekom osamdesetih pruža kvalitetniji uvid i u druge aspekte češkoga egzila te, između ostaloga, objavljuje prijevode tekstova iz časopisa koje su češki kulturnjaci pokretali u inozemstvu. Godine 1988. časopis

\footnotetext{
519 Časopis je „koncepcijski, sadržajno, kvantitativno i dizajnerski bitno [je] nadišao postojeće časopisne standarde“. Bagić, Krešimir Uvod u suvremenu hrvatsku književnost, Školska knjiga, Zagreb, 2016., str. 65. ${ }^{520}$ Primjerice, pjesme u prozi Mirka Valenta, pjesma Putopis Gorana Rema, fotografije vagine uz poeziju Borivoja Radakovića. Tatarin, Milovan Quorum - časopis mladih za sve generacije čitatelja, u: Sintaksa hrvatskoga jezika - Književnost i kultura osamdesetih, zbornik radova 39. seminara Zagrebačke slavističke škole, ur. Krešimir Mićanović, Filozofski fakultet Sveučilišta u Zagrebu, Zagrebačka slavistička škola, Hrvatski seminar za strane slaviste, Zagreb, 2011. str. 161.

${ }^{521}$ Gavran, Zdravko Terra Kunderiana, Quorum, br. 1, 1985., str. 119-122.

${ }^{522}$ Ivanković, Katica Sve Seifertove promjene, Quorum, br. 2, 1985., str. 140-143.

${ }^{523}$ Vučić, Miroslava Enigma enigme, Quorum, br. 4/5, 1986., str. 217-220.

${ }^{524}$ Ivanković, Katica Mladi češki narkomani, Quorum, br. 3, god. IV, 1988., str. 329-333.

525 Tatarin, Milovan Apsurdno nepoimanje situacije, Quorum, br. 3, god. V, 1989., str. 387-389.

${ }^{526}$ Ivanković, Katica Havel na Hrad, Quorum, 1(29), 6(1990), str. 2-17.

${ }^{527}$ Havel, Václav Iskušavanje, prijevod Katice Ivanković, Quorum, 6(1990), 1(29), str. 18-77.
} 
donosi prijevod Katice Ivanković teksta Slučaj Jazz-sekcije Petra Sedleckog prvotno objavljenog dvije godine ranije u pariškom egzilnom časopisu Svědectví. ${ }^{528}$ Godinu kasnije u časopisu je objavljen i intervju, preveden s njemačkoga jezika, s češkim slikarom koji nakon 1968. živi u Njemačkoj Jiříjem Dokoupilom. ${ }^{529}$

\section{5.15 dana}

Recepcija kulturnih sadržaja iz Čehoslovačke u časopisu 15 dana kvantitativno je najizdašnija neposredno nakon sloma reformnog pokreta u ljeto 1968., jenjava tijekom sedamdesetih godina, da bi se ponovno intenzivirala na valu liberalizacije u obama društvima u osamdesetima.

Časopis 15 dana dao je izuzetan obol u upoznavanju hrvatske javnosti s inozemnim kulturama i književnostima. Krajem šezdesetih časopis pokreće stalnu rubriku u kojoj donosi sadržaje stranih časopisa, sovjetskih, francuskih, slovenskih, a u listopadu 1968. i čeških i slovačkih. ${ }^{530}$ Tom prigodom 15 dana objavljuje tekstove raznolike tematike, poput intervjua s književnikom Ludvíkom Vaculíkom, ${ }^{531}$ prijevoda pjesme Ludvíka Kundere Pokušaj pohvale Charliea Chaplina, ${ }^{532}$ teksta Ovo je čehoslovački plakat Eugena Cankcija ${ }^{533}$ te prijevoda novinskih članaka slovačkih novina Slovački pogledi iz broja objavljenoga neposredno nakon 21. kolovoza odnosno, kako navodi uvodni tekst 15 dana, ,tragičnih dana ove bratske i socijalističke zemlje“534 . Samo dva broja kasnije u rubrici Portreti filmskih umjetnika objavljena je stvaralačka biografija redateljice Věre Chytilové Granice slobode ${ }^{535}$ te intervju s filmskim redateljima iz Čehoslovačke naslovljen Doba u kojem je glavni zadatak umjetnosti smjelost-vrijeme je mraka ${ }^{536}$.

\footnotetext{
${ }^{528}$ Sedlecký, Petr Slučaj Jazz-sekcije, Quorum, br. 3, god. IV, 1988., str. 210-220. Jazz-sekcija (Jazzová sekce) je udruga koja je u Čehoslovačkoj djelovala od 1971. do 1986., a čija je primarna zadaća bila promocija džez glazbe. Vremenom su aktivnosti udruge postale oporbene u odnosu na službeni režim i zasijecale i na područje neoficijelne kulture. http://www.slovnikceskeliteratury.cz/ showContent.jsp?docId=1886 (natuknica Jazzová sekce, pristupljeno 8. 8. 2019.)

${ }^{529}$ Razgovor s Jiř́jem Dokoupilom, prevela Darija Marjanović, Quorum, br. 4, god. V, 1989., str. 365-368.

${ }^{530}$ Sa stranica čeških i slovačkih časopisa, 15 dana, br. 7/8, 1968.

${ }^{531}$ Intervju s Ludvíkom Vaculíkom, 15 dana, br. 7/8, 1968., str. 17.

${ }^{532}$ Kundera, Ludvík Pokušaj pohvale Charliea Chaplina, 15 dana, br. 7/8, 1968., str. 36-37.

${ }^{533}$ Canki, Eugen Ovo je čehoslovački plakat, 15 dana, br. 7/8, 1968., str. 6.

${ }^{534}$ Proglas redakcije Slovačkih pogleda, 15 dana, br. 7/8, 1968.

${ }^{535}$ Granice slobode (Portreti filmskih umjetnika), 15 dana, br. 11/14, 1968., str. 37-39.

${ }^{536}$ Doba u kojem je glavni zadatak umjetnosti smjelost - vrijeme je mraka, 15 dana, br. 11/14, 1968.
} 
Najistaknutije prevoditeljsko ime časopisa 15 dana zasigurno je Renata Kuchar koja u tome časopisu tijekom 1980-ih objavljuje niz prijevoda češke neoficijelne književnosti uz, najčešće, kraće biografske tekstove autora. Dio svoga prevoditeljskoga rada u 15 dana Kuchar ostvaruje u suradnji s jezikoslovkom Nives Opačić. I dok se oficijelna češka književnost razdoblja normalizacije na stranice 15 dana ne uspijeva probiti, ondje je tijekom osamdesetih objavljen niz prijevoda poezije klasika češke književnosti Jaroslava Seiferta ${ }^{537}$ i Jiříja Šotole, ${ }^{538}$ ulomak romana Praznine Bohumila Hrabala, ${ }^{539}$ te neoficijelnih autora poput pripovijetke Srijeda ujutro Ivana Klíme, ${ }^{540}$ ulomaka Pisama Olgi Václava Havela ${ }^{541}$ te ulomka drame Largo desolato Václava Havela ${ }^{542}$ i romana Milana Kundere ${ }^{543}$.

Časopis 15 dana prostor otvara i temama iz povijesti češke književnosti, a objavljeni tekstovi mahom se vežu uz ime Gene Senečića. Svojim tekstom Senečić obilježava tridesetu godišnjicu smrti Vladislava Vančure, ${ }^{544}$ povodom sto i dvadesete godišnjice smrti Božene Němcove prevodi pripovijetku Petera Štrelingera Posjet Božene Němcové Samu Chalupki, ${ }^{545}$ stotu godišnjicu smrti Jiř́ja Mahena obilježava tekstom Mahenova Jugoslavija, ${ }^{546}$ te, također, prigodnim tekstom obilježava stotu obljetnicu rođenja Jaroslava Hašeka, ${ }^{547}$ klasika čije kraće tekstove časopis objavljuje u nekoliko svojih brojeva tijekom osamdesetih godina. ${ }^{548}$

Kako su područja interesa časopisa 15 dana sve umjetnosti i raznolike društvene teme, u njemu je snažna recepcija i češke likovne umjetnosti, osobito radova proslavljenih karikaturista Bohumila Štěpána, ${ }^{549}$ Ivana Steigera, ${ }^{550}$ i Vlastimila Zabranskog ${ }^{551}$ te

\footnotetext{
${ }^{537}$ Prijevod pjesama Jaroslava Seiferta, prevoditeljice Renata Kuchar i Nives Opačić, 15 dana, br. 6, 1985., str. 29-33.

538 Šotola, Jiří A koliko si imala ljubavnika, prevoditeljice Renata Kuchar i Nives Opačić, 15 dana, br. 3, 1986. str. 25-29.

${ }^{539}$ Hrabal, Bohumil Praznine (ulomak), prevoditeljica Renata Kuchar, 15 dana, br. 3, 1988., str. 34-38.

${ }^{540}$ Klíma, Ivan Srijeda ujutro, prevoditeljica Renata Kuchar, 15 dana, br. 6, 1988., str. 34-38.

${ }^{541}$ Havel, Václav Pisma Olgi (ulomci), prevoditeljice Renata Kuchar i Nives Opačić, 15 dana, br. 3, 1987., str. 21-25.

${ }^{542}$ Havel, Václav Largo desolato (ulomak), prevoditeljica Renata Kuchar, 15 dana, br. 3, 1987., str. $26-29$.

${ }^{543}$ Kundera, Milan Knjiga smijeha i zaborava (ulomak), prijevod Dagmar Ruljančić i Albert Goldstein, 15 dana, 1985., str. 12-13; Milan Kundera Nepodnošljiva lakoća postojanja (ulomak), prijevod Nikola Kršić, 15 dana, br. 7, 1987., zadnja stranica

544 Senečić, Geno Život je polazište i cilj književnosti (O tridesetoj obljetnici smrti Vladislava Vančure), 15 dana, br. 7, 1972.

545 Štrelinger, Peter Posjet Božene Němcové Samu Chalupki, 15 dana, br. 1/2, 1982., str. 48-50.

546 Senečić, Geno Mahenova Jugoslavija, 15 dana, br. 8, 1982., str. 35-37.

${ }^{547}$ Senečić, Geno Uz stotu obljetnicu rođena Jaroslava Hašeka, 15 dana, br. 3, 1983., str. 30-33.

${ }^{548}$ Hašek, Jaroslav Drobilekova ljubavna pustolovina, 15 dana, br. 3, 1983., str. 34-35; Hašek, Jaroslav Doživljaji dobrog vojaka Švejka (ulomak), 15 dana, br. 3, 1985., str. 35; Hašek, Jaroslav Povijest stranke umjerenog napretka u granicama zakona (ulomak), 15 dana, br. 1/2, 1990., str. 3-5; Hašek, Jaroslav Razgovori s cenzorom (ulomak), 15 dana, br. 6, 1990.

549 Štěpán, Bohumil (1913. - 1985.), češki slikar, grafičar i ilustrator.
} 
stvaralačkoga puta redatelja Miloša Formana koji nakon 1968. djeluje u Sjedinjenim Američkim Državama. Radove Štěpána, Steigera i Zabranskog 15 dana objavljuje u nekoliko navrata punih desetak godina, najčešće uz komentare hrvatskoga kritičara Fedora Kritovca. ${ }^{552}$ Tekstovi o Milošu Formanu u pravilu su pozitivno intonirani i iznose salve pohvala na Formanov rad čiji se film Svlačenje naziva „,remek-djelom““553, Forman ,jedn[im] od najbriljantnijih predstavnika stvaralačkog preporoda što ga je polovinom šezdesetih godina doživio čehoslovački film“"554 i redateljem koji se filmom Let iznad kukavičjeg gnijezda „Svrstao u sâm vrh režiserskog Olimpa“‘555. 556

\footnotetext{
${ }^{550}$ Steiger, Ivan (1939.), češki karikaturist, slikar i ilustrator. Od 1969. živi u Njemačkoj.

${ }^{551}$ Zabranský, Vlastimil (1936.), češki slikar, grafičar i karikaturist.

${ }^{552}$ Karikature Ivana Steigera, 15 dana, br. 5/6, 1968., str. 74, Suvremena karikatura - Bohumil Štěpán Naročito korisni i zahvalni pronalasci, 15 dana, godište XV, br.3-4, 1972., str. 58-59; Bohumil Štěpán Odmorište mašte, 15 dana, godište XV, broj 5, 1972., str. 51; Karikature Vlastimila Zabranskog, 15 dana, br. 1/2, 1974.;

Karikature Bohumila Štěpána, 15 dana, br. 6, 1981., str. 40; Karikature Vlastimila Zabranskog (tema Apel za ljudska prava), 15 dana, br. 3, 1982., str. 39.

${ }^{553}$ Munitić, Ranko Otkrivena Amerika (Svlačenje Miloša Formana), 15 dana, 1972., str. 28.

${ }^{554}$ Isto.

${ }^{555}$ Dundović, Hanibal Formanov Let iznad kukavičjeg gnijezda, 15 dana, 1976., str. 34-35.
}

Formanovim djelovanjem nakon odlaska u egzil bavi se niz tekstova u raznim hrvatskim časopisima: Darko Zubčević Miloš Forman i Taking Off (Prolog, br. 16, 1972.), Petar Krelja Taking Off (Republika, br. 11, 1973.), Veljko Žvan Let iznad kukavičjeg gnijezda Miloša Formana (Polet, br. 5/6, 1976.), Darko Zubčević Prikaz filma Kosa (Polet, br. 74, 1978.), Srećko Jurdana Dvosjekli mač (Polet, br. 123, 1980., str. 19), Ranko Munitić Otkrivena Amerika (15 dana, br. 1/2, 1972., str. 18), Hanibal Dundović Formanov let preko kukavičjeg gnijezda (15 dana, br. 6, 1976., str. 34-35), Miloš Forman (Oko, br. 106, 1976., str. 19), Duje Sladojević Isušenje psihijatrije (Oko, br. 120, 1976.), DC Slika kažnjeničkog društva (Oko, br. 106, 1976.), Tomislav Kurelac Teško je postati Amerikanac (Oko, br. 328, 1984., str. 13), Tomislav Kurelac Amadeus (Oko, br. 335, 1985., str. 12), Nakon reza 1968. (Danas, 18. 9. 1984.).

${ }^{556}$ Povodom dolaska Miloša Formana na beogradski filmski festival Fest 1987. kratak razgovor s redateljem objavljuje Večernji list. Osim dvojbe u pripadnost zemljama i društvima iz kojih je potekao i u kojima živi i stvara (,...ne znam koja je moja prava domovina. Da li zemlja u kojoj sam rođen i stekao prve spoznaje, gdje su moji kulturni korijeni, ili zemlja u kojoj živim i radim već 18 godina.") iz toga intervjua može biti zanimljiv odgovor na pitanje bi li snimao film prema književnom predlošku Milana Kundere ili Josefa Škvoreckog: „Da, ali jedino da ih radim u Čehoslovačkoj. Ne bih mogao prihvatiti da se ono što se odigrava u Čehoslovačkoj snima drugdje. Važno je čuti jezik, vidjeti lica, ulice.“ Stojanović, M. Dosljedan sebi, Večernji list, 4. 2. 1987. br. 8439 , str. 15 .

$\mathrm{O}$ analognim nedoumicama o pripadnosti i identitetu čeških emigranata piše i Virgil Kurbel u istim dnevnim novinama tri godine kasnije navodeći riječi Ote Filipa nakon povratka u Čehoslovačku poslije baršunaste revolucije: „Gdje nam je sada zavičaj, domovina? (...) Zavičaj je u Češkoj ili Moravskoj, ali kod kuće smo u svijetu.“ Kurbel, Virgil Povratničke neodoumice, Večernji list, 13. 2. 1990., br. 9513, str. 23. 


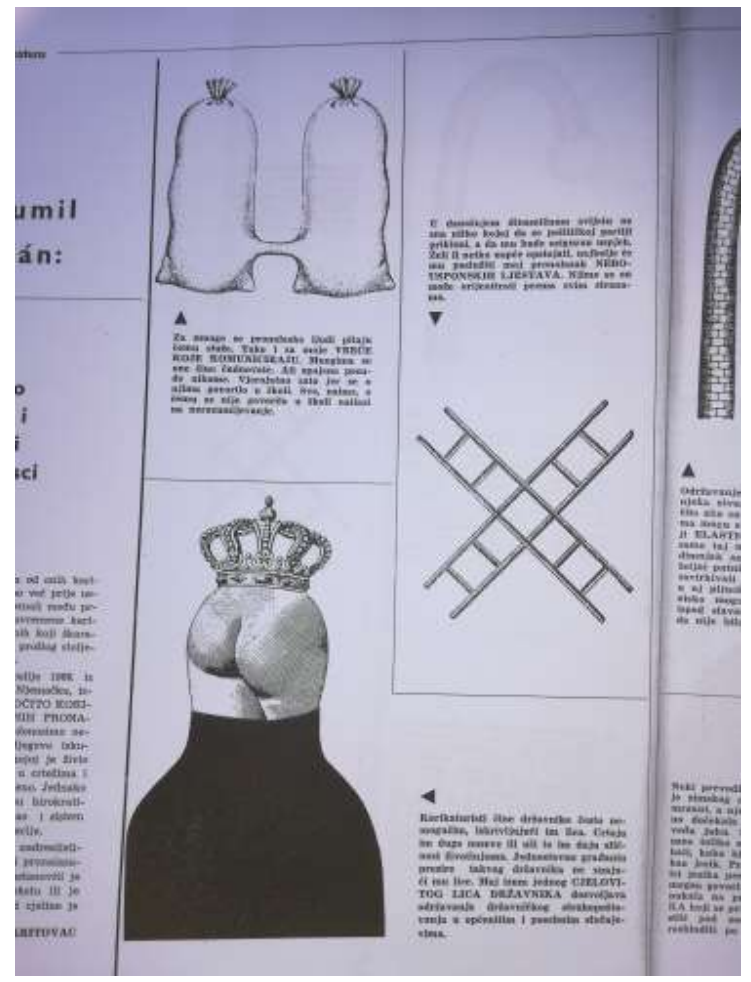

Fotografija I: Karikature Bohumila Štěpána

Izvor: Časopis 15 dana, godište XV, broj 3-4, god. 1972., str. 58.

\section{6. Oko}

Jedan od pokretača časopisa Oko 1973. i prvi glavni i odgovorni urednik, no samo prvih devet brojeva, jest komediograf Fadil Hadžić. Ta činjenica, zasigurno, dijelom objašnjava orijentaciju časopisa prema praćenju kazališnih zbivanja pa je, slijedom toga, očita nadzastupljenost kazališnokritičke recepcije neoficijelnih čeških dramatičara. Tako kazališne kritike Željka Falouta u Oku prate Havelove jednočinke Audijenciju i Izložbu u Gavelli 1980. te predstavu Milana Kundere Žak Fatalist i njegov gospodar u Teatru ITD iste godine. ${ }^{557}$ Godine 1984. Dubravka Turković objavljuje kritiku predstave Šala Milana Kundere u Satiričkom kazalištu Jazavac, ${ }^{558}$ a godinu dana kasnije Smilja Kursar Pupavac potpisuje tekst u kojem analizira predstavu Marija se bori s anđelima Pavela Kohouta u izvedbi Dramskoga kazališta Gavella. ${ }^{559}$ Inicijalima S. K. P. (Smilja Kursar Pupavac) 1985. potpisan je tekst Vesela igra ${ }^{560}$ o predstavi Jiř́ja Menzela Tri u drugom Teatra ITD, a posljednja kazališna

\footnotetext{
${ }^{557}$ Falout, Željko Jedna sretna večer, Oko, br. 208, 1980., str. 16.

558 Turković, Dubravka, Neslano s ozbiljnom šalom, Oko, br. 310, 1984., str. 13.

${ }^{559}$ Kursar Pupavac, Smilja U krletci vlastitih dilema, Oko, br. 338, 1985., str. 11.

${ }^{560}$ S. K. P. Vesela igra, Oko, br. 409, 1987., str. 13.
} 
kritika neoficijelnih čeških dramatičara u Oku tematizira Asanaciju Václava Havela ${ }^{561}$ prikazanu u zagrebačkome Hrvatskom narodnom kazalištu 1990.

Tekstovi ovoga časopisa dramske produkcije neoficijelnih autora rubno se dotiču i u tekstovima koji nisu kazališne kritike. O predstavama neoficijelnih autora riječ je i u izvještajima s kazališnih festivala i smotra poput Gavellinih večeri i Dana satire Satiričkoga kazališta Jazavac. ${ }^{562} \mathrm{O}$ počecima rada Teatra u gostima i Kunderinoj predstavi Ševa kojom započinje aktivnost najpoznatijega jugoslavenskog putujućeg kazališta 1975. piše glumac Relja Bašić u dnevničkim zapisima Izvaci iz dnevnika jednog putujućeg glumca. ${ }^{563}$

U dijelu svojih tekstova Oko se bavi i aktualnom kulturnom scenom Čehoslovačke te izdanjima oficijelnih autora koja objavljuju hrvatski nakladnici. O cenzuri koja je ovladala čehoslovačkom kulturnom scenom početkom sedamdesetih godina i čišćenju kazališnih repertoara od djela službenom režimu nepodobnih autora Oko detaljno piše 1978. u tekstu Kriza suvremenog autorstva ( $u$ Čehoslovačkoj) u kojem navodi da se u kazalištima diljem Čehoslovačke uočava malena zastupljenost domaćih autora, osobito u dramskom i komediografskom dijelu repertoara. ${ }^{564}$ Književnim su kritikama popraćena i hrvatska izdanja oficijelnih autora Jaroslava Bočeka i Ladislava Fuksa. Niz takvih tekstova 1986. započinje Cvjetko Milanja kritikom romana Slučaj doktora Karpete Jaroslava Bočeka, ${ }^{565}$ Miroslava Vučić 1989. potpisuje kritiku Gospodina Theodora Mundstocka Ladislava Fuksa, ${ }^{566}$ a 1990. u Oku su objavljene i dvije kritike Bočekova romana Prestolonasljednik ${ }^{567}$.

U Oku se, uz Polet, ostvaruje i najbolja recepcija aktivnosti rock-sastava The Plastic People od the Universe. O drugim zbivanjima na češkoj glazbenoj sceni toga doba prosječan je hrvatski građanin bio slabo informiran, no djelatnost članova ovoga rock-sastava itekako je izlazila iz granica pukoga glazbenog stvaralaštva. Časopis Polet 1982. objavljuje tekst Dražena Vukova Colića o aktualnim zbivanjima na čehoslovačkoj rock-sceni s naglaskom na represiju kojoj je bio podvrgnut javno najeksponiraniji član skupine The Plastic People i

\footnotetext{
561 Šuljić, Igor Za predsjedničku ložu, Oko, br. 24(488), 1990., str. 13.

562 Želimir Stublija objavljuje niz tekstova o Gavellinim večerima pa tako i 1986. i 1987. kada su u programu toga festivala Kunderin Žak Fatalist i njegov gospodar splitskoga Hrvatskog narodnog kazališta te Havelova Prosjačka opera beogradskoga Ateljea 212. Isti autor objavljuje i izvještaje s Dana satire u sklopu kojih je 1988. prikazan Havelov Largo desolato Kamernoga teatra 55 iz Sarajeva.

${ }^{563}$ Bašić, Relja Izvaci iz dnevnika jednog putujućeg glumca, Oko, br. 80, 1975., str. 5.

${ }^{564}$ L. L. Kriza suvremenog autorstva (u Čehoslovačkoj), Oko, br. 160, 1978., str. 23.

565 Milanja, Cvjetko, Pouka izvana, Oko, br. 372, 1986., str. 20.

${ }^{566}$ Vučić, Miroslava Ladislav Fuks Gosp. Theodor Mundstock, Oko, br. 446, 1989., str. 21.

${ }^{567}$ Prikaz romana Jaroslava Bočeka Prestolonasljednik, Oko, br. 15(479), 1990., str. 39; Matanović, Julijana Povijesni poučak, Oko, br. 19(483), 1990., str. 36.
} 
središnja osobnost underground-scene ${ }^{568}$ Ivan Jirous zbog, prema kriterijima onodobne čehoslovačke službene politike, neprimjerene izjave dane časopisu Vokno. Krajem analizirana razdoblja, u siječnju 1990., intervju s Jirousom u Oku objavljuje Katica Ivanković. ${ }^{569}$

\section{7. Tragedija Srednje Europe Milana Kundere i njeni odjeci u hrvatskome tisku}

\section{Časopis Gordogan ${ }^{570}$ neoficijelnoj češkoj književnosti posvećuje se dvama} književnokritičkim tekstovima iz prve polovice osamdesetih objavljenima u razmaku od pet godina, a oba se bave romanima Milana Kundere - Život je negdje drugdje i Nepodnošljivom lakoćom postojanja ${ }^{571}$ Kronološki između tih dviju književnih kritika Gordogan objavljuje i prijevod kritike memoara Zdeněka Mlynářa iz časopisa The Times. ${ }^{572}$ Međutim, recepciji neoficijelne češke kulturne scene Gordogan je, zasigurno, najviše pridonio prijevodom eseja Milana Kundere Tragedija Srednje Europe koji na stranice časopisa 1985. donosi Giga Gračan. ${ }^{573}$ U tekstu toga eseja autor, koji tada već desetak godina živi u Francuskoj, propituje niz dvojbi o identitetu srednje Europe, onoga dijela Staroga Kontinenta koji je zbog snažnoga

\footnotetext{
${ }^{568}$ Umjetnička je djelatnost underground-scene bila raznolika. Obuhvaćala je koncerte rock-sastava, organizaciju izložaba, kazališnih predstava, književno stvaralaštvo u kojem kvantitativno prevladava poezija, javna čitanja tekstova (npr. Egon Bondy svoj roman Invalidní sourozenci 1974. čita pred publikom jedne gostionice u okolici Praga). Teoretičarem i glasnogovornikom underground-scene smatra se Ivan Martin Jirous koji temeljne teze pokreta iznosi 1975. u tekstu Zpráva o třetím českém hudebním obrození. Nakon potpisivanja Povelje 77 predstavnici undergrounda intenziviraju komunikaciju i suradnju s ostalim pripadnicima neoficijelne scene. No, ubrzo dolazi do uhićenja Ivana Martina Jirousa i odlaska niza značajnijih predstavnika u emigraciju što utječe na organizaciju i snagu pokreta. Nova se generacija undergrounda javlja sredinom osamdesetih i čine je pjesnici Jáchym Topol, Petr Placák, J. H. Krchovský, Jan Kahan čiju poeziju hrvatska javnost, u prvom redu zahvaljujući periodici, intenzivnije recipira no onu utemeljitelja undergrounda iz sedamdesetih godina. Janoušek, Pavel i suradnici Dějiny české literatury 1945-1989, IV. knjiga 1969-1989, Academia, Prag, 2008., str. 279-290, 455. ${ }^{569}$ Ivanković, Katica Magor protiv Husaka, Oko, br. 2(466), 1990., str. 24.

570 O opozicijskom tonu časopisa Gordogan piše Ladislav Tadić u uvodnome dijelu Bibliografije Gordogana 1979. - 2013.: „Gordogan [je] trajno išao protiv 'struje' ili mimo nje, a da pritom nikad nije imao sigurnu zavjetrinu. (...) Stoga bi se za opći smjer časopisa, kad se god pozabavio stvarima kakve obično sažimljemo sintagmom signum temporis, moglo reći da je uglavnom bio - kaď̌to implicitno, kadšto manje implicitno opozicijski, dakako, ne u stranačkom smislu." Tadić, Ladislav Časopis Gordogan, Bibliografija 1979. - 2013., Novi Gordogan, udruga za kulturu, Zagreb, 2015., str. 11-12.

${ }^{571}$ Senker, Boris Miles gloriosus s perom u ruci, Gordogan, br. 5-6, siječanj-travanj 1980., str. 339-343; Ivić, Nenad Neoprostiva banalnost pisanja, Gordogan, br. 19, god. VII, 1985.

${ }^{572}$ Brown, Archie Život pri vrhu, Gordogan, br. 13-14, siječanj-travanj 1983., str. 329-332.

Kritika Archiea Browna Život pri vrhu objavljenja je u The Timesovoj rubrici The Times Literary Supplement, 23. siječnja 1981.

${ }^{573}$ Kundera, Milan Tragedija Srednje Europe, prevoditeljica Giga Gračan, Gordogan, br. 17/18, god. 07(1985), str. 289-305.
} 
sovjetskog utjecaja nakon 1945. „kulturno na Zapadu, a politički na Istoku““574 i gdje se, prema Kunderinim riječima, „tijekom posljednjih trideset i pet godina koncentrira drama Europe“6575. Kundera zaključuje da se:

„(...) Srednja Europa ne može definirati i odrediti političkim granicama (koje su neautentične, uvijek nametnute invazijama, osvajanjima i okupacijama), nego tim velikim zajedničkim situacijama što nanovo okupljaju narode, pregrupiraju ih na svagda nove načine duž imaginarnih i svagda promjenjivih međa koje obilježuju predio nastanjen istim uspomenama, istim problemima i sukobima, istom zajedničkom tradicijom. “576

Istovremeno s tragedijom na političkom polju kulturna scena ostvaruje neke od svojih najintenzivnijih razdoblja:

„Promatraču izvana teško je shvatiti taj paradoks; razdoblje poslije 1945. za Srednju Europu je u isti mah najtragičnije i jedno od najvećih u njezinoj kulturnoj povijesti. Pisani u egzilu (Gombrowicz, Milosz), ili uzimajući oblik tajne stvaralačke aktivnosti (u Čehoslovačkoj nakon 1968.), ili pod pritiskom javnog mnijenja tolerirani od vlasti - u bilo kojoj od tih okolnosti - filmovi, romani, drame i filozofska djela nastala u tom razdoblju u Srednjoj Europi često su vrhunski dosezi europske kulture. “577

Prvo je izdanje Kunderin esej doživio 1984., iste godine kada je Václavu Havelu dodijeljen počasni doktorat Sveučilišta u Toulouseu te i tom prigodom budući čehoslovački predsjednik u svome govoru tematizira prošlost i budućnost srednjoeuropskoga prostora. Analitičari ubrzo primjećuju koliko je tema identiteta srednje Europe postala eksploatirana, a novinarka Danasa Jasmina Kuzmanović u svome opsežnom tekstu o ideji srednje Europe u kulturi osamdesetih 1984. naziva ,godin[om] početka nove debate o Mitteleuropi“‘578. Objavljivanje Kunderina eseja itekako pridonosi kovitlacu rasprava o temi srednje Europe u drugoj polovici 1980-ih, a srpski književnik Bora Ćosić u intervjuu Vjesniku 1989. njeno tematiziranje smatra ,pravcem i modom“ ${ }^{“ 579}$. Na tom je tragu i novinar Boris Gregorić koji u istome tekstu govori o ,recentn[om] trend[u] srednjoevropejstva“ ${ }^{“ 580}$.

\footnotetext{
${ }^{574}$ Kundera, Milan Tragedija Srednje Europe, prevoditeljica Giga Gračan, Gordogan, br. 17/18, god. 07(1985), str. 289-305.

575 Isto.

576 Isto, str. 298.

${ }^{577}$ Isto, str. 291.

${ }^{578}$ Kuzmanović, Jasmina Utjeha za malene, Danas, 31. 3. 1987., str. 33-36.

${ }^{579}$ Gregorić, Boris Musil ili preokret poznate povijesti, Vjesnik, br. 15122, 23. 10. 1989., str. 9. ${ }^{580}$ Isto.
} 
Hrvatski književnik Antun Šoljan u svome tekstu Kantonizacija Evrope objavljenome 1988. u istome časopisu u kojem je objavljen i Kunderin esej primjećuje da je ideja srednje Europe ,posljednjih godina u modi poput neke nove tvrtke žvakaće gume (beskrajno rastezljiva, artificijelnog teka i sumnjive hranjivosti) koja se premeće po svačijim ustima. ${ }^{\text {“581 }}$ U zborniku s kraja 1990-ih posvećenu opusu toga hrvatskog književnika Žarko Paić primjećuje da je Šoljanov esej iz 1967. Metafizički ideal i pisac malog naroda nagovještaj Kunderine Tragedije Srednje Europe koja nastaje petnaestak godina kasnije. ${ }^{582}$

Na objavljivanje hrvatskoga prijevoda eseja u Gordoganu hrvatska periodika intenzivno reagira. Reakcija je kvantitativno najjača u istome časopisu koji u cjelini Pabirci uz temu - Srednja Evropa u dvama brojevima 1985. i 1987. donosi niz tekstova hrvatskih i inozemnih autora koji Kunderin tekst stavljaju u kontekst aktualnih rasprava o temi srednje Europe u okolnostima procijepa koji joj je donijela hladnoratovska podjela svijeta. Rasprava u Gordogana protegla se od objavljivanja teksta 1985. sve do 1990. kada završava Skicom za srednjoeuropski portret Györgyja Konráda. ${ }^{583}$

$\mathrm{U}$ istome broju u kojem je objavljen i znameniti Kunderin esej, Gordogan u cjelini Pabirci uz temu - Srednja Evropa koju uređuje Branko Matan objavljuje sljedeće tekstove: Branko Despot Srednja Evropa: snoviđenje, Carl E. Schorske Politika i psiha: Schnitzel $i$ Hofmannsthal, Boris Buden Filozof u posljednjim danima čovječanstva: uz knjigu Wittgenstein's Vienna Allana Janika i Stephena Toulmina, izdanu u New Yorku 1973. godine, Joseph Roth Posmrtna misa, Joseph Roth Hommage austrijskom duhu: govor ožujka 1938., Branimir Donat Varijacije na propalu temu, György Konrád Dobro je putovati. ${ }^{584}$ Upravo posljednji naveden tekst, onaj Györgyja Konráda, na Kunderinu tragu srednju Europu određuje kao „prostor između“6585, a njene stanovnike kao „ni zapadnja[ke], ni Rus[e]“586.

Dvije godine kasnije u cjelini istoga naziva Pabirci uz temu - Srednja Evropa Gordogan donosi tekstove Carla E. Schorskea Generacijska napetost i kulturna promjena: razmatranje na slučaju Beča, Mirjane Gross Židovi u Habsburškoj monarhiji u 19. stoljeću: o

\footnotetext{
581 Šoljan, Antun Kantonizacija Evrope, Gordogan, br. 28, god. X, 1988., str. 28.

Objavljeni tekst zapravo je referat koji je Antun Šoljan održao na simpoziju o srednjoj Europi na Sveučilištu u Amsterdamu u prosincu 1987.

582 Paić, Žarko Čudesan laboratorij opsjena, u: Šoljanov zbornik: Dani Antuna Šoljana u Rovinju, 1996. - 2000., ur. Boris Biletić, Pučko otvoreno učilište grada Rovinja, Istarski ogranak Društva hrvatskih književnika, Rovinj, Pula, 2001.

${ }^{583}$ Konrád, György Skica za srednjoeuropski model, Gordogan, 11(1990), br. 29-30, siječanj-travanj 1990., str. 110-117.

${ }^{584}$ Gordogan, br. 17-18, god. VII, siječanj-travanj 1985.

585 Konrád, György Dobro je putovati, Gordogan, br. 17/18, 1985., str. 273-288.

${ }^{586}$ Isto, str. 287.
} 
židovskom identitetu u doba modernizacije, od osnivanja zagrebačke židovske općine 1806. do zakona o ravnopravnosti Židova u Hrvatskoj 1873., Ive Banca Milan Kundera i povratak Srednje Evrope, Dagmar Ruljančić Polemike o Kunderinom eseju „,Tragedija Srednje Europe“, Martina Pollacka Austrijski put: epilog o manjini koja nestaje, Drage Jančara Terra incognita, Györgyja Konráda Beč \& Srednja Europa, Brune Popovića Apokalipsa Srednje Europe: povijest posljednje vijesti. ${ }^{587}$

Iako objavljeni neovisno o ovim tematskim cjelinama, istom se temom bave i Antun Šoljan 1988. u tekstu Kantonizacija Evrope ${ }^{588}$ te 1990. u Skici za srednjoeuropski portret György Konrád. ${ }^{589}$ Šoljan u svome tekstu, pročitanome na simpoziju o srednjoj Europi na Sveučilištu u Amsterdamu 1987. zaključuje da je pojam srednje Europe nepostojeći te da postoje samo istočna i zapadna Europa.

Tekstovi hrvatskih analitičara Ive Banca Milan Kundera i povratak Srednje Evrope i Dagmar Ruljančić Polemike o Kunderinom eseju „,Tragedija Srednje Europe“ prema Kunderinu eseju uvelike su polemički raspoloženi. Esejističkome tekstu češkoga romanopisca nalaze ozbiljne zamjerke koje, uglavnom, idu u smjeru tvrdnji o Kunderinu ignoriranju dijela povijesnih činjenica ili, pak, pogrešnome uzročno-posljedičnome povezivanju. Banac svoj tekst započinje kratim povijesnim pregledom češko-austrijskih i češko-ruskih odnosa, odnosno stavova vodećih imena češkoga društva prema položaju u Monarhiji te najmnogoljudnijoj slavenskoj zemlji i njenu odnosu prema ostalim Slavenima. Nadalje, polemizira s nekoliko Kunderinih tvrdnji onako kako ih je sâm iščitao u slavnome eseju:

„(...) (1) Istočna Evropa nije isto što i Srednja Evropa, a potonja je najevropskiji dio Evrope; sastoji se od obitelji malih naroda, koju ne određuje zemljopis koliko kultura ili sudbina; (2) Prava Istočna Evropa je Rusija, iako Rusija zapravo nije Evropa; jedinstvena ruska civilizacija od iskona je protivna Evropi, napose Srednjoj Evropi; (3) Slavizam - što će reći 'ideologija slavenskog svijeta' - puka je politička mistifikacija, koja je nastala u 19. stoljeću; (4) Srednja Evropa teži kozmopolitskoj kulturi, a Židovi su u 20. stoljeću bili njen glavni integrativni element; (5) Stvarna tragedija Srednje Evrope je poslijeratna barbarizacija Zapada - valjda radi američke političke i kulturne prevlasti (...) ${ }^{6590}$

\footnotetext{
${ }^{587}$ Gordogan, br. 23-24, god. IX, siječanj - travanj, 1987.

588 Šoljan, Antun Kantonizacija Evrope, Gordogan, br. 28, god. X, siječanj - veljača 1988., str. $28-34$.

${ }^{589}$ Konrád, György Skica za srednjoeuropski autoportret, Gordogan, br. 11, 1990., str. 110-117.

${ }^{590}$ Banac, Ivo Milan Kundera i povratak Srednje Evrope, Gordogan, br. 23-24, god. IX, siječanj - travanj 1987. str. 40 .
} 
U tekstu Polemike o Kunderinom eseju „,Tragedija Srednje Europe“ u kojemu daje pregled polemika iz pera Milana Šimečke, Milana Haunera, Jánosa Kisa, Françoisa Bondyja i Georgesa Nivata, a koje su objavljene u češkome egzilnom časopisu Svědectví 1985., Dagmar Ruljančić Kunderi prigovara jednostranost, uopćavanje i pojednostavljivanje te smatra da bi tekst mogao ,prouzrokovati popriličnu štetu: umjesto da rasvijetli problem srednje Europe, mogao bi ga učiniti nejasnim ili čak odvesti u carstvo legendi““591 te podsjeća da Kunderin esej nisu pohvalama dočekali ni neoficijelni autori u romanopiščevoj domovini gdje je tekst kolao u samizdatskim izdanjima. ${ }^{592}$

Ruljančić prenosi tekst Slovaka Milana Šimečke koji primjećuje da je srednjoeuropska kataklizma započela kada je „,nacizam savršeno ušutkao 'židovski genij'“6593. Šimečka ne amnestira utjecaj sovjetske ideologije, no naglašava da se pomalo zaboravlja na domaće kolaboracioniste:

„Neugodno je čitati da nas i Kundera lišava svake krivnje pred svijetom. '...kada su Rusi okupirali Čehoslovačku, učinili su sve moguće da unište češku kulturu.' (...)

Događaji nisu tako davni da se ne bi pamtili: češku kulturu koja je šezdesetih godina bila u tako obećavajućem zamahu nisu dokrajčili Rusi nego naši (Česi, op. pr.). Srednjoevropljani porijeklom i odgojem. (...) 'Bijafra duha' nosila je neizbrisiv pečat domaćeg porijekla, bila je oplemenjena našim domaćim ( $\mathrm{tj}$. češkim, op. pr.) miomirisima, zavidnošću, nadom u bolji položaj, slutnjom nagrade, strahom, kukavičlukom, brzim raspadanjem solidarnosti, itd. A ljudi koji su u posljednjih petnaest godina toliko otežavali život mojim prijateljima i meni, nama koji smo se trudili da spasimo nešto od 'autoriteta pojedinca koji razmišlja i sumnja', svi su govorili češki i slovački, mnoge sam od njih čak poznavao, prije su se pravili da su prijatelji." ${ }^{\text {594 }}$

\footnotetext{
${ }^{591}$ Ruljančić, Dagmara Polemike o Kunderinu eseju „Tragedija Srednje Europe“, Gordogan, br. 23-24, god. IX, siječanj - travanj 1987., str. 47.

${ }^{592}$ Svoj tekst Dagmar Ruljančić završava riječima češkoga egzilnog filozofa Ivana Svitáka o Kunderinu eseju: „Taj je esej pobudio više zanimanja za češke probleme nego sva emigrantska udruženja zajedno. Teško mi je pronaći u tom eseju rečenicu s kojom bih se mogao složiti. Miješanje literature i politike je naša narodna nesreća. “ Ruljančić, Dagmar Polemike o Kunderinom eseju „Tragedija Srednje Europe“, Gordogan, br. 23-24, god. IX, siječanj - travanj 1987., str. 62.

${ }^{593}$ Isto, str. 51.

${ }^{594}$ Isto, str. 51.
} 
Ignoriranje negativnoga utjecaja Hitlera i pojave nacizma na razvoj Europe Kunderi prigovara i Milan Hauner sa Sveučilišta u Wisconsinu u svom Pismu uredništvu The New York Review of Books, a u Kunderinu prikazivanju Rusa prepoznaje rasistička obilježja:

„U tome što naziva [Kundera] 'srednjoevropskom tragedijom' nedostaje mu zapravo dublje shvaćanje Hitlera i fašizma. Sam Hitler koji se u Kunderinom eseju ni na jednom mjestu ne spominje, bio je produkt srednjoevropske kulture par excellence; Staljin nije. Srednjoevropska kultura producirala je Auschwitz i masovne deportacije milijunâ ljudi. Ako Kundera ovo ne uvrsti u svoju literarnu lamentaciju, njegovo će shvaćanje 'srednjoevropske tragedije' biti krivo. “595

Reakciju na Kunderin esej u Gordoganu kvantitetom objavljenih tekstova slijedi ona $\mathrm{u}$ trima brojevima Novoga prologa 1988., 1989. i 1990. u cjelini Sindrom srednjoevropskog u suvremenom kazalištu, filmu... Broj 11 Novoga prologa objavljen na prijelomu 1988./1989. u cjelini Sindrom srednjoevropskog u suvremenom kazalištu, filmu... uz ulomke Havelovih Pisama Olgi objavljuje i sljedeće tekstove: Nikola Batušić Krleža i srednjoevropski mentalitet, Andrej Inkrat Zajedničko u različitom, različito u zajedničkom, Michael Merschmeier Staljin, Tabori i Beč, Razgovor: Strah je moj čuvar, Prizor iz Musilovih Sanjara, Truda Stamać O Musilovim Sanjarima, Prizor iz Musilovih Sanjara, Bogdan Malešević Musilovi Sanjari između prostora stvari i bezgraničnog prostora, Robert Musil Stvaralački i nestvaralački tipovi, Svetislav Jovanov Senke plime, Sławomir Mrožek Moja središnja Evropa, Hrvoje Hribar Akcija - njet adaptacija.

Sljedeći broj Novoga prologa u istome tematskome bloku donio je tekstove Jaceka Sieradzkija Mrožek čitan jedanput, Bogdana Maleševića Bernhardov monolog kao gnostička zmija, Liana Župevca Kantor ili Tragika danas, 12. veljače 1989. umro je u Gmundenu (Austrija) Thomas Bernhard, Oni su zaboravili svoje uloge, oni su ljudski ostaci, Emila Hrvatina Veliki vodozemac pod sistemom Kafke, Eschera...Serapionsa.

Treća je cjelina objavljena u prvoj polovici 1990. i sadrži tekstove Igora Mrduljaša Kako uspavati kazalište? ili Vlast se ne da vući za nos, Aleša Fuchsa Glumci i češka revolucija, Anatolija Vasiljeva Udine te ulomak Kunderina romana Besmrtnost pisanoga francuskim jezikom.

Tekstove o europskome identitetu, a osobito identitetu srednjoeuropskoga prostora, časopisi Republika i Oko objavljuju 1989. i 1990. te ih možemo promatrati i u svjetlu

${ }^{595}$ Ruljančić, Dagmar Polemike o Kunderinom eseju „Tragedija Srednje Europe“, Gordogan, br. 23-24, god. IX, siječanj - travanj 1987., str. 55. 
aktualnih političkih zbivanja u komunističkim zemljama srednje i istočne Europe. U Republici se 1988. tekstom Vidljiva i nevidljiva Europa nakon više od petnaest godina medijske izolacije javlja hrvatski književnik i političar Vlado Gotovac. ${ }^{596}$ Godinu kasnije isti časopis objavljuje tematsku cjelinu Srednja Europa s tekstovima Zorana Konstantinovića Srednja Evropa - Argumenti i Protivargumenti, Aleksandra Flakera Između estetskog $i$ socijalnog prevrednovanja: avangarda, Endrea Kissa Hermann Broch i Srednja Evropa, Sigurda Paula Scheichla Vrhunac opozicijske književnosti u Austriji - Karl Krauss, Johanna Strutza i Petera V. Zime Polikulturalnost fikcije. Između Alpa i Jadrana, Istvána Frieda Budimpešta kao izvor kulturnog značenja, Stefana H. Kaszyńskoga i Marije Krysztofiak Krakov - Razmišljanje o kulturnoj povijesti jednog srednjoeuropskog glavnog grada te Günthera Wytrzensa Lavov. Časopis Oko 1989. objavljuje tekst Ante Stamaća Naziv „,Srednja Evropa “ u zrcalu tropologije koji je, zapravo, Stamaćevo izlaganje na međunarodnom simpoziju Srednja Evropa - metafora in njen prevod održanom u sklopu dodjele međunarodne nagrade Vilenica za srednjoeuropske pisce koja se od 1986. dodjeljuje u Sloveniji. ${ }^{597}$

S objavom Kunderina teksta Tragedije Srednje Europe i polemičkim valom koji je slijedio objavu toga eseja vremenski korespondira komparatistički skup o književnostima i kulturama srednje Europe održan u austrijskome Innsbrucku, a s kojega za Vjesnik izvještava povjesničar književnosti Aleksandar Flaker. ${ }^{598}$ Znanstveni skup okupio je četrdesetak književnih znanstvenika iz zemalja istočne i srednje Europa, a glavna mu je tema bila dvojba mogu li se književnosti i kulture srednjoeuropskih naroda odrediti kao cjelina i, ako mogu, na koji način. U raspravi se prostor srednje Europe određuje kao „prostor između“, ne pripadajući ni europskome moćnom zapadu, niti istoku, a književnici koji ga svojih književnim radom obilježavaju tijekom osamdesetih godina dvadesetoga stoljeća su Danilo Kiš, Czesław Miłosz i Milan Kundera.

\section{8. Zaključak}

Kvantitativno različita obujma tekstove neoficijelne češke književnosti i djeliće neoficijelne češke kulturne scene pronalazimo u nizu časopisa koji su objavljivani u Hrvatskoj

\footnotetext{
${ }^{596}$ Gotovac, Vlado Vidljiva i nevidljiva Europa, Republika, br. 11/12, 1988.

${ }^{597}$ Stamać, Ante Naziv „Srednja Evropa“ u zrcalu tropologije, Oko, br. 457, 1989., str. 14.

${ }^{598}$ Flaker, Aleksandar Literarni atlas Evrope, Vjesnik, br. 13736, 7. 12. 1985., str. 15.
} 
tijekom sedamdesetih i osamdesetih godina 20. stoljeća. Nerijetko je intenzitet te zastupljenosti ovisio o profesionalnoj i/ili privatnoj povezanosti članova uredništva s češkim kulturnim krugom. Tako se, primjerice, može uočiti povećano zanimanje za neoficijelnu češku književnost, ali i ostale aspekte češke kulture, kada u uredništvo Književne smotre stupa bohemist Predrag Jirsak. Osim Predraga Jirsaka, tijekom osamdesetih godina u kojima dolazi i do snažna zamaha u recepciji, prijevodnom i književnokritičkom aktivnosti u periodici ističu se imena Renate Kuchar, koja časopisne prijevode nerijetko objavljuje u suradnji s kroatisticom Nives Opačić, te krajem desetljeća Katice Ivanković.

Neoficijelna češka književnost svoje mjesto nalazi, u većoj ili manjoj mjeri, na stranicama većine književnih časopisa koje povjesničari književnosti nazivaju jezgrenima. Već u prosincu 1968. na kolovoške događaje u Čehoslovačkoj posebnim brojem reagira časopis Republika koji, uz tekstove književnika i intelektualaca ostalih europskih kultura, objavljuje i prijevode čeških pisaca koji će samo koju godinu kasnije pripadati neoficijelnom korpusu. Konzervativniji časopisi, poput Foruma koji je glasilo Jugoslavenske akademije znanosti i umjetnosti, u razdoblju specifična razvoja češke književnosti prednost daju klasicima češke književnosti, a Forum se pojačano bavi i, u prvome redu zahvaljujući češkome kroatistu Dušanu Karpatskom, recepcijom hrvatske književnosti u Čehoslovačkoj. Ostali se časopisi okreću različitim područjima neoficijelne umjetničke produkcije, ovisno o prirodi i preferencijama samoga časopisa. Tako Prolog i Novi prolog, časopisi koji u osnovi prate kazališnu umjetnost, ali i časopis Oko, najviše pozornosti posvećuju neoficijelnoj dramskoj produkciji koja ostvaruje sve bolju recepciju u jugoslavenskim kazalištima u osamdesetima. Uz prijevode proznih ulomaka i poezije neoficijelnih književnika časopis 15 dana čitatelje u Jugoslaviji upoznaje i s aktivnostima čeških karikaturista i filmskih umjetnika, poput Miloša Formana, koji nakon 1968. život i rad nastavljaju u inozemstvu.

U časopisu Gordogan 1985. u prijevodu Gige Gračan objavljen je esej Milana Kundere Tragedija Srednje Europe koji i u hrvatskom javnom prostoru započinje raspravu o identitetu srednje Europe koja traje sve do pada željezne zavjese. Najsnažnija je reakcija na objavljivanje hrvatskoga prijevoda Kunderina eseja u istome časopisu 1985. i 1987. u tematskim blokovima s tekstovima domaćih i inozemnih analitičara. U polemici s Kunderinim tekstom iznimno su oštri Ivo Banac i Dagmar Ruljančić koji se u svojim analizama pozivaju i na teze inozemnih autora. Raspravi o temi srednje Europe tematskim se blokom pridružuje i časopis Novi prolog, a u osvit pada komunizma na samom kraju osamdesetih i Republika i Oko. 


\title{
6. RECEPCIJA NEOFICIJELNE ČEŠKE KNJIŽEVNOSTI U HRVATSKOJ ZNANOSTI O KNJIŽEVNOSTI I ZNANSTVENOGA RADA NEOFICIJELNIH ZNANSTVENIKA
}

\author{
6. 1. Neoficijelna češka književnost u Povijesti svjetske književnosti (1975.)
}

Najreprezentativniji pregled češke književnosti na hrvatskome jeziku u razdoblju od kraja šezdesetih do početka devedesetih godina 20. st. objavljen je 1975. u sedmome svesku kapitalne Povijesti svjetske književnosti zagrebačke izdavačke kuće Mladost i urednika Aleksandra Flakera. ${ }^{599}$ U dio koji obrađuje razvoj suvremene češke književnosti češki povjesničar književnosti Dušan Karpatský uključuje opuse neoficijelnih autora Milana Kundere, Josefa Škvoreckog, Václava Havela, Ludvíka Vaculíka i Pavela Kohouta te pjesnika čija je poezija sporadično objavljivanja i u hrvatskoj periodici poput Miroslava Holuba, Oldřicha Mikulášeka, Jana Skácela i Ivana Wernischa ${ }^{600}$. Osim njih, pregled češke književnosti Dušana Karpatskog uključe i književnike koji nakon 1968. nastavljaju djelovati u egzilu, poput Jiř́ija Koláŕa, ${ }^{601}$ Ivana Blatnog, ${ }^{602}$ Ludvíka Aškenazyja, Věre Linhartove ${ }^{603}$ i Vratislava Blažeka, ${ }^{604}$ a čiji su opusi slabije poznati hrvatskoj čitateljskoj publici. Iako je sedmi svezak Povijesti svjetske književnosti objavljen 1975., u svome tekstu Karpatský niti jednom riječju ne spominje iskustvo samizdata i/ili egzila navedenih književnika. Sredinom sedamdesetih ti su književnici u matičnoj zemlji već nekoliko godina potisnuti na margine javnoga prostora, a dio je njih u egzilu poput Josefa Škvorecký koji u inozemstvo odlazi već 1968. U popisu literature koji prati povijesni pregled češke književnosti iz pera Dušana

\footnotetext{
${ }^{599}$ Povijest svjetske književnosti, ur. Aleksandar Flaker, Mladost, Zagreb, 1975.

${ }^{600}$ Wernisch, Ivan (1942.), češki pjesnik. U samizdatu objavljuje samostalne zbirke poezije i sudjeluje u samizdatskim zbornicima. Wernischove pjesme uglazbljuje i rock-skupina The Plastic People of the Universe.

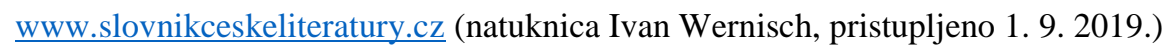

${ }^{601}$ Kolář, Ivan (1914. - 2002.), češki književnik. Razdoblje normalizacije provodi u inozemstvu, u Berlinu i Parizu, a djela su mu objavljena i u nizu samizdatskih edicija. U Parizu od 1981. objavljuje časopis Revue K.

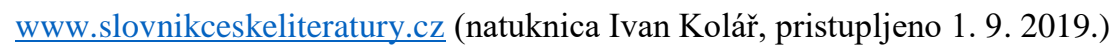

${ }^{602}$ Blatný, Ivan (1919. - 1990.), češki književnik. Tijekom normalizacije djeluje u inozemstvu, a djela mu objavljuju i samizdatski izdavači. www.slovnikceskeliteratury.cz (natuknica Ivan Blatný, pristupljeno 1. 9. 2019.)

${ }^{603}$ Linhartová, Věra (1938.), češka književnica. U Parizu živi od 1968., a od 1969. počinje pisati i francuskim jezikom. Tijekom normalizacije tekstovi su joj u Čehoslovačkoj objavljivani u samizdatskim edicijama i zbornicima. www.slovnikceskeliteratury.cz (natuknica Věra Linhartová, pristupljeno 1. 9. 2019.) ${ }^{604}$ Blažek, Vratislav (1925. - 1973.), češki književnik. Iz Čehoslovačke emigrira 1968., a od 1970. živi u Münchenu. www.slovnikceskeliteratury.cz (natuknica Vratislav Blažek, pristupljeno 1. 9. 2019.)
} 
Karpatskog kao najsuvremeniji izvor građe Karpatský navodi povijest češke književnosti Česká literatura 20. století Františeka Buriáneka. Prema mrežnom Rječniku češke književnosti Instituta za češku književnost Akademije znanosti i umjetnosti Republike Češke riječ je o izdanju koje je u prvoj polovici sedamdesetih godina dvadesetoga stoljeća izrazito ideološki obojeno. ${ }^{605}$

Ipak, raznolikost čehoslovačke kulturne scene toga vremena Karpatský pokušava dočarati grafičkim dodacima teksta. Pri tome se odlučuje za karikature Bohumila Štěpána, češkoga karikaturista koji 1969. odlazi u egzil u Zapadnu Njemačku. ${ }^{606}$

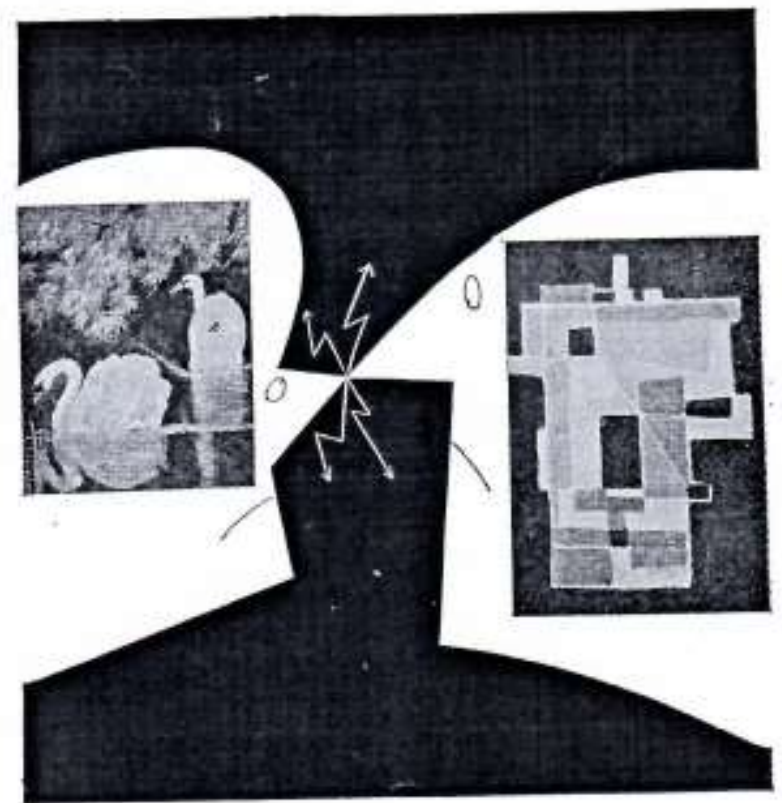

Ovako je vidio diskusiju o umjetnosti u Ceškoj god. 1963. karikaturist Bohumil Stëpán u Kritičkom godišnjaku za istu godinu. Ovaj je sudar dvaj̃u shvaćanja umjetnosti $i$ knjižzennosti općentite naravi, ali se u osebujnim i nekada vrlo oštrim oblicima pojavio $i$ u socijalistickin zemljama srednje $i$ istoćne Evrope, negdje već početkom pedesetih godina, a negdje nešto kasnije $i$, premda s manjom že. stinom, traje $i$ danas.

Fotografija II: Karikatura Bohumila Štěpána

Izvor: Povijest svjetske književnosti, knjiga 7, 1975., Mladost, Zagreb, str. 76

605 http://www.slovnikceskeliteratury.cz (natuknica František Buriánek, pristupljeno 16. 12. 2018.)

${ }^{606}$ Od kraja šezdesetih do početka osamdesetih uratke Bohumila Štěpána u nekoliko svojih brojeva objavljuje časopis 15 dana. 


\section{2. Češka znanost o književnosti u Hrvatskoj od 1968. do 1990.}

Osim niza prozaika, pjesnika i dramatičara koje je početkom sedamdesetih godina cenzura potisnula u prostor samizdata i istisnula u egzil, javno je djelovanje u Čehoslovačkoj onemogućeno i književnim znanstvenicima. Dio njihova rada, uglavnom zahvaljujući prijevodima u časopisima, dopire i do čitatelja u Hrvatskoj.

Godine 1971. u izdanju Matice hrvatske Tomislav Sabljak objavljuje zbornik Teatar $X X$. stoljeća u kojemu okuplja eseje klasika hrvatske i svjetske književnosti koji propituju zakonitosti kazališne umjetnosti. Uz, primjerice, eseje Miroslava Krleže i Eugènea Ionesca Sabljakov zbornik donosi, u prijevodu Dušana Karpatskog, i tekstove Jana Císařa, ${ }^{607}$ Jana Patočke i Václava Havela. ${ }^{608}$ Sva su tri objavljena eseja čeških autora preuzeta iz časopisa Divadlo koji pod cenzorskim pritiskom prestaje izlaziti 1970.

Havelov esej Osobitosti kazališta (Zvláštnosti divadla) ${ }^{609}$ u časopisu Divadlo objavljen je 1968., a iste godine kada se nalazi na stranicama Sabljakova zbornika objavljuje ga i splitski časopis Mogućnosti. ${ }^{610}$ Teze koje iznosi u Osobitostima kazališta uvelike mogu pomoći u razumijevanju odnosa prema kazališnoj umjetnosti najizvođenijega češkog neoficijelnog dramatičara u hrvatskim kazalištima. Navodeći posebnosti kazališta u odnosu na druge umjetnosti, Havel anticipira buduće događaje i recepciju, između ostaloga, i svojih djela:

„Moguće je zamisliti pjesmu, sliku, kip, muzički snimak, film, koje ne samo što nitko ne smatra umjetnošću, i koji dakle umjetnost de facto nisu, nego koje štoviše nitko i ne čita, ne gleda, ne sluša, ne projicira, o kojima nitko ne zna. Dakle ne samo što ne posreduju estetsku informaciju, nego oni ne funkcioniraju čak ni kao znakovi činjenične informacije. A ipak postoje: kao materijalne činjenice. Imaju prednost: kao mrtve stvari koje ne ovise o hirovima čovjeka, one mogu čekati godinama - zabačeno u ladicama, depozitima, arhivima - a još uvijek ima nade da će ih tkogod otkriti i ovako ili onako ostvariti; kao materijalne

\footnotetext{
${ }^{607}$ Císař, Jan (1932.), češki povjesničar književnosti, teoretičar književnosti, književni i kazališni kritičar, dramaturg, dugogodišnji profesor Akademije dramskih umjetnosti.

https://www.amaterskedivadlo.cz/main.php?data=osobnost\&id=123 (pristupljeno 1. 9. 2019.)

${ }^{608}$ U Sabljakovu zborniku objavljeni su sljedeći tekstovi čeških autora: Jan Císař Prirodnost teatra, Jan Patočka Uz ideju „narodnoga kazališta“ i Václav Havel Osobitosti kazališta.

${ }^{609}$ www.archive.vaclavhavel-library.org/Bibliography\#15310 (pristupljeno 16. 12. 2018.)

${ }^{610}$ Havel, Václav Osobitosti kazališta, Mogućnosti, br. 5-6, god. XVIII; Sabljak, Tomislav Teatar XX. stoljeća, Matica hrvatska, Zagreb - Split, 1971.
} 
činjenice one su bilo kada spremne da postanu sredina ljudske realizacije, a da nisu egzistencijalno uvjetovane tom realizacijom. Naime, čim su one bile stvorene, njihovo je materijalno postojanje prestalo biti ovisno o čovjeku. S kazalištem je druga stvar: ono stoji i pada s čovjekom, ne poznaje način kako da postoji bez njega ili kako da ga čeka, kako da bude njegova neostvarena prilika. Čovjek u kazalištu naime participira - za razliku od drugih umjetnosti - direktno kao u materijalnoj činjenici: ono se prikazuje njime i za njega; bez direktnog fizičkog sudjelovanja glumaca ili gledatelja nema kazališta; čovjek nema u njemu udjela samo u tom smislu da u njemu može ili ne mora sudjelovati: ako kazalište hoće uopće u bilo kojem obliku postojati, ne može jednostavno bez čovjeka. (...) Zaista, ako se sve može raditi „za ladicu“, za kazalište se sigurno ne može i pouzdati se u buduće prosvjećenije generacije u njegovu je slučaju besmislica. Svoju vječnost ono postiže isključivo svojom aktualnošću, historijsko priznanje samo posredstvom trenutačnog priznanja, opću vrijednost samo putem vrijednosti 'mjesne': ako ga, naime, ne prihvati ovaj ovdašnji gledalac, taj na kojega ga upućuje njegov djelokrug, ne može ga prihvatiti ni bilo tko drugi.“611

U godinama koje su slijedile objavljivanje ovoga teksta, dramatičar je kao izazov imao, upravo, ograničavanje stvaralačke slobode. Sve do pada komunizma u Čehoslovačkoj, odabravši sudbinu disidenta i odbivši odlazak u egzil, bio je onemogućen vidjeti svoje dramske tekstove uobličene u kazališnu predstavu. Iznimku su činile izvedbe u privatnim prostorima pred uskim krugom prijatelja, poznanika i istomišljenika te javna izvedba Prosjačke opere koja je organizirana 1975. u restoranu jedne praške četvrti. Na taj su način Havel, ali i ostali neoficijelni dramatičari, ostali bez one, kako je sâm u eseju naziva, pete dimenzije koju kazalište, za razliku od ostalih umjetnosti, posjeduje - čovjeka na pozornici i čovjeka u gledalištu, bez kojih pravoga kazališta nema. Osim gledatelja, ,,pete dimenzije kazališta“, osobitošću Havel smatra i političnost, njegovim riječima kazalište se odlikuje

\footnotetext{
${ }^{611}$ Havel, Václav Osobitosti kazališta, u: Tomislav Sabljak Teatar XX. stoljeća, 1971., Matica hrvatska, Zagreb Split, str. 458-460; Havel, Václav Osobitosti kazališta, Mogućnosti, br. 5-6, god. XVIII, Split, str. 662-664 O specifičnostima kazališne umjetnosti i dodatno nepovoljnom položaju neoficijelnoga dramatičara Havel govori i u intervjuu danom Karelu Hvížd'alu objavljenu u knjizi Saslušanje na daljinu. „K. Hvíżd'ala: Za koga danas pišete, kad nemate svog kazališta, svoga redatelja ili dramaturga, pa čak ne poznajete ni svoju publiku? Kako ste se pomirili s tom situacijom? V. Havel: To je vrlo mučna situacija, još teža od one u kojoj pjesnik ili romanopisac ne može publicirati u vlastitoj zemlji. Drama je, naime, prisnije povezana sodređenim 'sada' $i$ 'ovdje'; ona uvijek nastaje iz određene konkretne društvene i duhovne klime i retrogradno cilja i na jedno i na drugo; ona jednostavno treba svoj dom i postaje ono što jest istom tada kad je se u tom njezinu 'domu' može vidjeti u kazalištu - kao tekst ona je tek poluproizvod." Havel, Václav Saslušanje na daljinu (razgovor s Karelom Hvižd'alom), Irida, Zagreb, 2000., str. 80.
} 
„pojačanim osjećajem za političku, tj. društvenu problematiku svojega vremena (i kroz nju za 'društvenu problematiku uopće')“',612 no moguća anomalija te karakteristike je ,političnost konvencionalizirana i mistificirana kao volja ili potreba kazališta da služi određenom konkretnom političkom interesu, moći, vlasti, ideologiji ili doktrini“‘613.

Kvantitativno najopsežniju i najsustavniju recepciju rada čeških književnih teoretičara koji su tijekom normalizacije izbačeni iz službenoga bazena književnoteorijske misli u zemlji pruža nam časopis Umjetnost riječi. ${ }^{614}$ Časopis Hrvatskoga filološkog društva od kraja šezdesetih objavljuje studije Lubomíra Doležela, ${ }^{615}$ Felixa Vodičke, Miroslava Červenke, ${ }^{616}$ Květoslava Chvatíka ${ }^{617}$ Miroslava Drozde, ${ }^{618}$ Olega Susa, ${ }^{619}$ Roberta Kalivode ${ }^{620}$ i Milana Jankoviča ${ }^{621}{ }^{622}$ Većina navedenih autora svoju znanstvenu karijeru do nastupa normalizacije

${ }^{612}$ Havel, Václav Saslušanje na daljinu (razgovor s Karelom Hvižd'alom), Irida, Zagreb, 2000., str. 80. ${ }^{613}$ Isto.

${ }^{614}$ Časopis Umjetnost riječi tromjesečnik je u nakladi Hrvatskoga filološkog društva. Pokrenut je 1957. u okviru Zagrebačke stilističke škole. Utemeljitelj časopisa Zdenko Škreb uređivao ga je sve do 1985. Umjetnost riječi prvi je hrvatski časopis za teoriju i hermeneutičku problematiku književnosti te s njim surađuju svi vodeći hrvatski znanstvenici i teoretičari književnosti. http://www.enciklopedija.hr (natuknica Umjetnost riječi, pristupljeno 9. 7. 2015.)

${ }^{615}$ Doležel, Lubomír (1922. - 2017.), češki lingvist i teoretičar književnosti. Krajem 1968. odlazi u Kanadu gdje nastavlja djelovati kao sveučilišni nastavnik češkoga jezika i književnosti u Torontu, a, potom, i kao profesor komparativne književnosti. www.slovnikceskeliteratury.cz (natuknica Lubomír Doležel, pristupljeno 2. 9. 2019.) ${ }^{616}$ Červenka, Miroslav (1932. - 2005.), češki teoretičar književnosti i pjesnik. Godine 1971. morao otići s mjesta znanstvenoga suradnika Zavoda za češku književnost ČSAV-a. Tijekom normalizacije dulje vrijeme radi kao knjižničar, svoje tekstove objavljuje u samizdatu i inozemstvu, a prijevode tijekom osamdesetih godina pod imenom drugih osoba. www.slovnikceskeliteratury.cz (natuknica Miroslav Červenka, pristupljeno 2. 9. 2019.) ${ }^{617}$ Chvatík, Květoslav (1930. - 2012.), češki filozof, estetičar, teoretičar i povjesničar književnosti. Nakon početka normalizacije počinje raditi u knjižnici Zavoda za teoriju i povijest umjetnosti ČSAV-a, a 1980. dobiva politički azil u Saveznoj Republici Njemačkoj te surađuje s nizom čeških egzilnih časopisa. www.slovnikceskeliteratury.cz (natuknica Květoslav Chvatík, pristupljeno 2. 9. 2019.) ${ }^{618}$ Drozda, Miroslav (1924. - 1990.), češki rusist i prevoditelj. www.slovnikceskeliteratury.cz (natuknica Miroslav Drozda, pristupljeno 2. 9. 2019.)

${ }^{619}$ Sus, Oleg (1924. - 1982.), češki književni kritičar. Godine 1971. morao je napustiti radno mjesto nastavnika estetike na Filozofskome fakultetu u Brnu. U razdoblju koje je slijedilo, u Čehoslovačkoj svoje tekstove objavljuje pod tuđim imenima ili pseudonimima. www.slovnikceskeliteratury.cz (natuknica Oleg Sus, pristupljeno 2. 9. 2019.)

${ }^{620}$ Kalivoda, Robert (1923. - 1989.), češki filozof i povjesničar. Do početka normalizacije znanstvenik na Filozofskom institutu ČSAV-a, a zatim isključen iz javnoga života. Do smrti nije javno istupao.

www.slovnikceskeliteratury.cz (natuknica Robert Kalivoda, pristupljeno 2. 9. 2019.)

${ }^{621}$ Jankovič, Milan (1929.), češki teoretičar i povjesničar književnosti. Prije normalizacije znanstvenik na Zavodu za češku književnost ČSAV-a. Od početka sedamdesetih, sve do pada komunizma, zaposlen na radnim mjestima koja nisu vezana uz njegovu struku. www.slovnikceskeliteratury.cz (natuknica Milan Jankovič, pristupljeno 2.9. 2019.)

${ }^{622} \mathrm{U}$ časopisu Umjetnost riječi objavljene su sljedeće studije navedenih znanstvenika i prikazi njihovih knjiga (kronološki): Lubomír Doležel Karel Čapek i Vladislav Vančura (br. 4, 1969.), Ljudevit Bauer Struktura i književni proces (prikaz knjige Felixa Vodičke Struktura vývoje), br. 3, 1970., Miroslav Červenka Temeljne kategorije praškog književnoznanstvenog strukturalizma (br. 3, 1972.), Květoslav Chvatík Strukturalna estetika i poetika Jana Mukařovskog (br. 3, 1972.), Miroslav Drozda Trojni vid bezvremenosti (br. 1, 1975.), Miroslav 
veže uz Ústav pro českou literaturu (Zavod za češku književnost) Čehoslovačke akademije znanosti i umjetnosti. Na mjestu ravnatelja ondje je 1968. Felix Vodička, no kadrovske čistke do 1972. sa Zavoda miču i uglednoga ravnatelja i niz znanstvenika koji su na njemu radili, poput Jiř́ija Brabeca, Miroslava Červenke i Milana Jankoviča. ${ }^{623}$

Recepcija češke književnoteorijske misli u Umjetnosti riječi tijekom analizirana dva desetljeća u najvećoj se mjeri može zahvaliti prevoditeljskome radu Predraga Jirsaka koji 1975. izabire, prevodi i uređuje sve tekstove tematskoga broja Umjetnosti riječi posvećena češkoj znanosti o književnosti. ${ }^{624}$ Početkom osamdesetih godina Jirsak je kooptiran i u uredništvo časopisa, nastavlja s prevoditeljskom djelatnošću te na stranicama Umjetnosti riječi objavljuje i niz svojih studija o povijesti češke književnosti.

Jirsakovoj prevoditeljskoj i znanstvenoj djelatnosti treba zahvaliti i nekoliko tekstova objavljenih u časopisu Književna smotra tijekom sedamdesetih. Ondje je 1972. tiskan esej filozofa Karela Kosíka Hašek i Kafka ili groteskni svijet, ${ }^{625}$ a tri godine kasnije objavljen i Jirsakov tekst Strukturalna književna povijest Felixa Vodičke. ${ }^{626}$

\section{3. Zaključak}

Neoficijelna češka književnost kratkim je pregledom Dušana Karpatskog uključena u najreprezentativniju i jedinu sustavnu povijest svjetske književnosti objavljenu na hrvatskome jeziku tijekom sedamdesetih i osamdesetih godina 20. st., onu iz 1975. zagrebačke izdavačke kuće Mladost pod uredništvom Aleksandra Flakera. U godini objavljivanja 7. sveska Povijesti svjetske književnosti javni je prostor u Čehoslovačkoj, pa tako i književna scena, sustavno očišćen od svih imena i djela koji se svojim djelovanjem ili sadržajem nisu uklapali u ideju

\footnotetext{
Drozda Novele Vasilija Šukšina (br. 2, 1976.), Miroslav Drozda Skaz i groteska (br. 1, 1979.), Miroslav Drozda Groteska u romanu Petersburg A. Belog (tematski broj o ruskoj avangardi, 1981.), Květoslav Chvatík

Strukturalna teorija historijskog razvitka književnosti (br. 1-2, 1984.), Oleg Sus Formalizam i strukturalizam (br. 1-2, 1984.)

${ }^{623}$ Janoušek, Pavel i suradnici Dějiny české literatury 1945-1989, IV. knjiga 1969-1989, Academia, Prag, 2008. str. 207.

${ }^{624}$ U broju 2-4 1975. objavljeni su sljedeći tekstovi: Jan Mukařovský Strukturalizam u estetici i u nauci o književnosti, Roman Jakobson Što je poezija?, Felix Vodička Strukturalna književna povijest, Jiř́ Levý Geneza i recepcija književnog djela, Lubomír Doležel Perspektive strukturalne analize književnog djela, Miroslav Červenka Značenjsko ustrojstvo književnog djela, Květoslav Chvatík Mogućnost interpretacije umjetničkog djela, Robert Kalivoda Dijalektika strukturalizma i dijalektika estetike, Milan Jankovič Perspektive semantičke geste, Oleg Sus Prilog strukturalnoj teoriji estetske norme, Mojmír Otruba Mit i ritual.

${ }^{625}$ Kosík, Karel Hašek i Kafka ili groteskni svijet, Književna smotra, br. 12, 1972., str. 37-41.

${ }^{626}$ Jirsak, Predrag Strukturalna književna povijest Felixa Vodičke, Književna smotra, br. 20, 1975., str. 43-51.
} 
službene politike. Djelatnost književnika koje Karpatský uzima kao reprezentante suvremene češke književnosti, poput Škvoreckog, Kundere ili Kohouta već je godinama potisnuta u sferu samizdata ili egzila, no Karpatský u svome pregledu te činjenice iz njihovih životopisa prešućuje. Znakovito, naravno u suradnji s grafičkim urednicima, tekst grafički ilustrira radovima egzilnoga karikaturista Bohumila Štěpána.

Hrvatski časopisi i zbornik Teatar XX. stoljeća objavljen 1971. bilježe i književnoteorijske studije čeških književnih znanstvenika i pisaca kojima je nakon 1968. onemogućen javni rad. Među trima esejima čeških autora u zborniku urednika Tomislava Sabljaka zanimljivošću se ističu Osobitosti kazališta Václava Havela, esej koji dodatno osvjetljava odnos prema kazališnom mediju najistaknutijega neoficijelnog dramatičara. Kontinuirano se hrvatski prijevodi studija čeških znanstvenika objavljuju na stranicama časopisa Umjetnost riječi Hrvatskoga filološkoga društva, u najvećoj mjeri zahvaljujući uredničkoj i prevoditeljskoj djelatnosti bohemista Predraga Jirsaka koja se intenzivira tijekom osamdesetih godina kada je Jirsak i jedan od članova uredništva časopisa. Uglavnom je riječ o bivšim zaposlenicima Zavoda za češku književnost Čehoslovačke akademije znanosti i umjetnosti koji ga početkom sedamdesetih, pod pritiskom kadrovskih čistki, napuštaju. 


\section{KAZALIŠNA RECEPCIJA NEOFICIJELNIH DRAMATIČARA}

Osim recepcije na izdavačkom tržištu gdje dominiraju imena prozaista Milana Kundere i Josefa Škvoreckog tijekom razdoblja normalizacije u češkoj književnosti neoficijelnu umjetničku produkciju recipijenti u Hrvatskoj upoznaju i medijem kazališta.

Na samome početku analizirana razdoblja u hrvatskim kazališnim kućama gostuju osobnosti koje će cenzura u Čehoslovačkoj vrlo brzo potisnuti na margine javnoga djelovanja. Primjerice, praško Divadlo za bránou tijekom svoga zagrebačkog gostovanju u rujnu 1968. prikazuje dramu Sat ljubavi Josefa Topola ${ }^{627}$ te Zelenoga kakadua Arthura Schinzlera u režiji Otomara Krejče ${ }^{628}$. I dramatičar Topol i redatelj Krejča od početka sedamdesetih pripadaju neoficijelnoj kulturnoj sceni, a i samome je praškom Divadlu za bránou 1972. zabranjeno djelovanje. ${ }^{629}$ Drugi sličan primjer datira iz rujna 1969. kada u programu Internacionalnog festivala studentskih kazališta u Zagrebu sudjeluje vyškovsko Divadlo za branou predstavom poljskoga emigrantskog književnika Sławomira Mrožeka Kuća na granici (Dům na hranici). U Mrožekov je tekst, koji je, zapravo, kazališna prilagodba filmskoga scenarija temeljenoga na pripovijetki, uklopljena pjesma Svetozara Chytila i Mirke Forejtarové Motlidba 69 koja je u godinama koje su slijedile među češkim neoficijelnim kazalištarcima postala simbolom otpora protiv vladajućega režima. ${ }^{630}$ Iste godine kada gostuje na zagrebačkome festivalu, vyškovsko kazalište je i na desetodnevnoj turneji u Saveznoj Republici Njemačkoj, no samo godinu dana kasnije, u studenome 1970., zabranjen mu je rad. ${ }^{631}$

Izvedbe neoficijelnih čeških dramatičara u Hrvatskoj disperzirane su u nekoliko kazališta različite provenijencije, od splitskoga i zagrebačkoga Hrvatskog narodnog kazališta, dubrovačkoga Kazališta Marina Držića, sve do studentskoga Teatra ITD, ${ }^{632}$ Satiričkoga

\footnotetext{
${ }^{627}$ Topol, Josef (1935. - 2015.), češki dramatičar. Nakon sloma praškoga proljeća onemogućeno mu je javno djelovanje pa svoje tekstove objavljuje u samizdatskim časopisima i zbornicima. www.slovnikceskeliteratury.cz (natuknica Josef Topol, pristupljeno 2. 9. 2019.)

${ }^{628}$ Otomar Krejča potpisnik je manifesta 2000 riječi te je iz članstva Komunističke partije Čehoslovačke ispisan tijekom velike čistke članstva 1970.

${ }^{629}$ Grgičević, M. Što je to kazalište, Večernji list, br. 2831, 20. 9. 1968., str. 7.

${ }^{630}$ https://www.amaterskedivadlo.cz/main.php?data=soubor\&id=7247 (pristupljeno 24. 7. 2019.)

${ }^{631}$ Repertoar Internacionalnog festivala studentskih kazališta u Zagrebu, Prolog, god. II, br. 4, ožujak/travanj/ svibanj/lipanj, 1969.

${ }^{632}$ Teatar ITD osnovan je u okviru Studentskoga centra Sveučilišta u Zagrebu 1962. Specifičnost Teatra ITD bila je što kazalište nije imalo stalan glumački postav, već glumce angažira zasebno za svaku predstavu što omogućuje okupljanje najkvalitetnijih glumačkih imena. Krajem šezdesetih i početkom sedamdesetih godina 20. st. pozornost javnosti privlači uvrštavanjem na repertoar drama hrvatskih dramatičara snažnoga društvenokritičkog usmjerenja poput Predstave Hamleta u selu Mrduša Donja Ive Brešana 1971. te Mirisa, zlata i tamjana Slobodana Novaka 1974. Teatar ITD prvo je hrvatsko kazalište koje uprizoruje dramu Václava Havela
} 
kazališta Jazavac ${ }^{633}$ i putujuće glumačke družine Teatra u gostima. Po kvantitativnoj se zastupljenosti neoficijelnih dramatičara na repertoaru ističu Dramsko kazalište Gavella, Teatar ITD i splitsko Hrvatsko narodno kazalište, svi s izvedbama četiriju dramskih tekstova neoficijelnih autora.

Motivaciju za uvrštavanje neoficijelnih dramatičara u program Gavelle možda treba tražiti u činjenici da je u kontekstu zagrebačke kazališne scene druge polovice dvadesetoga stoljeća Dramsko kazalište Gavella osnovano početkom 1950-ih kao „čin pobun[e] protiv jedne tradicionalne kazališne institucije “634 „suprotstavljajući se tradicionalizmu HNK-a“6635. I u osamdesetima DK Gavella svojom programskom usmjerenošću nastavlja njegovati repertoarni „drugi put“. Neoficijelni se dramatičari na pozornicu državnoga kazališta u Zagrebu uspijevaju probiti tek od sredine osamdesetih, Pavel Kohout tekstom Peh pod krovom, odnosno 1990. kada, zapravo, više nisu bili zabranjeni, već su, poput Havela u svojstvu predsjednika države, primali inozemna izaslanstva na praškim Hradčanima, a premijeru predstave pohodila je nova, pobjednička politička nomenklatura s prvih višestranačkih izbora u Hrvatskoj.

Dramsko kazalište Gavella je, osim na svome repertoaru, dobar domaćin češkim dramatičarima bilo i tijekom tradicionalne smotre Gavellinih večeri na kojima, od pokretanja 1973., svojim gledateljima pruža kvalitativne repertoarne vrhunce najuglednijih kazališnih kuća iz svih republika tadašnje Jugoslavije. U programu Gavellinih večeri s predstavama

i to još 1966., dramu Drugarsko veče (Zahradní slavnost). Početkom osamdesetih godina publiku zagrebačkoga Teatra ITD činila je, uglavnom, studentska populacija. Prema podacima o prodanim ulaznicama čak $60 \%$ ulaznica u jednoj godini prodano je studentima. Međutim, u tom se razdoblju kazalište suočava i s velikim padom broja gledatelja - od 31000 1980. na 20800 u sljedećoj godini. A gledaoci?, Vjesnik, br. 12374, 9. 2. 1982., str. 6.

${ }^{633}$ Satirična scena Jazavac osnivača Fadila Hadžića s radom je započela 1964. U početku su izvedbe Jazavca imale karakter kabarea pa je polaznicima zagrebačke Akademije za dramsku umjetnost bilo zabranjeno sudjelovanje u njima budući da je uprava Akademije kabare smatrala nedostojnim glumačkoga poziva. U prvoj polovici osamdesetih Jazavac je sa svoje tri scene najproduktivnije kazalište tadašnje Jugoslavije koje godišnje prikazuje petstotinjak predstava pred više od 200000 gledatelja. O popularnosti Jazavčevih predstava u osamdesetima govori podatak da je 1984. predstava Državni lopov Fadila Hadžića izvedena 250. put. Prema novinskim napisima iz toga razdoblja, dokaz popularnosti kazališne predstave na zagrebačkoj sceni u to je vrijeme bila stota izvedba određene predstave. B. Vu. Državni lopov - 250. put, Večernji list, br. 7604, 22. 5. 1984.

${ }^{634}$ Repertoar hrvatskih kazališta, knjiga 1 - Repertoari kazališta, kazališnih družina i grupa, partizanskih kazališta, festivala, smotri i susreta, ur. Branko Hećimović, Jugoslavenska akademija znanosti i umjetnosti, Zagreb, 1990., str. 320.

${ }^{635}$ www.enciklopedija.hr (natuknica DK Gavella, pristupljeno 11. 7. 2015.) 
čeških neoficijelnih dramatičara 1976. sudjeluje Beogradsko narodno pozorište, ${ }^{636} 1986$. Hrvatsko narodno kazalište iz Splita, a godinu dana kasnije i beogradski Atelje $212^{637}$.

Kundera, Havel, Kohout, čiji dramski tekstovi čine čak 75\% ukupnoga broja uprizorenja, i ostali neoficijelni dramatičari na pozornicama hrvatskih kazališta mjesto nalaze tijekom cijeloga razdoblja zabranjenosti u svojoj domovini, no recepcija se intenzivira početkom osamdesetih. Tijekom toga desetljeća uočavamo i intenziviranje objavljivanja proznih radova u izdavačkim kućama i književnokritičke i kazališnokritičke aktivnosti koja se odvija u pozadini.

Tablica VI: Broj premijera drama neoficijelnih dramatičara u hrvatskim kazalištima od 1968. do 1990. prema godini.

\begin{tabular}{|c|c|c|c|c|c|c|c|c|c|c|c|}
\hline godina & 1968. & 1969. & 1970. & 1971. & 1972. & 1973. & 1974. & 1975. & 1976. & 1977. & 1978. \\
\hline premijere & 0 & 1 & 0 & 1 & 0 & 0 & 0 & 1 & 0 & 0 & 0 \\
\hline godina & 1979. & 1980 & 1981. & 1982. & 1983. & 1984. & 1985. & 1986. & 1987. & 1988. & 1989. \\
\hline premijere & 0 & 5 & 3 & 2 & 2 & 0 & 2 & 1 & 1 & 0 & 1 \\
\hline godina & 1990. & & & & & & & & & & \\
\hline premijere & 1 & & & & & & & & & & \\
\hline
\end{tabular}

\footnotetext{
${ }^{636}$ Beogradsko dramsko pozorište osnovano je 1947. i prvo je gradsko kazalište osnovano u Beogradu nakon 2. svjetskog rata. Zlatnim se razdobljem kazališta smatra prijelom pedesetih i šezdesetih godina 20. st., uglavnom zahvaljujući uvrštavanju na repertoar djela suvremenih američkih dramatičara. https://bdp.rs/o-nama/ (pristupljeno 2. 9. 2019)

${ }^{637}$ Atelje 212 beogradsko je kazalište osnovano 1956. Prepoznatljivo je po prikazivanju avangardnih kazališnih predstava pa je, tako, 1956. bilo prvo kazalište u istočnoj Europi koje je prikazalo dramu Čekajući Godota Samuela Becketta. https://atelje212.rs/?page $i d=11$ (pristupljeno 2. 9. 2019.)
} 
Dijagram VII: Broj premijera drama neoficijelnih dramatičara u hrvatskim kazalištima od 1968. do 1990. prema godini.

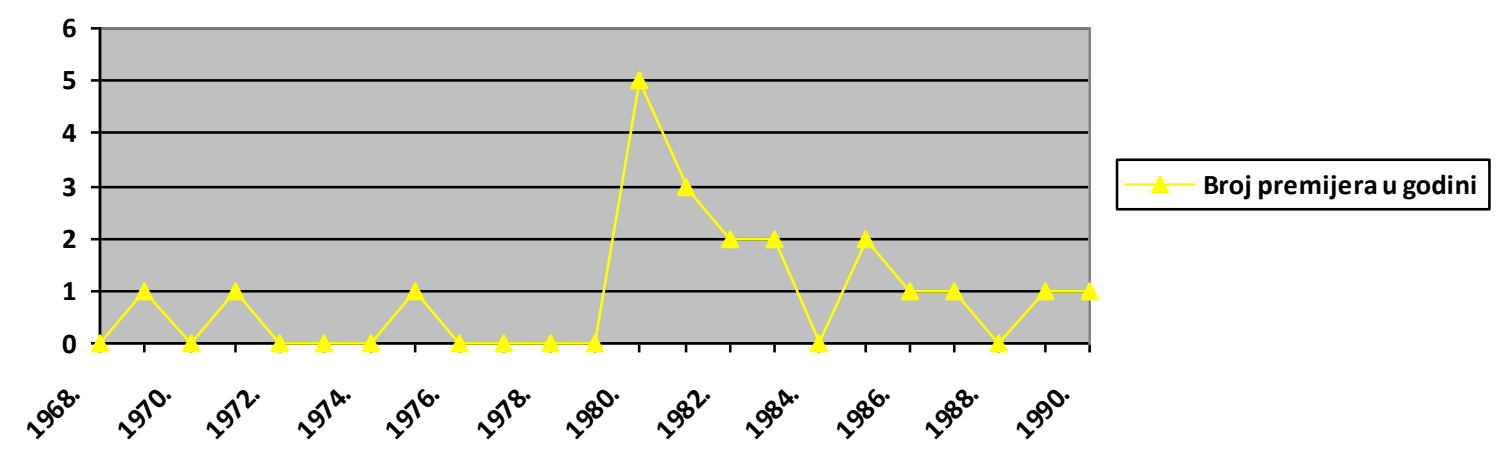

Tablica VII: Broj premijera drama neoficijelnih čeških autora u hrvatskim kazalištima od 1968. do 1990. prema autoru/autorima

\begin{tabular}{|l|l|l|l|l|l|l|}
\hline autor & $\begin{array}{l}\text { Cziviš, Jan, } \\
\text { Vostrá, Alena, } \\
\text { Vostrý, } \\
\text { Jaroslava } \\
\text { (dramatizacija) }\end{array}$ & $\begin{array}{l}\text { Gillar, } \\
\text { Jaroslav, } \\
\text { Škutina, } \\
\text { Vladimír }\end{array}$ & $\begin{array}{l}\text { Havel, } \\
\text { Václav }\end{array}$ & $\begin{array}{l}\text { Kohout, } \\
\text { Pavel }\end{array}$ & $\begin{array}{l}\text { Kundera, } \\
\text { Milan }\end{array}$ & $\begin{array}{l}\text { Škvorecký, } \\
\text { Josef }\end{array}$ \\
\hline $\begin{array}{l}\text { broj } \\
\text { premijera }\end{array}$ & 2 & 1 & 7 & 6 & 5 & 1 \\
\hline autor & Uhde, Milan & $\begin{array}{l}\text { Vostrý, } \\
\text { Jaroslav } \\
(\text { Jiř́́ } \\
\text { Menzel })\end{array}$ & 1 & & & \\
\hline $\begin{array}{l}\text { broj } \\
\text { premijera }\end{array}$ & 1 & &
\end{tabular}


Dijagram VIII: Broj premijera drama neoficijelnih čeških dramatičara u hrvatskim kazalištima od 1968. do 1990. prema autoru
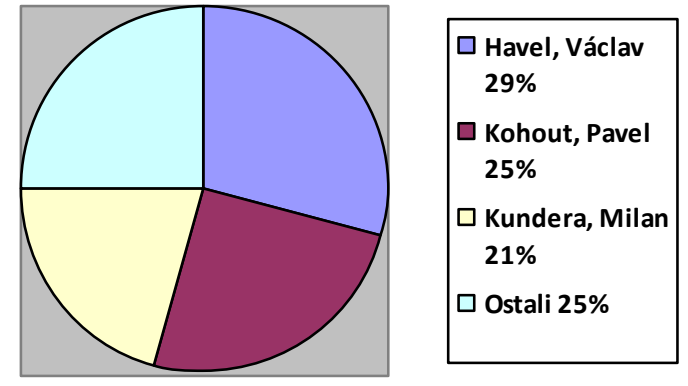

U vrijeme intenziviranja kazališne recepcije neoficijelnih dramatičara tijekom osamdesetih godina, hrvatska publika češku kazališnu produkciju upoznaje iz nekoliko izvora. Osim dramskih tekstova Kundere, Havela i Kohouta, na repertoarima su hrvatskih kazališta i tekstovi klasika češke književnosti koji su tijekom normalizacije bili prikazivani i u domovini, a u hrvatskim kazalištima gostuju i čehoslovačke kazališne kuće. ${ }^{638}$ Nerijetko se sve to događa u isto vrijeme. Tako, primjerice, u prvih šest mjeseci 1989. u Zagrebu gostuju praški Činoherní klub i Satirické divadlo Večerní Brno predstavom Dvije stotine četiri dana o sudbini Jana Husa, zagrebačko Hrvatsko narodno kazalište premijerno prikazuje Strogo kontrolirane vlakove Bohumila Hrabala, Dramsko kazalište Gavella Havelovu dramu Očajno smiješno, a u zagrebačkome Kazalištu Trešnja postavlja se dječja predstava Priča o tri pljuske suvremenog češkog autora Jana Vladislava. ${ }^{639}$ Neka hrvatska kazališta ostvaruju i suradnju s kazališnim djelatnicima kojima je u Čehoslovačkoj onemogućen rad. U zagrebačkome Malom kazalištu Trešnjevka 1983. angažman nalazi redatelj Evald Schorm te režira predstavu Braća Karamazovi prema istoimenom romanu ruskoga književnika Fjodora Mihajloviča

Dostojevskog. Schormu je, naime, u domovini tijekom normalizacije onemogućen rad na filmskoj režiji i područje djelovanja suženo na kazalište. ${ }^{640}$

\footnotetext{
${ }^{638}$ Dnevni tisak tijekom osamdesetih donosi vijesti o nekoliko gostovanja čehoslovačkih kazališta u Jugoslaviji. Godine 1986. na jugoslavenskoj je turneji Kazalište Jiř́ija Wolkera s dramom Gaudemaus igitur P. Dostala i R. Pogode. Praško kazalište u Jugoslaviji, Vjesnik, br. 14050, 21. 10. 1986.

${ }^{639}$ Vrgoč, Dubravka Otklon od bajke, Vjesnik, br. 14906, 18. 3. 1989., str. 8; Premijera u HNK-u, Vjesnik, br. 14950, 3. 5. 1989., str. 8; Grgičević, Marija Stari gost, Vjesnik, br. ,14990, 12. 6. 1989., str. 8; M. Š. Dani kulture Brna, Vjesnik, br. 14999, 21. 6. 1989., str. 9.

${ }^{640}$ Grgičević, Marija Vedar pogled na Dostojevskog, Večernji list, 23. 12. 1983., str. 5.
} 
Najutjecajnije hrvatske dnevne novine sedamdesetih i osamdesetih godina, Večernji list i Vjesnik, kontinuirano prate prisutnost čeških neoficijelnih dramatičara na repertoarima hrvatskih kazališta, prvenstveno najavama kazališnih predstava, a zatim i kazališnim kritikama. Kazališne kritike tih predstava objavljene u hrvatskome tisku, pokazat će analiza u nastavku rada, uglavnom su pozitivne. Kada je kritika negativna, mahom je riječ o kritici scenske realizacije, a tek se iznimno takve kritike referiraju na kvalitetu dramskoga teksta. Kada je tome tako, teret promašaja opet je na hrvatskim prilagodbama tekstova, poput nedovoljno kvalitetno pretočene romaneskne strukture u dramsku formu u kritici Kunderine Šale prikazane u Satiričkome kazalištu Jazavac 1983. Vjesnikov kritičar Branko Ježić zaključuje da su bogatstvo Kunderina romana i slojevitost likova svedeni na „politički sukob“641.

Većina je objavljenih kazališnih kritika i novinskih tekstova povezana dvjema tezama. Prva, dominantna početkom osamdesetih godina, jest tvrdnja o autobiografskoj potki tekstova te druga, dominantna krajem desetljeća, kojom se nerijetko i tumači dobra recepcija neoficijelnih dramatičara kod hrvatske publike, ideja o zrcaljenju prilika hrvatskoga društva u slici češkoga prikazanoga u uprizorenim tekstovima.

U svojim analizama tekstova neoficijelnih dramatičara, hrvatski kazališni kritičari naglašavaju autobiografske motive te traže poveznice autorove biografije i društveno-političkoga konteksta u kojemu je drama nastala s njenom fabulom. Primjerice, u kritici Havelovih jednočinki prikazanih u zagrebačkoj Gavelli 1980. Boris Senker ${ }^{642}$ stavlja znak jednakosti između dramatičara i lika Vaněka te tvrdi da, govoreći o Vaněku, zapravo, „neprekidno govorimo o Havelu, jer u odnosu spomenute trojke spram Vanjeka autor problematizira svoj položaj u čehoslovačkom društvu nakon ljeta '68. “643 Branko Vukšić 1981., najavljujući premijeru Havelova Protesta i Kohoutova Atesta u Teatru ITD, napominje kako su te „drame nepriznate od njihove 'službene' književnosti،“644, a Želimir Stublija ${ }^{645}$ ističe neodvojivost Havelovih i Kohoutovih drama od njihovih biografija i društvene angažiranosti. $\mathrm{Na}$ tome tragu, također u Prologovoj kritici, Igor Mrduljaš u liku Denisa Diderota u drami Teatra ITD Žak Fatalist i njegov gospodar vidi obrise stvaralačkoga habitusa Milana Kundere čije knjige, poput Diderotovih, ipak ne završavaju na lomači, no za koje ne postoji

\footnotetext{
${ }^{641}$ Ježić, Branko Nije šala igrati „ک̌alu“, Vjesnik, br. 13033, 16. 12. 1983., str. 6.

${ }^{642}$ Senker, Boris Pegaz u ormi, Prolog, br. 43, god. XII(1980), str. 159-163.

${ }^{643}$ Isto, str. 160.

${ }^{644}$ B. Vu. Večeras u Teatru ITD - Dvije jednočinke, Večernji list, br. 6808, 12. 10. 1981., str. 8.

${ }^{645}$ Stublija, Želimir Politizirana dramaturgija, Vjesnik, br. 12262, 15. 10. 1981., str. 7.
} 
zanimanje nakladnika u matičnoj zemlji. ${ }^{646}$ Nasuprot tome, puno se rjeđe disidentsko iskustvo autora uopće ne spominje, poput plakata Teatra ITD koji prati uprizorenja Havelove i Kohoutove drame u istome kazalištu. Taj plakat iz kratke biografije autora navodi da je Havelov Protest, ,igran u mnogim europskim zemljama“647, pri čemu se ne spominje nemogućnost postavljanja drame na pozornicu u matičnoj zemlji te da Pavel Kohout ,[s]ada živi (...) u Beču i radi u Burgtheatru“648, a da je „1980. primio (...) austrijsko državljanstvo“6649.

Krajem 1980-ih kada društvene promjene u srednjoj i istočnoj Europi, pa tako i u Hrvatskoj, ${ }^{650}$ postaju izvjesne, u novinskim se tekstovima o kazališnim predstavama neoficijelnih dramatičara, uglavnom onima Václava Havela, naglasak stavlja na ,zajedničko povijesno iskustvo češkoga i hrvatskoga naroda“ te se time tumači izuzetna prijemčivost hrvatskih kazališta i publike za Havelove, Kunderine, Kohoutove dramske tekstove. Takvo je iščitavanje dao naslutiti već 1980. Boris Senker u svojoj analizi premijere Havelovih jednočinki Audijencije i Izložbe u Dramskom kazalištu Gavella koju zaključuje riječima da je „,[t]o predstava s kojom se svatko neće solidarizirati - bio bi, uostalom, i njezin neuspjeh da se naši Sládeki, Vere i Michali oduševe Havelom - ali je mora barem uvažiti. “651 Istoj se tezi kasnije priklanja niz analitičara. Detaljno je analizira i srpska slavistica Aleksandra Korda-Petrović u svome tekstu iz 2008. o odličnoj recepciji čeških neoficijelnih autora u Srbiji. ${ }^{652}$ Korda-Petrović slaže se s razmišljanjem teatrologa Petra Volka objavljenim u beogradskoj Ilustrovanoj politici povodom postavljanja Havelova Protesta i Kohoutova Atesta u beogradskom Narodnom pozorištu. Volk, naime, tvrdi da kroz Havelove dramske tekstove jugoslavenska publika prepoznaje vrijeme i teme koje sama živi te da nam češki autori pružaju satiričko kazalište koje jugoslavenski nisu uspjeli razviti. Korda-Petrović nadovezuje se na Volkove riječi da „,[p]reko slike čehoslovačkog društva iz perioda staljinizma i normalizacije, srpski čitalac prepoznaje sliku vlastitog socijalističkog društva“"653. Autorica implicira da je u jugoslavenskome društvu postojala cenzura protiv koje su se jugoslavenska kazališta borila uvrštavanjem na repertoar drama čeških disidenata koji u takvoj situaciji

\footnotetext{
${ }^{646}$ Mrduljaš, Igor Diderot á la Pragois, Prolog, br. 46, god. XII(1980), str. 170-172.

${ }^{647}$ Plakat Teatra ITD

648 Isto.

649 Isto.

${ }^{650}$ Prva politička stranka u Hrvatskoj, osim Saveza komunista, osnovana je u svibnju 1989.

${ }^{651}$ Senker, Boris Pegaz u ormi, Prolog, br. 43, god. XII (1980.), str. 163.

${ }^{652}$ Korda-Petrović, Aleksandra Fenomen prihvaćenosti čeških disidentskih autora u srpskoj sredini, Zbornik Matice srpske za slavistiku 73, Matica srpska, Novi Sad, 2008.

${ }^{653}$ Isto, str. 234.
} 
postaju „glasnogovornici onoga što se iz pera domaćeg autora nije smelo čuti“654 te zaključuje:

„U delima čeških disidentskih autora srpska čitalačka i pozorišna publika prepoznala je skeniranu sliku vlastitog društva, prepoznala je mehanizme birokratskog i dogmatskog društva, modele njegovog pretvaranja u nehumani i otuđeni apsurd. Tipično češki, satirični i ironični pristup stvarnosti kojim se ukazuje na moralne slabosti i poroke društva, kao i pronicljiva psihološka analiza moralnih lomova koje doživljava socijalistički čovjek, bili su lako prepoznatljivi srpskom recipijentu i on ih je prihvatio kao sliku vlastite stvarnosti. U tome su sadržani koreni tako temeljne prihvaćenosti navedene grupe čeških autora u našoj sredini." 655

Ideje koje koreliraju s onima srpske slavistice razvijaju i kritičari, novinari i prevoditelji u Hrvatskoj još tijekom osamdesetih. U tekstu objavljenome u Republici 1980. povodom premijere Havelovih jednočinki Audijencije i Izložbe teatrolog Nikola Batušić tvrdi da tematika Havelovih drama nije ekskluzivno češka, već da se može proširiti svugdje gdje se ne tolerira postojanje različitosti mišljenja $\mathrm{i}$ iskazivanja istoga $\mathrm{i}$ gdje je na snazi „,birokratizacija duha“ čiju kritiku Havel ugrađuje u temelje svojih drama. ${ }^{656}$ Takva će tumačenja postati učestala kako se približavamo 1990. U intervjuu s Jiř́jjem Bartoškom, suradnikom Václava Havela u vrijeme disidentstva, objavljenom u tjedniku Danas u travnju 1990. kazališni kritičar Dalibor Foretić i kritičarka i prevoditeljica Dagmar Ruljančić Havela nazivaju „najautentičnij[im] jugoslavensk[im] dramsk[im] autor[om]“657 budući da „,njegove drame u dobroj mjeri pokazuju i našu situaciju“658.

U intervjuu Vjesniku u listopadu 1990. dramski umjetnik Vanja Drach povodom premijere Havelove Asanacije u zagrebačkome Hrvatskom narodnom kazalištu u kojoj igra glavnu ulogu, arhitekta dr. Zdeněka Bergmana, ističe:

„Havel je živio u istom političkom okružju kao i mi. Češki narod imao je istu ili sličnu sudbinu od rata na ovamo kao i mi, a negdje smo se istodobno i oslobodili komunističkog jednoumlja. Kako su nam sudbine slične, Havel je pišući o češkom iskustvu istodobno pisao i o našemu. Nekoliko puta sam u

\footnotetext{
${ }^{654}$ Korda-Petrović, Aleksandra Fenomen prihvaćenost čeških disidentskih autora u srpskoj sredini, Zbornik Matice srpske za slavistiku 73, Matica srpska, Novi Sad, 2008., str. 238.

${ }^{655}$ Isto, str. 238.

${ }^{656}$ Batušić, Nikola Havel u Gavelli, Republika, br. 7/8, 1980.

${ }^{657}$ Ispunjen Hamletov nalog (intervju s Jiříjem Bartoškom, razgovarali Dalibor Foretić i Dagmar Ruljančić), Danas, 17. 4. 1990., str. 37-39. ${ }^{658}$ Isto.
} 
posljednje vrijeme pročitao da se mi već nalazimo na drugoj obali i da je anakronizam baviti se 'socijalističkom stvarnošću'. No, repovi će se za nama vući još dugo i teško ćemo se osloboditi svega onoga o čemu piše Havel. Pa prema tome mislim da je ta vrsta literature aktualna i danas. “659

Princip zrcaljena jugoslavenskih okolnosti u dramskim tekstovima čeških disidentskih dramatičara redatelj Havelovih drama tijekom osamdesetih Božidar Violić naziva „komparativnim razlozima za režiranje Havelovih tekstova“6600 te u novinskome članku objavljenome, također, 1990. zaključuje da takvi razlozi više ne postoje. ${ }^{661}$

Istoj se tezi priklanja i Igor Mrduljaš koji tvrdi da se izlaz od nemogućnosti progovaranja o nekim temama kod hrvatskih dramatičara tražio u prikazivanju stranih drama u kojima iščitavamo svoje iskustvo. ${ }^{662}$ U tjedniku Danas 1990. glumac Zlatko Vitez, Violićev Vaněk u predstavi DK-a Gavella iz 1980., izjavljuje da je glumeći taj Havelov lik progovarao o sudbini jednog drugoj, hrvatskoga, intelektualca kojemu je tih godina bio onemogućen javni rad - hrvatskoga književnika i političara Vlade Gotovca ${ }^{663}{ }^{664}$ Početkom devedesetih, kada režira Asanaciju u zagrebačkome Hrvatskom narodnom kazalištu, redatelj Havelova Protesta i Kohoutova Atesta u Teatru ITD u listopadu 1981. Radovan Maričić potvrđuje da se početkom osamdesetih postavljanjem Havelovih drama na zagrebačke pozornice pokušavala riješiti sudbina Vlade Gotovca, ili se barem o njoj željelo javno progovoriti. ${ }^{665}$ Tezu o paralelizmu sudbina disidenata iz dviju država Václava Havela i Vlade Gotovca razvija i

${ }^{659}$ Vrgoč, Dubravka Poput precizne partiture besmisla (intervju s Vanjom Drachom), Vjesnik, br. 15486, 29. 10. 1990., str. 9.

${ }^{660}$ Prica, Jasmina Iz samice na prijestolje, Danas, 16. 1. 1990., str. 42-43.

U istome tekstu Božidar Violić duhovito-cinično dodaje zašto Havel nikada ne bi mogao biti predsjednik Jugoslavije: „, Osim što je pisac, i to dobar, Havelu je i odviše stalo do slobode, a premalo do vlasti da bi mogao postati našim predsjednikom. (...) Nismo mi bili u stanju imati ni svoga Dubčeka, pa kako bismo se onda usudili i pomisliti na našega potencijalnoga Havela. Već bi sama njegova kandidatura bila izigrana u režiranim sporovima oko problema da li je Slovak ili Čeh, što je kod nas presudnije od stjecanja slobode i ljudskih prava." str. 42

661 Isto.

${ }^{662}$ Mrduljaš, Igor Kako uspavati kazalište? ili Vlast se ne da vući za kosu, Novi prolog, br. 17/18, 1990.

${ }^{663}$ Hrvatski književnik i političar Vlado Gotovac (1930. - 2000.) uhićen je 1972. te osuđen na četiri godine zatvora, 1977. ponovno je optužen zbog zagovaranja nacionalnog programa i istupa u švedskim i talijanskim medijima (bilo mu je zabranjeno javno istupati) da bi 1981. bio osuđen na dvije godine zatvora i četverogodišnju zabranu javnoga djelovanja. U javni se život vratio potkraj 1980-ih. www.enciklopedija.hr (natuknica Vlado Gotovac, pristupljeno 11. 12. 2018.). Tijekom izdržavanja zatvorske kazne odbija potpisati i predati zahtjev za pomilovanjem jer bi, smatrao je, formulacija koju je zahtjev sadržavao negirala dio njegovih aktivnosti i ideja. Ćurković, Jasna Religiozna uporišta u liberalnoj ideji Vlade Gotovca, Crkva u svijetu, Vol. 45, No. 1, Split, 2010., 56-77.

${ }^{664}$ Prica, Jasmina Iz samice na prijestolje, Danas, 16. 1. 1990., str. 42-43.

${ }^{665}$ Kada novo postane staro (intervju Sanje Nikčević s Radovanom Maričićem), Večernji list, br. 9770, 30.10. 1990. 
novinarka Alemka Lisinski reagirajući na sve češći transfer radnika u kulturi na polje politike na prijelomu osamdesetih i devedesetih godina 20. st. ${ }^{666}$ Lisinski tvrdi da je Vlado Gotovac „sasvim sigurno hrvatski Havel“667 te poziva hrvatske političare koji stupaju na političku scenu s promjenom društvenoga uređenja početkom devedesetih, a s ciljem da ostvare kvalitetan omjer društvene angažiranosti i vjernosti političkim vrijednostima, da se ugledaju na Havela „koji je dio svog radnog vremena, između ostalog, posvetio i ozbiljnom razgovoru s Frankom Zappom“6668.

Pozivanje na zajedničko povijesno iskustvo nije jedina novina koju uočavamo u tekstovima s prijeloma osamdesetih i devedesetih. Novinski tekstovi iz 1990. o uprizorenjima drama neoficijelnih dramatičara u hrvatskim kazalištima donose niz zanimljivosti $u$ duhu vremena poput prigovora pretjeranom jezičnom purizmu u prijevodu teksta drame Asanacija, ${ }^{669}$ premijernih gostiju poput novoizabranog hrvatskog predsjednika Franje Tuđmana ${ }^{670}$ te popisa poslovnih partnera i sponzora kazališne premijere. ${ }^{671}$

Napisi o gostovanjima zagrebačkih kazališta s predstavama neoficijelnih autora $\mathrm{u}$ gradovima izvan Zagreba, a koje donosi tisak lokalnoga i regionalnoga karaktera poput Slobodne Dalmacije, riječkoga Novog lista, Varaždinskih vijesti i koprivničkoga Glasa Podravine, uglavnom ostaju na razini vijesti i pružanja informacije o održavanju predstave. ${ }^{672}$ Iz te se skupine tekstova kazališnokritičarskom sastavnicom izdvaja tek tekst Varaždinskih vijesti objavljen 12. lipnja 1980. u kojemu je izvedba Havelovih jednočinki Audijencije i Izložbe Dramskog kazališta Gavella na Danima kulture Varaždina iste godine ocijenjena izvrsnom. ${ }^{673}$

\footnotetext{
${ }^{666}$ Lisinski, Alemka Vlast bez Havela, Danas, 21. 11. 1990., str. 35-37.

667 Isto.

668 Isto.

${ }^{669}$ Hrovat, Boris B. Na granici podnošljivosti, Večernji list, br. 9771, 31. 10. 1990., str. 39.

${ }^{670}$ Vrgoč, Dubravka Pronalazak izvršitelja tuđe volje, Vjesnik, br. 15460, 3. 10. 1990., str. 9.

${ }^{671}$ S. Nč. Tko je protiv napretka, Večernji list, br. 9767, 27. 10. 1990., str. 51.

${ }^{672}$ Nesustavna slika o napisima u glasilima lokalnoga i regionalnoga karaktera sjeverozapadne Hrvatske može se dobiti prema objavljenome u bazi digitalnih novina na mrežnoj stranici www.library.foi.hr/novine (Varaždinske vijesti, Glas Podravine). Kratkim novinskim tekstovima popraćena su sljedeća gostovanja: Milan Kundera Ševa (gostovanje Teatra u gostima u Narodnom kazalištu u Varaždinu, redatelj Vanča Kljaković) Varaždinske vijesti, Václav Havel Audijencija (u tekstu napisano Audicija) i Izložba (gostovanje DK Gavella u Koprivnici) Glas Podravine 16. 5. 1980., Václav Havel Audijencija i Izložba (gostovanje DK Gavella u Narodnom kazalištu u Varaždinu) Varaždinske vijesti, Milan Kundera Jakob i njegov gospodar (gostovanje Slovenskog narodnog gledališča iz Celja u Varaždinu) Varaždinske vijesti svibanj 1982., Milan Kundera Žak Fatalist i njegov gospodar (gostovanje Teatra ITD u Imotskom, Trebinju i Metkoviću) Slobodna Dalmacija 21. 4. 1981., Milan Kundera Žak Fatalist i njegov gospodar (gostovanje Teatra ITD u Slavonskome Brodu) Novi list 7. 9. 1981. i lokalne slavonskobrodske novine - naziv novina nečitak 25. 9. 1981.

${ }^{673}$ Varaždinske vijesti, 26. 6. 1980., br. 25, str. 5; http://library.foi.hr/novine/broj1.aspx?C=3\&godina $=1980 \&$ broj $=000025$ (pristupljeno 24. 7. 2019.)
} 
Hrvatske dnevne novine objavljuju i vijesti o izvedbama neoficijelnih dramatičara i u drugim republikama tadašnje Jugoslavije. Osobito se redovno prate zbivanja na renomiranim kazališnim festivalima poput sarajevskoga MESS-a. U programu toga festivala 1988. sudjeluje sarajevski Kamerni teatar 55 s Havelovim Largom desolatom u režiji Egona Savina, koji će iste godine upotpuniti i program zagrebačkih Dana satire Satiričkoga kazališta Jazavac. ${ }^{674}$ Istoga dana, 14. travnja 1988., kritike te predstave u Večernjemu listu potpisuje Boris B. Hrovat, a u Vjesniku Dubravka Vrgoč. Oba su teksta kritički negativno intonirana. Hrovat Suvinu prigovara pretjeranu simplifikaciju teksta koja je dramu dovela na razinu komedije i farse te time, s jedne strane, pridobila publiku, no, istovremeno, „oslabila snagu Havelove umjetničke istine“675. Osim predstava na MESS-u hrvatski čitatelji tijekom osamdesetih informirani su o sudjelovanju Ateljea 212 s Havelovom Audijencijom i Izložbom na Susretu malih scena te premijeri Burleske i Iskušenja istoga autora u Primorskom dramskom kazalištu u slovenskoj Novoj Gorici. ${ }^{676}$ Također, kazališta drugih jugoslavenskih republika nerijetko svoje predstave postavljaju prema prijevodima hrvatskih prevoditelja. Tako beogradsko Narodno pozorište 1984. Havelove i Kohoutove jednočinke Protest i Atest postavlja prema prijevodu Ivana Kušana, a godinu kasnije Beogradsko dramsko pozorište prikazuje Kunderinu dramu Žak Fatalist i njegov gospodar u prijevodu Predraga Jirsaka.

Kao zasebnu cjelinu u recepciji neoficijelne dramske književnosti možemo izdvojiti radijske drame neoficijelnih dramatičara o čijem uvrštavanju u program Radija Zagreb nalazimo zapise u dnevnome tisku. Riječ je o drami Ludvíka Aškenazyja Mala strast s travanjskim snijegom koju Radio Zagreb izvodi 1976., ${ }^{677}$ a njena kritička recepcija u analiziranome tisku nije zabilježena.

\section{1. Milan Kundera}

Iako primarno doživljavan kao romanopisac, dramski tekstovi Milana Kundere i kazališne adaptacije njegovih proza tijekom sedamdesetih i osamdesetih godina ostvaruju

\footnotetext{
${ }^{674}$ Dani satire festival su komediografskih i satiričnih djela koji se održava od 1976. u zagrebačkome Kazalištu Kerempuh (kazalište je 1994. preimenovano iz Satiričkoga kazališta Jazavac). Od 2012. festival nosi naziv Dani satire Fadila Hadžića u spomen na utemeljitelja festivala, satiričara Fadila Hadžića.

${ }^{675}$ Hrovat, Boris B. Rasulo svijeta, Večernji list, br. 8864, 14. 4. 1988., str. 13.

${ }^{676}$ Male scene u Novoj Gorici - Prva večer „U agoniji“, Večernji list, br. 6886, 15. 1. 1982., str. 9; B. Z. Šesta premijera, Večernji list, br. 7238, 9. 3. 1983., str. 9; M. G. Drama Václava Havela, Vjesnik, br. 15221, 3. 2. 1990., str. 8.

${ }^{677}$ Ucjena muškaraca, Vjesnik u srijedu, br. 1242, 28. 2. 1975., str. 5.
} 
nekoliko premijera u hrvatskim kazalištima. Na početku analizirana razdoblja, 1971., splitsko Hrvatsko narodno kazalište u režiji Vanče Kljakovića na repertoar uvrštava dramu Ptákovina, prevedenu kao Monada ${ }^{678}$ Kunderinom Ševom započinje i dugogodišnji rad legendarnoga putujućeg Teatra u gostima 1974. Predstavu Žak Fatalist i njegov gospodar prvo postavlja zagrebački Teatar ITD u režiji Mire Međimorca 1980., a zatim i splitski HNK-a godinu dana kasnije. Dramatizacija kultnoga romana Šala premijerno je izvedena 1983. u Satiričkome kazalištu Jazavac.

Dio je kazališnih umjetnika koji su sudjelovali u pripremama i izvedbama predstava prema Kunderinim tekstovima izuzetno visoko valoriziran od strane stručnih žirija kazališnih festivala i susreta tijekom osamdesetih godina. Na početku desetljeća, 1982., splitska je glumica Zdravka Krstulović na dodjeli Prvomajskih nagrada Društva dramskih umjetnika Hrvatske za ulogu Krčmarice u Žaku Fatalistu nagrađena za najbolju žensku ulogu. ${ }^{679}$ Dvije godine kasnije na 9. danima satire Satiričkoga kazališta Jazavac za najbolju je žensku ulogu za lik Helene u Šali nagradom Zlatni smijeh nagrađena glumica Tatjana Verdonik. Nagrađivani nisu samo članovi glumačkih ansambala - nagradu žirija za kostimografiju predstave Žak Fatalist i njegov gospodar splitskoga Hrvatskog narodnog kazališta 1986. na 14. Gavellinim večerima osvaja Marija Žarak.

\section{1. 1. Milan Kundera Monada (HNK Split, 1971.)}

U godini kada svome nazivu pridodadaje atribut „hrvatsko“, splitsko Narodno kazalište na svoj repertoar uvrštava Kunderinu drama Monada. ${ }^{680} \mathrm{U}$ kratkome razdoblju od 20. ožujka do 29. travnja 1971. predstava u režiji Vanče Kljakovića izvedena je 6 puta. Repertoar splitskoga kazališta te je godine još uvijek velikim dijelom određen tehničkim ograničenjima koja su bila posljedica velikoga požara dvije godine ranije. Upravo uvjetima kazališnoga prostora Srećko Lorger u tekstu objavljenu u Prologu obrazlaže i Kunderinu Monadu na splitskoj sceni. ${ }^{681}$ Naime, jedini dio zgrade koji u požaru nije bio oštećen jest predvorje kazališta, a repertoar koji se u takvom prostoru mogao postaviti na improviziranu

\footnotetext{
${ }^{678}$ Riječ ptákovina doslovno znači „pizdarija“, prevedena je talijanizmom monada.

${ }^{679}$ Najbolji - „Banket“, Večernji list, br. 6988, 17. 5. 1982., str. 15.

${ }^{680}$ Repertoar hrvatskih kazališta, 1. knjiga (Repertoari kazališta, kazališnih družina i grupa, partizanskih kazališta, festivala, smotri i susreta), ur. Branko Hećimović, Globus, Jugoslavenska akademija znanosti i umjetnosti, 1990., str. 395.

${ }^{681}$ Lorger, Srećko Vrijeme športa i razonode (o kazališnoj situaciji u Splitu), Prolog, br. 15, god. IV(1971), str. 46.
} 
pozornicu Lorger naziva repertoarom „foyerske fizionomije“682. Nadalje, kritičar Lorger predstavu uglavnom atribuira negativno, navodi da se oni „koji nisu vidjeli ovu komediju ne moraju (...) osjećati nesretni jer jamačno ne bi doživjeli bogzna što vrijedno, atraktivno, novo, neprepoznatljivo“683 . Isti broj Prologa prenosi tekst Anatolija Kudrjavceva objavljen u Slobodnoj Dalmaciji u kojemu je negativno ocijenjena cijela sezona drame splitskoga HNK-a preko koje bi trebalo, tvrdi Kudrjavcev, ,prijeći šutke“684.

\section{1. 2. Milan Kundera Ševa (Teatar u gostima, 1974.)}

Kunderinom Ševom započeo je rad putujećega Teatra u gostima $1974 .{ }^{685}$ Tijekom kazališne sezone 1974./1975. predstava je prikazana 112 puta, od toga 58 puta u Zagrebu, 42 u drugim mjestima u Hrvatskoj te 6 puta u Bosni i Hercegovini i Sloveniji. ${ }^{686}$

U analiziranome tisku nisu pronađene kazališne kritike Kunderine Ševe u izvedbi Teatra u gostima. Predstavom se posredno bavi glumac Relja Bašić, jedan od osnivača kazališne družine, koji u časopisu Oko 1975. objavljuje dnevničke zapise uz popratni novinski tekst povodom stote izvedbe te predstave kojom je Teatar u gostima godinu dana ranije započeo svoj rad. Tekst u Oku svjedoči da su reakcije publike na Kunderinu Ševu izuzetno dobre, da se predstava mahom izvodi pred prepunim gledalištem i da je to nerijetko u manjim mjestima prva kazališna predstava izvedena nakon nekoliko godina. ${ }^{687}$

Recepciju te groteskne komedije dotiče i Boris Senker u svojoj kritici Kunderina romana Život je negdje drugdje objavljenoj u Gordoganu $1980 .{ }^{688}$ Analizirajući motive uvrštavanja Kunderina teksta na repertoar Teatra u gostima, Senker navodi da je sjajna recepcija romana Šala početkom sedamdesetih trebala gledatelje privući i ovom tekstu istoga

\footnotetext{
${ }^{682}$ Lorger, Srećko Vrijeme športa i razonode (o kazališnoj situaciji u Splitu), Prolog, br. 15, god. IV(1971), str. 46.

683 Isto.

${ }^{684}$ Isto.

${ }^{685}$ Putujuća glumačka družina Teatar u gostima javlja se sredinom 1970-ih u kontekstu osnutka niza manjih glumačkih družina koje Vlado Krušić naziva „teatrom s ruba“, a koji nastaju kao reakcija na pasivnost i nekreativnost u velikim kazališnim kućama. Krušić, Vlado Teatar s ruba, Prolog, br. 28, god. VIII(1976.), str. 45.

${ }^{686}$ Repertoar hrvatskih kazališta, 1. knjiga (Repertoari kazališta, kazališnih družina i grupa, partizanskih kazališta, festivala, smotri i susreta), ur. Branko Hećimović, Globus, Jugoslavenska akademija znanosti i umjetnosti, 1990., str. 364, Repertoar hrvatskih kazališta, 3. knjiga (Repertoari 1981. - 1990.), ur. Branko Hećimović, Hrvatska akademija znanosti i umjetnosti, 2002., str. 79; Teatar u gostima priprema nove tekstove, Vjesnik, 26. 10. 1975., str. 11.

${ }^{687}$ Bašić, Relja Izvaci iz dnevnika jednog putujućeg glumca, Oko, br. 80, 1975., str. 5.

${ }^{688}$ Senker, Boris Miles gloriosus s perom u ruci, Gordogan, br. 5-6, siječanj-travanj 1980., str. 339-343.
} 
autora. Međutim, sredinom sedamdesetih, u vrijeme kada su šezdesetosmaška zbivanja već izgubila na aktualnosti, to se nije dogodilo, ,,dijelom zbog prigušenosti vlastita govora, dijelom zbog godina tokom kojih je obnovljena čehoslovačka prošlost postala elementom svakodnevice te stoga i u svijesti publike sišla s 'naslovne strane' u rubriku 'dogodilo se na današnji dan'‘6689.

${ }^{689}$ Senker, Boris Miles gloriosus s perom u ruci, Gordogan, br. 5-6, siječanj-travanj 1980., str. 339. 


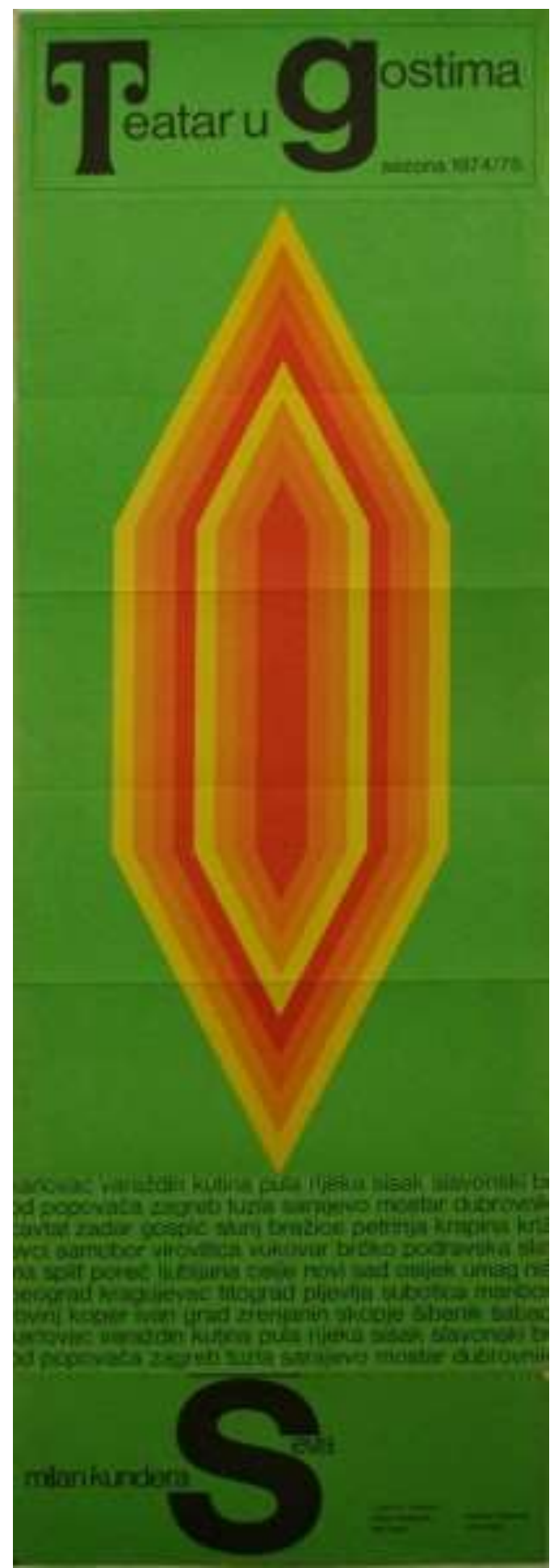

Fotografija III: plakat za predstavu Ševa Teatra u gostima, autor Ivan Picelj Izvor: digitalni arhiv Muzeja za umjetnost i obrt http://athena.muo.hr/?object=view\&id=65003, pristupljeno 2. 8. 2019. 


\section{1. 3. Milan Kundera Žak Fatalist i njegov gospodar (Teatar ITD, 1980.)}

\section{Na repertoar zagrebačkoga Teatra ITD Kundera dolazi predstavom Žak Fatalist $i$} njegov gospodar ${ }^{690}$ koja je nakon premijere 16. studenog 1980. ostvarila još 10 repriznih izvedaba. ${ }^{691}$ Prva je to u nizu predstava čeških neoficijelnih dramatičara koje na pozornicu nekoga hrvatskog kazališta postavlja redatelj Miro Međimorec čije su predstave još desetak godina prije, $u$ vrijeme hrvatskoga proljeća, nerijetko u javnosti dobivale, u svojim javnim istupima autor ističe nezasluženo, dodatne političke konotacije. ${ }^{692}$ Tri godine kasnije Međimorec će u Satiričkome kazalištu Jazavac režirati Kunderinu Šalu, a 1989. u Dramskome kazalištu Gavella i Očajno smiješno (Largo desolato) Václava Havela.

Kunderina popularnost zacijelo je pridonijela da, kao i o dramatizaciji $\breve{S} a l e$ tri godine kasnije, o ITD-ovu Žaku Fatalistu pišu sve značajnije hrvatske novine. Časopis Oko objavljuje čak dva teksta, kazališnu kritiku iz pera Željka Falouta te, 1981. intervju s autorom. U svojoj kritici Falout predstavi nalazi nekoliko zamjerki, od scenografije do naglašavanja scena koje su u Kunderinu predlošku manje važne. U zaključku predstavu ocjenjuje dobrom te naglašava glumačko umijeće velikana Ivice Vidovića i Vanje Dracha. ${ }^{693}$

Kako ujesen 1980. Zagreb posjećuje i sâm autor te nazoči premijeri svoje drame u Teatru ITD ${ }^{694}$ intervju s Milanom Kunderom u Oku u kojemu književnik iznosi svoje

\footnotetext{
${ }^{690}$ Ovim se tekstom Kundera do publike u Čehoslovačkoj uspijeva probiti još 1975 . Naime, u gradiću Ústí nad Labem u prosincu te godine prikazan je Žak Fatalist i njegov gospodar, a kao autor drame naveden je redatelj Evald Schorm. Janoušek, Pavel i suradnici Dějiny české literatury 1945-1989, IV. knjiga 1969-1989, Academia, Prag, 2008.

${ }^{691}$ Repertoar hrvatskih kazališta, 1. knjiga (Repertoari kazališta, kazališnih družina i grupa, partizanskih kazališta, festivala, smotri i susreta), ur. Branko Hećimović, Globus, Jugoslavenska akademija znanosti i umjetnosti, 1990, str. 334.

${ }^{692}$ U jeku hrvatskoga proljeća Međimorec je javnost uzburkao uprizorenjem drame Svrha od slobode Ivana Kušana na Dubrovačkim ljetnim igrama. Međimorčeva suradnja s Kušanom nastavlja se baš na Havelovim jednočinkama u Gavelli 1980. koje je Ivan Kušan preveo na hrvatski jezik. O političkim konotacijama koje je prikazivanje Kušanove drame 1971. dobilo, Međimorec progovara u intervjuu Prologu 1975. kada izražava negodovanje što su „burna društveno-politička događanja (...) mijenjala namjeru predstave na različite načine“, tvrdi da je ,[i] deja predstave vulgarno (je) čitana i simplificirana“. (Može li Lemnos biti od drveta?, intervju s Mirom Međimorcem, Prolog, br. 25, god. VII(1975), str. 24) Isti redatelj negira i političke konotacije koje su se vezale uz postavljanje drama poljskoga emigranta Sławomira Mrožeka u Teatru ITD tijekom osamdesetih te tvrdi da ,[d] rame Emigranti, Pješice i Portret, nedugo nakon nastanka, niti u ono vrijeme nismo radili iz političkog konteksta, već je presudna bila suigra nesretnih karaktera.“ www.cekate.hr/tnt/arhiva-tnt/s-mrozekemigranti-15-7-20-30/ (pristupljeno 16. 1. 2016.)

${ }^{693}$ Falout, Željko Njegova domovina je humor, Oko, br. 228, 1980., str. 15.

${ }^{694}$ Svoja sjećanja na susret s autorom u intervjuu Večernjemu listu u ožujku 2012. evocira redatelj Međimorec: „Redatelji bi morali više raditi s piscima. (...) To se meni dogodilo s Kunderom koji je bio u Zagrebu 1980. na premijeri, ali je rekao: 'Ja vam ne gledam ništa!' Čak nije htio doći na premijeru, ali je došao i oduševio se. Bio je to komad Jacques Fatalist." Derk, Denis Miroslav Međimorec: Nitko me ne može otjerati iz Hrvatske
} 
pozitivne dojmove nakon odgledane zagrebačke premijere objavljuju ,,praški učenici“ Rajko Grlić i Tomislav Kurelec. ${ }^{695} \mathrm{Na}$ samome početku intervjua Kundera navodi da je razočaran kazališnom umjetnošću i, uglavnom, nezadovoljan završnim ostvarenjima svojih dramskih tekstova u kazalištu. Za razliku od romana gdje, kao autor, svaki djelić teksta može držati pod kontrolom, završna izvedba u kazalištu u pravilu iznevjerava njegova očekivanja, a vizije redatelja i glumaca uglavnom su suprotne njegovima. Međutim, iznosi svoje oduševljenje zagrebačkim Žakom Fatalistom kojega ocjenjuje „,naprosto savršen[om] predstav[om] “696 te napominje da je bio „oduševljen poput djeteta“6697.

Vjesnikov tekst deskriptivne je prirode, bez razrađenijih vrijednosnih procjena, sve do posljednje rečenice koja zaključuje da je „,[p]ostavljanjem ovog Kunderinog romana 'Teatar ITD' ostvario (...) uistinu vrijednu predstavu. “698

Kritika Marije Grgičević u Večernjemu listu izuzetno je pozitivna. Grgičević hvali i Kunderin dramski tekst, naziva ga ,poticajn[im] suvremen[im] djelo[m] ${ }^{\text {“699 }}$, i izvedbu ITD-ova glumačkoga ansambla. Glumu Ivice Vidovića u tekstu opisuje kao ,izvanrednu kreaciju“, 700 Vere Zime kao „,bujnu i energičnu““, 701 a pohvale se nižu i na račun ostalih glumaca, kostimografkinje, autora glazbe i scenografa. Međutim, samo dva dana kasnije Večernji list donosi vijest kako se Kunderina drama na programu Teatra ITD nije ustalila iako je to ,predstava koju možete preporučiti znancima bez odveć straha da će vas oni sutradan napasti zbog prevare“6702.

U pozitivnoj kritici predstave koju za Prolog piše Igor Mrduljaš ${ }^{703}$ opisan je ignorantski odnos medija prema redatelju za kojega Mrduljaš kaže da ga je u proteklim godinama u zagrebačkome kazališnom miljeu dočekivala „gluhoća ili prijezir, pa on danas samo slučajno u Zagrebu može dobiti pozornosti vrijedan projekt, naravno u rubnom kazalištu“704. Scenski postupci koje, prema Mrduljašu, Međimorec na pozornicu uvodi još

www.vecernji.hr/kultura/miroslav-medjimorec-nitko-me-ne-moze-otjerati-iz-hrvatske-388017 (objavljeno 18. 3. 2012., pristupljeno 15. 12. 2018.)

${ }^{695}$ Nije riječ o laskanju (intervju s Milanom Kunderom, razgovarali Rajko Grlić i Tomislav Kurelec), Oko, br. 232, 1981., str. 10.

696 Isto.

697 Isto.

${ }^{698}$ Dijalogizirani Diderot, Vjesnik, br. 11940, 20. 11. 1980., str. 7.

${ }^{699}$ Grgičević, M. Svi smo mi plagijati, Večernji list, br. 6542, 25. 11. 1980., str. 10.

${ }^{700}$ Isto.

701 Isto.

${ }^{702}$ Sad me vidiš..., Večernji list, 27. 11. 1980., str. 11.

${ }^{703}$ Mrduljaš, Igor Diderot á la Pragois, Prolog, br. 46, god. XII(1980), str. 170-172.

${ }^{704}$ Isto, str. 172. 
početkom sedamdesetih godina kasnije su, zbog izostanka potpore „medijskih moćnika i dobrostojećih organizatora“", pripisivani drugim redateljima. ${ }^{705}$

ITD-ov Žak Fatalist jedna je od dviju predstava hrvatskih kazališta na sarajevskome Festivalu malih i eksperimentalnih scena Jugoslavije 1981. Predstava ondje ne osvaja niti jednu festivalsku nagradu, a novinski tekstovi, koji prate njeno uvrštavanje u program Festivala, zbog te činjenice izražavaju čuđenje te navode ocjenu da je to, zapravo, bila najbolja predstava u programu, ,jedina predstava koja zaslužuje da bude na ovom festivalu. “706

\section{1. 4. Milan Kundera Žak Fatalist i njegov gospodar (HNK Split, 1981.)}

Isti je dramski tekst premijeru u splitskome Hrvatskom narodnom kazalištu ostvario 2. lipnja 1981. Redatelj predstave, koja je u šest godina na repertoaru Kazališta ostvarila 25 repriznih izvedaba, bio je Dino Radojević. ${ }^{707}$ Krajem srpnja 1981. predstava je izvedena i na Splitskome ljetu te se u programu te kulturne manifestacije održala sljedeće četiri godine. ${ }^{708}$ Ujesen iste godine splitski HNK Radojevićevim Žakom Fatalistom sudjeluje u programu 14. Gavellinih večeri. U svome tekstu o toj kazališnoj smotri Branko Vukšić navodi da splitska predstava ,po svojoj idejnosti spada zasigurno u vrh Gavellinih večeri“6709.

U analiziranome tisku nisu zabilježene kritike splitske predstave. Motivaciju za njeno uvrštavanje u repertoar te kazališne godine iščitavamo iz intervjua Marina Carića, tadašnjega direktora drame splitskoga kazališta. Carić objašnjava, pozivajući se na riječi dramaturga Vjerana Zuppe, da je repertoar HNK-a te godine, koji premijerno prikazuje šest drama isključivo suvremenih autora, oblikovan ,,prema centralnom pitanju koje ovaj repertoar pokušava iznijeti: pitanje individualne odgovornosti pojedinca u vremenima izopačenih povijesnih prilika ${ }^{\text {“710. }}$

\footnotetext{
${ }^{705}$ Mrduljaš, Igor Diderot á la Pragois, Prolog, br. 46, god. XII(1980), str. 172.

${ }^{706}$ Zalihić, A. Festivalski razgovor o „Žaku fatalistu“ (Najbolja predstava MESS-a!?), Večernji list, 9. 4. 1981., str. 11.

${ }^{707}$ Repertoar hrvatskih kazališta, knjiga 3 - Repertoari 1981. - 1990., ur. Branko Hećimović, Hrvatska akademija znanosti i umjetnosti, 2002., str. 109.

${ }^{708}$ Isto, str. 189.

${ }^{709}$ Vukšić, Branko U vrhu kvalitete, Večernji list, br. 8355, 3. 11. 1986., str. 11.

710 Čudo koje smo planirali (intervju s Marinom Carićem, razgovarao Vojko Mirković), Večernji list, br. 6709, 16. 6. 1981., str. 5 .
} 


\section{1. 5. Milan Kundera Šala (Satiričko kazalište Jazavac, 1983.)}

Zagrebačko Satiričko kazalište Jazavac u prvoj je polovici osamdesetih na vrhuncu svoje popularnosti s petstotinjak predstava godišnje i ugledom vodeće komediografske kazališne kuće u Jugoslaviji. ${ }^{711}$ Godine 1983., kada obilježava dvadesetu obljetnicu svoga djelovanja, na repertoar uvrštava dvije drame neoficijelnih autora, dramatizaciju romana $\breve{S} a l a$ Milana Kundere i dramu Diktator na kruški (A na hrušce sedi diktátor) emigrantskoga dvojca Škutina - Gillar. ${ }^{712}$

Dramatizacija Kunderina romana u režiji Miroslava Međimorca ostvarila je 44 izvedbe i bila uvrštena u repertoar čiju su polovicu u godini premijere $\breve{S} a l e$ činile predstave utemeljitelja kazališta Fadila Hadžića. ${ }^{713}$ Izuzetno tržišno orijentirano kazalište, kakav je Jazavac bio, motive za postavljanje Šale zacijelo crpi iz sjajne recepcije Kunderina romana među hrvatskom čitateljskom publikom, a na toj su se činjenici gradila i očekivanja dobre recepcije predstave pa je premijera u dnevnome tisku reklamirana kao ,premijera književnoga bestselera“6714.

Popularnost romana zasigurno je pridonijela i snažnoj kritičkoj recepciji Jazavčeve predstave pa kritike pronalazimo u objema najtiražnijim hrvatskim dnevnim novinama toga vremena, Večernjemu listu i Vjesniku, zatim u časopisu Oko te najpopularnijem i najutjecajnijem omladinskom časopisu osamdesetih, Poletu. Međutim, suprotno očekivanjima, kazališna prilagodba proslavljenoga romana u tim kritičkim napisima nije pobrala pohvale poput romanesknoga predloška i Kunderina Žaka Fatalista u Teatru ITD tri godine ranije. Jedina je nedvosmisleno pozitivna kritika predstave ona Branka Vukšića koja načelno pohvalno ocjenjuje i književni predložak i razinu glumačke izvedbe Jazavčeva ansambla. ${ }^{715}$ Prema Vukšiću, tom je predstavom Jazavac dobio ,još jednu dobru i

\footnotetext{
${ }^{711}$ Vukšić, Branko Na početku - Šala, Večernji list, br. 4728, 21. 10. 1983., str. 5.

Poigravajući se granicama dopuštenoga u vlastitome društvu, Satiričko kazalište Jazavac 1986. svoju tradicionalnu manifestaciju Dane satire održava pod motom Cenzure nema - ima samo zabranjenih tema. Nikčević, Sanja Zabranjenih tema sve manje, Večernji list, 6. 6. 1986., br. 8228, str. 9.

712 Repertoar hrvatskih kazališta, knjiga 1 - Repertoari kazališta, kazališnih družina i grupa, partizanskih kazališta, festivala, smotri i susreta, ur. Branko Hećimović, Jugoslavenska akademija znanosti i umjetnosti, Zagreb, 1990., str. 338; Repertoar hrvatskih kazališta, knjiga 3 - Repertoari 1981. - 1990., ur. Branko Hećimović, Hrvatska akademija znanosti i umjetnosti, 2002., str. 57, str. 59.

${ }^{713}$ U repertoaru za 1983. čak je sedam predstava Fadila Hadžića: Državni lopov (hit s 270 prikazivanja tijekom devet godina na repertoaru), Čovjek na položaju, Punjena ptica, Piramida, Neprijatelj u tramvaju, Ugledni gost, Zmija.

714 Večernji list, br. 7470 i 7471, 10. 12. 1983., 11. 12. 1983.

715 Vukšić, Branko U fokusu kritike - kazalište - „Šala“, Večernji list, br. 7478, 20. 12. 1983., br. 5.
} 
discipliniranu ansambl predstavu, koja gledaoce uvlači u smijeh drugim, mnogo težim sredstvima“716. Unatoč negativnim kritikama, godinu se dana kasnije Jazavac upravo Kunderinom i Međimorčevom Šalom predstavlja na XI. danima satire koji su te godine bili posvećeni klasiku češke književnosti Jaroslavu Hašeku.

Kritička oštrica Dubravke Turković u časopisu Oko usmjerena je prema redateljskim rješenjima Miroslava Međimorca ${ }^{717}$ i dramaturškima Ivana Kušana. Turković navodi da je ,[j]edini razlog zbog kojeg bi valjalo pogledati ovu predstavu (...) neslana šala koju su redatelj i dramaturg učinili s dobrim Kunderinim romanom. “718 Postupke likova u dramskoj prilagodbi kritičarka smatra loše motiviranim i nejasnim, a likove nedorečenim, te negativno ocjenjuje i izvedbu glavnih glumaca Jadranke Elezović, Dubravka Sidora i Ivana Lovričeka kojemu zamjera da je lik Ludvika „doveo do toga da (...) djeluje nezanimljivo i statično.“719 Jedine pozitivne opaske upućene su redatelju Međimorcu za umješnost „dočaravanja povijesnoga vremena koje je osudilo Ludvikovu šalu“ ${ }^{720}$ te Mladenu Crnobrnji i Dušanu Gruboroviću za izvedbu dviju sporednih uloga.

Slični tonovi prevladavaju i u kritici Branka Ježića u Vjesniku koji ocjenjuje da su glumački ostvaraji uspjeli polovično te prigovara simplificiranje koje je dovelo do toga da su odnosi među likovima i bogatstvo Kunderina romana svedeni na „politički sukob“721. No, pritom Ježić naglašava težinu zadaće koju je imao redatelj Međimorec pristavši režirati i prilagoditi kazališnom mediju roman koji je ostvario tako snažnu recepciju kod publike i kritike uz mahom pohvalne ocjene.

Negativna je i kritika Vjeke Santrića objavljena u Poletu u kojoj kritičar uvrštavanje Šale na Jazavčev repertoar tumači znakom politizacije repertoara i uključivanja toga zagrebačkog kazališta u trend, u tome razdoblju rastući, tzv. političkoga teatra. U kritici znakovita naslova Trčkalica Santrić naglašava da je „od jedne sjetne knjige u Jazavcu (...) napravljena komedija, a od Kunderine Šale lakrdija. Prijaviti tu predstavu 'zbog rafiniranosti' na sarajevski MES isto je kao zamijeniti suncokretovo ulje ricinusovim““722. Santrić je oštar u svojoj kritici te kaže da je dramatizacija i ovoga romana shvaćena kao izlučivanje dijaloga iz

\footnotetext{
${ }^{716}$ Vukšić, Branko U fokusu kritike - kazalište - „Šala“, Večernji list, br. 7478, 20. 12. 1983., br. 5.

${ }^{717}$ U razdoblju koje prethodi redateljskome radu na Šali u Jazavcu redatelj Miroslav Međimorec dobiva značajne pohvale za svoj rad. U neslužbenom izboru najbolji kazalištaraca sezone 1981./1982., koje u svome programu organizira Radio Sljeme, proglašen je najboljim redateljem sezone za predstavu Sławomira Mrožeka Pješice koju režira u Teatru ITD. Najbolja predstava Pješice, Večernji list, br. 7025, 29. 6. 1982., str. 9.

718 Turković, Dubravka Neslano s ozbiljnom šalom, Oko, br. 310, 1984., str. 13.

719 Isto.

${ }^{720}$ Isto.

${ }^{721}$ Ježić, Branko Nije šala igrati „Šalu“, Vjesnik, br. 13033, 16. 12. 1983., str. 6.

${ }^{722}$ Santrić, Vjeko Trčkalica, Polet, br. 253, 1984.
} 
proznoga teksta. Predstavu naziva „,smušenom priredbom““723 s osobitim prigovorima naglašavanju komičnih situacija koje su u romanu tragikomične, scenografskim rješenjima te kulisama koje su „zbrda-zdola sklepane i razbacane“6724.

\section{2. Václav Havel}

Dramski je tekst najznačajnijeg dramatičara neoficijelne češke književnosti Václava Havela u hrvatskom kazalištu prvi put postavljen 1966., tri godine nakon Havelova dramskoga prvijenca u domovini ${ }^{725}$ i dvije godine prije vojne intervencije zemalja Varšavskoga ugovora na tlu Čehoslovačke. U veljači 1966. zagrebački Teatar ITD izvodi Havelovu dramu Drugarsko veče (Zahradní slavnost) u režiji Nikole Petrovića, a plakat za predstavu izrađuje tada mlad dizajner, a 2008. laureat nagrade za životno djelo Hrvatskoga dizajnerskog društva, Mihajlo Arsovski. Iste godine, 25. prosinca, u Zagrebačkome gradskom kazalištu Komedija održana je i premijera Havelove drame Izvještaj (Vyrozumění). Dok izvori korišteni pri izradi ovoga rada ne donose podatke o broju izvedaba Drugarske večeri u Teatru ITD, Izvještaj je kazalištu Komedija donio tek dva prikazivanja. ${ }^{726}$

Već nekoliko godina kasnije Havel zbog svoga opozicijskoga djelovanja i kritika upućenih vlasti biva potisnut na marginu društva. Njegov posljednji javni nastup prije dvadesetogodišnjeg disidentskog djelovanja zabilježen je u lipnju 1969. kada nastupa na političkome skupu u Ostravi. ${ }^{727} \mathrm{U}$ godinama koje slijede, kao dramatičar traži motivaciju za umjetnički rad koji je u okolnostima koje su vladale češkim društvom toga doba za dramski i kazališni rad dodatno otežan budući da je bio svjestan činjenice da dramski tekst svoju cjelovitost dobiva tek u sinergiji s publikom. ${ }^{728}$

\footnotetext{
${ }^{723}$ Santrić, Vjeko Trčkalica, Polet, br. 253, 1984.

724 Isto.

${ }^{725}$ Prva drama Václava Havela izvedena u Čehoslovačkoj je Vrtna svečanost (Zahradní slavnost), izvedena 1963. u praškome kazalištu Na zábradlí.

${ }^{726}$ Repertoar hrvatskih kazališta, knjiga 1 - Repertoari kazališta, kazališnih družina i grupa, partizanskih kazališta, festivala, smotri i susreta, ur. Branko Hećimović, Jugoslavenska akademija znanosti i umjetnosti, Zagreb, 1990., str. 347.

727 Šömen, Branko Češki sanjar: Václav Havel od disidenta do prezidenta, Profil, Zagreb, 2012., str. 93.

${ }^{728}$ U svome eseju Osobitosti kazališta, koji 1971. u zborniku Teatar XX. stoljeća objavljuje i Tomislav Sabljak, Havel razvija ideju o publici kao posebnoj, dodatnoj dimenziji dramske umjetnosti bez koje dramski tekst ne može ostvariti svoju cjelovitost. Ista razmišljanja iznosi u slavnome intervjuu koji s njim vodi Karel Hvižd'al, a koji je u hrvatskome prijevodu objavljen 2000.
} 
Uvjeti u kojima stvara tijekom normalizacije utječu na Havelovo ljudsko i umjetničko samopouzdanje. No, nakon početnoga šoka krajem šezdesetih i statusa quo početkom sedamdesetih, naime prvih šest godina normalizacije Havel naziva „,bezobličnom magluštinom“, ${ }^{729}$ sredinom toga desetljeća cijela disidentska scena oživljava. Sâm je Havel u svojim izjavama potvrdio da 1975. smatra prijelomnom u dvadesetogodišnjem razdoblju. Iste je godine organizirana amaterska izvedba njegove drame Prosjačka opera (Žebracká opera) u restoranu praške četvrti Horní Počernice, ${ }^{730}$ Havel osniva samizdatsku izdavačku kuću Edice Expedice, a piše i tekst Audijencije, jedne od svojih najpoznatijih drama. ${ }^{731}$ Disidentske aktivnosti potom su se još više razgranale: dvije godine kasnije jedan je od utemeljitelja Povelje 77, a 1978. osniva Odbor za obranu nepravedno progonjenih (VONS). Sva su ta zbivanja otvorila prostor slobode tijekom sljedećega desetljeća te pozitivno utjecala na ono što je Havelu kao dramatičaru, i čovjeku, bilo nužno potrebno - samopouzdanje. O osjećajima nakon amaterske izvedbe Prosjačka opera pred tristotinjak gledatelja u Horním Počernicama 1975. Havel krajem osamdesetih izjavljuje:

„Poslije sedam godina prvi sam put (i posljednji put, za sljedećih jedanaest godina) gledao svoj komad na pozornici i vlastitim se očima uvjerio da kad hoću, još mogu napisati nešto što se može izvoditi. Svi ti događaji zajedno vratili su mi osjećaj da sam još sposoban za nešto i ulili mi polet za novu aktivnost.“"732

Na tom je tragu i Havelov odgovor na pitanje novinara Karela Hvížd'ale kako je pisati dramu kada dramatičar nema ,,svog kazališta, svoga redatelja ili dramaturga“733. Dramatičar mu odgovara da je ,,[t]o vrlo mučna situacija, još teža od one u kojoj pjesnik ili romanopisac ne može publicirati u vlastitoj zemlji. Drama je, naime, prisnije povezana s određenim 'sada' i 'ovdje'; ona uvijek nastaje iz određene konkretne društvene i duhovne klime i retrogradno cilja

\footnotetext{
${ }^{729}$ Havel, Václav Saslušanje na daljinu (razgovor s Karelom Hvižd'alom), Irida, Zagreb, 2000., str. 132.

${ }^{730}$ Prema Havelovoj izjavi tekst Prosjačke opere napisan je po narudžbi za jedno praško kazalište koje je dramu trebalo izvesti pod tuđim imenom. Kada se to nije dogodilo, Havelov prijatelj Andrej Krob sa skupinom amatera uvježbava predstavu i izvodi je u restoranu Kod Čelikovskih u praškoj četvrti Horní Počernice. Izvedba je izazvala snažnu reakciju vlasti i nije se ponovila. Šömen, Branko Češki sanjar: Václav Havel od disidenta do prezidenta, Profil, Zagreb, 2012., str. 107-108.

${ }^{731} \mathrm{Na}$ vanjskopolitičkome planu 1975. prijelomna je zbog održavanja Konferencije o europskoj sigurnosti i suradnji u finskome Helsinkiju. Zaključke konferencije potpisuju i predstavnici zemalja komunističkoga društvenog uređenja i tako se, na načelno razini, obavezuju poštovati ljudska prava i slobodu govora.

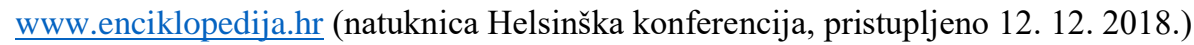

732 Šömen, Branko Češki sanjar: Václav Havel od disidenta do prezidenta, Profil, Zagreb, 2012., str. 108.

${ }^{733}$ Havel, Václav Saslušanje na daljinu (razgovor s Karelom Hvižd'alom), Irida, Zagreb, 2000., str. 80.
} 
i na jedno i na drugo; ona jednostavno treba svoj dom i postaje ono što jest istom tada kad je se u tom njezinu 'domu' može vidjeti u kazalištu - kao tekst ona je tek poluproizvod.“734

Tijekom cijeloga razdoblja zabranjenosti u matičnoj zemlji Havelov dramski rad dobiva niz priznanja u inozemstvu o čemu nerijetko izvještavaju i pisani mediji u Hrvatskoj. Od 1968. do sredine osamdesetih tri su njegove drame nagrađene brodvejskom nagradom Obie časopisa The Village Voice ${ }^{735}$ 1968. drama Izvještaj, 1970. Otežana mogućnost koncentracije te 1984. Izložba. Prvu je nagradu u Čehoslovačku prokrijumčario i predao dramatičaru 1984. Joseph Papp, osnivač New York Shakespeare Festivala, no na dodjelu nagrada iz 1970. i 1984. Havel čeka sve do $2006 .{ }^{736}$ Laureatom nizozemske nagrade Erazmo Rotterdamski u vrijednosti 200000 maraka postaje 1986. Prema napisima u hrvatskome dnevnom tisku koji donosi tu vijest, nizozemska kraljica pokušava uvjetovati sadržaj dramatičareva pozdravnoga govora budući da je htjela izbjeći kritiku tadašnje čehoslovačke političke elite. ${ }^{737}$ Tri godine kasnije Havel je dobitnik i nagrade za mir Frankfurtskoga sajma knjiga $^{738}$ čiji novčani dio od 25000 njemačkih maraka namjenjuje osnivanju izdavačke kuće Atlantis čija je aktivnost trebala biti objavljivanje djela autora neoficijelne književne scene. ${ }^{739}$

Svoj kvantitativni vrhunac na hrvatskim pozornicama Havelov opus doživljava početkom osamdesetih godina, u razdoblju koje je slijedilo potpisivanje Povelje 77 zbog čega dramatičar biva osuđen na zatvorsku kaznu. Godine 1980. zagrebačko Dramsko kazalište Gavella na repertoar uvrštava jednočinke Audijenciju i Izložbu, i to je prvo Havelovo pojavljivanje na pozornici nekog hrvatskoga kazališta od 1966. Novinski napisi koji prate Gavellinu premijeru 1980. bilježe da je Havelov dramski rad nepoznat našoj javnosti. ${ }^{70}$ Sljedeće godine prikazana je drama Protest u Teatru ITD, a 1982. Audijencija i Izložba u splitskome HNK-u. Talijanska drama riječkoga Narodnog kazališta Ivan Zajc iste jednočinke

\footnotetext{
${ }^{734}$ Havel, Václav Saslušanje na daljinu (razgovor s Karelom Hvižd'alom), Irida, Zagreb, 2000., str. 80. Uvodni tekst prvoga broja Prologa Zašto istupamo potpisanoga Redakcija, koju su u prvim brojevima činili Darko Gašparović, Drago Kekanović, Miro Međimorec, Vladimir Roksandić, Ante Rumora i Slobodan Šnajder, progovara o povezanosti aktualnoga stanja u društvu i situacije u kazalištu. Naime, Prologov uvodni tekst tvrdi da ,se upravo u kazalištu zbog njegove specifičnosti najjače i najdrastičnije, s gotovo seizmografskom osjetljivošću, registriraju svi potresi, usponi i padovi čiste umjetnosti u određenoj epohi, njen odnos prema društvu i svijetu i obrnuto. "Zašto istupamo, Prolog, god. 1, br. 1, 1968., str. 3-4.

${ }^{735}$ Nagradu Obie časopis The Village Voice dodjeljuje najuspješnijim dramskim predstavama Broadwaya koje nisu djela klasične dramske književnosti.

${ }^{736}$ Robertson, Campbell Better late than never https://www.nytimes.com/2006/12/01/theater/better-late-thannever.html (članak objavljen 1. 12. 2006., pristupljeno 15. 10. 2017.)

737 „Erazmo“ Václavu Havelu, Večernji list, br. 8116, 24. 1. 1986., str. 20; Kurbel, Virgil Prizma, Večernji list, br. 8349, 27. 10. 1986., str. 10.

${ }^{738}$ Havelu za mir, Večernji list, br. 9273, 11. 6. 1989., str. 28.

${ }^{739}$ Kurbel, Virgil Mogu više od dr. Koprive, Večernji list, br. 9399, 17. 10. 1989., str. 17.

${ }^{740}$ Stublija, Želimir Poremećena komunikacija, Vjesnik, 23. 2. 1980.
} 
postavlja 1984. Slijedi stanka sve do 1989. i Očajno smiješnoga (Largo desolato) u Dramskome kazalištu Gavella. Godine 1990. dramatičar, tada već i predsjednik Republike, tekstom drame Asanacija dolazi i do, možda, najprestižnije pozornice, one zagrebačkoga Hrvatskog narodnog kazališta.

Najizvođenija Havelova drama u hrvatskim kazalištima tijekom razdoblja normalizacije u domovini jest jednočinka Audijencija. Tijekom osamdesetih čak tri hrvatska kazališta na pozornicu postavljaju taj tekst, zagrebačka Gavella 1980., dvije godine kasnije Hrvatsko narodno kazalište u Splitu ${ }^{741}$ te 1984. Talijanska drama Narodnoga kazališta Ivan Zajc u Rijeci. ${ }^{742}$ Audijencija i Asanacija ujedno su i Havelovi tekstovi koji ostvaruju najsnažniju recepciju među hrvatskim kritičarima. U slučaju Asanacije korijene dijela medijske slave, zasigurno, možemo tražiti u činjenici da na pozornicu zagrebačkoga HNK-a dolazi u trenutku kada je Havel zvijezda čehoslovačke pa i europske političke scene.

Tekstovi hrvatskih kritičara i prevoditelja perpetuiraju tezu o Havelovim dramskim tekstovima, konkretnije sudbinama glavnih junaka njegovih drama, kao preslici njegova životnoga iskustva. U popratnome tekstu prijevoda ulomka drame Largo desolato prevoditeljica Renata Kuchar tvrdi da je ta Havelova drama „bez sumnje autobiografska“7743. Nikola Batušić ${ }^{744}$ i Boris Senker ${ }^{745}$ početkom osamdesetih autobiografsku potku uočavaju u tekstovima Audijencije i Izložbe, a tezu ponavlja i Aleš Fuchs desetak godina kasnije. ${ }^{746}$ Havelova drama kao preslika njegove biografije promatrana je i u tekstu objavljenu u Večernjemu listu 1990. povodom prve javne izvedbe njegova teksta u Pragu nakon praškoga proljeća. $^{747}$

Česta kritičarska poistovjećivanja svojih likova i autobiografije autor potvrđuje u nekim svojim javnim istupima. U intervjuu koji iz njemačkoga tiska 1989. prenosi Večernji list povodom dodjele nagrade za mir Frankfurtskoga sajma knjiga, Havel priznaje da u drami Largo desolato ima autobiografskih elemenata, no naglašava da svaki tumač njegovih drama koji povuče paralelu između sudbina njegovih likova i njegove vlastite - griješi. ${ }^{748} \mathrm{U}$ razgovoru s Karelom Hvížd'alom Havel navodi da je ista drama zaista nadahnuta njegovim

\footnotetext{
741 Repertoar hrvatskih kazališta, knjiga 3 - Repertoari 1981. - 1990., ur. Branko Hećimović, Hrvatska akademija znanosti i umjetnosti, 2002., str. 109.

742 Stipaničić, M. U dva dana - tri premijere, Vjesnik, br. 13093, 17. 2. 1984., str. 7.

${ }^{743}$ Kuchar, Renata Popratni tekst uz prijevod ulomka drame Largo desolato Václava Havela, 15 dana, br. 3 , 1987., str. 26-29.

744 Batušić, Nikola Havel u Gavelli, Republika, br. 7/8, 1980.

${ }^{745}$ Senker, Boris Pegaz u ormi, Prolog, 1980. br. 43, god. XII(1980), str. 159-163.

${ }^{746}$ Fuchs, Aleš Glumci i češka revolucija, Novi prolog, br. 17/18, 1990.

${ }^{747}$ Audijencija - i kod kuće, Večernji list, br. 9479, 10. 1. 1990., str. 31.

${ }^{748}$ Kurbel, Virgil Mogu više od dr. Koprive, Večernji list, br. 9399, 17. 10. 1989., str. 17.
} 
iskustvom te da je vlastite osjećaje i psihičko stanje utkao u lik dr. Kopřive. ${ }^{749}$ Nadalje, dramatičar tvrdi da lik Foustke u drami Iskušavanje ${ }^{750}$,govori stvari gotovo istovjetne onome što ja sâm o svemu tome mislim, i to vrlo sličnim riječima kojima ja to sâm govorim na drugome mjestu sad već posve ozbiljno i sad već posve sâm za sebe, primjerice u svojim pismima iz zatvora, ili u ovom našem razgovoru“751. Jednočinka Audijencija je, prema Havelovoj izjavi, nadahnuta desetomjesečnim radom u pivovari u češkoj provinciji početkom sedamdesetih. $^{752}$

Prema kraju osamdesetih, a osobito nakon Havelova preuzimanja predsjedničke funkcije, hrvatski tisak objavljuje vijesti o inflaciji zanimanja za, do prije nekoliko mjeseci, pripadnika neoficijelne kulturne scene. O potpuno izmijenjenim okolnostima za dramatičara/državnika u domovini kontinuirano pišu novinari tjednika Danas te hrvatske čitatelje izvještavaju, primjerice, o početku snimanja filma prema Havelovoj drami, ogromnim nakladama koje, sada više ne u ilegali, ostvaraju disidentski autori, uprizorenjima Havelovih drama na pozornicama praških kazališta. ${ }^{753} \mathrm{U}$ hrvatskom je tisku objavljen niz tekstova koji donose biografske podatke iz Havelova života, sjećanja vezana uz dramatičara hrvatskih kulturnih radnika, poput Božidara Violića, Pere Kvrgića, Zlatka Viteza, Ivana Kušana, koji su na različite načine s Havelovim dramskim radom bili povezani tijekom protekla dva desetljeća. ${ }^{754}$ Početkom 1990. zagrebački Vjesnik dulje od mjesec dana objavljuje feljton o novoizabranom čehoslovačkom predsjedniku, zapravo ulomke knjige Branka Šömena Češki sanjar koja je godinu ranije objavljena na slovenskome jeziku. Uspjeha Václava Havela na političkome polju dotiče se i u intervjuu Vjesniku u veljači 1990. György

\footnotetext{
${ }^{749}$ „Ta je drama zaista nadahnuta vlastitim iskustvima neposrednije negoli druge drame, što ne vrijedi samo za pojedine njezine konkretne motive, nego i za samu njezinu osnovnu temu: и Kopřivinu sam dekomponiranost zaista unio dio svoje vlastite rastrojenosti, u stanovitom je smislu to zaista karikirana slika nečega što potječe od mene i iz mojega poslijezatvorskog očajanja. Unatoč tome, to nije autobiografska drama u tom smislu da govori o meni i samo o meni kao takvom. Ona poglavito želi biti općeljudska prispodoba, ona govori takorekuć 'o čovjeku općenito'.“ Havel, Václav Saslušanje na daljinu (razgovor s Karelom Hvižd'alom), Irida, Zagreb, 2000., str. 75 .

${ }^{750}$ „Uz Kušnju: u tome me nitko, koliko mi je poznato, nije pokušavao prepoznati. Pri tome ta je drama također nadahnuta mojim osobnim iskustvom, čak i znatno dublje i bolnije nego Largo desolato... “ Havel, Václav Saslušanje na daljinu (razgovor s Karelom Hvižd'alom), Irida, Zagreb, 2000., str. 76.

${ }^{751}$ Isto, str. 213.

${ }^{752}$ Isto, str. 136.

${ }^{753}$ Pauk za vratom (intervju s Karelom Steigerwaldom, Dagmar Ruljančić), Danas, 9. 1. 1990., str. 40-42; Foretić, Dalibor Praška kazališta, Danas, 20. 3. 1990., str. 44-45; Pogled u jučer (intervju s Dušanom Karpatským, Jasmina Kuzmanović), Danas, 22. 5. 1990., str. 44-45; Snimanje po Havelu, Danas, 20. 11. 1990., str. 47.

${ }^{754}$ Butorac, Tomislav Bivši huligan, šef države, Danas, 9. 1. 1990., str. 54-55; Pauk za vratom (intervju s Karelom Steigerwaldom, Dagmar Ruljančić), Danas, 9. 1. 1990.; Prica, Jasmina Iz samice na prijestolje, Danas, 16. 1. 1990., str. 42-43, Molitva za Václava Havela, Vjesnik, br. 15222, 4. 2. 1990., str. 22.
} 
Konrád kada, analizirajući promjene u nizu zemalja srednje Europe, progovara i o spontanoj narodnoj simpatiji prema novoizabranome čehoslovačkom predsjedniku. ${ }^{755}$

Opsežnim prilogom povodom Havelova preuzimanja funkcije predsjednika Republike javlja se Katica Ivanković u časopisu Quorum. ${ }^{756}$ Ondje 1990. objavljuje tekst Havel na Hrad $^{757}$ i hrvatski prijevod Havelove drame Iskušavanje (Pokoušeni). ${ }^{758}$ Treći dio cjeline o Havelu u tome broju Quoruma čini prijevod s francuskoga dramatičarova govora Govorimo o riječima s dodjele Nagrade njemačkih knjižara na sajmu knjiga u Frankfurtu u listopadu 1989. ${ }^{759}$ Govoreći o moći riječi, Havel podsjeća na sudbinu umjetnika u zemljama totalitarnoga režima te na važnost i moć riječi zbog koje se nerijetko završavalo u zatvoru, a koja uvijek može biti okrenuta u dvama smjerovima: „Pred riječi čija sloboda i istinitost galvaniziraju, postoji i riječ koja hipnotizira, koja vara, koja fantazira, riječ bjesomučna, lažna, opasna, smrtonosna. Riječ - strijela. “760 U istome govoru Havel progovara i o ulozi intelektualca, korektiva u društva, temi koju obuhvaća i u dijelovima svojih zatvorskih Pisama Olgi početkom osamdesetih:

„Uostalom, ne počiva li upravo u tome, u nepovjerenju prema riječima i u otkrivanju strahota koje mogu prikriveno drijemati u njima, najspecifičnija misija intelektualca? Nekad je, u Pragu, moj prethodnik na tribini, André Glucksmann, usporedio intelektualca s Kasandrom, jer je njegova dužnost da dobro sluša riječi moćnika, da ih nadzire, da opominje i da proriče zlo što ga one mogu označiti ili do njih dovesti." ${ }^{\text {(761 }}$

Splitsko uprizorenje jednočinki Audijencije i Izložbe 1982. ostvarilo je najslabiju kritičku recepciju od svih Havelovih predstava u Hrvatskoj tijekom analizirana razdoblja. U tisku je uočena tek kraća najava premijere objavljena u Večernjemu listu. ${ }^{762}$ No, ta je predstava popraćena izdavanjem prilično iscrpne i zanimljive programske knjižice koja sadrži, osim faktografskih podataka o predstavi, fotografije predstave, zapis redatelja Vlatka

\footnotetext{
${ }^{755}$ Srednjoj Evropi trebaju mudraci (intervju s Györgyjem Konrádom, Jovo Paripović), Vjesnik, br. 15236, 18. 2. 1990., str. 14.

756 Ivanković, Katica Havel na Hrad, Quorum, 1(29), 6(1990), str. 2-17.

${ }^{757} \mathrm{U}$ tome tekstu Katica Ivanković donosi i periodizaciju Havelova dramskog rada pri čemu u njegovu drugu fazu ubraja drame Audijenciju, Izložbu i Protest, tzv. „drame iz razdoblja zabranjenosti“, sve tri napisane u drugoj polovici 1970-ih i na pozornice hrvatskih kazališta postavljene tijekom osamdesetih.

${ }^{758}$ Prijevod drame Iskušavanje (Pokoušení) objavljen je iste godine na srpskom jeziku u Gornjem Milanovcu u izdavačkoj kući Dečje novine. Srpski prijevod naslova drame glasi Iskušenje.

${ }^{759}$ Kako je riječ o 1989., godini u kojoj Havelu još uvijek nije dopušten izlazak iz zemlje, nagrada u Frankfurtu dodijeljena je u njegovoj odsutnosti.

${ }^{760}$ Havel, Václav Govorimo o riječima, Quorum, 6(1990), 1(29), str. 12.

761 Isto, str. 15.

762 Premijera Havelovih jednočinki, Večernji list, br. 6652, 9. 4. 1982., str 9.
} 
Perkovića, ulomke Havelova eseja Osobitosti kazališta objavljena desetak godina ranije u splitskom časopisu Mogućnosti i knjizi Teatar XX. stoljeća Tomislava Sabljaka te intervju s Aleksandrom Čakićem, glumcem koji je u splitskoj predstavi utjelovio lik Vaněka.

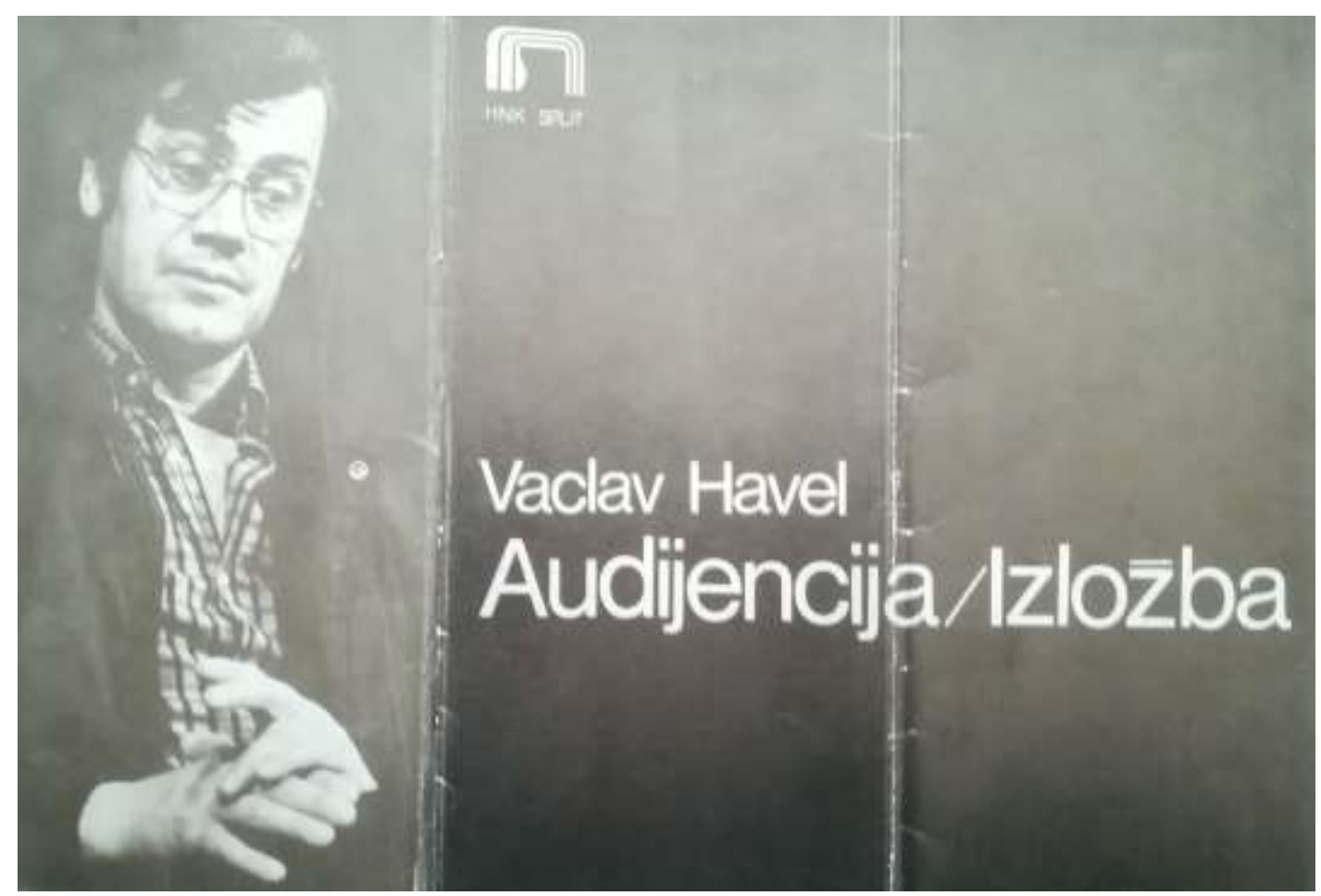

Fotografija IV: Naslovnica programske knjižice predstava Audijencija i Izložba Václava Havela, HNK Split, 1982.

Izvor: Odsjek za povijest hrvatskog kazališta HAZU-a 


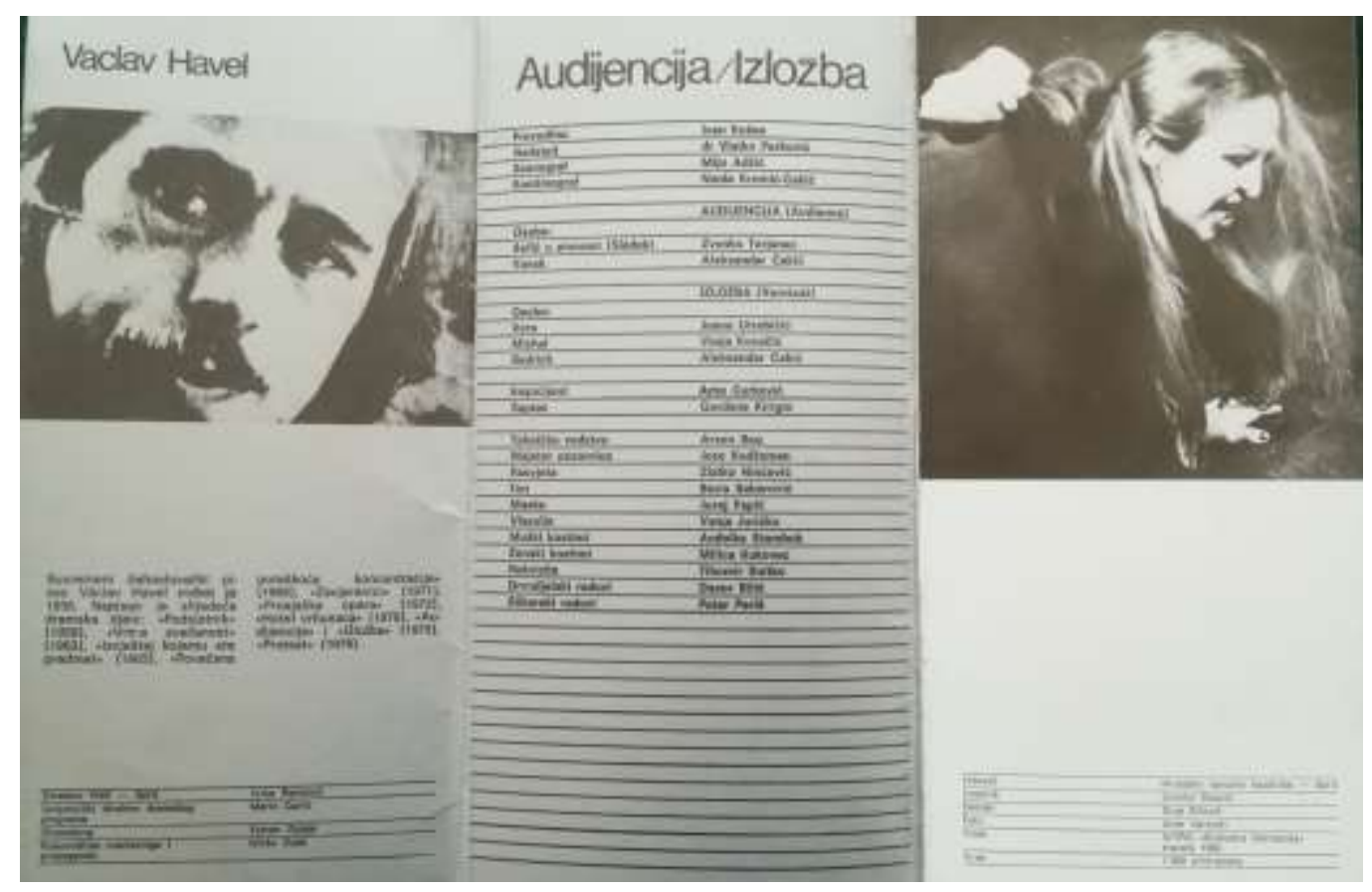

Fotografija V: Unutrašnja strana omota programske knjižice predstava Audijencija i Izložba Václava Havela, HNK Split, 1982.

Izvor: Odsjek za povijest hrvatskog kazališta HAZU-a 


\section{O DVA HAVELOVA KOMADA}

Umjatnik uvijek pretażo svoje bice u djela. III. kako bi to Havel rekao, otudujuci sebe - dohyaca sobe. otkrivajuci nam najvecu tajnu - Covjeka Moglo bi He, dakle, raci, kao sito je uostalom vec račeno, da uvijek nanovo I nanovo iskazuje jedno isto djelo.

I ako bi se tako rekio, ne bi se pogrijeẫilo. Stuar je samo 4 tome što se time ne bi rekto sve. Jer ma koliko svako umjetnikevo dlelo iskazuje umjetnika samoga. toliko ono iskazuje I samo sebe. A to znaci da I djelo ima avoje bicese. I na toj točci zapazanja po. staje moguce razluciti specifičnosti dvaju djeln Istog autora, baš kao 1 uoçiti njibovo zajednifitvo.

Vecer koju Gemo provesti a dvije Havelove jednotinke nudi nam da uocimo I njihove razlicitosti I nilhove zajednistvo.

-Audilencljam se bavi razotiknivanjem intimnog sano. obrambenog mehanizmn covjeka u datosti jedne drustvene situacije, Stvarnobt oveg djela otkriva se kao stvarnost samon zivota, I to ne samo ma razini ideolofike pretpostavke djoin, vec I na planu njegove for me: eatetaki realltet djela podudaran in 8 osjetom Elvothe pojavnosti, Cime autor učvrścuje uvjarljivost svoje ponude. Govoreci fkalskom terminologijom, reklo bi se reatisticko djelos, Medutim. unutar to atvarnosti djela, ifi, kako num to djelo nudi, stvamost same stvarnogti, svo ato je estavlieno covjeku je vríenje u krug. grickanje vlastitog rope, I eventualna iluzija da se nadmuthis mehanizsm samog kruga. Hivelova dva lica zarotirana unutar tog bezizlazja pokrece vlastita psithička motorika prema obrascima ved́ tradicionalnog nasfieda. Havelu fe, dalde. bilo nemoguce zenbici odredenu shemu, lor avako vríaje privodi nas ipak goo. metrijskim izvaristima. Medutim, shema nithovih obrtaja ispod neprobojnosti kruga ze vanjski pogled ostaje nevidifiva. Ona je tok trasa utopljenika koji se ne nazire ne ustaljonol povrbini. Na povrsini je realnost. Kružnl mahanizam situacije podvodni ie vir-

Znaci: Havel je napisao raalistiçco djelo7 $\mathrm{Da}$, recimo da jeset Jer niko bi odmah bilo moguce otkriti njegovu shemu, onaj realistickl omotad kojim je uvjetovan mehapizam situacije poknzao bl se kao proboitin A pro. bojnoat omotača okmjla bi njegovu uvjerijivost. Situa- elia bi time izqubila svoju razložnost, prestala bi biti stvarna stvarnost Vanekova I Slädekova. I tako bi bio oduzet razlog $I$ samoj shemi.

U drugom djelu, slzložbic, a njega, to je: jako važno, autor povezuje s -Audijancijom. istim licem, društvesso ingencenim knilzevnikom Vanekom, Havel iz realnosti altuaclie, dakle iz jedne Vanekove stvarnosti, prelazi ha razmatranje reperkusija to roainosti na obiteljski plan. On se sada bavi posljedicama situacije I pracenjum nilhovs razvoja I umnožavanjes prema jednoj ma. tematskoj logici. Time subjekt njegove jodnocirtke preetaje biti sama situacija cona ostaje samo znano lzvo. ríte svoga), dok subjekt postaje njena posljedica. Ti. me Havel iskaracuje in prethodne-realiaticke- datosti stvarnosti y gradi jedan novi stilski realitet djela, nešto poput matemutaki postavljene teoreme. I u tom reali. totu shema njegovsg prethodnog kruga jasnije se nazire na povssini, bez straha da co time ponistiti samu sebe.

Vlatko Perkovic

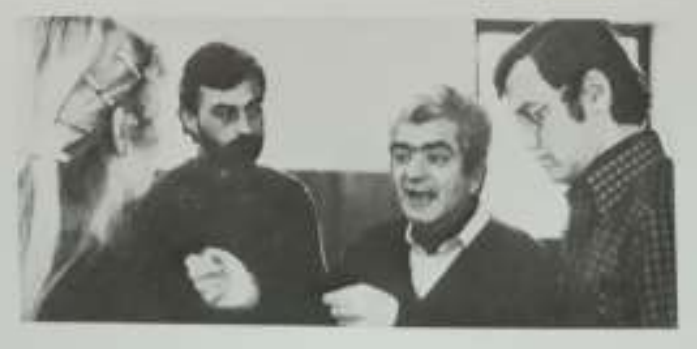

Fotografija VI: Zapis redatelja Vlatka Perkovića u programskoj knjižici predstava Audijencija i Izložba, HNK Split, 1982.

Izvor: Odsjek za povijest hrvatskog kazališta HAZU-a

\section{2. 1. Václav Havel Audijencija i Izložba (Dramsko kazalište Gavella, 1980.)}

Havelov prodor na hrvatske pozornice tijekom osamdesetih započinje premijerom jednočinki Audijencije i Izložbe 22. veljače 1980. u zagrebačkome Dramskom kazalištu Gavella. ${ }^{763}$ Do 27. siječnja 1982., dokad su bile u programu kazališta, jednočinke su

${ }^{763}$ Repertoar hrvatskih kazališta, knjiga 1 - Repertoari kazališta, kazališnih družina i grupa, partizanskih kazališta, festivala, smotri i susreta, ur. Branko Hećimović, Jugoslavenska akademija znanosti i umjetnosti, Zagreb, 1990., str. 320. 
reprizirane 55 puta, što je zadovoljavajući broj repriznih izvedaba. ${ }^{764}$ Repertoar DK-a Gavelle i te je kazališne sezone obilovao uglednim dramskim imenima pa se Havelove jednočinke u programu izmjenjuju s tekstovima klasika hrvatske i svjetske dramaturgije poput Miroslava Krleže, Milana Begovića, Williama Shakespearea, Augusta Strindberga i Antona Pavloviča Čehova.

Oba je teksta, u prijevodu Ivana Kušana, režirao Božidar Violić ${ }^{765}$ te pritom uloge dodijelio vodećim imenima tadašnjega zagrebačkog glumišta Peri Kvrgiću, Zlatku Vitezu, Heleni Buljan i Vlatku Duliću. Godinu i pol kasnije, u listopadu 1981., upravo je Havelova Audijencija predstava koja DK Gavellu predstavlja na 8. Gavellinim večerima što je, možemo pretpostaviti, pokazatelj da ju je uprava kazališta smatrala jednim od kvalitativnih vrhunaca Gavelline produkcije te kazališne sezone.

Jednočinke Audijencija i Izložba premijerno su prikazane 1976. u bečkome Burgtheateru. Iste godine Audijenciju izvodi Divadlo na tahu u privatnome prostoru Andrea Kroba u Hrádečku kod Trutnova - godinu ranije Krob je sa suradnicima organizirao i javnu izvedbu Havelove Prosjačke opere. ${ }^{766}$ Godine 1978. upravo Václav Havel i Pavel Landovský utjelovljuju dva glavna i jedina lika te drame - radnike u pivovari Vaněka i Sládeka te predstavu igraju u jednome privatnom stanu. Zvučni zapis izvedbe na gramofonskoj ploči objavljuje egzilni izdavač Šafrán 78 iz švedske Uppsale, a potom se snimka često nalazi u programu radijskih postaja Slobodna Evropa i Glas Amerike. ${ }^{767}$ Lik Vaněka, kao svojevrsna alter ega samoga autora, nosi tako snažnu simboliku da 1989. skupina Havelovih prijatelja, želeći dramatičaru javno čestitati rođendan što tada nije bilo moguće, u komunističkome glasilu Rudé právo plaća objavljivanje čestitke Ferdinandu Vaněku koja je bila objavljena uz

\footnotetext{
Dvije godine kasnije iste se jednočinke izvode i u splitskome HNK-u u režiji Vlatka Perkovića. Ondje su se na programu zadržale vrlo kratko, nešto više od mjesec dana, od sredine travnja do sredine svibnja 1982., te nakon premijere reprizno bile izvedene još samo četiri puta. Izvedbama se bavi kratak tekst objavljen u Večernjemu listu koji donosi podatke o redatelju i glumačkoj postavi, no bez vrijednosne procjene ikoje sastavnice predstave. (Od „Audijencije“ do „Izložbe“, Večernji list, br. 6946, 16. 4. 1982., str. 9)

${ }^{764}$ Gavelline predstave iz toga razdoblja koje su se na programu zadržale približno isto vrijeme kao Audijencija i Izložba - 11 mjeseci - mahom su imale manji broj repriznih izvedaba: August Strindberg Vjerovnici 18 izvedaba u 9 mjeseci, Milan Begović Pustolov pred vratima 36 izvedaba u 17 mjeseci.

765 U časopisu Gordogan 1990. objavljivani su dnevnički zapisi Božidara Violića nastali tijekom redateljeva višemjesečna boravka u Švedskoj početkom 1970-ih. U tekstu Violić svoj boravak ondje naziva ,stipendijskom emigracijom“ - razdoblje je nakon sloma hrvatskoga proljeća. Violić, Božidar Izgubljeni dnevnik: Švedska, Gordogan, 11(1990), 31-33, svibanj-prosinac, str. 71-116.

766 Janoušek, Pavel i suradnici Dějiny české literatury 1945-1989, IV. knjiga 1969-1989, Academia, Prag, 2008. str. 561.

${ }^{767}$ Janoušek, Pavel i suradnici Dějiny české literatury 1945-1989, IV. knjiga 1969-1989, Academia, Prag, 2008. str. 561.
} 
fotografiju Václava Havela. ${ }^{768}$ Do prve javne izvedbe Audijencije, odnosno službene čehoslovačke premijere, dolazi u listopadu 1989. kada dramski tekst u Brnu na scenu postavlja amaterska kazališna skupina Váha - prema inicijalima dramatičara - koju okuplja student tamošnjega Filozofskog fakulteta Roman Ráček. ${ }^{769}$

Postavljanje Audijencije i Izložbe 1980. u Dramskome kazalištu Gavella, u vrijeme kada autor u matičnoj zemlji služi zatvorsku kaznu zbog oporbenih aktivnosti, čehoslovačko veleposlanstvo u Zagrebu nije dočekalo s oduševljenjem. O tome u javnim istupima od 1990. svjedoče glavni akteri zbivanja poput redatelja Božidara Violića i glumca Pere Kvrgića. Časopis Gordogan 1990. objavljuje Violićeve dnevničke zapise nastale tijekom studijskoga boravka u Švedskoj početkom sedamdesetih i popratni tekst u kojem redatelj uspoređuje društvene okolnosti u Čehoslovačkoj i Hrvatskoj početkom osamdesetih. Pritom svjedoči o pritiscima čehoslovačkoga veleposlanstva koje je zahtijevalo zabranu izvođena ili, barem, skidanje s Gavellina repertoara Havelovih jednočinki. Tom zahtjevu nije udovoljeno. ${ }^{770} \mathrm{O}$ istim zbivanjima progovara i Pero Kvrgić u Vijencu 2013. Navodno su, prema tvrdnjama Pere Kvrgića iz istoga novinskog intervjua ${ }^{771}$ Gavellini glumci dramatičaru ilegalnim putem pokušali dopremiti kazališnu knjižicu predstave s potpisima glumaca, no u tome nisu uspjeli. ${ }^{772}$

\footnotetext{
${ }^{768}$ Václav Havel razvija lik Ferdinanda Vaněka u svojoj Audijenciji 1975. No, on u tolikoj mjeri nadahnjuje još neke neoficijelne dramatičare koji ga uzimaju za okosnice svojih drama. Nastaje cijeli ciklus drama tzv. vaňkovki. Godine 2006. objavljen je zbornik V hlavní roli Ferdinand Vaněk koji je okupio drame Václava Havela, Pavela Kohouta, Pavela Landovskog i Jiř́ija Diensbiera povezane istim likom.

${ }^{769}$ Janoušek, Pavel i suradnici Dějiny české literatury 1945-1989, IV. knjiga 1969-1989, Academia, Prag, 2008., str. 562.

${ }^{770}$ Violić, Božidar Izgubljeni dnevnik: Švedska, 11(1990), 31-33, svibanj - prosinac, Gordogan, str. 71-116. Opisujući svoj boravak u Švedskoj, Violić se sjeća susreta s češkim redateljem Alfredom Radokom u čijim je očima, kako kaže, uočio tugu: „Bila je to naša zajednička tuga socijalizma.“ (str. 78)

U tekstu Povijest predstave kao redateljska biografija Andree Zlatar objavljenu u Novom prologu 1988. o okolnostima postavljanja na pozornicu romana Slobodana Novaka Mirisi, zlato i tamjan u Teatru ITD u siječnju 1974. Zlatar navodi iskaz redatelja predstave Božidara Violića o svom švedskom boravku i radu na dramatizaciji Novakova romana kao formativnim čimbenicima za daljnji redateljski rad. Violić tumači da su mu ta iskustva omogućila da razvije ideju o ,geografsk[om] prostor [u] kao sudbini (...) U današnjoj, blokovskoj podjeli svijeta, svi narodi koji žive u zemljama realnog socijalizma, doživljavaju svoj život kao geografsko prokletstvo. Politika je prepotentno preuzela ulogu sudbine." Zlatar, Andrea Povijest predstave kao redateljska biografija, Novi prolog, br. 8/9, 1988., str. 107, 113.

${ }^{771}$ Kvrgić, Pero Pivo gdje se vari - dobro stoje stvari, Vijenac http://www.matica.hr/vijenac/174/ pivo-gdje-sevari-dobro-stoje-stvari-17234/ (objavljeno 2. 11. 2000., pristupljeno 21. 7. 2019.)

${ }^{772}$ Krajem sedamdesetih događa se analogna situacija kada predstavnici sovjetskoga veleposlanstva zahtijevaju odustajanje od objavljivanja knjige Arhipelag Gulag Aleksandra Solženjicina. Ta je intervencija polučila uspjeh pa je Solženjicinova knjiga u Jugoslaviji prvi put objavljena tek desetak godina kasnije u Beogradu. Stipčević , Aleksandar O savršenom cenzoru, Nakladni zavod Matice hrvatske, Zagreb, 1994., str. 18.

Iste godine (1980.) premijeru u DK-u Gavelli ostvaruje i drama Ive Brešana Smrt predsjednika kućnog savjeta. U razgovoru na Sajmu knjiga u Puli 2002. Brešan izjavljuje da je premijeru drame spasio Ivica Račan. Derk,
} 
Kazališne su kritike ovih Havelovih jednočinki mahom pozitivne. O njima pišu Nikola Batušić u Republici, Marija Grgičević u Večernjemu listu te Željko Falout u Oku. Batušić drame smatra izvrsnima te u njima iščitava autobiografsku potku. ${ }^{773} \mathrm{Na}$ Audijenciju i Izložbu u tekstu o sarajevskome festivalu MESS 1981. referira se i Marija Grgičević koja se pozitivno izražava o svim njihovim aspektima zapisavši da je predstava ,zahvaljujući izvrsno organiziranom, značenjima bogatom tekstu Václava Havela i isto tako promišljenoj režiji Božidara Violića, a nadasve bogatim glumačkim ostvarenjima iz prizora u prizor postajala sve jača, odjekujući smijehom i pljeskom punim razumijevanja i priznanja“7774. U rujnu 1981. Večernji list objavljuje pregled prethodne i najavu nove kazališne sezone u Dramskom kazalištu Gavella u kojem su Havelove jednočinke ocijenjene ,vrlo uspjel[ima]“775. Faloutova pozitivna procjena jednočinke naziva dvjema „minuciozno izveden[im] sonatama“776, a svoju kritiku završava optimističnim tonom i riječima da je to „bila jedna sretna večer, možda najčistija, najpotpunija u ovoj sezoni““777.

Sve su te pozitivne novinske kritike praćene i priznanjima struke. Audijenciju i Izložbu Hrvatsko društvo kazališnih kritičara i teatrologa proglašava najboljim predstavama sezone, a glumci Helena Buljan, Pero Kvrgić, Zlatko Vitez i Vlatko Dulić za svoje su izvedbe nagrađeni lovor-vijencem na sarajevskome Festivalu malih i eksperimentalnih scena.

Denis Brešan žali mnoge stvari https://www.vecernji.hr/kultura/bresan-zali-mnoge-stvari-727365 (objavljeno 5. 12. 2000., pristupljeno 11. 7. 2015.)

${ }^{773}$ Batušić, Nikola Havel u Gavelli, Republika, br. 7/8, 1980.

${ }^{774}$ Grgičević, Marija Ispod očekivanja, Večernji list, br. 6650, 6. 4. 1981., str. 5.

775 Vukšić, B. Predstave za antologiju, Večernji list, br. 6775, 3. 9. 1981., str. 11.

${ }^{776}$ Falout, Željko Jedna sretna večer, Oko, br. 208, 1980., str. 16.

777 Isto. 


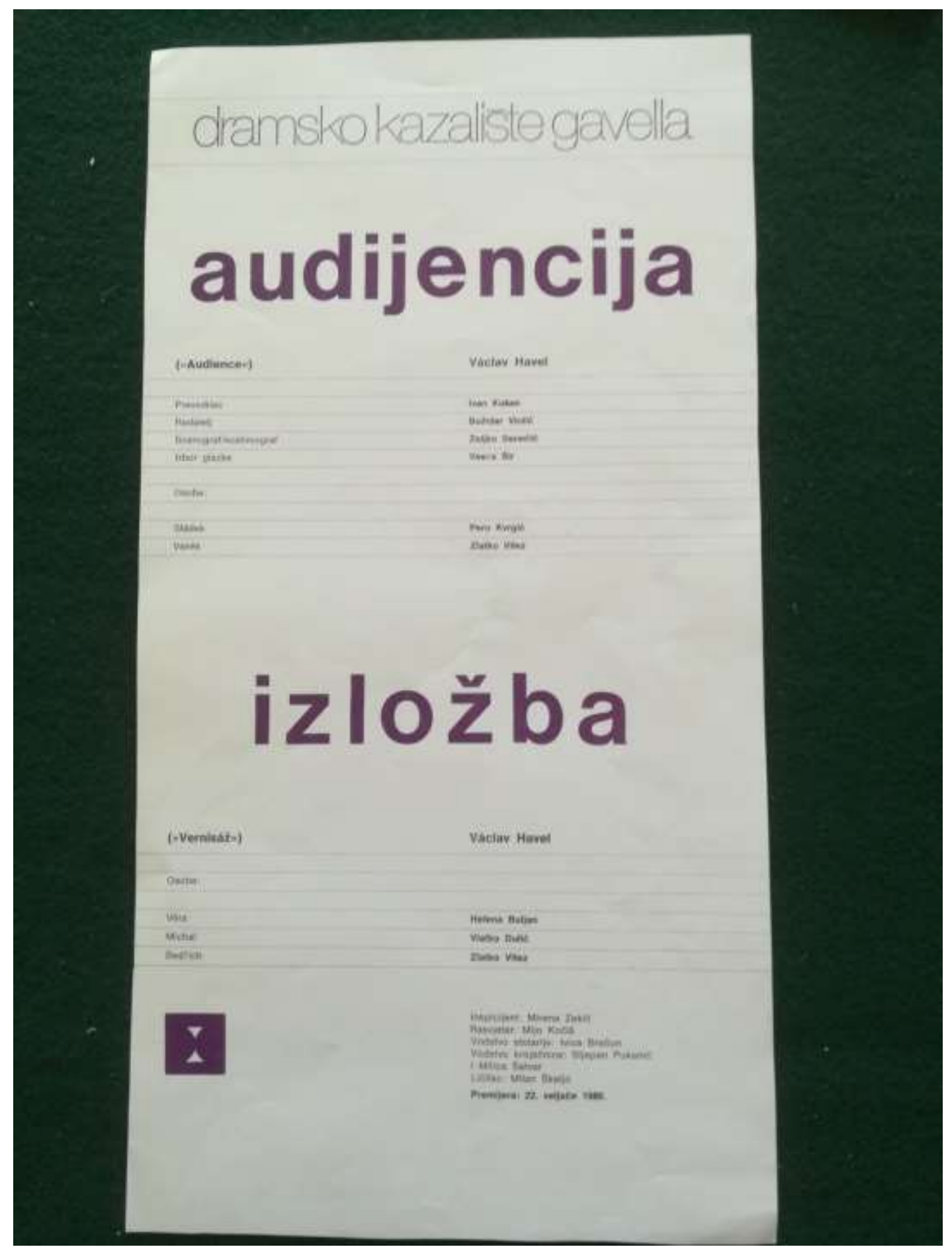

Fotografija VII: Plakat predstava Audijencija i Izložba Václava Havela u DK-u Gavella, 1980. Izvor: Odsjek za povijest hrvatskog kazališta HAZU-a 


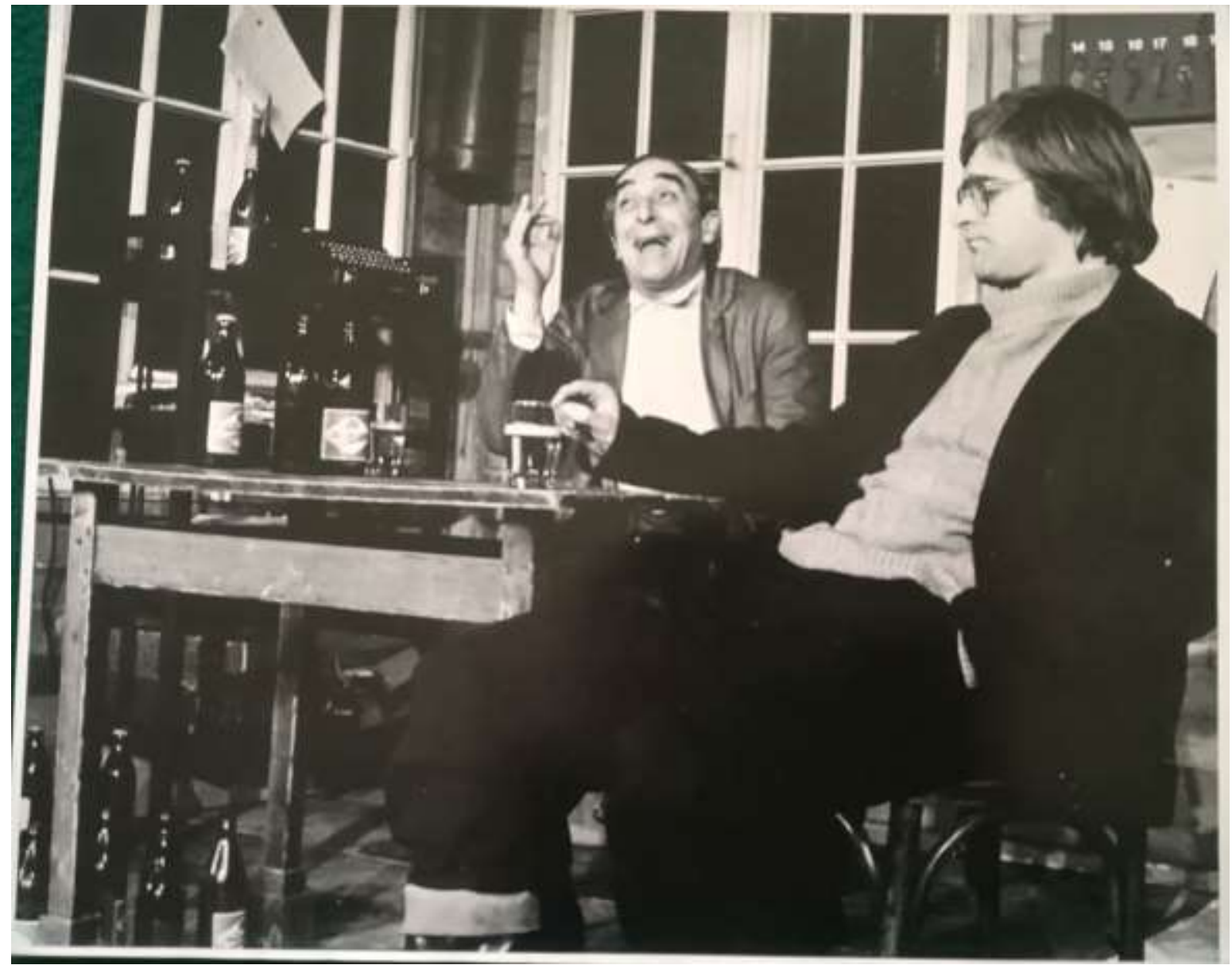

Fotografija VIII: Fotografija predstave Audijencija Václava Havela u DK-u Gavella, 1980. Izvor: Odsjek za povijest hrvatskog kazališta HAZU-a 


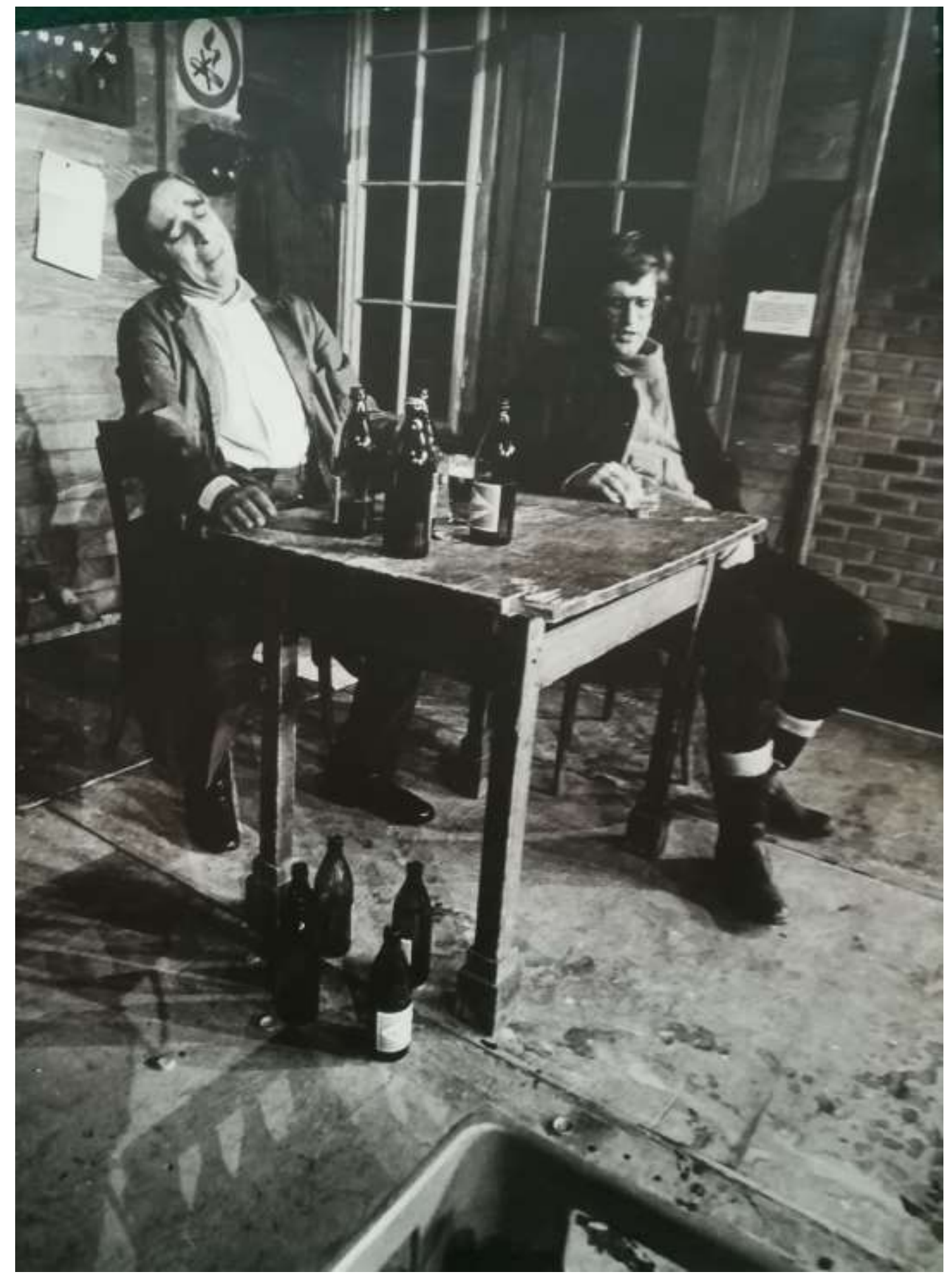

Fotografija IX: Fotografija predstave Audijencija Václava Havela u DK-u Gavella, 1980. Izvor: Odsjek za povijest hrvatskog kazališta HAZU-a 


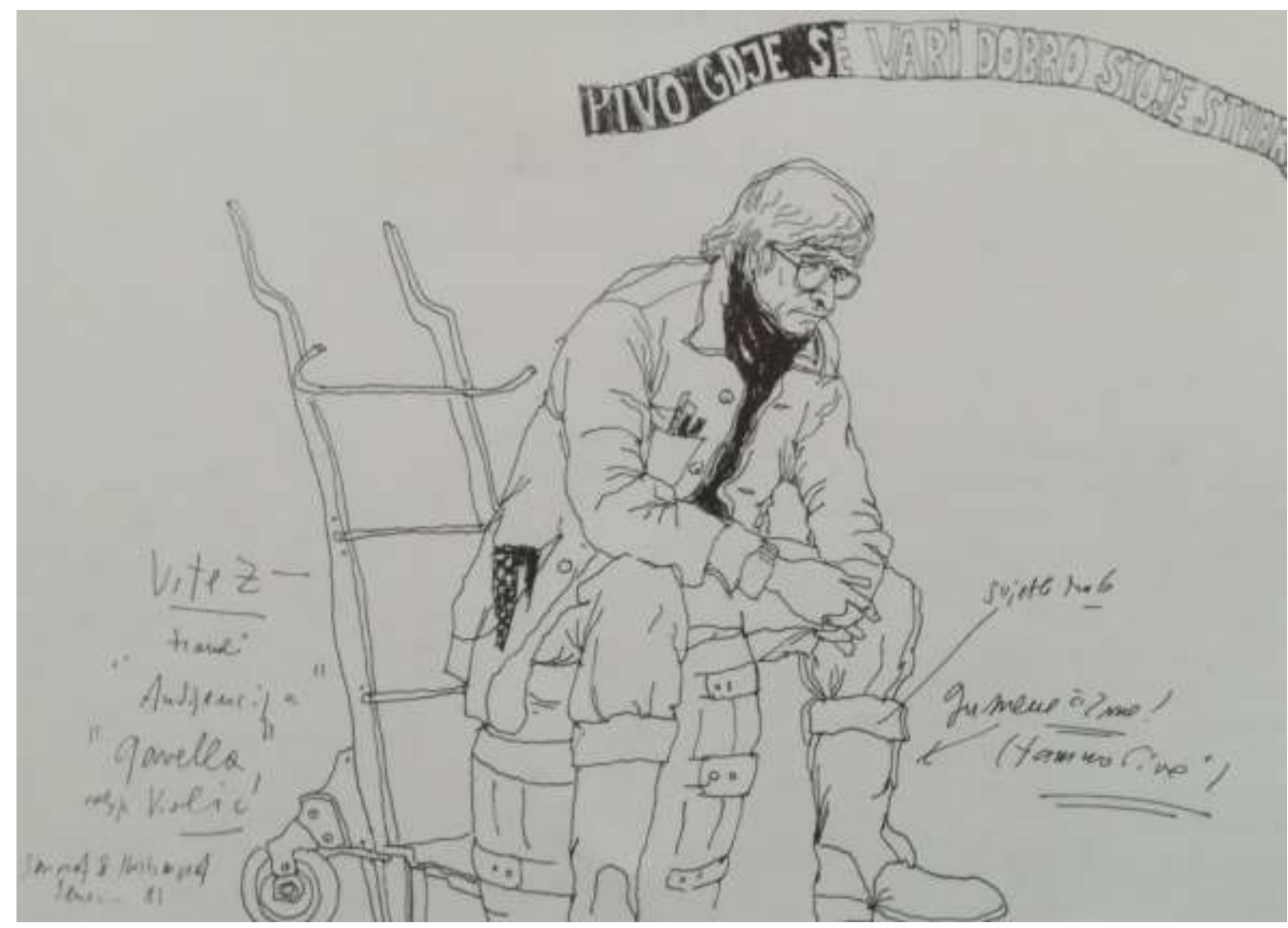

Fotografija X: Crtež Željka Senečića s probe Audijencije u DK-u Gavella Izvor: Državnik i dramatičar Václav Havel, ur. Branko Hećimović, Odsjek za povijest hrvatskoga kazališta HAZU-a, 2000., str. 13

7. 2. 2. Václav Havel Očajno smiješno (Dramsko kazalište Gavella, 1989.)

Četiri godine prošlo je od premijere Havelove drame Largo desolato u bečkome Burgtheateru $1985 .{ }^{778}$ do premijere pod naslovom Očajno smiješno u zagrebačkoj Gavelli. ${ }^{779}$ Predstava u režiji Miroslava Međimorca u programu toga kazališta održala se godinu dana i u tom je razdoblju reprizirana 25 puta. No, ona nije bio prvi doticaj zagrebačke publike s ovim Havelovim tekstom. Istim je tekstom, no originalna naslova Largo desolato, godinu dana

\footnotetext{
${ }^{778}$ Janoušek, Pavel i suradnici Dějiny české literatury 1945-1989, IV. knjiga 1969-1989, Academia, Prag, 2008. str. 566.

${ }^{779}$ Repertoar hrvatskih kazališta, knjiga 3 - Repertoari 1981. - 1990., ur. Branko Hećimović, Hrvatska akademija znanosti i umjetnosti, 2002., str. 56.
} 
ranije, 1988. na XII. danima satire gostovao sarajevski Kamerni teatar $55^{780}$ što je kritičkim napisima bilo zabilježeno i u hrvatskome tisku. ${ }^{781}$

U novinskim se kritikama Gavelline predstave Očajno smiješno ponavlja teza o preslici Havelove biografije u sudbini dr. Kopřive, glavnoga lika drame. Tu ideju razvija Želimir Stublija u kritici u časopisu Oko, no na samome početku teksta naglašava da postavljenje predstave na pozornicu Dramskoga kazališta Gavella nije moglo doći, marketinški gledano, u boljem trenutku. Naime, neposredno prije premijere dramatičar izlazi iz zatvora kamo je dospio zbog sudjelovanja u obilježavanju dvadesete godišnjice samospaljivanja Jana Palacha. ${ }^{782}$ Simbolički, premijeru predstave prati knjižica kreativno oblikovana poput policijskoga zapisnika koju započinje zapis Zvonimira Mrkonjića u kojem se ponavlja teza o autobiografičnosti teksta. Nadalje, bogata programska knjižica donosi kratku Havelovu biografiju, ulomke iz knjige Saslušanje na daljinu te zapise Dagmar Ruljančić, Milana Kundere, Jiř́ija Voskovca i sâmoga autora.

Kritičar Jozo Puljizević u Večernjemu listu predstavi zamjera odmak na područje komedije, što, smatra, Havelova drama u svojoj osnovi nije. ${ }^{783}$ Misao o glavnome liku Larga desolata dr. Kopřivi kao autorovu alter egu ponavlja se i u kasnijemu Vjesnikovu tekstu iz 1990. Havel ili život je san, objavljenu nakon dramatičareva stupanja na mjesto predsjednika Čehoslovačke. ${ }^{784}$ Kritiku predstave nakon premijere 1989. u Vjesniku potpisuje Marija Grgičević koja više pozornosti posvećuje odgonetavanju razloga Havelove popularnosti među hrvatskom kazališnom publikom, no analizi Gavelline predstave. Grgičević, tako, korijene Havelove popularnosti u Hrvatskoj vidi u aktualnosti i univerzalnosti koju dramatičar postiže „kritičk[im] angažman[om] u odnosu prema prepoznatljivoj društvenoj zbilji i autoironičnim

\footnotetext{
${ }^{780}$ Kamerni teatar 55 osnovan je u Sarajevu u ožujku 1955. Osobitost repertoara toga kazališta jest što je otvorio prostor predstavama kazališta apsurda, prikazivao je drame S. Becketta, E. Ionesca, pa, tako, i V. Havela. Od ostalih se kazališta, osim repertoarnom usmjerenošću, razlikuje i prstenastim gledalištem koje okružuje pozornicu. Tijekom rata u Bosni i Hercegovini od 1992. do 1995. Kamerni teatar 55 imao je 28 premijera. www.kamerniteatar55.ba (pristupljeno 13. 12. 2018.)

${ }^{781}$ Časopis Oko objavljuje čak dvije kritike Havelova Larga desolata u izvedbi Kamernoga teatra 55. Prvu, iznimno pozitivnu, autorice Ljubice Ostojić, povodom izvedbe predstave na 17. pozorišnim igrama Bosne i Hercegovine. (Ostojić, Ljubica Leopoldov Krik, Oko, br. 399, 1987., str. 12) Nakon gostovanja u Zagrebu na Danima satire kritiku u Oku objavljuje Želimir Stublija koji u Largu desolatu primjećuje otklon od Havelovih drama tzv. disidentskog ciklusa. Naime, u prijašnjim dramama Havel je, prema Stubliji, sklon crno-bijeloj shematizaciji likova i odnosa, dok u Largo desolatu ,s disidenta skida svetački oreol“‘. (Stublija, Želimir Proširene granice, Oko, br. 425, 1988., str. 12)

${ }^{782}$ Stublija, Želimir Antijunak u dvostrukoj klopci, Oko, br. 451, 1989., str. 14.

783 Puljizević, Jozo Nije to tako šaljivo, Večernji list, br. 9275, 13. 6. 1989., str. 18.

${ }^{784}$ M. G. Havel ili život je san, Vjesnik, br. 15204, 17. 1. 1990., str. 9.
} 
stajalištima koja i samu oporbu stavljaju pod znak pitanja““785 što je osobito privlačno „podnebljima (...) sa sličnim povijesnim iskustvom““786, kakvim Grgičević smatra i hrvatsko.

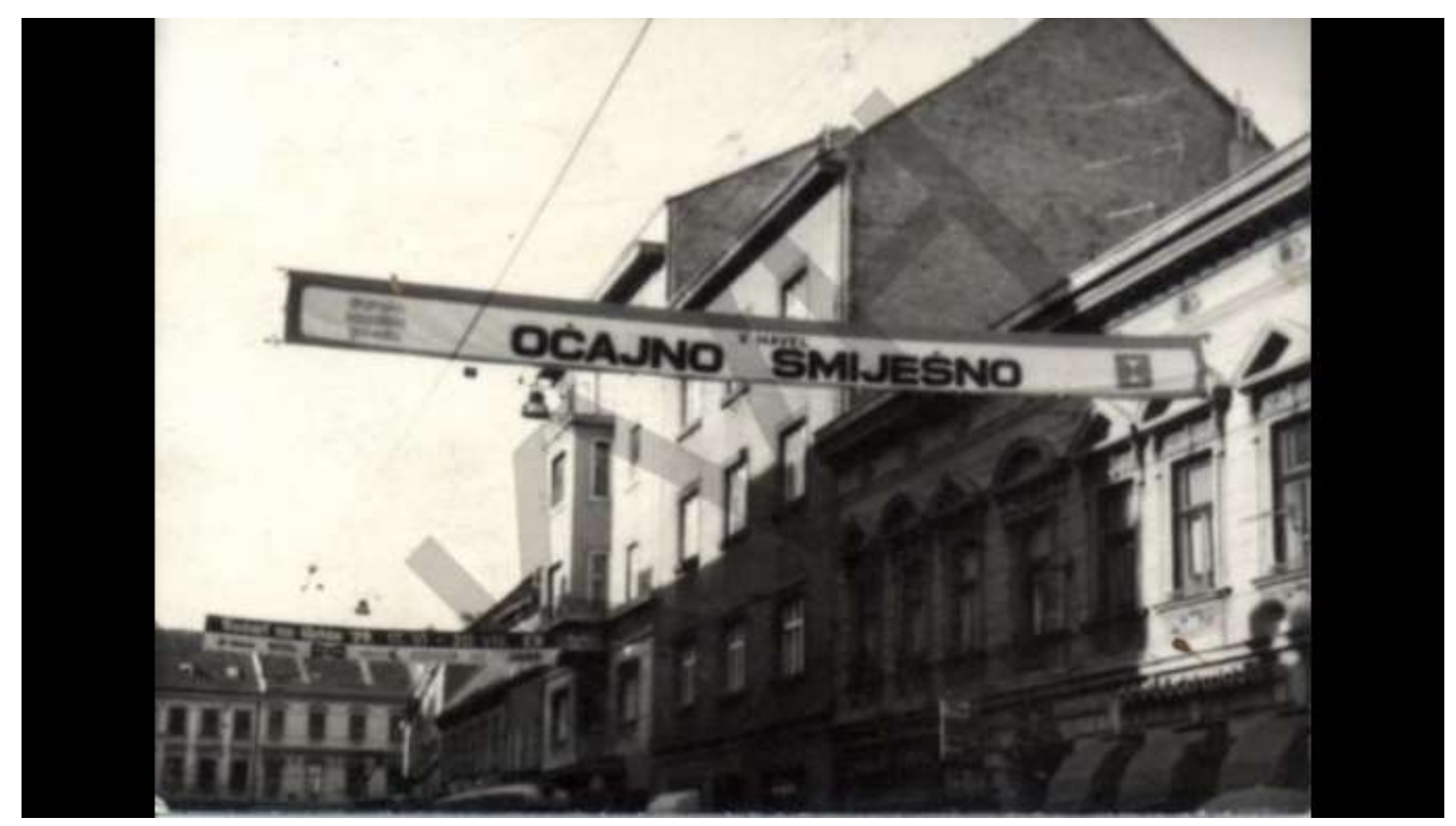

Fotografija XI: reklama za predstavu Očajno smiješno u Zagrebu, 1989.

Izvor: https://archive.vaclavhavel-library.org/Archive/Detail/26291, pristupljeno 2. 8. 2019.

${ }^{785}$ Grgičević, Marija Stari gost, Vjesnik, br. 14990, 12. 6. 1989., str. 8.

${ }^{786}$ Isto. 


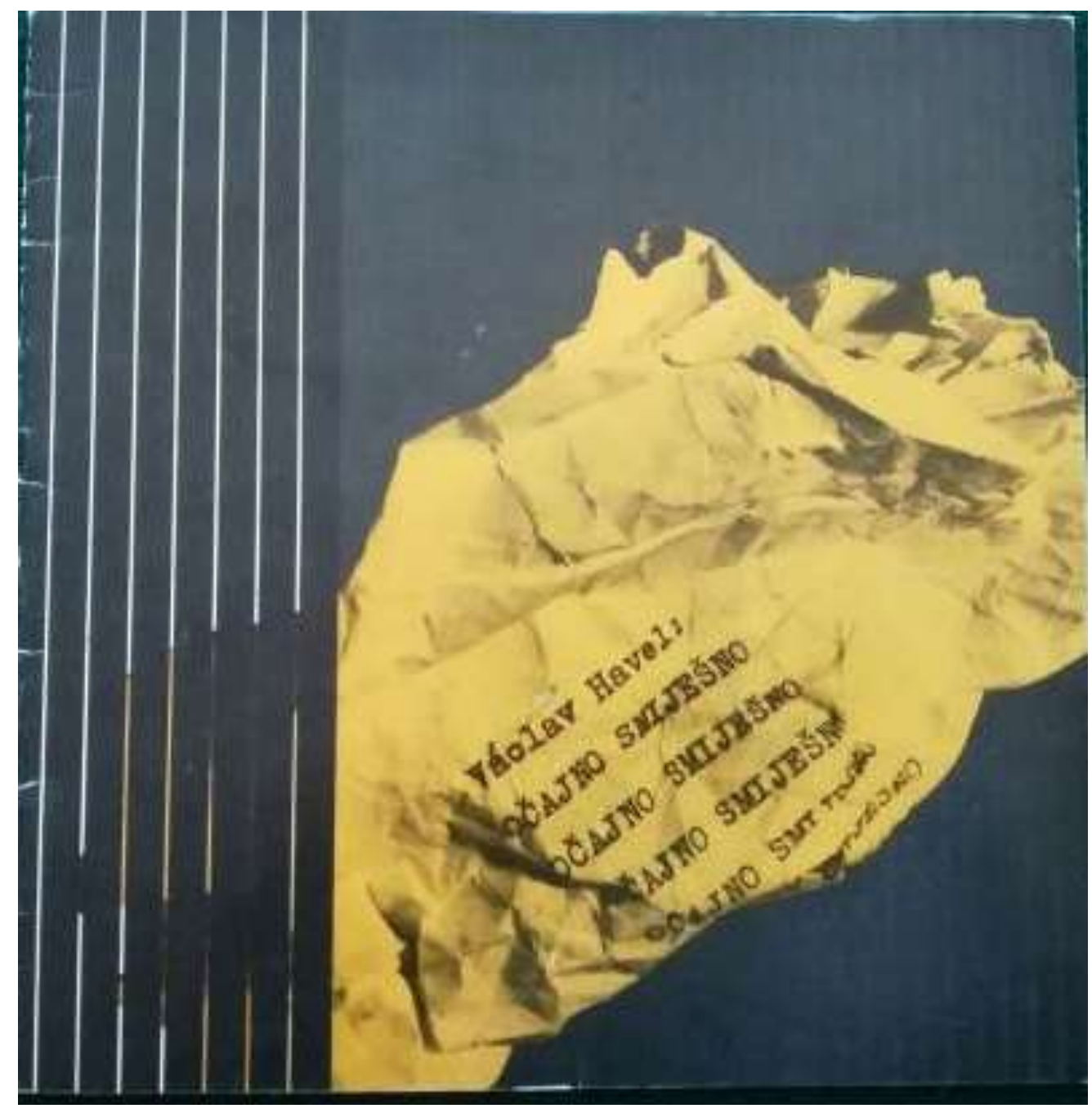

Fotografija XII: Programska knjižica predstave Očajno smiješno Václava Havela, DK-a Gavella

Izvor: Odsjek za povijest hrvatskoga kazališta HAZU-a 


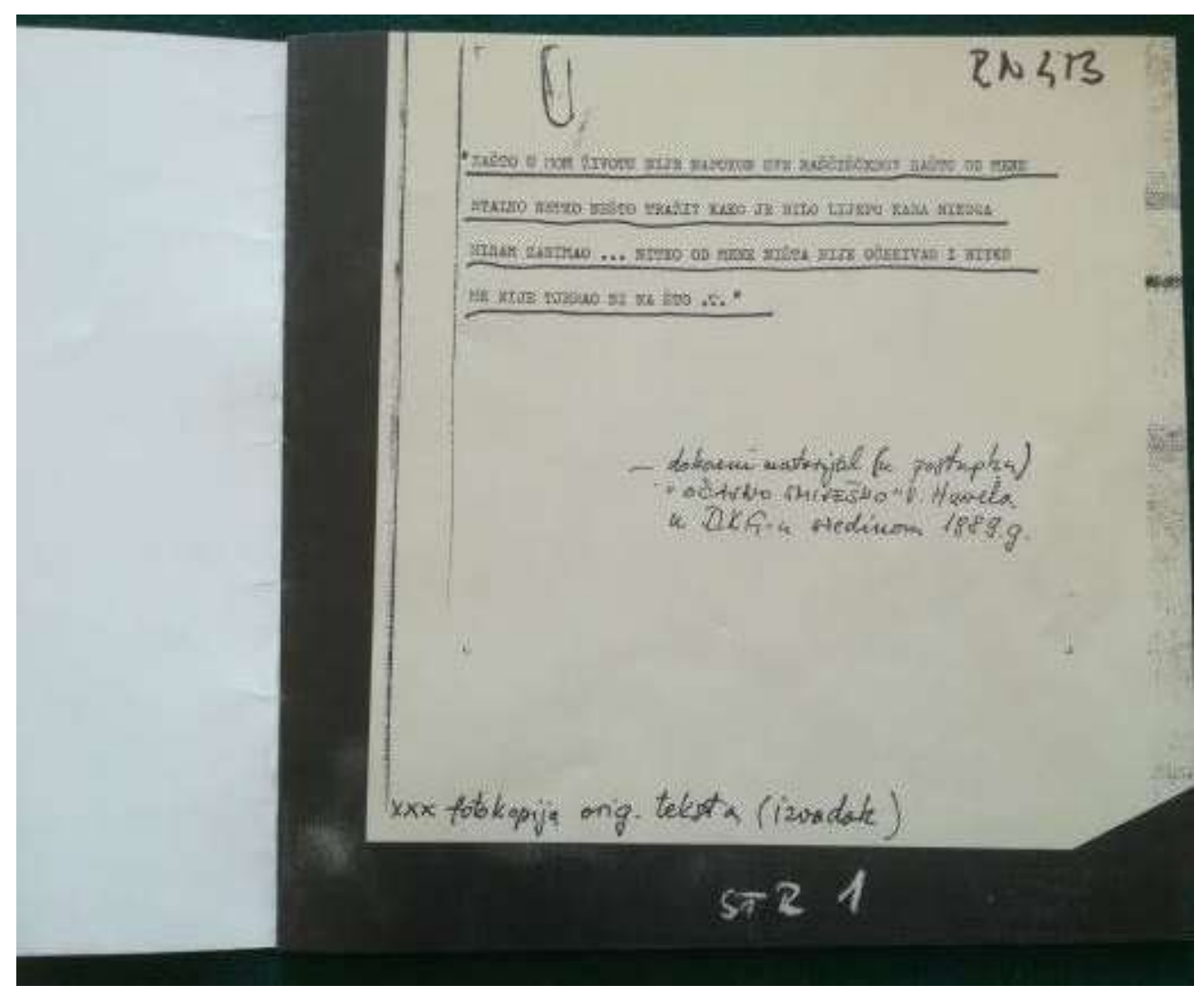

Fotografija XIII: Programska knjižica predstave Očajno smiješno Václava Havela DK-a Gavella, 1. stranica

Izvor: Odsjek za povijest hrvatskoga kazališta HAZU-a

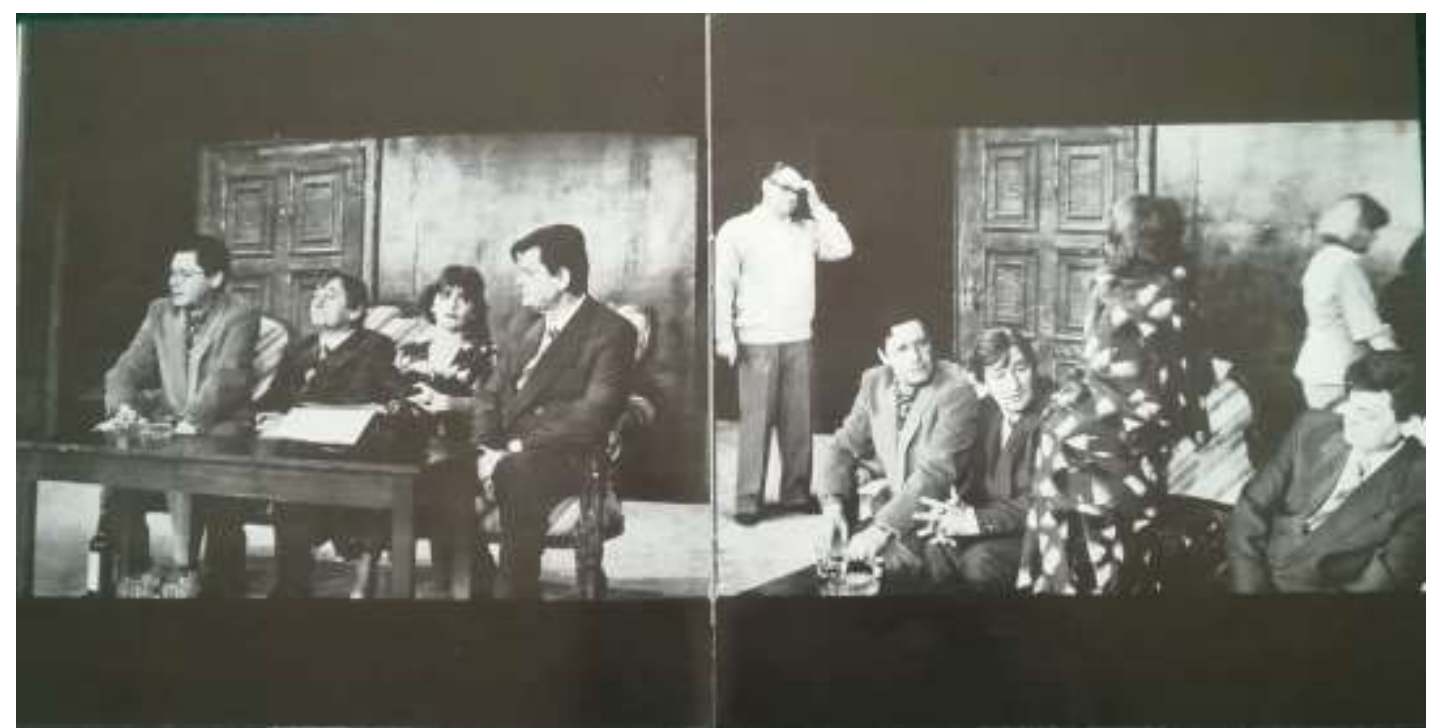

Fotografija XIV: Fotografija predstave predstave Očajno smiješno Václava Havela DK-a Gavella (programska knjižica)

Izvor: Odsjek za povijest hrvatskog kazališta HAZU-a 


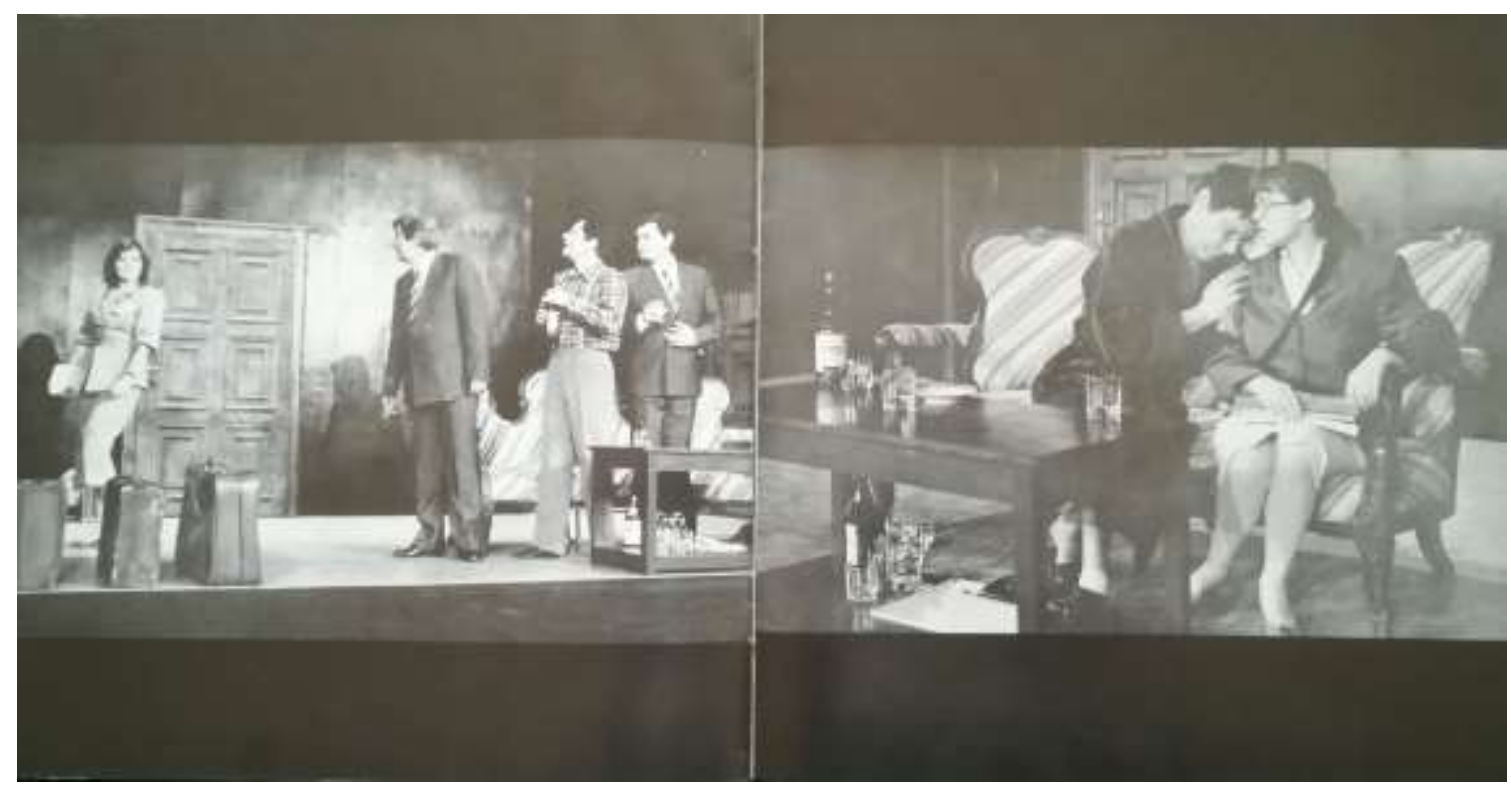

Fotografija XV: Fotografija predstave Očajno smiješno Václava Havela DK-a Gavella (programska knjižica)

Izvor: Odsjek za povijest hrvatskog kazališta HAZU-a

\section{2. 3. Václav Havel Asanacija (HNK Zagreb, 1990.)}

Predstava Asanacija svoju je hrvatsku premijeru ostvarila u zagrebačkome Hrvatskom narodnom kazalištu 29. listopada 1990. u režiji Radovana Maričića. ${ }^{787}$ Okolnosti u kojima se na zagrebačkoj pozornici svojim tekstom pojavljuje tada već predsjednik Čehoslovačke dijametralno su suprotne u obama društvima u odnosu na one 1980. kada pripremu Havelovih jednočinki u DK-u Gavella prate službeni prosvjedi čehoslovačkoga veleposlanstva u Zagrebu. Činjenica da se na pozornicu nacionalne kazališne kuće postavlja dramski tekst novoga čelnika države koji je iz ilegalne disidentske sfere kročio u svijet visoke politike uvelike će utjecati i na pojedine sastavnice predstave i na recepciju među gledateljima i u medijima. ${ }^{788}$ Asanacija nije prvi Maričićev rad na Havelovim dramama. Isti je redatelj, naime, 1981. u zagrebačkome Teatru ITD postavio jednočinke Protest i Atest Václava Havela i Pavela Kohouta.

\footnotetext{
787 Repertoar hrvatskih kazališta, knjiga 3 - Repertoari 1981. - 1990., ur. Branko Hećimović, Hrvatska akademija znanosti i umjetnosti, 2002., str. 17.

${ }^{788}$ Dnevni tisak s kraja 1990. najavljuje uprizorenje Havelova Iskušavanja u prvoj polovici 1991. i u jednoj drugoj nacionalnoj kući, riječkome HNK-u. Koščić, N. Iskušenja do kolovoza, Večernji list, br. 9741, 1. 10. 1990., str. 10.
} 
Havelova je Asanacija, kao i neki drugi njegovi tekstovi iz razdoblja zabranjenosti, premijeru doživjela u zapadnoj Europi, prvi je put odigrana u rujnu 1989. u ciriškome Schauspielhausu. ${ }^{789}$ No, kako ubrzo, u prosincu iste godine, Havel stupa na funkciju predsjednika države, zagrebačka premijera drame korespondira s inflacijom prikazivanja Havelovih drama i u samoj Čehoslovačkoj, a sama je Asanacija već tijekom 1990. doživjela uprizorenja na pozornicama u Pragu, Liberecu, Ostravi i Brnu. ${ }^{790}$ Dramaturg kazališta $\mathrm{Na}$ zábradlí Karel Steigerwald, s kojim intervju u tjedniku Danas u siječnju 1990. objavljuje Dagmar Ruljančić, uzroke inflaciji zanimanja za Havelov dramski rad vidi u tome što „mnogi korumpirani ljudi žele spasiti glavu pozivajući svoja kazališta da smjesta stave Havela na repertoar“791.

O utjecaju izvanknjiževnih i izvankazališnih čimbenika na recepciju Havelove drame piše Igor Šunjić u Oku te primjećuje micanje fokusa s teksta, predstave, dramskoga opusa autora na njegovu biografiju i politički aktivizam. Toj tezi u prilog ide činjenica da programska knjižica zagrebačke predstave uopće ne sadrži informacije o Havelovoj Asanaciji, no istovremeno sadrži dvije kartice teksta o Václavu Havelu u ulozi čehoslovačkoga predsjednika te petnaest kartica teksta o prijašnjem Havelovu dramskom radu i disidentskim aktivnostima. ${ }^{792}$ Šunjić u svojoj kritici Havelovu tekstu i HNK-ovoj inscenaciji nalazi niz zamjerki, ,poslovični češki humor“793 ocjenjuje šablonskim te zaključuje da se predstavi „osim dosade nema što prigovoriti““794.

Ni ostale kazališne kritike vrijednosno nisu jednoznačne. I dok redatelj predstave Maričić Asanaciju smatra jednom od najboljih Havelovih drama, ${ }^{795}$ u kritici znakovita naslova $\mathrm{Na}$ granici podnošljivosti Boris B. Hrovat drame iz prethodnoga Havelova stvaralačkog razdoblja smatra kvalitetnijima. Tekstu prigovara „sklonost pretjeranoj eksplicitnosti, verbalizmu, patetici“6796, što redatelj nije uspio minimizirati. Hrovat primjećuje da je prijevod Dagmar Ruljančić, koji načelno smatra korektnim, platio danak purističkim

\footnotetext{
789 Janoušek, Pavel i suradnici Dějiny české literatury 1945-1989, IV. knjiga 1969-1989, Academia, Prag, 2008.

${ }^{790}$ Václav Havel državnik i dramatičar, HAZU, Zagreb, 2000.

${ }^{791}$ Pauk za vratom (intervju s Karelom Steigerwaldom, Dagmar Ruljančić), Danas, 9. 1. 1990., str. 40-42.

792 Šuljić, Igor Za predsjedničku ložu, Oko, br. 24, 1990., str. 13.

793 Isto.

794 Isto.

${ }^{795}$ Kada novo postane staro (intervju s Radovanom Maričićem, Sanja Nikčević), Večernji list, br. 9770, 30. 10. 1990.

${ }^{796}$ Hrovat, B. Boris Na granici podnošljivosti, Večernji list, br. 9771, 31. 10. 1990., str. 39.
} 
tendencijama aktualnim u hrvatskome jeziku početkom devedesetih godina 20. st. pa je partijski sekretar nazvan stranačkim tajnikom. ${ }^{797}$

U dvjema se svojim kritikama objavljenima u listopadu 1990. Asanacijom bavi Dubravka Vrgoč. U tekstu s početka mjeseca Vrgoč piše o premijeri drame u Slovenskome narodnom gledališču u Ljubljani koja se odigrala neposredno prije zagrebačke premijere. Ondje ponavlja tezu o zbivanjima i atmosferi u Havelovim tekstovima kao preslici nama „prepoznatljivih prilika i bliske prošlosti““798, no primjećuje da je krajem 1990., u kontekstu velikih društvenih promjena koje su zahvatile srednju i istočnu Europu, dramski problem koji Havel obrađuje izgubio na svojoj aktualnosti. A, kako kaže, još je veći problem što zagrebačka premijera predstave tek slijedi. ${ }^{799} \mathrm{U}$ kritici zagrebačke izvedbe Vrgoč navodi da je scenografija podsjeća na atmosferu Kafkina Zamka. ${ }^{800}$

U duhu kapitalizma u povojima, u čijem se ozračju prikazuje Havelova drama u HNK-u, tekst o premijeri Asanacije u Večernjemu listu praćen je i kratkim navođenjem sponzora koji su financijski pomogli kazališnu produkciju. Tako saznajemo da su ,predstavu odjenuli uz pomoć 'Varteksa', pjenušac dobavili uz pomoć 'Vinske kleti', a pomogli su i 'Badel', 'Astra Mašinoimpex', 'Kemoboja', 'Voće export-import' i drugi.“"801

\footnotetext{
${ }^{797}$ Hrovat, B. Boris Na granici podnošljivosti, Večernji list, br. 9771, 31. 10. 1990., str. 39.

${ }^{798}$ Vrgoč, Dubravka Izgubljeni izvršitelji tuđe volje, Vjesnik, br. 15460, 3. 10. 1990., str. 8. 799 Isto.

${ }^{800}$ Vrgoč, Dubravka Pronalazak izvršitelja tuđe volje, Vjesnik, br. 15488, 31. 10. 1990., str. 9.

${ }^{801}$ S. Nč. Tko je protiv napretka, Večernji list, br. 9767, 27. 10. 1990., str. 51.
} 


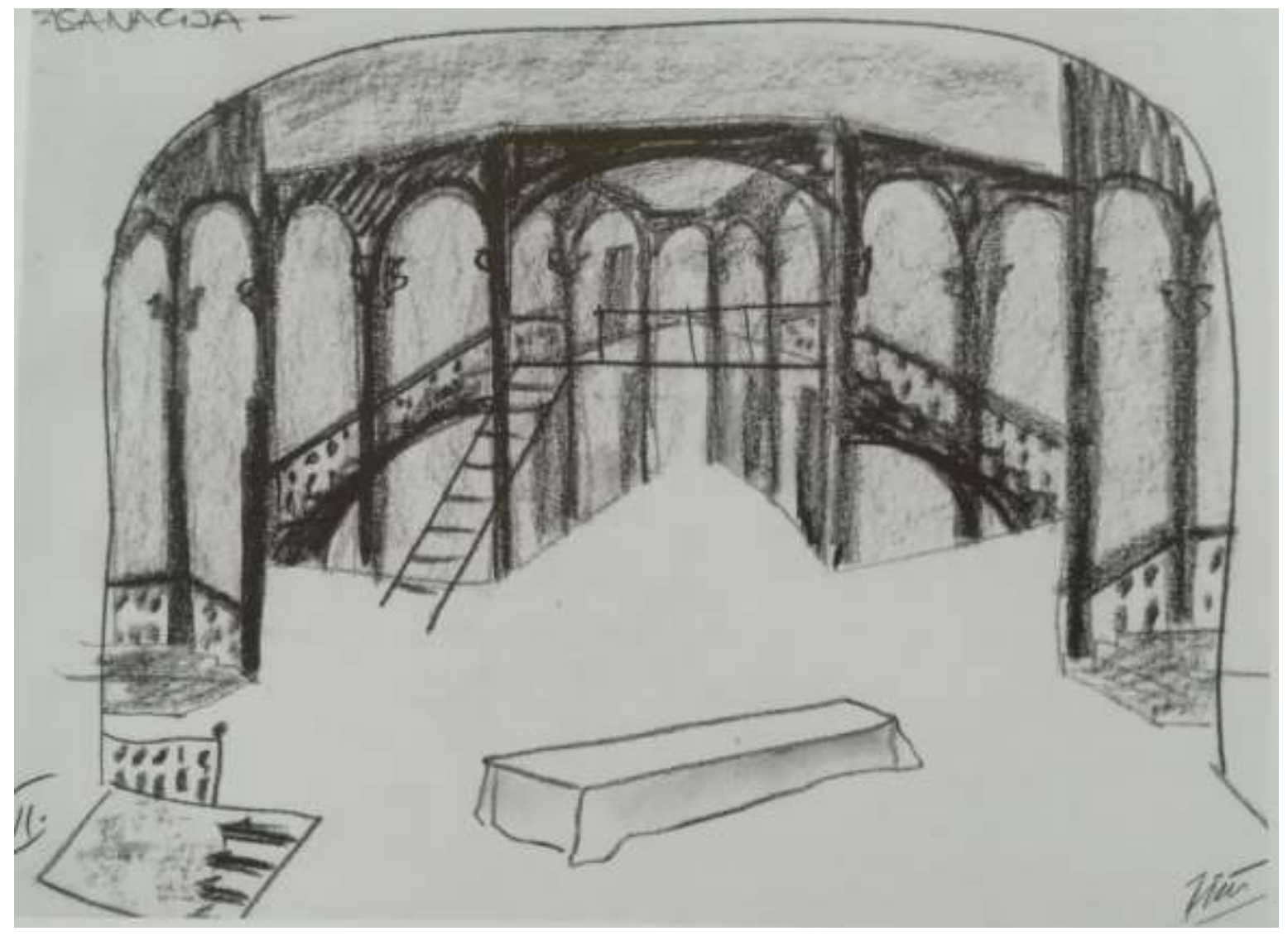

Fotografija XVI: Scenografska skica Dinke Jeričević za predstavu Asanacija Václava Havela u HNK-u Zagreb 1990.

Izvor: Državnik i dramatičar Václav Havel, ur. Branko Hećimović, Odsjek za povijest hrvatskog kazališta HAZU-a, 2000., str. 22 


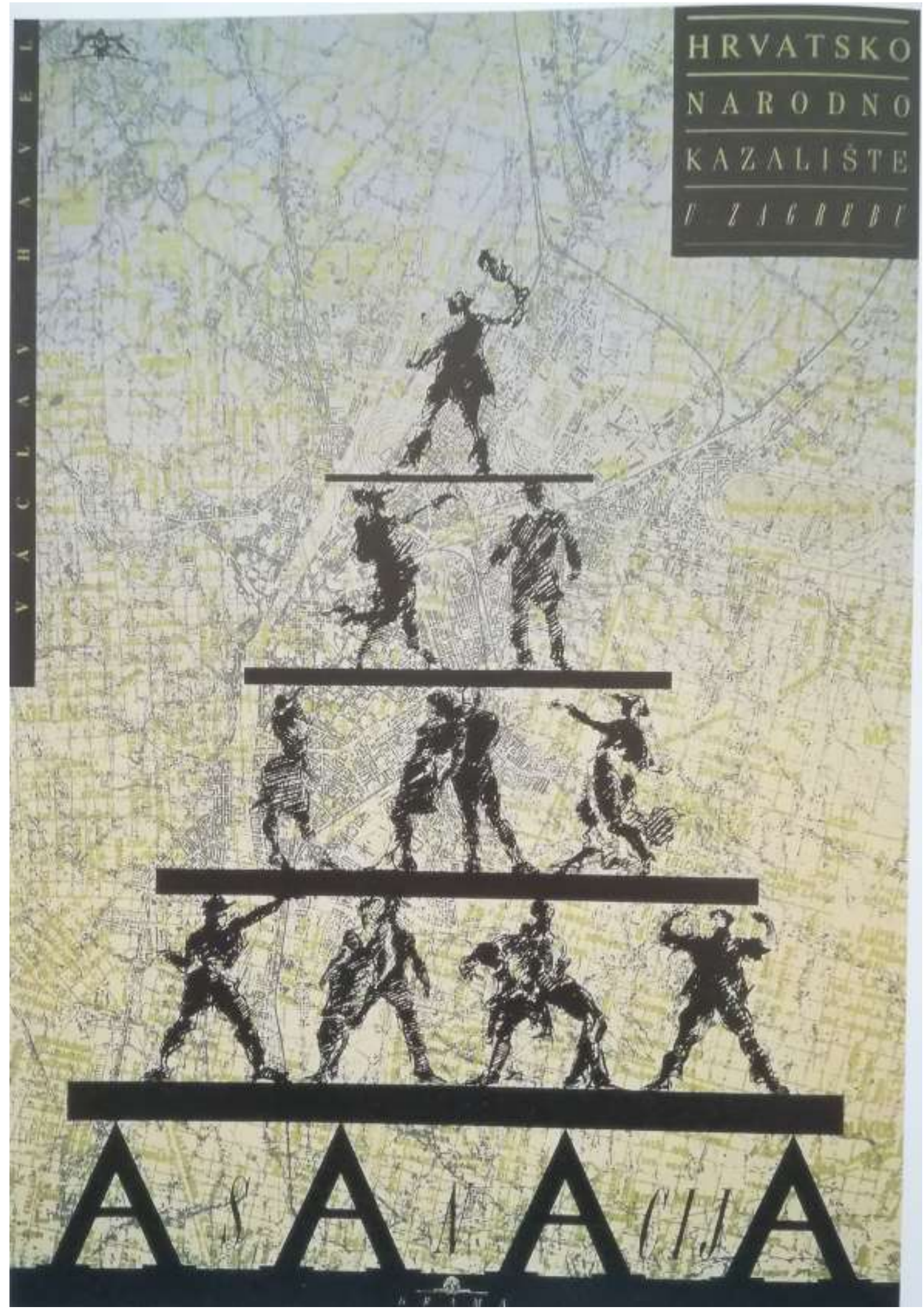

Fotografija XVII: Plakat predstave Asanacija Václava Havela, HNK Zagreb, 1990. Izvor: Odsjek za povijest hrvatskog kazališta HAZU-a 


\section{PRETPREMIJERA}

\section{VÁCLAVHAVEL.}

\section{ASANACIJA}

Priaves Deave Rutuives

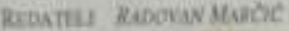

Diesearoke Las Katritas

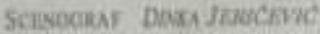

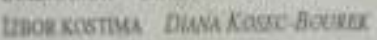

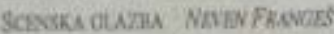

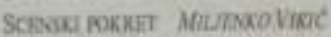

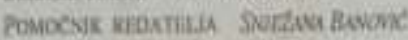

Oone

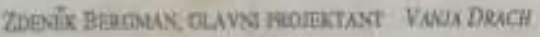

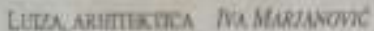

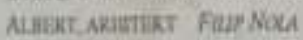

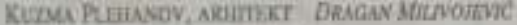

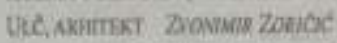

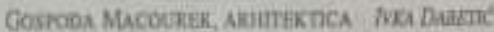

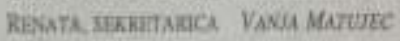

tamik MiLanko buercic

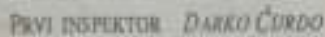

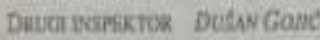

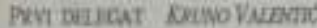

Ducar bescas ZINAD Gadić

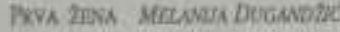

Derea ieva stabasmd

Dshoment MNA Fruele

SArTAC VSNA RAS

Fothake

5TAvKa Fosuli Thedeg ClNA

SvideTax oko 22 SATA

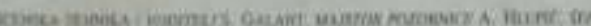

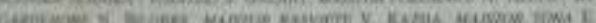

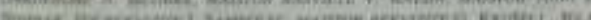

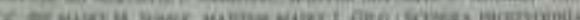

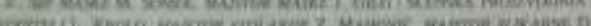

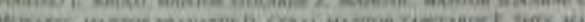

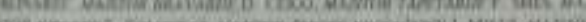

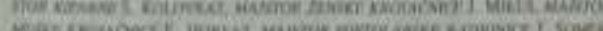

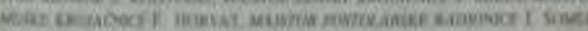

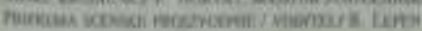
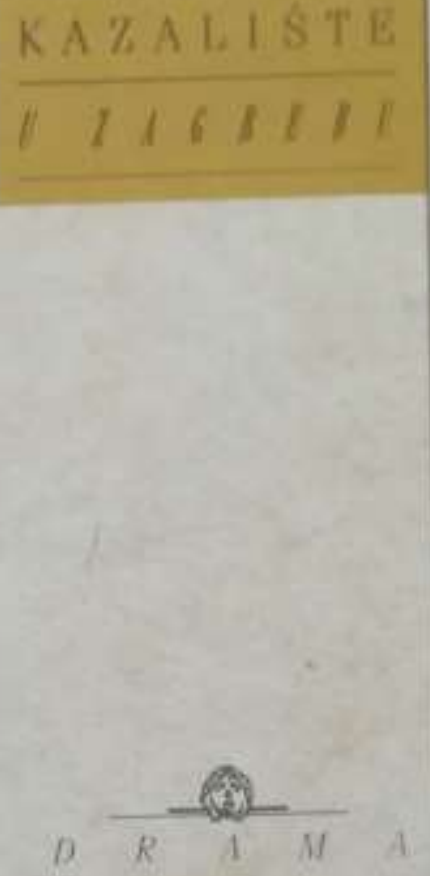


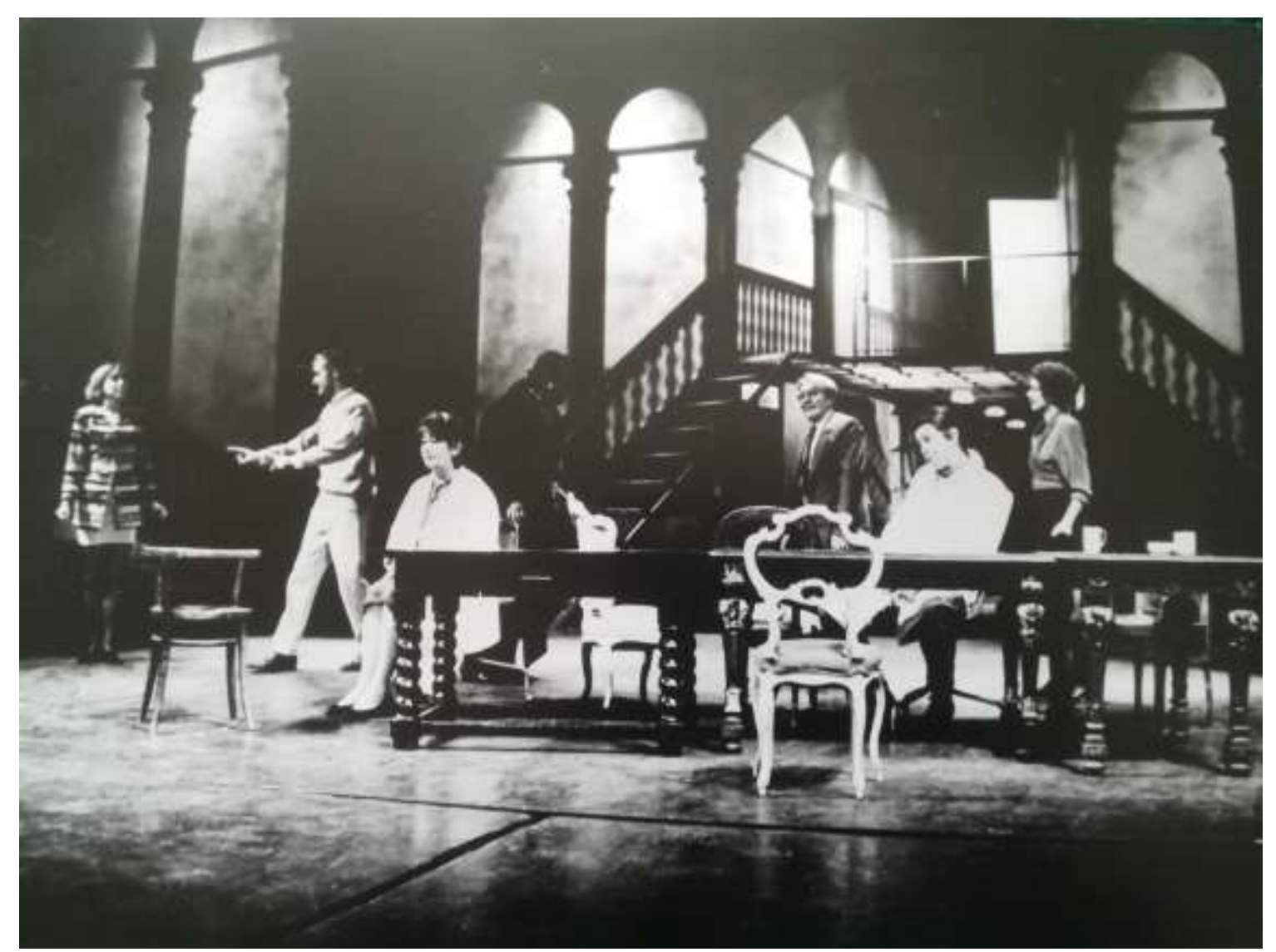

Fotografija XIX: Fotografija predstave Asanacija Václava Havela, HNK Zagreb, 1990. Izvor: Odsjek za povijest hrvatskog kazališta HAZU-a 


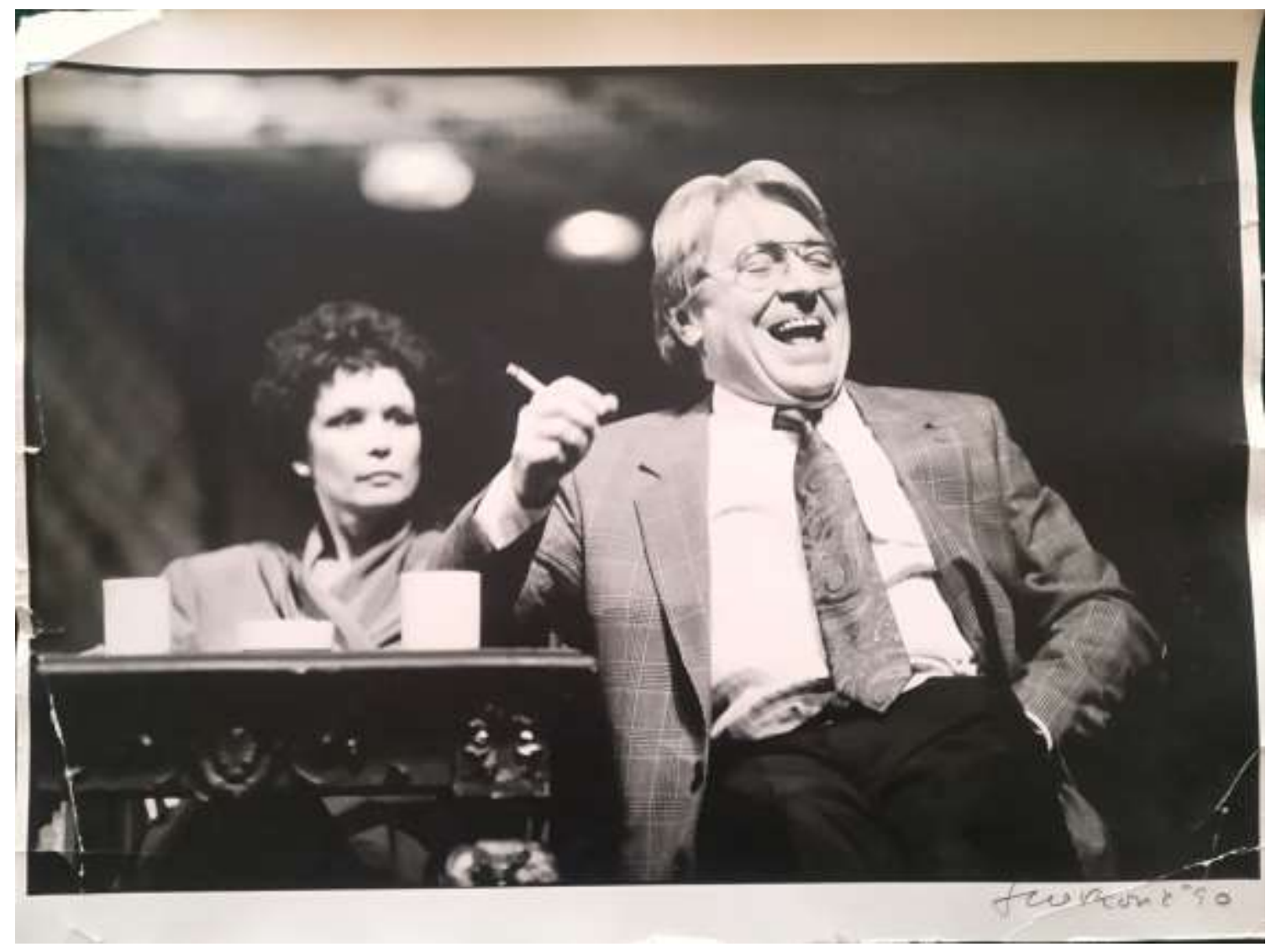

Fotografija XX: Fotografija predstave Asanacija Václava Havela, HNK Zagreb, 1990. Izvor: Odsjek za povijest hrvatskog kazališta HAZU-a

\section{3. Pavel Kohout}

Činjenica da je najizvođeniji češki dramatičar u inozemstvu, od siječnja 1968. do srpnja 1974. izvan matične zemlje premijerno je izvedeno čak 150 Kohoutovih drama i odigrano oko 3500 repriznih izvedaba, ${ }^{802}$ nije mogla spasiti Pavela Kohouta od potiskivanja u sferu neoficijelne književnosti nakon sloma praškoga proljeća. Na pozornicama hrvatskih kazališta njegov je dramski rad predstavljen s pet dramskih tekstova: Takva ljubav! (Taková láska!), Peh pod krovom (Pech pod střechou), Rat na trećem katu (Válka ve třetím poschodí), Atest (Atest), Marija se bori s anđelima (Marie zápasís anděly).

Na samome početku razdoblja koje je predmet analize ovoga rada, u travnju 1969. godine u kojoj je Pavel Kohout isključen iz članstva Komunističke partije Čehoslovačke čime počinje njegov dvadesetogodišnji rad u ilegali, a od 1979. i u egzilu, Kohoutovu dramu Takva

\footnotetext{
${ }^{802}$ Janoušek, Pavel i suradnici Dějiny české literatury 1945-1989, IV. knjiga 1969-1989, Academia, Prag, 2008. str. 582, 555 .
} 
ljubav! postavlja kazalište u Virovitici. ${ }^{803}$ Kazalište je osam izvedaba predstave odigralo u veoma kratkom razdoblju koliko je predstava bila u programu, od premijere 19. travnja do 18. svibnja. Vjerojatno plativši danak prikazivanja izvan velikoga kazališnog središta, predstava je izmaknula kritičkome oku hrvatskih pisanih medija toga vremena.

Nakon stanke u sedamdesetima sljedeći se put Kohout javlja na pozornici nekoga hrvatskog kazališta tek u listopadu 1980. kada dubrovačko Kazalište Marina Držića prikazuje njegove jednočinke Peh pod krovom i Rat na trećem katu. Od premijere 22. listopada 1980. do 21. prosinca iste godine zabilježeno je 11 repriznih izvedaba. Kohoutove su jednočinke bile uklopljene u repertoar koji je uglavnom bio lokalno obilježen i posvećen njegovanju bogate tradicije dubrovačke književnosti pa polovicu kazališnih predstava te godine čine tekstovi autora poput Feđe Šehovića, Iva Vojnovića, Džanluke Antice i Vlaha Stullija. ${ }^{804}$ I dok za ostale Kohoutove predstave ne postoje zapisi o konkretnim motivima njihova uvrštavanja na repertoare kazališnih kuća, Peh pod krovom i Rat na trećem katu ${ }^{805}$ u režiji Božidara Violića u dubrovačkome Kazalištu Marina Držića motivirani su logističkim razlozima. Naime, kako je potres koji je pogodio Dubrovnik 1979. djelomično oštetio i kazališnu dvoranu, dramski je repertoar sljedeće kazališne sezone sastavljen od predstava koje su mogle biti postavljene i na manjoj pozornici, poput one u Domu sindikata, a takve su predstave i Kohoutove jednočinke. ${ }^{806}$

Nakon zajedničke izvedbe jednočinki Václava Havela Protest i Kohoutove Atest $\mathrm{u}$ zagrebačkome Teatru ITD 1981., u veljači 1985. dramu Marija se bori s anđelima u Dramskome kazalištu Gavella režira Jakov Sedlar. Krajem iste godine zagrebački HNK prikazuje jednočinku Peh pod krovom u režiji Dubravka Torjanca, a novinske analize te

\footnotetext{
${ }^{803}$ Repertoar hrvatskih kazališta, knjiga 1 - Repertoari kazališta, kazališnih družina i grupa, partizanskih kazališta, festivala, smotri i susreta, ur. Branko Hećimović, Jugoslavenska akademija znanosti i umjetnosti, Zagreb, 1990., str. 757.

${ }^{804}$ Godine 1980. repertoar Kazališta Marina Držića u Dubrovniku činile su sljedeće predstave: Carlo Goldoni Kafeterija, Feđa Šehović Oriđinali, Feđa Šehović Betula, Feđa Šehović Novela od kapetana, Ivo Vojnović Na taraci, Max Frisch Igra biografijom, Džanluka Antica Jerko Škripalo, Zvonimir Bajsić Gle, kako dan divno počinje!, Mladen Širola Dugonja, trbonja i vidonja, Felicien Marceau Mališan, Ivo Vojnović Ekvinocijo, Pierre Abelard Heloise Abelardu, Ivo Vojnović Suton, Eduardo de Filippo Ratni bogatuni, Vlaho Stulli Kate Kapuralica, Anđelko Vuletić Daleka plava zvijezda. Repertoar hrvatskih kazališta, knjiga 1 -Repertoari kazališta, kazališnih družina i grupa, partizanskih kazališta, festivala, smotri i susreta, ur. Branko Hećimović, Jugoslavenska akademija znanosti i umjetnosti, Zagreb, 1990., str. 610.

${ }^{805}$ Jednočinke su, uz Požár v suterénu, dijelovi dramske trilogije Život v tichém domě. Ta je dramska trilogija u samizdatu objavljena 1974. Rat na trećem katu premijerno je prikazan u bečkome Burgtheateru 1970., a Peh pod krovom u ingoldštadskom Stadttheateru 1974. Janoušek, Pavel i suradnici Dějiny české literatury 1945-1989, IV. knjiga 1969-1989, Academia, Prag, 2008., str. 558.

${ }^{806}$ Konjevod, M. Na malim pozornicama, Večernji list, br. 7673, 13. 8. 1984., str. 5.
} 
predstave nisu brojne. U dva teksta objavljena u Vjesniku ističe se kvaliteta scenografskih i kostimografskih rješenja Zvonimira Šulera i Rute Knežević. ${ }^{807}$

Kvantitativno je recepcija Havelovih i Kohoutovih drama u Hrvatskoj od 1968. do 1990. približno jednaka, no kritička recepcija predstava prema Havelovim tekstovima i, uopće, njegove građanske i stvaralačke biografije, što je zasigurno uvjetovano i njegovim snažnim i kontinuiranim disidentskim djelatnostima izvan područja književnosti, višestruko je snažnija.

\section{3. 1. Václav Havel Protest i Pavel Kohout Atest (Teatar ITD, 1981.)}

U listopadu 1981. zagrebački Teatar ITD na pozornicu postavlja, u režiji Radovana Marčića, jednočinke Václava Havela Protest i Pavela Kohouta Atest koje su zajedno prikazivale i ostala jugoslavenska kazališta poput beogradskog Narodnog pozorišta i ljubljanskoga Slovenskog ljudskog gledališča. ${ }^{808}$ Obje drame, povezane likom Ferdinanda Vaněka premijerno su prikazane u bečkome Burgtheateru $1979 .{ }^{809}$ Pri izradi ITD-ova plakata za ovu predstavu nakon dugo je godina ostvarena suradnja s vrhunskim imenom hrvatske grafičke umjetnosti toga doba. Naime, nakon Mihajla Arsovskog, koji je autor plakata za Havelovu Drugarsku večer 1966., za predstavu ITD-a 1981. to čini Mirko Ilić. ${ }^{810}$

\footnotetext{
${ }^{807}$ Repertoar hrvatskih kazališta, knjiga 3 - Repertoari 1981. - 1990., ur. Branko Hećimović, Hrvatska akademija znanosti i umjetnosti, 2002., str. 22; M. G. Peh pod krovom, Vjesnik, br. 13735, 6. 12. 1985., str. 2 (Vjesnikov petak); Vrgoč, Dubravka Dopadljiva igra, Vjesnik, br. 13742, 12. 12. 1985., str. 11.

${ }^{808}$ Repertoar hrvatskih kazališta, knjiga 3 - Repertoari 1981. - 1990., ur. Branko Hećimović, Hrvatska akademija znanosti i umjetnosti, 2002., str. 65.

${ }^{809}$ Janoušek, Pavel i suradnici Dějiny české literatury 1945-1989, IV. knjiga 1969-1989, Academia, Prag, 2008. str. 563.

810 Šest godina kasnije, 1987., Mirko Ilić će, u suautorstvu s Lukom Mjedom, biti autor i grafičkoga rješenja za naslovnicu romana Mirakl Josefa Škvoreckog u izdanju Grafičkoga zavoda Hrvatske.
} 


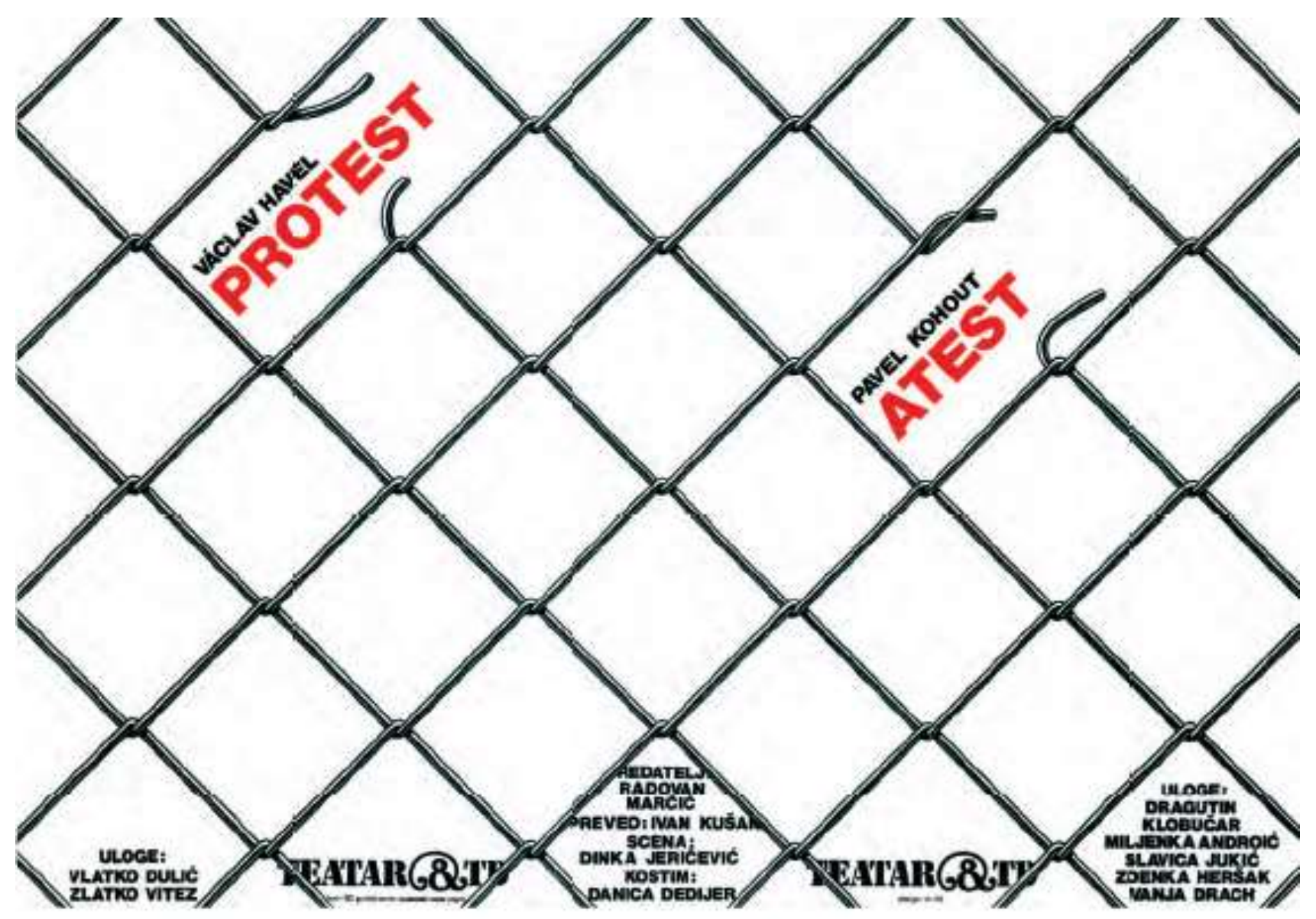

Fotografija XXI: plakat predstave Protest i Atest Václava Havela i Pavela Kohouta, autor Mirko Ilić

Izvor: http://timelinehrvatskogdizajna.com/2017/03/mirko-ilic-2/, pristupljeno 21. 8. 2019.

Kohoutove i Havelove jednočinke najavljene su kratkim tekstom u Večernjemu listu u kojemu se napominje da su drame nepriznate od službene češke književnosti te da tematiziraju sukob intelektualca s političkim pritiscima. ${ }^{811}$ Nakon premijere, a unatoč kvalitetnom glumačkom ansamblu koji su činili Vlatko Dulić, Zlatko Vitez, Zdenka Heršak, Vanja Drach, kazališna kritika predstavama nije bila sklona. Oštrica kritičara najvećim je dijelom uperena u redatelja Radovana Maričića koji „,ne postiže ujednačen ritam i tempo igre, pa ima mjesta gdje predstava djeluje razvučeno i brbljavo“6812. Večernjakov tekst, također, ističe da predstave nisu izazvale veliko zanimanje publike pa je premijera odigrana pred gledalištem koje je bilo napola prazno.

${ }^{811}$ Dvije jednočinke, Večernji list, br. 6808, 12. 10. 1981., str. 8.

${ }^{812}$ M. G. Nastavak u burleski (Premijera Teatra ITD), Večernji list, br. 6814, 19. 10. 1981., str. 8. 
Premijeru jednočinki prati objavljivanje programske knjižice koja uz osnovne informacije o predstavi donosi biografije dvojice autora, ulomke njihovih razgovora s Jiř́ijem Ledererom objavljene u Njemačkoj 1975. te prijevode njihovih tekstova objavljene $u$ njemačkome Bonnu povodom premijera Havelove Izložbe i Kohoutova Požara u prizemlju u tekstu o Havelu Kohout svoga kolegu opisuje na sljedeći način: „A takav je Havel u stvarnosti: lukav kao lisica, tvrdoglav poput ovna, vjeran kao pas i ponekad naivan poput životinje koju radije ne bih imenovao.“ ${ }^{813}$ Obrnuto, Havel, pišući o evoluciji njihova odnosa od 1950-ih pribjegava metaforama te navodi da je tijekom normalizacije to odnos „dvaju mornara u istom čamcu povezanih zajedničkim radom i zajedničkim ciljem. ${ }^{\text {“814 }}$

${ }^{813}$ Programska knjižica predstava Atest i Protest, Teatar ITD, prednja stranica. 814 Isto. 


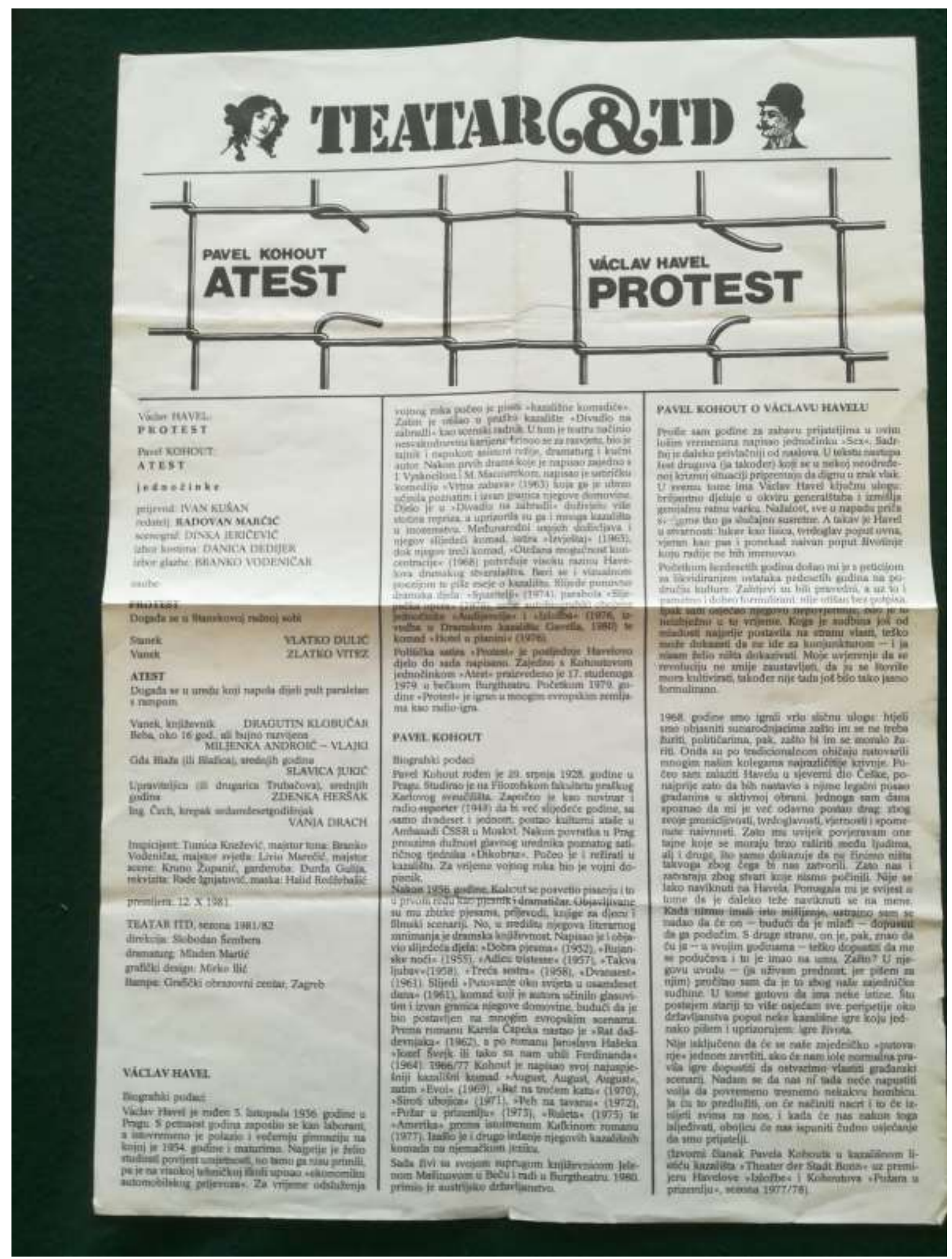

Fotografija XXII: Programska knjižica predstava Protest i Atest Václava Havela i Pavela Kohouta u Teatru ITD, prednja stranica Izvor: Odsjek za povijest hrvatskoga kazališta HAZU-a 


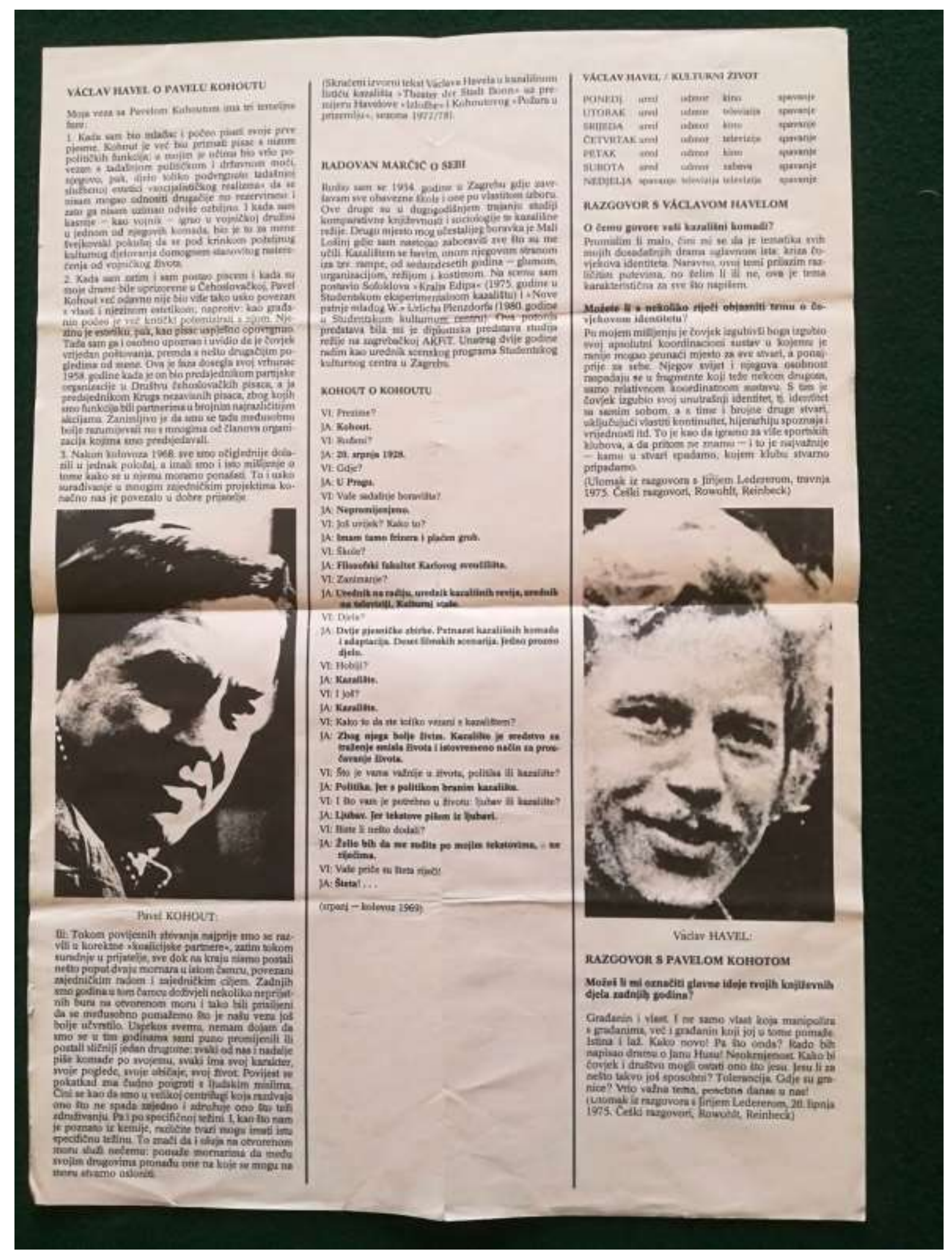

Fotografija XXIII: Programska knjižica predstava Protest i Atest Václava Havela i Pavela

Kohouta u Teatru ITD, stražnja stranica

Izvor: Odjel za povijest hrvatskoga kazališta HAZU-a 


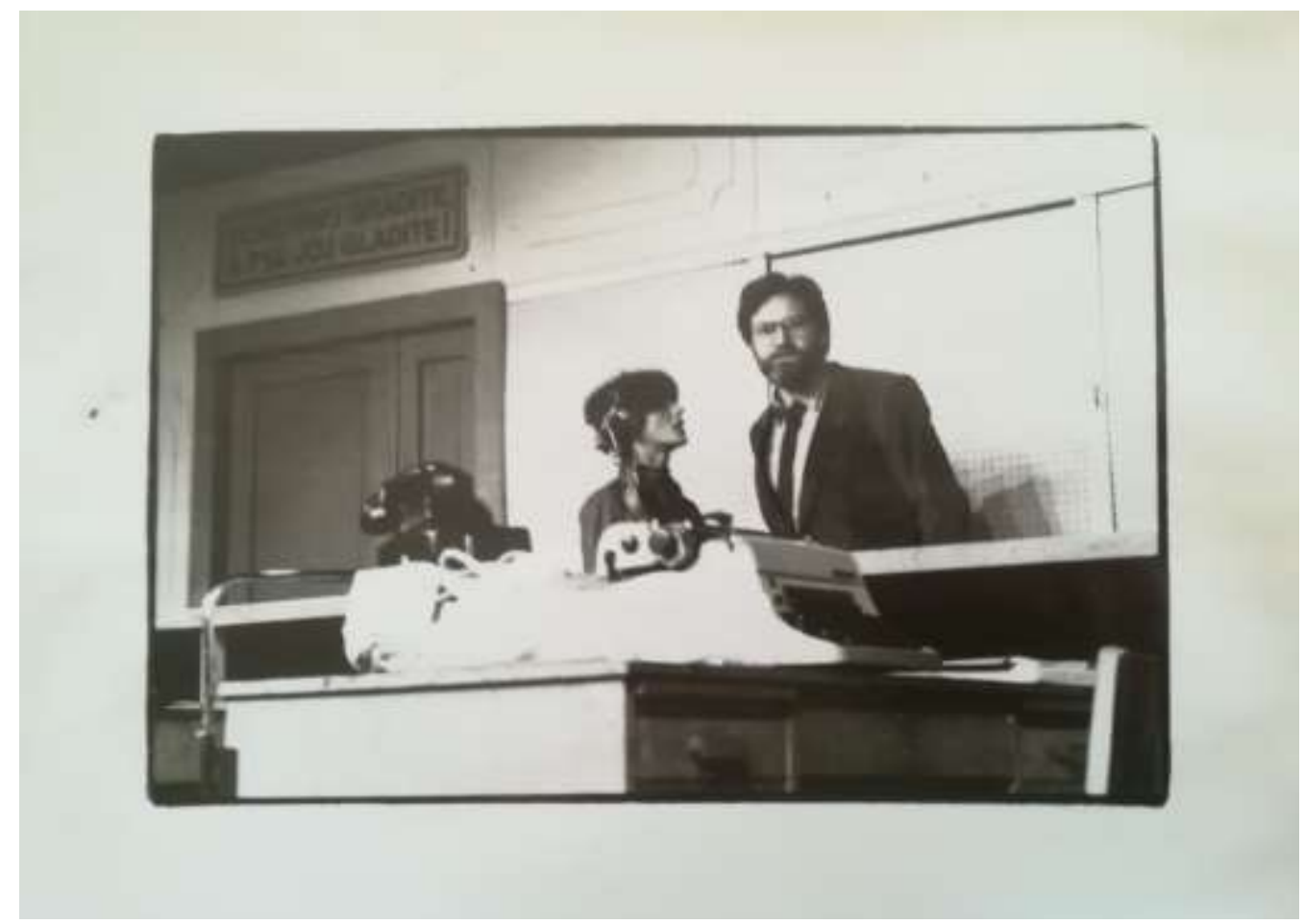

Fotografija XXIV: Fotografija predstava Protest i Atest Václava Havela i Pavela Kohouta u Teatru ITD, 1981.

Izvor: Odsjek za povijest hrvatskog kazališta HAZU-a

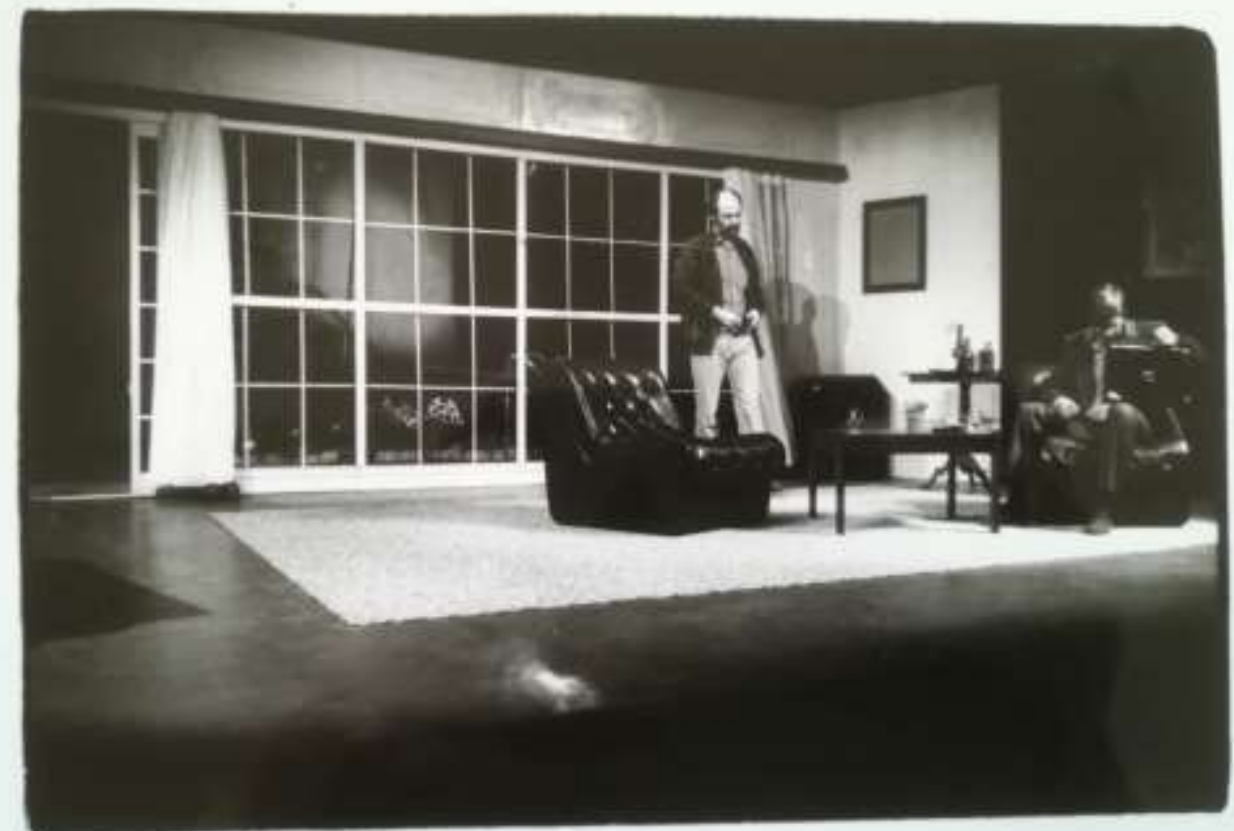

Fotografija XXV: Fotografija predstave Protest i Atest Václava Havela i Pavela Kohouta u Teatru ITD, 1981.

Izvor: Odsjek za povijest hrvatskog kazališta HAZU-a 
7. 3. 2. Pavel Kohout Marija se bori s anđelima (Dramsko kazalište Gavella, 1985.)

Redatelj Jakov Sedlar 1985. na pozornicu zagrebačkoga Dramskog kazališta Gavella postavlja dramu Pavela Kohouta Marija se bori s anđelima koja je svjetsku premijeru doživjela u bečkome Burgtheateru četiri godine ranije. Glavne uloge Gavelline predstave Sedlar povjerava uglednim glumačkim imenima zagrebačkoga teatra - Semki Sokolović-Bertok, Borisu Miholjeviću i Biserki Ipša. Osim u Zagrebu sredinom osamdesetih taj Kohoutov tekst ostvaruje snažnu recepciju i u drugim jugoslavenskim kazališnim središtima poput tadašnjega Titograda i Beograda, ${ }^{815}$ ali i u nekim drugim europskim zemljama, u Italiji je, primjerice, 1989. prema dramskome predlošku snimljena televizijska serija Gli angeli del potere (Andělé moci). ${ }^{816}$ U Gavelli se predstava 1985. na programu održala vrlo kratko, od 15. veljače do 27. ožujka, i u tome razdoblju ostvaruje 7 repriznih izvedaba. ${ }^{817}$

Povod nastanku dramskoga teksta bio je stvaran događaj - izvedba predstave za uzak krug ljudi u praškome stanu glumice Vlaste Hramostové čiji je autor dramatičar kojemu je onemogućeno javno objavljivati i djelovati. ${ }^{818}$ Pišući o Kohoutovoj Mariji i hrvatski su se novinari okrenuli biografskome tumačenju motiva, čemu nerijetko pribjegavaju i u svojim tekstovima o dramama Václava Havela. Tako Večernjakov novinar Boris B. Hrovat smatra kako je Kohout pišući tekst na umu imao, u prvome redu, Václava Havela, no i sve druge češke i slovačke dramatičare koji su tih godina pisali ,za ladicu“ ili izvedbe pred prijateljima, poznanicima i kolegama u privatnim stanovima. ${ }^{819}$

\footnotetext{
${ }^{815}$ Godine 1985. Kohoutova Marija se bori s anđelima, osim u zagrebačkoj Gavelli, igra u još dvama jugoslavenskim kazalištima. U tadašnjemu Titogradu u Crnogorskome narodnom pozorištu u režiji Blagote Erakovića te u proslavljenome beogradskom Ateljeu 212. Osobito je Ateljeova predstava u hrvatskim pisanim medijima praćena pohvalnim tekstovima, a dodatnu je pozornost dobila u studenom 1985. nakon što je beogradsko kazalište upravo tom Kohoutovom predstavom sudjelovalo u proslavi 125. godišnjice zagrebačkoga Hrvatskog narodnog kazališta. Kaurin, A. Mira Stupica oduševila, Večernji list, br. 7875, 10. 4. 1985., str. 9; Kaurin, A. Zlatni vijenac „Mariji“, Večernji list, br. 7883, 18. 4. 1985., str. 9; S. K. „Ateljeu 212“ prva nagrada, Vjesnik, br. 13508, 18. 4. 1985., str. 11; Hrovat, Boris B. Večer Mire Stupice, Večernji list, br. 8052, 6. 11. 1985., str. 5; Elezović, Slobodan Lijepi zagrebački dani, Večernji list, br. 8049, 2. i 3. 11. 1985., str. 13; Grgičević, Marija Veća i od legende, Vjesnik, br. 13707, 6. 11. 1985., str. 11.

${ }^{816}$ Janoušek, Pavel i suradnici Dějiny české literatury 1945-1989, IV. knjiga 1969-1989, Academia, Prag, 2008. str. 568.

${ }^{817}$ Repertoar hrvatskih kazališta, knjiga 3 - Repertoari 1981. - 1990., ur. Branko Hećimović, Hrvatska akademija znanosti i umjetnosti, 2002., str. 53.

818 Janoušek, Pavel i suradnici Dějiny české literatury 1945-1989, IV. knjiga 1969-1989, Academia, Prag, 2008. str. 568.

${ }^{819}$ Hrovat, Boris B. Večer Mire Stupice, Večernji list, br. 8052, 6. 11. 1985., str. 5. Tekst o predstavi Marija se bori s anđelima beogradskoga Ateljea 212 izvedene u Zagrebu povodom 125. sezone Hrvatskoga narodnog kazališta.
} 
U najtiražnijim hrvatskim dnevnim novinama zabilježena su dvije kazališne kritike Gavelline predstave od kojih niti jedna izvedbu ne ocjenjuje izuzetno pozitivno. Umjerenija kritika, ona Marije Grgičević u Večernjemu listu, predstavu ocjenjuje kao „korektno kazališno ostvarenje na standardnoj profesionalnoj razini, lišeno iznenađenja““ ${ }^{820}$ a Vjesnikova kritika iz pera Dubravke Vrgoč negativna je. ${ }^{821}$ Vrgoč primjećuje da u predstavi koju režira Jakov Sedlar ,[p]ublika prati razvodnjenu priču, usporenog ritma, ispričanu u nekoliko nepovezanih slika“"822, scenografiju naziva banalnom. Gavellinom izvedbom Kohoutova teksta bavi se i kazališna kritika Smilje Kursar Pupavac u časopisu Oko, no i ta kritičarka smatra da Sedlarova režija nije iskoristila sve potencijale dramskoga predloška. ${ }^{823}$

\footnotetext{
${ }^{820}$ Grgičević, Marija Gluma na ledu, Večernji list, br. 7832, 18. 2. 1985., str. 8.

${ }^{821}$ Vrgoč, Dubravka Izgubljena agresivnost, Vjesnik, 18. 2. 1985., str. 11.

822 Isto.

${ }^{823}$ Kursar Pupavac, Smilja U krleci vlastitih dilema, Oko, br. 338, 1985., str. 11.
} 


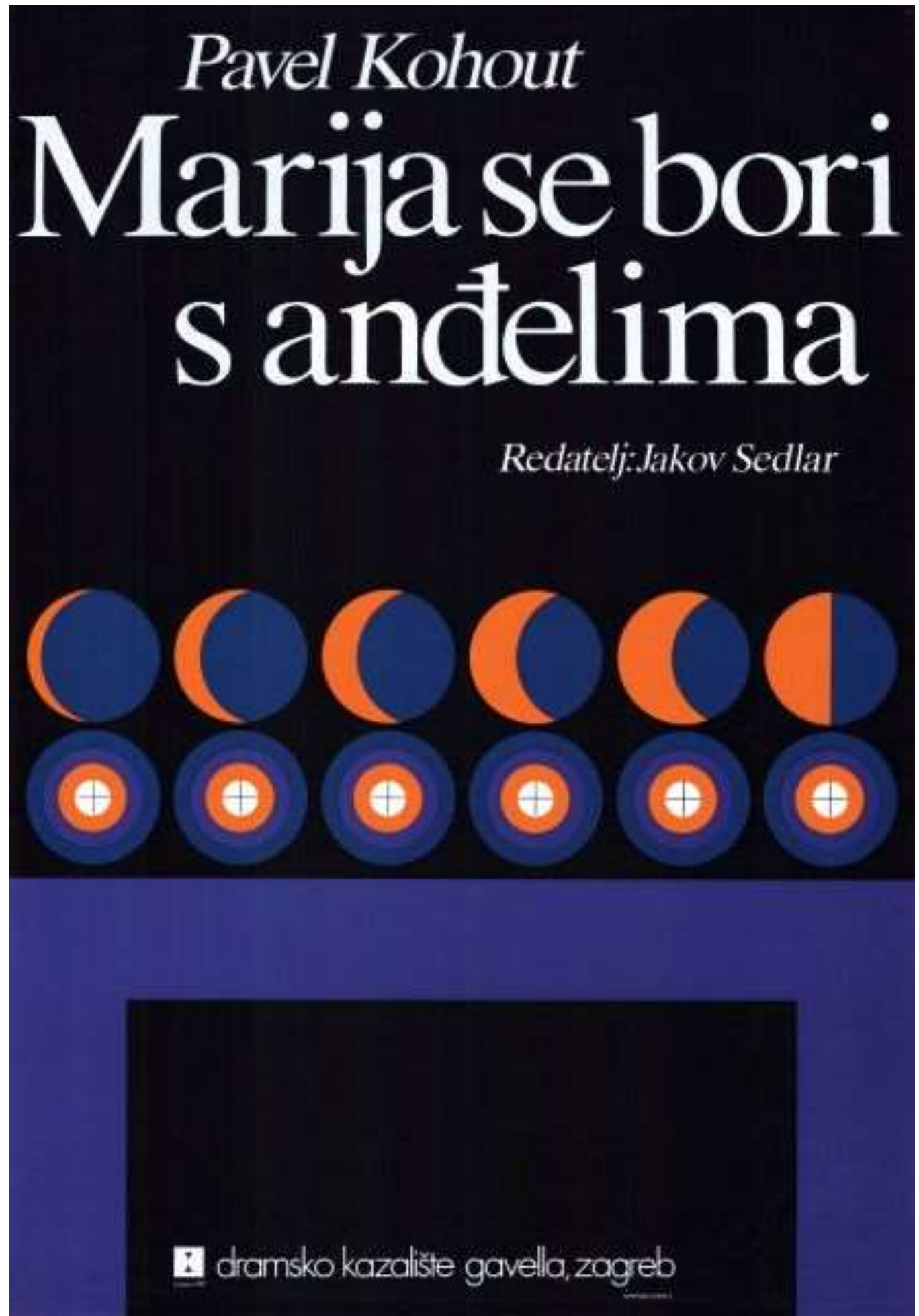

Fotografija XXVI: plakat predstave Marija se bori s anđelima Pavela Kohouta, autor Ivan Picelj

Izvor: http://athena.muo.hr/?object=detail\&id=64154, pristupljeno 2. 8. 2019. 


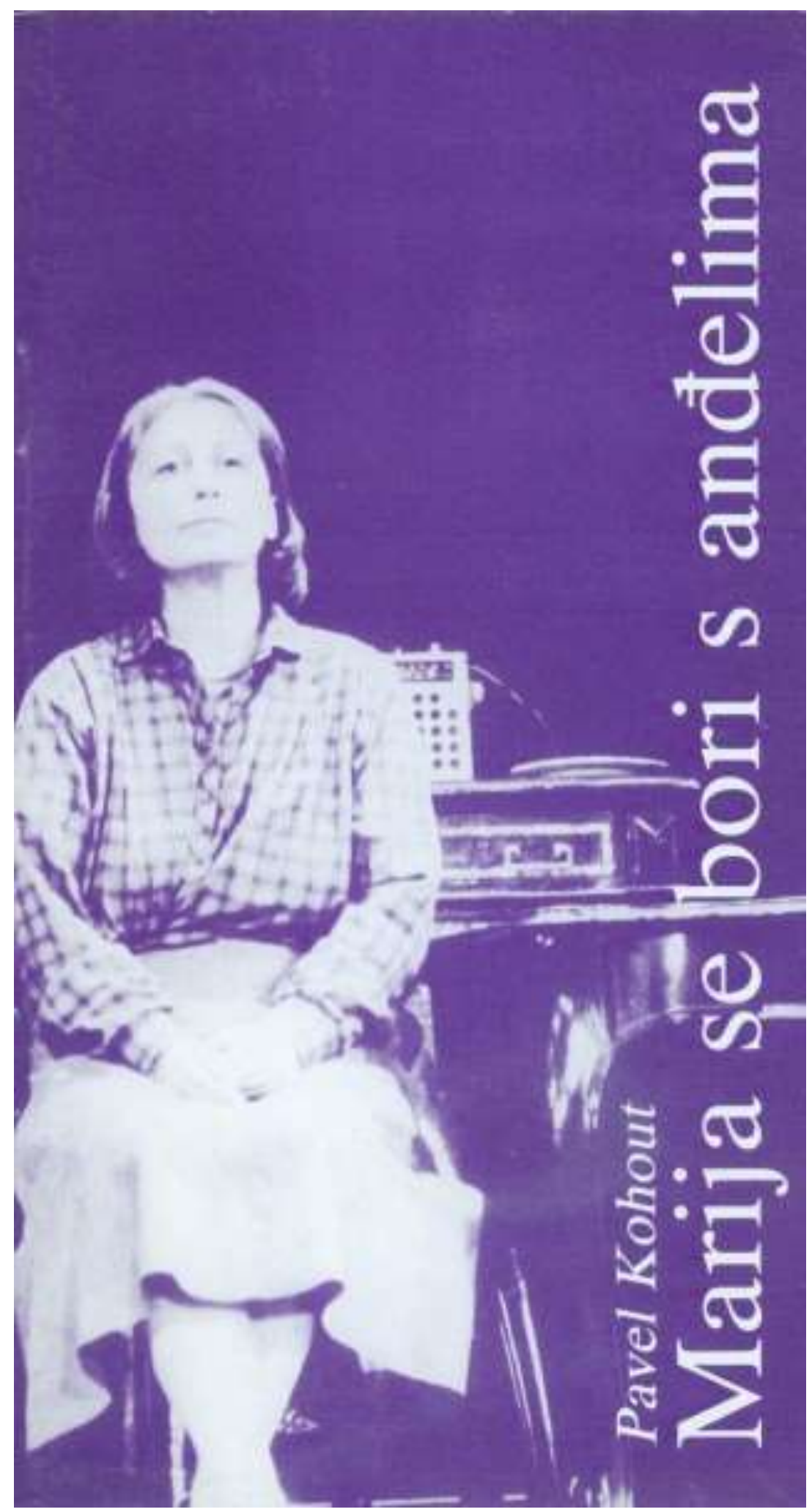

Fotografija XXVII: naslovnica programa predstave Marija se bori s anđelima Pavela Kohouta, autor Ivan Picelj

Izvor: http://athena.muo.hr/?object=view\&id=65980, pristupljeno 2. 8. 2019. 
7. 4. Recepcija drama ostalih neoficijelnih čeških dramatičara

Osim predstava prema tekstovima Milana Kundere, Václava Havela i Pavela Kohouta hrvatska kazališta u svoj program uvrštavaju i dramske tekstove dramatičara kojima je, također, u Čehoslovačkoj onemogućen kazališni rad ili otežan, primjerice, nužnošću djelovanja izvan većih kazališnih središta, a koji su hrvatskoj publici slabije poznati, poput Jaroslava Gillara, Vladimíra Škutine, Milana Uhdea, Jana Cziviša, Alene i Jaroslava Vostrog. Premijere svih tih predstava bilježimo u osamdesetim godinama.

Riječ je o trima originalnim dramskim tekstovima i dramatizaciji Voltaireova romana Candide koja kronološki stoji na početku ovoga niza. U režiji Tomislava Svetića i prijevodu Dana Zeljaka i Vlatka Perkovića uprizoruje ga Zagrebačko studentsko eksperimentalno kazalište u listopadu 1980. ${ }^{824}$ Autorstvo dramatizacije pripisuje se češkome trojcu koji čine Jan Cziviš, Alena Vostrá ${ }^{825}$ i Jaroslav Vostrý ${ }^{826}$. Ista je dramatizacija izvedena i 1983. na Splitskome ljetu, a obje su izvedbe izazvale negativne ocjene kritičara. Dalibor Foretić dramatizaciju naziva „,scenskim promašajem“627, unatoč tome što se glumačka postava sa Splitskoga ljeta sastojala od uglednih imena poput Ive Gregurevića, Nede Arnerić i Špire Guberine. $^{828}$

U godini kada je na repertoaru i proslavljena Kunderina $\breve{S} a l a$ od koje se puno očekivalo, no čija je kritička recepcija, pokazalo je vrijeme, uglavnom negativna, Satiričko kazalište Jazavac prikazuje i dramu Diktator na kruški (A na hrušce sedí diktátor) emigrantskoga dvojca Vladimíra Škutine ${ }^{829}$ i Jaroslava Gillara ${ }^{830}$. Horizont očekivanja kritike

\footnotetext{
${ }^{824}$ Repertoar hrvatskih kazališta, knjiga 3 - Repertoari 1981. - 1990., ur. Branko Hećimović, Hrvatska akademija znanosti i umjetnosti, 2002., str. 517.

${ }^{825}$ Vostrá, Alena (1938. - 1992.), češka prozaistica i dramatičarka. Tijekom normalizacije mogućnosti objavljivanja bile su joj ograničene. www.slovnikceskeliteratury.cz (natuknica Alena Vostrá, pristupljeno 2. 9. 2019.)

${ }^{826}$ Vostrý, Jaroslav (1931.), češki kazališni teoretičar, povjesničar, kritičar i dramatičar. Tijekom normalizacije djeluje kao redatelj u kazalištima izvan Praga (Kladně, Ústí nad Labem, Pardubice). Dramski su mu tekstovi prikazivani pod tuđim imenima, npr. drama Tři v tom izvođena pod imenom Jiř́ija Menzela.

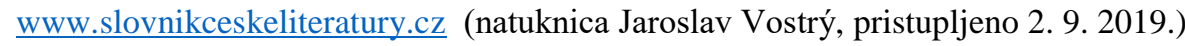

${ }^{827}$ Foretić, Dalibor Ljeto jednog kazališta, Danas, 30. 8. 1983., str. 57-58.

${ }^{828}$ Stublija, Želimir Bijeg od izazova, Vjesnik, br. 11914, 25. 10. 1980., str. 7; Mirković, Vojko Sličice lake komedije, Večernji list, br. 7354, 26. 7. 1983., str. 10.

${ }^{829}$ Škutina, Vladimír (1931. - 1995.), češki dramatičar. Od 1978. živi i radi u Švicarskoj. Drame koje je pisao u suautorstvu s Jaroslavom Gillarom nerijetko su izvodila njemačka i švicarska kazališta.

www.slovnikceskeliteratury.cz (natuknica Vladimír Škutina, pristupljeno 2. 9. 2019.)

${ }^{830}$ Gillar, Jaroslav (1942.), češki dramatičar i kazališni redatelj. U egzil odlazi 1974. Poznat i kao prevoditelj s francuskoga jezika. www.slovnikceskeliteratury.cz (natuknica Jaroslav Gillar, pristupljeno 2. 9. 2019.)
} 
oblikovan je, očito, pojmom tipičnoga „,̌̌škog humora“ budući da su u novinskim tekstovima kojim se najavljivala premijera humor i stil drame nazvani „hašekovskim“"831. No, kritike objavljene nakon premijere predstavi nisu laskale i uglavnom su bile usmjerene prema kvaliteti dramskoga predloška. Marija Grgičević tekst ocjenjuje standardnim, „na doličnoj razini kazališne pismenosti, ali ni izdaleka da bi nadmašio plodove naših dramatičara“ ${ }^{\text {(832 }}$. U novu predstavu na Jazavčevu repertoaru Večernjakova kritičarka ne polaže velike nade te uočava da se glumci „trude“6333, a publika „Zabavlja“6834. Još je oštriji Dalibor Foretić koji u Vjesniku predstavu naziva „komedij[om] bez smijeha“"835. Kritičar dvoji tko je pao s kruške nije li onaj tko je dramu uvrstio na repertoar?

Najbolju recepciju među gledateljima ostvarila je, premijerno izvedena u studenome 1987. u Teatru ITD, drama Tri u drugom (Tři v tom) koju režiraju Radovan Maričić i Jiří Menzel. Redatelj Menzel je tijekom osamdesetih potpisan i kao autor dramskoga teksta. ${ }^{836} \mathrm{Na}$ repertoaru zagrebačkoga kazališta predstava se održala prilično dugo, od studenoga 1987. do lipnja 1990. i u tome je razdoblju odigrana čak 66 puta uz dvije izvedbe na Danima Kazališne zajednice Rijeka 1988. i izvedbe 1989. u Saveznoj Republici Njemačkoj za radnike iz Jugoslavije na privremenom radu, a u organizaciji Zajednice klubova Jugoslavena iz Stuttgarta ${ }^{837}$ No, padom komunizma u Čehoslovačkoj u javnost dolazi informacija da je autor drame, zapravo, Jaroslav Vostrý koji tijekom normalizacije u Čehoslovačkoj nije mogao javno djelovati pa se predstava pod Menzelovim imenom čak osam godina nalazi i na repertoaru praškoga kazališta Činoherní klub. ${ }^{838}$

Izuzetno pozitivnu kritiku te predstave koja je ,istinsko savršenstvo“ ${ }^{639}$ objavljuje Tomislav Oštrić koji ocjenjuje da je ,[s]ve što se na pozornici događa - zabavno (...), logično

\footnotetext{
${ }^{831}$ Vukšić, Branko Diktator na kruški, Večernji list, br. 7190, 13. 1. 1983., str. 5.

${ }^{832}$ M. G. Kruška nakon jabuke, Večernji list, br. 7198, 21. 1. 1983., str. 5.

833 Isto.

${ }^{834}$ Isto.

${ }^{835}$ Foretić, Dalibor Tko je pao s kruške?, Vjesnik, br. 12711, 20. 1. 1983., str. 7.

${ }^{836}$ Repertoar hrvatskih kazališta, knjiga 3 - Repertoari 1981. - 1990., ur. Branko Hećimović, Hrvatska akademija znanosti i umjetnosti, 2002., str. 67.

${ }^{837}$ Repertoar hrvatskih kazališta, knjiga 3 - Repertoari 1981. - 1990., ur. Branko Hećimović, Hrvatska akademija znanosti i umjetnosti, 2002., str. 259; Teatar ITD u SR Njemačkoj, Vjesnik, br. 14952, 5. 5. 1989. str. 10.

${ }^{838}$ Janoušek, Pavel i suradnici Dějiny české literatury 1945-1989, IV. knjiga 1969-1989, Academia, Prag, 2008. str. 616; Vrgoč, Dubravka Tri u drugom, Vjesnik, br. 14422, 5. 11. 1987., str. 11.

Stublija, Želimir Bijeg od izazova, Vjesnik, br. 11914, 25. 10. 1980., str. 7; Mirković, Vojko Sličice lake komedije, Večernji list, br. 7354, 26. 7. 1983., str. 10.

${ }^{839}$ Oštrić, Tomislav Gorući dlanovi, Polet, br. 376, 1987.
} 
i odmjerena tempa ${ }^{\text {“840 }}$. Oštrić pozitivno ocjenjuje i glumačku postavu koju čine Alma Prica, Ratko Buljan, Mladen Vasary, Dubravka Ostojić i Miljenka Androić-Vlajki, a na čelu s Perom Kvrgićem te zaključuje da ,pljesak nakon završna čina nije bio odgovarajućeg trajanja iz jedinog razloga: fizički je nemoguće izdržati onoliko dugo pljeskati dlanom o dlan koliko predstava i njena izvedba to zaslužuju“ ${ }^{\text {(641 }}$. Stalna Vjesnikova kazališna kritičarka Marija Grgičević o predstavi u tim dnevnim novinama navodi da je „[p]repuna komike jarkih boja i bučnih eksplozija, pravo mahnitanje u žudnji za zaboravom i veseljem, burleskni optimizam bez početka i kraja“6842.

Niti u jednome se tekstu objavljenome nakon premijere $u$ analiziranim hrvatskim pisanim medijima ne dovodi u pitanje Menzelovo autorstvo drame sve do prosinca 1987. Kako se danas zna da je autor drame Jaroslav Vostrý, neke rečenice iz Vjesnikova teksta mogu zvučati kao naznaka Menzelova odmaka od pripisivanja autorstva. U uvodu se Menzel predstavlja kao „na plakatu potpisani autor“ ${ }^{“ 843}$, a on se sam u izjavi znakovito „odriče“ autorstva teksta te naglašava da je tekst „kolektivno djelo glumaca Činoherní klub“ i da ne bi htio biti hvaljen ,zbog onoga što su drugi uradili““844.

U listopadu 1989., u vrijeme kada već i kazališta u Čehoslovačkoj svoje pozornice otvaraju neoficijelnim dramatičarima, svjetsku premijeru u zagrebačkom Kazalištu Komedija ostvaruje drama Milana Uhdea ${ }^{845}$ Max\&Engel Private (Zvěstování aneb Bedřichu, jsi anděl) u režiji Želimira Oreškovića. U svojoj novinskoj kritici Branko Vukšić navodi da Uhde nije dramatičar poznat hrvatskoj publici, poput Havela, Kundere ili Kohouta, te postavlja pitanje zašto se ta drama uopće našla na repertoaru Komedije budući da je u njoj „humornost na razini prosječne novinske humoreske, u površnom dosluhu sa zatupljenom satirom “846. Najboljim dijelom izvedbe Vukšić smatra glumačku postavu koju čine Otokar Levaj, Lela

\footnotetext{
${ }^{840}$ Oštrić, Tomislav Gorući dlanovi, Polet, br. 376, 1987.

841 Isto.

${ }^{842}$ Grgičević, Marija Mahnitanje veselja, Vjesnik, br. 14426, 9. 11. 1987., str. 11.

${ }^{843}$ Grgičević, Marija Menzel se „odriče“ sebe, Vjesnik, br. 14466, 22. 12. 1987., str. 7.

${ }^{844}$ Isto.

${ }^{845}$ Uhde, Milan (1936.), češki dramatičar i prozaist. Tijekom normalizacije nije mogao javno djelovati, jedan je od potpisnika Povelje 77. Nakon pada komunizma dvije je godine ministar kulture Čehoslovačke. Niz mu je dramskih tekstova tijekom normalizacije premijerno izveden u privatnim prostorima njegovih prijatelja. http://www.slovnikceskeliteratury.cz (natuknica Milan Uhde, pristupljeno 2. 8. 2019.)

${ }^{846}$ Puljizević-Grbin, L. Takav je Ma(r)x privatno, Večernji list, br. 9401, 19. 10. 1989., str. 13; Vukšić, B. Spavaćica ne otkriva mnogo, Večernji list, br. 9404, 22. 10. 1989., str. 18.
} 
Margetić, Boris Pavlenić i debitantica Jasna Bilušić. Vrlo brzo nakon zagrebačke premijere Uhdeovu dramu izvodi i praško Malé české divadlo. ${ }^{847}$

7. 5. Kazališne smotre, festivali i gostovanja kazališnih kuća iz ostalih jugoslavenskih republika

Osim redovnih izvedaba u programima kazališnih kuća predstave prema tekstovima neoficijelnih dramatičara uvrštavane su i u programe najprestižnijih jugoslavenskih kazališnih smotra i festivala poput Gavellinih večeri, Jazavčevih Dana satire, sarajevskoga Festivala malih i eksperimentalnih scena Jugoslavije. Na navedenim se kazališnim manifestacijama prikazuju i predstave premijerno prikazivane u hrvatskim kazalištima, no kazališni su festivali i medij kojim hrvatska publika recipira izvedbe kazališnih kuća ostalih jugoslavenskih republika.

Da uprave kazališta, nerijetko, drame neoficijelnih dramatičara smatraju vrhuncem produkcije u određenoj kazališnoj sezoni svjedoči nam činjenica da su na sarajevskome Festivalu malih i eksperimentalnih scena Jugoslavije 1981. jedine dvije predstave hrvatskih kazališta, od ukupno 12 na Festivalu te godine, upravo Havelove jednočinke Audijencija i Izložba u produkciji Dramskoga kazališta Gavella te ITD-ov Žak Fatalist i njegov gospodar Milana Kundere. ${ }^{848}$ Godinu dana kasnije u program istoga festivala uvrštene su iste drame Václava Havela, no ovaj put u izvedbi beogradskoga Ateljea 212. Iako su glavne glumačke nagrade manifestacije 1982., lovor-vijence za glumu, osvojili glumci Audijencije i Izložbe Danilo Stojković i Petar Kralj, ${ }^{849}$ kritičarske ocjene Ateljeove predstave u hrvatskome tisku nisu bile pohvalne. U Vjesnikovoj kritici Gradimir Gojer daje oštru ocjenu da bi za Atelje 212 bilo „najbolje da je izostao s festivala“650 jer Havelove jednočinke nisu „,najreprezentativniji domet tog kazališta" ${ }^{651}$.

Gavelline večeri zagrebačkoga Dramskog kazališta Gavella u svome su programu tradicionalno okupljale vrhunce godišnje produkcije kazališnih kuća iz svih republika tadašnje

\footnotetext{
${ }^{847}$ Janoušek, Pavel i suradnici Dějiny české literatury 1945-1989, IV. knjiga 1969-1989, Academia, Prag, 2008., str. 570.

${ }^{848}$ Rekord na malim scenama, Večernji list, br. 6593, 29. 1. 1981. str. 11; Odabrane predstave, Večernji list, br. 6620, 2. 3. 1981., str. 10.

${ }^{849}$ A. Z. Kazališni praznik, Večernji list, br. 6948, 29. 3. 1982., str. 10; M. G. Nagrade u Mostar, Večernji list, br. 6955, 6. 4. 1982., str. 9.

${ }^{850}$ Gojer, Gradimir Sve manje tragalaštva, Vjesnik, br. 12453, 9. 4. 1982., str. 9.

851 Isto.
} 
Jugoslavije. Na toj se kazališnoj smotri izvodi čak šest dramskih tekstova Václava Havela i Milana Kundere, od čega tri predstave pred publiku donose kazališta izvan Zagreba. Kronološki prva dramatizacija je romana Šala Milana Kundere u režiji Aleksandra Ognjanovića kojom u programu smotre Beogradsko dramsko pozorište sudjeluje čak dvije godine 1976. i 1978. ${ }^{852}$ Slijedi 1986. Žak Fatalist i njegov gospodar splitskoga HNK-a, ${ }^{853}$ no u javnosti je najjače odjeknulo gostovanje slavnoga beogradskoga Ateljea 212 1987. s Havelovom Prosjačkom operom u režiji Ljubomira Draškića. ${ }^{854}$ Unatoč zvjezdanoj glumačkoj postavi koju čine velikani poput Dragana Nikolića, Mire Stupice, Nede Arnerić i Svetlane Bojković, Ateljeovu izvedbu Havelove predstave Želimir Stublija u Oku naziva jedinim razočaranjem kazališne smotre. ${ }^{855}$ Ivica Buljan u Poletu kritizira cijeli koncept Gavellinih večeri te godine u kojoj su, kako kaže, kolaps doživjeli i Splitsko ljeto i Dubrovačke ljetne igre, a predstavu Ateljea 212 vidi kao ,vrhunsk[u] igr[u] glumaca na bljedunjavoj i neupitnoj podlozi“656. U skladu s tendencijama vremena 1987. ta je kazališna smotra obogaćena novinama poput interne televizije koja je omogućila videosnimke svih kazališnih predstava te okrugle stolove koje moderira Igor Mandić. ${ }^{857}$

Unatoč ne pretjerano laskavim kritikama koje su slijedile, beogradska glumačka elita bila je snažan mamac za publiku pa su ulaznice za dvije izvedbe te predstave i najbrže prodane. ${ }^{858} \mathrm{U}$ jednome je danu predstava odigrana čak tri puta, sva tri pred punim gledalištem uz to što je jedan dio publike, zbog manjka sjedećih mjesta u dvorani, čitava dva i pol sata koliko predstava traje predstavu gledao stojeći. ${ }^{859}$ Razlog trima izvedbama u jednome danu bili su problemi s prijevozom jer je slijetanje aviona s beogradskim glumcima bilo onemogućeno zbog zagrebačke magle pa je prva predstava zbog kašnjenja ansambla prebačena na drugi dan. ${ }^{860} \mathrm{U}$ svojoj kazališnoj kritici Branko Vukšić potvrđuje dobar prijam kod publike, no sâm smatra da se izvedba „može (...) svrstati u popularni program bez

\footnotetext{
${ }^{852}$ Repertoar hrvatskih kazališta, knjiga 1 - Repertoari kazališta, kazališnih družina i grupa, partizanskih kazališta, festivala, smotri i susreta, ur. Branko Hećimović, Jugoslavenska akademija znanosti i umjetnosti, Zagreb, 1990., str. 916.

${ }^{853}$ Isto, str. 267.

${ }^{854}$ Isto, str. 268.

855 Stublija, Želimir Još malo pa festival, Oko, br. 399, 1987.

${ }^{856}$ Buljan, Ivica Le soirs de Gavella, Polet, br. 377, 1987., str. 33.

${ }^{857}$ Foretić, Dalibor Povratak kućnom festivalu, Danas, 17. 11. 1987., str. 38-39.

${ }^{858}$ S. Nč. Put k festivalu, Večernji list, br. 8703, 30. 10. 1987., str. 11.

${ }^{859}$ Grgičević, Marija Počinju Gavelline večeri, Vjesnik, br. 14417, 31. 10. 1987., str. 9; Vukšić, B. Tri predstave - prepuna dvorana, Večernji list, br. 8713, 9. 11. 1987., str. 10.

${ }^{860}$ Grgičević, Marija Lepršava satira, Vjesnik, br. 14427, 10. 11. 1987., str. 11.
} 
prevelikih umjetničkih pretenzija“661 . Kritičar smatra da su sjajnoj recepciji i iznimnom zanimanju publike uvelike pridonijela i proslavljena glumačka imena s kojima beogradski teatra dolazi u Zagreb. Vukšić Ateljeovoj izvedbi pronalazi niz zamjerki poput spora ritma, nedovoljno razrađenih likova i nesigurnosti dijela glumačke postave. Iako beogradsko kazalište naziva „miljenikom zagrebačke publike“ ${ }^{6862}$, Prosjačkom operom nije impresioniran i smatra da Atelje 212 tom predstavom „nije postigao ništa više od dopadnosti, što, ipak, za

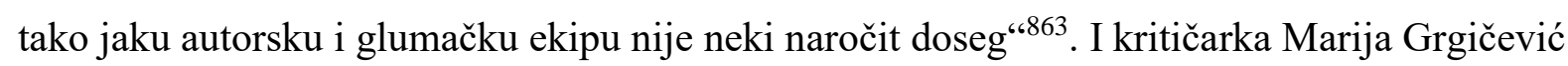
najveću kvalitetu predstave prepoznaje u „lakoć[i] i šarm[u] glumačke ekipe“664. Poraznu kritiku predstave u tjedniku Danas piše Dalibor Foretić koji je opisuje kao „,apsolutno razočaranje ${ }^{6665}$, razočaravajućima smatra i Havelov dramski tekst, i režiserska rješenja Ljubomira Draškića, i glumačke izvedbe. Svoju kritiku zaključuje riječima da „od onog famoznog Ateljeova glumačkog šarma koji je katkad tako sjajno znao pokriti i manjkavosti predstave, u Prosjačkoj operi nije ostalo gotovo ništa, a o nekim dubljim vrijednostima predstave da i ne govorimo“866. Kritičke napise kao da su osluhnuli i članovi žirija pa Gavelline večeri te godine niti jednu svoju nagradu nisu dodijelili Ateljeovoj i Havelovoj Prosjačkoj operi.

Atelje 212 pozornost hrvatskih pisanih medija zaokupio je već 1985. gostovanjem u Zagrebu dramom Pavela Kohouta Marija se bori s anđelima prigodom obilježavanja 125. godišnjice zagrebačkoga Hrvatskog narodnog kazališta. ${ }^{867}$ Glavna zvijezda Ateljeove glumačke postave koja je, prema napisima kazališnih kritičara, i glavni mamac za zagrebačku publiku i tada je bila glumica Mira Stupica. ${ }^{868}$ Beogradsko kazalište na zagrebačku proslavu dolazi s vrhunskim ostvarenjem svoje produkcije. Naime, Kohoutova je drama, u režiji Ljubomira Draškića, u godini premijere, 1984., proglašena najboljom predstavom kazališne sezone u Beogradu. Istom su predstavom Beograđani sudjelovali i na 26. festivalu jugoslavenskoga teatra u Sarajevo gdje su nagrađeni festivalskim nagradama ${ }^{869}$ te

\footnotetext{
${ }^{861}$ Vukšić, B. Dopadljivost prije svega, Večernji list, br. 8715, 11. 11. 1987., str. 16.

${ }^{862}$ Vukšić, B. Negdje između, Večernji list, br. 8718, 15. 11. 1987., str. 8.

863 Isto.

${ }^{864}$ Grgičević, Marija Lepršava satira, Vjesnik, br. 14427, 10. 11. 1987., str. 11.

${ }^{865}$ Foretić, Dalibor Povratak kućnom festivalu, Danas, 17. 11. 1987., str. 38-39.

866 Isto.

${ }^{867}$ Dvadeset predstava, Večernji list, br. 7848, 8. 3. 1985., str. 9.

${ }^{868}$ Elezović, Slobodan Lijepi zagrebački dani, Večernji list, br. 8049, 2. i 3. 11. 1985., str. 13; Hrovat, Boris B. Večer Mire Stupice, Večernji list, br. 8052, 6. 11. 1985., str. 5; Grgičević, Marija Veća i od legende, Vjesnik, br. 13707, 6. 11. 1985., str. 11.

${ }^{869}$ Kaurin, A. Mira Stupica oduševila, Večernji list, br. 7875, 10. 4. 1985., str. 9; Kaurin, A. Zlatni vijenac „Mariji“, Večernji list, br. 7883, 18. 4. 1985., str. 9.
} 
Beogradskom internacionalnom teatarskom festivalu (BITEF). Na sudjelovanje Ateljea $212 \mathrm{u}$ programu BITEF-a tekstom u Danasu reagira Dalibor Foretić koji predstavi prigovara „,pamfletsku površnost ${ }^{6870}$ te primjećuje da je tema države kao autoriteta koji pojedincu propisuje granice slobode, pri čemu su mehanizmi manipulacije svugdje slični, aktualna u mnogim društvima, ne samo čehoslovačkom. U tekstu o istoj predstavi u Vjesniku nakon sarajevskoga festivala Foretić naglašava kvalitetu glumačke postave. ${ }^{871}$

Havelov Largo desolato prikazan je 1988. u programu Dana satire Satiričkoga kazališta Jazavac u izvedbi sarajevskoga Kamernog teatra 55. ${ }^{872}$ Predstava ne izaziva snažniju reakciju pisanih medija i na nju reagira Branko Vukšić u tekstu u kojemu povlači paralele između Havelova teksta i ozračja Kafkinih proza, a iz cjeline predstave izdvaja kvalitetu izvedbe glavnoga glumca Zijaha Sokolovića. ${ }^{873}$ Istu predstavu, pod naslovom Nepodnošljivo lako, u režiji Egona Savina zagrebačkoj i riječkoj publici u proljeće 1989. prikazuje beogradsko Malo pozorište „Duško Radović“،. Zagrebačka izvedba predstave u Studentskom kulturnom umjetničkom centru izazvala je veliko zanimanje publike, vjerojatno, dijelom potaknuto i slavnim glumačkim imenima Jelisavete Sablić, Zijaha Sokolovića i Bogdana Diklića. ${ }^{874}$

\section{6. Zaključak}

Među neoficijelnim češkim dramatičarima kvantitetom uprizorenih tekstova u hrvatskim se kazalištima, ali i recepcijom među gledateljstvom, ističu Václav Havel sa sedam premijera dramskih tekstova te Pavel Kohout s njih šest. Slijedi ih, hrvatskoj publici poznatiji kao romanopisac, Milan Kundera. Od prikazanih predstava najbolju recepciju među kazališnom publikom ostvarila je Ševa Milana Kundere kojom 1974. rad započinje legendarni zagrebački Teatar u gostima, putujuća glumačka družina. U sljedećih nekoliko godina predstava će u Zagrebu i drugim mjestima biti prikazana čak 147 puta. Na drugome je mjestu

\footnotetext{
${ }^{870}$ Foretić, Dalibor Bog, vrag i anđeli, Danas, 9. 10. 1984., str. 53-54.

${ }^{871}$ Foretić, Dalibor Začarani svijet bajke, Vjesnik, br. 13500, 10. 4. 1985., str. 9; S. K. „Ateljeu 212“ prva nagrada, Vjesnik, br. 13508, 18. 4. 1985., str. 11.

872 Repertoar hrvatskih kazališta, knjiga 3 - Repertoari 1981. - 1990., ur. Branko Hećimović, Hrvatska akademija znanosti i umjetnosti, 2002., str. 285.

${ }^{873}$ Vukšić, Branko Sokolovićev Leopold, Večernji list, br. 8924, 16. 6. 1988., str. 19.

${ }^{874}$ Puljizević-Grbin, L. Sokolovićevo traganje, Večernji list, br. 9196, 23. 3. 1989., str. 14; N. K. Rijeka gostuje „Duško Radović“, Večernji list, br. 9197, 24. 3. 1989., str. 11.
} 
drama Jaroslava Vostroga Tri u drugom, čije se autorstvo dugo pripisivalo Jiř́iju Menzelu, u Teatru ITD sa 66 izvedaba. Brojem repriznih izvedaba slijede je jednočinke Václava Havela Audijencija i Izložba u Dramskome kazalištu Gavella 1980. s 55 predstava te kazališna adaptacija najpoznatijega Kunderina romana Šala koja je u Satiričkome kazalištu Jazavac nakon premijere 1983. prikazana čak 44 puta. Osim tih kazališnih kuća, dramske tekstove neoficijelnih dramatičara na svoje repertoare uvrštavaju i dubrovačko Kazalište Marina Držića, virovitičko kazalište te zagrebačko i splitsko Hrvatsko narodno kazalište. Među navedenim se kazalištima brojem premijera, svako po četiri, izdvajaju zagrebački DK Gavella, Teatar ITD te Hrvatsko narodno kazalište iz Splita.

Promjenu u uvjetima u kojima se uprizoruju drame neoficijelnih dramatičara $\mathrm{u}$ Hrvatskoj od početka osamdesetih godina do kraja toga desetljeća najbolje ilustriraju okolnosti vezane uz izvedbe tekstova najpoznatijega disidenta Václava Havela. I dok 1980., u vrijeme kada je Havel u matičnoj zemlji na izdržavanju zatvorske kazne, premijeru njegovih jednočinki u Gavelli prate, prema svjedočenju uključenih aktera, oštri prosvjedi čehoslovačkoga veleposlanstva pa čak i zahtjevi za skidanjem predstave s kazališnoga repertoara, premijeru Asanaciju 1990. povodom godišnjice osnivanja zajedničke države Čeha i Slovaka u zagrebačkome HNK-u iz svečane lože prate i novoizabrani hrvatski Predsjednik i čehoslovački veleposlanik.

Intenziviranje recepcije neoficijelnih dramatičara u Hrvatskoj bilježi se od početka osamdesetih godina što korespondira s intenziviranjem recepcije prozne produkcije na izdavačkom tržištu. U tom razdoblju hrvatska kazališta nerijetko usporedo s uprizorenjima predstava prema tekstovima neoficijelnih dramatičara u program uključuju i drame klasika češke književnosti koje se tijekom normalizacije neometano prikazuju i u matičnoj zemlji, tekstove čeških književnika za djecu te organiziraju gostovanja čehoslovačkih kazališnih kuća.

Kritička recepcija kvantitativno je najizdašnija u kulturnim rubrikama najtiražnijih dnevnih novina, Vjesnika i Večernjega lista. Brojem objavljenih kritika te novine slijede Oko, a zatim, s dva do tri objavljena teksta tijekom cijeloga razdoblja Polet, Republika, Novi prolog i Prolog. Stvaralaštvo neoficijelnih dramatičara tema je i tekstova objavljivanih u tjedniku Danas u drugoj polovici osamdesetih godina, no ondje se ono, u pravilu, motri u kontekstu širih društvenih promjena u čehoslovačkome društvu. Dok su Václav Havel i Pavel Kohout brojem uprizorenih dramskih tekstova u hrvatskim kazalištima najizvođeniji autor, $u$ kritičkim je napisima očita kvantitativna prevaga analiza Havelovih drama što se može objasniti i zanimljivošću njegove građanske biografije. 
Analizom kazališnih kritika uočava se perpetuiranje dviju teza. Prve, osobito naglašene u kritikama drama Václava Havela, da je riječ o tekstovima autobiografske podloge te druge, koja sve snažnije dolazi do izražaja prema kraju osamdesetih godina i kojom se nerijetko i tumači odlična recepcija čeških neoficijelnih dramatičara pred hrvatskom publikom, da u slici prikazanoga češkoga, odnosno čehoslovačkoga društva možemo iščitati društvene prilike u Hrvatskoj o kojima hrvatski dramatičari nisu smjeli ili nisu željeli pisati. $\mathrm{Na}$ tome tragu, uprizorenja Havelovih dramskih tekstova početkom osamdesetih, prema svjedočenjima suvremenika koje novinski tekstovi prenose, bila su način da se ukaže na sudbinu hrvatskog intelektualca Vlade Gotovca koji je zbog svojih oporbenih aktivnosti i suprotstavljanja službenome jugoslavenskom režimu na prijelomu sedamdesetih i osamdesetih osuđen na zatvorsku kaznu.

Nesumnjivo je da su motivi uvrštavanja pojedinih dramskih tekstova bili, uglavnom, komercijalne prirode. $\mathrm{Na}$ vrhuncu svoje popularnosti 1983. iznimno komercijalno usmjereno Satiričko kazalište Jazavac uprizoruje dramsku adaptaciju romana Šala Milana Kundere. Predstava od koje je vodstvo kazališta, zasigurno, puno očekivalo, svoje ambicije temeljeći na uspjehu romanesknoga predloška, u dnevnome se tisku reklamira kao „premijera književnoga bestselera“. Jazavčeva predstava doživljava snažnu, uglavnom negativno obojenu kritičku recepciju te ostvaruje 44 reprizne izvedbe što je relativno dobar uspjeh. Prema novinskim napisima tek je rijetko koja predstava u tome kazalištu zbog manjka zanimanja publike iz programa izbačena nakon pedesetak izvedbi, većina ih je ostvarivala i preko stotinu repriza. ${ }^{875}$

Osim odlične recepcije kod publike neke predstave neoficijelnih dramatičara ostvaruju i priznanja struke te osvajaju stručne nagrada. Ponekad su predstave nagrađene u cijelosti, poput Gavellinih jednočinki Audijencije i Izložbe 1980. koje Hrvatsko društvo kazališnih kritičara i teatrologa proglašava najboljim predstavama sezone, a nagrađivani su i pojedini glumci i suradnici nagradama kazališnih smotri poput Dana satire, Gavellinih večeri, sarajevskoga Festivala malih i eksperimentalnih scena, Prvomajske nagrade Društva dramskih umjetnika Hrvatske. Na kazališnim smotrama i festivalima gledatelji u Hrvatskoj upoznaju produkciju neoficijelnih dramatičara u izvedbama kazališta iz drugih jugoslavenskih republika poput sarajevskoga Kamernoga teatra 55 te Beogradskoga dramskog pozorišta i Ateljea 212. Potonji izaziva osobito zanimanje gledatelja na Gavellinim večerima 1987. Havelom Prosjačkom operom čemu je, zacijelo, pridonijela i zvjezdana glumačka ekipa koju su činili Mira Stupica, Dragan Nikolić, Neda Arnerić i Svetlana Bojković.

875 Vukšić, Branko Na početku - Šala, Večernji list, br. 4728, 21. 10. 1983., str. 5. 
Osim slavnoga trojca koji čine Havel, Kundera i Kohout hrvatska kazališta na svoje repertoare uvrštavaju i po jedan dramski tekst manje poznatih neoficijelnih dramatičara: autorskoga dvojca Jaroslava Gillara i Vladimíra Škutine, Jaroslava Vostrog, Milana Uhdea, dramatizaciju romana Josefa Škvoreckog te Jana Cziviša, Alene Vostre i Jaroslava Vostrog čija je suradnja rezultirala dramatizacijom Voltaireova romana Candide koja se prikazuje u Zagrebačkom studentskom eksperimentalnom kazalištu. Od navedenih je dramskih tekstova najbolju recepciju ostvarila predstava Tri u drugom Jaroslava Vostrog koja se u programu zagrebačkoga Teatra ITD nalazi tri godine i ostvaruje 66 repriznih izvedaba. Osim toga, život dramskoga teksta Tri u drugom ilustrativni je primjer kako je tijekom normalizacije funkcionirao dio neoficijelne češke književne scene. Zbog nemogućnosti javnoga djelovanja autora Jaroslava Vostrog, predstava se godinama, i u Čehoslovačkoj i u inozemstvu, pa tako i u Hrvatskoj, igrala pod imenom redatelja Jiř́ija Menzela, a pravi autor dramskoga teksta javnosti je otkriven tek početkom devedesetih. 


\section{NEOFICIJELNA ČEŠKA KNJIŽEVNOST U BIJELOJ KNJIZI 1984.}

U ožujku 1984. Centar za informiranje i propagandu Centralnoga komiteta Saveza komunista Hrvatske kao interni radni materijal sudionicima partijskoga savjetovanja koje će se održati u Zagrebu u svibnju iste godine dostavlja dokument službenoga naziva $O$ nekim idejnim i političkim tendencijama u umjetničkom stvaralaštvu, književnoj, kazališnoj i filmskoj kritici, te o javnim istupima jednoga broja kulturnih stvaralaca u kojima su sadržane politički neprihvatljive poruke. Istovremeno, jugoslavenska izdavačka scena hrva se s brojnim problemima prouzročenima manjkom deviza, poput nedostatka papira zbog smanjena uvoza ili neisplaćivanja honorara inozemnim autorima zbog čega se izdavačke kuće okreću djelima klasika za koja se više ne plaćaju autorska prava. ${ }^{876}$ Kasnije će tekst dokumenta kolokvijalno biti nazvan Bijelom knjigom, a na njegovim stranicama, paradoksalno u godinama kada je broj prijevoda predstavnika neoficijelne češke književne scene i uključenost dramskih tekstova neoficijelnih dramatičara u repertoare kazališta u Jugoslaviji na vrhuncu, svoje mjesto nalaze i češki emigranti Milan Kundera i Jiř́i Pelikán.

U većem dijelu teksta Bijela knjiga sadrži osvrte na tekstove i javne istupe autora koji pripadaju srpskoj kulturnoj sceni, poput Antonija Isakovića, Gojka Đoge, Slobodana Pauljevića, ${ }^{877}$ Jovana Radulovića, ${ }^{878}$ Vuka Draškovića, Dobrice Ćosića. Kvantitativnu dominaciju srpskih autora u Bijeloj knjizi Krešimir Bagić pokušava objasniti trima razlozima: slobodom javnog govora koja je u prvoj polovici osamdesetih u Beogradu bila osjetno veća no u Zagrebu, ${ }^{879}$ apolitičnošću, šifriranošću i ,ezopovskim govorom“ hrvatske književnosti te tzv. hrvatskom šutnjom koja datira još od sloma hrvatskoga proljeća $1971 .{ }^{880}$ Činjenicu

\footnotetext{
${ }^{876}$ Zima, Zdravko Dobar dan, klasiko, Vjesnik, br. 12374, 9. 2. 1982., str. 6; Šigir, Mirjana Mogući put koprodukcija, Vjesnik, br. 12722, 31. 1. 1983., str. 8.

${ }^{877}$ Pauljević je autor romana Strašno buđenje čija je glavni lik informbiroovac koji 1948. bježi u Rumunjsku.

${ }^{878}$ Jovan Radulović autor je drame Golubnjača čija su tema zločini ustaša nad srpskim stanovništvom tijekom Drugoga svjetskog rata u Dalmatinskoj zagori. Predstava je izvedena u Srpskom narodnom pozorištu u Novom Sadu 1982., no ubrzo je skinuta s repertoara. Godinu kasnije odlučeno je da se ne uvrsti u program uglednoga novosadskog kazališnog festivala Sterijina pozorja. Tijekom okupacije dijela Hrvatske početkom 1990-ih obnašao je funkciju ministra vanjskih poslova Vlade tzv. Republike Srpske Krajine.

${ }^{879}$ Istu tezu zagovara i povjesničar Dušan Bilandžić: ,, U Zagrebu do sredine osamdesetih kritičkoga vala u području kulturnog stvaralaštva, u ideologiji i informiranju jedva da je i bilo. Tamo gdje se je, u klici, pojavio odmah se reagiralo i spriječilo njegovo širenje.“ Bilandžić, Dušan Hrvatska moderna povijest, Golden marketing, Zagreb, 1999., str. 707.

${ }^{880}$ Bagić, Krešimir Od partije bez teksta do strasti razlike, u: Književnost i kultura osamdesetih, zbornik radova 39. seminara zagrebačke slavističke škole, Filozofski fakultet, Zagrebačka slavistička škola, Hrvatski seminar za strane slaviste, Zagreb, 2011.
} 
dominacije srpskih autora u Bijeloj knjizi Čale Feldman tumači i ,kao napad prije svega hrvatske političke birokracije na prije svega srpsku kulturu i intelektualnu elitu“6881.

Od hrvatskih kulturnih radnika na stranicama Bijele knjige svoje su mjesto našli književni povjesničar Stanko Lasić i njegova knjiga Krleža - kronologija života i rada, roman Bogumil $^{882}$ Joze Laušića, novinski tekstovi i javni istupi Igora Mandića, Stanka Lasića, Predraga Matvejevića i Rajka Grlića te tekstovi hrvatskih novinara objavljeni u Nedjeljnoj Dalmaciji, Vjesniku i tjedniku Danas. Kriterij po kojem su autori i tekstovi uključeni u korpus Bijele knjige mogao bi se sažeti u rečenici koja se ponavlja nekoliko puta na stranicama toga dokumenta, da je riječ o djelima koja se ,[j]avnosti [nude] kao velika i značajna (...), čija je umjetnička vrijednost osrednja ili nikakva, ali ih se iz političkih razloga veliča i natura“683.

Čeških se tema tekst Bijele knjige dotiče u dvama poglavljima. Javni istupi Predraga Matvejevića povodom potpisivanja Povelje 77, poput pisma čehoslovačkome veleposlanstvu u Beogradu, navedeni su u poglavlju Javni istupi, napisi i intervjui nekih kulturnih stvaralaca. A u posljednjem dijelu Bijele knjige, naslovljenom Napisi, razgovori i poruke nekih poljskih i istočnoevropskih autora te osvrti na neke knjige, drame i filmove stranih autora, problematiziraju se novinski napisi o Kunderinim i Pelikánovim djelima objavljeni u Jugoslaviji, mahom u srpskome tisku - Politici, Intervjuu, Književnoj reči i NIN-u od 1982. do 20. ožujka 1984., kada je tekst analize i završen. U ovoj su se cjelini partijskoga dokumenta Kundera i Pelikán našli u društvu tekstova o Nadeždi Mandeljštam, drame Lenjin, Staljin i Trocki francuskog dramatičara C. Vermorela, američkoga filma Ninočka, filmova poljskog redatelja Andrzeja Wajde Čovjek od mramora i Čovjek od gvožđa te tekstova poljskog disidenta Adama Michnika.

Analize autora Bijele knjige koje se bave Milanom Kundera u većoj su mjeri usmjerene prema novinskim napisima u jugoslavenskome tisku o Kunderinim prozama, a manje se pozivaju na tekstove samoga romanopisca. Pregled napisa potvrđuje da su svi objavljeni osvrti u tisku „odreda pohvalni“ ${ }^{684}$. Detaljnije se raščlanjuju dva teksta, oba objavljena u prvoj polovici osamdesetih u beogradskom časopisu Književna reč. U svibnju 1982. ondje je objavljen intervju s Milanom Kunderom u kojem književnik iznosi misli o

\footnotetext{
${ }^{881}$ Čale Feldman, Lada Bijela knjiga, nepoćudna književnost u kulturnostudijskoj perspektivi, u: Devijacije $i$ promašaji, etnografija domaćeg socijalizma, ur. Lada Čale Feldman i Ines Prica, Institut za etnologiju i folkloristiku, Zagreb, 2006., str. 61.

${ }^{882}$ Glavni motiv romana Bogumil Joze Laušića koji se našao na udaru sastavljača Bijele knjige jest motiv izmirenja braće koja su se tijekom Drugoga svjetskog rata borili na sukobljenim stranama - partizanskoj i ustaškoj.

${ }^{883}$ Bijela knjiga, Večernjakova edicija, Zagreb, 2010., str. 269.

${ }^{884}$ Isto, str. 253.
} 
Čehoslovačkoj kao dijelu zapada. Ideje su to koje će jugoslavenska javnost bolje upoznati tri godine kasnije u Kunderinu eseju Tragedija Srednje Europe čiji prijevod objavljuje zagrebački časopis Gordogan. Godinu dana nakon ovoga teksta u Književnoj je reči objavljen zapis Nikolaja Timčenka o Kunderinu romanu Knjiga smijeha i zaborava u kojemu autor toga teksta navodi da su neke rečenice romana u prijevodu na „,naš jezik“685 „,izgubljene“: „Rusi su ga (Husaka -n. n.) postavili na vlast 1969. godine. Od 1621. godine historija češkog naroda nije upoznala sličan masakr kulture i misli. (...) Svuda se misli da je Husak progonio samo svoje protivnike. Ali borba protiv političke opozicije bila je za Ruse samo prilika da poduzmu, posredstvom svog lajtnanta, neke mnogo fundamentalnije stvari.“ ${ }^{* 886}$

Od novinskih tekstova o memoarskim zapisima Jiř́ja Pelikána Praško proljeće autori Bijele knjige izdvajaju dva teksta autora Zdravka Zime i Bože Kovačevića. Zimin tekst objavljen u Vjesniku 20. 2. 1983. ocijenjen je ,„penegirikom Pelikánovoj knjizi“6887. Nasuprot tome, urednik Globusovih izdanja, među kojima je i Praško proljeće, Božo Kovačević u svome tekstu u Književnoj reči osjetno je kritičniji prema Pelikánovim zapisima. Analiza Bijele knjige iz Kovačevićeva teksta iščitava stav da je Pelikán u svom djelu „mogao reći mnogo više, mogao (...) biti mnogo kritičniji i prema sebi i prema onome što se dešavalo“ ${ }^{* 888}$.

Uvažavajući zahtjeve tržišta, objavljujući češke prozaike u bibliotekama najvećih naklada i uz bok autorima svjetskih bestselera te uključivanjem u program neoficijelnih dramatičara izuzetno komercijalno usmjerenih kazališnih kuća, hrvatske su se izdavačke kuće i kazališta tijekom osamdesetih, iako u državnom vlasništvu što je otvaralo veliki prostor intervencijama političkoga establišmenta u uređivačku politiku, paradoksalno našle $u$ procijepu zahtjeva svojih čitatelja, odlične zarade i ,preporuka“ monopolističkoga Saveza komunista. ${ }^{889}$ Međutim, u društvu koje je u vrijeme nastanka Bijele knjige već itekako načeto napuklinama u vladajućoj partiji izazvanima smrću Josipa Broza Tita i borbom za dominaciju koja je slijedila, rastućom ekonomskom krizom i porastom republičkih nacionalizama, utjecaj

\footnotetext{
${ }^{885}$ Bijela knjiga, Večernjakova edicija, Zagreb, 2010, str. 256.

${ }^{886}$ Isto, str. 257.

O izbacivanju dijela teksta u zagrebačkome prijevodu Knjige smijeha i zaborava koji objavljuje Grafički zavod Hrvatske 1982. (prevoditelji Dagmar Ruljančić i Albert Goldstein) piše i srpska slavistica Aleksandra Korda-Petrović u svome tekstu Fenomen prihvaćenosti čeških disidentskih autora u srpskoj sredini.

${ }^{887}$ Isto, str. 258.

888 Isto.

${ }^{889}$ Analogan primjer osluškivanja zahjeva tržišta jest „,sovjetska faza“ hrvatskih izdavačkih kuća u drugoj polovici osamdesetih. Naime, uslijed zbivanja na sovjetskoj društveno-političkoj sceni, urednici izdavačkih kuća shvaćaju da je ,perestrojka u modi“ te intenziviraju objavljivanje autora iz Sovjetskoga Saveza i nefikcionalnih proza poput autobiografija disidenata i biografije Mihaila Gorbačova. Kuzmanović, Jasmina Hitovi - budući i bivši, Danas, 9. 2. 1988., str. 44.
} 
ideoloških smjernica koje se u tekstu nalaze zanemariv je. Bijela se knjiga javlja u društvu građenome na ideologiji koja je u vrijeme njena nastanka nagrizena da bi, prema kraju desetljeća, doživjela potpuni raspad. Jedan od autora sa stranica internoga partijskog dokumenta, Stjepan Čuić, u svome osvrtu iz 1990. doživljava je kao „pokušaj poništavanja ideološke granice između nas i Varšavskoga pakta. (...) Taj gemišt koji su napravili trebao je poslužiti tome da se uništi razlikovni element između nas i Istočne Europe.“690

Iako neki od jugoslavenskih autora čija se imena nalaze na stranicama Bijele knjige početkom osamdesetih itekako osjećaju granice dopuštena javnog govora, primjerice Jovanu Raduloviću skinuta je drama Golubnjača s programa novosadskog kazališta, ${ }^{891}$ a nakon pretpremijere u Zagrebu daljnje izvedbe nije doživjela ni drama Orden Stjepana Čuića, Krešimir Bagić tekst Bijele knjige tumači kao jalov pokušaj obračuna službene vlasti s oporbenim glasovima koji su bili sve glasniji kako su osamdesete odmicale. U praksi se tekst toga dokumenta sveo na „puko kolažiranje fragmenata opozicijskih diskurza“692, dok ga Jurica Pavičić naziva najčuvenijim press-clippingom u povijesti Jugoslavije. ${ }^{893}$

\section{1. Zaključak}

Četiri godine nakon smrti doživotnoga predsjednika Socijalističke Federativne Republike Jugoslavije Josipa Broza Tita njegovi nasljednici u Savezu komunista za partijsko savjetovanje priređuju interni dokument $O$ nekim idejnim i političkim tendencijama $u$ umjetničkom stvaralaštvu, književnoj, kazališnoj i filmskoj kritici, te o javnim istupima jednoga broja kulturnih stvaralaca u kojima su sadržane politički neprihvatljive poruke, kasnije nazivan, a pod tim nazivom i objavljen u knjižnome izdanju, Bijelom knjigom. Analiza

\footnotetext{
${ }^{890}$ Pišem za Francusku (intervju sa Stjepanom Čuićem, Jasmina Kuzmanović), Danas, 21. 11. 1990., str. $38-40$.

${ }^{891}$ Prema odluci Zbora radnika Dramskog centra Srpskog narodnog pozorišta u Novom Sadu od daljnjih se izvedbi Golubnjače odustalo jer su „u predstavi i događajima oko nje izraženi pristupi, političke poruke i ciljevi koji dovode do negativnih društvenih reagiranja kao i zbog neprihvatljivog tretiranja međunacionalnih odnosa $u$ predstavi... Odluka se donosi i zbog mogućnosti manipuliranja predstavom radi njene zloupotrebe od strane neprijatelja naše suvremene socijalističke samoupravne stvarnosti.“ F. Ijevljev „Golubnjača“ skinuta s repertoara, Večernji list, br. 7167, 15. 12. 1982., str. 5.

Međutim, primjer ove predstave ilustrativan je kako u osamdesetima u Jugoslaviji sadržaj cenzuriran u jednoj sredini put do publike brzo nalazi u drugoj. Već krajem prosinca iste godine predstava je igrana u beogradskom Studentskom kulturnom centru. „Golubnjača“ gostovala u Beogradu, Večernji list, br. 7178, 28. 12. $1982 .$, str. 5. ${ }^{892}$ Bagić, Krešimir Uvod u suvremenu hrvatsku književnost 1970. - 2000., Školska knjiga, Zagreb, 2016., str. 58. ${ }^{893}$ Pavičić, Jurica Po čemu je danas važna Bijela knjiga https://www.jutarnji.hr/arhiva/po-cemu-je-danas-vaznabijela-knjiga/2113302/ (objavljeno 10. 7. 2000., pristupljeno 3. 8. 2019.)
} 
partijskih stručnjaka čiji je rad rezultirao tekstom Bijele knjige uglavnom obuhvaća tekstove srpskih autora te napise iz srpskoga tiska. Ta je činjenica kasnije objašnjavanja većom razinom kontrole javne riječi u Hrvatskoj pa je, posljedično, takvoga materijala bilo manje, no i međurepubličkim obračunima koji su na različitim razinama bujali nakon Titove smrti.

Analitičari Bijele knjige ne ulaze u tumačenja Kunderinih i Pelikánovih proza, od neoficijelnih autora na njenim se stranicama spominju ta dva imena, već se osvrću na novinske napise o njima u jugoslavenskome tisku. Primjećuju da su kritike, i Kunderinih proza i Pelikánovih memoarskih zapisa, mahom pozitivne. Tekst Bijele knjige, u osvit raspada jugoslavenskoga društva, možda jest otvorio prostor za rasprave o do tada prešućivanim temama, no, kada je riječ o neoficijelnoj češkoj književnosti u Hrvatskoj, na opseg i kvalitetu njene recepcije nije utjecao niti na koji način. 


\section{NEOFICIJELNA ČEŠKA KNJǏEVNOST I HRVATSKA KNJIŽEVNOST OD 1968. DO 1990.}

Sintagmu hrvatske šutnje kojom se primarno misli na zamiranje disidentskih aktivnosti nakon sloma hrvatskoga proljeća početkom sedamdesetih dio povjesničara hrvatske književnosti pretače i na polje književnoga stvaralaštva na kojemu se ona, također, realizira kao izbjegavanje izravne kritike službenoga režima i sukobljavanja s njime. ${ }^{894}$ Međutim, uslijed društveno-političkih promjena, na koje je zasigurno snažno utjecala Titova smrt, odnos jugoslavenske, a tako i hrvatske javnosti tijekom sedamdesetih i osamdesetih godina prema temama koje su društveno provokativne itekako se mijenja pa se, tako, nakon 1980. intenziviraju javni istupi u kojima se propituje prostor slobode u Jugoslaviji. ${ }^{895}$ Četiri godine kasnije, u vrijeme obilježeno nastankom Bijele knjige na čijim se stranicama spominje i njegovo ime, na Kongresu književnika Jugoslavije hrvatski književnik i publicist Igor Mandić detektira dihotomiju jugoslavenskoga društva dominantnu u drugoj polovici dvadesetoga stoljeća te ga naziva ,porno-birokratskim“ zbog mehanizma kojim se „,s jedne strane dozvoljava pornografija na način zapadnih država, ali s druge strane suspreže mišljenje na način istočnih društava“6896 897

\footnotetext{
${ }^{894}$ Hrvatskom šutnjom metaforički se naziva opadanje opozicijskih i disidentskih aktivnosti nakon sloma reformnih nastojanja u vrhu Saveza komunista Hrvatske početkom 1970-ih, poznatih kao hrvatsko proljeće. Sredinom osamdesetih u javnom se prostoru, pa i u književnosti, otvara niz do tada tabuiziranih tema poput žrtava Drugoga svjetskog rata, uloge pojedinih jugoslavenskih naroda u tome ratu, komunističkoga zatvora na Golome otoku i sl. Cipek, Tihomir i Spehnjak, Katarina Disidenti, opozicija i otpor - Hrvatska i Jugoslavija 1945.-1990., Ćasopis za suvremenu povijest, 39(2), Zagreb, 2007., str. 281.

${ }^{895}$ U prethodnome je razdoblje, prema Krešimiru Nemecu, takva prijelomna točka hrvatsko proljeće 1971. Nemec smatra da je periodizacija književnosti nerijetko usko vezana uz društveno-političke promjene koliko god povjesničari književnosti nastojali ostati unutar granica svoje struke, , upravo događaji u političkoj ili kulturnoj povijesti uvjetuju smjenu pravaca ili modela“. Rez 1971. i kontrola javne riječi koja je slijedila uvjetovali su da je sljedeća, 1972., prema broju objavljenih romana jedna od najsiromašnijih godina od završetka Drugoga svjetskog rata. Nemec, Krešimir Povijest hrvatskog romana od 1945. do 1990., Školska knjiga, Zagreb, 2003., str. 257-258; Cvjetko Milanja smatra da je hrvatskoj književnosti nakon 1971. ponovno zaprijetio koncept socrealizma. Milanja, Cvjetko Hrvatski roman 1945. - 1990.: nacrt moguće tipologije hrvatske romaneskne prakse, Zavod za znanost o književnosti Filozofskog fakulteta, Zagreb, 1996., str. 12.

${ }^{896}$ Bagić, Krešimir Od partije bez teksta do strasti razlike, u: Književnost i kultura osamdesetih, zbornik radova 39. seminara zagrebačke slavističke škole, ur. Krešimir Mićanović, Filozofski fakultet, Zagrebačka slavistička škola, Hrvatski seminar za strane slaviste, Zagreb, 2011., str. 86 (citat: Mandić, Igor Savjetovanje o idejnoj borbi u sferi kulture i stvaralaštvu, Naše teme, 1984., str. 165)

${ }^{897}$ O svojevrsnom ,hibridnom karakteru“ hrvatske kulture u vrijeme socijalističke Jugoslavije na raskoraku između istoka i zapada piše i Feđa Vukić koji u njoj uočava aspekte ,političko-ideologijskog Istoka $i$ komercijalno-ideologijskog Zapada“. Feđa Vukić Moša Pijade i Jim Morrison: Vizualna kultura osamdesetih u Hrvatskoj, u: Književnost i kultura osamdesetih, zbornik radova 39. seminara zagrebačke slavističke škole, ur.
} 
Na samome početku analizirana razdoblja, početkom sedamdesetih, reakcije javnosti na tekstove nekih hrvatskih književnika burne su pa oni odlučuju svoje tekstove objavljivati pod pseudonimima ili u inozemstvu. ${ }^{898}$ Dio predstavnika hrvatske književnosti slijedi liniju tematskoga odmaka od društvene stvarnosti različitim postupcima. Razvija se scena novopovijesnoga romana, oformljuje se generacija fantastičara, ${ }^{899}$ a dio literata bježi u alegoriju. ${ }^{900}$ Sve su to načini na koje dio hrvatskoga književnog korpusa pokušava izmaknuti pritisku u „vrijeme pojačane ideološke represije“ ${ }^{\text {“901 }}$. Mehanizmi su to koje uočavamo u razvoju češke oficijelne književne scene tijekom normalizacije. Parafrazirajući dio uvodnoga izlaganja Nikice Petraka sa sastanka PEN-a u Dubrovniku 1990. u kojemu, govoreći o ulozi

Krešimir Mićanović, Filozofski fakultet, Zagrebačka slavistička škola, Hrvatski seminar za strane slaviste, Zagreb, 2011., str. 202.

${ }^{898}$ Ivan Raos nakon burnih reakcija javnosti na dijelove njegova romana Prosjaci i sinovi, a zatim i televizijski serijal snimljen prema roman, primoran je 1974. svoj roman Župnik na kamenu tiskati u glasilu Katoličke Crkve Glasu koncila pod pseudonimom fra Ivan Glagoljaš. Ivan Supek roman Krunski svjedok protiv Hebranga objavljuje u Chicagu 1983. Ivana Dragojevića na jednogodišnju kaznu zatvora osuđuju nakon objavljivanja romana $R 2$ 1973. o partizanskim zločinima na otoku Daksi 1944. Roman su, potom objavili hrvatski emigranti u Njemačkoj.

${ }^{899}$ Fantastičarima, mladom/novom prozom (termin Velimira Viskovića) ili borgesovcima (termin Branimira Donata koji želi naglasiti utjecaj J. L. Borgesa) naziva se generacija prozaika koja se u hrvatskoj književnosti razvija od kraja šezdesetih do sredine sedamdesetih godina. Pavičić, Jurica Hrvatski fantastičari: jedna književna generacija, Zavod za znanost o književnosti Filozofskoga fakulteta Sveučilišta u Zagrebu, Zagreb, 2000.

${ }^{900}$ Roman Luka Antuna Šoljana koji alegorijski obrađuje motiv propale investicije u socijalizmu, pri čemu se teško otrgnuti od asocijacija na izgrađenu, no nikada djelatnu tvornicu glinice u Obrovcu, Ante Stamać smatra najboljim romanom hrvatske književnosti o komunizmu. Stamać, Ante Šoljanovo doba, u: Šoljanov zbornik, Dani Antuna Šoljana u Rovinju 1996. - 2000., prir. i ur. Boris Biletić, Pučko otvoreno učilište grada Rovinja, Istarski ogranak Društva hrvatskih književnika, Rovinj - Pula, 2001., str. 18; Alegorijom Luku smatra i Krešimir Nemec (,No Luka (...) [je] i politička alegorija: ekološka tema poslužila je tek kao povod za analizu naličja socijalističkog društva i njegova birokratskog mehanizma s jasnim naznakama skore propasti cijela projekta. “ Nemec, Krešimir Povijest hrvatskog romana od 1945. do 1990., Školska knjiga, Zagreb, 2003., str. 136), ali i Šoljanov raniji roman iz 1965. Kratki izlet (,,Kratki izlet, usporedo sa stvarnim zbivanjima i dramom egzistencije, nizom jasnih aluzija otvara i problem suvremenog totalitarizma, samozvanih vođa i demagoga, povijesne 'misije' socijalizma i smisla kretanja 'lijevim putom'“ Nemec, Krešimir Povijest hrvatskog romana od 1945. do 1990., Školska knjiga, Zagreb, 2003., str. 134). Zanimljiv nam može biti i primjer romana Anđelka Vuletića iz 1969., tiskanoga tek 1994., Dva hrama, dvije razvaline, politička antiutopija čiji je glavni lik, znakovitoga imena, Jožef Brož koji u fiktivnoj zemlji Tamaritskoj osniva boljševičku vlast i gradi kult ličnosti. Nemec, Krešimir Povijest hrvatskog romana od 1945. do 1990., Školska knjiga, Zagreb, 2003.

U literaturi možemo naći niz primjera povijesnih drama hrvatskih dramatičara napisanih od kraja šezdesetih do kraja devedesetih godina 20. st. koje mogu biti protumačene kao alegorije komunističkoga društva: Ivan Bakmaz Šimun Cirenac, Tomislav Baković Malj koji ubija, Nedjeljko Fabrio Reformatori, Ivan Supek Heretik. Mišković, Grgo i Peričić, Helena Hrvatska drama s religijskim elementima u razdoblju komunizma, u: Krležini dani u Osijeku 2009., ur. Branko Hećimović, Zavod za povijest hrvatske književnosti, kazališsta i glazbe HAZU, Hrvatsko narodno kazalište, Filozofski fakultet, Zagreb - Osijek, 2010. str. 162-177; Mrkonjić, Zvonimir Između krika i šutnje, Hrvatska drama od 1945. do 1990., Prolog, VI [XXIII](1991.), br. 19/20/21 ${ }^{901}$ Nemec, Krešimir Povijest hrvatskog romana od 1945. do 1990., Školska knjiga, Zagreb, 2003., str. 297; Kuvač-Levačić, Kornelija Društveni i politički ideologemi hrvatske fantastične proze (na primjeru Desnice, Čuića i Brešana), u: Croatica et Slavica Iadertina, Zadar, 8/I (2012), str. 287. 


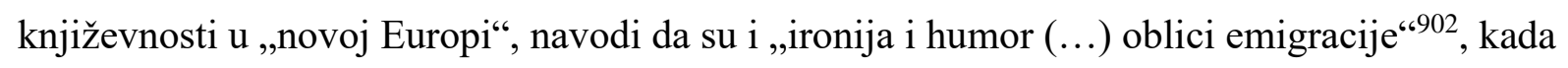
govorimo o hrvatskoj književnosti to možemo reći za „,bijeg u povijest, fantastiku i alegoriju“9903. No, iste godine Nikica Petrak, kao predstavnik hrvatskoga PEN-a, sudjeluje i na bečkom simpoziju Književnost i politička obnova - od narodnih demokracija prema demokraciji. U svome tekstu o tome simpoziju objavljenome u časopisu Oku, što je osobito zanimljivo za temu ovoga rada, Petrak pravi distinkciju između društvenoga ustrojstva u Jugoslaviji i onih u Čehoslovačkoj i/ili Mađarskoj na primjeru recepcije djela Thomasa Manna i Franza Kafke koji su dugi niz godina, dok su se u Jugoslaviji njihova djela slobodno objavljivala, ondje bili politički suspektni. ${ }^{904}$

Prema kraju osamdesetih, pokazao je dio ovoga rada koji analizira kritičku recepciju neoficijelnih dramatičara, sve su češća tumačenja da je postavljanje Havelovih, Kohoutovih, Kunderinih drama na pozornicama hrvatskih kazališta, zapravo, bio način da se progovori o neuralgičnim točkama jugoslavenskoga društva o kojem jugoslavenski, odnosno hrvatski, književnici nisu mogli ili, iz samo njima znanih razloga, nisu htjeli pisati. Rijetki su zapisi gdje se direktno i nedvosmileno uspoređuje sklonost kritici režima čeških neoficijelnih autora i hrvatskih književnika. Rubno je o tome riječ u tekstu Dagmar Ruljančić objavljenom u časopisnom prilogu Studio 1981. povodom premijere Havelova Protesta i Kohoutova Atesta u Teatru ITD $^{905}$ u kojemu Ruljančić postavlja pitanje dramaturgu toga kazališta Mladenu

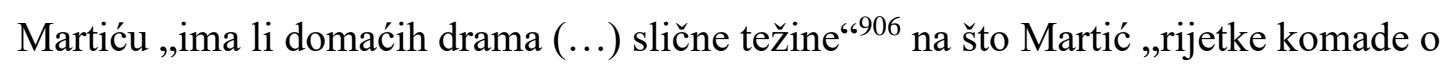
sadašnjosti“‘907 opisuje kao „blago kritične, bez dublje analize i značenja“‘908.

Nerevolucionarnoga duha hrvatski su književnici, zaključuje Velimir Visković, prostor slobode osvajali ili kada im je put otvorila službena politika (poput razdoblja nakon 1952. ${ }^{909} \mathrm{i}$ u 1960-ima) ili kada je, kao u osamdesetima, sustav bio toliko ruiniran da više ništa nije mogao kontrolirati. ${ }^{910}$ Istim se pitanjem - zašto se u Hrvatskoj, odnosno Jugoslaviji, druge polovice 20. st. nije razvila snažna disidentska scena bavi i pripovjedač Tribusonova romana

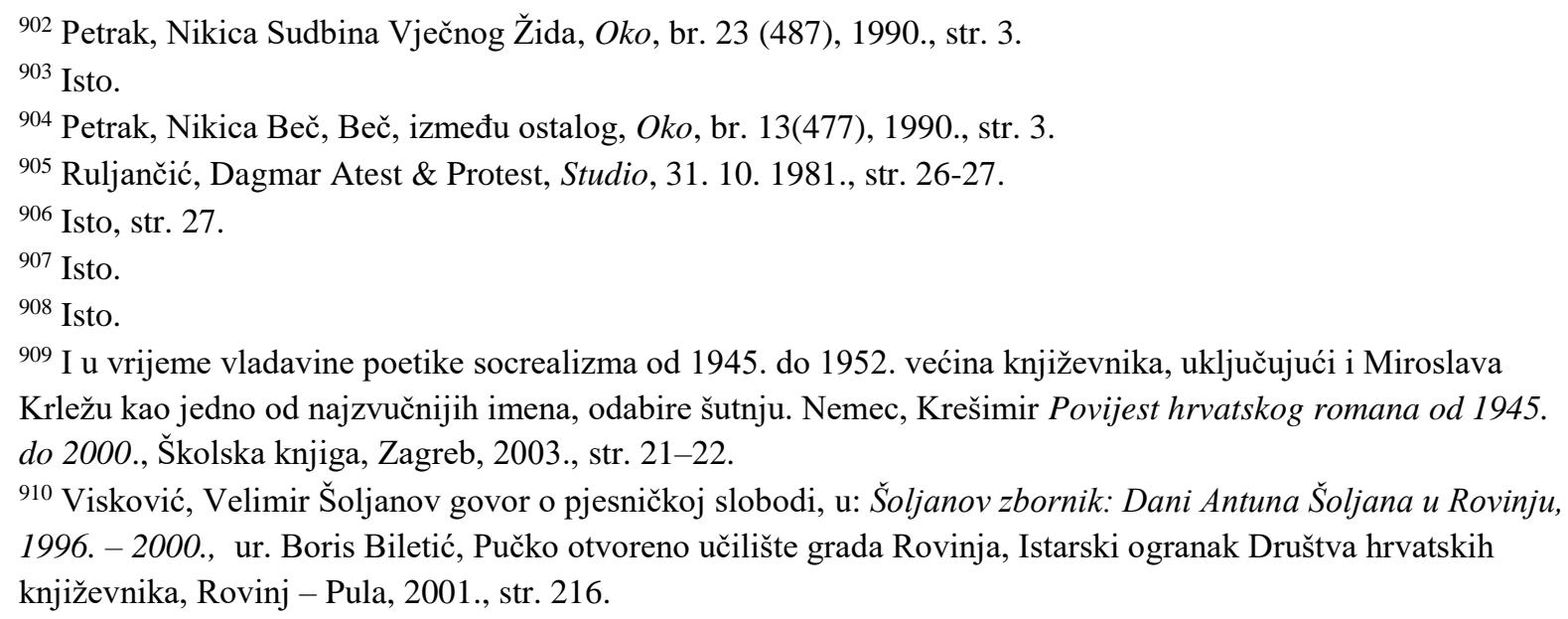


Made in U. S. A. koji cinično zaključuje da „ova zemlja nikada nije dala ni velikih umjetnika, ni značajnih mislilaca, ni znamenitih znanstvenika, pa tako neće dati ni iole relevantnijih disidenata." ${ }^{\text {"911 }}$

Bavimo li se usporedbom češke neoficijelne produkcije i hrvatske književnosti toga razdoblja polazišne točke mogu biti sljedeće teme: utjecaj Franza Kafke, motivi angloameričke kulture, razvoj žanrovske književnosti, pitanje identiteta te ciklička slika povijesti.

Nakon jačanja Kafkina utjecaja među češkim prozaicima poslije rehabilitacije 1963., ${ }^{912}$ Kafka se tijekom normalizacije vraća na popis nepoželjnih uzora, a o njemu kao jednom od izvora svoje poetike nekoliko puta otvoreno govori i Václav Havel. ${ }^{913}$ U hrvatskoj prozi nekoliko povjesničara književnosti upućuje na Kafkin utjecaj na hrvatske književnike postmodernizma, osobito generaciju fantastičara. ${ }^{914}$ Velimir Visković tu sastavnicu ističe u analizama opusa Stjepana Čuića i Saše Meršinjaka, s naglaskom na motivima odnosa pojedinca prema mehanizmima vlasti i birokraciji. ${ }^{915}$

Hrvatski književnici poticaje iz zapadnoeuropskih i sjevernoameričkih kultura i književnosti dobivaju već od 1950-ih s generacijom tzv. krugovaša čija je pripovjedna proza snažno pod utjecajem autora poput Ernesta Hemingwaya i Williama Faulknera. Trend se nastavlja s generacijom književnika okupljenih oko časopisa Razlog pokrenutog 1961. Ta se snažna i kvalitetna prevoditeljska aktivnost pretače u nakladničke planove izdavačkih kuća poput Mladosti i Zore koje objavljuju središnje modernističke romane. ${ }^{916} \mathrm{U}$ prilog tome idu i mogućnost slobodnoga putovanja i sve veća otvorenosti jugoslavenskoga društva inozemstvu. Zapadne utjecaje tijekom normalizacije predstavnici češkoga neoficijelnog kulturnog kruga mogu zahvaliti, uglavnom, činjenici da je jedno od najsnažnijih središta emigrantske aktivnosti smješteno u kanadski Toronto kamo na početku normalizacije odlazi Josef

\footnotetext{
911 Tribuson, Goran Made in U. S. A., Znanje, Zagreb, 1986., str. 205.

${ }^{912}$ Brabec, Jiří Otazník nad literární historií sedmdesátých a osmdesátych let, u: Život je jinde...?, Česká literatura, kultura a společnost v sedmdesátých a osmdesátých letech dvacátého století, prir. Jan Matonoha. Ústav pro českou literaturu AV ČR, Prag, 2002.; Kosková, Helena Vývojové souvislosti české prózy sedmdesátých a osmdesátých let, u: Život je jinde...?, Česká literatura, kultura a společnost v sedmdesátých a osmdesátých letech dvacátého století, prir. Jan Matonoha. Ústav pro českou literaturu AV ČR, Prag, 2002., str. 23.

${ }^{913}$ Havel, Václav Saslušanje na daljinu (razgovor s Karelom Hvižd'alom), Irida, Zagreb, 2000., str. 11.

${ }^{914}$ Pavičić, Jurica Hrvatski fantastičari, jedna književna generacija, Zavod za znanost o književnosti Filozofskoga fakulteta Sveučilišta u Zagrebu, Zagreb, 2000.

${ }^{915}$ Visković, Velimir Komparativni pregled hrvatske proze šezdesetih i sedamdesetih, u: Hrvatska književnost u evropskom kontekstu, ur. Aleksandar Flaker i Krunoslav Pranjić, Zavod za znanost o književnosti Filozofskog fakulteta Sveučililšta u Zagrebu, Zagreb, 1978, str. 663-688.

${ }^{916}$ Nemec, Krešimir Povijest hrvatskog romana od 1945. do 2000., Školska knjiga, Zagreb, 2003.
} 
Škvorecký. Snažna osobnost Josefa Škvoreckog, koji se bavio i prevoditeljskim radom prevodeći na češki jezik Ernesta Hemingwaya i Williama Faulknera - književnike koje navodi kao svoje uzore, ${ }^{917}$ dugogodišnja plodna djelatnost izdavačke kuće 68 Publishers u Torontu, njegov znanstveni rad koji rezultira doktorskom disertacijom na temu američke filozofije - sve su to kanali koji u češku neoficijelnu književnost dovode snažan impuls angloameričke kulture.

I u hrvatskoj književnosti i u neoficijelnom dijelu češke književnosti, doduše u manjoj mjeri što je uvjetovano njenim specifičnim razvojem, dolazi do postmodernističkoga brisanja granice između „visoke“ i ,niske“ književnosti koje rezultira razvojem žanrovske proze. Dok u hrvatskoj književnosti sedamdestih i osamdesetih godina žanrovska književnost buja, u opusima neoficijelnih prozaika taj dio produkcije nije osobito plodan vjerojatno zbog toga što bi književnik koji bi se odlučio pisati takav tip proze, ako nije imao disidentskih aktivnosti u svojoj građanskoj biografiji, i u Čehoslovačkoj imao slobodan put do čitatelja. U korpusu neoficijelne proze iznimku čini kriminalistički žanr čije je najzvučnije ime Josef Škvorecký koji detektivskoj, žanrovskoj prozi ostaje vjeran cijelo prvo desetljeće koje provodi u emigraciji pišući o složenim kriminalističkim slučajevima koje rješava njegov policijski inspektor Borůvka. ${ }^{918}$ Do hrvatskih čitatelja i književnika dopiru i njegovi književnoteorijski zapisi koje Željko Valentić preporučuje kao poželjnu literaturu u tekstu o recepciji lika Sherlocka Holmesa u hrvatskoj i češkoj književnosti. ${ }^{919}$

Sljedeća tematska os oko koje svoje tekstove isprepleću češki neoficijelni autori i pojedini hrvatski književnici analiziranoga razdoblja jest pitanje identiteta. I dok se Škvorecký u nekim svojim prozama bavi češkom emigrantskom zajednicom u Kanadi, Kundera u nizu svojih romana gradi likove Čeha koji tumaraju Europom nakon kolovoza 1968., likovi emigranata u hrvatskoj su književnosti toga razdoblja rijetki. Cvjetko Milanja primjećuje da hrvatska književnost u svom jugoslavenskom razdoblju nije tematizirala lik političkoga emigranta, a razlozi za to mogu biti od „otvorene ideološkopartijske cenzure do

\footnotetext{
${ }^{917}$ Humor kao oružje protiv očaja (intervju s Josefom Škvoreckým, Dagmar Ruljančić), Danas, 29. 10. 1985., str. 52-55.

918 Dijelu opusa Josefa Škvoreckoga kriminalističke tematike pripadaju sljedeći naslovi: zbirka pripovijedaka Hřichy pro pátera Knoxe (1973.), Konec poručíka Borůvky (1975.), Návrat poručníka Borůvky (1981.). Janoušek, Pavel i suradnici Dějiny české literatury 1945-1989, IV. knjiga 1969-1989, Academia, Prag, 2008., str. 726.

919 Valentić, Željko Škvorecký o Holmesu, Večernji list, br. 8379, 3. 12. 1986., str. 20.

Tekst Josefa Škvoreckog o poetici detektivskoga romana Nápady čtenáře detektivek 1970. objavljuje splitski časopis Mogućnosti.
} 
autocenzure i sigurne zavjetrine 'arkadijskog mira'“920. Tek 2002. u romanu Trimeron, trećemu dijelu svoje Jadranske trilogije, lik Ecija, hrvatskoga komunista koji nakon hrvatskoga proljeća emigrira u Švedsku, razvija Nedjeljko Fabrio koji se pitanjima identiteta, onoga u okolnostima multikulturalne Rijeke tijekom 19. i prve polovice 20. stoljeća, bavi i u prvim dvama dijelovima svoje romaneskne trilogije.

Postmodernističko obilježje obiju književnosti jest i odmak od prikaza povijesti u maniri tradicionalnoga povijesnog romana - kao učiteljice života. Povijest dobiva snagu cikličkoga zbivanja koje određuje sudbine likova. Kada građu za svoje proze, između ostaloga, crpe iz povijesnih zbivanja i okolnosti, književnici više ne pišu povijesni/historijski roman, već, kako kaže Predrag Matvejević analizirajući opus Milana Kunderu i razloge njegove izvanredne prihvaćenosti kod hrvatskih čitatelja, ,roman historije“(921. Takvu ideju povijesti uočavamo kod neoficijelnih romanopisaca poput Škvoreckoga i Kundere, ${ }^{922}$ a u hrvatskoj književnosti u Jadranskoj trilogiji Nedjeljka Fabrija ${ }^{923}$ i u opusima ostalih predstavnika novopovijesnog romana. Upravo Fabrio u javnim istupima kao svoju lektiru navodi romane Josefa Škvoreckog i Milana Kunderu pridodajući im epitete klasične vrijednosti i djelâ kojima ćemo se uvijek vraćati jer su „muku svoga vremena znala ispričati potresno i katarktički“‘924.925

${ }^{920}$ Milanja, Cvjetko Tipovi likova iseljenika u novijoj hrvatskoj književnosti, Društvena istraživanja, časopis za opća društvena pitanja, Vol. 20, No. 3(113), str. 863.

${ }^{921}$ Matvejević, Predrag Milan Kundera - naš pisac, Danas, 12. 10. 1982., str. 66-68.

${ }^{922}$ Prikaz besmisla povijesnih zbivanja i srednje Europe koja je stoljećima poligon za smjene vladara, režima i država u prozi Škvoreckog i Kundere ilustrirat ćemo dvama stilski i semantički bliskim ulomcima romana Mirakl i Knjiga smijeha i zaborava Josefa Škvoreckog i Milan Kundere:

„Kostelec i njegova glavna ulica, koja je posljednjih trideset godina redom posvećivana Edvardu Benešu, Friedrichu Velikom, Staljinu, Lenjinu, profesoru Nejedlom i T. G. Masaryku, a sada opet Lenjinu... “ Škvorecký, Josef Mirakl, Grafički zavod Hrvatske, 1987., str. 18.

„Ulica u kojoj se rodila Tamina zvala se Schwerinova. To je bilo za vrijeme rata kada je Prag bio pod njemačkom okupacijom. Njen otac se rodio na Černokosteleckom bulevaru. To je bilo vrijeme Austro-Ugarske. Majka se doselila u očev stan na Bulevaru maršala Fochea. To je bilo poslije prvog svjetskog rata. Tamina je provela djetinjstvo na Staljinovom bulevaru, a njen muž ju je odveo u novi dom iz Vinohradskog bulevara. A bila je to, ustvari, uvijek jedna te ista ulica kojoj su samo mijenjali imena, ispirali joj mozak da poblesavi. "

Kundera, Milan Knjiga smijeha i zaborava, „Veselin Masleša“, Sarajevo, 1984., str. 170.

${ }^{923}$ Nemec, Krešimir Problem identiteta u ,Jadranskoj trilogiji“ Nedjeljka Fabrija, u: Rijeka Fabriju. Zbornik radova s Međunarodnoga znanstvenoga kolokvija održanoga u Rijeci 16. 11. 2007., ur. Danijela Bačić-Karković, Filozofski fakultet Sveučilišta u Rijeci, Rijeka, 2009., str. 35-46.

${ }^{924}$ Književnost je nepotkupljivo zrcalo (intervju s Nedjeljkom Fabrijem), Danas, 28. 5. 1985., str. 51-53. ${ }^{925} \mathrm{U}$ žanru povijesnoga romana češke oficijelne književnosti čest je postupak smještanja radnje u povijesnu perspektivu koja je, prema tumačenjima, alegorija suvremenosti i prikaz funkcioniranja totalitarnog mehanizma vlasti. Taj princip nerijetko koriste i autori povijesnih romana u hrvatskoj književnosti. Primjerice, roman Extraordinarius Ivana Supeka iz 1974. radnju smješta u sredinu 18. st., a, prema tumačenju Krešimira Nemeca, referentni događaj su zbivanja vezana uz hrvatsko proljeće. Nemec, Krešimir Povijest hrvatskog romana od 1945. do 1990., Školska knjiga, Zagreb, 2003. 
U književnokritičkim analizama nekoliko je opažanja o motivskim analogijama između pojedinih djela hrvatskih i neoficijelnih čeških književnika. Na motivske paralele dominantne faustovske teme drama Nečastivi na Filozofskome fakultetu Ive Brešana, tiskane u časopisu Prolog 1975., i Hrvatski Faust Slobodana Šnajdera, praizvedene 1982. na Splitskome ljetu, s Havelovim Iskušavanjem, premijerno prikazanim u Beču 1986., upozorava Vjesnikova kritičarka Marija Grgičević. ${ }^{926}$ Naravno, pretenciozno bi bilo govoriti o utjecaju hrvatskih dramatičara na dramski rad Václava Havela, već možemo pretpostaviti da je riječ o kulturnome bazenu zapadne civilizacije koji je izvor svim trima autorima.

Ono što su, smatramo, dokazala prethodna poglavlja ovoga rada jest da je uspjeh najzvučnijih imena češke neoficijelne scene tijekom normalizacije među hrvatskim recipijentima nesumnjiv. No, prema riječima Ive Hergešića, uspjeh ne treba poistovijetiti s utjecajem iako je on „najsigurnija i najnormalnija priprava za utjecaj“927, no ,iza te prve faze ne mora nužno slijediti druga.“928 Neki analitičari idu korak dalje pa govore i o izravnome utjecaju. Tako, primjerice, Predrag Matvejević likove mladih obožavatelja džeza iz Škvoreckýjevih proza prepoznaje u kasnijim tekstovima tzv. proze u trapericama te djelima književnika poput Danila Kiša i Mome Kapora. ${ }^{929}$ A simboličku snagu džeza u prozama Škvoreckoga zasigurno možemo prepoznati u romanima Gorana Tribusona u rock-glazbi. ${ }^{930}$

Produktivnu recepciju neoficijelne češke književnosti u hrvatskoj književnosti bilježimo ako fokus našeg promatranja pomaknemo izvan vremenskih granica primarnoga interesa, u devedesete godine 20. st. Hrvatski dramatičar Borislav Vujčić 1995. u zbirci drama Crne komedije objavljuje dramu Tandem. U sjeni Berlinskog zida. U navedenoj drami Sibila

\footnotetext{
${ }^{926}$ M. G. Drama Václava Havela, Vjesnik, br. 15221, 3. 2. 1990., str. 8.

${ }^{927}$ Hegešić, Ivo Komparativna književnost, Ex libris, Zagreb, 2005., str. 83.

${ }^{928}$ Isto, str. 84.

${ }^{929}$ Matvejević, Predrag Književnost i emigracija (Sivocrni humor), Danas, 4. 11. 1986., str. 36-38.
} Imena Danila Kiša i Milana Kundere u istom se kontekstu spominju u tekstu o portugalskom prijevodu Kiševe zbirke pripovijedaka Enciklopedija mrtvih u kojem se prenose kritike iz portugalskoga tiska koje naglašavaju da se u „Kišu ne traži epigon Milana Kundere“, da je „Kiš otkriće na portugalskom jednako onom otkriću što ga je predstavljao M. Kundera“. Brala, Želimir Oduševljenje Kišem, Danas, 24. 11. 1987., str. 41.

Dvije godine kasnije Danas u tekstu Mirka Galića prenosi navodne Kunderine riječi jednom francuskom kritičaru u kojem mu preporučuje da obavezno čita djela Danila Kiša „[z]ato što je genije“. Galić, Mirko Pisci u fokusu: Danilo Kiš, Danas, 3. 1. 1989., str. 36.

${ }^{930}$ Kada je riječ o očitim podudarnostima, iz skromnoga korpusa oficijelne književnosti među čitateljima u Hrvatskoj tijekom normalizacije izdvaja se primjer romana Jaroslava Bočeka i hrvatskoga fantastičara Pavla Pavličića. U dvama se književnim kritikama, onoj Cvjetka Milanje u Oku i Miroslave Vučić u Quorumu, pozornost skreće na paralelizam kriminalističkih i fantastičnih motiva u romanima Slučaj doktora Karpete i Kraj mandata. I Milanja i Vučić odlaze i korak dalje pa napominju da je očita i fabulativna sličnost tih dvaju romana. Milanja, Cvjetko Pouka izvana, Oko, br. 372, 1986., str. 20; Vučić, Miroslava Enigma enigme, Quorum, br. 4/5, 1986., str. 217-220. 
Petlevski primjećuje Vujčićevo nasljedovanje Havela na više razina te iščitava intertekstualnost na razini motiva, likova i postupaka.

Na samome početku, jedan od četiriju likova Vujčićeve drame jest Predsjednik (bivši) pisac, biografska crtica koja nužno rađa asocijacije na životni put najpoznatijega čehoslovačkog disidenta. Na stilskoj razini Petlevski analogiju s Havelovom Audijencijom povlači uočavajući postupak ponavljanja replika. Dramu Tandem Borislav Vujčić gradi oko motiva dolaska dramske osobe dramatičaru, odnosno dolaska „ostarjelog Sladeka u audijenciju piscu koji je u međuvremenu postao predsjednik države“931. Prema Petlevski:

„Sladek je samo povod za Vujčićevu 'audijenciju' kod Havela i za njegovo razračunavanje s pozicijom disidentskog pisca u odnosima postkomunističke promjene društvenih i političkih paradigmi. (...)

Vujčićev Sladek odgovara replikom na repliku Havelova Sladeka pa se dramska zamisao Tandema neposredno vezuje uz nezaboravni trenutak kad Havelov Sladek (u hrvatskoj sredini upamćen u ulozi Pere Kvrgića) glasno razmišlja o principima koji se visoko cijene i na kojima će intelektualac jednoga dana lijepo zaraditi, jer od njih i živi, za razliku od njega koji se pita kakvu šansu ima u budućnosti. Havelov Sladek predviđa da će se poniženi intelektualac jednog dana vratiti među svoje glumce, praviti se važan da je kotrljao burad u pivnici i biti junak, dok se on - tipični produkt svojeg vremena i svoje sredine - nema kamo vratiti. Pitanja koja postavlja egzistencijalna su - kamo se vratiti, tko će ga primijetiti, tko će ocjenjivati njegove postupke, što ima od života i što ga očekuje? - da bi naposljetku jedno završno opće i nedefinirano 'Što?' u sebi ujedinilo i saželo sva navedena pitanja. Čitava dramaturška konstrukcija Vujčićeva Tandema proširena je replika toga završnog, očajno smiješnog 'Što?' iz Havelove Audijencije. “932

Vujčićeva drama dovršena 1992. i objavljena u Crnim komedijama tri godine kasnije sredinom devedesetih godina u Hrvatskoj ostaje bez ikakve kazališne recepcije zbog, navodne, anakronosti teme. Petlevski u svome tekstu prenosi dramatičarevu bilješku uz tekst drame: „Tandem, nepostavljen i do ovog objavljivanja neobjavljen. Kazališta kojima je ponuđen otklonila su postavljanje ovog komada tvrdnjom da ih politika (?) ne zanima. Časopis Novi prolog imao je ovaj naslov u pripremi za objavljivanje, ali nepodmitljivim

\footnotetext{
${ }^{931}$ Petlevski, Sibila Tandem, Vujčićeva drama za neizvođenje, Dani Hvarskoga kazališta: Građa i rasprave o hrvatskoj književnosti i kazalištu, Vol. 33 No. 1, 2007., str. 521.

932 Isto, str. 521, 523.
} 
mišljenjem obiju strana (urednika i autora) da ne sudjelujemo u agoniji, otklonjeno je tiskanje." "933

\section{1. Zaključak}

Usporedbom razvoja hrvatske i češke oficijelne i neoficijelne književnosti sedamdesetih i osamdesetih godina 20. st. uočavamo niz podudarnosti na tematskoj, motivskoj i žanrovskoj razini. Hrvatski se književnici toga razdoblja, neskloni izravnoj kritici službenoga režima, izražavaju proznim modalitetima poput novopovijesnoga romana, alegorije i fantastične proze, koje češka književnost normalizacije ostvaruje na svom oficijelnom polju. Istovremeno, bez zaogrnutosti u povijesnu alegoriju princip cikličke povijesti koji u hrvatskoj književnosti razvija novopovijesni roman uočljiv je i u prozama, primjerice, Milana Kundere.

Društvena klima koja je u Jugoslaviji i Čehoslovačkoj tijekom normalizacije bila različita usmjerila je i kulturna i književna kretanja. Jedan od primjera koji to pokazuju jest i odnos prema klasicima svjetske književnosti poput Franza Kafke koji je u Čehoslovačkoj rehabilitiran tek krajem normalizacije. Kafku kao snažan uzor u češkoj književnosti imenuju neoficijelni autori, dok je u hrvatskoj književnosti legitiman uzor najzvučnijim imenima sedamdesetih i osamdesetih godina pa i cijeloj generaciji pisaca poput one generacije fantastičara.

Angloamerički utjecaj, snažan u hrvatskoj kulturi i na češkoj neoficijelnoj sceni, dolazi iz različitih izvora. U Hrvatskoj on prodire u zemlju zahvaljujući prevoditeljskoj djelatnosti i relativnoj otvorenosti društva zapadnim utjecajima, dok se među češkim neoficijelnim autorima može zahvaliti činjenici da su neki od najsnažnijih čeških egzilnih središta nakon 1968. na engleskom govornom području te da su najsnažnije osobnosti neoficijelne scene privatno i profesionalno povezane s angloameričkim kulturnim krugom.

Unatoč motivskim paralelizmima koji su davno uočeni, poput faustovske teme $\mathrm{u}$ dramama Ive Brešana, Slobodana Šnajdera i Václava Havela te iskorištavanja simbola popularne kulture svojstvene prozi u trapericama u prozama Josefa Škvoreckoga i Gorana Tribusona, pravi primjer produktivne recepcije u dramskome mediju pronalazimo tek izvan

${ }^{933}$ Petlevski, Sibila Tandem, Vujčićeva drama za neizvođenje, Dani Hvarskoga kazališta: Građa i rasprave o hrvatskoj književnosti i kazalištu, Vol. 33 No. 1, 2007., str. 522. 
vremenskih granica kojima je omeđen ovaj rad, u drami Tandem. U sjeni Berlinskog zida Borislava Vujčića iz devedesetih godina dvadesetoga stoljeća. 


\section{ZAKLJUČAK}

Nakon vojne intervencije zemalja Varšavskoga ugovora na tlu tadašnje Čehoslovačke u kolovozu 1968., a koja je bila odgovor službenih režima zemalja istočnoga bloka na reformne pokrete koji su se razvili u Čehoslovačkoj komunističkoj partiji, slijedi proces tzv. normalizacije koji je značio, između ostaloga, onemogućavanje javnoga djelovanja osobama koji su sudjelovali u reformnome pokretu. Kao posljedica normalizacije i cenzure koja je bila jedno od njenih najjačih oruđa, češka se književnost dijeli na službenu, koju čine književnici koji svoja djela i dalje neometano objavljuju u državnim izdavačkim kućama, zatim neoficijelnu, koju čine književnici koji su u godinama koje slijede prisiljeni objavljivati u samizdatu i emigraciji ili slušati vijesti o izvedbama svojih dramskih tekstova na pozornicama isključivo inozemnih kazališta, i tzv. sivu zonu u koju čini manji broj autora koji djeluju na obama poljima ovisno o promjenjivim okolnostima i svojoj sklonosti kompromisu.

Iako se u dva desetljeća normalizacije češka kultura, a osobito njen neoficijelni krak, razvija u izuzetno nepovoljnim društveno-političkim okolnostima, neprestano kontrolirana i usmjeravana od strane službenoga režima cenzorskim mjerama, analitičari su suglasni u ocjeni da je jedno od najtežih razdoblja češke povijesti iznjedrilo jedno od najsvjetlijih razdoblja češke umjetnosti. Češka književnost toga doba zaokuplja ogromnu pozornost inozemne javnosti predvođena proslavljenim imenom Milana Kundere kao jednoga od najpopularnijih književnika u Europi osamdesetih godina 20. st. Ugled analogan onome u zapadnoj Europi češka neoficijelna književnost gradi i u Jugoslaviji koja je jedina komunistička zemlja srednje i istočne Europe, uz iznimku Poljske u kojoj se nekoliko Havelovih drama prikazuje u kazalištima početkom osamdesetih godina, u kojoj predstavnici neoficijelne češke književne scene imaju slobodan put do publike. Iako su i u Jugoslaviji zabilježeni pritisci političkih krugova, poput prosvjedne note čehoslovačkoga veleposlanstva početkom osamdesetih povodom premijere jednočinki Václava Havela u zagrebačkom Dramskom kazalištu Gavella i uključivanja imena Milana Kundere i Jiř́ja Pelikána u tekst Bijele knjige 1984., oni nisu negativno utjecali na recepciju među hrvatskim čitateljima i kazališnom publikom.

Zadaća je istraživanja koje je rezultiralo izradom ove disertacije recepcija češke neoficijelne književnosti u Hrvatskoj na sinkronijskoj razini, odnosno među prvobitnim čitateljima u razdoblju od sloma praškoga proljeća i uvođenja cenzure u Čehoslovačkoj do 
pada komunizma u objema zemljama. Istraživanje je pokazalo da se recepcija neoficijelne češke književnosti u Hrvatskoj ostvaruje u sva tri pojavna oblika prema klasifikaciji Manfreda Schmelinga - i kao pasivna, i kao reproducirajuća, i kao produktivna.

U uvodnome dijelu istraživanja koje je rezultiralo ovom disertacijom postavljene su četiri hipoteze koje je, u konačnici, istraživanje i potvrdilo:

- djela neoficijelne češke književnosti u analiziranome su razdoblju dobro prihvaćena od strane čitatelja u Hrvatskoj

- čitateljima u Hrvatskoj dostupnija su djela književnika koji su stvarali u egzilu, no onih koji objavljuju u Čehoslovačkoj u samizdatu

- objavljujući djela neoficijelne češke književnosti, hrvatski nakladnici primarno osluškuju zahtjeve tržišta

- tijekom analiziranoga razdoblja, osobito prema kraju osamdesetih godina dvadesetoga stoljeća, dolazi do promjene u intenzitetu recepcije na području izdavaštva i kazališta te promjena u kritičkoj recepciji uvjetovanih novom konstelacijom društveno-političkih odnosa u Hrvatskoj.

Tijekom dvadeset godina češke normalizacije izdavačke kuće u najvećim jugoslavenskim kulturnim središtima kontinuirano objavljuju književnu produkciju češkoga egzila i samizdata. Među knjižnim izdanjima analiziranima u ovome radu primjećuje se očita prevaga egzilnih autora čiji tekstovi čine čak $91 \%$ svih naslova. Intenziviranje izdavačke djelatnosti primjetno je tijekom osamdesetih godina, osobito od 1984. do 1987. kada je, u samo četiri godine, objavljeno 56\% svih knjižnih izdanja.

Hrvatski su čitatelji zbog jedinstvenoga književnog tržišta i zajedničke države u kojoj su živjeli snažno bili usmjereni i na izdanja beogradskih i sarajevskih izdavača. Riječ je o najvećim i najuglednijim jugoslavenskim izdavačkim kućama poput zagrebačkoga Znanja, sarajevskoga „Veselina Masleše“ i beogradske Prosvete koji prijevode čeških neoficijelnih autora objavljuju u svojim tržišno najuspjelijim bibliotekama. Prijevodi čeških neoficijelnih autora objavljivani su i u ljubljanskim i skopskim izdavačkim kućama, no zbog jezične barijere čitatelji u Hrvatskoj na ta izdanja nisu bili upućeni i to je razlog što ona nisu uključena u ovu analizu.

U prevedenim i objavljenim djelima dominiraju prozni tekstovi, osobito romani, a zatim i zbirke pripovijedaka, a brojem objavljenih naslova ističu se imena Milana Kundere i Josefa Škvoreckog čiji prozni tekstovi čine čak $86 \%$ ukupnih proznih knjižnih izdanja. U razdoblju od 1968. do 1990. hrvatskim je čitateljima dostupno čak jedanaest prijevoda djelâ 
Josefa Škvoreckog te pet romana i jedna zbirka pripovijedaka Milana Kundere, većina njih u tržišno najuspješnijim bibliotekama izdavačkih kuća poput Biblioteke Hit i Evergrina zagrebačke izdavačke kuće Znanje. Kvalitativni vrhunci neoficijelne češke književne produkcije u jugoslavenskim se izdavačkim kućama objavljuju uz bok kvalitativnim vrhuncima svjetske književnosti uopće. Na sinkronijskoj je razini od neoficijelnih prozaika zasigurno najsnažnija recepcija romana Milana Kundere koji tijekom osamdesetih godina doživljavaju ponovljena izdanja i velike naklade u više jugoslavenskih republika. Od Kunderinih je proza najviše ponovljenih izdanja, čak osam, ostvario njegov proslavljeni roman Šala koji se u kritičkoj recepciji njegova proznog rada nerijetko uzima kao polazišna točka vrednovanja i ostalih proznih tekstova. Kako se evidencija posudbe knjiga u knjižnicama u sedamdesetim i osamdesetim godinama 20. st. u Hrvatskoj nije računalno obrađivala, pri izradi ovoga rada nije bilo moguće doći do podataka o posudbi izdanja neoficijelnih autora. No, potvrda iznimne i kontinuirano dobre recepciji među čitateljima zasigurno mogu biti ljestvice najčitanijih i najprodavanijih knjiga u hrvatskim knjižnicama i knjižara koje u osamdesetima povremeno objavljuju najtiražnije hrvatske dnevne novine, a na kojima su naslovi iz korpusa neoficijelne češke književnosti nerijetko zastupljeni i visoko pozicionirani. Recepcija neoficijelnih čeških autora u Hrvatskoj tijekom dva analizirana desetljeća nije zakašnjela. Naprotiv, prijevodi zagrebačkih, sarajevskih i beogradskih izdavačkih kuća vrhunce neoficijelne produkcije čitateljima u Jugoslaviji čine dostupnima u veoma kratkom vremenskom razdoblju nakon prvih izdanja tih naslova. Najdulje su na hrvatsko izdanje čekali prozni tekstovi Josefa Škvoreckog, ponekad i više od deset godina od premijernoga izdanja na češkom jeziku.

Prijevode poezije, u pravilu tržišno manje atraktivne, uglavnom objavljuju časopisi poput Republike, Foruma, 15 dana, riječkoga Rivala. Jedini književnik koji dijelom svojih aktivnosti zasijeca u polje neoficijelne češke književne scene tijekom normalizacije, a čija je poezija objavljena u zasebnoj zbirci, jest laureat Nobelove nagrade za književnost 1984. i klasik češke književnosti Jaroslav Seifert. Također, medij poezije koji, slažu se analitičari, omogućava snažniji odmak od dnevnopolitičkih trzavica u usporedbi s prozom i dramom, uvjetuje situaciju da se neoficijelni pjesnici u hrvatskome tisku nerijetko objavljuju uz bok onima kojima tijekom normalizacije slobodno objavljuju i u Čehoslovačkoj.

Kako je primarni medij dramske književnosti kazalište, bilježimo, također, malen broj tiskanih izdanja dramskih tekstova neoficijelnih dramatičara. Tek je krajem osamdesetih u zagrebačkome časopisu Quorum objavljen prijevod drame Iskušavanje Václava Havela, a, potom, iste drame i Asanacije u izdanju Dečjih novina iz Gornjega Milanovca. No, tijekom 
analizirana dva desetljeća izuzetno je dobra kazališna recepcija neoficijelnih dramatičara koja jača tijekom osamdesetih godina, što korespondira sa situacijom na izdavačkom tržištu. Havelovi, Kohoutovi, Kunderini kazališni tekstovi, drame navedenih autora čine čak 75\% svih premijernih naslova, i tekstovi drugih dramatičara, manje poznatih hrvatskoj publici, svoj put do publike nalaze i u nacionalnim kazališnim kućama, poput zagrebačkoga, riječkog i splitskog Hrvatskog narodnog kazališta, ali i u, uglavnom, studentskoj publici okrenutome Teatru ITD te putujućem Teatru u gostima kojemu je primaran zadatak kazalište dovesti u manje sredine, a koji dramom Ševa Milana Kundere 1974. započinje svoj tridesetogodišnji rad. S četiri naslova neoficijelnih dramatičara na repertoaru prednjače splitski HNK, zagrebačko Dramsko kazalište Gavella te Teatar ITD. Bogatstvo hrvatskoga, osobito zagrebačkoga, kazališta tijekom analizirana razdoblja nerijetko na pozornicu istoga kazališta u jednoj kazališnoj sezoni, uz predstavu neoficijelnoga dramatičara, dovodi i uprizorenje dramskoga teksta klasika češke književnosti, ali i gostujuće izvedbe čehoslovačkih kazališta. Također, predstave neoficijelnih dramatičara kazališne uprave nerijetko smatraju vrhuncem svoje produkcije određene sezone te je niz primjera da upravo ti tekstovi predstavljaju kazališne kuće na smotrama i festivalima poput Gavellinih večeri i Festivala malih i eksperimentalnih scena Jugoslavije. Snažnu kazališnu recepciju prati i razvijena kazališnokritička recepcija, no njen opseg djelomice ovisi i izvanknjiževnim čimbenicima. Tako je, iako su po broju uprizorenih dramskih tekstova Václav Havel i Pavel Kohout skoro izjednačeni, sa sedam, odnosno šest naslova, kritička recepcija predstava prema Havelovim tekstovima kod hrvatskih kazališnih kritičara višestruko snažnija.

Recepcija djela službene češke književnosti, odnosno književnika koji tijekom normalizacije djeluju u Čehoslovačkoj i objavljuju u državnim izdavačkim kućama, među čitateljima u Hrvatskoj je slabija što se književno djelo više uklapalo u poetiku propisane, službene literature. Naime, izdavačke kuće nisu niti zainteresirane za objavljivanje takvih izdanja, a oni predstavnici službene književnosti koji su bili objavljivani i čitani u Hrvatskoj, poput Ladislava Fuksa i Vladimíra Párala, predstavljaju kvalitativne vrhunce službene književne produkcije. Također, usporedo sa sjajnom recepcijom neoficijelne produkcije, osobito prozne, teče suradnja na institucionalnoj razini pa predstavnici udruženja koja okupljaju čehoslovačke književnike, one oficijelne, redovno sudjeluju na stručnim okupljanjima poput Zagrebačkih književnih razgovora.

Do pojačane recepcije, i u izdavačkim kućama i na kazališnim pozornicama, dolazi nakon 1980. U prvome desetljeću normalizacije dobru su recepciju čeških neoficijelnih autora hrvatski kritičari očekivali na valu zanimanja za događaje iz ljeta 1968. koji su u 
jugoslavenskome javnom prostoru snažno odjeknuli. Do osamdesetih godina 20. st. češka je književnost među čitateljima u Jugoslaviji izgradila već takav ugled da je izdavanje neoficijelnih autora za jugoslavenske izdavače posao koji donosi odličnu zaradu. Pojedini češki književnici bili su toliko dobro poznati čitateljima da je objavljivanje njihovih knjiga za izdavače bila igra na sigurno, čemu je, zasigurno, pridonijela i njihova popularnost $\mathrm{u}$ zemljama zapadne Europe. Dostupnosti neoficijelne produkcije u Jugoslaviji tijekom osamdesetih u prilog ide i razina organiziranosti koju je ona do toga vremena već izgradila. No, na to je, zasigurno, utjecalo i ozračje društvene liberalizacije u Jugoslaviji uvjetovane smrću Josipa Broza Tita, karizmatičnoga vođe još od kraja Drugoga svjetskog rata, gospodarskim teškoćama koje sve jače nagrizaju kvalitetu života te novom konstelacijom odnosa na međunarodnome planu.

Društvene promjene koje se u drugoj polovici osamdesetih naziru utječu na promjene u recepciji, osobito onoj kritičkoj, odnosno tumačenje uzroka odlične prihvaćenosti neoficijelne produkcije u Hrvatskoj. U prethodnom je razdoblju ona objašnjavana horizontom očekivanja hrvatskih, odnosno jugoslavenskih, čitatelja koji je izgradila češka književna tradicija Karela Čapeka i Jaroslava Hašeka te sjajnom prihvaćenosti specifičnoga „češkog humora“. Prema kraju osamdesetih analize se okreću u smjeru dobre prihvaćenosti kao posljedice zajedničkoga povijesnog iskustva dvaju naroda, odnosno zrcaljenja slike jugoslavenskoga društva, o kojoj hrvatski književnici nisu mogli ili nisu htjeli pisati, u tekstovima čeških književnika. Konkretno, krajem osamdesetih niz aktera izravno uključenih u postavljanja Havelovih drama u zagrebačkim kazalištima početkom toga desetljeća svjedoči da se tim činom željela skrenuti pozornost na sudbinu Vlade Gotovca u tadašnjoj Jugoslaviji.

U hrvatskome obrazovnom sustavu recepcija neoficijelnih autora ne postoji. Ta se činjenica može objasniti nesklonošću sastavljača nastavnih programa književnosti u hrvatskim srednjim školama suvremenim autorima. Naime, kronološki princip podučavanja književnosti u hrvatskim srednjim školama koji je prevladavao, i još uvijek prevladava u dijelu škola koje nisu obuhvaćene reformnim procesima na početku školske godine 2019./2020., u nastavne je programe i čitanke uključivao iznimno malen broj djela, mahom hrvatskih autora, nastalih nakon 1970. Prijedlog reforme nacionalnoga kurikuluma koji u javnost izlazi 2016. u širi popis za izbor lektirnih djela uvrštava tekstove Milana Kundere i Václava Havela. Međutim, do implementacije toga prijedloga u hrvatskom obrazovnom sustavu nije došlo. U konačnom Popisu klasičnih hrvatskih i svjetskih književnih tekstova za cjelovito čitanje ili čitanje ulomaka u kurikulumu za nastavni predmet Hrvatski jezik za gimnazijski program i Popisu 
klasičnih hrvatskih i svjetskih književnih djela za čitanje ulomaka za četverogodišnje strukovne škole na početku školske godine 2019./2020. nema niti jednog češkog autora.

Saznanja o recepciji neoficijelne češke književnosti u Hrvatskoj od 1968. do 1990. i promjena u recepciji uslijed promjenjivih društvenih okolnosti zasigurno upotpunjuju spoznaje o hrvatsko-češkim književnim i kulturnim vezama u drugoj polovici dvadesetoga stoljeća.

Tekst o životu češke neoficijelne književnosti među hrvatskim čitateljima i kazališnom publikom u posljednja dva desetljeća komunizma u Europi završit ćemo ulomkom govora Václava Havela na plenarnoj sjednici Saveza čehoslovačkih književnika u svibnju 1965. kojim je anticipirao sudbinu češke književnosti tijekom dva desetljeća normalizacije: „Također, ne smijemo zaboraviti da se sve dobro i pozitivno prije ili poslije pouzdano potvrđuje, jer je to ipak povijesna nužnost. Čekao je Holan, čekao je Hrabal, čekao je Škvorecký. Čeka Kolář. Čeka i Wiener, čeka Kabešev izbor iz djela Ladislava Klíme, čekaju redigirani izabrani radovi Jakuba Demla. Zbog čekanja, Holan nije izgubio svoju kvalitetu ako je netko izgubio, bila je to češka poezija.“934

934 Šömen, Branko Češki sanjar: Václav Havel od disidenta do prezidenta, Profil, Zagreb, 2012., str. 66. 


\section{POPIS IZVORA I LITERATURE}

1. A tko to ide, Hrvatski prilozi XV. međunarodnom slavističkom kongresu, ur. Marija Turk. Zagreb: Hrvatsko filološko društvo, 2013.

2. Bagić, Krešimir. Uvod u suvremenu hrvatsku književnost 1970. - 2000. Zagreb: Školska knjiga, 2016.

3. Batović, Ante. Liberalno-nacionalni pokret u Hrvatskoj od 1966. do 1972. i svijet (doktorski rad). Zadar: Sveučilište u Zadru, 2010.

4. Beker, Miroslav. Uvod u komparativnu književnost. Zagreb: Školska knjiga, 1996.

5. Bijela knjiga. Zagreb: Večernjakova edicija, 2010.

6. Bilandžić, Dušan. Hrvatska moderna povijest. Zagreb: Golden marketing, 1999.

7. Biti, Vladimir. Pojmovnik suvremene književne teorije. Zagreb: Matica hrvatska, 1997.

8. Brabec, Jiří. Panství ideologie a moc literatury. Studie, kritiky, portréty (1991-2008). Prag: Akropolis, 2009.

9. Crnković, Zlatko. Knjigositnice. Rijeka: Otokar Keršovani d. o. o., 2003.

10. Česká literatura na konci tisícletí II. Prag: Ústav pro českou literaturu AV ČR, 2001.

11. Česká literatura od počátků k dnešku. ur. Jan Lehár, Alexandr Stich, Jaroslava Janáčková, Jiří Holý. Prag: Lidové noviny, 2006.

12. Devijacije i promašaji, etnografija domaćeg socijalizma. ur. Lada Čale Feldman i Ines Prica. Zagreb: Institut za etnologiju i folkloristiku, 2006.

13. Dani Hvarskoga kazališta: Građa i rasprave o hrvatskoj književnosti i kazalištu, Vol. 33, No. 1. Split: HAZU i Književni krug Split, 2007.

14. Dějiny českých zemí. ur. Jaroslav Pánek i Oldřich Tůma. Prag: Karolinum, 2008.

15. Dramatičar i državnik Václav Havel. Zagreb: HAZU, 2000.

16. Egzil, emigracija: Novi kontekst, zbornik. ur. Irena Lukšić. Zagreb: Hrvatsko filološko društvo, 2002.

17. Goldstein, Ivo. Hrvatska povijest. Zagreb: Novi liber, 2008.

18. Goldstein, Ivo. Povijest Hrvatske. Zagreb: EPH media d. o. o, 2011.

19. Hanáková, Jitka. Edice českého samizdatu. Prag: Národni knihovna České Republiky, 1997.

20. Havel, Václav. Saslušanje na daljinu (razgovor s Karelom Hvižd'alom). Zagreb: Irida, 2000.

21. Hergešić, Ivo. Komparativna književnost. Zagreb: Ex libris, 2005. 
22. Hodnoty a hranice, Svět v české literatuře, česká literatura ve světě, Otázky českého kánonu. Sborník př́spěvků z III. kongresu světové literárněvědné bohemistiky. ur. Stanislava Fedrová. Prag: Ústav pro českou literaturu AV ČR, 2006.

23. Hrvatska književnost prema evropskim književnostima: od narodnog preporoda k našim danima. ur. Aleksandar Flaker i Krunoslav Pranjić. Zagreb: Liber, 1970.

24. Hrvatska književnost u evropskom kontekstu. ur. Aleksandar Flaker i Krunoslav Pranjić. Zagreb: Zavod za znanost o književnosti Filozofskog fakulteta Sveučilišta u Zagrebu, 1978. 25. Hrvatsko proljeće 40 godina poslije (XXXIII). ur. Tvrtko Jakovina. Zagreb: Centar za demokraciju i pravo Miko Tripalo, Filozofski fakultet Sveučilišta u Zagrebu, Fakultet političkih znanosti Sveučilišta u Zagrebu, Pravni fakultet Sveučilišta u Zagrebu, 2012. 26. Janoušek, Pavel i suradnici. Dějiny české literatury 1945-1989, IV. knjiga 1969-1989. Prag: Academia, 2008.

27. Jauss, Hans Robert. Estetika recepcije. Beograd: Nolit, 1978.

28. Klasić, Hrvoje. Jugoslavija i svijet 1968. Zagreb: Naklada Ljevak, 2012.

29. Književnost i kultura osamdesetih, Zbornik radova 39. seminara Zagrebačke slavističke škole. ur. Krešimir Mićanović. Zagreb: Filozofski fakultet Sveučilišta u Zagrebu, Zagrebačka slavistička škola, Hrvatski seminar za strane slaviste, 2011.

30. Književnost između dviju domovina, zbornik radova 13. seminara zagrebačkih književnih razgovora. ur. Ernest Fišer. Zagreb - Varaždin: posebno izdanje Društva književnika Hrvatske, Autorske agencije za SR Hrvatsku i uredništva časopisa Gesta, 1986.

31. Kolanović, Maša. Udarnik! Buntovnik? Potrošač... popularna kultura i hrvatski roman od socijalizma do tranzicije. Zagreb: Naklada Ljevak, 2011.

32. Kopeček, Lubomír. Éra nevinnosti: Česká politika 1989-1997. Brno: Barrister \& Principal, 2010.

33. Krležini dani u Osijeku 1997., zbornik, knjiga 1. prir. Branko Hećimović. Zagreb - Osijek: Zavod za povijest hrvatske književnosti, kazališta i glazbe HAZU, 1999.

34. Krležini dani u Osijeku 2009. ur. Branko Hećimović. Zagreb - Osijek: Zavod za povijest hrvatske književnosti, kazališta i glazbe HAZU, Hrvatsko narodno kazalište, Filozofski fakultet, 2010.

35. Milanja, Cvjetko. Hrvatski roman 1945. - 1990.: nacrt moguće tipologije hrvatske romaneskne prakse. Zagreb: Zavod za znanost o književnosti Filozofskog fakulteta, 1996. 36. Nemec, Krešimir. Povijest hrvatskog romana od 1945. do 1990. Zagreb: Školska knjiga, 2003. 
37. Panství ideologie a moc literatury. Studie, kritiky, portréty (1991-2008). Prag: Akropolis, 2009.

38. Pavičić, Jurica. Hrvatski fantastičari: jedna književna generacija. Zagreb: Zavod za znanost o književnosti Filozofskoga fakulteta Sveučilišta u Zagrebu, 2000.

39. Postmodernizam, iskustva jezika u hrvatskoj književnosti i umjetnosti, zbornik radova. ur. Cvjetko Milanja. Zagreb: Altagama, 2003.

40. Povijest svjetske književnosti, knj. 7, češka, slovačka, poljska, lužičkosrpska, stara ruska, novija ruska, bjeloruska, ukrajinska i bugarska književnost; baltičke književnosti, armenska i gruzijska književnost; književnosti drugih kavkaskih naroda. ur. Aleksandar Flaker. Zagreb: Mladost, 1975.

41. Prostor u jeziku; Književnost i kultura šezdesetih: zbornik radova 37. seminara Zagrebačke slavističke škole. ur. Krešimir Mićanović. Zagreb: Filozofski fakultet, Zagrebačka slavistička škola, 2009.

42. Rada, Ivan i dr. Povijest Češke. Zagreb: Sandorf, 2013.

43. Repertoar hrvatskih kazališta, knjiga 1 -Repertoari kazališta, kazališnih družina i grupa, partizanskih kazališta, festivala, smotri i susreta. ur. Branko Hećimović. Zagreb:

Jugoslavenska akademija znanosti i umjetnosti, 1990.

44. Repertoar hrvatskih kazališta, knjiga 3 - Repertoari 1981. - 1990.. ur. Branko Hećimović. Zagreb: Hrvatska akademija znanosti i umjetnosti, 2002.

45. Rijeka Fabriju, Zbornik radova s Međunarodnog znanstvenog kolokvija održanog u Rijeci 16. 11. 2007. ur. Danijela Bačić-Karković. Rijeka: Filozofski fakultet Sveučilišta u Rijeci, 2009.

46. Sabljak, Tomislav. Teatar XX. stoljeća. Zagreb - Split: Matica hrvatska, 1971.

47. Stipčević, Aleksandar. O savršenom cenzoru. Zagreb: Nakladni zavod Matice hrvatske, 1994.

47. Šoljanov zbornik: Dani Antuna Šoljana u Rovinju, 1996. - 2000.. ur. Boris Biletić. Rovinj - Pula: Pučko otvoreno učilište grada Rovinja, Istarski ogranak Društva hrvatskih književnika, 2001.

48. Šömen, Branko. Češki sanjar: Václav Havel od disidenta do prezidenta. Zagreb: Profil, 2012.

49. Tadić, Ladislav. Časopis Gordogan, Bibliografija 1975.-2013., Zagreb: Novi Gordogan, udruga za kulturu, 2015.

50. Teorija recepcije u nauci o književnosti. ur. Dušanka Maricki. Beograd: Nolit, 1978.

51. Tribuson, Goran. Made in U. S. A. Zagreb: Znanje, 1986. 
52. Tripalo, Miko. Hrvatsko proljeće. Zagreb: Nakladni zavod Matice hrvatske, 2001.

53. Zbornik Matice srpske za slavistiku. Novi Sad: Matica srpska, Odeljenje za književnost i jezik, 2008.

54. Zbornik radova 38. seminara Zagrebačke slavističke škole. ur. Krešimir Mićanović.

Zagreb: Filozofski fakultet, Zagrebačka slavistička škola, 2010.

55. Zlatá šedesátá. Česká literatura a společnost v letech taní, kolotání a ... zklamání. ur. R.

Deremarková. Prag: Ústav pro českou literaturu AV ČR, 2000.

56. Život je jinde...?, Česká literatura, kultura a společnost v sedmdesátých a osmdesátých letech dvacátého století. prir. Jan Matonoha. Prag: Ústav pro českou literaturu AV ČR, 2002. 57. Život, literatura - Sabrana dela Danila Kiša (knj. 14). Beograd: Beogradski izdavačko-grafički zavod, 1995.

Novinski i časopisni članci

1. Bacalja, Robert Slavenske književnosti u dalmatinskim periodicima u razdoblju hrvatske moderne, Fluminensia, god. 22(2010), br. 2, 21-35

2. Cipek, Tihomir i Spehnjak, Katarina Disidenti, opozicija i otpor - Hrvatska i Jugoslavija 1945.-1990., Časopis za suvremenu povijest, 39(2), Zagreb, 2007., 255-297

3. Ćurković, Jasna Religiozna uporišta u liberalnoj ideja Vlade Gotovca, Crkva u svijetu, Vol. 45, No. 1, Split, 2010., 56-77

4. Ivačić, Matija Češki književni underground (Značenje i granice), Umjetnost riječi: časopis za znanost o književnosti, LV (2001), 3 - 4, 195-220

5. Ivanković, Katica Socrealizam u tragovima. Uz hrvatsku recepciju češke književnosti u 1950-ima, Književna smotra: časopis za svjetsku književnost, XLV/2013, br. 167(1), 37-42

6. Končelík, Jakub Dva tisíce slov, Zrod a di̊sledky nečekaně vlivného provolání, Soudobé dějiny, XV(3-4), 2008., 485-545 http://www.usd.cas.cz/cs/stranky/casopis-soudobedejiny/rocnik-xv2008/cislo-iiiiv2008 (pristupljeno 9. 3. 2014.)

7. Kuvač-Levačić, Kornelija Društveni i politički ideologemi hrvatske fantastične proze (na primjeru Desnice, Čuića i Brešana), Croatica et Slavica Iadertina, Zadar, 8/I (2012), str. 287297 
8. Lalović, Dragutin Prijelomno desetljeće (1962. - 1972.) - od krize stabilnosti do stabilizacije krize. Politička misao, 49(2), 2012., 11-34 http://hrcak.srce.hr/index.php?show =clanak\&id_clanak_jezik=132100 (pristupljeno 19. 8. 2014.)

9. Milanja, Cvjetko Tipovi likova iseljenika u novijoj hrvatskoj književnosti, Društvena istraživanja, časopis za opća društvena pitanja, Vol. 20, No. 3(113), 861-876

10. Michnik, Adam Velika priča Václava Havela, Zarez, Zagreb, 18. 1. 2012., godište XIV, broj $325-326,14-15$

11. Mrkonjić, Zvonimir Između krika i šutnje, Hrvatska drama od 1945. do 1990., Prolog, VI [XXIII](1991.), br. 19/20/21

12. Pelikán, Jan Pokušaj stvaranja jezgra čehoslovačke emigracije u Jugoslaviji nakon sovjetske okupacije Čehoslovačke u augustu 1968. godine. Tokovi istorije, 1-2, 2007., 81-106, www.scindeks.ceon.rs (pristupljeno 9. 6. 2014.)

13. Pecnik, Aron Od praškog proljeća do baršunaste revolucije, Književna revija, br. 3/4, 2010., 95-132

14. Petlevski, Sibila Tandem, Vujčićeva drama za neizvođenje, Dani Hvarskog kazališta: Građa i rasprave o hrvatskoj književnosti i kazalištu, Vol. 33, No. 1, 2007.

15. Sesar, Dubravka Povelja 77 u kontekstu češke disidentske književnosti: pogled na jedan pokret, Književna smotra, 29(1997), 2/3(104/105), str. 125-130

16. Šoljan, Antun Kratka povijest Kratkog izleta, Republika, br. 7/8, 1990., 59-65

Mrežni izvori

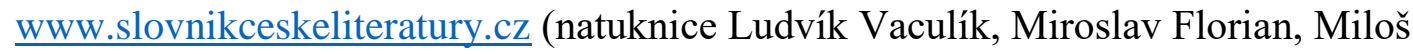
Macourek, Jiří Šotola, Gabriel Laub, Ivan Klíma, Ludvík Kundera, Jazzová sekce, František Buriánek, Milan Uhde, Jarmila Urbánková, Josef Peterka, Kamil Mařík, Ladislav Fuks, Vladimír Páral, Alexej Pludek, Jindřiška Smetanová, Ludvík Aškenazy, Vladimír Holan, Jan Skácel, Miroslav Holub, Jan Zábrana, Pavel Janský, Vladimír Janovic, Vladimír Burda, Věra Provazníková, Jiří H. Krchovský, Jan Kahan, Petr Placák, Jáchym Topol, Ivan Kolář, Ivan Blatný, Věra Linhartová, Vratislav Blažek, František Buriánek, Lubomír Doležel, Felix Vodička, Miroslav Červenka, Květoslav Chvatík, Miroslav Drozda, Oleg Sus, Robert Kalivoda, Milan Jankovič, Josef Topol, Alena Vostrá, Jaroslav Vostrý, Vladimír Škutina Jaroslav Gillar) 
www.enciklopedija.hr (natuknice perestrojka, Republika, Forum, Prolog, Umjetnost riječi, DK Gavella, Vlado Gotovac, Helsinška konferencija, Karel Kosík, Milovan Đilas, Aleksandr Solženjicin, Mirko Ilić, Leo Mates, Josif Aleksandrovič Brodski, Prolog, Hans Robert Jauss, Hans-Georg Gadamer, Dušan Karpatský, Krsto Špoljar, Predrag Jirsak, Predrag Matvejević, Boris Senker, Josip Broz - Tito, Alexander Dubček, Mihail Sergejevič Gorbačov, Savka Dabčević-Kučar)

www.proleksis.lzmk.hr (natuknice Povelja 77, glasnost)

www.databazeknih.cz (natuknica Rudolf Chmel)

www.britannica.com (natuknice István Eörsi, Antonín Novotný)

https://leksikon.muzej-marindrzic.eu/kvapil-miroslav/ (natuknica Miroslav Kvapil), pristupljeno 2. 8. 2019.

https://bdp.rs/o-nama/, pristupljeno 2. 9. 2019.

https://atelje212.rs/?page id=11, pristupljeno 2.9. 2019.

www.kamerniteatar55.ba, pristupljeno 13. 12. 2018.

https://www.uni-saarland.de/lehrstuhl/solte-

gresser/lehrstuhl/mitarbeiterinnen/manfredschmeling/manfredschmeling.html, pristupljeno 2 . 8. 2019.

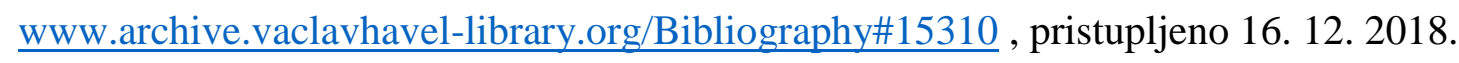
www.totalita.cz/norm/norm_03.php, pristupljeno 22. 12. 2018.

www.libpro.cz/katalog/emil/emil3.htm, pristupljeno 27. 12. 2018.

Arhiva: S. Mrožek: „Emigranti““

www.cekate.hr/tnt/arhiva-tnt/s-mrozek-emigranti-15-7-20-30/, pristupljeno 16. 1. 2016

Benčić, Luka Može li Palach opet biti središte riječke kulture

www.jutarnji.hr/kultura/glazba/moze-li-palach-opet-biti-srediste-rijecke-kulture/1200890/, pristupljeno 20. 12. 2018.

Buljan, Ivica Nepodnošljiva lakoća obećanja

https://www.skolskiportal.hr/clanak/10211-nepodnosljiva-lakoca-obecanja/, pristupljeno 20.

7. 2019.

Derk, Denis Brešan žali mnoge stvari https://www.vecernji.hr/kultura/bresan-zali-mnogestvari-727365, pristupljeno 11. 7. 2015.

Derk, Denis Miroslav Međimorec: Nitko me ne može otjerati iz Hrvatske

www.vecernji.hr/kultura/miroslav-medjimorec-nitko-me-ne-moze-otjerati-iz-hrvatske-388017 pristupljeno 15. 12. 2018.

Divadlo Za branou Vyškov 
https://www.amaterskedivadlo.cz/main.php?data=soubor\&id=7247, pristupljeno 24. 7. 2019. Hertl, David Dušan Hamšík - spisovatel, kterého samlela doba https://plus.rozhlas.cz/dusan-hamsik-spisovatel-ktereho-semlela-doba-7563434, pristupljeno 26. 12. 2018.

Kvrgić, Pero Pivo gdje se vari - dobro stoje stvari http://www.matica.hr/vijenac/174/pivo-gdje-se-vari-dobro-stoje-stvari-17234/, pristupljeno 22. 12. 2018.

Machovec, Martin The Types and Functions of Samizdat Publications in Czechoslovakia 1948-1989

https://read.dukeupress.edu/poetics-today/article/30/1/1/20983/The-Types-and-Functions-ofSamizdat-Publications, pristupljeno 22. 1. 2019.

Mihajlović, Branka Raspad Jugoslavije se vidio još 1968. godine (intervju s Hrvojem Klasićem) http://www.slobodnaevropa.org/content/klasic_raspad_jugoslavije_se_vidio_jos_1968_godin e/24534252.html, pristupljeno 3. 7. 2014.

Naslovnica programske knjižice predstave Marija se bori s anđelima Pavela Kohouta http://athena.muo.hr/?object=view\&id=65980, pristupljeno 2. 8. 2019.

Osobnosti: Císař, Jan https://www.amaterskedivadlo.cz/main.php?data=osobnost\&id=123, pristupljeno 1. 9. 2019. Pavičić, Jurica Po čemu je danas važna Bijela knjiga https://www.jutarnji.hr/arhiva/po-cemu-je-danas-vazna-bijela-knjiga/2113302/, pristupljeno 3. 8. 2019.

Pelikán, Jiří Kdo byl kdo v našich dějinách ve 20. století http://www.listy.cz/pelikan.php?text=kdo-byl-kdo, pristupljeno 1. 9. 2019.

Plakat predstave Ševa Teatra u gostima, Muzej za umjetnost i obrt http://athena.muo.hr/?object=view\&id=65003 , pristupljeno 2. 8. 2019.

Plakat predstave Protest i Atest Václava Havela i Pavela Kohouta http://timelinehrvatskogdizajna.com/2017/03/mirko-ilic-2/, pristupljeno 21. 8. 2019. Plakat predstave Marija se bori s anđelima Pavela Kohouta http://athena.muo.hr/?object=detail\&id=64154, pristupljeno 2. 8. 2019.

Rašović, Renata Nepodnošljiva lakoća bacanja blata na vozača kamiona https://www.vecernji.hr/premium/nepodnosljiva-lakoca-bacanja-blata-na-vozaca-kamiona1325450, pristupljeno 20. 7. 2019.

Reklama za predstavu Očajno smiješno u Zagrebu 
https://archive.vaclavhavel-library.org/Archive/Detail/26291, pristupljeno 2. 8. 2019.

Robertson, Campbell Better late than never

https://www.nytimes.com/2006/12/01/theater/better-late-than-never.html, pristupljeno 15. 10. 2017.

Růžička, Daniel Televize v roce 1968. - krátké období bez cenzury

https://cz.ejo-online.eu/5542/svoboda-tisku/televize-v-roce-1968-kratke-obdobi-bez-cenzury , pristupljeno 31. 7. 2019.

Varaždinske vijesti, br. 1329, 10. 6. 1970.

https://library.foi.hr/novine/broj1.aspx $\mathrm{v}=1 \& \mathrm{t}=1 \& \mathrm{C}=3 \&$ godina $=1970 \&$ broj=000022\&stranic $\underline{\mathrm{a}=004 \& \mathrm{u}=\mathrm{kundera},}$, pristupljeno 12. 1. 2019.

Varaždinske vijesti, 26. 6. 1980., br. 25

http://library.foi.hr/novine/broj1.aspx?C=3\&godina=1980\&broj=000025, pristupljeno 24.7. 2019.

Zdeněk Mlynář

http://www.totalita.cz/vysvetlivky/o_mlynarz.php, pristupljeno 1. 9. 2019. 


\section{BIBLIOGRAFIJA PRIJEVODA ${ }^{935}$}

\section{KNJIŽNA IZDANJA}

1. Havel, Václav. Pisma Olgi. Prijevod Aleksandar Ilić. Beograd: Prosveta, 1989.

2. Havel, Václav. Pazite! Iskušenje, Asanacija (dve drame). Prijevod Aleksandar Ilić. Gornji Milanovac: Dečje novine, 1990.

3. Klíma, Ivan. Ljeto ljubavi. Prijevod Renata Kuchar. Zagreb: Naprijed, Biblioteka Odabrani ljubavni romani, 1985.

4. Kundera, Milan. Šala. Prijevod Nikola Kršić. Zagreb: Znanje, Biblioteka Hit, 1969.

5. Kundera, Milan. Šala. Prijevod Nikola Kršić. Zagreb: Znanje, Biblioteka Evergrin, 1982.

6. Kundera, Milan. Šala. Prijevod Nikola Kršić. Sarajevo: Izdavačka kuća „Veselin Masleša“, 1984.

7. Kundera, Milan. Šala. Prijevod Nikola Kršić. Sarajevo: Izdavačka kuća „Veselin Masleša“, 1985.

8. Kundera, Milan. Šala. Prijevod Nikola Kršić. Beograd: Beogradski izdavačko-grafički zavod, 1987.

9. Kundera, Milan. Šala. Prijevod Nikola Kršić. Beograd: Beogradski izdavačko-grafički zavod, 1990.

10. Kundera, Milan. Šala. Prijevod Nikola Kršić. Sarajevo: Izdavačka kuća „Veselin Masleša“, 1990.

11. Kundera, Milan. Život je negdje drugdje. Prijevod Nikola Kršić. Zagreb: Znanje, Biblioteka Hit, 1979.

12. Kundera, Milan. Život je drugdje. Prijevod Nikola Kršić. Sarajevo: Izdavačka kuća „Veselin Masleša“", 1984.

13. Kundera, Milan. Život je drugdje. Prijevod Nikola Kršić. Sarajevo: Izdavačka kuća „Veselin Masleša“, 1985.

14. Kundera, Milan. Život je drugdje. Prijevod Nikola Kršić. Sarajevo: Izdavačka kuća „Veselin Masleša“, 1990.

\footnotetext{
${ }_{935} \mathrm{U}$ bibliografiji prijevoda književnih djela predstavnika neoficijelne književne scene tijekom razdoblja normalizacije književnici su navedeni abecednim redom, a književna djela određenoga književnika kronološki prema prvome izdanju teksta.
} 
15. Kundera, Milan. Knjiga smijeha i zaborava. Prijevod Albert Goldstein i Dagmar Ruljančić. Zagreb: Grafički zavod Hrvatske, Biblioteka Zora, 1982.

16. Kundera, Milan. Knjiga smijeha i zaborava. Prijevod Nikola Kršić. Sarajevo: Izdavačka kuća „Veselin Masleša“, 1984.

17. Kundera, Milan. Knjiga smijeha i zaborava. Prijevod Nikola Kršić. Sarajevo: Izdavačka kuća „Veselin Masleša“, 1985.

18. Kundera, Milan. Smešne ljubavi. Prijevod Aleksandar Ilić. Beograd: Prosveta, Beograd, 1983.

19. Kundera, Milan. Smiješne ljubavi. Prijevod Nikola Kršić. Sarajevo: Izdavačka kuća „Veselin Masleša“, 1984.

20. Kundera, Milan. Smiješne ljubavi. Prijevod Nikola Kršić. Sarajevo: Izdavačka kuća „Veselin Masleša“, 1985.

21. Kundera, Milan. Smiješne ljubavi. Prijevod Nikola Kršić. Beograd: Beogradski izdavačko-grafički zavod, 1987.

22. Kundera, Milan. Smešne ljubavi. Prijevod Aleksandar Ilić. Beograd: Prosveta, Beograd, 1988.

23. Kundera, Milan. Smiješne ljubavi. Prijevod Nikola Kršić. Sarajevo: Izdavačka kuća „Veselin Masleša“, Sarajevo, 1990.

24. Kundera, Milan. Oproštajni valcer. Prijevod Nikola Kršić. Sarajevo: Izdavačka kuća „Veselin Masleša“, Sarajevo, 1984.

25. Kundera, Milan. Oproštajni valcer. Prijevod Nikola Kršić. Sarajevo: Izdavačka kuća „Veselin Masleša“, 1985.

26. Kundera, Milan. Oproštajni valcer. Prijevod Nikola Kršić. Beograd: Beogradski izdavačko-grafički zavod, 1987.

27. Kundera, Milan. Oproštajni valcer. Prijevod Nikola Kršić. Sarajevo: Izdavačka kuća „Veselin Masleša“, 1990.

28. Kundera, Milan. Nepodnošljiva lakoća postojanja. Prijevod Nikola Kršić. Sarajevo: Izdavačka kuća „Veselin Masleša“, 1984.

29. Kundera, Milan. Nepodnošljiva lakoća postojanja. Prijevod Nikola Kršić. Sarajevo: Izdavačka kuća „Veselin Masleša“, 1985.

30. Kundera, Milan. Nepodnošljiva lakoća postojanja. Prijevod Nikola Kršić. Sarajevo: Izdavačka kuća „Veselin Masleša“, 1986.

31. Kundera, Milan. Nepodnošljiva lakoća postojanja. Prijevod Nikola Kršić. Sarajevo: Izdavačka kuća „Veselin Masleša“, 1990. 
32. Liehm, Antonín J. Miloš Forman: događaji. Prijevod Aleksandar Ilić. Beograd: Institut za film, 1987.

33. Mlynář, Zdeněk. Mraz dolazi iz Kremlja. Prijevod Romeo Vikić. Zagreb: OOUR Globus, Izdavačka djelatnost, Biblioteka Globus, 1985.

34. Pelikán, Jiří. Praško proljeće. Prijevod Tatjana Brodnjak. Zagreb: OOUR Globus, Izdavačka djelatnost, Biblioteka Globus, 1982.

35. Škvorecký, Josef. Oklopni bataljon. Prijevod Nikola Kršić. Zagreb: Znanje, Biblioteka Hit, 1972.

36. Škvorecký, Josef. Oklopni bataljon: fragmenti iz doba kulta ličnosti. Prijevod Nikola

Kršić. Zagreb: Znanje, Biblioteka Evergrin, 1986.

37. Škvorecký, Josef. Lavica. Prijevod Mirko Jirsak. Zagreb: Stvarnost, 1973.

38. Škvorecký, Josef. Bas saksofon i druge priče o džezu. Prijevod Aleksandar Ilić. Beograd: Prosveta, 1986.

39. Škvorecký, Josef. Sjajna sezona (tekst o najvažnijim stvarima u životu). Prijevod Dagmar Ruljančić. Zagreb: Mladost, 1986.

40. Škvorecký, Josef. Iz života češkog društva. Prijevod Milan Čolić. Gornji Milanovac: Dečje novine, 1987.

41. Škvorecký, Josef. Mirakl. Prijevod Dagmar Ruljančić. Zagreb: Grafički zavod Hrvatske, 1987.

42. Škvorecký, Josef Inženjer ljudskih duša: osvrt na stare teme o životu, ženama, sudbini, sanjarenju, radničkoj klasi, uhodama, ljubavi i smrti. Prijevod Dagmar Ruljančić. Zagreb: Izdavačka kuća „August Cesarec“, 1989.

43. Vaculík, Ludvík. Sekira. Prijevod Jara Ribnikar. Beograd: Rad, 1969.

Prijevodi umjetničke proze objavljeni u periodici

1. Aškenazy, Ludvík Jaje, prijevod Mirko Jirsak, Vjesnik u srijedu, br. 1194, 26. 3. 1975., 20

2. Havel, Václav Pisma Olgi, prijevod Renata Kuchar i Nives Opačić, 15 dana, br. 3, 1987. $21-25$

3. Klíma, Ivan Srijeda ujutro, prijevod Renata Kuchar, 15 dana, br. 6, 1988., 34-38

4. Kundera, Milan Ishitreni autostop, prijevod Predrag Jirsak, Republika, 12, XXIV(1968), 764 
5. Kundera, Milan Knjiga smijeha i zaborava (ulomak), prijevod Dagmar Ruljančić i Albert Goldstein, 15 dana, 1985., 12-13

6. Kundera Milan Nepodnošljiva lakoća postojanja (ulomak), prijevod Nikola Kršić, 15 dana, 1985., 12

7. Kundera, Milan Nepodnošljiva lakoća postojanja (ulomak), prijevod Nikola Kršić, 15 dana, br. 7, 1987., zadnja stranica

8. Kundera, Milan Tragedija Srednje Europe, prijevod Giga Gračan, Gordogan, god. 07(1985), br. 17/18, 289-305

9. Pelikan, Jiř́ Praško proljeće (ulomci, objavljeni u nastavcima), Danas, br. 21 (13. 7. 1982.), br. 22 (20. 7. 1982.), br. 23 (27. 7. 1982.)

10. Smetanová, Jindřiška Kiša, prijevod B. Škritek, Republika, br. 11, 1971., 1225-1232

11. Škvorecký, Josef Pjesma zaboravljenih godina, prijevod Mirko Jirsak, Republika, 12, XXIV(1968), 746-748

Prijevodi poezije objavljeni u periodici

1. Iz suvremene češke poezije (Vladimir Holan, Jiří Šotola i Milan Nápravník), prijevod Mirko Jirsak i Branko Plivelić, Republika, 12, XXIV(1968), 725-736

2. Izbor iz poezije (Jan Zábrana, Pavel Janský, Jiří Gruša, Josef Hanzlík, Vladimír Janovic, Oldřích Dadák, Vladimír Burda, Pavel Šrut, Antonín Brousek, Věra Provazníková, Ivan Wernisch, Petr Kabeš), Vidik, br. 21, 1970., 30-56

3. Kundera, Ludvík Pokušaj pohvale Charliea Chaplina, 15 dana, br. 7/8, 1968., 36-37

4. Mikulášek, Oldřich (izbor iz poezije), prijevod Predrag Jirsak, Književna smotra, br. 23, 1976.

5. Mlađe češko pjesništvo (J. H. Krchovský, Jan Kahan, Petr Placák, Jáchym Topol), prijevod Katica Ivanković, Rival, br. 3-4, 1990., 106-120

6. Sat između psa i vuka (Ogled povijesne strukture modernog češkog pjesništva), prijevodi Iz suvremene češke poezije (Jan Skácel, Jiří Šotola, Miroslav Holub, Oldřich Mikulášek, Vladimír Holan, Jaroslav Seifert, František Hrubín, Josef Kainar), prijevod Predrag Jirsak, Književna smotra, br. 54/55, 1984., 97-108

7. Skácel, Jan Stupanje u grob, prijevod Ljudevit Bauer, Republika, br. 6, 1970., 251

8. Zbogom i maramica (izbor iz češke ljubavne poezije: Josef Hora, František Gellner, Antonín Sova, Vitězslav Nezval, František Halas, Jaroslav Seifert, Oldřich Mikulášek, 
František Hrubín, Jan Pilař, Jiří Šotola, Miloš Macourek, Miroslav Florian), prijevod Zvonimir Golob, Republika, br. 10, god. XXXIV, listopad 1978., 1107-1120

Prijevodi dramskih tekstova objavljeni u periodici

1. Havel, Václav Largo desolato (ulomak), prijevod Renata Kuchar, 15 dana, 1987., Zagreb, 26-29

2. Havel, Václav Iskušavanje, prijevod Katica Ivanković, Quorum, Zagreb, 6(1990), 1(29), $18-77$

Prijevodi češke poezije i proze u hrvatskome tisku od 1968. do 1990. koji ne pripadaju neoficijelnoj češkoj književnosti:

proza

1. Hrabal, Bohumil Automat svijet, Književna smotra, VI(1974), br. 19, 31-36

2. Hrabal, Bohumil Dijamantno oko, Republika, god. XXIV, br. 12, 1968., 708-711

3. Hrabal, Bohumil Praznine (ulomak), 15 dana, br. 3, 1988., 36-38

4. Hrabal, Bohumil Zeba, Republika, br. 4, 1984.

5. Nesvadba, Josef Vampir Ltd, Pitanja, br. 28, 1971., 856-860

6. Parál, Vladimír Ljubavnici i ubojice (ulomak), Republika, br. 10, 1977., 61-73

7. Seifert, Jaroslav Sve zemaljske ljepote (ulomak), prijevod Renata Kuchar, Republika, br. 10/11/12, 1984.

8. Souček, Ludvík Anđeoska misija, Oko, br. 184, 1979., 12

poezija

1. Bartušek, Antonín Naopaka čudesa, Rival, br. 3-4, 1989., 175-176

2. Hanzlík, Josef, Oko (naslovna stranica), br. 275, 1982.

3. Holub, Miroslav Izbor iz poezije, prijevod na srpski jezik Božidar Grubišić i Luka Šteković), Revija, br. 2, 1973., 78-92

4. Holub, Miroslav Izbor iz poezije, prijevod Ljudevit Bauer, Forum, br. 6, 1974., 984-995

5. Seifert, Jaroslav Izbor iz poezije, prijevod Renata Kuchar, Republika, br. 10/11/12, 1984. 
6. Seifert, Jaroslav Izbor iz poezije, prijevod Renata Kuchar i Nives Opačić, 15 dana, br. 6, 1985., 29-33

7. Seifert, Jaroslav Koncert na otoku (izbor pjesama), prijevod Dušan Karpatský, Forum, god. 9(1970), knj. 20, br. 9, 389-405

8. Šotola, Jiří A koliko si imala ljubavnika, prijevod Renata Kuchar i Nives Opačić, 15 dana, br. 3, 1986., 25-29

9. Šotola, Jiř́i Mislim na tebe, prijevod Renata Kuchar i Nives Opačić, Oko, br. 388, 1986.

10. Šotola, Jiř́ Poezija, prijevod Renata Kuchar i Nives Opačić, 15 dana, br. 3, 1986., 25-29

11. Tri češka pjesnika (Josef Hanzlík, Kamil Mařík, Miroslav Florian), Forum, br. 7/8, 1984., $144-152$ 


\section{BIBLIOGRAFIJA TEKSTOVA U ČASOPISIMA I NOVINAMA}

\section{DANA}

Canki, Eugen Ovo je čehoslovački plakat, br. 7/8, 1968., str. 6

Doba u kojem je glavni zadatak umjetnosti smjelost - vrijeme je mraka, br. 11/14, 1968.

Dundović, Hanibal Formanov let preko kukavičjeg gnijezda, br. 6, 1976., 34-35

Granice slobode (Portreti filmskih umjetnika), br. 11/14, 1968., str. 37-39

Intervju s Jiř́ijem Menzelom (razgovarao Tomislav Kurelac), br. 3, 1984., 14-17

Intervju s Ludvíkom Vaculíkom (razgovarao Antonín Liehm), br. 7/8, 1968., 17

Karikature Bohumila Štěpana, br. 6, 1981.

Karikature Ivana Steigera, br. 5/6, 1968., 74

Karikature Vlastimila Zábranskog, br. 1/2, 1974.; br. 3, 1982., str. 39

Kuchar, Renata Popratni tekst u prijevod ulomka drame Largo desolato Václava Havela, br. 3, 1987., 26-29

Kuchar, Renata i Opačić, Nives Jaroslav Seifert, br. 6, 1985., 29

Kuchar, Renata i Opačić, Nives Poezija Jiř́ija Šotole, br. 3, 1986., 25-29

Kurelac, Tomislav Intervju s Jiř́ijem Menzelom, br. 3, 1984., 12-17

Munitić, Ranko Otkrivena Amerika, br. 1/2, 1972., 28

Proglas redakcije Slovačkih pogleda, br. 7/8, 1968.

Rubrika Otisci, br. 7, 1987., zadnja stranica

Sa stranica čeških i slovačkih novina, br. 7/8, 1968.

Senečić, Geno Mahenova Jugoslavija, br. 8, 1982, str. 35-37

Senečić, Geno Uz stotu obljetnicu rođenja Jaroslava Hašeka, br. 3, 1983., str. 30-33

Senečić, Geno Život je polazište i cilj književnosti (O tridesetoj obljetnici smrti Vladislava Vančure), br. 7, 1972.

Suvremena karikatura - Bohumil Štěpán Naročito korisni i zahvalni pronalasci, godište XV, br. 3-4, 1972., str. 58-59

Štěpán, Bohumil Odmorište mašte, godište XV, br. 5, 1972., str. 51

Štrelinger, Peter Posjet Božene Němcové Samu Chalupki, br. 1/2, 1982., str. 48-50 


\section{DANAS}

Bez tradicije sve su vrijednosti prolazne (intervju s Božidarom Violićem, Igor Mrduljaš), 16.

4. 1984., 54-57

Bilopavlović, Tito In memoriam Jaroslav Seifert, 21. 1. 1986., 43

Bosanac, Savo Tamnica za pisca, 28. 2. 1989., 55

Bosanac, Savo Tihi kas brončanih konjanika, 30. 8. 1988., 53-54

Brala, Želimir Oduševljenje Kišem, 24. 11. 1987., 41

Butorac, Tomislav Bivši huligan, šef države, 9. 1. 1990., 54-55

Butorac, Tomislav Dubčekova samorehabilitacija, 14. 3. 1989., 53

Butorac, Tomislav Prevareni ljubavnici, 6. 3. 1990., 55

Dino Radojević, 19. 8. 1986., 41

Đukić, Milo U potrazi za novim rješenjima, 32

Foretić, Dalibor Bog, vrag i anđeli, 9. 10. 1984., 53-54

Foretić, Dalibor Ljeto jednog kazališta, 30. 8. 1983., 57-58

Foretić, Dalibor Povratak kućnom festivalu, 17. 11. 1987., 38-39

Foretić, Dalibor Praška kazališta, 20. 3. 1990., 44-45

Foretić, Dalibor Publika ga voli, 20. 3. 1984., 59

Foretić, Dalibor Teatar ITD u Pragu, 20. 3. 1990.

Galić, Mirko (Pisci u fokusu: Danilo Kiš) Pariz, 3. 1. 1989., 36

Humor kao oružje protiv očaja (intervju s Josefom Škvoreckým, Dagmar Ruljančić), 29. 10. 1985., 52-55

Ispunjen Hamletov nalog (intervju s Jiř́ijem Bartoškom, Dalibor Foretić i Dagmar Ruljančić), 17. 4. 1990., 37-39

Ivanković, Nenad Pomirenje u Münchenu, 9. 1. 1990., 53

Jirsak, Predrag Mag poezije, 16. 10. 1984., 48

Kamenski, Branka Samica ili prijestolje, 13. 3. 1990., 35-37

Književnost je nepotkupljivo zrcalo (intervju s Nedjeljkom Fabrijem), 28. 5. 1985., 51-53

Krleža je superioran (intervju s Dušanom Karpatským, Mirko Galić), 2. 7. 1987., 44-46

Krušelj, Željko Zaleđeno proljeće, 23. 9. 1986., 53-55

Kuzmanović, Jasmina Hitovi, budući i bivši, 9. 2. 1982., 43-44

Kuzmanović, Jasmina Sudbina Bijele knjige, 13. 11. 1990., 35-37

Kuzmanović, Jasmina Utjeha za malene, 31. 3. 1987., 33-36 
Lisinski, Alemka Vlast bez Havela, 21. 11. 1990., 35-37

M. K. Milan Kundera (Njim samim), 8. 5. 1990.

Matvejević, Predrag Književnost i emigracija (Sivocrni humor), 4. 11. 1986., 36-38

Matvejević, Predrag Milan Kundera - naš pisac, 12. 10. 1982., 66-68

Matvejević, Predrag Od disidenta do prezidenta, 18. 12. 1990.

Milošević, Đorđe Kreator realne politike (Gustav Husak), 18. 1. 1983., 52

Milošević, Đorđe Prijelomne šezdesete, 23. 4. 1985., 63

Mnogo tišine oko veličine (intervju s Jiř́ijem Menzelom, Branka Malčić), 24 .8. 1982., 67-69

Moral u trapericama (intervju s Radekom Johnom, Andrea Majstorović), 1. 11. 1988., 46-47

Nacizam nije negdje drugdje, 11. 12. 1990.

Nakon reza 1968., 18. 9. 1984.

Nepodnošljiva lakoća povratka, 21. 11. 1989.

Nepodnošljiva lakoća pripadanja, 7. 12. 1987.

Osporavanje kao stav (intervju s Aleksandrom Flakerom), 30. 10. 1984., 51-54

Parada i ludost života - Nisam emigrant, ni vanjski ni unutrašnji (intervju s Bohumilom

Hrabalom, Dževdet Tuzlić), 64-65

Pauk za vratom (intervju s Karelom Steigerwaldom, Dagmar Ruljančić), 9. 1. 1990., 40-42

Pišem za Francusku (intervju sa Stjepanom Čuićem, Jasmina Kuzmanović), 21. 11. 1990., $38-40$

Pogled u jučer (intervju s Dušanom Karpatským, Jasmina Kuzmanović), 22. 5. 1990., 44-45

Posljednji disident, 6. 3. 1990., 46

Poziv na pretplatu na izdanja Milana Kundere, 14. 2. 1984.

Poziv na pretplatu na izdanja Milana Kundere, 17. 12. 1985.

Poziv na pretplatu na izdanja Milana Kundere, 5. 6. 1990.

Prica, Jasmina Iz samice na prijestolje 16. 1. 1990., 42-43

Prica, Jasmina Pobjeda intelekta nad municijom, 23. 1. 1990., 40-41

Ruljančić, Dagmar Kraj starih vremena, 23. 1. 1990., 42-43

Sloboda prema zasluzi (intervju s Věrom Aldovom, Mirko Galić), 2. 6. 1987., 50

Snimanje po Havelu, 20. 11. 1990., 47

Stojanović, Momčilo Nakon reza 1968., 18. 9. 1984., 61

Teatar je negdje drugdje, 16. 9. 1986.

Tomašević, Dragana Dva Jana u plamenu, 21. 8. 1990.

Tomić, Vladimir Istočni val u zapadnim knjižarama, 2. 4. 1984., 61-62

Tuzlić, Dževdet Novi sjaj velike tradicije, 20. 12. 1983., 50-51 
Visković, Velimir Ljubav i skepsa, 26. 2. 1985., 58-59

Župan, Ivica Proboj iz Tetschen-Bodenbacha, 2. 8. 1983., 59-60

\section{DUBROVNIK}

Premijera jednočinki Pavela Kohouta u Dubrovniku, br 6, 1980., 107-108

Pejaković, Hrvoje Milan Kundera Nepodnošljiva lakoća postojanja, br. 5/6, 1985., 141-144

\section{FORUM}

Bauer, Ljudevit Pjesništvo Miroslava Holuba, br. 6, 1974., 984-995

Gosiorovský, Miloš Povijesne pretpostavke češko-slovačke federacije, br. 10-11(1968), 10281056

Jagić, Vatroslav Hrvatska književnost, br. 3/4, 1989.

Karpatský, Dušan Braća Čapek, br. 1-2, 1972.

Karpatský, Dušan František Xaver Šalda, br. 1-2, 1978.

Karpatský, Dušan Jaroslav Seifert, god. 9(1970), knj.20, br. 9, 382-388

Karpatský, Dušan Prijevodi hrvatske književnosti kod Čeha, br. 1/2, 1984., 412-415

Krleža, Miroslav Osam pisama Dušanu Karpatskom, Pismo Anni Urbanovoj, Sedam pisama Ireni Wenigovoj, br. 10-12, 1982., 1004-1027

Kuchar, Renata i Opačić, Nives Nobelovac Jaroslav Seifert, god. 25(1985), knj. 50, br. 7-8, $372-383$

Kvapil, Miroslav O Miroslavu Krleži, njegovoj prozi i poeziji u Čehoslovačkoj između dva rata, br. 1-2, 1981., 96-121

Tuđman, Franjo Opasnost neostaljinističke ekspanzije, 8(1969), knj. 17, 543-555

Tuđ̋an, Franjo Evropa u procijepu između Istoka i Zapada, 7(1968), knj. 16, 623-648

Tušek Šimunović, Miroslava August Šenoa u očima češke kritike, br. 11/12, 1989. 


\section{GORDOGAN}

Banac, Ivo Milan Kundera i povratak Srednje Evrope, br. 23-24, god. IX, siječanj-travanj 1987., 39-53

Brown, Archie Život pri vrhu (prijevod Gordana Visković), br. 13-14, siječanj-travanj 1983., 329-332

Donat, Branimir Varijacije na propalu temu, br. 17-18, god. VII, siječanj-travanj 1985., 257-272

Ivić, Nenad Neoprostiva banalnost pisanja, br. 19, god. VII, 1985., 316-319

Jančar, Drago Terra incognita, br. 23-24, god. IX, siječanj-travanj 1987., 71-80

Konrád, György Beč i Srednja Europa, br. 23-24, god. IX, siječanj-travanj 1987., 81-95

Konrád, György Dobro je putovati, br. 17/18, 11(1990), br. 29-30, siječanj-travanj 1990., 273-288

Konrád, György Skica za srednjoeuropski portret, 11(1990), br. 29-30, siječanj-travanj 1990., $110-117$

Popović, Bruno Apokalipsa srednje Europe, br. 23-24, god. IX, siječanj-travanj 1987., 97-106

Ruljančić, Dagmar Polemike o Kunderinom eseju „Tragedija Srednje Evrope“, br. 23-24, god. IX, siječanj-travanj 1987., 47-62

Senker, Boris Miles gloriosus s perom u ruci, br. 5-6, siječanj-travanj 1980., 339-343

Šoljan, Antun Kantonizacija Europe, br. 28, god. X, siječanj - veljača 1988., 28-34

Violić, Božidar Izgubljeni dnevnik: Švedska, 11(1990), 31-33, svibanj - prosinac, 71-116

\section{KNJIŽEVNA SMOTRA}

Bauer, Ljudevit Bratstvo Isusovo, br. 3, 1970.

Iveković, Nada Nepodnošljiva lakoća besramlja, br. 63/64 1986.

Jirsak, Predrag Češki usud, br. 1, 1969.

Jirsak, Predrag Prostor raspoznavanja (O antiiluzivnosti moderne češke proze), VI(1974),

br. $18,89-96$

Jirsak, Predrag Sat između psa i vuka (Ogled povijesne strukture modernog češkog pjesništva), Književna smotra, br. 54/55, 1984., 97-108

Jirsak, Predrag Strukturalna književna povijest Felixa Vodičke, br. 20, 1975., 43-51

Kosík, Karel Hašek i Kafka ili groteskni svijet, br. 1972., 37-41 (preveo Predrag Jirsak) 
Opelík Jiří Zaumni stihovi Oldřicha Mikulášeka, br. 23, 1976.

\section{NOVI PROLOG}

Fuchs, Aleš Glumci i češka revolucija, br. 17/18, 1990.

Mrduljaš, Igor Kako uspavati kazalište ili Vlast se ne da vući za kosu, br. 17/18, 1990.

Prilozi za povijest cenzure u našem glumištu (Iz zagrebačkih kazališnih razgovora), br. 11, 1988./1989., 17-21

Zlatar, Andrea Tri u drugom, Menzel u Zagrebu, Zagreb iz Praga, br. 6/7, 1987./1988., 194-201

Zlatar, Andrea Povijest predstave kao redateljska biografija, Novi prolog, br. 8/9, 1988., 106-115

\section{$\mathrm{OKO}$}

Bašić, Relja Izvaci iz dnevnika jednog putujućeg glumca, br. 80, 1975., 5

Cvitan, Dalibor Nepodnošljiva lakoća antirasizma, br. 19(483), 1990., 26

Dani satire, br. 425, 1988., 12

DC Slika kažnjeničkog društva, br. 106, 1976.

Dopustite mi da s vremena na vrijeme budem tužan (intervju s Jaroslavom Seifertom, Luboš Jurík, sa slovačkog preveo Geno Senečić), br. 332, 1984., 6-7

Falout, Željko Jedna sretna večer, br. 208, 1980., 16

Falout, Željko Njegova domovina je humor, br. 228, 1980, 15

Film Resnaisa i Kundere, br. 335, 1985., 30

Frndić, Nasko Osme Gavelline večeri (Dobro smiksan dramski koktel), br. 225, 1980., 20

Godina češke poezije, br. 83, 1975., 19

Hedl, Drago Život je negdje drugdje, br. 335, 1985., 2

In memoriam Jaroslavu Seifertu, br. 362, 1986., 22

Intervju s Jiř́ijem Menzelom - Stalno (sebi) smijem (Ivan Hetrich), br. 221, 1980., 5

Ivanković, Katica Magor protiv Husaka (intervju s Ivanom Jirousom), br. 2(466), 1990., 24

Ivanković, Katica i Valentić, Željko Socijalizam je mrzio knjigu, br. 464, 1989., 28-29

Jirsak, Predrag Češka znanstvena fantastika, br. 184, 1979., 12 
Jirsak, Predrag Tema seifertiana, br. 329, 1984., 20

Knjiga 1989. u SR Hrvatskoj (Prijedlozi izdavačkih planova izdavača), br. 444, 1989. poseban prilog

Kundera u režiji Susan Sontag, br. 337, 1985., 30

Kurelac, Tomislav Amadeus, br. 335, 1985., 12

Kurelac, Tomislav Teško je postati Amerikanac, br. 328, 1984., 13

Kursar Pupavac, Smilja U krletci vlastitih dilema, br. 338, 1985., 11

L. L. Kriza suvremenog autorstva (u Čehoslovačkoj), br. 160, 1978., str. 23

M. B. 8. Zagrebački književni razgovori (I književnost je pobijedila), br. 83, 1975., 2

Mařík, Kamil Zagrebački književni razgovori (očima jednog gosta), br 269, 1982., 19

Matanović, Julijana Povijesni poučak, br. 19 (483), 1990., 36

Matvejević, Predrag Za oslobođenje Václava Havela, ponovno, br. 445, 1989., 2-3

Milanja, Cvjetko Pouka izvana, br. 372, 1986., 20

Miloš Forman dobitnik Oscara, br. 106, 1976., 19

Nije riječ o laskanju (intervju s Milanom Kunderom, Tomislav Kurelac i Rajko Grlić), br.

$232,1981 ., 10$

Nikčević, Sanja Nepodnošljiva lakoća čitanja, br. 432, 1988., 21

Nove knjige: Jaroslav Seifert Sve lepote sveta, br. 445, 1989., 20

Nove knjige: Josef Škvorecký Inženjer ljudskih duša, br. 461, 1989., 20

Očajno smiješno Václava Havela u Gavelli, br. 451, 1989., 14

Ostojić, Ljubica Leopoldov krik, br. 399, 1987., 12

Petrak, Nikica Beč, Beč između ostalog, br. 13(477), 28. 6. 1990., 3

Petrak, Nikica Sudbina Vječnog Žida, br. 23(487), 1990., 3

Podnošljiva težina postojanja, br. 449, 1989. 23

Popis prihvaćenih naslova za sufinanciranje programa društveno vrijednih knjiga u 1987., br. 393, 1987., 16-17

Popis prihvaćenih naslova za sufinanciranje programa društveno vrijednih knjiga u 1988., br. 418, 1988., 21

Prijedlozi izdavačkih planova (Poslovna zajednica izdavača i knjižara Hrvatske), br. 7(471), 1990.

Prikaz knjige Jaroslava Bočeka Prestolonasljednik, br. 15(479), 1990., 39

Rang-lista Timea, br. 5(469), 1990., 6

Razborita komedija o luđacima, br. 122, 1976.

S. K. P. Vesela igra, br. 409, 1987., 13 
Sladojević, Duje Isušenje psihijatrije, br. 120, 1976.

Stamać, Ante Naziv „Srednja Evropa“ u zrcalu tipologije, br. 457, 1989. 14

Strogo kontrolirani teatar demokracije, br 449, 1989., 9

Stublija, Želimir IX. dani satire (Nikad bogatiji program), br. 321, 1984., 13

Stublija, Želimir Gavelline večeri br. 383, 1986., 11

Stublija, Želimir U močvari slučajnog kazališta, br. 372, 1986., 12

Stublija, Želimir Veliki kolo vode, br. 320, 1984., 11

Stublija, Želimir Antijunak u dvostrukoj klopci, br. 451, 1989., 14

Stublija, Želimir IX. dani satire, br. 321, 1984., 13

Stublija, Želimir Još malo pa festival, br. 399, 1987.

Stublija, Želimir XV. dani satire, br. 409, 1987., 16-17

Stublija Želimir XVI. Gavelline večeri, br. 434, 1988., 15

Stublija, Želimir Skromnije, ali ne slabije, br. 434, 1988., 15

Šuljić, Igor Za predsjedničku ložu, br. 24(488), 1990., 13

Teatar je ipak negdje drugdje, br. 426, 1988., 12

Tomašević, Boško Signum strukturalizma, br. 408, 1987., 20

Turković, Dubravka Neslano s ozbiljnom šalom, br. 310, 1984., 13

Vučić, Miroslava Ladislav Fuks Gosp. Theodor Mundstock, br. 446, 1989., 21

Ž. S. Proširene granice, br. 425, 1988., 12

PITANJA

Gaja, Vojtěch Esej o humoru i komičnosti, preveo Antun Horak, br. 37, 1972., 1641-1648

Gruić, Iva Povratak publici kao lagodna mogućnost, 195-200

Matijašević, Željka Kaos i metoda, br. 5/6, 1988., 209-210

\section{POLET}

Avdić, Senad Zemlja plača i zaborava, br. 406, 1989.

Barni (Nenad Bartolčić) En passant, br. 378, 1987.

Bašić, Mate Život je negdje ovdje, br. 389, 1988., 16

Buljan, Ivica Erotski naboj MESS-a, br. 388, 1988. 
Buljan, Ivica Le soirs de Gavella, br. 377, 1987., 33

Cvjetičanin, Marija Nepodnošljiva teškoća mogućeg, br. 412, 1989.

Čegec, Branko Sjećanja iz '68., 1988.

Dragojević Harapin, Snježana Bolnica na kraju pameti, br. 411, 1989.

Jović, Dejan Intervju s Jaroslavom Jerenálom, predsjednikom SSO Čehoslovačke, br.

328/329, 1985.

Jurdana, Srećko Dvosjekli mač, br. 123, 1980., 19

Kovačević, Neven Mraz dolazi sa sjevera, br. 405, 1989.

Lozanović, Goranka Zbirka šesnaest autora (Milan Kundera Smiješne ljubavi i Oproštajni valcer), br. $177,1981 ., 6$

Mirakl kao „knjiga godine“, br. 381, 1988.

Oštrić, Tomislav, Gorući dlanovi, br. 376, 1987.

Pejaković, Hrvoje Milan Kundera Knjiga smijeha i zaborava, br. 220, 1983.

Pezo, Zoran Nevjerojatni „HIT“, br. 127, 1990.

Pezo, Zoran Ujed tržišta (razgovor sa Zdravkom Židovcem), br. 126, 1980.

Pezo, Zoran Zlatko Crnković: ulog je atrakcija, br. 127, 1980.

Santrić, Vjeko Trčkalica, br. 253, 1984.

Svi poševili (Candide Studentskog eksperimentalnog kazališta), br. 143, 1980.

Španović, Srđan Nepodnošljiva lakoća izvještavanja, br. 399, 1988., 5

Tatić, Dubravka Sjećaš li se Španije?, br. 402, 1989., 26

U SKUC-u (Žak Fatalist Milana Kundere u Teatru ITD), br. 144, 1980.

Vresnik, Viktor Hrvatska kao Čehoslovačka, br. 419/420, 1989.

Vukov Colić, Dražen Rokerski pokušaji u Čehoslovačkoj, br. 215, 1982.

Zubčević, Darko Kosa Miloša Formana, br. 74, 1978.

Žvan, Veljko „Let iznad kukavičjeg gnijezda“ kao kritika građanskoga društva

Žvan, Veljko Let iznad kukavičjeg gnijezda Miloša Formana, br. 5/6, 1976.

Žvan, Veljko Patološke mjere ili nešto drugo? (Uz čehoslovačku kritiku Povelje 77), br. 15, 1977., 4

\section{PROLOG}

Kazalište, umjetnost sjena (intervju s Božidarom Violićem, Igor Mrduljaš), dvobroj 36-37, $\operatorname{god} \mathrm{X}(1978)$ 
Krušić, Vlado Teatar s ruba, br. 28, god. VIII(1976.), 45

Lorger, SrećkoVrijeme športa i razonode, br. 15, god. IV(1971), 46

Mrduljaš, Igor Diderot á la Pragois, br. 46, god. XII(1980), 170-172

Može li Lemnos biti od drveta? (intervju s Mirom Međimorcem, Vlado Krušić), br. 25, god.

VII(1975), 24

Repertoar Internacionalnog festivala studentskih kazališta u Zagrebu, br. 4, god. 2, ožujak/travanj/svibanj/lipanj, 1969.

Senker, Boris Pegaz u ormi, br. 43, god. XII(1980), 159-163

Zašto istupamo?, Prolog, god. 1, br. 1, ožujak/travanj 1968., 4

Zubčević, Darko Miloš Forman i Taking Off, br. 16, 1972.

\section{QUORUM}

Bašić, Mato Jugoslavenski studenti u Pragu, br. 4, 1989., 414-427

Gavran, Zdravko Terra Kunderiana, br. 1, 1985., 119-122

Havel, Václav Govorimo o riječima, prijevod Bosiljka Brlečić, 6(1990), 1(29), 12

Ivanković, Katica Havel na Hrad, br. 1(29), 6(1990), 2-17

Ivanković, Katica Mladi češki narkomani, br. 3, god. IV, 1988., 329-333

Ivanković, Katica Radek John Memento, br. 3, 1988.

Ivanković, Katica Sve Seifertove promjene, br. 2, 1985., 140-143

Razgovor s Jiř́ijem Dokopilom, br. 4, god. V, 1989., 365-368

Sedlecký, Petr Slučaj jazz-sekcije, br. 3, god. IV, 1988., 210-220

Tatarin, Milovan Apsurdno nepoimanje situacije, br. 2, god. V, 1989., 387-389

Vučić, Miroslava Enigma enigme, br. 4/5, 1986., 217-220

\section{REPUBLIKA}

Republika, tematski broj, br. 12, prosinac 1968.

Batušić, Nikola Havel u Gavelli, br. 7/8, 1980.

Beganović, Davor Kritika romana Mirák1, br. 9/10, 1988.

Donat, Branimir Kritika knjige Mraz dolazi iz Kremlja, br. 11/12, 1986.

Gotovac, Vlado Vidljiva i nevidljiva Evropa, br. 11/12, 1988. 
Horvatić, Dubravko Biblioteka HIT (IV. kolo), br. 2/3, 1971., 301-311

Horvatić, Dubravko Uz Vltavu, Berounku i Labu, br. 5, 1969., 248-251

Kačer, Miroslav K značenju izgradnje dramske groteske, prijevod Mirko Jirsak, 12, XXIV(1968), 755-757

Karpatský, Dušan Jugoslavensko-čehoslovački mozaik, br. 5, 1968.

Krelja, Petar Taking Off, br. 11, 1973.

Kuchar, Renata Novi nobelovac, br. 10/11/12, 1984.

Pecnik, Jaroslav Sizifova istina, br. 7-8, 1976., 59-63

Podrug, Toma Starim Pragom, br. 8, 1976., 915-925

Ribnikar, Vladislava Milan Kundera kao romansijer, 46(1990), 1-2, 33-51

Senker, Boris Zapisi iz zamračenog gledališta (Kazališna kronika), br. 7/8, 1988.

Simić, Novak Trojica ispred zaborava, br. 2/3, 1971., 276

Simić, Novak Žrtveni ovnovi „Dnevnik jednog kontrarevolucionara“ Pavela Kohouta, br. 8, 1969., 48

Špoljar, Krsto Roman iz češkog „mrtvog doma“, br. 26, 6(1970), 286

\section{REVIJA}

Bujić, Goran Milan Kundera Oproštajni valcer, br. 3, 1982., 97-101

Matanović, Julijana Jaroslav Boček Prestolonasljednik, br. 7, 1990., 112-115

RIVAL

Jensterle, Alenka Mlađe češko pjesništvo - Na krhotinama slobode, br. 3-4, 1990., 99-120

Lukežić, Irvin Priča o crnoj družbi, br. 1-2, 1989., 187-189

\section{STUDIO}

Ruljančić, Dagmar Atest\&Protest, 31. 10. 1981., 26-27 


\section{UMJETNOST RIJEČI}

Bauer, Ljudevit Struktura i književni proces, br. 3, 1970.

Červenka, Miroslav Temeljne kategorije praškog književnoznanstvenog strukturalizma, br. 3, 1972.

Červenka, Miroslav Značenjsko ustrojstvo književnog djela, br. 2-4, 1975.

Doležel, Lubomír Karel Čapek i Vladislav Vančura, br. 4, 1969.

Doležel, Lubomír Perspektive strukturalne analize književnog djela, br. 2-4, 1975.

Drozda, Miroslav Groteska u romanu Petersburg A. Belog, 1981.

Drozda, Miroslav Novele Vasilija Šukšina, br. 2, 1976.

Drozda, Miroslav Skaz i groteska, br. 1, 1979.

Drozda, Miroslav Trojni vid bezvremenosti, br. 1. 1975.

Chvatík, Květoslav Mogućnost interpretacije umjetničkog djela, br. 2-4, 1975.

Chvatík, Květoslav Strukturalna estetika i poetika Jana Mukařovskog, br. 3, 1972.

Chvatík, Květoslav Strukturalna teorija historijskog razvitka književnosti, br. 1-2, 1984.

Jankovič, Milan Perspektive semantičke geste, br. 2-4, 1975.

Kalivoda, Robert Dijalektika strukturalizma i dijalektika estetike, br. 2-4, 1975.

Levý, Jiří Geneza i recepcija književnog djela, br. 2-4, 1975.

Mukařovský, Jan Strukturalizam u estetici i u nauci o književnosti, br. 2-4, 1975.

Otruba, Mojmír Mit i ritual, br. 2-4, 1975.

Sus, Oleg Formalizam i strukturalizam, br. 1-2, 1984.

Sus, Oleg Prilog strukturalnoj teoriji estetske norme, br. 2-4, 1975.

Vodička, Felix Strukturalna književna povijest, br. 2-4, 1975.

VEČERNJI LIST (kronološki poredak tekstova)

Izjava predsjednika Tita (naslovnica), br. 2806, 22. 8. 1968.

Pomoć i podrška čehoslovačkim turistima, br. 2806, 22. 8. 1968., 5

Prihvat turista iz ČSSR (zadnja stranica), br. 2806, 22. 8. 1968.

Apel Turističkog saveza Hrvatske (Z. F.), br. 2806 (zadnje izdanje toga dana), 22. 8. 1968., 5

Jugoslavija osuđuje agresiju (naslovnica), br. 2807, 23. 8. 1968.

Solidarnost Beograđana (A. Č.), br. 2807, 23. 8. 1968., 3

Čehoslovaci zbrinuti, br. 2807, 23. 8. 1968., 5 
Solidarnost na svakom koraku, br. 2808, 24. 8. 1968., 5

10000 Osječana na mitingu solidarnosti (D. M.), br. 2809, 26. 8. 1968., 5

INA osigurala benzin (N.), br. 28. 8. 1968., 4

Aragonov predgovor češkom romanu, br. 2827, 16. 9. 1968., 57

Što je to kazalište (M. Grgičević), br. 2831, 20. 9. 1968., 7

U očekivanju razgovora (Melita Singer), br. 2832, 21. 9. 1968., 4

Književni petak Duh se ne može okupirati (D. M.), br. 2839, 30. 9. 1968., 7

Naši pisci i okupacija ČSSR, br. 2866, 31. 10. 1968., 7

Koliko nas prevode? (M. Stojanović), br. 6518, 28. 10. 1980., 11

Sedam premijera (N. Ožegović), br. 6520, 30. 10. 1980., 11

Kako Kundera „vidi“ Diderota (M. J.), br. 6533, 14. 11. 1980., 11

Svi smo mi plagijati (M. Grgičević), br. 6542, 25. 11. 1980., 10

Sad me vidiš..., br. 6544, 27. 11. 1980., 11

Prvenstveno domaći autori (Dragutin Brenčun), br. 6562, 20. i 21. 12. 1980., 12

Rekord na malim scenama, br. 6593, 29. 1. 1981., 11

Odabrane predstave, br. 6620, 2. 3. 1981., 10

Ispod očekivanja (Marija Grgičević), br. 6650, 6. 4. 1981., 5

Posljednji je otpisan (M. G.), br. 6651, 7. 4. 1981., 11

Festivalski razgovor o „Žaku fatalistu“ (Najbolja predstava MESS-a!?, Zalihić A.), br. 6653, 9. 4. 1981., 11

Dvije dramske premijere (V. M.), br. 6665, 23. 4. 1981., 10

Žak Fatalist u Splitu, br. 6670, 29. 4. 1981., 11

Čudo koje smo planirali (Vojko Mirković), br. 6709, 16. 6. 1981., 5

Predstave za antologiju (B. Vukšić), br. 6775, 3. 9. 1981., 11

Prvi - Žak Fatalist, br. 6779, 8. 9. 1981., 5

Bez žirija, bez nagrada (J. Š.), br. 6782, 11. 9. 1981., 5

Večeras u Teatru ITD - Dvije jednočinke (B. Vu.), br. 6808, 12. 10. 1981., 8

Nastavak u burleski (M. G.), br. 6814, 19. 10. 1981., 8

Male scene u Novoj Gorici - Prva večer „U agoniji“, br. 6886, 15. 1. 1982., 9

Kazališni praznik (A. Z.), br. 6948, 29. 3. 1982., 10

Nagrade u Mostar (M. G.), br. 6955, 6. 4. 1982., 9

Premijera Havelovih jednočinki, br. 6652, 9. 4. 1982., 9

Od „Audijencije“ do „Izložbe“ (V. M.), br. 6946, 16. 4. 1982., 9

Dijalog o ironiji (A. L.), br. 6980, 7. 5. 1982., 8 
Ironija u književnosti (A. L.), br. 6984, 12. 5. 1982., 5

Milovanje prije sna, br. 6984, 12. 5. 1982., 5

Najbolji - „Banket“, br. 6988, 17. 5. 1982., 15

Najbolja predstava Pješice, br. 7025, 29. 6. 1982., 9

Miloš Forman u Barandovu, br. 7098, 23. 9. 1982., 9

„Golubnjača“ skinuta s repertoara (F. Ijevljev), br. 7167, 15. 12. 1982., 5

„Golubnjača“ gostovala u Beogradu, br. 7178, 28. 12. 1982., 5

Dvoboj teorije i beletristike (A. L.), br. 7187, 10. 1. 1983., 10

Diktator na kruški (Branko Vukšić), br. 7190, 13. 1. 1983., 5

Kruška nakon jabuke (M. G.), br. 7198, 21. 1. 1983., 5

Svjedok povijesti (U fokusu kritike Marka Marića), br. 7214, 9. 2. 1983., 9

Šesta premijera (B. Z.), br. 7238, 9. 3. 1983., 9

Sličice lake komedije (Vojko Mirković), br. 7354, 26. 7. 1983., 10

Na početku - Šala (Branko Vukšić), br. 4728, 21. 10. 1983., 5

Reklama za premijeru Šale, br. 7470 i 7471, 10. 12. 1983, 11. 12. 1983.

U fokusu kritike - kazalište - „Šala“( Branko Vukšić), br. 7478, 20. 12. 1983., 5

Vedar pogled na Dostojevskog (Marija Grgičević), 23. 12. 1983., 5

Tinejdžerski HIT (A. L.), br. 7509, 27. 1. 1984., 14

Imamo o čemu govoriti (Branko Vukšić), br. 7558 i 7559, 24. i 25. 3. 1984.

Dvojezičnost kao most (A. L.), br. 7581, 20. 4. 1984., 14

B. Vu. Državni lopov - 250. put, br. 7604, 22. 5. 1984.

Na početku - kartanje (B. Vukšić), br. 7611, 29. 5. 1984., 5

Na malim pozornicama (M. Konjevod), br. 7673, 13. 8. 1984., 5

Malo, ali dobro (M. Stojanović), br. 7701, 13. 9. 1984., 9

Na dobrim tradicijama (Jure Ilić), br. 7706, 19. 9. 1984., 9

Čestitka Seifertu, br. 7729, 16. 10. 1984., 9

Kunderin Žak Fatalist, br. 7803, 15. 1. 1985., 9

Još deset prijava, br. 7816, 30. 1. 1985., 9

Marija i njeni ,„anđeli“ (B. Vu.), br. 7829, 14. 2. 1985., 9

Jevtušenko i Kundera, br. 7830, 15. 2. 1985., 20

Gluma na ledu (Marija Grgičević), br. 7832, 18. 2. 1985., 8

Rasprodano „lijepo ponašanje“ (M. St.), br. 7838, 25. 2. 1985., 5

Dvadeset predstava, br. 7848, 8. 3. 1985., 9

Mira Stupica oduševila (A. Kaurin), br. 7875, 10. 4. 1985., 9 
Fialkin teatar u Gavelli, (M. G.) br. 7882, 17. 4. 1985., 9

Zlatni vijenac „Mariji“(A. Kaurin), br. 7883, 18. 4. 1985., 9

Kundera na filmu, br. 7902, 13. 5. 1985., 9

Seksizam glavnog lika (Jure Ilić), br. 7912, 24. 5. 1985., 20

Zamka lika koji priča (S. Nikčević), br. 7947, 5. 7. 1985., 9

Velikan science-fictiona (Tomislav Sabljak), br. 7975, 8. 8. 1985., 9

Tko nas čita, br. 7996, 2. 9. 1985., 9

Skupocjeni Amadeus (Dražen Ilinčić), br. 8027, 8. 10. 1985., 8

Umjetnici iz Brna u HNK (M. St.), br. 8036, 18. 10. 1985., 5

Pisac - ogledalo svog doba (M. Stojanović), br. 8039, 22. 10. 1985., 5

Obavijest o gostovanju Ateljea 212 u HNK-u, br. 8046, 31. 10. 1985.

Lijepi zagrebački dani (Slobodan Elezović), br. 8049, 2. i 3. 11. 1985., 13

Atelje 212 u HNK (S. Nč.), br. 8050, 4. 11. 1985., 8

Gostovanje Ateljea 212, br. 8051, 5. 11. 1985., 24

Večer Mire Stupice (Borisa B. Hrovat), br. 8052, 6. 11. 1985., 5

Peh pod krovom (S. Nč.), br. 8074, 4. 12. 1985, 12

Peh pod krovom (B. Vu.), br. 8080, 11. 12. 1985., 12

Veliki mag riječi, br. 8106, 13. 1. 1986., 8

„Erazmo“ Václavu Havelu, br. 8116, 24. 1. 1986., 20

Nemirni pokop, br. 8118, 27. 1. 1986., 10

Poseban prilog Bestseler, br. 8173, 1. 4. 1986., 11

Što je poštena kritika (A. Lendvaj), br. 8203, 7. 5. 1986., 19

Zabranjenih tema sve manje (Sanja Nikčević), br. 8228, 6. 6. 1986., 9

Stari znanci (Že. V.), br. 8333, 8. 10. 1986., 15

Počinje sa Švejkom (S. Nč.), br. 8344, 21. 10. 1986., 20

Prizma (Virgil Kurbel), br. 8349, 27. 10. 1986., 10

Rang-lista Bestselera, br. 8350, 28. 10. 1986., 11

U vrhu kvalitete (Branko Vukšić), br. 8355, 3. 11. 1986., 11

O staljinizmu - ozbiljno i ironično (Že. V.), br. 8379, 3. 12. 1986., 15

Škvorecký o Holmesu (Željko Valentić), br. 8379, 3. 12. 1986., 20

Satira ih zbližuje (S. Nikčević), br. 8393, 17. 12. 1986., 16

Knjiga - najbolji dar (Že. V.), br. 8393, 17. 12. 1986., 15

Poslije praznika dolazi knjiga (Že. V.), br. 8411, 9. 1. 1987., 15

Dosljedan sebi (M. Stojanović), br. 8439, 4. 2. 1987., 15 
Tematska raznovrsnost (Že. V.), br. 8440, 5. 2. 1987., 18

Čitanje bez predaha (Že. V.), br. 8468, 5. 3. 1987., 19

Na listama ništa novo (Že. V.), br. 8496, 2. 4. 1987., 19

Šotola za Trešnju (S. Nč.), br. 8506, 12. 4. 1987., 7

Horoskop u modi (Že. V.), br. 8516, 22. 4. 1987., 14

Prizma, br. 8602, 20. 7. 1987., 12

Smiřický vodi priču (S. Nč.), br. 8689, 16. 10. 1987., 23

Sam a - bataljon (bvu), br. 8691, 18. 10. 1987., 8

Put k festivalu (S. Nč.), br. 8703, 30. 10. 1987., 11

Menzel i djevojke (S. Nč.), br. 8710, 6. 11. 1987., 20

Žene za aplauz (Nč.), br. 8712, 8. 11. 1987., 9

Tri predstave - prepuna dvorana (B. Vukšić), br. 8713, 9. 11. 1987., 10

Dopadljivost prije svega (B. Vukšić), br. 8715, 11. 11. 1987., 16

Negdje između (B. Vukšić), br. 8718, 15. 11. 1987., 8

Najbolji „Ludi dani“(S. Nč.), br. 8719, 16. 11. 1987., 10

Likovne preobrazbe (E. C.), br. 8730, 26. 11. 1987., 19

Nagrada Kunderi, br. 8742, 11. 12. 1987., 11

Kafka opet kod kuće, br. 8755, 24. 12. 1987., 19

Rasulo svijeta (Boris B. Hrovat), br. 8864, 14. 4. 1988., 13

Smijeha sa svih strana (S. Nč.), br. 8910, 2. 6. 1988., 13

Sokolovićev Leopold (B. Vukšić), br. 8924, 16. 6. 1988., 19

Dramatika, br. 9057, 13. 10. 1988., 25

Rasprodane Balade (f. k.), br. 9068, 10. 11. 1988., 21

Knjiga je najbolji dar, br. 9094, 8. 12. 1988., 21

Pile u Trešnji (L. P. G.), br. 9109, 23. 12. 1988., 6

Pile vidi dalje (Boris B. Hrovat), br. 9114, 28. 12. 1988., 23

Zamjena za glasnost? (B. Ka.), br. 9173, 28. 2. 1988., 11

Revizor iz Brna, br. 9180, 7. 3. 1989., 11

Sokolovićevo traganje (L. Puljizević-Grbin), br. 9196, 23. 3. 1989., 14

Rijeka - gostuje „Duško Radović““ (N. K.), br. 9197, 24. 3. 1989., 11

Prizma, br. 9255, 24. 5. 1989., 10

Kulturološka šifra (A. Luić), br. 9260, 29. 5. 1989., 8

Dani satire '89., br. 9261, 30. 5. 1989., 23

Očajno smiješno, br. 9269, 7. 6. 1989., 11 
Očajno smiješno (L. P. G.), br. 9271, 9. 6. 1989., 10

Havelu za mir, br. 9273, 11. 6. 1989., 28

Nije to tako šaljivo (Jozo Puljizević), br. 9275, 13. 6. 1989., 18

Naoko korektni Mrožek (Ž. Valentić), br. 9277, 15. 6. 1989., 14

Dani kulture Brna (Đ. M.), br. 9288, 26. 6. 1989., 10

Federacija intelektualaca (B. Kamenski), br. 9360, 8. 9. 1989., 12

Nemojmo sanjati (B. Kamenski), br. 9365, 13. 9. 1989., 12

Havel - izdavač zabranjenih, br. 9397, 15. 10. 1989., 18

Mogu više od dr. Koprive (Virgil Kurbel), br. 9399, 17. 10. 1989., 17

Takav je Ma(r)x privatno (L. Puljizević-Grbin), br. 9401, 19. 10. 1989., 13

Spavaćica ne otkriva mnogo (B. Vukšić), br. 9404, 22. 10. 1989., 18

I ČSSR ruši „zavjesu“, br. 9443, 2. 12. 1989., zadnja stranica

Havel za predsjednika (Maroje Mihovilović), br. 9449, 8. 12. 1989., zadnja stranica

Izlazak iz podruma (Virgil Kurbel), br. 9454, 13. 12. 1989., 40

Havel i Dubček vode ČSSR, br. 9471, 30., 31. 12. 1989. i 1., 2. 1. 1990., zadnja stranica

Audijencija - i kod kuće, br. 9479, 10. 1. 1990., 31

Povratničke nedoumice (Virgil Kurbel), br. 9513, 13. 2. 1990., 23

Cenzure su prošlost?, br. 9532, 4. 3. 1990., 20

Holivudska glasnost (Branko Šömen), br. 9582, 23. 4. 1990., 10

Pseudonimom protiv „grijeha“(Branka Kamenski), br. 9600, 13. 5. 1990., 20

Kako nakon „baršunaste revolucije“? (Virgil Kurbel), br. 9612, 25. 5. 1990., 12

Prvi film o Havelu, br. 9636, 18. 6. 1990., 13

Delon i Kundera - vitezovi časti, br. 9666, 18. 7. 1990., 10

Kome Kristal Vilenice (V. Zagorac), br. 9716, 6. 9. 1990., 11

Treći među nama (Ž. Ciglar), br. 9731, 21. 9. 1990., 9

Havelova zbirka u SSSR-u, br. 9736, 26. 9. 1990., 38

Nagradili Havela, br. 9736, 26. 9. 1990., 38

Iskušenja do kolovoza (N. Koščić), br. 9741, 1. 10. 1990., 10

Nije vam lako! (Nevenka Mikac), br. 9744, 4. 10. 1990., 9

Tko je protiv napretka (S. Nč.), br. 9767, 27. 10. 1990., 51

Kad novo postane staro (intervju Sanje Nikčević s Radovanom Maričićem), br. 9770

(zagrebačko izdanje), 30. 10. 1990.

Na granici podnošljivosti (Boris B. Hrovat), br. 9771, 31. 10. 1990., 39

Havel i na filmu, br. 9793, 22. 11. 1990., 11 


\section{VIDIK}

Karpatský, Dušan Uvodna riječ, br. 21, 1970, 30-34

VJESNIK (kronološki poredak tekstova)

Osuda i zaprepaštenje, br. 7727, 22. 8. 1968., 5

Čehoslovaci dragi gosti Zagrepčana, br. 7728, 23. 8. 1968., 15

Čehoslovaci na putu u domovinu, br. 7734, 29. 8. 1968., 3

Teatar u gostima priprema nove tekstove (M. Š.), br. 10029, 26. 10. 1975., 11

Poremećena komunikacija (Želimir Stublija), 23. 2. 1980.

Bijeg od izazova (Želimir Stublija), br. 11914, 25. 10. 1980., 7

Sedam premijera dubrovačkog kazališta (N. Ožegović), br. 11916, 27. 10. 1980., 7

Dijalogizirani Diderot, br. 11940, 20. 11. 1980., 7

Književni portreti - Na otoku strasti (Zdravko Zima), br. 12258, 11. 10. 1981., 11

Politizirana dramaturgija (Želimir Stublija), br. 12262, 15. 10. 1981., 7

A gledaoci?, br. 12374, 9. 2. 1982., 6

Dobar dan, klasiko (Zdravko Zima), br. 12374, 9. 2. 1982., 6

Sve manje tragalaštva (Gradimir Gojer), br. 12453, 9. 4. 1982., 9

Obavezno za jedriličare (Z. Z.), br. 12525, 13. 7. 1982., 8

Pohvala prevodilaštvu (Geno Senečić), br. 12528, 16. 7. 1982., 7

Svjetlo u grobnici (Zdravko Zima), br. 12699, 9. 1. 1983., 11

Tko je pao s kruške (Dalibor Foretić), br. 12711, 20. 1. 1983., 7

Moguć put koprodukcija (Mirjana Šigir), br. 12722, 31. 1. 1983., 8

Nije šala igrati „Šalu“ (Branko Ježić), br. 13033, 16. 12. 1983., 6

U dva dana - tri premijere (M. Stipaničić), br. 13093, 17. 2. 1984., 7

Kritički o manipuliranju Seifertom, br. 13327, 14. 10. 1984., naslovnica

Čestitka Seifertu, br. 13329, 16. 10. 1984., 11

U pravim rukama (Predrag Jirsak), br. 13327, 31. 10. 1984., 13

Marija se bori s anđelima (D. P.), br. 13445, 14. 2. 1985., 11

Kandidati za „Hemingwaya“, br. 13447, 16. 2. 1985., 13

Izgubljena agresivnost (Dubravka Vrgoč), 18. 2. 1985., 11

Šutljivi dijalog knjigom (Sineva Pasini), br. 13468, 9. 3. 1985., 12 
Začarani svijet bajke (Dalibor Foretić), br. 13500, 10. 4. 1985., 9

„Ateljeu 212“ prva nagrada (S. K.), br. 13508, 18. 4. 1985., 11

Obrana dostojanstva (M. Stojanović), br. 13694, 24. 10. 1985., 11

Josef Škvorecký: liječnik ljudskih duša (Branko Šömen), br. 13703, 2. 11. 1985., 18

Gostuje Atelje 212 (Br. Š.), br. 13705, 4. 11. 1985., 11

Veća i od legende (Marija Grgičević), br. 13707, 6. 11. 1985., 11

Peh pod krovom (M. G.), br. 13735, Vjesnikov petak, 6. 12. 1985., 2

Literarni atlas Evrope (Aleksandar Flaker), br. 13736, Panorama subotom, 7. 12. 1985., 15

Dopadljiva igra (Dubravka Vrgoč), br., 13742, 12. 12. 1985., 11

Posljednja prevodiočeva bitka (Zlatko Crnković), br. 13875, 26. 4. 1986., 16

Književna desetka - Tahir Mujičić, br. 14005, Panorama subotom, 6. 9. 1986., 17

Ljestvica najtraženijih knjiga, br. 14020, 21. 9. 1986., 15

U labirintima krimića (Zdravko Zima), br. 14026, Panorama subotom, 27. 9. 1986., 16

Ljestvica najtraženijih knjiga, br. 14034, 5. 10. 1986., 15

Praško kazalište u Jugoslaviji, br. 14050, 21. 10. 1986.

Ljestvica najtraženijih knjiga, br. 14076, 16. 11. 1986., 14

Dnevni leksikon - Jaroslav Seifert, br. 14397, 11. 10. 1987., 17

Krađa u crkvi, br. 14403, Panorama subotom,17. 10. 1987., 15

Počinju Gavelline večeri (Marija Grgičević), br. 14417, 31. 10. 1987., 9

Tri u drugom (Dubravka Vrgoč), br. 14422, 5. 11. 1987., 11

Mahnitanje veselja (Marija Grgičević), br. 14426, 9. 11. 1987., 11

Lepršava satira (Marija Grgičević), br. 14427, 10. 11. 1987., 11

Menzel se „odriče“ sebe (Marija Grgičević), br. 14466, 22. 12. 1987., 7

Zapostavljen Kafka, br. 14469, 25. 12. 1987., 12

Balet po Šotoli (N. O.), br. 14570, 7. 4. 1988., 8

Ljubavna pjesma (Nina Ožegović), br. 14573, 10. 4. 1988., 3

Antologijski prizor svađe (Dubravka Vrgoč), br. 14577, 14. 4. 1988., 8

Ljestvica najtraženijih knjiga, br. 14580, 17. 4. 1988., 14

Cenzura - društveni teret (Savo Bosanac), br. 14623, 2. 6. 1988., 3

U čast Cervantesu (D. V.), br. 14624, 3. 6. 1988., 12

200. hit, br. $14820,19.12 .1988 ., 8$

Roman je bolji (Marija Grgičević), br. 14827, 26. 12. 1988., 8

Protest zbog hapšenja Havela, br. 14877, 17. 2. 1989., 9

Tko je Havel? (Zdravko Zima), br. 14890, 2. 3. 1989., 11 
Presuda je stroga, ne podržavam je (S. Pa.), br. 14899, 11. 3. 1989., 7

Otklon od bajke (Dubravka Vrgoč), br. 14906, 18. 3. 1989., 8

Premijera u HNK-u, br. 14950, 3. 5. 1989., 8

Teatar ITD u SR Njemačkoj, br. 14952, 5. 5. 1989., 10

Havelu nagrada Frankfurtskoga sajma knjiga, br. 14988, 10. 6. 1989., 8

„Očajno smiješno“ u „Gavelli“, br. 14988, 10. 6. 1989., 8

Stari gost (Marija Grgičević), br. 14990, 12. 6. 1989., 8

Dani kulture Brna (M. Š.), br. 14999, 21. 6. 1989., 9

Glasovi iz Moravske, br. 15122, 19. 10. 1989., 9

Musil ili preokret poznate povijesti (Boris Gregorić), br. 15122, 23. 10. 1989., 9

Začudan svijet (Dubravka Vrgoč), br. 15136, 6. 11. 1989., 8

Havel ili život je san (M. G.), br. 15204, 17. 1. 1990., 9

Od disidenta do predsjednika (feljton Branka Šömena u nastavcima), br. 15205 - br. 15207,

18. 1. 1990. - 7. 2. 1990.

Narod i njegov pjesnik, br. 15206, 19. 1. 1990., 10

Michal Černík i Daniel Strož, br. 15207, 20. 1. 1990., 9

Jan Werich, br. 15208, 21. 1. 1990., 19

Dominik Tatarka, br. 15209, 22. 1. 1990., 11

Pismo redatelja, 15210, 23. 1. 1990., 12

Alexandar Dubček, br. 15211, 24. 1. 1990., 11

Ludvík Vaculík, br. 15212, 25. 1. 1990., 9

Karel Kryl, br. 15213, 26. 1. 1990., 9

Ivan Jirous, br. 15215, 28. 1. 1990., 15

Jiř́i Gruša, br. 15216, 29. 1. 1990., 9

Jiř́i Diensbier, br. 15217, 30. 1. 1990., 9

Pavel Kohout, br. 15218, 31. 1. 1990., 12

Jan Trefulka, br. 15219, 1. 2. 1990., 9

Milan Šimecka i Josef Vohryzek, br. 15220, 2. 2. 1990., 9

Pavel Landovský, br. 15221, 3. 2. 1990., 9

Drama Václava Havela (M. G.), br. 15221, 3. 2. 1990., 8

Molitva za Václava Havela, br. 15222, 4. 2. 1990., 22

Eva Kantůrková, br. 15223, 5. 2. 1990.

Karel Šiktanc, br. 15224, 6. 2. 1990. 
Srednjoj Evropi trebaju mudraci (intervju Jove Paripovića s Györgyjem Konrádom), br.

15236, 18. 2. 1990., 14

Izgubljeni izvršitelji tuđe volje (Dubravka Vrgoč), br. 15460, 3. 10. 1990., 8

Poput precizne partiture besmisla (Dubravka Vrgoč, intervju s Vanjom Drachom), br. 15486,

29. 10. 1990., 9

Pronalazak izvršitelja tuđe volje (Dubravka Vrgoč), br. 15488, 31. 10. 1990., 9

\section{VJESNIK U SRIJEDU}

Butorac, Tomislav Sedam dana koji su smirili Prag, br. 853, 4. 9. 1968., 6

Butorac, Tomislav Vrtnja u zatvorenom krugu, br. 874, 29. 1. 1969., naslovna stranica i str. 6

Hamšík, Dušan Atentat na socijalizam, br. 852, 28. 8. 1968., 4

Puljizević, Jozo Pometove intrige izazvale Prag, br. 1092, 11. 4. 1973., 18-19

Puljizević, Jozo U slavnim kolima tradicije, br. 1118, 10. 10. 1973., 31

Tović, Drago Dnevnik agresije, br. 852, 28. 8 .1968., naslovna stranica, 4

Ucjena muškaraca, br. 1242, 28. 2. 1975., 5 
POPIS KAZALIŠNIH PREDSTAVA ${ }^{936}$

Narodno kazalište Split (Hrvatsko narodno kazalište Split)

\begin{tabular}{|c|c|c|c|c|c|c|}
\hline autor & $\begin{array}{c}\text { naziv } \\
\text { predstave }\end{array}$ & redatelj & prevoditelj & $\begin{array}{c}\text { ostali članovi } \\
\text { ansambla }\end{array}$ & $\begin{array}{l}\text { datum } \\
\text { premijere }\end{array}$ & $\begin{array}{l}\text { broj } \\
\text { izve- } \\
\text { daba }\end{array}$ \\
\hline $\begin{array}{l}\text { Kundera, } \\
\text { Milan }\end{array}$ & Monada & $\begin{array}{l}\text { Vanča } \\
\text { Kljaković }\end{array}$ & $\begin{array}{l}\text { Borislav } \\
\text { Mrkšić }\end{array}$ & $\begin{array}{l}\text { scenograf } \\
\text { Miodrag Adžić, } \\
\text { kostimograf } \\
\text { Ivica Raunig }\end{array}$ & 20.3.1971. & 6 \\
\hline $\begin{array}{l}\text { Kundera, } \\
\text { Milan }\end{array}$ & $\begin{array}{l}\text { Žak } \\
\text { Fatalist } i \\
\text { njegov } \\
\text { gospodar } \\
\text { (Denisu } \\
\text { Diderotu u } \\
\text { čast) }\end{array}$ & $\begin{array}{l}\text { Dino } \\
\text { Radojević }\end{array}$ & $\begin{array}{l}\text { Predrag } \\
\text { Jirsak }\end{array}$ & $\begin{array}{l}\text { scenograf Marin } \\
\text { Gozze, } \\
\text { kostimograf } \\
\text { Marija Žarak, } \\
\text { koreograf } \\
\text { Miljenko } \\
\text { Štambuk }\end{array}$ & 2.6.1981. & 26 \\
\hline $\begin{array}{l}\text { Havel, } \\
\text { Václav }\end{array}$ & Audijencija & $\begin{array}{l}\text { Vlatko } \\
\text { Perković }\end{array}$ & Ivan Kušan & $\begin{array}{l}\text { scenograf Mijo } \\
\text { Adžić, } \\
\text { kostimografkinja } \\
\text { Naida Kromić- } \\
\text {-Čakić }\end{array}$ & 12.4. 1982. & 5 \\
\hline $\begin{array}{l}\text { Havel, } \\
\text { Václav }\end{array}$ & Izložba & $\begin{array}{l}\text { Vlatko } \\
\text { Perković }\end{array}$ & Ivan Kušan & $\begin{array}{l}\text { scenograf Mijo } \\
\text { Adžić, } \\
\text { kostimografkinja } \\
\text { Naida Kromić- } \\
\text {-Čakić }\end{array}$ & 12.4. 1982. & 5 \\
\hline $\begin{array}{l}\text { Voltaire } \\
\text { (dramati- } \\
\text { zacija } \\
\text { Jana } \\
\text { Cziviša, } \\
\text { Alene } \\
\text { Vostré i } \\
\text { Jaroslava } \\
\text { Vostrog) }\end{array}$ & Candide & $\begin{array}{l}\text { Vanča } \\
\text { Kljaković }\end{array}$ & $\begin{array}{l}\text { Dan } \\
\text { Zeljak, } \\
\text { Vlatko } \\
\text { Perković, } \\
\text { prilagodio } \\
\text { Ivan Kušan }\end{array}$ & $\begin{array}{l}\text { scenograf Željko } \\
\text { Drakulić, } \\
\text { kostimografkinja } \\
\text { Vida Tućan, } \\
\text { koreografkinja } \\
\text { Olga Glavina, } \\
\text { lutke Željko } \\
\text { Drakulić, glumci } \\
\text { Ivo Gregurević, } \\
\text { Neda Arnerić, } \\
\text { Špiro Guberina, } \\
\text { Jasna Utrobičić, }\end{array}$ & $\begin{array}{l}\text { 20.7. } 1983 . \\
\text { (Splitsko } \\
\text { ljeto) }\end{array}$ & 17 \\
\hline
\end{tabular}

Gradsko dramsko kazalište Gavella, Zagreb

\begin{tabular}{|l|l|l|l|l|l|l|}
\hline \multicolumn{1}{|c|}{ autor } & \multicolumn{1}{c|}{$\begin{array}{c}\text { naziv } \\
\text { predstave }\end{array}$} & \multicolumn{1}{c|}{ redatelj } & prevoditelj & \multicolumn{1}{c|}{$\begin{array}{c}\text { ostali članovi } \\
\text { ansambla }\end{array}$} & $\begin{array}{c}\text { datum } \\
\text { premijere }\end{array}$ & $\begin{array}{c}\text { broj } \\
\text { izvedaba }\end{array}$ \\
\hline $\begin{array}{l}\text { Havel, } \\
\text { Václav }\end{array}$ & Audijencija & $\begin{array}{l}\text { Božidar } \\
\text { Violić }\end{array}$ & $\begin{array}{l}\text { Ivan } \\
\text { Kušan }\end{array}$ & $\begin{array}{l}\text { scenograf i } \\
\text { kostimograf }\end{array}$ & 22.2 .1980$. & 55 \\
\hline
\end{tabular}

${ }^{936}$ Dramske izvedbe pojedinoga kazališta navedene su kronološkim redoslijedom. 


\begin{tabular}{|c|c|c|c|c|c|c|}
\hline & & & & $\begin{array}{l}\text { Željko Senečić, } \\
\text { glumački } \\
\text { ansambl Zlatko } \\
\text { Vitez, Pero } \\
\text { Kvrgić, Helena } \\
\text { Buljan, Vlatko } \\
\text { Dulić }\end{array}$ & & \\
\hline $\begin{array}{l}\text { Havel, } \\
\text { Václav }\end{array}$ & Izložba & $\begin{array}{l}\text { Božidar } \\
\text { Violić }\end{array}$ & $\begin{array}{l}\text { Ivan } \\
\text { Kušan }\end{array}$ & $\begin{array}{l}\text { scenograf i } \\
\text { kostimograf } \\
\text { Željko Senečić, } \\
\text { glumački } \\
\text { ansambl Zlatko } \\
\text { Vitez, Pero } \\
\text { Kvrgić, Helena } \\
\text { Buljan, Vlatko } \\
\text { Dulić }\end{array}$ & 22.2. 1980 . & 55 \\
\hline $\begin{array}{l}\text { Kohout, } \\
\text { Pavel }\end{array}$ & $\begin{array}{l}\text { Marija se } \\
\text { boris } \\
\text { anđelima }\end{array}$ & $\begin{array}{l}\text { Jakov } \\
\text { Sedlar }\end{array}$ & $\begin{array}{l}\text { Renata } \\
\text { Ulmanski }\end{array}$ & $\begin{array}{l}\text { scenograf i } \\
\text { kostimograf } \\
\text { Zvonimir Šuler, } \\
\text { glumački } \\
\text { ansambl Semka } \\
\text { Sokolović- } \\
\text {-Bertok, Boris } \\
\text { Miholjević, } \\
\text { Biserka Ipša }\end{array}$ & 15.2. 1985 . & 7 \\
\hline $\begin{array}{l}\text { Havel, } \\
\text { Václav }\end{array}$ & $\begin{array}{l}\text { Očajno } \\
\text { smiješno }\end{array}$ & $\begin{array}{l}\text { Miroslav } \\
\text { Međimorec }\end{array}$ & $\begin{array}{l}\text { Dagmar } \\
\text { Ruljančić }\end{array}$ & $\begin{array}{l}\text { scenograf Ratko } \\
\text { Janjić Jobo, } \\
\text { kostimografkinja } \\
\text { Nada Došen }\end{array}$ & 10.6. 1989. & 25 \\
\hline
\end{tabular}

Teatar ITD, Zagreb

\begin{tabular}{|c|c|c|c|c|c|c|}
\hline autor & $\begin{array}{c}\text { naziv } \\
\text { predstave }\end{array}$ & redatelj & prevoditelj & $\begin{array}{l}\text { ostali članovi } \\
\text { ansambla }\end{array}$ & $\begin{array}{l}\text { datum } \\
\text { premijere }\end{array}$ & $\begin{array}{c}\text { broj } \\
\text { izvedaba }\end{array}$ \\
\hline $\begin{array}{l}\text { Kundera, } \\
\text { Milan }\end{array}$ & $\begin{array}{l}\text { Žak Fatalist } \\
\text { i njegov } \\
\text { gospodar } \\
\text { (Denisu } \\
\text { Diderotu u } \\
\text { čast) }\end{array}$ & $\begin{array}{l}\text { Miro } \\
\text { Međimorec }\end{array}$ & $\begin{array}{l}\text { Predrag } \\
\text { Jirsak }\end{array}$ & $\begin{array}{l}\text { scenograf } \\
\text { Zvonko Šuler, } \\
\text { kostimografkinja } \\
\text { Ingrid Begović, } \\
\text { koreograf } \\
\text { Miljenko Vikić, } \\
\text { glumački } \\
\text { ansambl Vanja } \\
\text { Drach, Ivica } \\
\text { Vidović, Vera } \\
\text { Zima }\end{array}$ & 16. 11. 1980. & 11 \\
\hline $\begin{array}{l}\text { Havel, } \\
\text { Václav }\end{array}$ & Protest & $\begin{array}{l}\text { Radovan } \\
\text { Maričić }\end{array}$ & $\begin{array}{l}\text { Ivan } \\
\text { Kušan }\end{array}$ & $\begin{array}{l}\text { glumci Vlatko } \\
\text { Dulić, Zlatko } \\
\text { Vitez }\end{array}$ & 12.10.1981. & \\
\hline Kohout, & Atest & Radovan & Ivan & glumci Dragutin & 12.10.1981. & \\
\hline
\end{tabular}




\begin{tabular}{|c|c|c|c|c|c|c|}
\hline Pavel & & Maričić & Kušan & $\begin{array}{l}\text { Klobučar, } \\
\text { Miljenka } \\
\text { Androić, Slavica } \\
\text { Jukić, Zdenka } \\
\text { Heršak, Vanja } \\
\text { Drach }\end{array}$ & & \\
\hline $\begin{array}{l}\text { Jiří } \\
\text { Menzel } \\
\text { (Jaroslav } \\
\text { Vostrý) }\end{array}$ & $\begin{array}{l}\text { Tri u } \\
\text { drugom }\end{array}$ & Jiří Menzel & $\begin{array}{l}\text { Dagmar } \\
\text { Ruljančić }\end{array}$ & $\begin{array}{l}\text { glumci } \\
\text { Dragoljub } \\
\text { Lazarov, Ljubo } \\
\text { Zečević, } \\
\text { Dubravka } \\
\text { Ostojić, } \\
\text { Miljenka } \\
\text { Androić- } \\
\text {-Vlajki, Pero } \\
\text { Kvrgić, Alma } \\
\text { Prica, Matko } \\
\text { Raguž, Darko } \\
\text { Janeš, } \\
\text { scenograf } \\
\text { Velimir } \\
\text { Domitrović, } \\
\text { kostimografkinja } \\
\text { Ika Škomrlj, }\end{array}$ & 6.11. 1987. & 66 \\
\hline
\end{tabular}

Teatar u gostima, Zagreb

\begin{tabular}{|l|l|l|l|l|l|l|}
\hline \multicolumn{1}{|c|}{ autor } & \multicolumn{1}{|c|}{$\begin{array}{c}\text { naziv } \\
\text { predstave }\end{array}$} & redatelj & prevoditelj & $\begin{array}{c}\text { ostali članovi } \\
\text { ansambla }\end{array}$ & \multicolumn{1}{c|}{$\begin{array}{c}\text { datum } \\
\text { premijere }\end{array}$} & $\begin{array}{c}\text { broj } \\
\text { izvedaba }\end{array}$ \\
\hline $\begin{array}{l}\text { Kundera, } \\
\text { Milan }\end{array}$ & Ševa & Vanča & Borislav & scenograf Drago & $\begin{array}{l}29.9 .1975 . \\
\text { Kljaković } \\
\text { (Karlovac) }\end{array}$ & 147 \\
Mrkšić & & $\begin{array}{l}\text { Turina, } \\
\text { kostimografkinja } \\
\text { Diana Kosec- } \\
\text {-Bourek }\end{array}$ & & \\
\hline
\end{tabular}

Kazalište Marina Držića, Dubrovnik

\begin{tabular}{|c|c|c|c|c|c|c|}
\hline autor & $\begin{array}{c}\text { naziv } \\
\text { predstave }\end{array}$ & redatelj & prevoditelj & $\begin{array}{l}\text { ostali članovi } \\
\text { ansambla }\end{array}$ & $\begin{array}{c}\text { datum } \\
\text { premijere }\end{array}$ & $\begin{array}{c}\text { broj } \\
\text { izvedaba }\end{array}$ \\
\hline $\begin{array}{l}\text { Kohout, } \\
\text { Pavel }\end{array}$ & $\begin{array}{l}\text { Peh pod } \\
\text { krovom }\end{array}$ & $\begin{array}{l}\text { Božidar } \\
\text { Violić }\end{array}$ & $\begin{array}{l}\text { Renata } \\
\text { Kuchar }\end{array}$ & $\begin{array}{l}\text { kostimograf } \\
\text { Božidar Violić, } \\
\text { scenograf Drago } \\
\text { Turina }\end{array}$ & 22.10 .1980$. & 11 \\
\hline $\begin{array}{l}\text { Kohout, } \\
\text { Pavel }\end{array}$ & $\begin{array}{l}\text { Rat na } \\
\text { trećem katu }\end{array}$ & $\begin{array}{l}\text { Božidar } \\
\text { Violić }\end{array}$ & $\begin{array}{l}\text { Žarko } \\
\text { Anić- } \\
\text {-Antić }\end{array}$ & $\begin{array}{l}\text { kostimograf } \\
\text { Božidar Violić, } \\
\text { scenograf Drago } \\
\text { Turina }\end{array}$ & 22.10. 1980. & 11 \\
\hline
\end{tabular}


Hrvatsko narodno kazalište Zagreb

\begin{tabular}{|l|l|l|l|l|l|l|}
\hline \multicolumn{1}{|c|}{ autor } & \multicolumn{1}{|c|}{$\begin{array}{c}\text { naziv } \\
\text { predstave }\end{array}$} & redatelj & prevoditelj & \multicolumn{1}{c|}{$\begin{array}{c}\text { ostali članovi } \\
\text { ansambla }\end{array}$} & \multicolumn{1}{c|}{$\begin{array}{c}\text { datum } \\
\text { premijere }\end{array}$} & $\begin{array}{c}\text { broj } \\
\text { izvedaba }\end{array}$ \\
\hline $\begin{array}{l}\text { Kohout, } \\
\text { Pavel } \\
\text { Peh pod } \\
\text { krovom }\end{array}$ & $\begin{array}{l}\text { Dubravko } \\
\text { Torjanac }\end{array}$ & $\begin{array}{l}\text { Renata } \\
\text { Kuchar }\end{array}$ & $\begin{array}{l}\text { scenograf } \\
\text { Zvonimir Šuler, } \\
\text { kostimografkinja } \\
\text { Ruta Knežević, } \\
\text { dramaturginja } \\
\text { Sanja Ivić }\end{array}$ & 10.12 .1985$. & 21 \\
\hline $\begin{array}{l}\text { Havel, } \\
\text { Václav }\end{array}$ & Asanacija & $\begin{array}{l}\text { Radovan } \\
\text { Maričić }\end{array}$ & $\begin{array}{l}\text { Dagmar } \\
\text { Ruljančić }\end{array}$ & $\begin{array}{l}\text { scenografkinja } \\
\text { Dinka Jeričević }\end{array}$ & 27.10.1990. & \\
\hline
\end{tabular}

Satiričko kazalište Jazavac, Zagreb

\begin{tabular}{|c|c|c|c|c|c|c|}
\hline autor & $\begin{array}{c}\text { naziv } \\
\text { predstave }\end{array}$ & redatelj & prevoditelj & $\begin{array}{c}\text { ostali članovi } \\
\text { ansambla }\end{array}$ & $\begin{array}{c}\text { datum } \\
\text { premijere }\end{array}$ & $\begin{array}{c}\text { broj } \\
\text { izvedaba }\end{array}$ \\
\hline $\begin{array}{l}\text { Gillar, } \\
\text { Jaroslav } \\
\text { i } \\
\text { Škutina, } \\
\text { Vladimír }\end{array}$ & $\begin{array}{l}\text { Diktator na } \\
\text { kruški }\end{array}$ & $\begin{array}{l}\text { Želimir } \\
\text { Mesarić }\end{array}$ & $\begin{array}{l}\text { Dagmar } \\
\text { Ruljančić }\end{array}$ & $\begin{array}{l}\text { scenograf Drago } \\
\text { Turina, } \\
\text { kostimografkinja } \\
\text { Danica Dedijer }\end{array}$ & 14. 1. 1983. & 18 \\
\hline $\begin{array}{l}\text { Kundera, } \\
\text { Milan }\end{array}$ & Šala & $\begin{array}{l}\text { Miroslav } \\
\text { Međimorec }\end{array}$ & $\begin{array}{l}\text { Nikola } \\
\text { Kršić }\end{array}$ & $\begin{array}{l}\text { scenograf Ratko } \\
\text { Janjić Jobo, } \\
\text { kostimografkinja } \\
\text { Ranka Gregorić, } \\
\text { koreografkinja } \\
\text { Ivanka } \\
\text { Šerbedžija, } \\
\text { dramatizacija } \\
\text { Ivan Kušan }\end{array}$ & 15. 12. 1983. & 44 \\
\hline
\end{tabular}

Kazalište Virovitica

\begin{tabular}{|c|c|c|c|c|c|c|}
\hline autor & $\begin{array}{c}\text { naziv } \\
\text { predstave }\end{array}$ & redatelj & prevoditelj & $\begin{array}{c}\text { ostali članovi } \\
\text { ansambla }\end{array}$ & $\begin{array}{c}\text { datum } \\
\text { premijere }\end{array}$ & $\begin{array}{c}\text { broj } \\
\text { izvedaba }\end{array}$ \\
\hline $\begin{array}{l}\text { Kohout, } \\
\text { Pavel }\end{array}$ & $\begin{array}{l}\text { Takva } \\
\text { ljubav! }\end{array}$ & $\begin{array}{l}\text { Karel } \\
\text { Lhota }\end{array}$ & $\begin{array}{l}\text { Borislav } \\
\text { Mrkšić }\end{array}$ & $\begin{array}{l}\text { scenograf } \\
\text { Vladimir Grigić, } \\
\text { kostimografkinja } \\
\text { Olga Grigić }\end{array}$ & 19.4. 1969. & 8 \\
\hline
\end{tabular}


Zagrebačko studentsko eksperimentalno kazalište

\begin{tabular}{|l|l|l|l|l|l|}
\hline $\begin{array}{c}\text { autor/autori } \\
\text { dramatizacije }\end{array}$ & \multicolumn{1}{|c|}{$\begin{array}{c}\text { naziv } \\
\text { predstave }\end{array}$} & redatelj & prevoditelj & $\begin{array}{c}\text { ostali članovi } \\
\text { ansambla }\end{array}$ & $\begin{array}{c}\text { datum } \\
\text { premijere }\end{array}$ \\
\hline Voltaire/ & Candide & Tomislav & Dan & Ranko Stojić & 1980. \\
Cziviš, Jan, & & Svetić & Zeljak, & - Stoja, & \\
Vostrá, & & & Vlatko & Ljubomir & \\
Alena i & & & Perković & Koraj, Željko & \\
Vostrý, & & & & Medić, & \\
Jaroslav & & & & Snježana & \\
& & & & Brljević, Jozo & \\
& & & & Vidović & \\
\hline
\end{tabular}

Kazalište Komedija, Zagreb

\begin{tabular}{|c|c|c|c|c|c|}
\hline autor & $\begin{array}{c}\text { naziv } \\
\text { predstave }\end{array}$ & redatelj & prevoditelj & $\begin{array}{c}\text { ostali članovi } \\
\text { ansambla }\end{array}$ & $\begin{array}{c}\text { datum } \\
\text { premijere }\end{array}$ \\
\hline $\begin{array}{l}\text { Uhde, } \\
\text { Milan }\end{array}$ & $\begin{array}{l}\text { Max\&Engel } \\
\text { Private }\end{array}$ & $\begin{array}{l}\text { Želimir } \\
\text { Orešković }\end{array}$ & $\begin{array}{l}\text { Dagmar } \\
\text { Ruljančić }\end{array}$ & $\begin{array}{l}\text { glumci Otokar } \\
\text { Levaj, Lela } \\
\text { Margetić, Boris } \\
\text { Pavlenić, Jasna } \\
\text { Bilušić, } \\
\text { scenografkinja } \\
\text { Dinka Jeričević, } \\
\text { kostimografkinja } \\
\text { Ljubica Wagner, } \\
\text { skladatelj Neven } \\
\text { Frangeš }\end{array}$ & $\begin{array}{l}13.9 . \\
1989 .\end{array}$ \\
\hline
\end{tabular}

Klub Karaka, Zagreb

\begin{tabular}{|l|l|l|l|l|}
\hline \multicolumn{1}{|c|}{ autor } & \multicolumn{1}{|c|}{ naziv predstave } & \multicolumn{1}{c|}{ redatelj } & dramatizacija & \multicolumn{1}{c|}{$\begin{array}{c}\text { datum } \\
\text { premijere }\end{array}$} \\
\hline $\begin{array}{l}\text { Škvorecký, } \\
\text { Josef }\end{array}$ & $\begin{array}{l}\text { Oklopni bataljon } \\
\text { (monodrama u } \\
\text { izvedbi Slobodana } \\
\text { Milovanovića) }\end{array}$ & $\begin{array}{l}\text { Slobodan } \\
\text { Milovanović } \\
\text { (stručna pomoć } \\
\text { Georgija Para) }\end{array}$ & $\begin{array}{l}\text { Slobodan } \\
\text { Milovanović }\end{array}$ & 16.10 .1987$. \\
& \multicolumn{3}{|l}{} & \\
\hline
\end{tabular}


KAZALIŠNE SMOTRE I FESTIVALI U REPUBLICI HRVATSKOJ

Gavelline večeri, Zagreb

\begin{tabular}{|l|l|l|l|}
\hline \multicolumn{1}{|c|}{ autor } & \multicolumn{1}{|c|}{ naziv predstave } & \multicolumn{1}{c|}{ kazalište } & \multicolumn{1}{c|}{ datum izvedbe } \\
\hline Kundera, Milan & Šala & Beogradsko dramsko pozorište & $\begin{array}{l}28.6 .1976 . \\
14.6 .1978 .\end{array}$ \\
\hline Havel, Václav & Audijencija & Dramsko kazalište Gavella & 21.10 .1981$. \\
\hline Havel, Václav & Izložba & Dramsko kazalište Gavella & 21.10 .1981$. \\
\hline Kundera, Milan & $\begin{array}{l}\text { Žak Fatalist i njegov } \\
\text { gospodar }\end{array}$ & Hrvatsko narodno kazalište Split & 2.11 .1986$. \\
\hline Havel, Václav & Prosjačka opera & Atelje 212, Beograd & 8.11 .1987$. \\
\hline Havel, Václav & Očajno smiješno & Dramsko kazalište Gavella & 3.11 .1989$. \\
\hline
\end{tabular}

Susret profesionalnih kazališta Hrvatske, Slavonski Brod

\begin{tabular}{|c|l|c|c|}
\hline \multicolumn{1}{|c|}{ autor } & \multicolumn{1}{|c|}{ naziv predstave } & kazalište & \multicolumn{1}{c|}{ datum izvedbe } \\
\hline Kundera, Milan & $\begin{array}{l}\text { Žak Fatalist } \text { i njegov } \\
\text { gospodar }\end{array}$ & Teatar ITD, Zagreb & 25. 9. 1981. \\
\hline
\end{tabular}

Splitsko ljeto

\begin{tabular}{|c|l|l|l|}
\hline \multicolumn{1}{|c|}{ autor } & \multicolumn{1}{|c|}{ naziv predstave } & \multicolumn{1}{c|}{ kazalište } & datum izvedbe \\
\hline Kundera, Milan & $\begin{array}{l}\text { Žak Fatalist } \text { i njegov } \\
\text { gospodar }\end{array}$ & $\begin{array}{l}\text { Hrvatsko narodno } \\
\text { kazalište Split }\end{array}$ & \begin{tabular}{c}
31.7 .1982$. \\
\hline
\end{tabular}
\end{tabular}

Dani satire Jazavca, Zagreb

\begin{tabular}{|c|l|l|l|}
\hline \multicolumn{1}{|c|}{ autor } & \multicolumn{1}{|c|}{ naziv predstave } & \multicolumn{1}{c|}{ kazalište } & \multicolumn{1}{c|}{ datum izvedbe } \\
\hline Havel, Václav & Largo desolato & $\begin{array}{l}\text { Kamerni teatar 55, } \\
\text { Sarajevo }\end{array}$ & \begin{tabular}{l} 
15. 6. 1988. \\
\hline
\end{tabular} \\
\hline
\end{tabular}




\section{POPIS DIJAGRAMA I TABLICA}

1. Dijagram I: Razvoj češke književnosti nakon 1968.

2. Dijagram II: Knjižna izdanja neoficijelnih čeških autora na hrvatskome izdavačkom tržištu od 1968. do 1990. prema književnome rodu

3. Dijagram III: Knjižna izdanja proze neoficijelnih čeških autora na hrvatskome izdavačkom tržištu od 1968. do 1990. prema književnoj vrsti

4. Dijagram IV: Knjižna izdanja neoficijelnih čeških autora na hrvatskome izdavačkom tržištu od 1968. do 1990. prema autoru

5. Dijagram V: Knjižna izdanja neoficijelnih čeških autora na hrvatskome izdavačkom tržištu od 1968. do 1990. prema godini objavljivanja

6. Dijagram VI: Omjer knjižnih izdanja egzilnih i samizdatskih autora na hrvatskome izdavačkom tržištu od 1968. do 1990.

7. Dijagram VII: Broj premijera drama neoficijelnih čeških dramatičara u hrvatskim kazalištima od 1968. do 1990. prema godini

8. Dijagram VIII: Broj premijera drama neoficijelnih čeških dramatičara u hrvatskim kazalištima od 1968. do 1990. prema autoru

9. Tablica I: Knjižna izdanja neoficijelnih čeških autora na hrvatskome izdavačkom tržištu od 1968. do 1990. prema književnome rodu

10. Tablica II: Knjižna izdanja proze neoficijelnih čeških autora na hrvatskome izdavačkom tržištu od 1968. do 1990. prema književnoj vrsti

11. Tablica III: Knjižna izdanja neoficijelnih čeških autora na hrvatskome izdavačkom tržištu od 1968. do 1990. prema autoru

12. Tablica IV: Knjižna izdanja neoficijelnih čeških autora na hrvatskome izdavačkom tržištu od 1968. do 1990. prema godini objavljivanja

13. Tablica V: Omjer knjižnih izdanja egzilnih i samizdatskih autora na hrvatskome izdavačkom tržištu od 1968. do 1990.

14. Tablica VI: Broj premijera drama neoficijelnih dramatičara u hrvatskim kazalištima od 1968. do 1990. prema godini.

15. Tablica VII: Broj premijera drama neoficijelnih čeških autora u hrvatskim kazalištima od 1968. do 1990. prema autoru/autorima 


\section{POPIS FOTOGRAFIJA}

1. Fotografija I: karikature Bohumila Štěpána

2. Fotografija II: karikatura Bohumila Štěpána

3. Fotografija III: plakat za predstavu Ševa Teatra u gostima, autor Ivan Picelj

4. Fotografija IV: Naslovnica programske knjižice predstava Audijencija i Izložba Václava Havela, HNK Split, 1982.

5. Fotografija V: Unutrašnja strana omota programske knjižice predstava Audijencija i Izložba Václava Havela, HNK Split, 1982.

6. Fotografija VI: Zapis redatelja Vlatka Perkovića u programskoj knjižici predstava Audijencija i Izložba, HNK Split, 1982.

7. Fotografija VII: Plakat predstava Audijencija i Izložba Václava Havela u DK-u Gavella, 1980.

8. Fotografija VIII: Fotografija predstave Audijencija Václava Havela u DK-u Gavella, 1980.

9. Fotografija IX: Fotografija predstave Audijencija Václava Havela u DK-u Gavella, 1980.

10. Fotografija X: Crtež Željka Senečića s probe Audijencije u DK-u Gavella

11. Fotografija XI: reklama za predstavu Očajno smiješno u Zagrebu, 1989

12. Fotografija XII: Programska knjižica predstave Očajno smiješno Václava Havela, DK-a

Gavella

13. Fotografija XIII: knjižica predstave Očajno smiješno DK-a Gavella, prva stranica

14. Fotografija XIV: Fotografija predstave predstave Očajno smiješno Václava Havela DK-a Gavella (programska knjižica)

15. Fotografija XV: Fotografija predstave predstave Očajno smiješno Václava Havela DK-a Gavella (programska knjižica)

16. Fotografija XVI: Scenografska skica Dinke Jeričević za predstavu Asanacija Václava Havela u HNK-u Zagreb 1990.

17. Fotografija XVII: Plakat predstave Asanacija Václava Havela, HNK Zagreb, 1990.

18. Fotografija XVIII: Kazališna cedulja predstave Asanacija Václava Havela, HNK Zagreb, 1990.

19. Fotografija XIX: Fotografija predstave Asanacija Václava Havela, HNK Zagreb, 1990.

20. Fotografija XX: Fotografija predstave Asanacija Václava Havela, HNK Zagreb, 1990.

21. Fotografija XXI: plakat predstave Protest i Atest Václava Havela i Pavela Kohouta, autor Mirko Ilić 
22. Fotografija XXII: Programska knjižica predstava Atest i Protest Pavela Kohouta i Václava Havela u Teatru ITD, prednja stranica

23. Fotografija XXIII: Programska knjižica predstava Atest i Protest Pavela Kohouta i

Václava Havela u Teatru ITD, stražnja stranica

24. Fotografija XXIV: Fotografija predstava Atest Pavela Kohouta i Protest Václava Havela u Teatru ITD, 1981.

25. Fotografija XXV: Fotografija predstave Atest Pavela Kohouta i Protest Václava Havela u Teatru ITD, 1981.

26. Fotografija XXVI: Plakat predstave Marija se bori s anđelima, autor Ivan Picelj

27. Fotografija XXVII: Naslovnica programa predstave Marija se bori s anđelima, autor Ivan Picelj 


\section{POPIS KRATICA}

BITEF Beogradski internacionalni teatarski festival

CK Centralni komitet

DK Dramsko kazalište

HAZU Hrvatska akademija znanosti i umjetnosti

HNK Hrvatsko narodno kazalište

IK Izvršni komitet

KPČ Komunistička partija Čehoslovačke

MESS Male i eksperimentalne scene Sarajevo

PEN Poets Essayists and Novelists

SKBIH Savez komunista Bosne i Hercegovine

SKH Savez komunista Hrvatske

SKJ Savez komunista Jugoslavije

SSSR Savez Sovjetskih Socijalističkih Republika

VONS Výbor na obranu nespravedlivě stíhaných 


\section{ŽIVOTOPIS DOKTORANDICE}

Helena Roštaš rođena je u Virovitici 2. travnja 1981. Osnovnu i srednju školu pohađa i završava u Slatini. Na Filozofskom fakultetu Sveučilišta u Zagrebu 2006. stječe zvanje profesora hrvatskoga jezika i književnosti i češkoga jezika i književnosti obranivši diplomski rad Češki samizdat na Katedri za bohemistiku, a pod mentorstvom dr. sc. Katice Ivanković.

Nakon završetka studija zaposlena je na radnom mjestu nastavnice Hrvatskoga jezika u srednjoj školi u Slatini te 2017. napreduje u zvanje nastavnika mentora.

Tijekom 2020. znanstveni rad Hrvatska recepcija drama Václava Havela objavit će u časopisu Književna smotra Hrvatskoga filološkog društva. 